MARIANA MALZONI FURTADO

ESTUDO EPIDEMIOLÓGICO DE PATÓGENOS CIRCULANTES NAS POPULAÇÕES DE ONÇA-PINTADA E ANIMAIS DOMÉSTICOS EM ÁREAS PRESERVADAS DE tRÊS biomas brasileiros: CerRado, PANTANAl e Amazônia

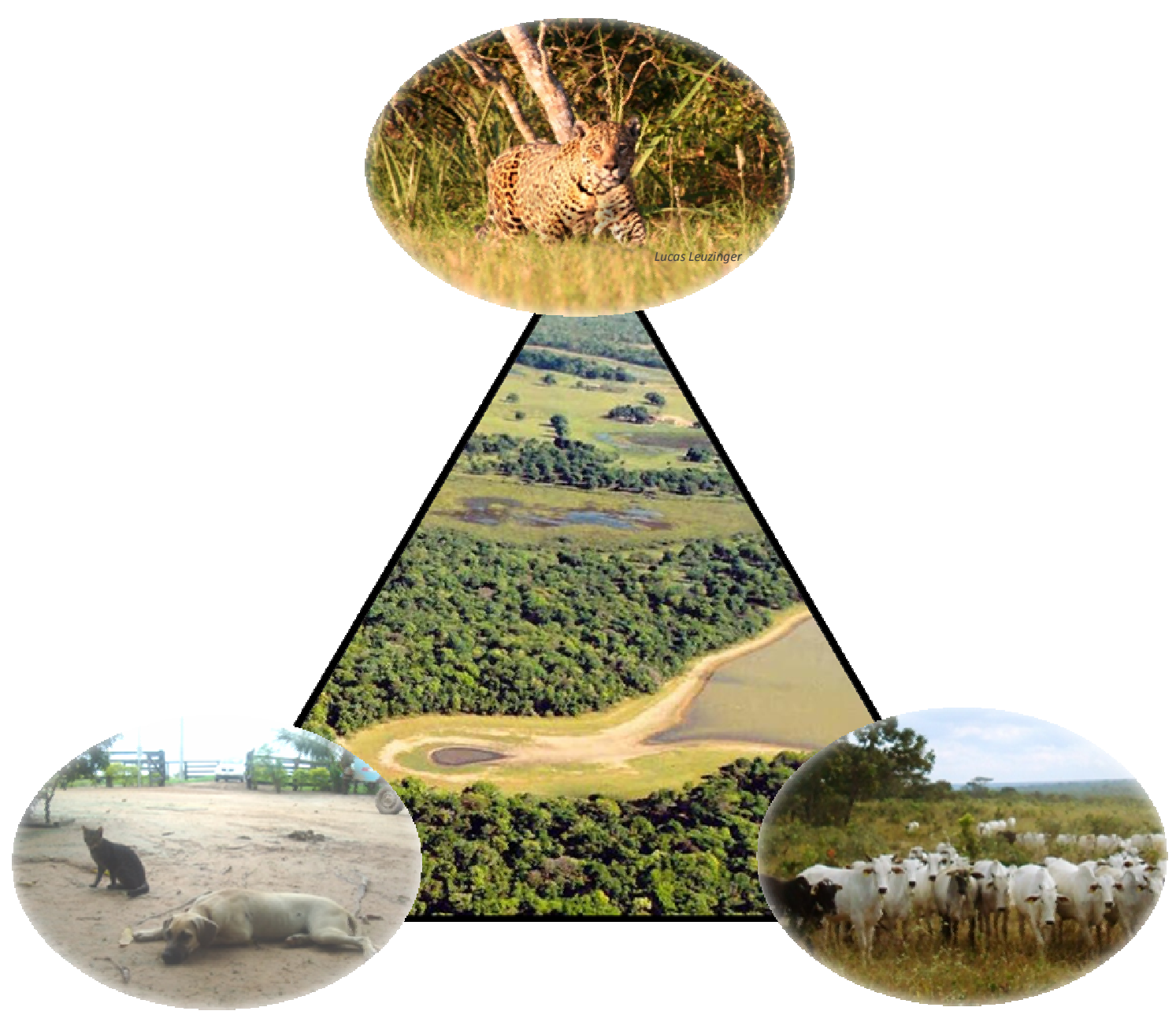

São Paulo 



\section{Estudo epidemiológico de patógenos circulantes nas populações de onça-pintada e animais domésticos em áreas preservadas de três biomas brasileiros: Cerrado, Pantanal e Amazônia}

Tese apresentada ao Programa de PósGraduação em Epidemiologia Experimental Aplicada às Zoonoses da Faculdade de Medicina Veterinária e Zootecnia da Universidade de São Paulo para obtenção do título de Doutor em Ciências

Departamento:

Medicina Veterinária Preventiva e Saúde Animal

Área de concentração:

Epidemiologia Experimental Aplicada às Zoonoses

Orientador:

Prof. Dr. José Soares Ferreira Neto 
Autorizo a reprodução parcial ou total desta obra, para fins acadêmicos, desde que citada a fonte.

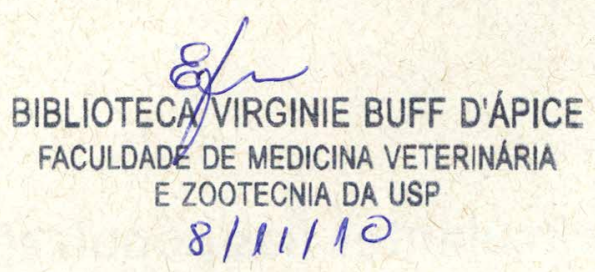

DADOS INTERNACIONAIS DE CATALOGAÇÃO-NA-PUBLICAÇÃO

(Biblioteca Virginie Buff D’Ápice da Faculdade de Medicina Veterinária e Zootecnia da Universidade de São Paulo)

Furtado, Mariana Malzoni

Estudo epidemiológico de patógenos circulantes nas populações de onça-pintada e animais domésticos em áreas preservadas de três biomas brasileiros: Cerrado, Pantanal e Amazônia / Mariana Malzoni Furtado. -- 2010.

282 p. : il.

Tese (Doutorado) - Universidade de São Paulo. Faculdade de Medicina Veterinária e Zootecnia. Departamento de Medicina Veterinária Preventiva e Saúde Animal, São Paulo, 2010.

Programa de Pós-Graduação: Epidemiologia Experimental Aplicada às Zoonoses. Área de concentração: Epidemiologia Experimental Aplicada às Zoonoses.

Orientador: Prof. Dr. José Soares Ferreira Neto.

1. Onças. 2. Panthera onca. 3. Medicina da conservação. 4. Epidemiologia veterinária. 5. Doenças infecciosas em animais. I. Título. 


\section{FACULDADE DE MEDICINA VETERINÁRIA E ZOOTECNIA}

\section{CERTIFICADO}

Certificamos que o Projeto intitulado "Relação epidemiológica das populações de onça-pintada (Panthera onça) e animais domésticos em três biomas brasileiros: Cerrado, Pantanal e Amazônia", protocolado sob o n¹471/2008, utilizando 30 (trinta) onças-pintadas, 150 (cento e cinqüenta) cachorros, 150 (cento e cinqüenta) gatos e 2000 (dois mil) bovinos, sob a responsabilidade do Prof. Dr. José Soares Ferreira Neto, está de acordo com os princípios éticos de experimentação animal da Comissão de Bioética da Faculdade de Medicina Veterinária e Zootecnia da Universidade de São Paulo e foi aprovado em reunião de 01/10/08.

We certify that the Research "Epidemiologic relation between jaguar (Panthera onca) population and domestic animals in three Brazilian Biomes: Cerrado, Pantanal and Amazon", utilizing 30 (thirty) jaguar, 150 (one hundred fifty) dogs and 150 (one hundred fifty) bovines, protocol number 1471/2008, under the responsibility Prof. Dr. José Soares Ferreira Neto, agree with Ethical Principles in Animal Research adopted by Bioethic Commission of the School of Veterinary Medicine and Animal Science of University of São Paulo and was approved in the meeting of day 10/01/08.
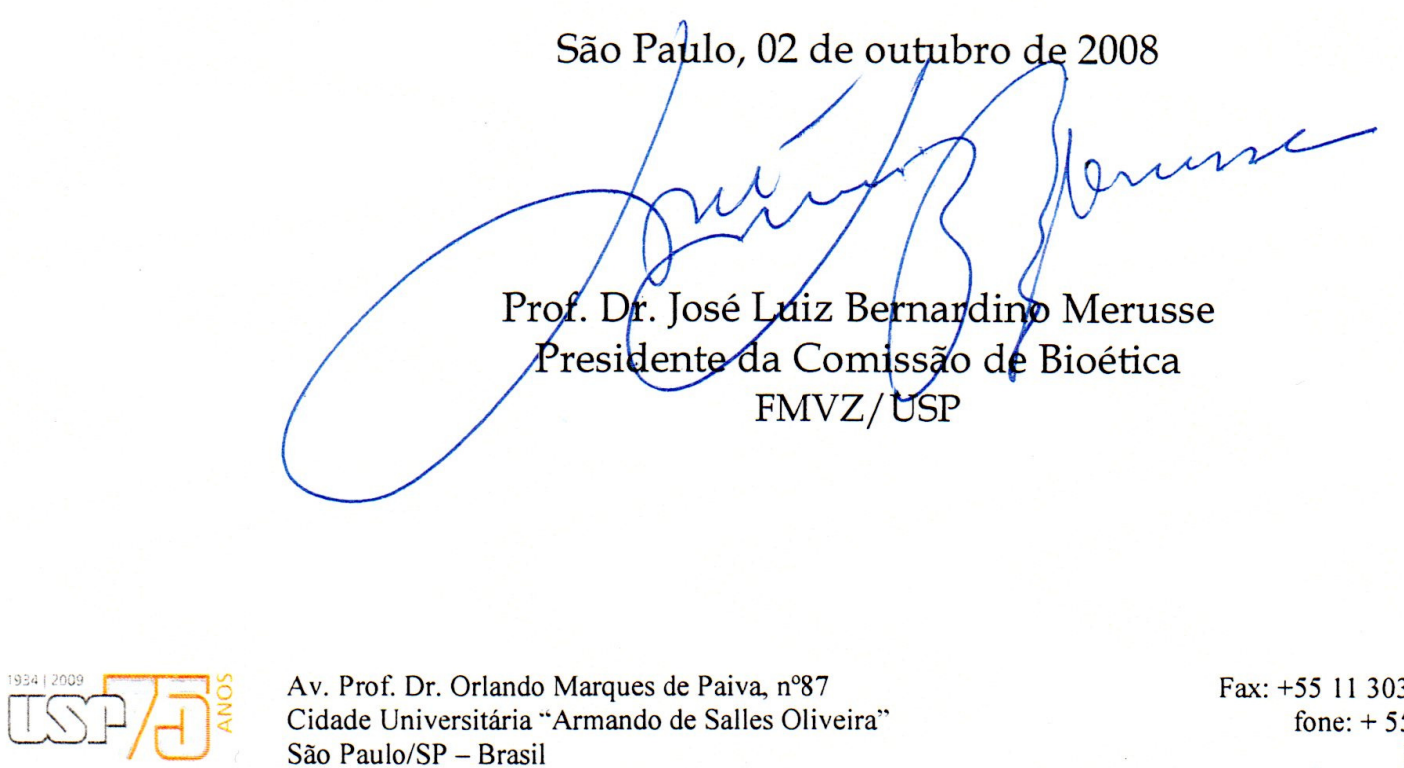



\section{FOLHA DE AVALIAÇÃO}

Nome: FURTADO, Mariana Malzoni

Título: Estudo epidemiológico de patógenos circulantes nas populações de onça-pintada e animais domésticos em áreas preservadas de três biomas brasileiros: Cerrado, Pantanal e Amazônia

Tese apresentada ao Programa de Pós-Graduação em Epidemiologia Experimental Aplicada às Zoonoses da Faculdade de Medicina Veterinária e Zootecnia da Universidade de São Paulo para obtenção do título de Doutor em Ciências.

Data:

\section{Banca Examinadora}

Prof. Dr. Instituição:

Assinatura: Julgamento:

Prof. Dr. Instituição:

Assinatura: Julgamento:

Prof. Dr. Instituição:

Assinatura: Julgamento:

Prof. Dr. Instituição:

Assinatura: Julgamento:

Prof. Dr. Instituição: Julgamento: 



\section{DEDICATÓRIA}

\section{Ao Mario,}

marido, amigo e grande incentivador do meu trabalho. Obrigada pelo apoio, compreensão, paciência, carinho, amor e companheirismo. A vida só é completa com você ao meu lado. 



\section{AGRADECIMENTOS}

Para um trabalho como este, talvez a parte mais difícil seja escrever os agradecimentos. Foram diversas pessoas envolvidas, desde o planejamento, a elaboração e execução de cada uma das etapas. Costumo dizer que foi um trabalho de equipe, que só se tornou real pelo auxílio $e$ envolvimento de cada um. Sozinha, eu nunca teria realizado e chegado até aqui. Gostaria de agradecer, do fundo do coração, a cada um que de uma maneira ou outra, contribuiu para a conclusão deste projeto - me ajudando, apoiando, ensinando e compartilhando comigo principalmente durante as atividades de campo - as aventuras, alegrias, dificuldades $e$ imprevistos. Gostaria de dividir com vocês o resultado final deste trabalho.

\section{Aos meus pais, João e Maria Jacira,}

Pela minha educação e formação, ensinamentos e, acima de tudo, pelo amor incondicional. Obrigada por apoiarem minhas decisões, minhas escolhas e me incentivarem, permitindo que minhas "loucuras" se tornassem realidade. Por compreenderem a importância do meu trabalho, minha distância e ausência em momentos importantes. Obrigada por me ensinarem a amar a natureza e querer conservá-la. Vocês são meus exemplos de pessoas.

\section{Aos meus irmãos, Erison e Jonas,}

Pelo apoio, amizade e conselhos. Obrigada pela revisão gramatical da tese na etapa final. Tenho grande admiração por vocês.

Às minhas cunhadas, Débora e Roberta, e sobrinhos, Raphael, Bruna, Alexandre e Helena, Por me darem suporte para aguentar a distância, mostrarem que a vida não é só trabalho e que os momentos em família têm que ser vividos e aproveitados. Vocês são muito importantes pra $\operatorname{mim}$.

\section{Aos meus sogros, Sr. Carlos e Dạ. Myriam, e cunhados, Nenê, Sam e Dani,}

Por entenderem a importância do meu trabalho e compreenderem a ausência em tantos momentos. Obrigada por formarem essa familia maravilhosa, da qual tenho orgulho de fazer parte. Obrigada também Felipe, Vitor e Vivian.

\section{Ao Instituto Onça-Pintada,}

Por acreditar no meu trabalho, dar oportunidades e investir na minha formação como pesquisadora. Agradeço a oportunidade e privilégio de ter conhecido e convivido com todos os pesquisadores que fazem e fizeram parte dessa instituição, pessoas maravilhosas que muito ajudaram para a realização desse projeto. 


\section{Aos coordenadores e amigos, Dr. Leandro Silveira e Drạ. Anah Tereza A. Jácomo,}

Pela confiança e amizade desde o início. Por acreditarem no meu potencial e ajudarem na minha formação como pesquisadora. Por terem me aberto as portas para a pesquisa com conservação e com as onças-pintadas - dando a oportunidade de trabalhar com aquilo que mais amo. Sem dúvida, os resultados deste trabalho são nossos, e têm o incentivo, apoio e colaboração de vocês em cada uma das etapas. Obrigada por tudo.

\section{Ao meu orientador, Prof. Dr. José Soares Ferreira Neto,}

Pela confiança: em mim, no meu projeto e trabalho. Pela amizade e a oportunidade de trabalharmos juntos. Pelas orientações, sugestões e conselhos. Pelas discussões e ajuda na elaboração do documento final.

\section{À amiga Rahel Sollmann,}

São tantos agradecimentos pra você. Primeiro pela amizade, pelo carinho e companheirismo durante os últimos anos. Pela elaboração dos modelos para as análises estatísticas deste estudo. Pelos conselhos, revisões e sugestões na elaboração do documento final. Pela ajuda nas coletas dos materiais biológicos dos bovinos e pelo monitoramento do Jacuba em Emas. Por ser uma ótima companheira de campo, tornando esses momentos agradáveis e prazerosos.

\section{À amiga Grasiela E. O. Porfírio,}

Tarefa difícil agradecer tudo o que fez por mim. Pela amizade, dedicação e seriedade com que me ajudou em diversas etapas deste trabalho. Pelas coletas dos materiais biológicos dos animais domésticos do Pantanal (inclusive realizando algumas delas sozinha! uma veterinária nata), e principalmente pela contenção dos gatos domésticos ferais! Só nós sabemos o que atravessamos para conseguir o número final de amostras! Obrigada por ser meu braço direito durante as capturas de onças, sempre pronta a ajudar. Se não bastasse o campo, ainda me ajudou na revisão deste documento! Sou imensamente grata por tudo, amiga.

\section{À amiga Natália M. Tôrres,}

Pela amizade ao longo desses anos, por estarmos juntas nessa caminhada desde o início e com o mesmo objetivo final. Obrigada pela ajuda com os mapas no início deste trabalho, por todo suporte e companheirismo nessa empreitada.

\section{Aos amigos Eduardo de Freitas Ramos (Negão), Tiago Boscarato e Raphael de Almeida,}

Pela amizade e pela colaboração em diversas etapas deste trabalho. Sem a ajuda de vocês, este resultado não seria possível. Negão, obrigada pelas capturas e monitoramento das onças no Pantanal. Tiago, obrigada pela coordenação da logística do esforço de captura com gaiolas, pela ajuda nas capturas de onça, e visitas às fazendas do entorno de Emas. Rapha, obrigada pela coleta das fezes de onças com o Tupã, pela realização dos mapas no início do trabalho e por me ensinar os segredos do ArcGis. Aos três, obrigada pelo período agradável em campo. 


\section{Aos amigos Samuel Astete, Marina Zanin, Luana Delgado, Flávia Rodrigues, Nuno Negrões e Darivan Nogueira}

Pela ajuda em algum momento deste projeto. Pela amizade e incentivo durante esse período. Marina, obrigada pela ajuda na elaboração dos mapas da tese - sem a sua ajuda, ainda não teria terminado - você tornou tudo mais fácil. Luana, obrigada pela ajuda com as planilhas, colocando os dados em ordem para serem analisados! Nuno, obrigada pelo esforço de captura com gaiolas no Cantão. Obrigada a todos pela companhia.

\section{Ao James e Fabiano Bortolini,}

Pela captura das onças do Pantanal, Emas e Cantão. Pelos sucessos e pelas tentativas. Pela seriedade e confiança com que realizam esse trabalho.

\section{Ao Marcelo Carvalho, Mario Antônio Ferraro Rego e Natália Camargo,}

Pelas coletas de material biológico dos animais domésticos do entorno de Emas e do Cantão. Pelos bons momentos no campo, pela seriedade e dedicação com que realizaram as atividades. Pelas horas no laboratório... pipetando e organizando todas as amostras. Obrigada pelo número final de animais domésticos. Marcelo, obrigada pela contenção física dos gatos domésticos!

\section{Ao Guilherme Ribeiro Lana,}

Pela dedicação e seriedade com que revisou as gaiolas em Emas durante o segundo semestre de 2008. Obrigada por todo seu esforço.

\section{Ao Raphael Oliveira (Rasta), Bruna Miranda, Fabio Gamba e voluntários do Instituto Earthwatch,}

Pelo auxílio na armação das gaiolas para captura de onças-pintadas em Emas. Rasta, obrigada também pela ajuda no esforço de captura (sem sucesso!) no Cantão.

\section{Aos voluntários do Instituto Earthwatch - agosto 2009, e Thiago (Projeto Arara Azul)}

Pela contenção física dos gatos ferais do entorno do Parque Nacional das Emas e Pantanal - um trabalho de equipe.

\section{À Carly Vynne,}

Pela coleta de algumas das amostras de fezes de onças-pintadas no Parque das Emas utilizadas neste trabalho.

\section{À Cyntia K. Kashivakura, Cláudia Ferro e Diego Suero,}

Pela ajuda e amizade no início do trabalho de campo, quando este projeto ainda era um sonho. Pelos bons momentos que passamos juntos nessa época. Aprendi muito com vocês, ensinamentos que levarei para vida toda. Cyntia, obrigada especialmente a você, pelos ensinamentos no início dos trabalhos de campo, pelas onças capturadas no Pantanal e Cantão e por todo o seu esforço para que isso se concretizasse. Você colaborou muito para o início deste trabalho. 


\section{À Cassia Ykuta,}

Pela ajuda na organização das amostras coletadas. Pelo auxílio na realização dos testes para leptospirose, brucelose e Mycobacterium spp. Pela ajuda na resolução de "assuntos gerais", quando eu não estava em São Paulo. Obrigada por sua dedicação e seriedade.

Ao Laboratório de Zoonoses Bacterianas - VPS/FMVZ/USP, em especial à Gisele Oliveira de Souza, Zenaide M. de Morais e Flávia Morato,

Pelo auxílio na realização dos testes sorológicos para leptospirose, brucelose e/ou pesquisa de Mycobacterium spp. Pelos momentos descontraídos no laboratório.

À Biovet, em especial ao José Domingues de Ramos Filho, Drạ Sandra Fernandez, Drạ Jane Fraga e Eliana de Barros Corrêa,

Pela realização dos testes sorológicos para cinomose. Ao José Domingues pela orientação na interpretação dos resultados e atenção dispensada.

Ao Departamento de Parasitologia - IB/UNESP - Botucatu, em especial à Prof $\underline{a}$ Dr $\underline{a}$ Lúcia Helena O'Dwyer e Betina Metzger,

Pela realização dos testes moleculares para hemoparasitas. Obrigada, especialmente, à Betina pela dedicação com que realizou os testes, apesar de todas os imprevistos e dificuldades encontradas.

Ao Laboratório de Doenças Parasitárias - VPS/FMVZ/USP, em especial À Prof $\underline{a}$ Dr $\underline{a}$ Solange M. Gennari e Dr ${ }^{\underline{a}}$ Hilda F. J. Pena,

Pela ajuda na realização dos testes sorológicos para toxoplasmose, ensinamento das técnicas e supervisão durante as análises.

Ao Prof. Dr. Rodrigo Martins Soares e Sheila Oliveira de Souza, Pela realização dos testes moleculares para pesquisa de parasitas intestinais.

Ao Prof. Dr. Marcelo Labruna e Thiago Martins,

Pela identificação dos ectoparasitas. Ao Thiago, por toda dedicação, atenção e rapidez na identificação deste material.

Ao Instituto Pasteur, em especial à Drọ Ivanete Kotait, Karin Corrêa Scheffer Ferreira e Paula Sônia Cruz,

Pela realização das análises sorológicas para o vírus da raiva. Obrigada Karin, pela atenção e orientação para interpretação dos resultados.

Ao Instituto Biológico - São Paulo,

Pela doação dos antígenos para realização dos testes sorológicos para brucelose.

Ao Prof. Dr. João Pessoa de Araújo Jr., Denise Dutra Menezes Leal e Karina S. Paduan, Pela colaboração durante algumas etapas das análises dos hemoparasitas. 
Ao Dr. Rodrigo S. P. Jorge, Dr. Jean Carlos Ramos da Silva, e Drạ Maria Fernanda Vianna Marvulo,

Pelo incentivo e sugestões no início deste projeto, quando tudo ainda estava no papel. Rodrigo (Mogli!), obrigada pelos contatos iniciais com alguns dos laboratórios parceiros. Jean $e$ Fernanda, obrigada por me apresentarem ao Prof. Zezé - orientador deste trabalho.

\section{Ao Renato, Aline, Marcos, Carol e Andréia do Laboratório de Doenças Parasitárias/VPS}

Pelo auxílio e companhia durante a realização dos testes de toxoplasmose - fazendo com que o tempo despendido no laboratório fosse prazeroso.

\section{À Vanessa Miranda Reis e Erika M. K. Hayashi,}

Vanessa, pelo auxílio nos testes de toxoplasmose. Mas, principalmente, pelo auxilio com as referências bibliográficas deste trabalho - sem a sua ajuda não teria finalizado a tempo. Obrigada por sua dedicação. Erika, pelo auxílio nos testes de brucelose e, por conferir a numeração das tabelas e figuras do documento final.

Ao Departamento de Biologia da Conservação - Estación Biológica de Doñana e ao Laboratório de Biologia Genômica e Molecular, Faculdade de Biociências - PUCRS,

Em especial, aos pesquisadores Dr. Francisco Palomares, Dra Séverine Roques e Dr. José Antônio Godoy, Dráa Taiana Haag e Dr. Eduardo Eizirik pelas análises genéticas das amostras de fezes de onças-pintadas.

\section{Ao Refúgio Ecológico Caiman,}

Pelo apoio logístico durante as coletas de amostras biológicas no Pantanal. Em especial ao Dr. Roberto Klabin pelo apoio à pesquisa e ao Instituto Onça-Pintada. Ao Sr. César Queiroz, Sr. Zé Carlos, Tio (in memorian), Sr. Geraldo (in memorian), Ratão e a todos os funcionários da fazenda pelo apoio durante as capturas de onças-pintadas. Ao veterinário Marcelo, pela colaboração durante as coletas de amostras dos animais domésticos.

\section{À Fazenda Santa Fé, em especial ao Dr. Marcos Mariani e Sr. Aldomiro,}

À Fazenda Fartura, em especial ao Sr. Inabel, Sr. Zé Leite e Dạ Bia, À Fazenda Barranco Alto, em especial ao Lucas Leuzinger e Marina Schweizer,

Pelo apoio logístico durante as coletas de amostras biológicas dos animais domésticos e campanhas para captura de onças-pintadas. Ao Lucas e a Marina, obrigada também pelo monitoramento da Barbie.

\section{Ao Sr. Higino Piacentini,}

Pela colaboração e conselhos no início das coletas das amostras biológicas dos animais domésticos. Por ser uma pessoa muito querida, sempre disposta a ajudar. Obrigada por tudo. 
Aos fazendeiros, gerentes e funcionários das propriedades rurais do entorno do Parque Nacional das Emas, região do Pantanal e entorno do Parque Estadual do Cantão,

Por permitirem e realizarem o manejo do gado para as coletas de materiais biológicos dos animais domésticos. Obrigada pela atenção dispensada durante as visitas às propriedades.

\section{À FAPESP - Fundação de Amparo à Pesquisa do Estado de São Paulo,}

Pelo apoio financeiro, concessão do auxilio pesquisa (processo $\left.n^{\circ} 2007 / 50941-5\right)$, minha bolsa de doutorado direto (processo $n^{\circ} 2007 / 50942-1$ ) e as bolsas de treinamento técnico (processos $n^{\circ} 2009 / 02101-3$ e 2009/0277-3).

Ao Memphis Zoo, Earthwatch Institute, Fundação Monsanto e Instituto Onça-Pintada Pelo apoio financeiro para realização das atividades de campo.

Ao CNPq - Conselho Nacional de Pesquisa e Desenvolvimento Científico e Tecnológico, Pelo apoio financeiro e bolsa de doutorado nos primeiros 6 meses deste projeto (processo $\left.n^{\circ} 143019 / 2006-6\right)$.

\section{Ao CENAP/ICMBio,}

Pelo armazenamento e envio das amostras biológicas das onças-pintadas. Obrigada especialmente a Rose Lilian Gasparini Morato e Ronaldo Morato.

Ao ICMBio, IBAMA e NATURATINS, Pelas licenças para captura de onças-pintadas. À Gerência do Parque Nacional das Emas e NATURATINS pelo apoio logístico durante as atividades de campo.

Às minhas amigas do coração, Fernanda M. Lopes (Mimosa), Flávia Z. lannicelli (Ká) e lara I. Nakao (Dadá),

Todas vocês, em algum momento me ajudaram. Por serem as pessoas maravilhosas e queridas que são, me darem o suporte e força com a amizade de vocês. Pela descontração nos momentos de lazer. E, porque não, também na parte prática? Mi, obrigada pela ajuda para armar as gaiolas para captura de onça e castração dos cães de captura! Ká, obrigada pelas consultas veterinárias por telefone! Dad's obrigada por ajudar com as aquisições de vacinas para os cães!

\section{À minha eterna orientadora, Profá. Drạ. Silvia R. Gaido Cortopassi,}

Que me orientou e incentivou no começo dos trabalhos com animais silvestres, quando tudo ainda era um sonho e começava a ser moldado. Obrigada por confiar em mim e apoiar minhas decisões. Obrigada pelos conselhos, orientações e principalmente pela amizade em todos esses anos.

\section{Ao Prof. Dr. José Luiz Catão Dias,}

Pelo exemplo de profissionalismo e pesquisador, que com certeza me inspirou e fez acreditar que trabalhar com animais silvestres, poderia sim, ser real. Obrigada pelos conselhos no início de tudo. 


\section{Ao Prof. Arthur Gruber,}

Pelo exemplo de pesquisador e pelos ensinamentos científicos durante a graduação. Por ter compreendido e aceitado naquela época a minha escolha, os felinos agradecem.

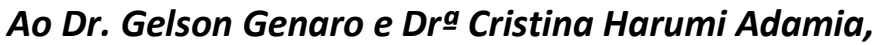

Por terem me apresentado o trabalho com os felinos e, Gelson por ter me apresentado o caminho científico. Obrigada pela oportunidade.

\section{Ao Prof. Dr. Marcelo A. B. V. Guimarães,}

Foi durante uma palestra sua no Zoológico de São Paulo em 1998, que me despertou o interesse, vontade e determinação de trabalhar com os animais silvestres. Indiretamente, você foi importante na minha escolha profissional. Obrigada.

Aos funcionários do VPS/FMVZ/USP e do Serviço de Pós-Graduação, Por estarem sempre prontos a ajudar e solucionar os problemas que sempre aparecem.

Aos colegas pós-graduandos e do Laboratório de Zoonoboses Bacterianas - VPS/FMVZ/USP Por tornarem agradável o período no doutorado, realização das disciplinas e tempo no laboratório.

Aos funcionários da biblioteca Virginie Buff D'Ápice - FMVZ /USP, em especial à Elza Faquim e Sandra Toledo,

Pelo auxílio na normalização das referências. Obrigada pela atenção e... paciência.

A todos os cães utilizados para as capturas, em especial ao Bugio, Baguá, Maiada, Shinaia e Zagaia,

Por todas as onças-pintadas capturadas para este trabalho. Tudo isso só foi possível pela competência de vocês.

E por último, mas não menos importante: a todas as onças-pintadas capturadas,

Por, literalmente, terem dado o sangue para realização deste estudo. Que os dados aqui apresentados ajudem para a conservação deste felino, majestoso, predador topo de cadeia alimentar. 

"Faz das espécies em perigo uma presença vivida na vida de toda a gente. Esclarece que cada uma destas espécies tem um nome, tem uma história de milhões de anos e tem o seu lugar no mundo. Traz-nos cara a cara com cada uma dessas espécies. Faz-nos reconhecer que elas são as nossas companheiras na biosfera. Elas não são apenas qualquer coisa para considerar de vez em quando, mas fazem parte de nossa existência... fazem parte de nós."

(Edward O. Wilson) 



\section{RESUMO}

FURTADO, M. M. Estudo epidemiológico de patógenos circulantes nas populações de onçapintada e animais domésticos em áreas preservadas de três biomas brasileiros: Cerrado, Pantanal e Amazônia. [Epidemiologic study of pathogens circulating in populations of jaguar and domestic animals in preserved areas of three Brazilian biomes: Cerrado, Pantanal and Amazon]. 2010. 282 f. Tese (Doutorado em Ciências) - Faculdade de Medicina Veterinária e Zootecnia, Universidade de São Paulo, São Paulo, 2010.

A fragmentação de habitats e o aumento da proximidade entre as comunidades humanas, animais domésticos e silvestres podem ser responsáveis pelo aparecimento de doenças emergentes, disseminação de patógenos e alterações nos padrões epidemiológicos das doenças. Declínios populacionais em felinos silvestres devido a doenças já foram relatados, porém, pouco se conhece sobre o potencial papel dos patógenos nas populações de onçapintada. Este estudo teve por objetivo pesquisar a presença de patógenos nas populações de onça-pintada e animais domésticos das regiões do Parque Nacional das Emas-PNE, Parque Estadual do Cantão-PEC e Pantanal sul mato-grossense, e identificar possíveis associações nos diagnósticos encontrados. Entre fevereiro de 2000 e janeiro de 2010, foram coletadas amostras biológicas de 31 onças-pintadas, 1246 bovinos, 179 cães e 36 gatos. Foram realizados diagnósticos sorológicos para brucelas lisas (AAT), Leptospira spp. (SAM), Toxoplasma gondii (MAT; RIFI), vírus da raiva (RFFIT), vírus da cinomose (SN), FIV e FeLV (Snap ${ }^{\mathrm{TM}}$ ); e diagnósticos moleculares para Babesia spp., Hepatozoon spp., Cytauxzoon spp., Mycoplasma haemofelis, 'Candidatus Mycoplasma haemominutum' e 'Candidatus Mycoplasma turicensis'. Amostras de fezes de onças-pintadas foram analisadas para Giardia intestinalis, Cryptosporidium spp., protozoários da Família Sarcocystidae e Mycobacterium spp. O monitoramento das onçaspintadas, através do radiotransmissor, permitiu o mapeamento da ocorrência dos patógenos. As populações de bovinos das três áreas apresentaram alta exposição à $B$. abortus, mas apenas uma onça-pintada do PNE foi exposta à brucela lisa. Os sorovares mais prováveis de Leptospira spp. identificados em onças-pintadas do PNE e Pantanal foram distintos dos encontrados nos animais domésticos. As onças-pintadas, cães e gatos das três áreas foram altamente expostos ao T. gondii. Onças-pintadas do PNE e Pantanal foram expostas ao vírus da raiva, assim como as onças-pintadas do Pantanal e os cães das três áreas foram expostos ao vírus da cinomose. Dois gatos do entorno do PEC foram soropositivos para FeLV, mas nenhuma onça-pintada foi exposta 
ao agente ou ao FIV. Cães do entorno do PNE e do PEC foram positivos para Babesia spp., enquanto todas onças-pintadas foram negativas para o hemoparasita. Todas as onças-pintadas do Pantanal e PNE, e três de quatro onças do PEC foram positivas para Hepatozoon spp. e Cytauxzoon felis, sendo que cães e gatos também foram expostos ao Hepatozoon spp., mas não ao Cytauxzoon spp. As onças-pintadas das três áreas apresentaram alta exposição ao 'Candidatus Mycoplasma haemominutum', e alguns indivíduos do Pantanal e PEC foram positivos para o Mycoplasma haemofelis e 'Candidatus Mycoplasma turicensis'. Poucos gatos foram positivos para os hemoplasmas felinos. Não houve evidências de exposição ao Mycobacterium bovis, e a presença de Cryptosporidium spp. e Giardia intestinalis foi detectada em onças do PNE. De acordo com os resultados, a cinomose e a raiva podem ser consideradas potenciais ameaças às populações de onça-pintada; a brucelose e a leptospirose podem ter sido transmitidas por animais domésticos; e, provavelmente as onças-pintadas possuem papel importante na manutenção do T. gondii, Cytauxzoon felis, Hepatozoon spp. e 'Candidatus Mycoplasma haemominutum' no ambiente. Esses dados são relevantes e devem ser considerados na elaboração de estratégias para a conservação de onça-pintada na natureza.

Palavras-chaves: Onças. Panthera onca. Medicina da conservação. Epidemiologia veterinária. Doenças infecciosas em animais. 


\begin{abstract}
FURTADO, M. M. Epidemiologic study of pathogens circulating in populations of jaguar and domestic animals in preserved areas of three Brazilian biomes: Cerrado, Pantanal and Amazon. [Estudo epidemiológico de patógenos circulantes nas populações de onça-pintada e animais domésticos em áreas preservadas de três biomas brasileiros: Cerrado, Pantanal e Amazônia]. 2010. 282 f. Tese (Doutorado em Ciências) - Faculdade de Medicina Veterinária e Zootecnia, Universidade de São Paulo, São Paulo, 2010.
\end{abstract}

Habitat fragmentation and the increasing proximity between humans, domestic and wild animals can be responsible for emerging and re-emerging diseases, dissemination of pathogens and alterations in host-pathogen relationships. Declines in wild felids due to disease have recently been reported; however, little is known about their potential role in wild jaguar populations. This study aimed to investigate the presence of pathogens in jaguar populations and domestic animals in the regions of Emas National Park (ENP), Cantão State Park (CSP) and the Pantanal of Mato Grosso do Sul, and to identify possible associations in the obtained diagnoses. Between February 2000 and January 2010, biological samples were collected from 31 jaguars, 1246 cattle, 179 dogs and 36 cats. Serological surveys for smooth Brucella (RBT), Leptospira spp. (MAT), Toxoplasma gondii (MAT; IFAT), rabies virus (RFFIT), distemper virus (SN), FIV and FeLV (Snap ${ }^{\mathrm{TM}}$ ), and molecular tests for Babesia spp., Hepatozoon spp., Cytauxzoon spp., Mycoplasma haemofelis, 'Candidatus Mycoplasma haemominutum' and 'Candidatus Mycoplasma turicensis' were performed. Jaguar scats were analyzed for Giardia intestinalis, Cryptosporidium spp., protozoas of the Sarcocystidae Familiy and Mycobacterium spp. Monitoring of jaguars through radio-transmitter provided pathogen occurrence maps. Cattle populations from all sites were highly exposed to B. abortus, but only one jaguar from ENP was exposed to smooth Brucella. The most detectable serotypes of Leptospira spp. identified in jaguars from ENP and the Pantanal were distinct from those found in the domestic animals. Jaguars, dogs and cats in the three areas were highly exposed to T. gondii. Jaguars from ENP and the Pantantal were exposed to rabies, and jaguars from the Pantanal and dogs from the three areas were exposed to distemper virus. Two cats from the surroundings of CSP were seropositive for FeLV, but no jaguars were exposed to this agent or to FIV. Dogs from the surroundings of ENP and CSP were positive for Babesia spp., while all jaguars were negative for the hemoparasite. All jaguars from the Pantanal and ENP and three of four jaguars from the CSP were positive for 
Hepatozoon spp. and Cytauxzoon felis. Dogs and cats were also exposed to Hepatozoon spp., but not to Cytauxzoon spp. The jaguars from the three areas were highly exposed to 'Candidatus Mycoplasma haemominutum', and some individuals from the Pantanal and CSP were positive for Mycoplasma haemofelis and 'Candidatus Mycoplasma turicensis'. Few domestic cats were positive for feline hemoplasms. There were no evidences of exposure to Mycobacterium bovis, but Cryptosporidium spp. and Giardia intestinalis were detected in jaguars from ENP. According to the results, distemper and rabies should be considered potential threats to jaguar populations; brucellosis and leptospirosis could have been transmitted by domestic animals; and jaguars probably play an important role in the maintenance of $T$. gondii, Cytauxzoon felis, Hepatozoon spp. and 'Candidatus Mycoplasma haemominutum' in nature. These data should be taken into account when elaborating conservation strategies for jaguars in the wild.

Key words: Jaguar. Panthera onca. Conservation medicine. Veterinary epidemiology. Animals infectious diseases. 


\section{LISTA DE ABREVIATURAS E SIGLAS}

\begin{tabular}{ll} 
AAT & Antígeno Acidificado Tamponado \\
DNA & Ácido desoxirribonucléico \\
EDTA & Ácido dietilenodiaminotetracético \\
EUA & Estados Unidos da América \\
FeLV & Vírus da Leucemia Felina \\
FIV & Vírus da Imunodeficiência Felina \\
FMVZ & Faculdade de Medicina Veterinária e Zootecnia \\
IB & Instituto de Biociências \\
IBAMA & Instituto Brasileiro do Meio Ambiente e dos Recursos Naturais Renováveis \\
ICTV & Comitê Internacional de Taxonomia Viral \\
IOP & Instituto Onça-Pintada \\
IUCN & International Union for Conservation of Nature \\
JCF & Jaguar Conservation Fund \\
LDP & Laboratório de Doenças Parasitárias \\
LZB & Laboratório de Zoonoses Bacterianas \\
MAPA & Ministério da Agricultura, Pecuária e Abastecimento \\
MAT & Técnica de Aglutinação Modificada \\
MMA & Ministério do Meio Ambiente \\
MS & Mato Grosso do Sul \\
MT & Mato Grosso \\
OIE & Office International des Epizooties \\
OMS & Organização Mundial da Saúde \\
PAN & Pantanal \\
pb & Pares de base \\
PCR & Reação em Cadeia Polimerase - Polymerase Chain Reaction \\
PEC & Parque Estadual do Cantão \\
PNCEBT & Programa Nacional de Controle e Erradicação da Brucelose e Tuberculose \\
PNE & Parque Nacional das Emas \\
RFFIT & Teste de Inibição de Focos Fluorescentes \\
RIFI & Reação de Imunofluorescência Indireta \\
RNA & Ácido ribonucléico \\
rpm & Rotações por minuto \\
RPPN & Reservas Particulares do Patrimônio Natural \\
rRNA & Ácido ribonucléico ribossômico \\
S & Sul \\
SAM & Microtécnica de Soroaglutinação Microscópica \\
SN & Soroneutralização \\
SP & São Paulo \\
USP & Universidade de São Paulo \\
UV & Ultravioleta \\
VPS & Departamento de Veterinária Preventiva e Saúde Animal \\
W & Oeste \\
\hline
\end{tabular}


LISTA DE SÍMBOLOS

\begin{tabular}{|c|c|}
\hline$\%$ & porcentagem \\
\hline${ }^{\circledR}$ & marca registrada \\
\hline $\mathrm{kg}$ & quilograma \\
\hline ha & hectare \\
\hline $\mathrm{m}$ & metro \\
\hline $\mathrm{km}$ & quilômetro \\
\hline $\mathrm{mg}$ & miligrama \\
\hline${ }^{\circ} \mathrm{C}$ & graus Celsius \\
\hline $\mathrm{mM}$ & milimolar \\
\hline$\geq$ & maior ou igual \\
\hline$\leq$ & menor ou igual \\
\hline TM & Trade Mark \\
\hline $\mathrm{pH}$ & potencial hidrogeniônico \\
\hline$\mu l$ & microlitro \\
\hline $\mathrm{cm}$ & centímetro \\
\hline$M$ & molar \\
\hline$\mu \mathrm{m}$ & micrometro \\
\hline $\mathrm{ml}$ & mililitro \\
\hline $\mathrm{m}$ & metro \\
\hline$v$ & volume \\
\hline g & grama \\
\hline $\mathrm{N}$ & normal \\
\hline \pm & mais ou menos \\
\hline $\mathrm{cm}$ & centímetro \\
\hline $\mathrm{N}^{\circ}$ & número \\
\hline UI & Unidade Internacional \\
\hline $\mathrm{n}$ & número amostral \\
\hline$<$ & menor \\
\hline$>$ & maior \\
\hline $\mathrm{MHz}$ & Mega Hertz \\
\hline
\end{tabular}




\section{SUMÁRIO}

1 INTRODUÇÃO

2 OBJETIVOS

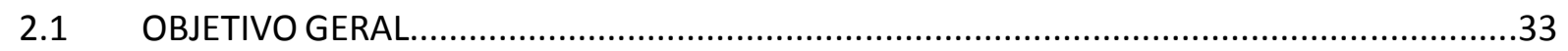

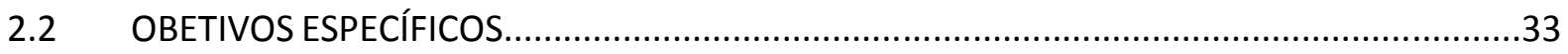

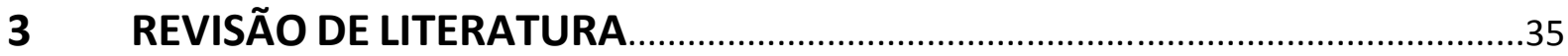

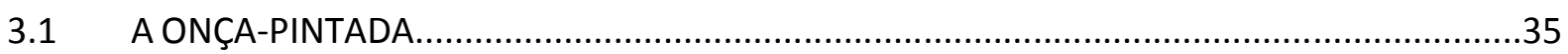

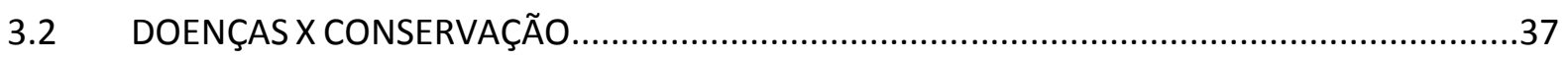

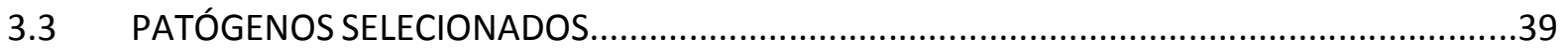

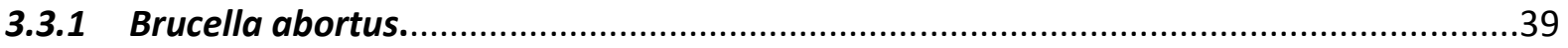

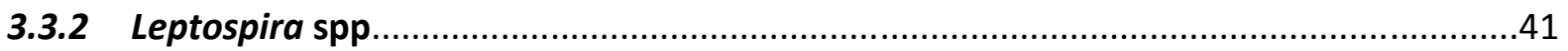

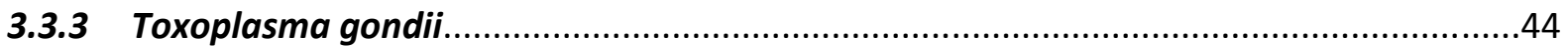

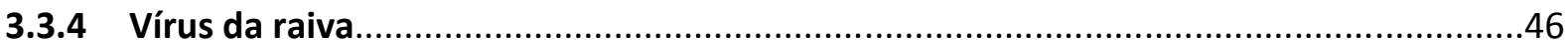

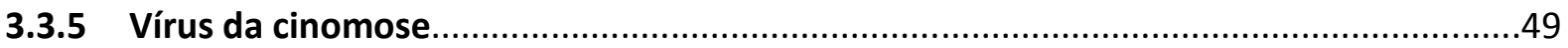

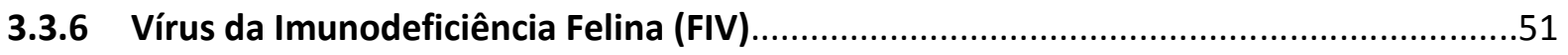

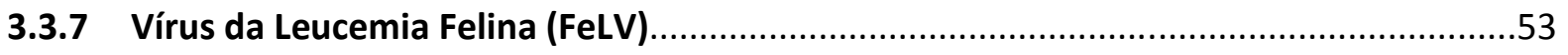

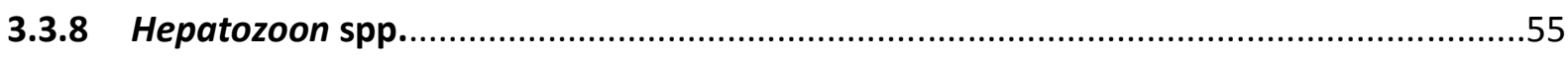

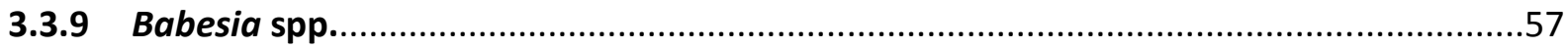

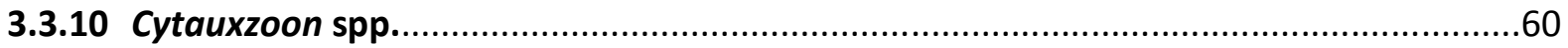

3.3.11 Hemoplasmas felinos: Mycoplasma haemofelis, 'Candidatus Mycoplasma haemominutum'e ‘Candidatus Mycoplasma turicensis' .................................................62

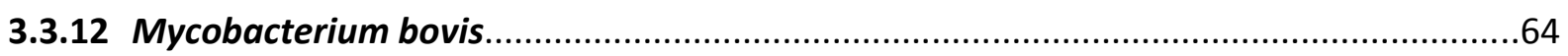

3.3.13 Parasitas intestinais: Cryptosporidium spp., Giardia spp., Sarcocystis spp. e Hammondia

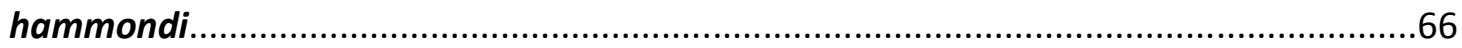

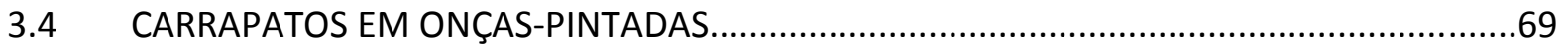

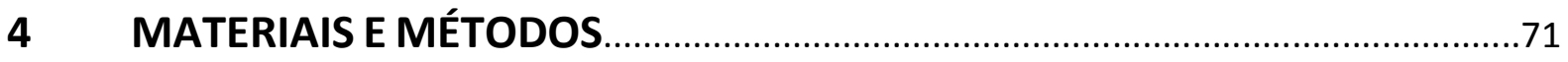

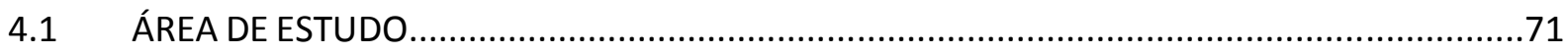

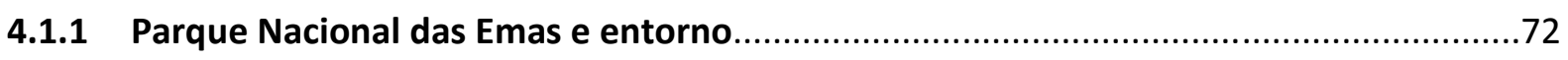

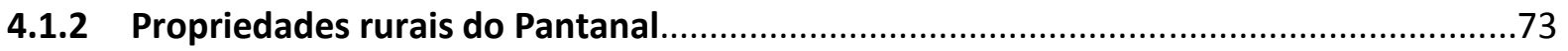

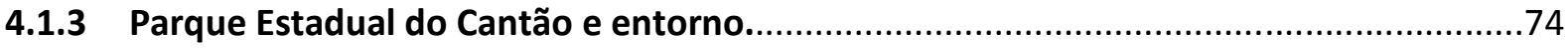




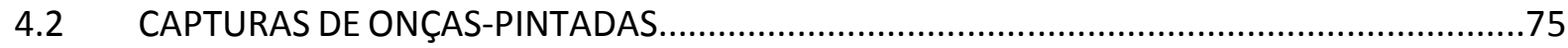

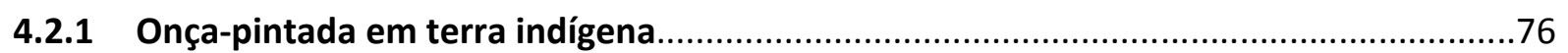

4.2.2 Imobilização, exame físico e colocação de radiotransmissor..........................................78

4.2.3 Coleta e armazenamento de sangue e ectoparasitas de onças-pintadas.......................79

4.2.4 Coleta e armazenamento de fezes de onças-pintadas................................................80

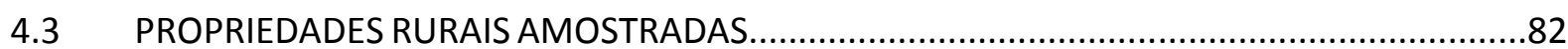

4.3.1 Coleta e armazenamento de sangue e ectoparasitas de animais domésticos................82

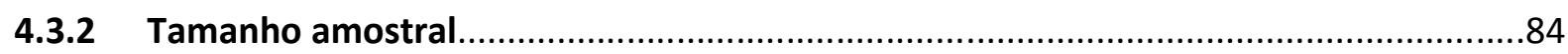

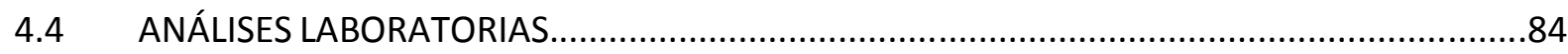

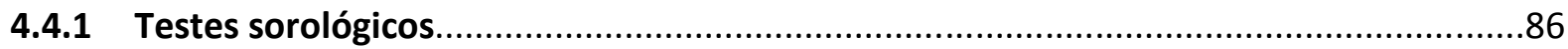

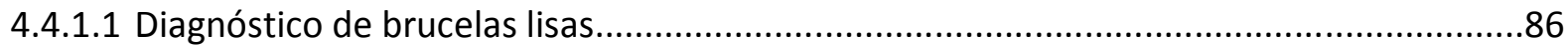

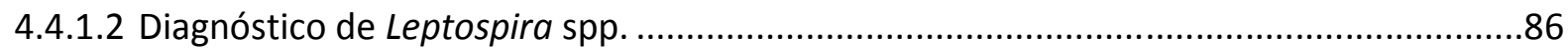

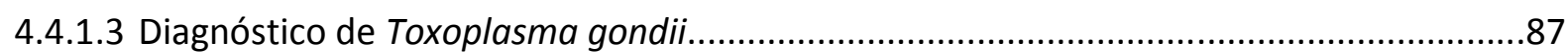

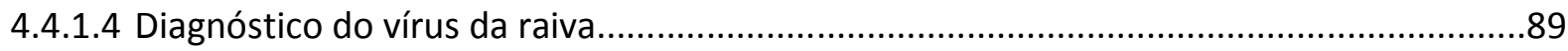

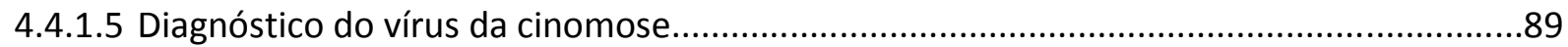

4.4.1.6 Diagnóstico do vírus da imunodeficiência felina e leucemia felina..................................90

4.4.2 Testes moleculares nas amostras sanguíneas............................................................90

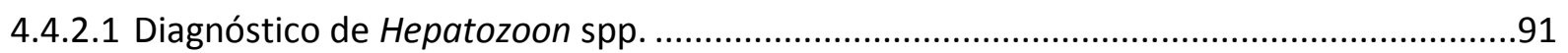

4.4.2.2 Diagnóstico dos Piroplasmas: Babesia spp. e Cytauxzoon spp. ……................................91

4.4.2.3 Diagnóstico dos hemoplasmas felinos: Mycoplasma haemofelis, 'Candidatus Mycoplasma haemominutum'e 'Candidatus Mycoplasma turicensis' ...................................................94

4.4.2.4 Sequenciamento dos hemoparasitas........................................................................96

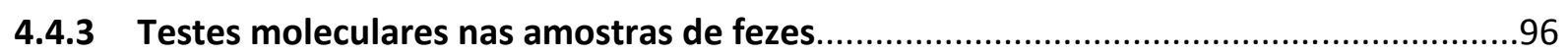

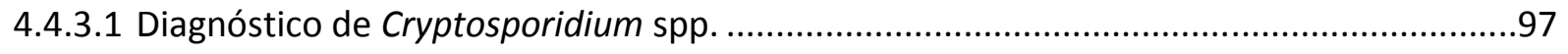

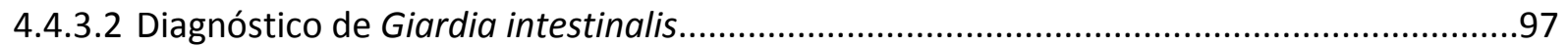

4.4.3.3 Diagnóstico de protozoários da Família Sarcocystidae...................................................98

4.4.3.4 Visualização do produto amplificado..........................................................................99

4.4.3.5 Diagnóstico de Mycobacterium spp...........................................................................99

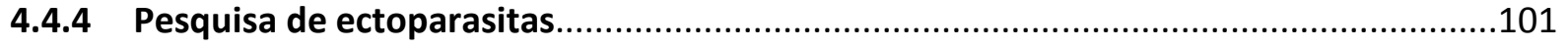

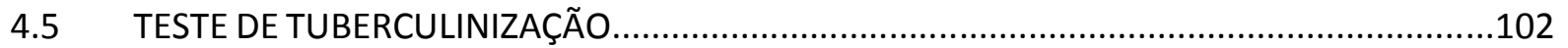

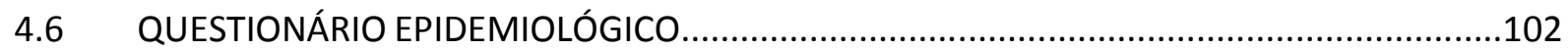

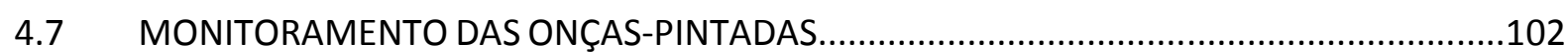

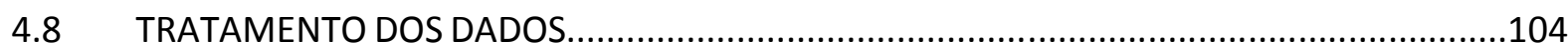


4.8.1.1 Efeito da área de estudo e espécie amostrada na ocorrência dos patógenos selecionados

4.8.1.2 Efeito do sexo e idade na ocorrência de patógenos nas onças-pintadas .105

$5 \quad$ RESULTADOS

5.1 CAPTURAS DE ONÇAS-PINTADAS. 107

5.2 CARACTERIZAÇÃO DAS ONÇAS-PINTADAS CAPTURADAS. 110

5.3 COLETA E ARMAZENAMENTO DE SANGUE E ECTOPARASITAS DAS ONÇAS-PINTADAS....112

5.4 COLETA E ARMAZENAMENTO DE FEZES DAS ONÇAS-PINTADAS.................................113

5.5 CARACTERIZAÇÃO DAS PROPRIEDADES RURAIS AMOSTRADAS ...................................113

5.6 COLETA E ARMAZENAMENTO DE SANGUE E ECTOPARASITAS DOS ANIMAIS DOMÉSTICOS.

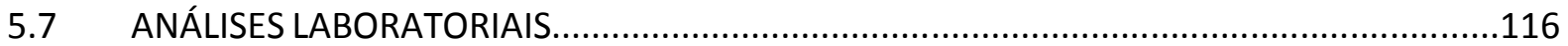

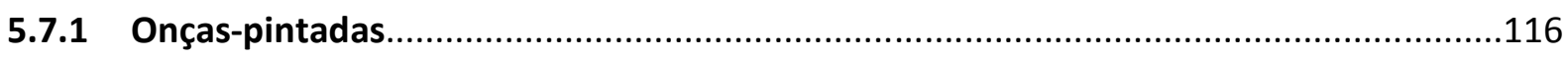

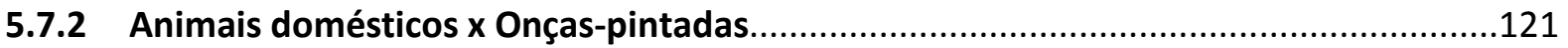

5.7.2.1 Diagnóstico sorológico para brucelas lisas..................................................................121

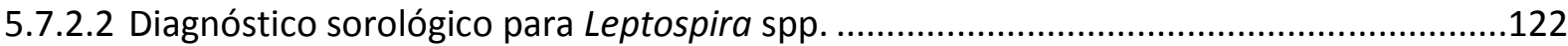

5.7.2.3 Diagnóstico sorológico para Toxoplasma gondii..............................................................122

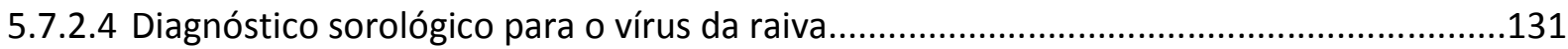

5.7.2.5 Diagnóstico sorológico para o vírus da cinomose.........................................................132

5.7.2.6 Diagnóstico sorológico para o vírus da imunodeficiência felina e leucemia felina...........132

5.7.2.7 Diagnóstico molecular para Hepatozoon spp.............................................................139

5.7.2.8 Diagnóstico molecular dos Piroplasmas: Babesia spp. e Cytauxzoon spp.......................139

5.7.2.9 Diagnóstico molecular dos hemoplasmas felinos: Mycoplasma haemofelis, 'Candidatus Mycoplasma haemominutum' e 'Candidatus Mycoplasma turicensis' ...........................140

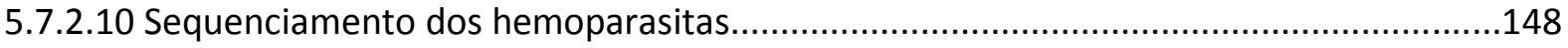

5.7.2.11 Diagnóstico para Mycobacterium bovis.....................................................................149

5.7.2.12 Diagnóstico molecular de parasitas intestinais.............................................................149

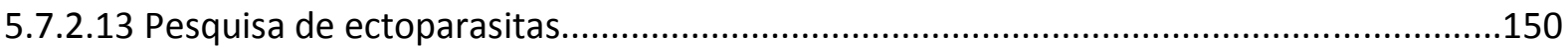

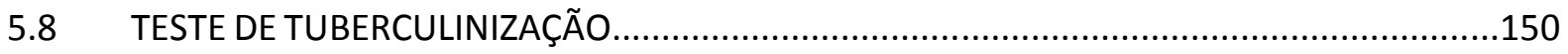

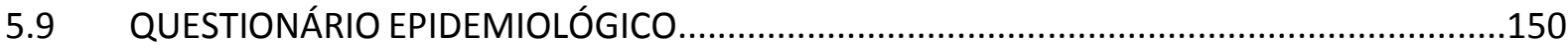

6 DISCUSSÃO

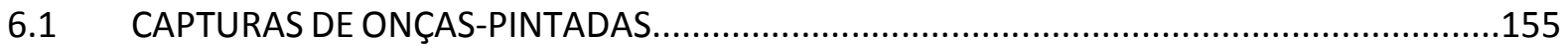




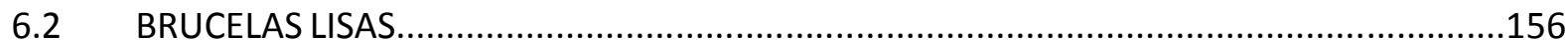

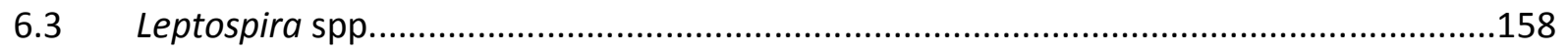

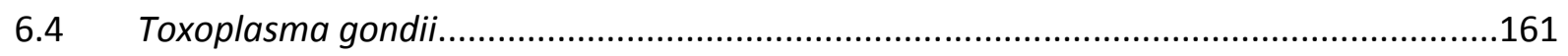

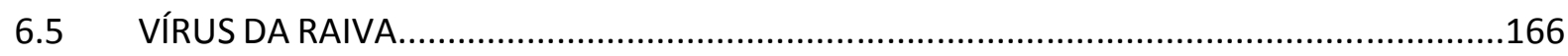

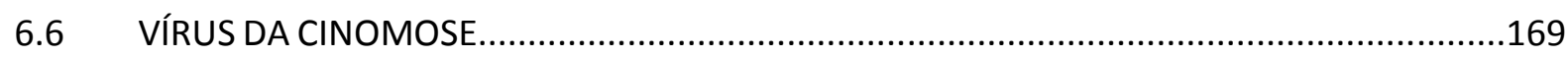

$6.7 \quad$ FIV

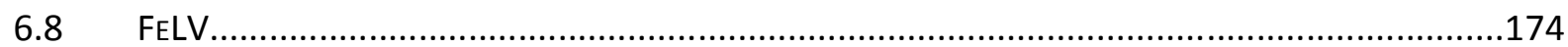

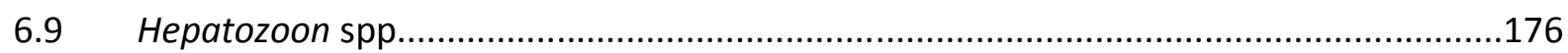

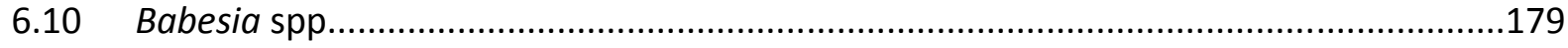

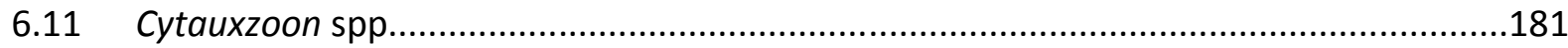

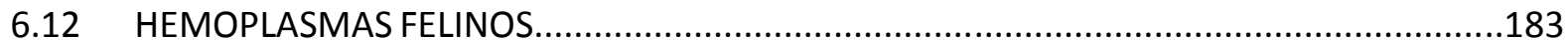

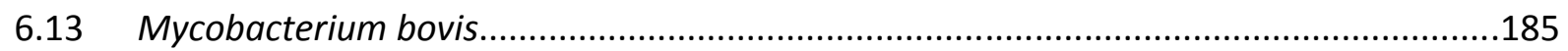

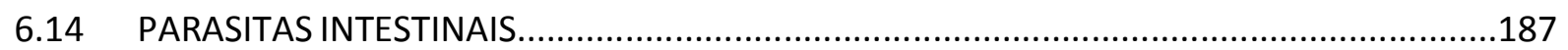

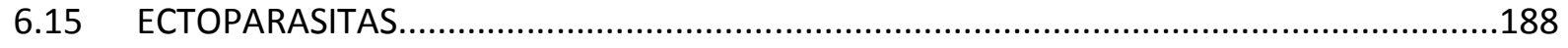

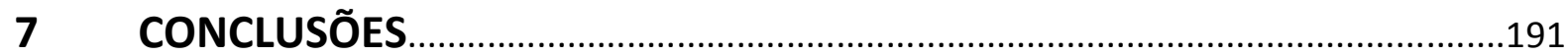

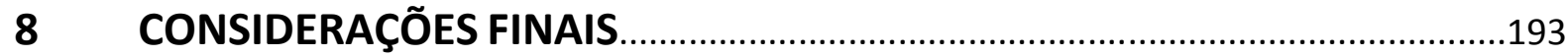

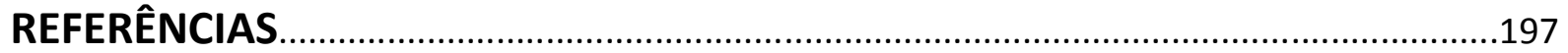

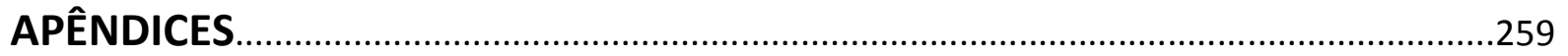




\section{INTRODUÇÃO}

A fragmentação de hábitats e a caça predatória são as principais ameaças para a conservação de animais silvestres (REDFORD, 1992; HANSKI, 2005; PEDERSEN et al., 2007). Em menor escala, as doenças infecciosas são também consideradas responsáveis por declínios populacionais significativos e representam uma ameaça à biodiversidade (DASZAK; CUNNINGHAM; HYATT, 2000; LAFFERTY; GERBER, 2002; LAURENSON et al., 2005; SMITH; BEHRENS; SAX, 2009).

O papel das doenças na dinâmica populacional dos carnívoros silvestres ainda é pouco conhecido; podem, porém, ter efeitos devastadores quando ocorrem em populações ameaçadas, em declínio, ou que sofrem de má nutrição, estresse ou baixa variabilidade genética (MURRAY et al., 1999; ALTIZER; HARVELL; FRIEDLE, 2003; PEDERSEN et al., 2007). O vírus da cinomose, por exemplo, foi responsável por declínios populacionais em cachorros-selvagensafricanos (Lycaon pictus) (ALEXANDER; APPEL, 1994), furões-de-pata-negra (Mustela nigripes) (WILLIAMS et al., 1988) e leões (Panthera leo) coinfectados com Babesia spp. (ROELKE-PARKER et al., 1996; MUNSON et al., 2008). O vírus da raiva causou declínios populacionais em lobos-daetiópia (Canis simensis) (SILLERO-ZUBIRI; KING; MACDONALD, 1996) e cachorros-selvagensafricanos (GASCOYNE et al., 1993; KAT et al., 1995); e, a leucemia felina, em linces-ibéricos (Lynx pardinus) (LÓPEZ et al., 2009). Em muitos desses surtos, os animais domésticos foram as principais fontes de infecção, e acredita-se que, na sua ausência, as infecções não teriam se propagado e persistido nos animais silvestres (PEDERSEN et al., 2007).

A prática da agropecuária no entorno de reservas naturais tem proporcionado o aumento do contato entre as populações humanas, os animais domésticos e os animais silvestres, favorecendo a disseminação de agentes etiológicos para novos ambientes e espécies (CLEAVELAND et al., 2000; DASZAK; CUNNINGHAM; HYATT, 2000; BENGIS; KOCK; FISCHER, 2002; SMITH; BEHRENS; SAX, 2009), sendo os patógenos generalistas, os que representam maior risco para as populações silvestres (CLEAVELAND; LAURENSON; TAYLOR, 2001; LAFFERTY; GERBER, 2002). No Brasil, diversos estudos epidemiológicos em carnívoros silvestres de vida livre estão sendo desenvolvidos (COURTENAY; QUINNELL; CHALMERS, 2001; CURI; TALAMONI, 2006; FILONI et al., 2006; WHITEMAN et al., 2007; JORGE, 2008; NAVA, 2008; WIDMER, 2009), porém, o impacto da circulação dos patógenos nessas populações ainda é desconhecido. 
A onça-pintada (Panthera onca) é o maior felino das Américas, predador topo de cadeia alimentar, que desempenha importante função ecológica para o equilíbrio dos ecossistemas onde ocorre (SOULÉ; TERBORGH, 1999). Possui alta exigência ecológica: grandes áreas com boa qualidade de hábitats e abundância de presas, sendo sensível às perturbações ambientais de origem antrópica (SWANK; TEER, 1989; WEBER; RABINOWITZ, 1996; SILVEIRA, 2004). Assim, a presença da onça-pintada em uma determinada área indica a boa situação de conservação da mesma.

Dentro desse contexto, este projeto escolheu a onça-pintada como espécie sentinela e teve como objetivo pesquisar a presença de selecionados patógenos nas populações de onçapintada, bovino, cão e gato doméstico em áreas preservadas de três biomas brasileiros: Cerrado, Pantanal e Amazônia. Áreas conhecidas pela ocorrência de onças-pintadas e por serem regiões onde a espécie e os animais domésticos utilizam o mesmo hábitat ou hábitats adjacentes. 


\section{OBJETIVOS}

Constituíram o objetivo geral e os específicos deste trabalho:

\subsection{OBJETIVO GERAL}

Pesquisar a exposição de populações de onça-pintada, bovino, cão e gato domésticos a patógenos selecionados em áreas preservadas de três biomas brasileiros: Cerrado, Pantanal e Amazônia. Identificar possíveis associações nos diagósticos encontrados.

\subsection{OBJETIVOS ESPECÍFICOS}

- $\quad$ Pesquisar a presença de:

- $\quad$ anticorpos contra brucelas lisas em onças-pintadas, bovinos e cães domésticos;

- anticorpos contra Leptospira spp. e contra Toxoplasma gondii em onças-pintadas, bovinos, cães e gatos domésticos;

- anticorpos contra o vírus da raiva em onças-pintadas, cães e gatos domésticos;

- anticorpos contra o vírus da cinomose em onças-pintadas e cães domésticos;

- anticorpos contra o vírus da imunodeficiência felina e do antígeno viral da leucemia felina em onças-pintadas e gatos domésticos;

- Babesia spp., Hepatozoon spp. e Cytauxzoon felis em onças-pintadas, cães e gatos domésticos;

- Mycoplasma haemofelis, 'Candidatus Mycoplasma haemominutum' e 'Candidatus Mycoplasma turicensis' em onças-pintadas e gatos domésticos;

- Mycobacterium bovis em onças-pintadas e a exposição de bovinos ao agente;

- Giardia intestinalis, Cryptosporidium spp., e protozoários da Família Sarcocystidae em onças-pintadas;

- Identificar os ectoparasitas presentes nas onças-pintadas, bovinos e cães domésticos;

- Mapear a ocorrência dos principais patógenos encontrados. 


\section{REVISÃO DE LITERATURA}

Esta revisão de literatura foi elaborada com o intuito de oferecer informações relevantes sobre a espécie focal - a onça-pintada, o papel das doenças na conservação de animais silvestres e, os patógenos pesquisados no presente trabalho.

\subsection{A ONÇA-PINTADA}

A onça-pintada (Panthera onca), pertencente à Ordem Carnivora, Família Felidae, é o maior felino das Américas e único representante do gênero Panthera no continente americano (SEYMOUR, 1989). É um predador topo de cadeia alimentar com papel importante no equilíbrio dos ecossistemas, regulando principalmente as populações de suas espécies presas (TERBORGH, 1988; SOULÉ; TERBORGH, 1999). É considerada tanto uma espécie guarda-chuva - cuja conservação resulta na conservação de outras espécies componentes do mesmo ecossistema (ROBERGE; ANGELSTAM, 2004) - quanto uma espécie bandeira - ou seja: carismática para o público e usada como ícone para proteger determinada área (HOME et al., 2009).

A área de ocorrência histórica da onça-pintada abrange do Sudoeste dos Estados Unidos ao Sul da Argentina (SEYMOUR, 1989), e atualmente sua distribuição geográfica foi reduzida em $55 \%$ da extensão original (ZELLER, 2007). Aproximadamente 50\% dessa área de distribuição localiza-se em território brasileiro, tornando o Brasil um país extremamente importante para a conservação da espécie em longo prazo (SOLLMANN; TÔRRES; SILVEIRA, 2008; TÔRRES et al., 2008). A onça-pintada encontra-se altamente ameaçada devido à conversão de seu hábitat natural em áreas de agricultura e pastagem e à caça predatória em retaliação ao prejuízo que causa no rebanho doméstico (AZEVEDO; MURRAY, 2007a; SILVEIRA et al., 2008). Globalmente, é considerada quase ameaçada de extinção pela União Internacional para a Conservação da Natureza (IUCN, 2010) e, no Brasil, é considerada vulnerável pelo Ministério do Meio Ambiente (2008).

A espécie ocorre em cinco biomas brasileiros: Amazônia, Caatinga, Cerrado, Pantanal e Mata Atlântica (revisado por ASTETE; SOLLMANN; SILVEIRA, 2008). Entre esses, a Amazônia é onde habita a maioria das populações de onça-pintada no país, com capacidade de manter 
populações viáveis em longo prazo (SANDERSON et al., 2002; SOLLMANN; TÔRRES; SILVEIRA, 2008). Nos demais ambientes, a fragmentação do habitat e o consequente isolamento de suas populações são as maiores ameaças para a espécie, sendo a restauração de conexões entre populações isoladas a principal estratégia de conservação para a onça-pintada (SILVEIRA et al., 2009a; RABINOWITZ; ZELLER, 2010).

O maior felino das Américas possui um corpo robusto, compacto e musculoso, pesa entre 35 e $130 \mathrm{~kg}$, e mede entre 1,7 e 2,4 metros (SEYMOUR, 1989). É considerado oportunista em relação a seus hábitos alimentares, cujas principais presas são animais de médio e grande porte - como queixadas (Tayassu pecari), veados, capivaras (Hydrochoerus hydrochaeris), tamanduásbandeira (Myrmecophaga tridactyla) e antas (Tapirus terrestris) (SEYMOUR, 1989; LOPEZGONZALEZ; MILLER, 2002; SILVEIRA, 2004; AZEVEDO; MURRAY, 2007b; PORFÍRIO, 2009; CAVALCANTI; GESE, 2010). A extensão da área de vida da onça-pintada pode variar de acordo com o hábitat. Áreas de vida de $25 \mathrm{~km}^{2}$ foram estimadas no Pantanal (SCHALLER; CRAWSHAW, 1980) e de $265 \mathrm{~km}^{2}$ no Cerrado (SILVEIRA, 2004), sendo que os machos apresentam áreas de vida maiores que as das fêmeas (CONDE et al., 2010). Ao longo de sua distribuição, a onçapintada ocorre em densidades que variam de aproximadamente 2 a 6,7 indivíduos adultos por $100 \mathrm{~km}^{2}$ (SILVEIRA, 2004; SOISALO; CAVALCANTI, 2006), e utiliza preferencialmente hábitats próximos a cursos d'água com densa cobertura vegetal, podendo também ser encontrada em cerrado aberto e vegetação semiárida na Caatinga (CRAWSHAW; QUIGLEY, 1991; SILVEIRA, 2004; CULLEN; ALGER; RAMBALDI, 2005; ASTETE; SOLLMANN; SILVEIRA, 2008; SILVEIRA et al., 2009b).

As onças-pintadas concentram suas atividades no período crepuscular-noturno, comportamento este que pode variar conforme a região (SEYMOUR, 1989; SILVEIRA, 2004). É um animal de hábito solitário, interagindo com outros indivíduos da espécie apenas no período reprodutivo (SEYMOUR, 1989) - período que se estende por todo o ano, quando as onçaspintadas machos e fêmeas interagem por alguns dias, copulando por várias vezes (EATON, 1978). O tempo de gestação da onça-pintada varia entre 92 e 102 dias, podendo nascer de um a quatro filhotes, sendo comum o nascimento de dois filhotes por ninhada (SEYMOUR, 1989). Os filhotes acompanham a mãe até completarem aproximadamente um ano e meio. A maturidade sexual é atingida pelas fêmeas em 24 meses e, pelos machos, em 36 meses, aproximadamente (SEYMOUR, 1989).

No Brasil, diversos projetos foram ou estão sendo realizados com onças-pintadas na natureza, com o objetivo de estudar a ecologia, a genética, a distribuição e o status de conservação da espécie na Amazônia (MICHALSKI; PERES 2007; RAMALHO; MAGNUSSON, 2008; 
NEGRÕES, 2009), Caatinga (MORATO et al., 2007; SILVEIRA et al., 2009b), Cerrado (SILVEIRA; JÁCOMO, 2002; SILVEIRA, 2004), Mata Atlântica (LEITE et al., 2002; CONFORTI; AZEVEDO 2003; CULLEN; ALGER; RAMBALDI, 2005; PAVIOLO et al., 2008; MAZZOLLI, 2009) e Pantanal (QUIGLEY; CRAWSHAW 1992; SILVEIRA, 2004; AZEVEDO; MURRAY, 2007b; CAVALCANTI; GESE, 2010). Levantamentos epidemiológicos e o estudo do papel das doenças em populações de onçapintada vêm sendo cada vez mais inseridos em projetos de conservação (FURTADO; FILONI, 2008) nos biomas Cerrado, Pantanal, Amazônia e Mata Atlântica (FURTADO et al., 2007; NAVA, 2008; FURTADO et al., 2009; WIDMER, 2009).

O registro de doenças em animais silvestres é documentado desde os séculos passados (AGUIRRE; STARKEY, 1994; DASZAK; CUNNINGHAM; HYATT, 2000). Em 1933, Aldo Leopold já relatava que o papel das doenças na conservação de animais silvestres era subestimado (LEOPOLD, 1933 apud DEEM; KARESH; WEISMAN, 2001, p. 1225). Porém, apenas em 1970-1980, a importância do papel das doenças na conservação das espécies passou a ser reconhecido, aumentando o número de estudos e incorporando abordagens epidemiológicas em projetos de pesquisa (MAY, 1988; SCOTT, 1988; MURRAY et al., 1999; DASZAK; CUNNINGHAM; HYATT, 2000; OSOFSKY; HIRSCH, 2000; DEEM, KARESH; WEISMAN, 2001; LANFRANCHI et al., 2003; GORTAZAR et al., 2007; ACEVEDO-WHITEHOUSE, 2009; MEDINA-VOGEL, 2010). Hoje, é um consenso que as doenças são responsáveis por declínios populacionais significativos em animais silvestres e representam uma ameaça à biodiversidade (MURRAY et al., 1999; DASZAK; CUNNINGHAM; HYATT, 2000; DEEM; KARESH; WEISMAN, 2001; DOBSON; FOUFOPOULOS, 2001; BENGIS; KOCK; FISCHER, 2002; LAFFERTY; GERBER, 2002; LAURENSON et al., 2005; SMITH; SAX; LAFFERTY, 2006; CLEAVELAND et al., 2007; PEDERSEN et al., 2007; SMITH; BEHRENS; SAX, 2009), mesmo que em menor escala do que a fragmentação de hábitats naturais e a caça predatória ( WILCOVE; CHEN, 1998; PURVIS et al., 2000; PEDERSEN et al., 2007). Smith, Sax e Lafferty (2006) atribuiram que $3,7 \%$ das extinções de espécies foram causadas direta ou indiretamente por doenças infecciosas.

Embora ainda seja desconhecido o impacto dos patógenos na dinâmica populacional de carnívoros silvestres (MURRAY et al., 1999), estima-se que o impacto de infecções e doença na população tende a crescer nos próximos 50-100 anos (SCOTT, 1988). Antigamente, as doenças 
infecciosas eram vistas como uma forma de seleção natural nas populações silvestres (MAY, 1988; AGUIRRE; STARKEY, 1994; DEEM; KARESH; WEISMAN, 2001). Porém, sabe-se que fatores antrópicos influenciam na ocorrência ou emergência de doenças, como a fragmentação e conversão de hábitats naturais, o aumento da ocupação humana no entorno de áreas naturais e, o consequente aumento do contato entre animais domésticos e silvestres ( MURRAY et al., 1999; DASZAK, CUNNINGHAM; HYATT, 2000; DASZAK; CUNNINGHAM; HYATT, 2001; DEEM; KARESH; WEISMAN, 2001; BENGIS; KOCK; FISCHER, 2002; LAFFERTY; GERBER, 2002; LANFRANCHI et al., 2003; AGUIRRE, 2009; SMITH; BEHRENS; SAX, 2009; WOODFORD, 2009; MEDINA-VOGEL, 2010). O isolamento genético de populações é outro fator importante, causado pela fragmentação de habitats, que resulta na perda da variabilidade genética das espécies, aumentando a suscetibilidade dos indivíduos e exposição a agentes infecciosos (LYLES; DOBSON, 1993; WOODROFFE, 1999; DEEM; KARESH; WEISMAN, 2001; ALTIZER; HARVELL; FRIEDLE, 2003; MCCALLUM et al., 2009). Assim, a transmissão de patógenos pode ocorrer em ambas as direções: de domésticos para silvestres, ou de silvestres para domésticos (CLEAVEAND, LAURENSON; TAYLOR, 2001; BENGIS; KOCK; FISCHER, 2002; LANFRANCHI et al., 2003).

Basicamente, existem três categorias de doenças que ocorrem em animais silvestres: a) doenças endêmicas, que normalmente ocorrem em determinadas áreas geográficas e hospedeiros; b) doenças exóticas, que foram introduzidos em determinada região e c) doenças emergentes, que foram recentemente detectadas, estão aumentando sua incidência ou, atravessaram as barreiras entre as espécies (BENGIS; KOCK; FISCHER, 2002). Ao ocorrer uma nova interação entre espécie e patógeno, o novo hospedeiro pode agir de diferentes maneiras: se tornar um hospedeiro final para a doença e não ser capaz de mantê-la no ambiente; agir como um hospedeiro "spill-over", capaz de manter a infecção com a ajuda de outras fontes externas; ou agir como um hospedeiro de manutenção, capaz de manter, sozinho, a infecção, sem a interferência de outras espécies (RHYAN; SPRAKER, 2010).

Dentro desse contexto, é de extrema importância integrar a medicina da conservação em programas de monitoramento de animais silvestres e capacitar profissionais para esse trabalho (DEEM; KARESH; WEISMAN, 2001; AGUIRRE, 2009). A medicina da conservação é uma ciência interdisciplinar que busca promover a saúde ecológica na sociedade e na natureza através da interação entre as saúdes humana, animal e ambiental (TABOR, 2002; AGUIRRE, 2009). É necessário conduzir estudos epidemiológicos efetivos, realizando levantamentos para adquirir informações basais da ocorrência dos patógenos nas populações silvestres, domésticas e no ambiente, e realizar posterior monitoramento em longo prazo dessas populações (SCOTT, 1988; 
MURRAY et al., 1999; DOBSON; FOUFOPOULOS, 2001; CLEAVELAND et al., 2007; FURTADO; FILONI, 2008; SMITH; BEHRENS; SAX., 2009; WOODFORD, 2009).

\subsection{PATÓGENOS SELECIONADOS}

Os patógenos selecionados neste estudo estão descritos a seguir, contemplando a etiologia, epidemiologia, cadeia de transmissão, sinais clínicos, tratamento e controle de cada um, assim como as espécies silvestres que podem acometer.

\subsubsection{Brucella abortus}

A Brucella abortus é uma bactéria intracelular facultativa, responsável por uma das principais zoonoses de distribuição mundial, a brucelose (CUTLER; WHATMORE; COMMANDER, 2005; PAPPAS et al., 2006). É uma das nove espécies do gênero Brucella spp. (FOSTER et al., 2007; SCHOLZ et al., 2008). Altamente patogênica, acomete principalmente os bovinos, podendo infectar também suínos, cães, búfalos e outros animais domésticos e silvestres, ou mesmo o homem (PAULIN; FERREIRA NETO, 2003).

A brucelose é uma doença infectocontagiosa de evolução geralmente crônica, associada a grandes prejuízos em rebanhos bovinos e consequente queda na produção de carne e leite (ACHA; SZYFRES, 2001; PAULIN; FERREIRA NETO, 2003). Devido a sua importância econômica e na saúde pública, é uma doença de notificação obrigatória (OIE, 2008). Medidas sanitárias foram adotadas pela maioria dos países desenvolvidos para a erradicação da doença (GODFROID; KÄSBOHERER, 2002). No Brasil, é considerada endêmica em todo território nacional e, em 2001, com o objetivo de diminuir a prevalência e a incidência dessa enfermidade, o Ministério da Agricultura, Pecuária e Abastecimento (MAPA) lançou o Programa Nacional de Controle e Erradicação da Brucelose e Tuberculose (PNCEBT), que vem sendo implementado desde então (POESTER; GONÇALVEZ; LAGE, 2002; PAULIN; FERREIRA NETO, 2003; BRASIL, 2006).

A principal fonte de infecção é a vaca prenhe, que elimina grandes quantidades do agente durante o aborto ou parto (e durante um período de 30 dias após o parto), 
contaminando, assim, água, alimentos, pastagens e fômites. O leite, sêmen e urina também podem servir como vias de eliminação. As bactérias podem permanecer viáveis no meio ambiente por longos períodos (dias a meses), sobrevivendo principalmente em alta umidade e baixa temperatura. A principal porta de entrada é o trato digestivo - pela ingestão de água e alimentos contaminados ou hábito de lamber crias recém-nascidas. $O$ animal pode também se infectar pelo hábito de cheirar fetos abortados, permitindo a penetração da bactéria pelas mucosas do nariz e olhos (ACHA; SZYFRES, 2001; PAULIN; FERREIRA NETO, 2003; BRASIL, 2006).

Os sinais clínicos da brucelose podem surgir em poucas semanas, meses ou anos e variam conforme o hospedeiro. As principais manifestações clínicas são o aborto e nascimentos de bezerros enfraquecidos ou natimortos. Em machos, podem aparecer inflamações na vesícula seminal, testículos e epidídimos, causando infertilidade ou esterilidade (ACHA; SZYFRES, 2001). Não há tratamento eficaz para bovinos com brucelose, e o controle é feito através da vacinação de fêmeas de 3 a 8 meses, e diagnóstico e sacrifício de animais positivos (BRASIL, 2006).

Relatos de brucelose em populações de animais silvestres existem desde o início do século 20 (DAVIS; ELZER, 2002; KILPATRICK; GILLIN; DASZAK, 2009). Ungulados silvestres são suscetíveis à infecção e doença, e podem transmitir o agente tanto para outros animais silvestres como para o gado (WILLIAMS et al., 1993; CROSS et al., 2010). Após décadas de programas de controle e erradicação, os Estados Unidos foram declarados como livre de brucelose em 2008; porém, no mesmo ano, novas infecções no gado foram encontradas. As populações de bisão (Bison bison) e cervos (Cervus elaphus canadensis) de vida livre foram identificadas como as principais fontes de transmissão da doença para humanos, configurando potencial risco de reintrodução da brucelose para o gado (DAVIS; ELZER, 2002; CROSS et al., 2010; PROFFITT; WHITE; GARROTT, 2010). Estudos mostram que a soropositividade para brucelose nessas populações em Yellowstone chega a 50\% (MEYER; MEAGHER, 1995). Como medida de controle, a vacinação desses animais vem sendo realizada. No entanto, as vacinas usualmente utilizadas em domésticos (S19 e RB51) não se mostraram eficazes para bisões ou cervos e novas vacinas deverão ser desenvolvidas (DAVIS; ELZER, 2002; PLUMB et al., 2007; KILPATRICK; GILLIN; DASZAK, 2009). Acredita-se que dificilmente seja possível a erradicação da brucelose bovina nos Estados Unidos, sem que antes a doença seja erradicada nas populações silvestres (DAVIS; ELZER, 2002; BIENEN; TABOR, 2006; KILPATRICK; GILLIN; DASZAK, 2009). A Europa, por sua vez, apresenta um cenário diferente: estudos mostram que os animais silvestres ao invés de agirem como reservatórios, são, na verdade, vítimas ocasionais da brucelose 
transmitida pelo gado, não possuindo um papel importante na manutenção da doença (GORTAZAR et al., 2007; MUÑOZ et al., 2010).

Entre os carnívoros, os relatos ocorrem em menor quantidade, e a infecção ocorre por meio da ingestão de fetos abortados de animais contaminados (ACHA; SZYFRES, 2001). Embora exista um relato da transmissão de B. abortus de cão infectado para o gado em condições experimentais e indícios de que essa transmissão possa também ocorrer em campo (KIOK et al., 1978; GARIN-BASTUJI et al., 1988 apud FORBES, 1990, p. 911), os carnívoros não são considerados potenciais fontes de infeç̧ão (ACHA; SZYFRES, 2001). Relatos de isolamento de $B$. abortus e/ou exposição ao patógeno foram descritas para canídeos e ursídeos nos Estados Unidos, mustelídeos na Argentina (DAVIS, 1990; ACHA; SZYFRES, 2001), e grandes felinos mantidos em cativeiro, como leões, nos Estados Unidos (DAVIS, 1990) e onça-pintada, no Chile (OLIVARES; RIVEROS; PINOCHET, 1993).

No Brasil, exposição à $B$. abortus foi descrita em queixadas do Pantanal sul matogrossense (ITO et al., 1998) e do Cerrado (KASHIVAKURA et al., 2004), catetos (Tayassu tajacu) mantidos em cativeiro no leste da Amazônia (MAYOR et al., 2006), lobos-guará (Chrysocyon brachyurus) provenientes da natureza e cativeiro (MAIA et al., 2000), e em uma onça-pintada de vida livre da Mata Atlântica (NAVA, 2008).

\subsubsection{Leptospira spp.}

As bactérias helicoidais do gênero Leptospira são causadoras da leptospirose, uma zoonose identificada como um problema de saúde pública mundial, que afeta animais domésticos, silvestres e humanos (ACHA; SZYFRES, 1986; LANGONI, 1999; LEVETT, 2001; VIJAYACHARI; SUGUNAN; SHRIRAM, 2008). Baseado em suas características fenotípicas, existem duas espécies de Leptospira: a L. interrogans, que é patogênica, e a L. biflexa, não patogênica. A L. interrogans possui mais de 200 variantes sorológicas, denominadas sorovares, que são definidas com base em características antigênicas. Cada sorovar está associado a uma espécie hospedeira em particular (ACHA; SZYFRES, 1986; LEVETT, 2001; O'KEEFE, 2002; VIJAYACHARI; SUGUNAN; SHRIRAM, 2008).

A leptospirose já foi diagnosticada em todos os continentes, apresentando maior ocorrência em países de clima tropical e subtropical, principalmente em estações de altos níveis 
pluviométricos (ACHA; SZYFRES, 1986; VIJAYACHARI; SUGUNAN; SHRIRAM, 2008). É uma enfermidade relacionada às características sócioeconômicas, enchentes, e aspectos ocupacionais dos indivíduos (LANGONI, 1999; ARDUINO et al., 2009). No Brasil, a leptospirose é endêmica e está presente no rebanho bovino, em porcentagens que variam de $25,2 \%$ a $62,5 \%$ (FAVERO et al., 2001; MINEIRO et al., 2007), em porcos domésticos, com porcentagens de 47,1\% (OSAVA et al., 2010), em cães, com porcentagens de 2,66\% a 28,85\% (FURTADO et al., 1997; JOUGLARD; BROD, 2000), e raramente ocorre em gatos (ACHA; SZYFRES, 1986).

Pequenos mamíferos silvestres são os principais reservatórios da leptospirose na natureza (LANGONI, 1999; LEVETT, 2001). O gado, o porco e o cão são também considerados reservatórios da leptospirose (ACHA; SZYFRES, 1986; VIJAYACHARI; SUGUNAN; SHRIRAM, 2008). A transmissão direta ocorre principalmente pela excreção da bactéria na urina dos reservatórios, podendo ocorrer também através de tecidos e fluídos de animais infectados, na forma transplacentária ou pelo leite materno (ACHA; SZYFRES, 1986; LEVETT, 2001; VIJAYACHARI; SUGUNAN; SHRIRAM, 2008). A transmissão indireta é considerada a mais comum e ocorre através da água, solos ou alimentos contaminados pela urina do animal excretor (ACHA; SZYFRES, 1986). As bactérias sobrevivem por longos períodos em ambientes úmidos (ACHA; SZYFRES, 1986; VIJAYACHARI; SUGUNAN; SHRIRAM, 2008), e a porta de entrada no hospedeiro pode ser a pele intacta ou lesionada e mucosas oral, nasal ou conjuntiva (ACHA; SZYFRES, 1986).

Os animais podem ser divididos em hospedeiros de manutenção ou hospedeiros acidentais (LEVETT, 2001). Hospedeiros de manutenção apresentam uma infecção crônica nos túbulos renais, mantendo a excreção do agente por um longo período e, embora possam desenvolver a doença, normalmente são cometidos por infecções subclínicas (LEVETT, 2001). Os hospedeiros acidentais, que incluem os humanos, podem ser assintomáticos ou apresentarem sinais clínicos severos (RICHARDSON; GAUTHIER, 2003), sendo capazes de excretar a leptospira por curto período de tempo (ACHA; SZYFRES, 1986). Em bovinos a forma crônica da doença está relacionada com perdas econômicas devido a problemas reprodutivos como infertilidade, aborto, nascimento de bezerros fracos e diminuição da produção leiteira (ACHA; SZYFRES, 1986). Em cães, a infecção pode variar de uma forma assintomática a quadros clínicos graves com icterícia e insuficiência renal. Os gatos raramente apresentam a enfermidade (ACHA; SZYFRES, 1986; ANDRÉ-FONTAINE, 2006). O controle da leptospirose é feito através da vacinação dos suscetíveis, do tratamento dos animais doentes com antibioticoterapia, do controle dos reservatórios selvagens e da eliminação de excesso de água no ambiente (GUIMARÃES et al., 1982/83; ACHA; SZYFRES, 1986; ARDUINO et al., 2009). 
Evidências de exposição à Leptospira sp. foram descritas em diversas espécies de carnívoros silvestres de vida livre como o guaxinim (Procyon lotor), camgambá (Mephitis mephitis) (RICHARDSON; GAUTHIER, 2003), lobos-cinzentos (Canis lupus) (KHAN et al., 1991) e raposas-da-ilha (Urocyon littoralis) (CLIFFORD et al., 2006) nos Estados Unidos; e linces-ibéricos na Espanha (MILLÁN et al., 2009). O isolamento do agente foi relatado por Kingscote (1986) em raposas-vermelhas (Vulpes vulpes) de vida livre no Canadá. Alguns felinos do gênero Panthera, como o leão, o leopardo (Panthera pardus) e o tigre (Panthera tigris) mantidos em cativeiro em zoológico do México apresentaram sorologia positiva para a Leptospira sorovar Hebdomadis, Grippothyphosa e Pyrogenes, respectivamente - a única onça-pintada amostrada neste estudo não foi reagente (LUNA-ALVAREZ et al., 1996). Um leão mantido em cativeiro na Índia apresentou quadro clínico da leptospirose com hematúria e anorexia, e teve a leptospira isolada da urina (VIJAYARANI et al., 2009).

No Brasil, há relatos de exposição à Leptospira spp. em animais de vida livre como veados-campeiros (Ozotoceros bezoarticus) (MATHIAS; GIRIO; DUARTE, 1999), cachorros-domato (Cerdocyon thous), lobos-guará, cachorros-vinagres (Speothos venaticus), jaguatiricas (Leopardus pardalis), mão-pelada (Procyon cancrivorus) e onças-pardas (Puma concolor) (JORGE, 2008), no Pantanal mato-grossense; e em queixadas, catetos e capivaras (ITO et al., 1998), porcos-monteiros (Sus scrofa), veado-campeiro e veado-mateiro (Mazama americana) (GIRIO et al., 2004), no Pantanal sul mato-grossense. Em animais mantidos em cativeiro no Sul, Guerra Neto et al. (2004) relataram a exposição à Leptospira spp. de onças-pardas, jaguatiricas, gatosmaracajá (Leopardus wiedii), gatos-do-mato-pequeno (Leopardus tigrinus) e 2 das 4 onçaspintadas amostradas (sorovares Castellonis e Hardjo). Anticorpos contra Leptospira spp. também foram encontrados em onças-pintadas mantidas em cativeiro no zoológico de São Paulo (CORRÊA, 2000) e no Zoológico do Rio de Janeiro (sorovar Copenhageni) (LILENBAUM et al., 2004). Em 11 onças-pintadas mantidas em cativeiro no Norte do Brasil nenhum animal foi positivo (ALMEIDA et al., 2009), e uma de oito onças-pintadas de vida livre amostradas na Mata Atlântica foi soropositiva para o sorovar Pomona (NAVA, 2008). 


\subsubsection{Toxoplasma gondii}

O Toxoplasma gondii é um protozoário, coccídeo intracelular obrigatório, pertencente à Família Sarcocystidae. É o parasita de maior sucesso no mundo, com capacidade de infectar, virtualmente, todas espécies homeotérmicas, incluindo os humanos (DUBEY; BEATIE, 1988; DUBEY, 2008; INNES, 2010). Os membros da Família Felidae, tanto domésticos quanto silvestres, são essenciais para o ciclo evolutivo do $T$. gondii, sendo os únicos hospedeiros definitivos do parasita (FRENKEL; DUBEY; MILLER, 1970; DUBEY; BEATIE, 1988).

A toxoplasmose é uma infecção de ampla distribuição geográfica, sendo que aproximadamente um terço da população humana possui anticorpos para T. gondii (MONTOYA; LIESENFELD, 2004). É uma enfermidade de grande importância na Saúde Pública, acometendo principalmente mulheres grávidas e pacientes imunossuprimidos (URQUHART et al., 1998), responsável por grande impacto econômico, devido a problemas reprodutivos causados em animais de produção (MILLAR et al., 2008). No Brasil, estima-se que a prevalência de anticorpos para T. gondii em gatos varie de 10,2\% (BRACCINI et al., 1992) a 87,3 \% (CAVALCANTE et al., 2006); em cães, de 3,1\% (CHAPLIN et al., 1984) a 91 \% (GERMANO; ERBOLATO; ISHIZUKA, 1985); e em bovinos de 3,4\% (SILVA et al., 1982/83) a 71\% (SANTOS et al., 2009b).

O ciclo de vida do $T$. gondii possui três estágios de infecção: o taquizoíto e o bradizoíto (contido em cistos), que são formas assexuais e estão presentes em tecidos dos hospedeiros intermediários ou definitivos; e o esporozoíto (contido em oocistos), forma sexual, presente no trato gastrointestinal do hospedeiro definitivo. Os felinos se infectam principalmente através da ingestão de taquizoítos ou bradizoítos presentes em tecidos de roedores ou outros animais infectados (DUBBEY; BEATTIE, 1988; DUBEY, 1998; URQUHART et al., 1998; INNES, 2010). Podem também se infectar pela ingestão de oocistos esporulados ou pela transmissão transplacentária ou transmamária (URQUHART et al., 1998; revisado por FIALHO; TEIXEIRA; ARAÚJO, 2009). Uma vez infectado, os felinos liberam os oocistos em suas fezes. No ambiente, os oocistos esporulam e se tornam infectantes (LINDSAY; BLAGBURN; DUBEY, 1997). O oocisto esporulado pode sobreviver em solos ou areias úmidas por até 18 meses (FRENKEL; DUBEY; MILLER, 1970; DUBEY; BEATIE, 1988). Gatos infectados com um ou mais bradizoítos podem excretar milhões de oocistos de T. gondii por um período de 1 a 2 semanas (DUBEY, 2001; DUBEY; SU, 2009). Os hospedeiros intermediários, por sua vez, se infectam através da ingestão do oocisto esporulado presente no ambiente (alimento ou água contaminada) ou pela ingestão de bradizoítos e 
taquizoítos na carne de outro hospedeiro intermediário (URQUHART et al., 1998; DUBEY et al., 2005).

Na maioria das vezes, a infecção dos animais e humanos é assintomática. Porém, em quadros severos, a toxoplasmose pode comprometer o sistema nervoso central, causar alterações oculares ou aborto (URQUHART et al., 1998; MCALLISTER, 2005). Os hospedeiros definitivos, embora apresentem uma elevada soroprevalência de $T$. gondii, raramente manifestam a doença clínica (URQUHART et al., 1998; FIALHO; TEIXEIRA; ARAÚJO, 2009). Não há um tratamento completamente satisfatório, e uma associação de pirimetamina com sulfadiazina é utilizada com sucesso (URQUHART et al., 1998). Para controle da infecção, em animais de produção, recomenda-se diminuir o número de gatos e ratos presentes nas criações (VIDOTTO et al., 1990; MILLAR et al., 2008) e incinerar restos fetais, com o objetivo de prevenir a infecção de gatos e outros animais (DUBEY, 1994). Para diminuir a infecção em cães, gatos ou animais silvestres mantidos em cativeiro recomenda-se não fornecer carnes cruas ou mal passadas, e evitar contato dos animais com solo ou areia contaminados (GREENE, 1990; SILVA et al., 2001a; BRESCIANI et al., 2008). Atualmente, existe apenas uma vacina comercial para ovinos, com o objetivo de reduzir abortos e a mortalidade neonatal (INNES, 2010).

Algumas espécies de animais silvestres, como macacos do novo mundo (EPIPHANIO et al., 2000), marsupiais australianos (DUBEY; BEATTIE, 1988; HARTLEY; DUBEY; SPIELMAN, 1990), mamíferos marinhos (MILLER et al., 2004) e o gato-de-pallas (Otocolobus manul) (BROWN et al., 2005) são extremamente sensíveis ao Toxoplasma gondii. Diversos canídeos e felinos mantidos em cativeiro ou em vida livre nas Américas do Norte, Central e Sul já foram descritos como soropositivos para o parasita (ZARNKE et al., 2000; ZARNKE et al., 2001; KIKUCHI et al., 2004; RILEY; FOLEY; CHOMEL, 2004; DEEM; EMMONS, 2005; FIORELLO et al., 2006). Felinos do gênero Panthera mantidos em cativeiro apresentam alta frequência de exposição ao agente, como descrito em leões, tigres, leopardos e onça-pintada nos Estados Unidos (SPENCER; HIGGINBOTHAM; BLAGBURN, 2003; DE CAMPS; DUBEY; SAVILLE, 2008) e na Austrália (HILL et al., 2008); e leões no Senegal (KAMGA-WALADJO et al., 2009). Há também relatos da presença de sinais clínicos da toxoplasmose em um tigre (DORNY; FRANSEN, 1989) e dois leões (OCHOLI; KALEJAIYE; OKEWOLE, 1989) mantidos em zoológicos da Bélgica e Nigéria, respectivamente. Em animais de vida livre, leopardos e leões na África (SPENCER; MORKEL, 1993; PENZHORN et al., 2002) foram expostos ao agente, e oocistos similares ao de $T$. gondii foram identificados nas fezes de onça-pintada em Belize (PATTON et al., 1986), e de leopardo na Tailândia (PATTON; RABINOWITZ, 1994). Recentemente, Demar et al. (2008) isolaram e fizeram a caracterização 
molecular do T.gondii presente em uma onça-pintada de vida livre na Guiana Francesa, descrevendo uma variação genotípica atípica do parasita.

No Brasil, existem relatos de lobos-guará (VITALIANO et al., 2004), quatis (Nasua nasua), mãos-peladas, gatos-do-mato-pequeno e jaguatiricas (SOGORB; JAMRA; GUIMARÃES, 1977) mantidos em cativeiro e jaguatiricas de vida livre (WHITEMAN, 2007) soropositivos para $T$. gondii. Em felinos do gênero Panthera mantidos em zoológicos brasileiros, Silva et al. (2001b) e Rivetti Júnior et al. (2008) relataram a soropositividade para o agente em leões, tigres e leopardos. E, em amostragem com 865 felinos neotropicais mantidos em cativeiro, Silva et al. (2001a) relataram 54,6\% dos animais, incluindo todas espécies de felinos neotropicais brasileiros, soropositivas ao agente, sendo que 63,2\% (134/212) das onças-pintadas foram soropositivas. Pimentel et al. (2009) também relataram a soropositividade de uma onça-pintada mantida em cativeiro no Nordeste do Brasil.

\subsubsection{Vírus da raiva}

O vírus da raiva, Família Rhabdoviridae, gênero Lyssavirus, é o agente etiológico da raiva, uma das zoonoses mais temidas e fatais do mundo (RODRIGUEZ et al., 2007; HAMPSON et al., 2009). Responsável por sérios problemas veterinários e na saúde pública, a raiva atinge todos os mamíferos, sendo endêmica em cães ou animais silvestres, e tendo o homem como um hospedeiro acidental (FU, 1997; CORRÊA; PASSOS, 2001; BELOTTO et al., 2005).

Com exceção da Austrália e Antártica, a raiva está presente em todos os continentes, e é responsável por aproximadamente 55.000 casos fatais em humanos por ano (OMS, 2010a). Através da vacinação massiva de cães domésticos, alguns países - como a Inglaterra, Irlanda e Japão - obtiveram sucesso na erradicação da doença (FU, 1997; RODRIGUEZ et al., 2007). Em países da Europa e América do Norte, embora erradicada em cães, a doença foi mantida na população de animais silvestres, como raposas, cangambás, coiotes e guaxinins (RUPPRECHT, 1999; LACKAY; KUANG; FU, 2008; BLANTON et al., 2009). Em países da Ásia, África e América Latina, os cães continuam sendo os principais reservatórios, mantendo a alta incidência da raiva (BELOTTO et al., 2005). No Brasil, o Programa Nacional de Controle da Raiva foi implementado em 1974 pelo Ministério da Saúde, e consiste na vacinação dos cães, tratamento de pessoas mordidas por cães e realização de levantamentos epidemiológicos da doença (BELOTTO, 1988; 
BELLOTO et al., 2005). Controlada na região Sul, a raiva encontra-se em declínio nas demais regiões do país, onde casos de raiva entre cães e gatos diminuíram, e os registros da doença em morcegos e animais silvestres terrestres aumentaram nos últimos anos (1997-2006) (BELOTTO et al., 2005; RODRIGUEZ et al., 2007; TEIXEIRA et al., 2008).

A principal forma de transmissão do vírus é através da mordedura de animais infectados (ACHA; SZYFRES, 1986; RODRIGUEZ et al., 2007). Embora raras, podem também ocorrer transmissões por via aérea, contato com ferimentos ou membranas mucosas (RODRIGUEZ et al., 2007). Fora do hospedeiro a resistência do vírus é baixa, sendo rapidamente inativado (RUPPRECHT, 1999; RODRIGUEZ et al., 2007). O vírus da raiva possui um ciclo urbano e um ciclo silvestre, e tende a se adaptar a um hospedeiro, que mantém o vírus no ecossistema, e ocasionalmente infecta outras espécies (ACHA; SZYFRES, 1986; RUPPRECHT, 1999). Os felinos, por exemplo, apesar de serem transmissores efetivos da doença, não são considerados como reservatórios (ACHA; SZYFRES, 1986; RUPPRECHT, 1999).

A raiva é uma doença grave, caracterizada por hipersalivação, agressividade, incoordenação motora, alteração no comportamento e morte inevitável (ACHA; SZYFRES, 1986; RUPPRECHT, 1999; RODRIGUEZ et al., 2007). Embora ainda não esclarecido, sabe-se que alguns hospedeiros expostos ao vírus adquirem imunidade natural, e não desenvolvem infecções letais - é o caso das raposas-vermelhas, cangambás e guaxinins (ACHA; SZYFRES, 1986; RODRIGUEZ et al., 2007; BOLZONI et al., 2008). Não há terapia efetiva para raiva. Os animais domésticos não vacinados e expostos ao vírus devem ser eutanasiados imediatamente. Animais saudáveis, quando mordem pessoas devem ser isolados e observados por 10 dias (NASPHV, 2001). Para animais silvestres ameaçados de extinção, a eutanásia não é uma pratica adotada, principalmente se não existirem precedentes, se o animal estiver em bom estado de saúde e se a mordida tiver sido provocada (RUPPRECHT, 1999). Dessa forma, o animal deve ser mantido em quarentena (RUPPRECHT, 1999). A prevenção da raiva baseia-se na vacinação de hospedeiros e controle de reservatórios (BELOTTO et al., 2005; RODRIGUEZ et al., 2007; JACKSON, 2008). O ciclo urbano vem sendo controlado pela vacinação de animais domésticos; os ciclos silvestres, porém, são de difícil controle (RODRIGUEZ et al., 2007). Em países da Europa e América do Norte, apesar da complexidade, a vacinação, através de vacinas recombinantes ou atenuadas, de raposas, guaxinins e coiotes é um sucesso (RUPPRECHT, 1999; CROSS; BUDDLE; ALDWELL, 2007;BLANTON et al., 2009; revisado por SLATE et al., 2009). Porém, nem todas as vacinas orais são eficazes para todas as espécies de reservatórios terrestres (HENDERSON et al., 2009). 
A raiva foi responsável por declínios populacionais em espécies ameaçadas como os cachorros-selvagens-africanos no Quênia (KAT et al., 1995) e no Serengeti (GASCOYNE et al., 1993) e os lobos-da-etiópia (SILLERO-ZUBIRI; KING; MACDONALD, 1996). Em Zimbabwe, um estudo retrospectivo do vírus em 2.107 amostras de animais silvestres diagnosticou casos de raiva em $73,1 \%$ das amostras, evidenciando que, na região, o ciclo silvestre da doença é mantido principalmente por chacais (Canis mesomelas e C. adustus) (79,8\% dos positivos; PFUKENYI et al., 2009). Este mesmo estudo apresentou espécies de felinos como serval (Felis serval), gatoselvagem (Felis lybica), guepardo (Actinonyx jubatus), leopardo e leão positivos para a raiva (PFUKENYI et al., 2009). Casos de raiva em felinos silvestres foram registrados em leões, tigres, leopardos, guepardos, onças-pardas, lince-pardo (Lynx rufus) e jaguatiricas (JAYAKUMAR et al., 1989; revisado por RUPPRECHT, 1999). Nos Estados Unidos, linces-pardos e onças-pardas foram positivas para o vírus (BLANTON et al., 2009); e no Quênia, um leão diagnosticado com raiva veio a óbito (BWANGAMOI; ROTTCHER; WEKESA, 1990). Na Namíbia, Thalwitzer et al. (2010) descreveram guepardos de vida livre e cativeiro soropositivos para o vírus e, no Peru, uma jaguatirica criada como animal de estimação apresentou sinais clínicos e desfecho fatal da doença (FRYE; CUCUEL, 1968). Onças-pintadas também foram diagnosticadas com raiva por Santos e Tokarnia (1969 apud JAYAKUMAR et al., 1989, p. 1076).

No Nordeste do Brasil, o crescente caso de raiva em cachorros-do-mato chamou a atenção para a existência de um ciclo silvestre da doença na região, onde o canídeo silvestre é o principal reservatório, evidenciando também a necessidade de medidas de controle da raiva específicas para a espécie (CARNIELI JÚNIOR et al., 2006; CARNIELI JÚNIOR et al., 2008; CARNIELI JÚNIOR et al., 2009). Casos de raiva já foram diagnosticados também em uma onça-pintada (PICCININI; FREITAS, 1985), uma jaguatirica e um gato-do-mato-pequeno (GAMBETA et al., 1979 apud CORRÊA; PASSOS, 2001, p. 494), além do diagnóstico da raiva em primatas, mãos-peladas, quatis (FAVORETTO et al., 2006; CARNIELI JÚNIOR et al., 2009), capivara e lontra (Lutra longicaudis) (PICCININI; FREITAS, 1985). Exposição ao vírus foi relatada por Jorge (2008) em cachorro-do-mato, cachorro-vinagre, mão-pelada e onça-parda de vida livre no Pantanal matogrossense e em onça-pintada por Widmer (2009) no Pantanal sul mato-grossense. 


\subsubsection{Vírus da cinomose}

O vírus da cinomose, pertencente ao gênero Morbillivirus, Família Paramixoviridae, é o agente etiológico da doença infecciosa mais importante de cães domésticos em todo o mundo (DEEM et al., 2000). Diferentes famílias da Ordem Carnivora são suscetíveis ao vírus - Canidae, Felidae, Hyaenidae, Mustelidae, Procyonidae, Ursidae e Viverridae (ANDERSON, 1995; APPEL; SUMMERS, 1995; revisado por DEEM et al., 2000; ARNS; SPILKI; ALMEIDA, 2007) -, sendo responsável por causar significativos declínios populacionais em animais silvestres de vida livre como os furões-de-pata-negra, nos Estados Unidos (WILLIAMS et al., 1988), cachorros-selvagensafricanos, no Quênia (ALEXANDER; APPEL, 1994), e leões, no Serengeti (ROELKE-PARKER et al., 1996).

A cinomose tem ocorrência mundial. Mesmo países desenvolvidos que reduziram a incidência da doença através da vacinação regular da população canina ainda apresentam surtos esporádicos (ARNS; SPILKI; ALMEIDA, 2007). No Brasil, a enfermidade é endêmica, podendo representar até $6 \%$ de todas as ocorrências clínicas e $11 \%$ dos óbitos em cães (HEADLEY; GRAÇA, 2000).

Os cães domésticos são os principais reservatórios (ALEXANDER et al., 1995; ROELKEPARCKER et al., 1996). Porém, carnívoros silvestres, como os mustelídeos e procionídeos, também podem ser reservatórios da infecção (VAN MOLL et al., 1995; KAPIL et al., 2008). O vírus é transmitido por contato direto com as secreções nasais e orais e urina dos animais infectados, aerossóis ou fômites (APPEL; SUMMERS, 1995; KENNEDY-STOSKOPF, 1999; DEEM et al., 2000; ARNS; SPILKI; ALMEIDA, 2007) e, embora excretado por períodos prolongados, é rapidamente inativado fora do hospedeiro (KENNEDY-STOSKOPF, 1999; ARNS; SPILKI; ALMEIDA, 2007).

A patogenicidade do vírus varia de acordo com a espécie acometida, podendo resultar em uma infecção inaparente ou causar alta taxa de mortalidade (KENNEDY-STOSKOPF, 1999; ARNS; SPILKI; ALMEIDA, 2007). A maioria dos cães domésticos infectados desenvolve uma resposta imune celular e humoral eficaz e não manifesta sinais clínicos (DEEM et al., 2000; ARNS; SPILKI; ALMEIDA, 2007). Os gatos domésticos são assintomáticos, apresentando uma infecção não patogênica, e não eliminam o vírus (APPEL et al., 1974; HARDER et al., 1996; ARNS; SPILKI; ALMEIDA, 2007). Quando ocorrem, os sinais clínicos, nos cães, incluem o sistema respiratório e gastrointestinal, apresentando secreções nasais e oculares e diarreia; na forma grave, o vírus atinge o sistema nervoso central, causando alterações como encefalite e desmielinização 
(APPEL; SUMMERS, 1995; DEEM et al., 2000; ARNS; SPILKI; ALMEIDA, 2007). Não há terapia específica e nenhum protocolo existente possui eficiência comprovada, sendo uma doença de prognóstico desfavorável (DEEM et al., 2000; ARNS; SPILKI; ALMEIDA, 2007). A vacina com vírus atenuado, disponível no mercado, embora segura e eficiente para cães domésticos, pode ser perigosa para diversos carnívoros silvestres (MONTALI et al., 1994; APPEL; SUMMERS, 1995; KENNEDY-STOSKPOF, 1999). A vacina inativada, que seria eficaz e segura para felinos silvestres, não está disponível comercialmente (APPEL; SUMMERS, 1995).

A cinomose foi responsável por dois importantes surtos em grandes felinos: em 1992, nos Estados Unidos, quando uma epidemia acometeu leões, leopardos, tigres e uma onçapintada mantidos em cativeiro (APPEL et al., 1994); e em 1994, no Serengeti, quando dizimou $30 \%$ da população de leões de vida livre daquela região (ROELKE-PARKER et al., 1996). Na epidemia dos Estados Unidos, 35 dos 74 animais infectados apresentaram sinais clínicos da doença, e 17 vieram a óbito (APPEL et al., 1994). Este surto infectou também onças-pardas, linces-pardos, serval e gato-maracajá, mas apenas os membros do gênero Panthera vieram a óbito (APPEL et al., 1994). Acredita-se que os guaxinins, residentes nas áreas do entorno, foram os responsáveis pela transmissão do vírus (APPEL et al., 1994). No Serengeti, o vírus provavelmente se originou dos cães domésticos que moram no entorno do parque, que infectaram os canídeos silvestres (hienas - Crocuta crocuta, cachorro-selvagem-africano, raposas-de-orelha-de-morcego - Otocyon megalotis), e esses agiram como hospedeiros transitórios entre os cães domésticos e os leões (ROELKE-PARKER et al., 1996; CLEAVELAND et al., 2000; CLEAVELAND et al., 2007). Os testes moleculares posteriormente realizados comprovaram a similaridade genética dos vírus isolados nas epidemias com o vírus dos cães domésticos (ROELKE-PARKER et al., 1996; CARPENTER et al., 1998).

O exemplar monitoramento da população de leões no Serengeti, que permitiu a coleta sistemática de amostras biológicas da população ao longo dos anos, demonstrou que exposições ao vírus da cinomose também ocorreram em anos anteriores (ROELKE-PARKER et al., 1996; PACKER et al., 1999) e posteriores ao surto relatado, porém, em ambos os casos, sem estar associado à morbidade ou mortalidade de animais (CLEAVELAND et al., 2007; MUNSON et al., 2008). Em recente estudo, Munson et al. (2008) relataram que o alto nível de hemoparasitas, Babesia spp., encontrado nos animais infectados por cinomose pode ter contribuído para a epidemia fatal da doença no surto de 1994.

A exposição ao vírus com sinais clínicos da doença e óbito foram também relatados em um tigre (BLYTHE et al., 1983), dois leopardos-das-neves (Uncia uncia) (FIX et al., 1989) e dois 
filhotes de tigres mantidos em cativeiro nos Estados Unidos (GOULD; FENNER, 1983). Exposição ao vírus em felinos mantidos em cativeiro foi descrita em leões da Índia (RAMANATHAN; MALIK; PRASAD, 2007) e do Japão (ENDO et al., 2004), onças-pintadas dos Estados Unidos (APPEL et al., 1994); e guepardos da Namíbia (THALWITZER et al., 2010). Em felinos de vida livre, a soropositividade para cinomose foi relatada em leões da Uganda (DRICIRU et al., 2006), guepardos, leopardos e caracais (Felis caracal) da Namíbia (MUNSON et al., 2004; THALWITZER et al., 2010) e jaguatiricas da Bolívia (FIORELLO et al., 2007). Além de ter sido relatada a exposição à cinomose em diversos canídeos de cativeiro e vida livre (DAVIDSON et al., 1992; GESE et al., 1991; VAN DE BILDT et al., 2002; DEEM; EMMONS, 2005; CLIFFORD et al., 2006; FIORELLO et al., 2007; FERREYRA et al., 2009; GOWTAGE-SEQUEIRA et al., 2009; MILLÁN et al., 2009).

No Brasil, a ocorrência da cinomose foi relatada em canídeos e mustelídeos mantidos em cativeiro (REGO et al., 1997) e como causa morte de 19,4\% de lobos-guará de cativeiros, que apresentaram sinais clínicos da doença (MAIA; GOUVEIA, 2002). Exposição ao vírus foi relatada em lobos-guará, mão-pelada, onça-parda, cachorros-do-mato e jaguatirica de vida livre no Pantanal (JORGE, 2008). O vírus foi também isolado de um cachorro-do-mato encontrado em área suburbana no Brasil, com sinais clínicos da doença (MEGID et al., 2009). Na Mata Atlântica, seis onças-pintadas e uma onça-parda de vida livre foram soropositivas para o vírus em análises de 30 amostras de felinos silvestres (NAVA et al., 2008).

\subsubsection{Vírus da Imunodeficiência felina (FIV)}

O vírus da imunodeficiência felina (FIV), assim como o vírus da leucemia felina (FeLV), é membro da Família Retroviridae, causa infecção persistente em gatos domésticos e é importante para a conservação das espécies de felinos silvestres ameaçadas em todo o mundo (KENNEDYSTOSKOPF, 1999; FILONI et al., 2008).

O FIV pertence ao gênero Lentivirus, mesmo gênero do vírus da imunodeficiência humana (HIV). Embora apenas duas espécies de lentivírus felinos sejam reconhecidas pelo Comitê Internacional de Taxonomia Viral (ICTV, 2009), vírus espécie-específicos já foram isolados em sete felinos não domésticos: onça-parda, leão, leopardo, guepardo, jaguatirica, gato- 
mourisco (Puma yagouaroundi) e gato-de-pallas (OLMSTED et al., 1992; BROWN et al., 1994; OSOFSKY et al., 1996; TROYER et al., 2004; TROYER et al., 2005; O’BRIEN et al., 2006b).

Estudos mostram que 31 espécies de felinos são susceptíveis a infecção pelo FIV, podendo ser infectadas pelo vírus espécie-específico ou o vírus não nativo (TROYER et al., 2005; O'BRIEN et al., 2006b; PECON-SLATTERY et al., 2008). A distribuição do FIV é endêmica nas populações de felinos silvestres de vida livre da África e, em menor frequência, na maioria das populações da América do Sul, sendo rara em felinos da Europa ou Ásia (TROYER et al., 2005; O'BRIEN et al., 2006b). Em gatos domésticos, a situação epidemiológica mundial mostra uma frequência do FIV entre 2,5\% e 44\% (HARTMANN, 1998; LURIA et al., 2004; LEVY et al., 2006; BLANCO et al., 2009; GLEICH; KRIEGER; HARTMANN, 2009), e, no Brasil, estudos realizados na região sudeste apresentaram uma frequência de 2,7\% a 75,8\% (CAXITO et al., 2006; MENDES-DEALMEIDA et al., 2007).

A principal forma de transmissão do vírus, em gatos domésticos, ocorre através de mordidas, pela saliva. Pode ser também transmitido pelo sêmen, leite ou fômites (RAVAZZOLO; COSTA, 2007; HOSIE et al., 2009). O vírus não permanece por muito tempo no ambiente e rapidamente é inativado (KENNEDY-STOSKOPF, 1999; HOSIE et al., 2009). Embora ainda não elucidado, acredita-se que a transmissão do vírus entre felinos silvestres seja similar, sendo que felinos com hábitos sociais, que vivem em grupos, têm mais chances de transmitir o vírus do que felinos com hábitos solitários. Diversos estudos relatam que a transmissão em silvestres deve ocorrer através de brigas durante períodos reprodutivos ou, entre espécies diferentes, durante encontros agressivos que possam resultar na predação do animal infectado (BROWN; MITHTHAPALA; OBRIEN, 1993; FRANKLIN et al., 2007; FILONI et al., 2008; TROYER et al., 2008). O risco da transmissão entre felinos domésticos e silvestres não é conhecido, porém Nishimura et al. (1999) relataram a transmissão do FIV de gato doméstico para um gato-leopardo (Prionailurus bengalensis) de vida livre.

Os sinais clínicos em gatos domésticos são variados e frequentemente não específicos. Normalmente os animais infectados passam por um período assintomático seguido de depleção dos linfócitos T auxiliares (CD4+), imunossupressão e infecções secundárias, apresentando alta mortalidade. Podem apresentar linfoadenopatia generalizada, febre, depressão e neutropenia, ou mesmo nunca desenvolverem sinais clínicos relacionados ao FIV (RAVAZZOLO; COSTA, 2007; HOSIE et al., 2009). Os sinais da infecção em felinos silvestres ainda são desconhecidos, e embora acredite-se que não sigam os padrões das manifestações observadas em gatos domésticos (OLMSTED et al., 1992; CARPENTER; O'BRIEN, 1995; O'BRIEN et al., 2006b), sinais 
clínicos, imunológicos e patológicos semelhantes aos causados pelo lentivirus já foram relatados em leões infectados de vida livre (ROELKE et al., 2009) e mantidos em cativeiro (POLI et al., 1995). Estudos filogenéticos atribuem a baixa patogenicidade do FIV em felinos silvestres como consequência da coadaptação das cepas espécie-específicas com seus respectivos hospedeiros (OLMSTED et al., 1992; BROWN; MITHTHAPALA; OBRIEN, 1993; BROWN et al., 1994; CARPENTER et al., 1995; O'BRIEN et al., 2006b; PECON-SLATTERY et al., 2008; TROYER et al., 2008). Porém, considerando que espécies de lentivírus próximas são conhecidas por causar imunodeficiência em gatos domésticos, humanos e algumas espécies de primatas asiáticos, a infecção em felinos silvestres deve ser cuidadosamente monitorada (OLMSTED et al., 1992; BROWN; MITHTHAPALA; O'BRIEN, 1993; KENNEDY-STOSKOPF, 1999; TROYER et al., 2005; O'BRIEN et al., 2006b; ROELKE et al., 2009). O controle em felinos domésticos é feito através da separação de animais infectados (FILONI et al., 2008; HOSIE et al., 2009). A vacina para FIV, existente nos Estados Unidos, Austrália e Nova Zelândia, parece não ser efetiva e não é recomendada, assim como a eutanásia de animais positivos, uma vez que os animais podem ser assintomáticos e nunca desenvolverem sinais clínicos (KENNEDY-STOTSKOPF, 1999; FILONI et al., 2008; HOSIE et al., 2009). É recomendado manter gatos domésticos longe de áreas preservadas e longe de criatórios ou zoológicos com o objetivo de evitar a transmissão para felinos selvagens (FILONI et al., 2008).

Troyler et al. (2005) relataram que animais de vida livre apresentam maior incidência do FIV (40-50\%) do que animais de cativeiro (7-13\%), em estudo realizado com 3.055 indivíduos de 35 espécies de felinos. Este trabalho demonstrou também que as cinco espécies do gênero Panthera já foram expostas ou apresentaram o vírus. Onças-pintadas mantidas em cativeiro foram soropositivas para o agente (BARR et al., 1989; BROWN; MITHTHAPALA; O'BRIEN, 1993) e, no Brasil, Leal e Ravazzolo (1998) também detectaram a presença do agente em cinco de oito onças-pintadas analisadas. Na Mata Atlântica, em recente estudo realizado por Nava (2008), oito onças-pintadas não reagiram para o FIV.

\subsubsection{Vírus da Leucemia Felina (FeLV)}

O FeLV pertence ao gênero Gammaretrovirus, possui distribuição mundial e ao contrário do FIV, não parece ser endêmico de felinos selvagens (KENNEDY-STOSKOPF, 1999). Apesar de 
poucos relatos existirem e de normalmente não representar risco para maioria das populações (KENNEDY-STOSKOPF, 1999; FROMONT et al., 2000; FILONI et al., 2008), algumas espécies já se mostraram mais suscetíveis ao vírus, como o lince-ibérico (LÓPEZ et al., 2009; MELI et al., 2009) e o gato-selvagem-europeu (Felis silvestris) (DANIELS et al., 1999; LEUTENEGGER et al., 1999; FROMONT et al., 2000). Em gatos domésticos, a prevalência da doença em locais de grande densidade de animais é de até $33 \%$, e $1 \%$ em ambientes onde o contato entre os gatos é apenas casual (RAVAZZOLO; COSTA, 2007). Na região sudeste do Brasil, estudos relataram a frequência de até 39,4\% do FeLV em gatos domésticos (MENDES-DE-ALMEIDA et al., 2007; MACIEIRA et al., 2008).

A principal fonte de infecção do FeLV é o gato doméstico. A transmissão ocorre principalmente por contato direto, através da saliva ou secreções nasais. Apesar de também estar presente em urinas e fezes, estas não são as principais vias de transmissão, pois o vírus sobrevive pouco tempo no ambiente. Há também a possibilidade de transmissão vertical ou através de fômites (HOOVER et al., 1991; KENNEDY-STOSKOPF, 1999; RAVAZZOLO; COSTA, 2007). Embora não esteja descartada a hipótese de que o vírus seja capaz de se manter em algumas populações de felinos selvagens (MCORIST et al., 1991; LUTZ et al., 1992; DANIELS et al., 1999), acredita-se que na maioria dos casos seja resultado de interações com gatos domésticos, através de agressão ou predação (CITINO, 1986; JESSUP et al., 1993; KENNEDY-STOSKOPF, 1999; LÓPEZ et al., 2009).

Gatos domésticos infectados podem apresentar linfomas, leucemia, anemia, além do quadro de imunodeficiência. A infecção pode progredir para uma recuperação clínica completa ou infecção latente (HOOVER et al., 1991; KENNEDY-STOSKOPF, 1999; RAVAZZOLO; COSTA, 2007). Em gatos-selvagens-europeus a infecção não apresenta alta patogenicidade (DANIELS et al., 1999; FROMONT et al., 2000), porém, para as demais espécies de felinos silvestres, o FeLV é considerado patogênico (WORLEY; WILLIANS; BARKER, 2001; MARKER et al., 2003; FILONI et al., 2008; LÓPEZ et al., 2009). Não há tratamento para gatos infectados e o controle envolve o isolamento de animais positivos (HARTMANN et al., 1999). As vacinas contra o FeLV são eficientes, e podem também ser utilizadas em felinos silvestres. Entretanto, a vacinação de animais em locais com baixo risco de exposição ao agente não é recomendada (KENNEDYSTOSKOPF, 1999; RAVAZZOLO; COSTA, 2007; FILONI et al., 2008). Assim, recomenda-se afastar gatos domésticos de áreas preservadas, criatórios ou zoológicos (KENNEDY-STOSKOPF, 1999).

Na Espanha, recentemente, o FeLV foi responsável por um surto nas populações de linces-ibéricos de vida livre, causando sinais agudos da doença e morte de muitos animais 
(LÓPEZ et al., 2009; MELI et al., 2009). Um plano de manejo foi estabelecido por profissionais com objetivo de controlar o foco da infecção, reduzindo a população de gatos ferais do entorno, vacinando todos os linces negativos para o patógeno e removendo linces virêmicos da natureza (LÓPEZ et al., 2009).

Antígenos virais do FeLV foram detectados em leopardo nebuloso (Neofelis nebulosa) mantido em cativeiro (CITINO, 1986) e em onças-pardas (CUNNINGHAM et al., 2008) e gatos-dodeserto (Felis margarita) (OSTROWSKI et al., 2003) de vida livre. O vírus foi isolado de um guepardo (MARKER et al., 2003) e um gato-leopardo (RASHEED; GARDNER, 1981) mantidos em cativeiro, além de onças-pardas (JESSUP et al., 1993; CUNNINGHAM et al., 2008), gatos-silvestres (BOID et al., 1991; MCORIST et al., 1991; DANIELS et al., 1999) e linces-ibéricos de vida livre (LÓPEZ et al., 2009; MELI et al., 2009).

No Brasil, o vírus foi isolado de uma jaguatirica e um gato-do-mato-pequeno mantidos em cativeiro (GUIMARÃES et al., 2009), e antígenos virais ou sorologia positiva ao FeLV foram detectados em onças-pardas, gatos-maracajás, gato-mourisco, jaguatirica, gato-do-matopequeno, gato-do-mato-grande (Oncifelis geoffroyi), gato-palheiro (Leopardus colocolo) e onçapintada mantidos em cativeiro, e jaguatirica (SCHMITT et al., 2003) e onças-pardas (FILONI et al., 2006) de vida livre.

\subsubsection{Hepatozoon spp.}

Hepatozoon spp. é um protozoário do Filo Apicomplexa, Família Hepatozoidae, causador da hepatozoonose, doença transmitida por artrópodes, que acomete principalmente os carnívoros domésticos e silvestres (BANETH, 2003; PALUDO et al., 2005).

Duas espécies são encontradas infectando os cães: o Hepatozoon canis, na África, Ásia, Europa e América do Sul; e o Hepatozoon americanum, nos Estados Unidos (BANETH, 2003; LI et al., 2008; RUBINI et al., 2008). No Brasil, a espécie Hepatozoon canis foi recentemente caracterizada molecularmente (RUBINI et al., 2005), tendo sido descrita na região Sudeste, Centro-Oeste e Sul, com frequências de 5,9\% a 77,39\% (PALUDO et al., 2003; O'DWYER et al., 2006; MUNDIM et al., 2008; LASTA et al., 2009). A hepatozoonose felina é rara, sendo que poucos relatos existem na Índia, África, Estados Unidos, Israel, Brasil, Espanha e França (BANETH, 2003; ORTUÑO et al., 2008). Pouco se conhece sobre a infecção nos gatos, e a espécie de 
Hepatozoon responsável pela enfermidade, nos felinos, continua indeterminada (BANETH et al., 1998). Com base na diferença morfológica entre os gametócitos, Beaufils, Martin-Granel e Jumelle (1998) sugeriram aceitar duas espécies: H. canis e $H$. felis, da mesma forma que CriadoFornelio et al. (2006). No Brasil, porém, Rubini et al. (2006) descreveram o H. felis molecularmente semelhante ao $\mathrm{H}$. canis.

A transmissão ocorre através da ingestão do artrópode vetor contendo o oocisto do Hepatozoon spp. (BANETH, 2003). Após a ingestão do vetor, ou parte dele, o oocisto se rompe, os esporozoítos são liberados no intestino, penetram em sua parede, invadem células mononucleares e são disseminados para órgãos hemolinfáticos (como pulmão, coração e baço) do hospedeiro. Nestes órgãos, são formados os merontes, e no seu interior, por divisão assexuada, merozoítos, que formam os micromerozoítos e os macromerozoítos. Os macromerozoítos são liberados e invadem novas células, formando novos merontes; e os micromerozoítos invadem os leucócitos ou monócitos, desenvolvendo os gamontes. $\mathrm{O}$ artrópode vetor se torna infectado ao se alimentar de um hospedeiro parasitêmico (BANETH, 2003). O principal vetor do $H$. canis é o carrapato Rhipicephalus sanguineus (BANETH, 2003), sendo que no Brasil identificou-se a capacidade do Amblyomma ovale em transmitir a doença (FORLANO et al., 2005; RUBINI et al., 2009). Acredita-se que outras espécies do gênero Amblyomma possam também transmitir $H$. canis no Brasil (O'DWYER; MASSARD; SOUZA, 2001; RUBINI et al., 2008; SPOLIDORIO et al., 2009). Embora não se conheça o vetor da hepatozoonose felina (BANETH, 2003; ORTUÑO et al., 2008), sabe-se que outros artrópodes, como as pulgas, atuam como vetores para diferentes espécies de Hepatozoon spp. (WATKINS; MOSHIER; PINTER, 2006). Mc Cully et al. (1975) e Smith (1996) sugerem a transmissão através da predação de animais infectados.

Os sinais clínicos da infecção causada pelo $H$. canis variam de inaparentes a severos, e a doença pode ser secundária a outras enfermidades, dependendo da parasitemia e imunidade do animal (URQUHART et al., 1998; O'DWYER; MASSARD; SOUZA, 2001; BANETH, 2003; MUNDIM et al., 2008; SPOLIDORIO et al., 2009). Os cães podem apresentar febre, letargia, perda de peso e anemia (GONDIM et al., 1998; BANETH, 2003; O'DWYER et al., 2006). Os gatos podem apresentar os mesmos sinais clínicos (PEREZ; RUBINI; O'DWYER, 2004), sendo que, na maioria dos casos há evidências de que os tecidos musculares são afetados, elevando os níveis de suas enzimas musculares (BANETH et al., 1998; PEREZ; RUBINI; O’DWYER, 2004). O tratamento consiste em uma combinação de antiprotozoários (BANETH, 2003), e a prevenção é feita através do controle regular dos carrapatos (URQUHART et al., 1998; BANETH, 2003). 
Hepatozoon spp. foi diagnosticado parasitando raposas-vermelhas em Portugal (CONCEIÇÃO-SILVA et al., 1988) e Espanha (CRIADO-FORNELIO et al., 2006); cachorros-selvagensafricanos na África do Sul (VAN HEERDEN et al., 1995; MATJILA et al., 2008); hienas na Tanzânia e África do Sul (MCCULLY et al., 1975; EAST et al., 2008), chacal na África do Sul (MCCULLY et al., 1975); guaxinim na Venezuela (CRIADO-FORNELLIO et al., 2009); coiote (Canis latrans) (DAVIS; ROBINSON; CRAIG, 1978; MERCER et al., 1988), lince-pardo (LANE; KOCAN, 1983; MERCER et al., 1988) e jaguatiricas (MERCER et al., 1988) nos Estados Unidos; gato-de-pallas (BARR et al., 1993), gatos-selvagens do Japão (KUBO; MIYOSHI; YASUDA, 2006), leões, leopardos e guepardos na Tanzânia, Quênia e África do Sul (BROCKLESBY; VIDLER, 1963; MCCULLY et al., 1975; AVERBECK et al., 1990; MUNSON et al., 2008); e uma onça-pintada de vida livre na Venezuela (CRIADOFORNELLIO et al., 2009).

No Brasil, Hepatozoon canis foi identificado em capivaras (CRIADO-FORNELLIO et al., 2009), cachorros-do-mato e raposinha-do-campo (Pseudalopex vetulus) de vida livre (CRIADOFORNELLIO et al., 2006) na região Sul do país, e em cachorro-do-mato de vida livre na região Sudeste (ALENCAR; SANTAREM; KOHAYAGAWA, 1997). Criado-Fornellio et al. (2006) identificaram em um cachorro-do-mato espécie semelhante ao $\mathrm{H}$. americanum. Metzger et al. (2008) relataram a presença de Hepatozoon spp. em um gato-do-mato-pequeno e jaguatiricas nascidas em vida livre, todas sem sinais clínicos. Widmer (2009) identificou Hepatozoon spp. com 98\% de similaridade ao $\mathrm{H}$. felis em 10 onças-pintadas de vida livre do Pantanal, MS.

\subsubsection{Babesia spp.}

A Babesia spp. é um hematozoário da Classe Piroplasmida, Família Babesiidae responsável por uma das principais doenças transmitida por carrapatos no mundo, a babesiose (URQUHART et al., 1998). Diversas espécies do gênero Babesia são conhecidas, parasitando diferentes espécies de animais domésticos (AYOOB; HACKNER; PREITTE, 2010).

No Brasil, os bovinos são normalmente parasitados pelo B. bovis e B. bigemina com índices de 27,80\% (ALVES, 1987) a 98,72\% (LINHARES et al., 1992), tendo o carrapato Rhipicephalus microplus como principal vetor (SOARES et al., 2000). A maioria dos casos de babesiose canina no Brasil é causada pela B. canis vogeli (PASSOS et al., 2005), porém existem alguns relatos recentes de $B$. gibsoni como agente etiológico (TRAPP et al., 2006). Endêmica em 
todas as regiões do Brasil, a frequência da babesiose canina varia de 1,9\% (SOARES et al., 2006) a 66,9\% (RIBEIRO et al., 1990) e é transmitida pelo Rhipicephalus sanguineus (MAIA et al., 2007; DANTAS-TORRES, 2008). Apesar de poucos relatos, a presença de inclusões semelhantes a Babesia spp. já foi relatada em gatos domésticos no Brasil (GAZETA; MONTEIRO; ABOUD-DUTRA, 2004; MENDES-DE-ALMEIDA et al., 2004; DANTAS-TORRES; FIGUEIREDO, 2006).

No hospedeiro definitivo, a Babesia spp. multiplica-se por fissão binária nas hemácias, produzindo merozoítos. Os carrapatos vetores são infectados ingerindo o sangue parasitêmico do hospedeiro. No carrapato, os merozoítos passam por um ciclo complexo que resulta na produção de esporozoítos nas glândulas salivares dos carrapatos. Através da saliva do carrapato, os esporozoítos infectantes são transmitidos para a circulação do hospedeiro (URQUHART et al., 1998). Essa transmissão ocorre entre 2 e 3 dias após a fixação do carrapato no hospedeiro (UILENBERG, 2006), no qual, após a fissão binária na hemácia, a célula se rompe e os organismos são liberados, penetrando em novas hemácias (URQUHART et al., 1998).

A patogenicidade da Babesia spp. depende das espécie e cepa infectantes (TABOADA; MERCHANT, 2001). Na infecção com uma espécie de baixa patogenicidade, os sinais podem ser inaparentes ou moderados (URQUHART et al., 1998). A babesiose é caracterizada por anemia, febre, anorexia, desidratação e perda de peso (URQUHART et al., 1998; PASSOS et al., 2005). Fármacos antiprotozoários e tratamento suporte são as principais terapias (DANTAS-TORRES; FIGUEIREDO, 2006; AYOOB; HACKNER; PRITTIE, 2010). A prevenção, por sua vez, é feita evitando-se a infestação de carrapatos (URQUHART et al., 1998), sendo importante o conhecimento da biologia e ecologia do vetor para definição das estratégias de controle (GEORGE; DAVEY; POUND, 2002; DANTAS-TORRES; FIGUEREDO; BRANDÃO, 2006). Recentemente, foi disponibilizada no mercado uma vacina preventiva para babesiose canina sua eficácia e segurança, porém, ainda não são conhecidas (DANTAS-TORRES, 2008).

Em revisão feita por Penzhorn (2006), Babesia spp. já foi descrita em mustelídeos, viverrídeos, procionídeos, herpestídeos, hienídeos, canídeos e felídeos, na maioria das vezes sem a manifestação de sinais clínicos. Penzhorn (2006) relata também que, ao que parece, cada espécie de Babesia spp. tem especificidade por um hospedeiro, indicando que Babesia spp. de animais domésticos poderiam ser fatais para animais silvestres, principalmente em momentos de estresse ou estado de imunossupressão. Casos de babesiose fatal foram relatados em cachorros-selvagens-africanos no zoológico da África do Sul (COLLY; NESBIT, 1992), e em uma leoa nascida em vida livre e criada em cativeiro (ADAMSON, 1962 apud PENZHORN, 2006, p. 18). A alta infecção de Babesia spp., em decorrência da alta infestação de carrapatos, foi associada 
aos leões que vieram a óbito no surto de cinomose em 1994 no Serengeti, onde provavelmente as alterações climáticas favoreceram a coinfecção por Babesia spp. (B.felis, B. leo, B. gibsoni e Babesia spp.) e alteraram a relação hospedeiro-parasita (MUNSON et al., 2008).

Babesia felis foi descrita pela primeira vez em um gato-selvagem-africano (Felis ocreata) sem manifestação clínica da infecção (DAVIS, 1929) e posteriormente em caracais na África do Sul (PENZHORN; SCHOEMAN; JACOBSON, 2004). Babesia pantherae foi descrita em leopardo no Quênia (DENNING; BROCKLESBY, 1972) e B. herpailuri em gato-mourisco na América Central (DENNING, 1967 apud PENZHORN, 2006, p. 12). Babesia spp. foi relatada em leopardo (BROCKLESBY; VIDLER, 1963), em um provável lince-pardo (WENYON; HAMERTON, 1930), tigres (NAGAR et al., 1979 apud PENZHORN, 2006, p. 14), onça-parda (FUTTER; BELONJE, 1980) e guepardos (AVERBECK et al., 1990). Em 47 leões examinados no Parque Nacional do Kruger, todos os indivíduos foram diagnosticados infectados com uma nova espécie de Babesia - B. Leo - sem manifestação clinica da doença (LOPEZ-REBOLLAR et al., 1999; PENZHORN et al., 2001). B. leo foi descrita também em leopardo de vida livre (PENZHORN et al., 2001). Recentemente, Bosman, Venter e Penzhorn (2007) identificaram nova espécie de Babesia parasitando guepardos e leões de vida livre na África do Sul e Suazilândia, e Ayoob; Hackner e Preitte (2010) identificaram onças-pardas positivas para Babesia spp. no Texas. Na Flórida, foram isoladas Babesia spp. em 32 de 39 onças-pardas amostradas - os animais amostrados não apresentavam sinais clínicos (YABSLEY; MURPHY; CUNNINGHAM, 2006). Uma onça-pintada amostrada na Guiana Francesa e duas onças-pintadas amostradas na Venezuela, ambas de vida livre, foram negativas para Babesia spp. (THOISY et al., 2000; CRIADO-FORNELIO et al., 2009).

No Brasil, Babesia sp., provisoriamente chamada de Babesia sp. capybara 1, foi isolada em capivaras (CRIADO-FORNELIO et al., 2009). Em felídeos, há relato de identificação de Babesia spp. em esfregaço sanguíneo em um gato-do-mato-pequeno mantido em cativeiro (CORRÊA; TEIXEIRA, 2003), e presença de anticorpos anti-Babesia canis em 73,6\% ( $n=53)$ dos felinos silvestres mantidos em cativeiro entre gatos-do-mato-pequeno, gatos-maracajás, gatospalheiros, gato-mourisco, onças-pardas e seis onças-pintadas (ANDRÉ, 2008). 


\subsubsection{Cytauxzoon spp.}

Hemoprotozoário, pertence à mesma Classe que a Babesia spp., o Cytauxzoon spp., da Família Theileriidae, é o agente etiológico da cyutauxzoonose, doença transmitida por carrapatos (URQUHART et al., 1998). Cytauxzoon felis é um parasita de felinos domésticos e selvagens, caracterizado por uma taxa de mortalidade extremamente alta em gatos domésticos (MEINKOTH; KOCAN, 2005).

Relatado pela primeira vez em 1976 em Missouri, a cytauxzoonose ainda é considerada uma doença infecciosa emergente no centro-sul e sudoeste dos Estados Unidos, onde é normalmente identificada (MEINKOTH; KOCAN 2005; BIRKENHEUER et al., 2006). No Brasil, mesmo a doença sendo pouco conhecida e raramente diagnosticada (MAIA, 2007), Mendes-deAlmeida et al. (2007), através de análise de esfregaços sanguíneos, diagnosticaram o parasita em $48,5 \%$ de 33 gatos analisados no Rio de Janeiro.

No organismo do hospedeiro, no interior de macrófagos de tecidos como pulmão, fígado e baço, ocorre a fase de esquizogonia. Em seguida, os merozoítos são formados e penetram em novos macrófagos ou hemácias. No interior das hemácias são denominados piroplasmas, se reproduzem por fissão binária e rompem as hemácias (KIER; WAGNER; KINDEN, 1987; MEINKOTH; KOCAN, 2005). A transmissão ocorre através dos esporozoítos presentes na saliva dos carrapatos (KOCAN et al., 1992) e aderência do vetor por horas no hospedeiro (MEINKOTH; KOCAN, 2005). Até recentemente, suspeitava-se que o lince-pardo era o hospedeiro natural do C. felis, e os gatos domésticos, devido à infecção rápida e letal, pareciam ser os hospedeiros acidentais do parasita (BLOUIN et al., 1984; MEINKOTH; KOCAN, 2005). Porém, relatos de gatos domésticos assintomáticos positivos para $C$. felis levantaram a hipótese de que estes possam também se comportar como reservatórios (HABER et al., 2007; BROWN et al., 2008).

A incidência da doença é sazonal, e correlacionada com a atividade dos carrapatos vetores (MEINKOTH; KOCAN, 2005; REICHARD et al., 2008). A competência do carrapato Dermacentor variabilis em transmitir o C. felis já foi demonstrada (BLOUIN et al., 1984). Recentemente, a transmissão experimental por Amblyomma americanum foi relatada por Reichard et al. (2009). Entretanto, relatos do C. felis no Brasil, onde conhecidamente estas espécies de carrapatos não ocorrem, demonstram que outras espécies de ixodídeos podem eventualmente ser os vetores do parasita (PEIXOTO et al., 2007; ANDRÉ et al., 2009). 
Em gatos domésticos, as infecções, na quase totalidade dos casos, resultam em febre aguda e morte em aproximadamente de 8 a 20 dias (WAGNER et al., 1980; KIER; WAGNER; KINDEN, 1987; BIRKENHEUER et al., 2006). Os gatos ficam deprimidos, desidratados e anoréxicos (WAGNER et al., 1980; BIRKENHEUER et al., 2006). Em felinos silvestres, a infecção normalmente é assintomática, embora existam relatos de cytauxzoonose fatal (GLENN; KOCAN; BLOUIN, 1983; GARNER et al., 1996; NIETFELD; POLLOCK, 2002; PEIXOTO et al., 2007). Em gatos domésticos também existem relatos esporádicos de animais que sobrevivem à infecção experimental ou natural (MOTZEL; WAGNER, 1990; WALKER; COWELL, 1995; MEINKOTH et al., 2000; BIRKENHEUER et al., 2006; HABER et al., 2007), o que levantou a hipótese da existência de cepas menos ou mais virulentas e possível resposta imune nos animais (REICHARD et al., 2009). Não há vacinas e a prevenção é baseada na limitação da exposição aos carrapatos vetores (MEINKOTH; KOCAN, 2005).

A cytauxzoonose fatal foi reportada em tigres mantidos em cativeiro na Flórida (GARNER et al., 1996) e na Alemanha (JAKOB; WESEMEIER, 1996). O diagnóstico do C. felis em animais assintomáticos foi relatado em onças-pardas de vida livre no Texas (ROTSTEIN et al., 1999) e na Flórida (YABSLEY; MURPHY; CUNNINGHAM, 2006); guepardos (ZINKL et al., 1981) e lincesibéricos de vida livre na Espanha (LUACES et al., 2005; MILLÁN et al., 2007; MELI et al., 2009; GARCIA-BOCANEGRA et al., 2010). Na Mongólia, um gato-de-pallas apresentou uma nova espécie de Cytauxzoon spp., denominada Cytauxzoon manul (KETZ-RILEY et al., 2003; REICHARD et al., 2005).

Na América do Sul, a cytauxzoonose fatal foi descrita pela primeira vez em leões mantidos em cativeiro no Brasil (PEIXOTO et al., 2007). No Brasil, também há o relato de Cytauxzoon spp. em onça-parda, jaguatirica, gato-do-mato-pequeno e onça-pintada mantidas em cativeiro e sem manifestações de sinais clínicos da doença (SOARES, 2001; FILONI, 2006; PEIXOTO et al., 2007; ANDRÉ et al., 2009). Metzger (2009) identificou uma onça-parda nascida em vida livre positiva para C. felis, enquanto Widmer (2009) detectou C. felis em 10 onçaspintadas de vida livre amostradas no Pantanal sul mato-grossense. 


\subsubsection{Hemoplasmas felinos: Mycoplasma haemofelis, 'Candidatus Mycoplasma haemominutum' e 'Candidatus Mycoplasma turicencis'}

Conhecidos antigamente como Haemobartonella e Eperythrozoon, os micoplasmas hemotrópicos ou hemoplasmas são pequenas bactérias da Família Mycoplasmaceae capazes de infectar os eritrócitos e causar uma severa anemia hemolítica (SYKES, 2010; TASKER, 2010). Quatro espécies foram identificadas em felinos: Mycoplasma haemofelis (antiga Haemobartonella felis), 'Candidatus Mycoplasma haemominutum', 'Candidatus Mycoplasma turicensis' e, recentemente, 'Candidatus Mycoplasma haematoparvum' (WILLI et al., 2005; SYKES et al., 2007; SYKES, 2010; TASKER, 2010). O termo 'Candidatus' se refere a uma classificação provisória na nomenclatura das bactérias, pois, até o momento, não foi possível o cultivo dessas espécies in vitro e, consequentemente, sua caracterização (SYKES, 2010; TASKER, 2010). O Mycoplasma haemofelis, mesmo não tendo sido cultivado in vitro, não é designado 'Candidatus', pois substituiu uma espécie já existente, $H$. felis, e não pode ser retrospectivamente reclassificado (SYKES, 2010; TASKER, 2010).

Espécies de hemoplasmas já foram descritas em todos os continentes, exceto na Antártica, comprovando a distribuição mundial do agente (BIONDO et al., 2009). Segundo Tasker (2010), 'Candidatus M. haemominutum' tem sido o hemoplasma mais encontrado, seguido por 'Candidatus M. turicensis' e M. haemofelis. No Brasil, em estudos realizados nas regiões Sul e Sudeste, a frequência para M. haemofelis foi de 4\% (MACIEIRA et al., 2006) a 38\% (SANTOS, 2008); para 'Candidatus M. haemominutum', de aproximadamente 10\% (MACIEIRA et al., 2006; SANTOS, 2008); e para 'Candidatus M. turicensis', entre 0,37\% (HORA, 2008) e 4,6\% (SANTOS et al., 2009a).

O modo de transmissão dos hemoplasmas felinos ainda é desconhecido (SYKES, 2003; WILLI et al., 2007b; TASKER, 2010). Embora 'Candidatus M. turicensis' e 'Candidatus M. haemominutum' tenham sido encontrados nas salivas de gatos infectados (WILLI et al., 2007a; DEAN et al., 2008), as tentativas de transmissão direta entre gatos via oral ou inoculação subcutânea não foram bem sucedidas (MUSEUX et al., 2009). Acredita-se que interações agressivas entre gatos poderiam transmitir o agente (WILII et al., 2007a; TASKER, 2010), assim como, suspeita-se do papel de carrapatos (TAROURA et al., 2005; WILLI et al., 2007c; FYUMAGWA et al., 2008), e pulgas (Ctenocephalides felis) (WOODS et al., 2005), como vetores. A identificação das três espécies de hemoplasmas em felinos selvagens sugere a possibilidade de agirem como reservatórios, portadores assintomáticos do agente (WILLI et al., 2007b, 2007c). 
Mycoplasma haemofelis é a espécie mais patogênica entre os hemoplasmas felinos e a mais associada com sinais clínicos, sendo frequentemente responsável por causar anemia hemolítica em infecções agudas (TASKER, 2006; TASKER et al., 2009; TASKER, 2010). A infecção por 'Candidatus M. haemominutum' raramente resulta em sinais clínicos significantes e, normalmente, a anemia não é induzida, embora possa ocorrer queda nos parâmetros dos glóbulos vermelhos. Quando associada com infecções causadas por retrovírus, como FELV, pode resultar em anemia (GEORGE et al., 2002; TASKER, 2006; WILLI et al., 2006a; SYKES et al., 2007; MACIEIRA et al., 2008; TASKER et al., 2009; SYKES, 2010). Sozinho, 'Candidatus M. turicensis' parece não causar anemia, porém, quando associado a outros agentes e a imunossupressão, podem causar queda nos parâmetros dos glóbulos vermelhos ou induzir a anemia (WILLI et al., 2006b, 2007c; FUJIHARA et al., 2007; TASKER et al., 2009; TASKER, 2010). Ou seja, não é apenas o agente infectante que influencia nos sinais clínicos, mas também a duração da infecção e a presença de outras doenças associadas (TASKER, 2010). Pode ocorrer, também, do gato ser portador do hemoplasma e nunca demonstrar sinal clínico (WILLI et al., 2007b; TARKER, 2010). Os sinais clínicos comuns são letargia, anorexia, perda de peso, depressão e desidratação (MESSICK, 2003; SYKES, 2003; SYKES, 2010; TASKER, 2010). Gatos que se recuperam devem permanecer cronicamente infectados, tornando-se reservatórios do agente (TASKER, 2006; TASKER, 2010), embora a ausência do parasita, após tratamento ou cura espontânea, já tenham sido reportadas (WILLI et al., 2006a), assim como a reativação da doença (TASKER et al., 2006). Animais assintomáticos e portadores do agente não devem ser tratados (SYKES, 2010; TASKER, 2010), pois, até o momento, não há tratamento que realmente elimine o agente, sendo indicado apenas quando associado a outras infeç̧ões (WILLI et al., 2007b; SYKES, 2010; TASKER, 2010). O relato de hemoplasmoses em humanos sugere a possibilidade de um potencial zoonótico dos hemoplasmas (SYKES, 2003; SANTOS et al., 2009a; SYKES, 2010; TASKER, 2010).

Uma amostragem de 257 felinos silvestres identificou que animais de vida livre foram mais infectados por hemoplasmas do que animais mantidos em cativeiro (WILLI et al., 2007c). Mycoplasma haemofelis, 'Candidatus M. haemominutum' e 'Candidatus M. turicensis' foram identificados em linces-ibéricos de vida livre (WILLI et al., 2007c; MELI et al., 2009) e mantidos em cativeiro (WILLI et al., 2007c) na Espanha, em linces-euroasiáticos (Lynx lynx) de vida livre na Suiça, gatos-selvagens-europeus de vida livre na França e leões de vida livre na Tanzânia (WILLI et al., 2007c). 'Candidatus M. haemominutum' foi detectado em leões de vida livre no Serengeti (MUNSON et al., 2008); e Mycoplasma haemofelis foi identificada em dois tigres anêmicos mantidos em cativeiro nos Estados Unidos (HAEFNER et al., 2003). 
As três espécies de hemoplasmas felinos já foram diagnosticadas em felinos selvagens do Brasil (WILLI et al., 2007c). Em estudo realizado com 110 felinos selvagens mantidos em cativeiro, 'Candidatus M. haemomintum' foi identificado em leão, gato-do-mato-grande, gatomaracajá, jaguatiricas, gatos-do-mato-pequeno e onça-parda; M. haemofelis foi encontrado em um gato-maracajá e uma jaguatirica e 'Candidatus $M$. turicensis' foi identificado em uma jaguatirica (WILLI et al., 2007c). Em levantamento realizado no Nordeste, seis jaguatiricas e um gato-mourisco foram positivos para 'Candidatus M. haemominutum e/ou M. haemofelis' (SANTOS, 2008). 'Candidatus M. haemominutum' foi também identificado em leões mantidos em cativeiro (GUIMARÃES et al., 2007) e em jaguatiricas e gato-mourisco nascidos em vida livre (METZGER, 2009). Existem também relatos da presença de Mycoplasma haemofelis em gatomaracajá mantido em cativeiro (GUIMARÃES, 2008) e em jaguatiricas, onça-parda, gatomourisco, gato-do-mato-pequeno e gato-maracajá nascidos em vida livre (METZGER, 2009).

\subsubsection{Mycobacterium bovis}

O Mycobacterium bovis é uma bactéria da Família Mycobacteriaceae e uma das quatro micobactérias pertencente ao complexo M. tuberculosis (O'REILLY; DABORN, 1995). É o agente etiológico da tuberculose bovina, doença de alta relevância econômica no contexto da pecuária, afetando diretamente a produtividade animal, e importante também para animais silvestres e para a saúde pública afetando também os humanos (MORRIS; PFEIFFER; JACKSON, 1994; O'REILLY; DABORN, 1995; ACHA; SZYFRES, 2001; RENWICK; WHITE; BENGIS, 2007).

De ocorrência mundial, a tuberculose bovina é considerada pela Organização Mundial da Saúde uma zoonose negligenciada principalmente por países em desenvolvimento (OMS, 2010b). Os programas de controle e erradicação da doença estão direcionados ao seu principal reservatório, o bovino, testando e sacrificando os animais positivos (MORRIS; PFEIFFER; JACKSON, 1994; COLLINS, 2001). Em países desenvolvidos, a prevalência da enfermidade vem diminuindo significativamente; porém, em países onde os animais silvestres tornaram-se os principais reservatórios - como o texugo (Meles meles) no Reino Unido (DELAHAY; CHEESEMAN; CLIFTON-HADLEY, 2001) e o veado-de-cauda-branca (Odocoileus virginianus) em Michigan, Estados Unidos (O'BRIEN et al., 2006a) - a erradicação da doença tornou-se uma meta elusiva (MORRIS; PFEIFFER; JACKSON, 1994; DE KANTOR et al., 2008). No Brasil, o Programa Nacional de 
Controle e Erradicação da Brucelose e Tuberculose Animal vem sendo desenvolvido desde 2001 e a prevalência média da tuberculose em bovinos é de 1,3\% (BRASIL, 2006).

A principal via de transmissão é a aerógena, porém pode ocorrer também através da ingestão de água ou alimentos contaminados ou pelo contato com exsudatos eliminados por animais infectados (MORRIS; PFEIFFER; JACKSON, 1994; ACHA; SZYFRES, 2001; BENGIS, 1999). No ambiente, o $M$. bovis pode sobreviver até 332 dias em fezes, sangue ou urina e, quando expostos aos raios solares, sobrevivem até 31 dias (revisado por MORRIS; PFEIFFER; JACKSON, 1994). Em carnívoros, a transmissão pela via entérica parece ser a mais importante, ocorrendo inclusive pela ingestão de carcaças infectadas (MORRIS; PFEIFFER; JACKSON, 1994; BENGIS, 1999; CLEAVELAND et al., 2005). A contaminação do pasto pela urina de texugos é a principal via de transmissão do agente para os bovinos no Reino Unido (MORRIS; PFEIFFER; JACKSON, 1994; DELAHAY; CHEESEMAN; CLIFTON-HADLEY, 2001).

Caracterizada como uma doença de caráter crônico e de evolução lenta, os sinais clínicos se manifestam apenas após estágio avançado da doença (MORRIS; PFEIFFER; JACKSON, 1994; ACHA; SZYFRES, 2001; BENGIS, 1999; THOEN; LOBUE; DE KANTOR, 2006). Há o desenvolvimento de lesões nodulares, que podem localizar-se em qualquer órgão ou tecido, sendo que os sinais exibidos dependem da extensão e localização das lesões. Geralmente, os animais apresentam anorexia, fraqueza, dispneia, febre e broncopneumonia (MORRIS; PFEIFFER; JACKSON, 1994; BRASIL, 2006; THOEN; LOBUE; DE KANTOR, 2006). Os gatos são relativamente resistentes a infecção por M. bovis (MORRIS; PFEIFFER; JACKSON, 1994; ACHA; SZYFRES, 2001). O tratamento é demorado, com drogas antituberculosas, e o resultado é incerto, pois as cepas podem se tornar resistentes ao longo do tratamento (ACHA; SZYFRES, 2001; MICHEL; MULLER; VAN HELDEN, 2010). Em silvestres, devido ao longo período, a terapia é inviável para animais de vida livre (BENGIS, 1999; MICHEL; MULLER; VAN HELDEN, 2010). Realizado em bovinos, o controle é extremamente difícil em animais silvestres, a não ser que medidas drásticas sejam tomadas, como a remoção dos animais infectados, como realizado em búfalos aquáticos na Austrália (CLIFTON-HADLLEY et al., 2001; BENGIS, 1999; ZANELLA et al., 2008). Não há vacinas disponíveis comercialmente, mas pesquisas de vacinas orais contra $\circ M$. bovis estão sendo desenvolvidas para animais silvestres (SALAZAR et al., 2007; CROSS; LAMBETH; ALDWELL, 2009).

O M. bovis já foi diagnosticado em mais de 40 espécies de animais silvestres de vida livre (MICHEL; MULLER; VAN HELDEN, 2010). Animais silvestres da Família Bovidae e Cervidae têm a capacidade de se tornarem reservatórios do $M$. bovis, enquanto os carnívoros são acidentalmente infectados e agem como hospedeiros "spill-over", não sendo capazes, 
normalmente, de manter a doença no ecossistema (MORRIS; PFEIFFER; JACKSON, 1994; BENGIS, 1999). No Serengeti, um estudo retrospectivo indicou que a tuberculose está presente na região há décadas, e que a principal via de transmissão para os leões é a predação de búfalos infectados (CLEAVELAND et al., 2005). No Parque Nacional do Kruger (KNP), a alta prevalência da doença em búfalos (Syncerus caffer), de 5 a $45 \%$, é uma ameaça para todas as populações silvestres da região (BENGIS et al., 1996; KEET et al., 1996; RODWELL et al., 2001; CROSS; LAMBETH; ALDWELL, 2009). Já foi diagnosticada em leões, guepardo e leopardo que habitam o KNP (KEET et al., 1996; DE VOS et al., 2001), e Kirberger, Keet e Wagner (2006), através da radiologia, diagnosticaram lesões ósseas induzidas por micobactérias em 15 leões de vida livre. No Reino Unido, os texugos mantêm a infecção persistente na população e chegaram a ser responsáveis por $90 \%$ da incidência da tuberculose no gado no noroeste da Inglaterra (CLIFTONHADLEY et al., 2001; DELAHAY; CHEESEMAN; CLIFTON-HADLEY, 2001). O M. bovis já foi isolado também de coiotes, guaxinins, raposa-vermelha, lince-pardo e linces-ibéricos nos Estados Unidos, França, e Espanha (BRUNING-FANN et al., 1998; BRIONES et al., 2000; PEREZ et al., 2001; PALMER; WATERS; WHIPPLE, 2002; MARTIN-ATANCE et al., 2005; ZANELLA et al., 2008; MILLÁN et al., 2009). E em grandes felinos do gênero Panthera, mantidos em cativeiro, foi isolado de um tigre-siberiano (VANDEWAT; ZWART; BAKKER, 1972), leão (MORRIS; THOEN; LEGENDRE, 1996) e leopardos (THOREL et al., 1998).

No Brasil, primatas e felinos selvagens mantidos em cativeiro apresentaram reação positiva para o teste de tuberculina (COSTA; DINIZ; FAVA NETTO, 1997). Em animais de vida livre, Luna et al. (2002) analisaram amostras de cervos-do-pantanal (Blastocerus dichotomus) do Mato Grosso do Sul e não encontraram nenhum animal positivo.

\subsubsection{Parasitas intestinais: Cryptosporidium spp., Giardia spp., Sarcocystis spp. e Hammondia hammondi}

Protozoários parasitas intestinais como Giardia spp., Cryptosporidium spp.; Sarcocystis spp. e Hammondia spp. podem causar infecções clínicas ou subclínicas em gatos de todas idades (KIRKPATRICK et al., 1986; LAPPIN et al., 1997; DE SANTIS-KERR et al., 2006). O Cryptosporidium spp. e a Giardia spp. são considerados parasitas zoonóticos e possuem uma ampla variedade de espécies hospedeiras, atingindo humanos, domésticos e silvestres (THOMPSON, 2000; FAYER, 2004; THOMPSON; MONIS, 2004; APPELBEE; THOMPSON; OLSON, 2005; POLLEY, 2005; PAPINI et 
al., 2007; PAZIEWSKA et al., 2007; BAJER, 2008). O Sarcocystis spp., também uma zoonose, normalmente possui predadores carnívoros e onívoros como hospedeiros definitivos e herbívoros ou onívoros como hospedeiros intermediários (DUBEY, 1976; FIGUEIREDO; LOPES; SERRA-FREIRE, 1991; LOPES, 2004). O gato é o único hospedeiro definitivo conhecido da Hammondia hammondi (DUBEY; SREEKUMAR, 2003).

A combinação dos estudos de prevalência com técnicas moleculares tem providenciado informações valiosas em relação à especificidade de hospedeiros e possíveis vias de transmissão, principalmente para Giardia spp. e Cryptosporidium spp. (APPELBEE; THOMPSON; OLSON, 2005). É conhecido que mamíferos silvestres são infectados com genótipos de Cryptosporidium spp. adaptados à espécie e que não apresentam riscos para a saúde pública (XIAO; RYAN, 2004; FENG et al., 2007; FENG, 2010). Appelbee, Thompson e Olson (2005) acreditam que o papel dos animais silvestres e de produção na manutenção e transmissão desses agentes seja superestimado. No Brasil, o potencial zoonótico de protozoários a partir de hospedeiros silvestres ainda é pouco estudado (SILVA et al., 2008; SOARES et al., 2008).

A transmissão desses parasitas intestinais pode ocorrer através da ingestão de oocistos (Cryptosporidium spp.; Hammondia hammondi) ou de cistos (Giardia spp.; Sarcocystis spp.) contidos nas fezes, pastagens, ambiente, água, alimento ou presas (ROBERTSON; THOMSON, 2002; MATSUBAYASHI et al., 2005). No ciclo evolutivo do Cryptosporidium spp. são produzidos dois tipos de oocistos: a maioria com paredes espessas, que são eliminados nas fezes, e outros com paredes mais finas, que liberam esporozoítos no intestino e causam autoinfecção (URQUHART et al., 1998; SIDDIKI; MASUDUZZAMAN, 2009; CHALMERS; DAVIES, 2010). A esporulação ocorre no hospedeiro: os oocistos, com quatro esporozoítos cada um, são eliminados nas fezes e, após a ingestão, os esporozoítos invadem as microvilosidades dos enterócitos e os trozoítos rapidamente se diferenciam, formando esquizontes com quatro a oito merozoítos. Após uma ou duas gerações de esquizontes ocorre a gametonia e produção de oocistos (URQUHART et al., 1998; SIDDIKI; MASUDUZZAMAN, 2009; CHALMERS; DAVIES, 2010). No ciclo do protozoário flagelado Giardia spp., a transmissão ocorre através da ingestão dos cistos pelo hospedeiro. No interior do hospedeiro, os cistos liberam no intestino os trofozoítos, que se multiplicam assexuadamente na superfície mucosa e liberam resistentes cistos nas fezes (THOMPSON; KUTZ; SMITH, 2009). No ciclo do Sarcocystis spp., a infecção no hospedeiro final ocorre através da ingestão de cistos de bradizoítos nos músculos do hospedeiro intermediário. Os bradizoítos são então liberados no intestino, e se diferenciam em micro e macrogametócitos. Após a conjugação dos gametas, formam-se os oocistos de paredes finas, que esporulam no 
corpo, formando dois esporocistos, cada qual contendo quatro esporozoítos, que são encontrados nas fezes (URQUHART et al., 1998; XIANG et al., 2009). No hospedeiro intermediário, a infecção ocorre pela ingestão dos esporocistos. Ocorrem três ciclos assexuados, sendo que, no primeiro, os esporozoítos são liberados pelos esporocistos e invadem a parede intestinal. No terceiro ciclo, nos linfócitos circulantes, os merozoítos penetram em células musculares, se encistam e dão origem aos bradizoítos contidos em um cisto, que é denominado sarcocisto maduro, e é o estágio infectante para o hospedeiro final carnívoro (URQUHART et al., 1998; XIANG et al., 2009). Para o protozoário Hammondia hammondi, o hospedeiro final é o gato. Os hospedeiros intermediários são os pequenos roedores (URQUHART et al., 1998). Oocistos não esporulados são produzidos nas fezes e, após a infecção de roedores a multiplicação de taquizoítos na parede intestinal é seguida pela produção de cistos contendo bradizoítos na musculatura esquelética (URQUHART et al., 1998).

As infecções por Cryptosporidium spp. e Giardia spp. podem causar anorexia, diarreia e perda de peso em animais jovens ou imunossuprimidos (URQUHART et al., 1998; XIAO; RYAN, 2004; SIDDIKI; MASUDUZZAMAN, 2009; CHALMERS; DAVIES, 2010) e podem também ser autolimitante em alguns indivíduos (MUNDIM et al., 2003; PAPINI et al., 2007). Não se conhece o impacto da infecção em animais silvestres de vida livre (APPELBEE; THOMPSON; OLSON, 2005; THOMPSON et al., 2008; THOMPSON; KUTZ; SMITH, 2009). A infecção por Sarcocystis spp. no hospedeiro final normalmente não é patogênica. No hospedeiro intermediário, infecções maciças podem causar anorexia, febre, anemia e perda de peso (URQUHART et al., 1998). A infecção por Hammondia hammondi não é considerada patogênica para nenhum hospedeiro (URQUHART et al., 1998). Nem o Sarcocystis spp., nem a Hammondia spp. são considerados patogênicos para gatos (BOWMAN, 1999). Não existe tratamento específico para esses protozoários (URQUHART et al., 1998; SIDDIKI; MASUDUZZAMAN, 2009). Assim, as medidas de controle são as de higiene, sendo que cães e gatos de propriedades rurais não devem ser mantidos próximos a áreas de contato de animais de produção ou silvestres (URQUHART et al., 1998).

Em estudo realizado com felinos de vida livre na Tailândia, Patton e Rabinowitz (1994) relataram leopardos e tigres positivos para Sarcocystis spp. e leopardos positivos para Giardia spp. e para oocistos semelhantes a Hammondia spp. e Toxoplasma spp. Em Belize, oocistos de Hammondia pardalis foram isolados de amostras fecais de onças-pintadas, jaguatiricas e onçaparda de vida livre; oocistos semelhantes a Toxoplasma gondii/Hammondia hammondi foram isolados de onças-pintadas e jaguatiricas; e em nenhuma dessas espécies identificou-se oocistos 
de Sarcocystis spp. (PATTON et al., 1986). A presença de Sarcocystis spp. identificado como $S$. felis foi observado em guepardos (BRIGGS; LEATHERS; FOREYT, 1993), linces-pardos (ANDERSON et al., 1992; DUBEY et al., 1992), onça-parda (GREINER et al., 1989) e leão (DUBEY; BWANGAMOI, 1994). A presença de Sarcocystis spp. foi também relatada em músculo e fezes de uma onça-parda mantida em cativeiro (DUBEY, 1982), e em músculos de leões da Namíbia (KINSEL et al., 1998).

Cryptosporidium spp. já foi detectado em ampla variedade de carnívoros silvestres como raposa, coiote, lobo-cinzento, lince-pardo, guaxinim (ZHOU et al., 2004; FENG et al., 2007; PAZIEWSKA et al., 2007; ZIEGLER et al., 2007). Lim et al. (2008) em estudo realizado em zoológico na Malásia, relataram que felinos geralmente são mais positivos para parasitas intestinais que primatas ou ungulados. Nesse estudo, Cryptosporidium spp. foi o segundo protozoário mais encontrado, tendo sido relatado em tigres - porém, duas onças-pintadas amostradas foram negativas para o agente. Em animais de cativeiro, Matsubayashi et al. (2005) pesquisou Giardia spp. e Cryptosporidium spp. em onças-pintadas, mas nenhum animal foi positivo. Alves et al. (2005) pesquisou a presença de Cryptosporidium em onça-pintada do zoológico de Lisboa, também não encontrando animal positivo.

No Brasil, o parasitismo por Giardia spp. foi relatado em onças-pintadas, onças-pardas, gatos-do-mato-pequeno e gato-do-mato-grande mantidos em cativeiro (MÜLLER; GREINERT; SILVA FILHO, 2005; SILVA et al., 2008), em ouriços-cacheiros (Coendou villosus) (SOARES et al., 2008; LALLO et al., 2009) e gato-maracajá de vida livre (OLIVEIRA et al., 2008).

\subsection{CARRAPATOS EM ONÇAS-PINTADAS}

Carrapatos pertencem à Classe Arachnida, Subclasse Acari, Ordem Parasitiformes e Subordem Ixodida (BARROS-BATTESTI; ARZUA; BECHARA, 2006). São ectoparasitas de animais vertebrados terrestres, voadores ou semiaquáticos de todos os continentes do mundo (HOOGSTRAAL, 1981; LABRUNA et al., 2005). Devido ao impacto negativo em animais de produção e na saúde pública, são uma grande preocupação (LIMA E SILVA; SZABO; BECHARA, 2004), agindo como vetores de microorganismos e causando alterações na pele e fisiologia do hospedeiro (BARROS-BATTESTI; ARZUA; BECHARA, 2006; ANDERSON; MAGNARELLI, 2008; DANTAS-TORRES, 2008; DANTAS-TORRES et al., 2010). 
Acredita-se que as mudanças climáticas tenham impacto na emergência de doenças infecciosas em todo o mundo, alterando a distribuição dos vetores e doenças transmitidas por eles (GEORGE; DAVEY; POUND, 2002; MUNSON et al., 2008; AGUIRRE, 2009; GILBERT, 2010). A crescente interação entre humanos, animais silvestres e domésticos conduz também para novas associações hospedeiro-carrapato, possibilitando a transmissão de patógenos entre diferentes espécies (HOOGSTRAAL, 1981; DASZAK; CUNNINGHAM; HYATT, 2000; LIMA E SILVA; SZABO; BECHARA, 2004).

Normalmente, os carrapatos possuem um único ciclo de vida, alimentam-se de sangue em hospedeiros vertebrados e passam $90 \%$ de sua vida fora dos hospedeiros, vulneráveis no ambiente (LABRUNA et al., 2005). Dessa forma, vegetação, altitude, longitude, temperatura, umidade e a presença do hospedeiro principal são cruciais para a sobrevivência do carrapato (LABRUNA et al., 2005; ANDERSON; MAGNARELLI, 2008). As espécies de carrapatos possuem predileção por uma espécie de hospedeiro, porém, na sua ausência, podem parasitar outras espécies distintas (LABRUNA et al., 2002; LABRUNA et al., 2005).

Mais de 800 espécies de carrapatos já foram descritas no mundo (KEIRANS, 1992; CAMICAS et al., 1998). No Brasil, há 54 espécies, sendo 33 do gênero Amblyomma (ARAGÃO; FONSECA, 1961; GUIMARÃES; TUCCI; BARROS-BATTESTI, 2001). Segundo Labruna et al. (2005), as espécies de carrapatos mais comuns parasitando carnívoros silvestres no Brasil são Amblyomma ovale, Amblyomma cajennense, Amblyomma aureolatum, Amblyomma tigrinum, Amblyomma parvum e Rhiphicephalus microplus.

Em onças-pintadas de vida livre do Chaco Paraguaio foi relatado a presença de Amblyomma cajennense, A. parvum, A. tigrinum, A. triste (DURDEN et al., 2006) e Ornithodoros rostratus (MASSI PALLARÉS; BENÍTEZ USHER, 1982 apud DURDEN et al., 2006, p. 190). Na literatura, existe também relato das seguintes espécies em onças-pintadas: $A$. ovale, no Panamá e Venezuela, e I. affinis, Ixodes boliviensis, no Panamá (FAIRCHILD et al., 1966 apud DURDEN et al., 2006, p. 190; JONES et al., 1972 apud DURDEN et al., 2006, p. 190; HOOGESTEIJN; MONDOLFI, 1992).

No Brasil, foi identificado a presença de Amblyomma sp., Amblyomma brasiliense, A. cajennense, A. coelebs, A. oblongoguttatum, A. ovale, A. parvum, A. tigrinum, A. triste, Dermacentor nitens e Rhipicephalus microplus em onças-pintadas (ARAGÃO, 1936; ARAGÃO; FONSECA, 1961; SINKOC et al., 1998; LABRUNA et al., 2002; LABRUNA et al., 2005; NAVA, 2008; WIDMER, 2009).

MASSI PALLARÉS, R., BENÍTEZ USHER, C. A. De La distribución de Ixodina (Vander Hammen, 1968) em el Paraguay. Revista Paraguaya de Microbiología, v. 17, p. 49-52, 1982.

FAIRCHILD, G. B.; KOHLS, G. M.; TIPTON, V. J. The ticks of Panama (Acarina: Ixodoidea). In: WENZEL, R. L.; TIPTON, V. J. (eds.). Ectoparasites of Panama. Chicago: Field Museum of Natural History, 1966. p. 167-219.

JONES, E. K.; CLIFFORD, C. M.; KEIRANS, J. E.; KOHLS, G. M. The ticks of Venezuela (Acarina: Ixodoidea) with a key to the species of Amblyomma in the Western hemisphere. Brigham Young Univ. Sci. Bull. Biol. Ser., v. 17, n. 4, p. 1-40, 1972. 


\section{MATERIAIS E MÉTODOS}

São descritos a seguir, os materiais e métodos utilizados para alcançar os objetivos deste trabalho.

\section{1 ÁREA DE ESTUDO}

O presente estudo foi realizado em áreas preservadas de três biomas brasileiros: na região do Parque Nacional das Emas (PNE) e propriedades rurais do entorno, no estado de Goiás, no bioma Cerrado; na região do Refúgio Ecológico Caiman e propriedades rurais do entorno e Fazenda Barranco Alto, no estado do Mato Grosso do Sul, no bioma Pantanal; e na região do Parque Estadual do Cantão (PEC) e propriedades rurais do entorno, nos estados de Tocantins e Pará, em área de transição entre os biomas Cerrado e Amazônia (Figura 1).

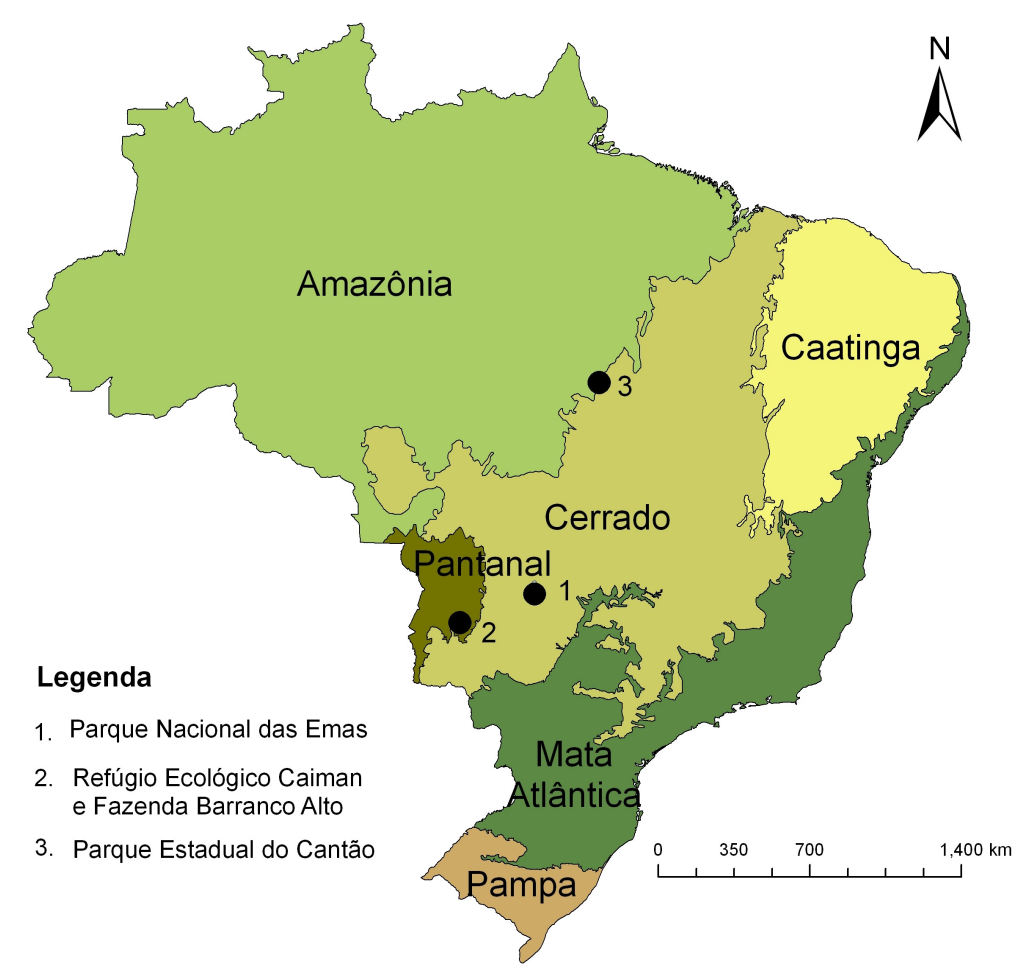

Figura 1 - Localização das áreas de estudo nos biomas brasileiros 


\subsubsection{Parque Nacional das Emas e entorno}

O Cerrado, segundo maior bioma brasileiro, é considerado um "hotspot" ecológico, com aproximadamente $80 \%$ de sua área degradada pelo homem (MYERS et al., 2000; CAVALCANTI; JOLY, 2002). O Parque Nacional das Emas (PNE), com 132.000 hectares, é uma das maiores áreas preservadas de habitat do Cerrado. Localiza-se no sudoeste do estado de Goiás, nos limites entre os estados do Mato Grosso e Mato Grosso do Sul, a -18,061146 S e -52,941067 W, em uma das regiões de maior produção agrícola do Brasil (KLINK; MOREIRA, 2002). A vegetação nativa do entorno do PNE foi convertida em extensas áreas de agricultura - principalmente de soja, milho e, mais recentemente, cana-de-açúcar - e, em menor escala, de pecuária extensiva. Atualmente, o parque é literalmente uma ilha de vegetação natural em um mar de terras agrícolas, tornandose um dos últimos refúgios para diversas espécies silvestres da região, entre elas a onça-pintada (Figura 2). A fragmentação e perda de habitats são as principais ameaças à população de onçapintada neste bioma (SILVEIRA; JÁCOMO, 2002).

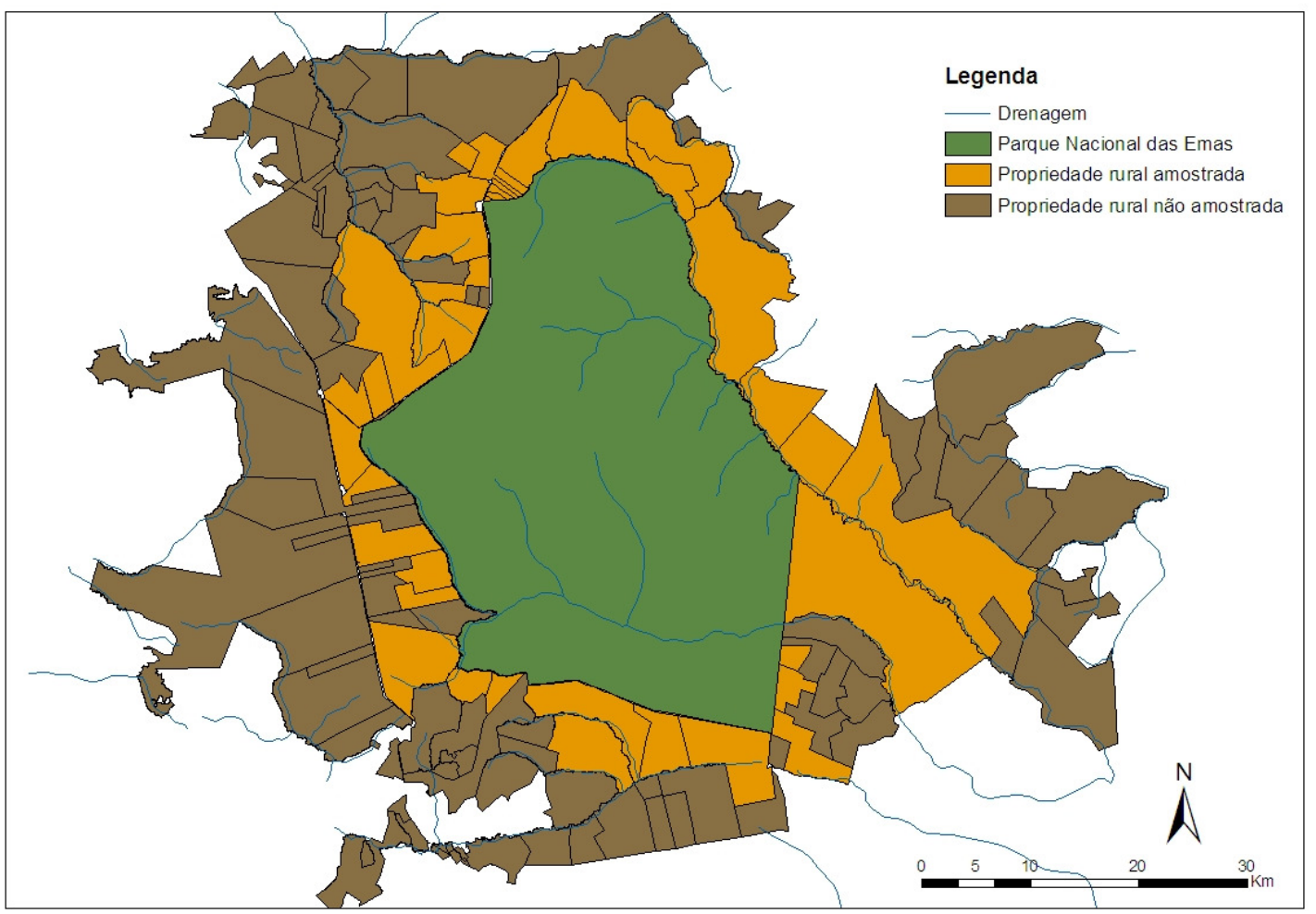

Figura 2 - Parque Nacional das Emas e propriedades rurais do entorno amostradas no presente estudo 


\subsubsection{Propriedades rurais do Pantanal}

O Pantanal é a maior planície inundável do mundo, reconhecido como Reserva da Biosfera e Patrimônio Natural da Humanidade pela UNESCO. A área de estudo, neste bioma, compreendeu o Pantanal sul mato-grossense, na região do Refúgio Ecológico Caiman, com 53.000 ha, e propriedades rurais do entorno, situadas na região de Miranda, coordenadas 19,80319 S e -56,27373 W, e na Fazenda Barranco Alto com 11.000 ha, situada na região de Aquidauana, coordenadas $-19,57643$ S e -56,16144 W (Figura 3). As propriedades rurais dessa área dedicam-se principalmente à pecuária extensiva e, algumas delas, ao ecoturismo. $\mathrm{O}$ Pantanal representa um dos maiores blocos integrado de habitats para a onça-pintada fora da região amazônica. Assim, sua conservação é estrategicamente importante, tanto em escala ecossistêmica, quanto regional, permitindo a manutenção do fluxo gênico entre populações dos biomas vizinhos (SANDERSON et al., 2002). Aproximadamente $95 \%$ da área total deste bioma estão na forma de propriedades privadas ou públicas (CRAWSHAW; QUIGLEY, 1991; HARRIS et al., 2005), sendo que as reservas privadas (RPPNs) representam um importante papel para a conservação da onça-pintada na região. $O$ abate ilegal de onças-pintadas em retaliação aos prejuízos que causam aos rebanhos domésticos é a principal ameaça à espécie neste bioma (CRAWSHAW; QUIGLEY, 2002).

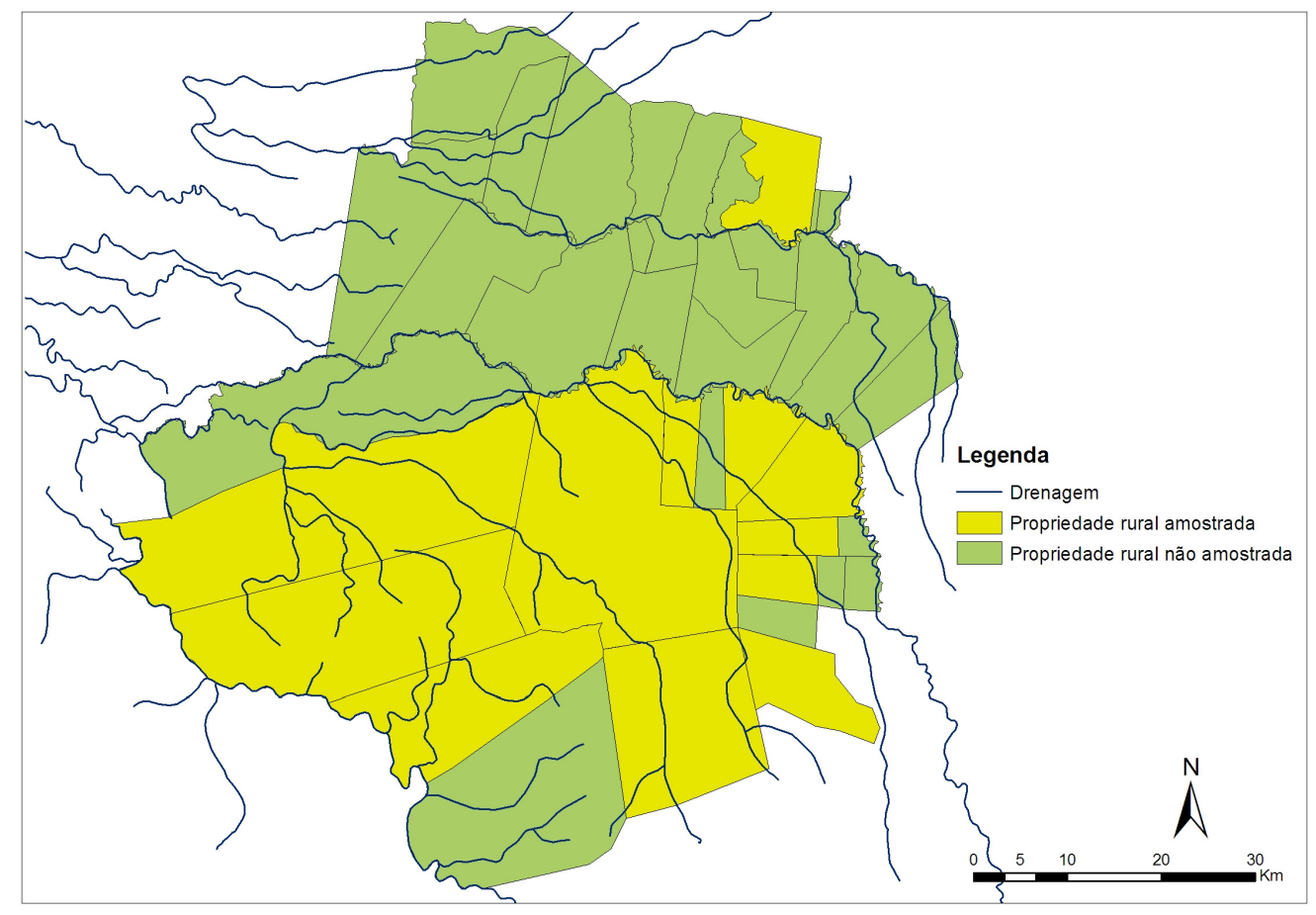

Figura 3 - Propriedades rurais do Pantanal amostradas no presente estudo 


\subsubsection{Parque Estadual do Cantão e entorno}

Localizado ao extremo sudoeste do estado do Tocantins, nas coordenadas geográficas 9,64503 S e -50,13065 W, o Parque Estadual do Cantão (PEC), com 90.000 ha, situa-se em uma região de transição entre os biomas da Amazônia e Cerrado (Figura 4). Situado ao norte da Ilha do Bananal, em continuidade com o Parque Nacional do Araguaia, formam juntos um conjunto de mais de 700.000 ha de extensão, sendo uma das grandes áreas conservadas ao longo do rio Araguaia. Sua localização geográfica consiste em um ecótono de fundamental importância para a manutenção da biodiversidade dos ecossistemas envolvidos e das populações de onça-pintada da região. As propriedades rurais do entorno desenvolvem a pecuária de corte como principal atividade econômica, e terras indígenas são encontradas nas proximidades deste parque estadual. Bioma com maior porcentagem de áreas protegidas e habita a maior população de onça-pintada em território nacional, a Amazônia é extremamente importante para a conservação em longo prazo da espécie (SOLLMANN; TÔRRES; SILVEIRA, 2008). Porém, o desmatamento, principalmente nas proximidades de fronteiras agropecuárias, é a principal ameaça para a espécie na região (MORTON et al., 2006).

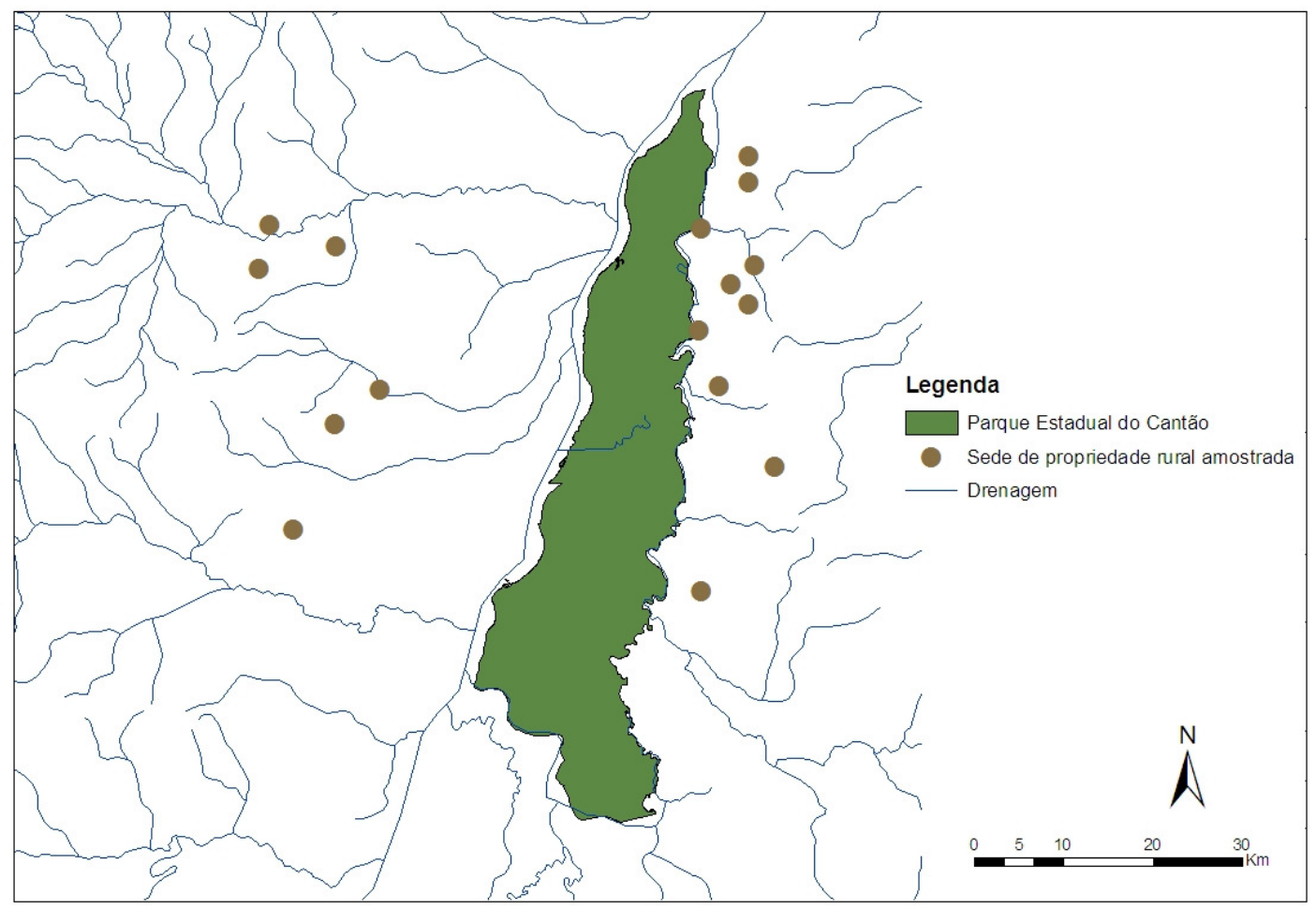

Figura 4 - Parque Estadual do Cantão e localização das sedes das propriedades rurais do entorno amostradas no presente estudo 


\subsection{CAPTURAS DE ONÇAS-PINTADAS}

As onças-pintadas foram capturadas entre fevereiro de 2000 e maio de 2009, como parte do Programa de Monitoramento de Longa Duração das Populações de Onça-Pintada do Instituto Onça-Pintada (JAGUAR CONSERVATION FUND, 2008). Foram utilizados dois métodos de captura de acordo com a área de estudo: cães rastreadores e armadilhas do tipo gaiolas.

As armadilhas do tipo gaiolas $(2,40 \mathrm{~m} \times 0,90 \mathrm{~m} \times 0,90 \mathrm{~m})$ possuíam porcos domésticos como isca e um sistema de desarme tipo "guilhotina", acionado por um gatilho no momento em que o animal entrava na gaiola para capturar a isca (Figuras 5 e 6) (RABINOWITZ, 1986; FURTADO et al., 2008).

Esforços de captura com gaiolas foram realizados no PNE, em 2007 e 2008, e na região do PEC, em 2006. Durante o ano de 2008, 34 armadilhas foram dispostas sistematicamente em áreas onde conhecidamente havia incidência de onça-pintada no PNE. As armadilhas foram distribuídas com uma distância de 1,5 a 3 km entre elas (Figura 7), e, no período em que ficaram abertas, eram vistoriadas diariamente, alimentando-se a isca em caso da não captura da espécie alvo.

Os cães rastreadores foram utilizados para farejar e trilhar a onça-pintada após a localização de seus rastros frescos (Figura 8) (MCBRIDE JÚNIOR; MCBRIDE, 2007; FURTADO et al., 2008). Esse método foi utilizado em todas as áreas de estudo. Uma vez encontrada, a onçapintada foi acuada em cima da árvore (Figura 9) ou no chão (Figura 10) e anestesiada, utilizandose rifle ou pistola a gás. Em caso de acuação em árvore, armou-se uma rede para amortecer a queda do animal e fez-se uma cama com vegetação embaixo da rede para evitar quedas traumáticas (Figura 11). Em seguida, o dardo anestésico foi atirado, a área foi evacuada e os cães rastreadores recolhidos e amarrados de forma a permitir que a onça descesse e fugisse, ou caísse em cima da rede armada (Figura 12). Em casos em que a onça permaneceu em cima da árvore depois de anestesiada (sem cair), um dos pesquisadores subiu na árvore e conduziu a descida do animal com o auxílio de uma corda. A captura utilizando cães rastreadores foi realizada de forma pontual, através de campanhas de captura com duração de 1 a 10 dias de saídas a campo. 


\subsubsection{Onça-Pintada em terra indígena}

Uma onça-pintada jovem, que foi criada em terra indígena próxima ao Parque Estadual do Cantão, também fez parte da amostragem deste trabalho (Figura 13). O animal, de aproximadamente um ano, foi retirado da aldeia pela agência ambiental local (IBAMA-MT) atendendo a solicitação dos moradores. Realizou-se a contenção química do animal para os procedimentos deste estudo e, posteriormente, o animal foi encaminhado a um criadouro conservacionista.

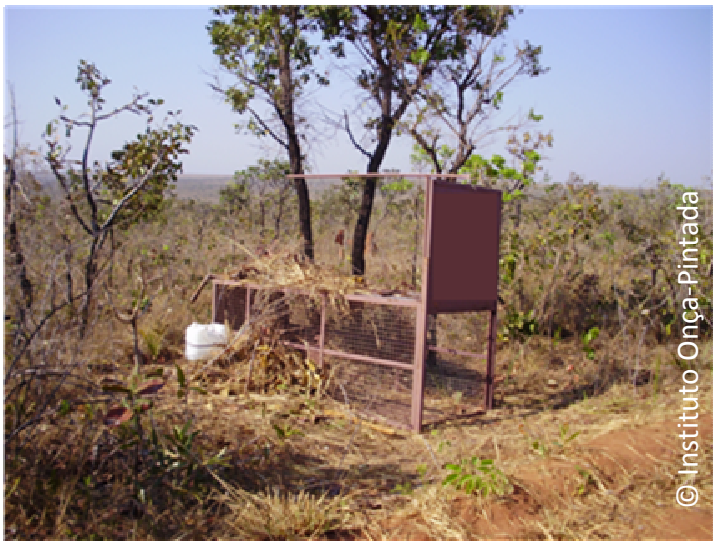

Figura 5 - Armadilha do tipo gaiola utilizada para captura de onça-pintada no PNE

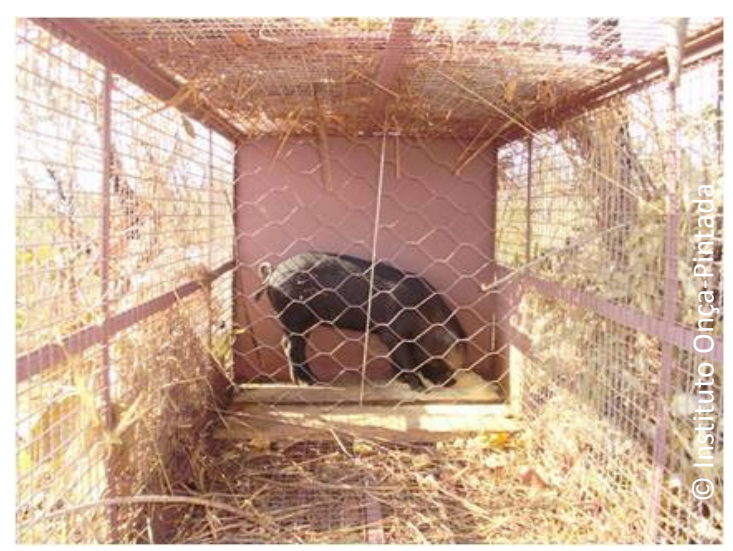

Figura 6 - Porco doméstico utilizado como isca, no interior da gaiola para captura de onça-pintada

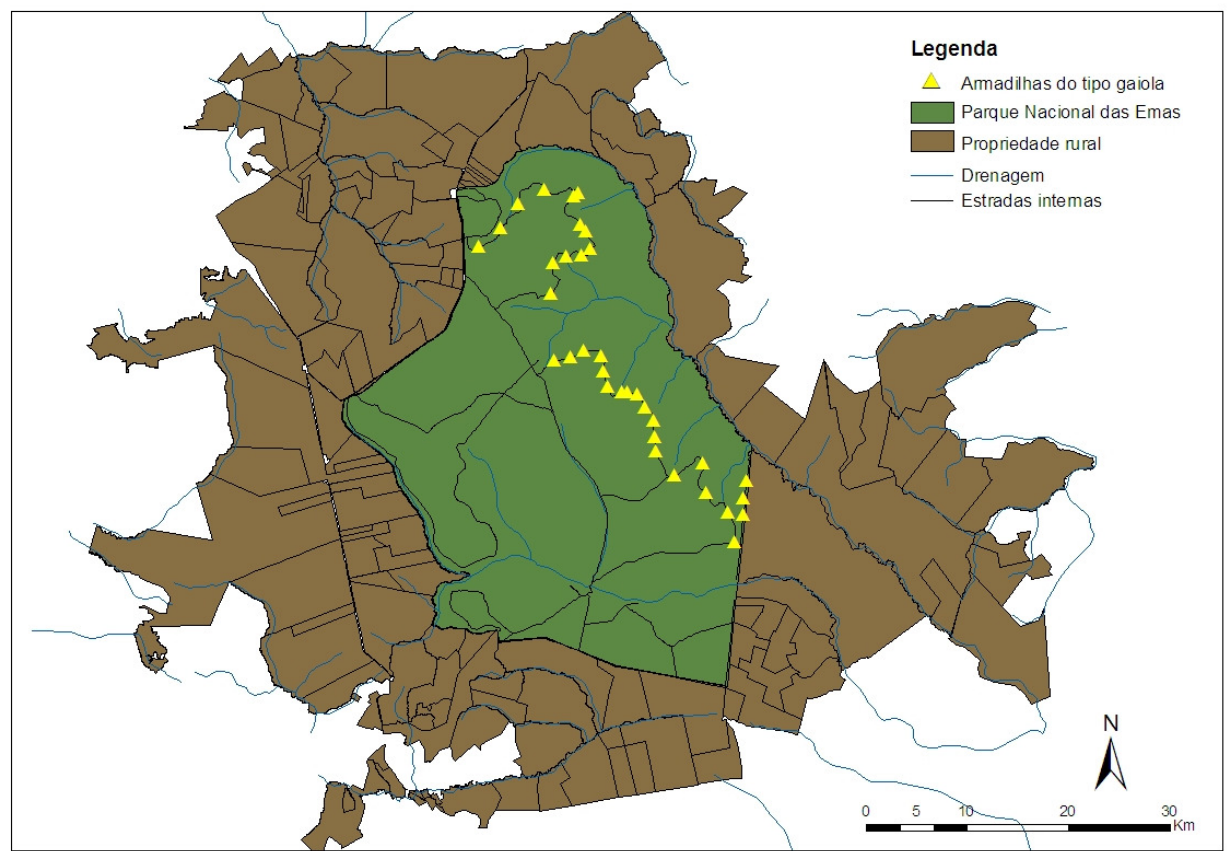

Figura 7 - Distribuição das 34 armadilhas do tipo gaiola para captura de onçaspintadas no interior do PNE 


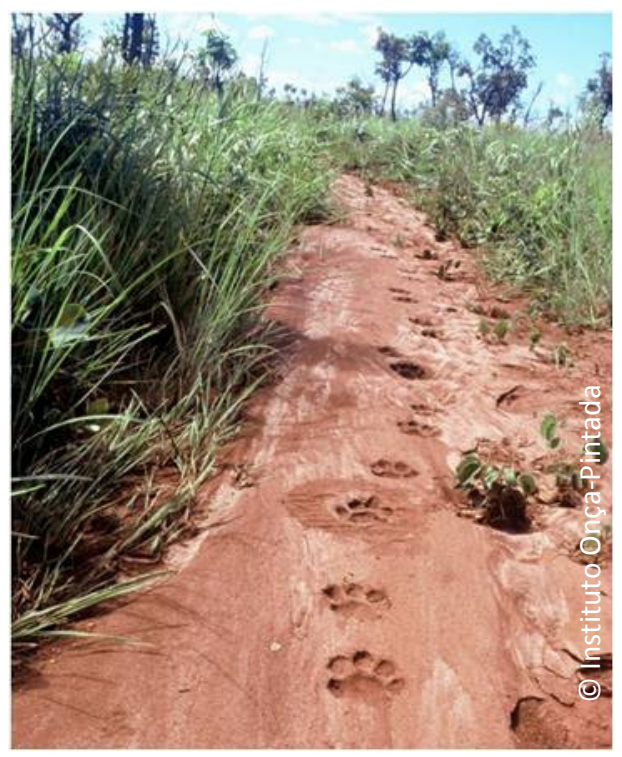

Figura 8 - Rastro fresco de onça-pintada nas estradas do PNE

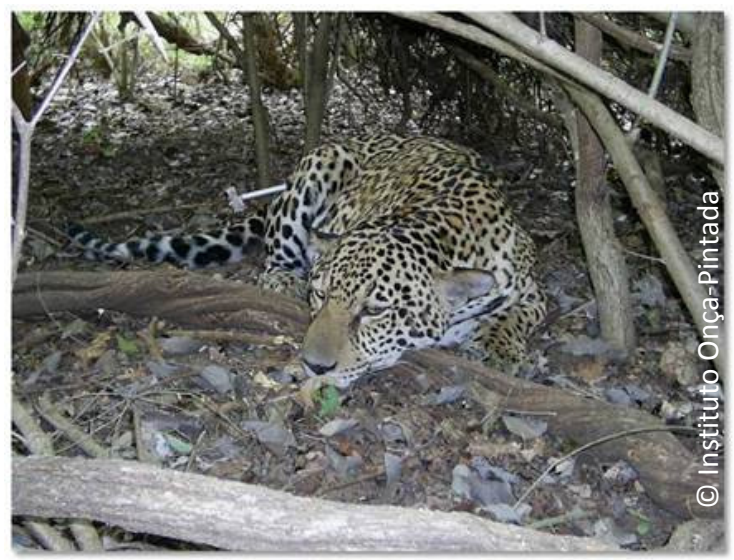

Figura 10 - Onça-pintada acuada no chão, após ser atingida pelo dardo anestésico no PEC

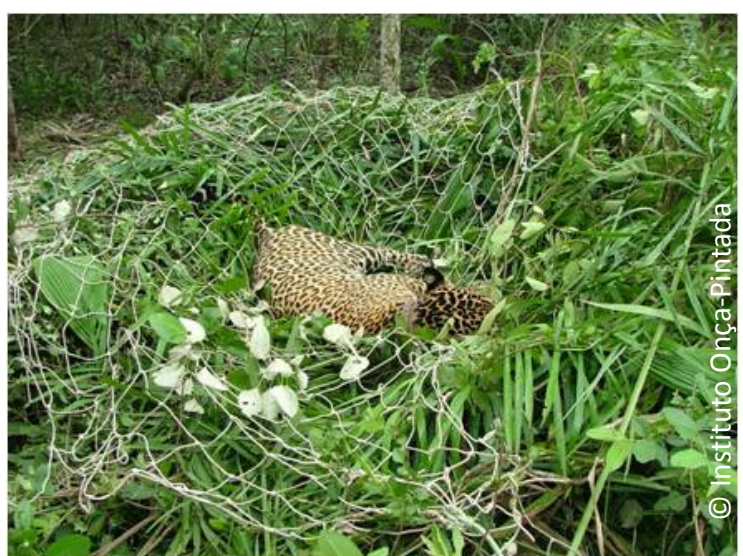

Figura 12 - Onça-pintada anestesiada após queda da árvore em cima da rede e da cama de vegetação

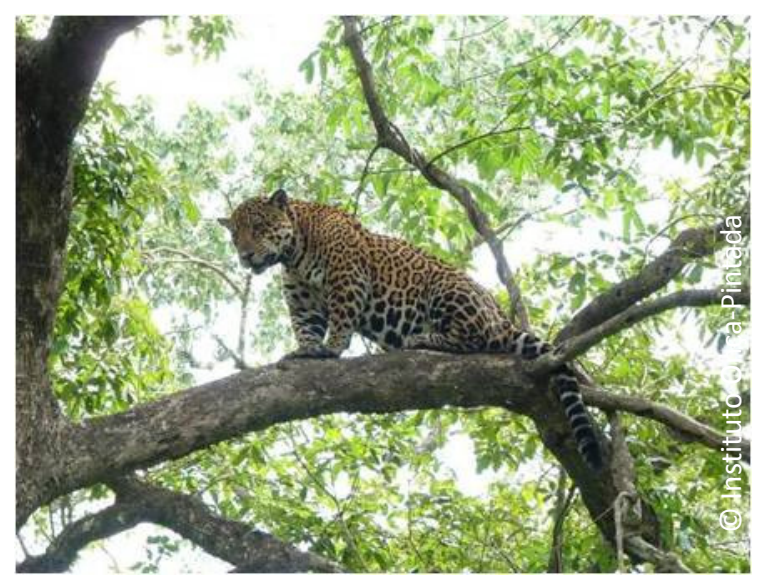

Figura 9 - Onça-pintada acuada em árvore no Pantanal após ser localizada pelos cães rastreadores

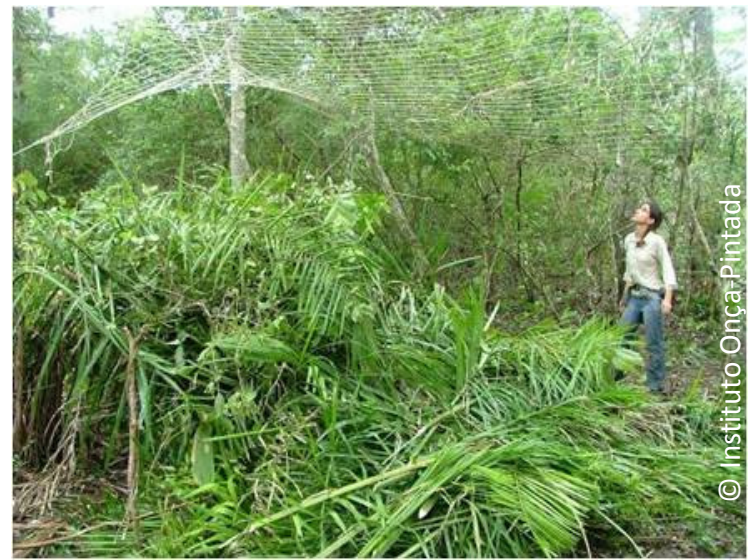

Figura 11 - Rede armada para amortecer e evitar quedas traumáticas da onça-pintada, com cama de vegetação embaixo

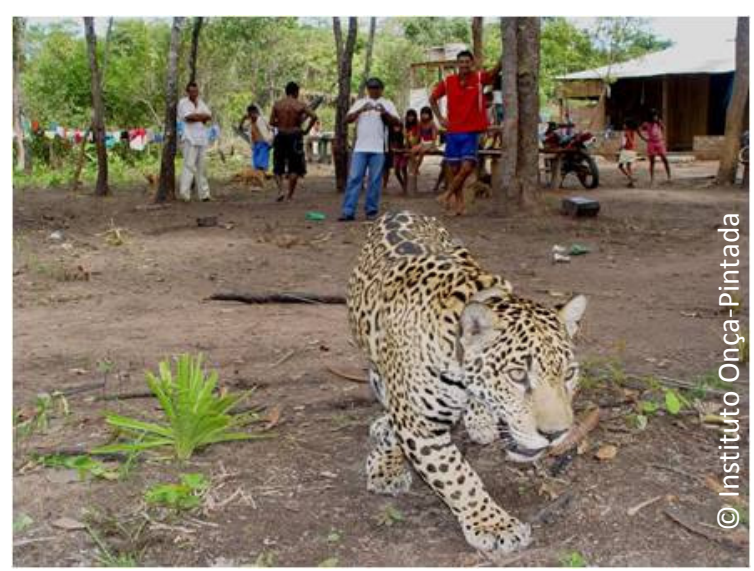

Figura 13 - Onça-pintada criada em terra indígena próxima ao PEC 


\subsubsection{Imobilização, exame físico e colocação de radiotransmissor}

As onças-pintadas foram anestesiadas com a associação de cloridrato de tiletamina com cloridrato de zolazepam (Zoletil ${ }^{\circledR}$ ou Telazol ${ }^{\circ}$ ), na dose estimada de $10 \mathrm{mg} / \mathrm{kg}$, via intramuscular. Após a visualização do animal, seu peso foi estimado para a administração da dosagem aproximada do anestésico. Os dardos anestésicos foram administrados utilizando pistola ou rifle a gás, atingindo, preferencialmente, a região da musculatura coxofemural, na parte traseira, ou musculatura do tríceps, na região dianteira.

Imediatamente após o animal estar completamente imobilizado, realizou-se a avaliação dos parâmetros fisiológicos (frequência respiratória, frequência cardíaca e temperatura), que foram monitorados em intervalos de 10 minutos (Figura 14). 0 dardo anestésico foi retirado do animal, e o local afetado foi limpo e tratado com um antibiótico/cicatrizante/repelente tópico. O animal foi colocado em uma posição que permitisse a fácil respiração e, sempre que possível, entubado utilizando uma sonda endotraqueal de tamanho adequado para o indivíduo (Figura 15). As onças foram colocadas em decúbito lateral e seus olhos protegidos com uma pomada oftálmica (Epitezan), prevenindo possíveis ressecamentos durante a imobilização. A veia cefálica ou femoral foi canulada, permitindo, se necessário, o acesso venoso durante todo o procedimento e a veiculação de soro fisiológico (Figura 16).

Após os procedimentos iniciais, realizou-se o exame físico e a pesagem do indivíduo (Figura 17). Os animais foram classificados, de acordo com o desgaste dentário e peso corpóreo, em adultos (idade superior a 2 anos), subadultos (entre 1 e 2 anos), jovens (6 meses a 1 ano) ou filhotes (0 a 6 meses).

Para exame físico geral, utilizou-se a ficha clínica que se encontra no apêndice A. Através da inspeção direta, observou-se a condição física do indivíduo, a hidratação, tempo de preenchimento capilar e a presença ou não de lesões, fraturas ou possíveis sinais característicos de enfermidades. As mucosas oculares, nasal, bucal (Figura 18), vulvar, prepucial e anal foram observadas quanto à coloração, ulceração, hemorragia e secreções. No sistema músculoesquelético, para procurar possíveis alterações, realizou-se inspeção direta, palpação e manipulação das estruturas do sistema. Possíveis alterações no sistema digestório foram verificadas através da inspeção direta da cavidade bucal, lábios, língua, dentes e palpação abdominal. Verificou-se o sistema genitourinário através da inspeção direta e palpação. 
Todas as onças-pintadas adultas foram equipadas com radiotransmissor, para monitoramento através da técnica da radiotelemetria (Figura 19). Cada radiotransmissor possuía uma frequência nas faixas de $150.000 \mathrm{MHz}$ ou $151.000 \mathrm{MHz}$ e bateria com duração entre 24 e 36 meses.

O animal foi mantido em local sombreado e tranquilo para sua recuperação pósanestésica. Permaneciam no local a médica veterinária e um auxiliar, a uma distância segura que permitisse a observação do animal. Quando a onça apresentava-se levantando a cabeça e em decúbito esternal, os pesquisadores se retiravam do local e passavam a monitorá-la através da radiotelemetria.

Foram realizadas capturas de indivíduos, e recapturas de indivíduos previamente capturados e que já possuíam radiotransmissor. As recapturas foram realizadas, com intervalo superior a 60 dias, para a troca do radiotransmissor quando necessário, e coleta de material biológico, mantendo dessa forma contínuo o monitoramento sanitário destes indivíduos.

\subsubsection{Coleta e armazenamento de sangue e ectoparasitas de onças-pintadas}

As amostras sanguíneas das onças-pintadas foram coletadas pela punção da veia femoral interna em tubos a vácuo (tipo vacutainer) com e sem anticoagulante (EDTA) (Figuras 20 e 21). As amostras foram transportadas até a base de pesquisa, onde o soro foi extraído após centrifugação por 5 minutos e congelado em freezer a $-20^{\circ} \mathrm{C}$. As amostras de sangue total foram separadas em alíquotas com um volume igual de solução salina saturada (100 mM Tris, 100 mM EDTA, 2\% SDS) ou em alguns casos sem a adição do tampão, foram congeladas em freezer a $20^{\circ} \mathrm{C}$.

Os ectoparasitas foram detectados por inspeção no corpo do animal, e cuidadosamente removidos manualmente (Figura 22). Os exemplares coletados foram armazenados em tubos contendo álcool $70 \%$ até sua identificação taxonômica.

Nem sempre foi possível a coleta de todos os materiais biológicos (soro, sangue total e ectoparasita) em todos os eventos de captura. 


\subsubsection{Coleta e armazenamento de fezes de onças-pintadas}

As amostras de fezes frescas de onça-pintada foram coletadas em campo com o auxilio de cães farejadores de fezes (Figura 23). Uma parte das amostras foi acondicionada em sacos plásticos e congeladas a $-20^{\circ} \mathrm{C}$, e outra parte acomodada em frascos coletores universais contendo solução de bicromato de potássio a $2 \%$ e mantidas sob refrigeração a $4^{\circ} \mathrm{C}$.

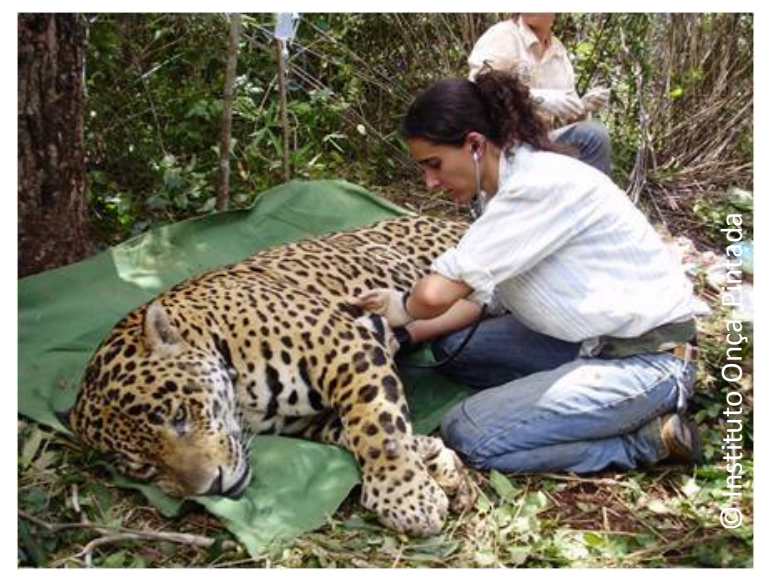

Figura 14 - Monitoramento da frequência cardíaca de macho capturado no PNE

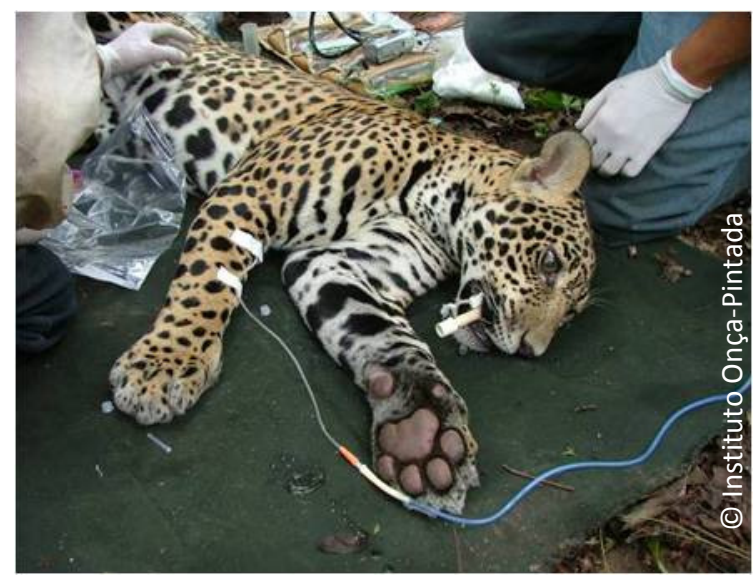

Figura 16 - Detalhe para a veia canulada em onça-pintada durante realização dos procedimentos
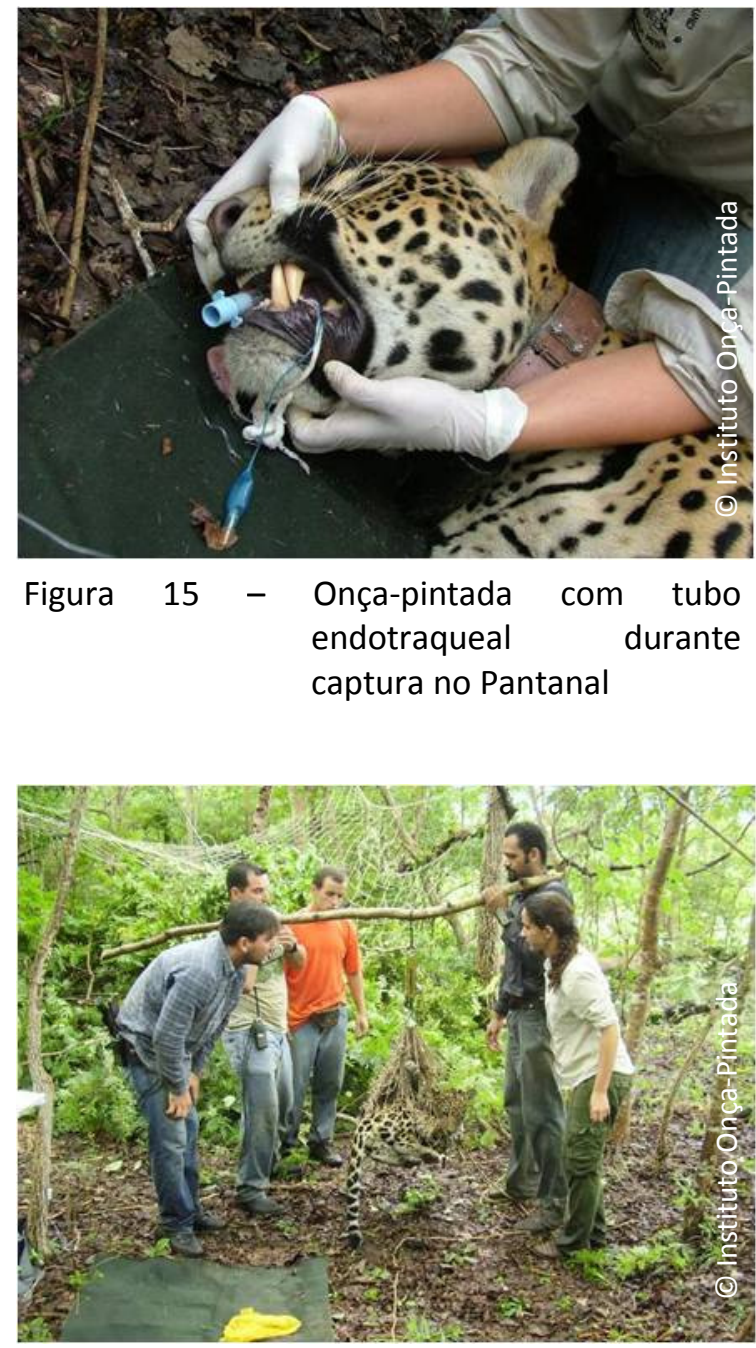

Figura 17 - Onça-pintada fêmea sendo pesada no Pantanal 


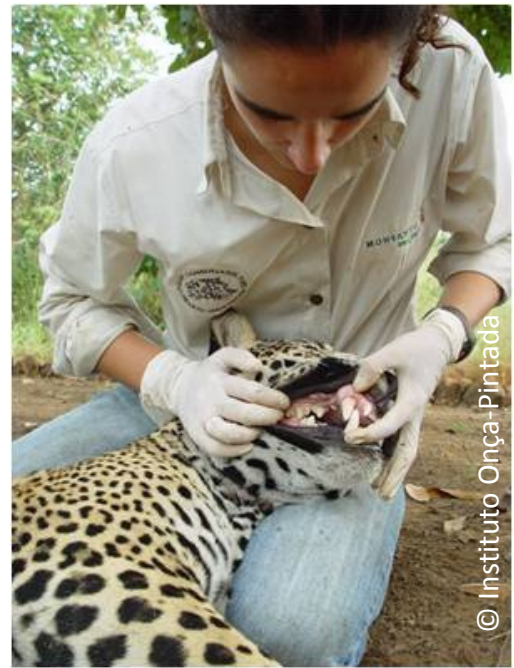

Figura 18 - Observação da coloração da mucosa oral durante exame físico

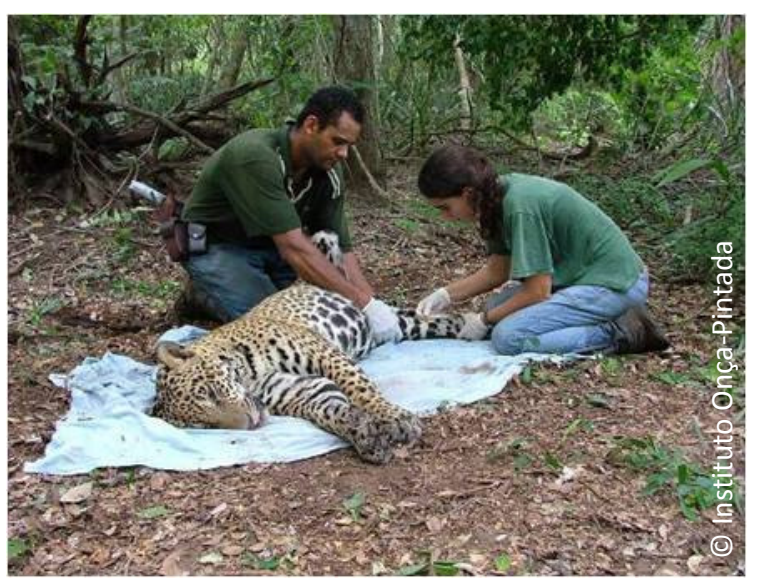

Figura 20 - Coleta de sangue pela veia femoral interna de macho jovem capturado no Pantanal

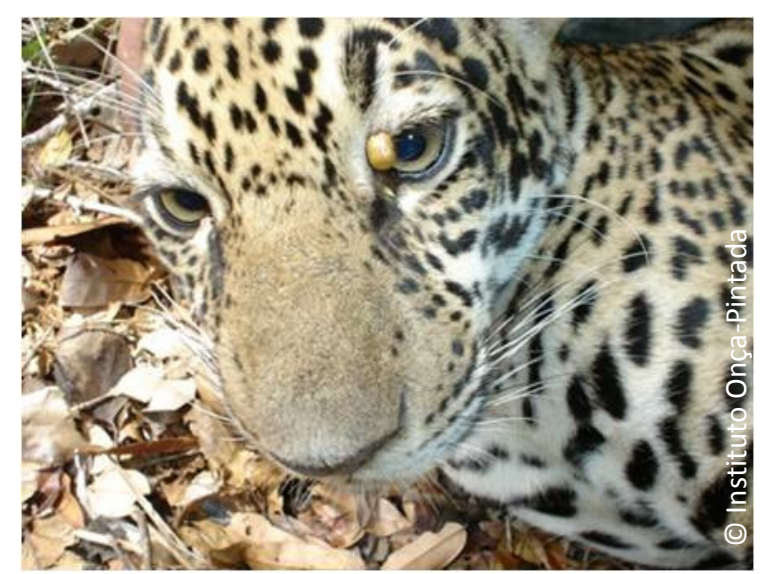

Figura 22 - Destaque para carrapto localizado na pálpebra esquerda de onçapintada

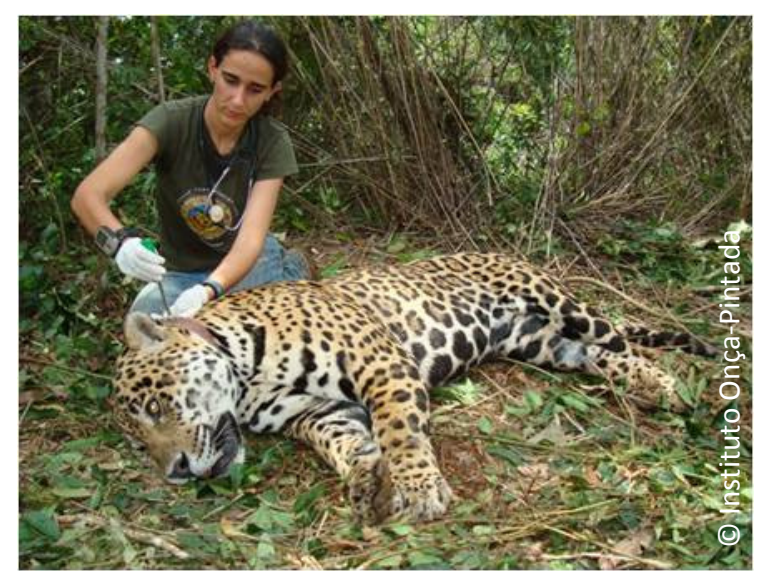

Figura 19 - Colocação de rádio-colar em macho de onça-pintada capturado no PNE

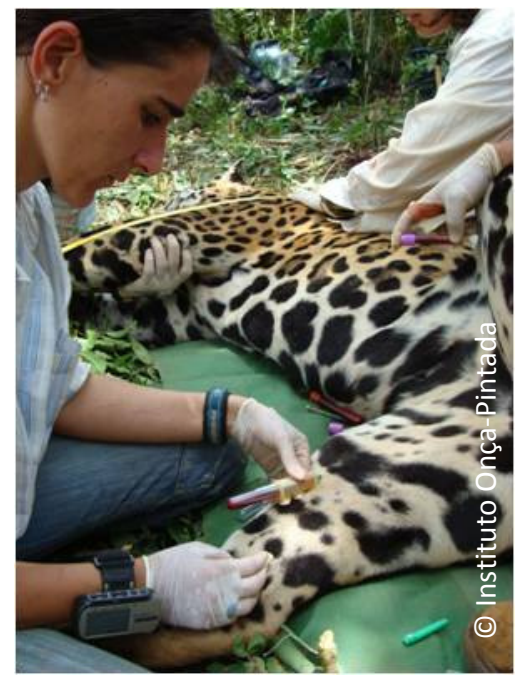

Figura 21 - Detalhe para a coleta de sangue pela veia femoral interna

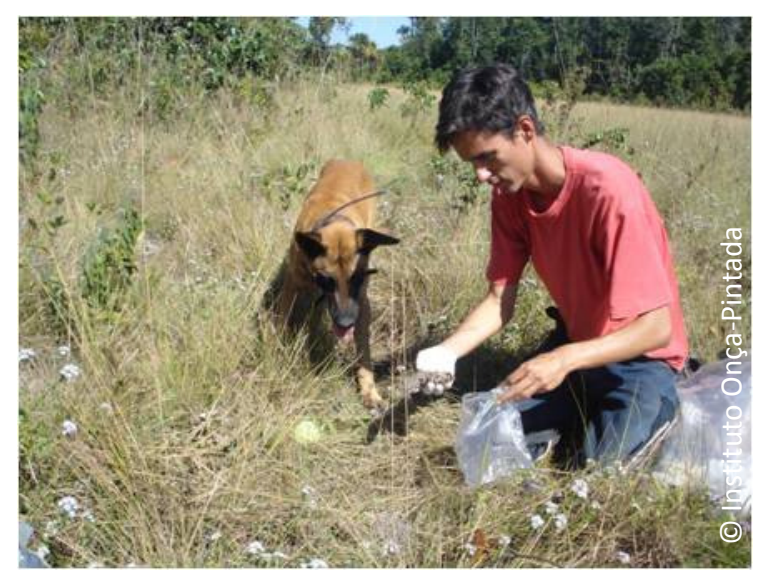

Figura 23 - Coleta de fezes de onça-pintada localizada com o auxílio de cão farejador 


\subsection{PROPRIEDADES RURAIS AMOSTRADAS}

Entre maio de 2008 e janeiro de 2010, realizou-se a coleta de amostras biológicas dos bovinos, cães e gatos domésticos das propriedades rurais. Procurou-se amostrar o maior número de propriedades que fazem limite direto com as áreas preservadas amostradas neste estudo. Porém, devido às dificuldades logísticas, ausência do proprietário ou funcionário na propriedade ou a não autorização do proprietário para a realização das coletas, nem sempre foi possível amostrar todas as propriedades do entorno (ver figuras 2, 3 e 4).

\subsubsection{Coleta e armazenamento de sangue e ectoparasitas de animais domésticos}

Os bovinos amostrados foram em sua maioria fêmeas com idade $\geq 24$ meses, sendo que, em uma das propriedades rurais do entorno do PNE, amostrou-se indivíduos machos. As amostras sanguíneas do gado foram coletadas pela punção da veia da cauda, em tubos a vácuo (tipo vacutainer) sem anticoagulante (Figura 24). As amostras sanguíneas de cães e gatos domésticos foram coletadas, pela punção da veia jugular ou cefálica, em tubos a vácuo com e sem anticoagulante (Figuras 25 a 27). As amostras foram transportadas até a base de pesquisa e, após centrifugação por 5 minutos das amostras dos tubos sem anticoagulante, o soro foi extraído e congelado em freezer a $-20^{\circ} \mathrm{C}$. As amostras de sangue total, coletadas em tubos com anticoagulante, foram separadas em alíquotas e congeladas em freezer a $-20^{\circ} \mathrm{C}$ (Figuras 28 e 29).

Amostras de ectoparasitas dos animais domésticos foram coletadas e conservadas em tubos contendo álcool $70 \%$ até sua identificação taxonômica. 


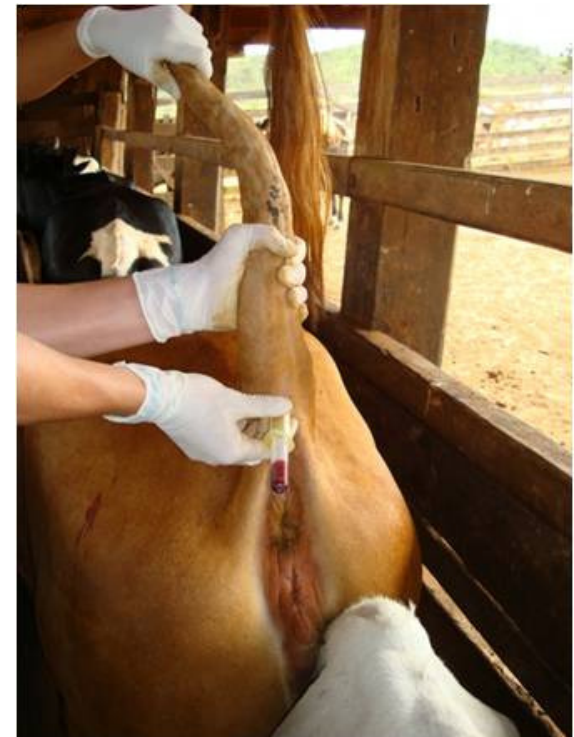

Figura 24 - Coleta de sangue de bovino através da punção da veia da cauda

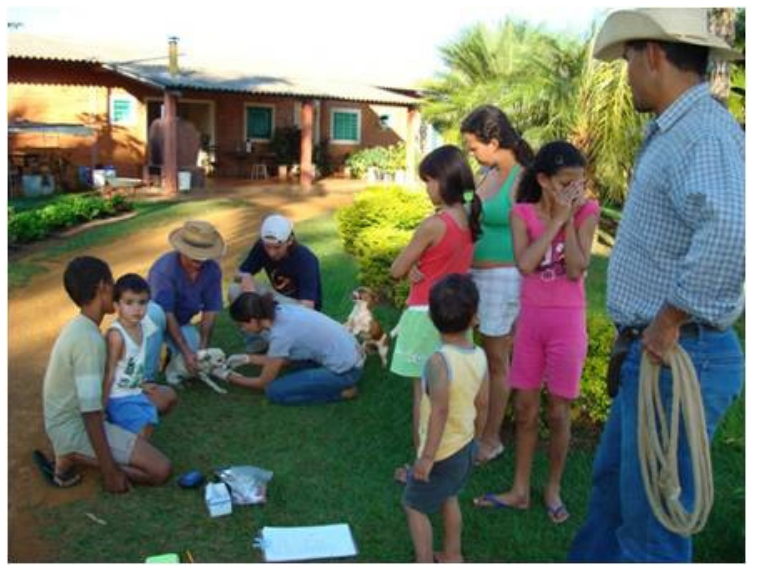

Figura 26 - Funcionários e crianças da fazenda acompanhando a coleta de sangue de cão doméstico

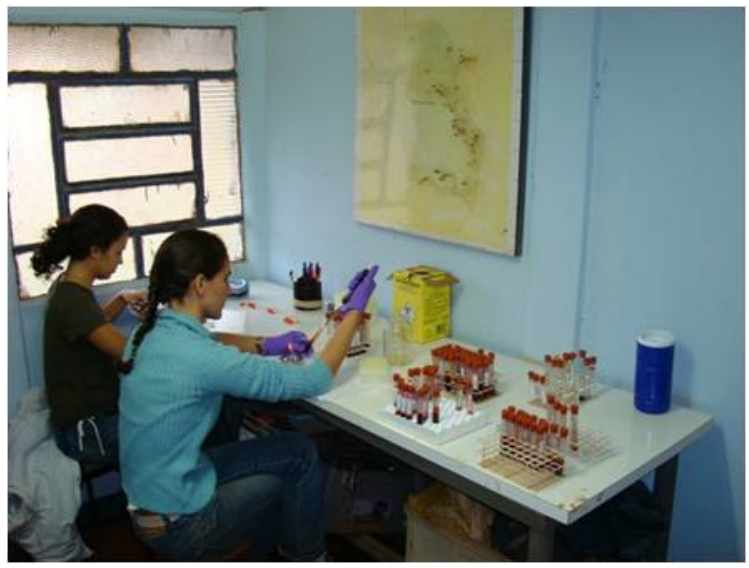

Figura 28 - Extração do soro e armazenamento das amostras coletadas

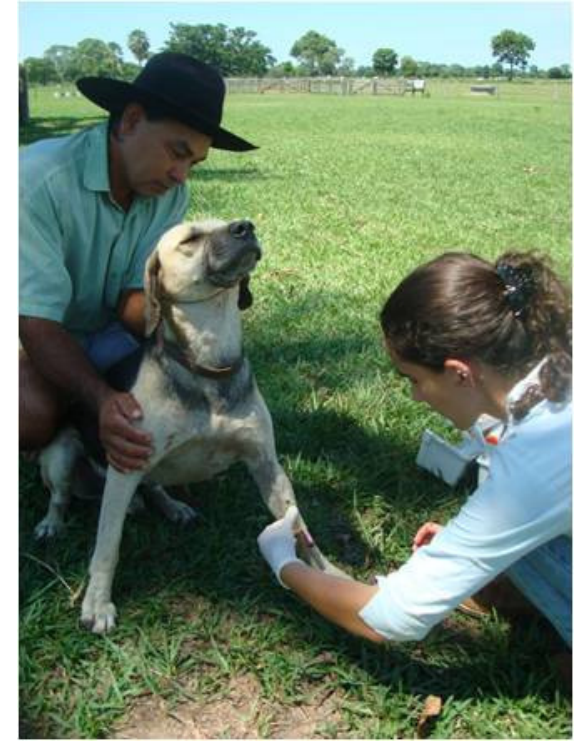

Figura 25 - Coleta de sangue pela veia cefálica de cão doméstico

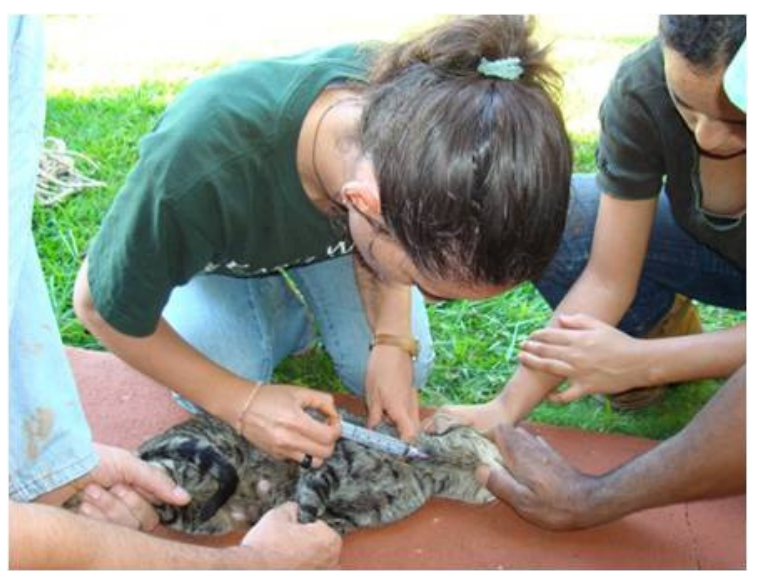

Figura 27 - Coleta de sangue de gato doméstico pela veia jugular no entorno do PNE

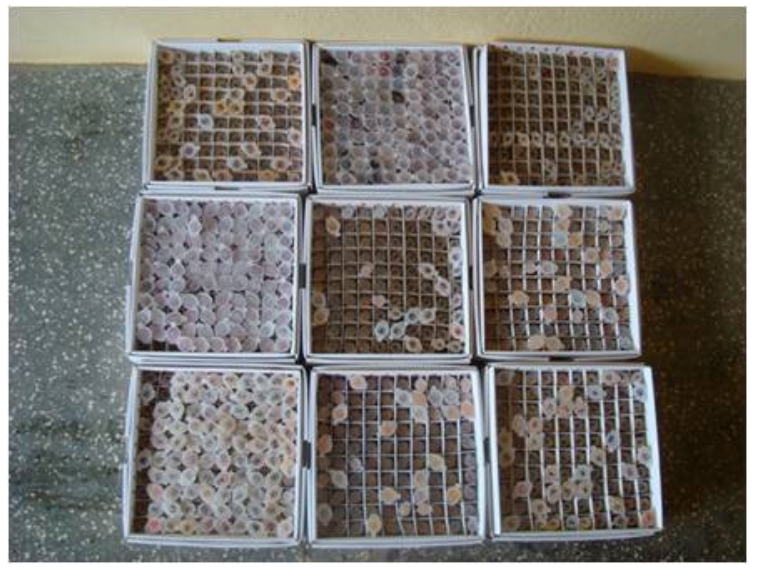

Figura 29 - Amostras identificadas e separadas em alíquotas 


\subsubsection{Tamanho Amostral}

As onças-pintadas foram capturadas de acordo com as atividades dos projetos de pesquisas do Instituto Onça-Pintada (IOP).

Os cães foram amostrados sempre que presentes nas propriedades, e os gatos domésticos, sempre que possível sua contenção física.

O planejamento amostral para as propriedades com bovinos visou simplesmente detectar a presença das enfermidades. Para o cálculo do tamanho da amostra, a população foi considerada como sendo infinita, o nível de confiança adotado foi de $95 \%$ e a prevalência intrarrebanho foi considerada como sendo de 5\%. Através da tabela de Cannon e Roe (1982), obteve-se que 59 bovinos em cada propriedade seriam necessários para os objetivos desse estudo. As visitas às propriedades rurais foram, em sua maioria, agendadas para o período de vacinação do gado, de forma a maximizar os esforços do manejo pela propriedade. Algumas propriedades, porém, se prontificaram a manejar o gado apenas para as coletas propostas neste estudo. Assim, dado o caráter voluntário dessa atividade e as dificuldades logísticas das regiões estudadas, nem sempre foi possível obedecer ao planejamento amostral para os bovinos.

\subsection{ANÁLISES LABORATORIAIS}

O material biológico coletado em campo foi transportado, em média por 12 horas, em isopor com gelo reciclável, até a cidade de São Paulo-SP, e armazenado em freezer a $-20^{\circ} \mathrm{C}$, para posterior envio aos laboratórios parceiros para a realização dos testes diagnósticos propostos. 0 quadro 1 resume os testes realizados, laboratórios responsáveis e patógenos pesquisados em cada espécie.

A identificação de ectoparasitas foi realizada no Laboratório de Doenças Parasitárias no Departamento de Medicina Veterinária Preventiva e Saúde Animal da Faculdade de Medicina Veterinária e Zootecnia da Universidade de São Paulo. Os testes de tuberculinização foram realizados nas propriedades rurais. 


\begin{tabular}{|c|c|c|c|c|}
\hline $\begin{array}{l}\text { Material } \\
\text { Biológico }\end{array}$ & Patógenos Pesquisados & $\begin{array}{c}\text { Teste } \\
\text { Diagnóstico }\end{array}$ & $\begin{array}{l}\text { Laboratório } \\
\text { Responsável }\end{array}$ & Espécies Amostradas \\
\hline Soro & $\begin{array}{l}\text { Brucela lisas } \\
\text { Leptospira spp. } \\
\text { Toxoplasma gondii } \\
\text { Vírus da raiva } \\
\text { Vírus da cinomose } \\
\text { Vírus da imunodeficiência felina } \\
\text { Vírus da leucemia felina }\end{array}$ & $\begin{array}{l}\mathrm{AAT}^{1} \\
\mathrm{SAM}^{7} \\
\mathrm{MAT}^{8} / \mathrm{RIFI}^{9} \\
\mathrm{RFFIT}^{11} \\
\mathrm{SN}^{12} \\
\text { Snap }^{\mathrm{TM}} \\
\text { Snap }^{13} \\
\end{array}$ & $\begin{array}{l}\text { LZB }^{2} / \mathrm{VPS}^{3} / \mathrm{FMVZ}^{4} / \mathrm{USP}^{5} \\
\text { LZB/VPS/FMVZ/USP } \\
\text { LDP }^{10} / \mathrm{VPS} / \mathrm{FMVZ/USP} \\
\text { Instituto Pasteur } \\
\text { Biovet } \\
\text { LZB/VPS/FMVZ/USP } \\
\text { LZB/VPS/FMVZ/USP } \\
\end{array}$ & $\begin{array}{l}\text { Onça }{ }^{6} \text {, Bovino, Cão, Gato } \\
\text { Onça, Bovino, Cão, Gato } \\
\text { Onça, Bovino, Cão, Gato } \\
\text { Onça, Cão, Gato } \\
\text { Onça, Cão } \\
\text { Onça, Gato } \\
\text { Onça, Gato }\end{array}$ \\
\hline $\begin{array}{c}\text { Sangue } \\
\text { Total }\end{array}$ & $\begin{array}{l}\text { Hepatozoon spp. } \\
\text { Babesia spp. } \\
\text { Cytauxzoon spp. } \\
\text { Mycoplasma haemofelis } \\
\text { C.Mycoplasma haemominutum } \\
\text { C. Mycoplasma turicensis }\end{array}$ & $\begin{array}{l}\text { PCR }^{14} \\
\text { PCR } \\
\text { PCR } \\
\text { Nested-PCR } \\
\text { Nested-PCR } \\
\text { Nested-PCR }\end{array}$ & $\begin{array}{l}\mathrm{DP}^{15} / \mathrm{IB}^{16} / \mathrm{UNESP}^{17} \\
\mathrm{DP} / \mathrm{IB} / \mathrm{UNESP} \\
\mathrm{DP} / \mathrm{IB} / \mathrm{UNESP} \\
\mathrm{DP} / \mathrm{IB} / \mathrm{UNESP} \\
\mathrm{DP} / \mathrm{IB} / \mathrm{UNESP} \\
\mathrm{DP} / \mathrm{IB} / \mathrm{UNESP}\end{array}$ & $\begin{array}{l}\text { Onça, Cão, Gato } \\
\text { Onça, Cão, Gato } \\
\text { Onça, Cão, Gato } \\
\text { Onça, Cão, Gato } \\
\text { Onça, Cão, Gato } \\
\text { Onça, Cão, Gato }\end{array}$ \\
\hline Fezes & $\begin{array}{l}\text { Mycobacterium spp. } \\
\text { Cryptosporidium spp. } \\
\text { Giardia intestinalis } \\
\text { Sarcocystidae }\end{array}$ & $\begin{array}{l}\text { PCR } \\
\text { Nested-PCR } \\
\text { Nested-PCR } \\
\text { Nested-PCR }\end{array}$ & $\begin{array}{l}\text { LZB/VPS/FMVZ/USP } \\
\text { LDP/VPS/FMVZ/USP } \\
\text { LDP/VPS/FMVZ/USP } \\
\text { LDP/VPS/FMVZ/USP }\end{array}$ & $\begin{array}{l}\text { Onça-pintada } \\
\text { Onça-pintada } \\
\text { Onça-pintada } \\
\text { Onça-pintada }\end{array}$ \\
\hline
\end{tabular}

${ }^{1}$ Teste do Antígeno Acidificado Tamponado. ${ }^{2}$ Laboratório de Zoonoses Bacterianas. ${ }^{3}$ Departamento de Medicina Veterinária e Saúde Animal. ${ }^{4}$ Faculdade de Medicina Veterinária e Zootecnia. ${ }^{5}$ Universidade de São Paulo. ${ }^{6}$ Onça-pintada. ${ }^{7}$ Microtécnica de Soroaglutinação Microscópica. ${ }^{8}$ Técnica de Aglutinação Modificada. ${ }^{9}$ Reação de Imunofluorescência Indireta. ${ }^{10}$ Laboratório de Doenças Parasitárias. ${ }^{11}$ Teste de Inibição de Focos Fluorescentes. ${ }^{12}$ Soroneutralização. ${ }^{13}$ Snap $^{\text {TM }}$ Combo FeLV Antigen/FIV Antibody Test Kit (IDEXX Laboratories). ${ }^{14}$ Reação em Cadeia de Polimerase-Polymerase Chain Reaction. ${ }^{15}$ Departamento de Parasitologia. ${ }^{16}$ Instituto de Biociências. ${ }^{17}$ Universidade Estadual Paulista, Botucatu-SP.

Quadro 1 - Patógenos pesquisados de acordo com o material biológico utilizado, teste diagnóstico realizado, laboratório responsável e espécies amostradas

Em algumas situações foi necessário priorizar as análises a serem realizadas de acordo com a quantidade de soro disponível para cada indivíduo. Para os bovinos, priorizou-se a realização dos testes sorológicos de brucelose, leptospirose e toxoplasmose nesta sequência; para os cães domésticos priorizou-se o sorodiagnóstico da cinomose, raiva, leptospirose, toxoplasmose e brucelose, nesta ordem; e, para os gatos domésticos priorizou-se o diagnóstico da imunodeficiência felina, leucemia felina, toxoplasmose, leptospirose e raiva.

As amostras de fezes foram primeiramente submetidas ao Laboratório de Biologia Genômica e Molecular - PUCRS e ao Departamento de Biologia da Conservação - Estación Biológica de Doñana para análise genética e confirmação de que, realmente, eram de onçapintada. Quando comprovado geneticamente serem da espécie alvo, foram submetidas aos testes propostos neste estudo.

Os métodos utilizados para cada teste diagnóstico estão detalhados a seguir. 


\subsubsection{Testes sorológicos}

São descritos a seguir os testes sorológicos utilizados no presente estudo para diagnóstico de determinados patógenos.

\subsubsection{Diagnóstico de brucelas lisas}

Para pesquisa de anticorpos contra brucelas lisas foi realizado o teste de rosa bengala com Antígeno Acidificado Tamponado (AAT) utilizando como antígeno Brucella abortus (cepa 1119-3), de acordo com as normas do Programa Nacional de Controle e Erradicação da Brucelose e da Tuberculose (BRASIL, 2006). O teste foi preparado com o antígeno na concentração de $8 \%$, tamponado em pH ácido $(3,65)$ e corado com o rosa de bengala. Com o soro e o antígeno à temperatura ambiente, colocou-se $30 \mu \mathrm{l}$ de soro em uma placa de vidro e 30 $\mu l$ do antígeno ao lado do soro. O soro e o antígeno foram misturados com movimentos circulares, obtendo-se um círculo aproximado de $2 \mathrm{~cm}$. Após 4 minutos, a placa de vidro foi colocada na caixa de leitura com luz indireta, e a identificação da reação foi observada pela presença ou não de grumos. Foram utilizados controles positivo e negativo, previamente conhecidos.

\subsubsection{Diagnóstico de Leptospira spp.}

Para pesquisa de anticorpos contra Leptospira spp., os soros sanguíneos foram submetidos à Microtécnica de Soroaglutinação Microscópica (SAM) (FAINE, 1982) com uma coleção de antígenos vivos que inclui 22 variantes sorológicas de leptospiras patogênicas (Australis, Bratislava, Autummnalis, Butembo, Castellonis, Bataviae, Canicola, Whitcombi, Cynopteri, Grippotyphosa, Hebdomadis, Copenhageni, Icterohaemorrhagiae, Javanica, Panama, Pomona, Pyrogenes, Hardjo, Wolffi, Shermani, Tarassovi e Sentot) e duas de leptospiras saprófitas (Andamana e Patoc). 
Os sorovares de Leptospira spp. foram repicados semanalmente, em meio liquido EMJH modificado, tendo como inóculo $10 \%$ do volume do meio. Foram utilizados apenas cultivos puros, isentos de contaminação, livres de autoaglutinação, com cinco a quinze dias de crescimento. As amostras de soros foram diluídas para triagem em solução tamponada de Sorënsen, inicialmente na diluição de 1:50, que, com acréscimo de igual volume de antígeno, o ponto de corte na diluição passou a ser de 1:100. Foi considerado reagente o soro que apresentou $50 \%$ de leptospiras aglutinadas. As amostras reagentes na triagem foram reexaminadas até sete diluições geométricas seriadas de razão de dois. O valor do título foi considerado a recíproca da sua maior diluição que apresentou $50 \%$ de aglutinação. A leitura das reações foi realizada em microscópio de campo escuro após a incubação da mistura soroantígeno por três horas em temperatura de $28^{\circ} \mathrm{C}$. Foram utilizados controles positivo e negativo, previamente conhecidos.

Para efeito do cálculo da frequência considerou-se soropositivo qualquer animal reagente para um ou mais sorovares. Para a determinação do sorovar mais provável (ou sorovar infectante), considerou-se o sorovar que apresentou maior título. Os indivíduos que apresentaram dois ou mais sorovares com títulos idênticos foram excluídos dessa análise Entretanto, esses animais foram considerados soropositivos para pelo menos um sorovar no cálculo da frequência (VASCONCELLOS et al., 1997; FIGUEIREDO et al., 2009). Os sorovares mais prováveis foram calculados por espécie e área de estudo.

\subsubsection{Diagnóstico de Toxoplasma gondii}

Para a detecção de anticorpos contra $T$. gondii em onças-pintadas foi utilizada a Técnica de Aglutinação Modificada (MAT) (DUBEY; DESMONTS, 1987). A MAT foi escolhida para a sorologia das onças, uma vez que não necessita de um conjugado antiespécie específico (DUBEY; THULLIEZ, 1989; DUBEY et al. 1995).

A diluição dos soros foi feita em microplacas (96 poços) em solução salina tamponada pH 7,2 ( $\mathrm{NaCl}$ 0,146M; $\mathrm{NaH}_{2} \mathrm{PO}_{4}$ 0,008M) filtrada em membrana de $45 \mu \mathrm{m}$ de porosidade. Primeiramente, foram feitas diluições de 1:25, 1:50 e 1:500. Em seguida, $120 \mu \mathrm{l}$ de antígeno (taquizoítos inteiros fixados em formalina) foram diluídos em $2,5 \mathrm{ml}$ de solução salina tamponada pH 8,95 ( $\mathrm{NaCl} 0,12 \mathrm{M} ; \mathrm{H}_{3} \mathrm{BO}_{3}$ 0,05M; $\mathrm{NaN}_{3}$ 0,03m), $35 \mu$ l de Mercaptoetanol 0,2M e 
$50 \mu \mathrm{l}$ de Azul de Evans 0,2\%. Essa mistura foi homogeneizada e distribuída imediatamente em uma microplaca (96 poços) com fundo em "U", resultando em $25 \mu$ de reagentes por poço. Os soros diluídos foram transferidos para essa microplaca $(25 \mu \mathrm{l})$ e misturados aos reagentes $(\mathrm{v} / \mathrm{v})$. A placa foi selada com plástico adesivo, para evitar evaporação, e incubada durante a noite, por 12 horas, em estufa a $37^{\circ} \mathrm{C}$. A leitura foi realizada no dia seguinte, sendo que a formação de um botão de contorno definido na base do poço da placa foi considerada como resultado negativo; um carpete completo ou um véu de contorno pouco definido foi anotado como positivo (DUBEY; THULLIEZ, 1989). Os indivíduos com títulos maiores ou iguais a 25 foram considerados positivos. Os títulos dos soros foram determinados pela maior diluição que apresentou aglutinação (DUBEY et al., 1995). Em todas as reações foram utilizados controles positivo e negativo, previamente conhecidos.

Para a detecção de anticorpos contra T. gondii nos animais domésticos foi utilizada a Reação de Imunofluorescência Indireta (RIFI) (CAMARGO, 1964). Foram utilizadas lâminas contendo taquizoítos da cepa padrão $(\mathrm{RH})$ do parasito e soros controles. Para os bovinos, utilizou-se como ponto de corte a diluição de 1:64 e, para cães e gatos domésticos, a diluição de 1:16. Os soros foram diluídos em solução salina tamponada de fosfatos ( $P B S 0,01 \mathrm{M} \mathrm{pH} \mathrm{7,2).} \mathrm{Em}$ cada cavidade da lâmina pipetou-se aproximadamente $20 \mu \mathrm{l}$ de cada soro. Após 30 minutos de incubação à temperatura de $37^{\circ} \mathrm{C}$ em câmara úmida, realizaram-se três lavagens de 10 minutos das lâminas em uma cuba de vidro contendo PBS. Após a secagem das lâminas, acrescentou-se, em cada cavidade, o conjugado anti Ig-G específico para cada espécie (SIGMA ${ }^{\circ}$ ) previamente diluído em solução de azul de Evans $0,01 \%$. Após 30 minutos, em câmara úmida, a $37^{\circ} \mathrm{C}$, realizaram-se as lavagens de 10 minutos em PBS. Após secagem, as lâminas foram montadas com glicerina tamponada com carbonato-bicarbonato $0,5 \mathrm{M} \mathrm{pH} \mathrm{8,5}$ e lamínulas para leitura. A leitura das lâminas foi feita na objetiva 40X, em microscópio de epifluorescência com sistema de filtros para fluoresceína e lâmpada de mercúrio. Considerou-se positiva a reação onde a maioria dos campos observados apresentou taquizoítos com fluorescência verde em toda membrana celular, contra o fundo vermelho das formas coradas pelo Azul de Evans. A ausência de fluorescência ou a maioria dos campos com fluorescência apenas nas extremidades dos parasitas, conhecida como fluorescência apical, foram consideradas como reações negativas. As amostras positivas para o ponto de corte foram posteriormente diluídas para obtenção do título máximo da reação. 


\subsubsection{Diagnóstico do vírus da raiva}

Para pesquisa de anticorpos contra raiva foi utilizado o Teste de Inibição de Focos Fluorescentes (RFFIT) (SMITH; YAGER; BAER, 1996).

Primeiramente os soros foram inativados em banho-maria a $56^{\circ} \mathrm{C}$ por 30 minutos. Realizou-se seis diluições seriadas de cada soro, na razão 2, começando de 1:5, colocando-se 25 $\mu \mathrm{l}$ de soro no primeiro orifício e adicionando-se $50 \mu \mathrm{l}$ de Meio Essencial Mínimo de Eagle (MEM), com sais de Earle, suplementando com $10 \%$ de soro fetal bovino inativado. Após a diluição, adicionou-se $50 \mu \mathrm{l}$ de vírus cepa CVS (Challenge Standard Virus) diluído previamente em banho de gelo. As microplacas foram então incubadas a $37^{\circ} \mathrm{C}$ em estufa com $5 \%$ de $\mathrm{CO}_{2}$, por um período de uma hora e meia. Adicionou-se $50 \mu$ le suspensão de celular BHK-21 na concentração $2,5 \times 10^{4}$ células $/ \mathrm{ml}$ ). E, novamente, as microplacas foram incubadas a $37^{\circ} \mathrm{C}$ em estufa com $5 \%$ de $\mathrm{CO}_{2}$ por 20 horas. Após esse período, as células foram fixadas em banho de gelo, utilizando acetona 80\% gelada (SMITH; YAGER; BAER, 1996; CHAVES et al., 2006). A reação foi revelada com adição de conjugado antivírus da raiva produzido pelo Instituto Pasteur (CAPORALE et al. 2009). A leitura foi realizada em microscópio de fluorescência invertido LEICA DMIL com aumento de 200X.

Para os cães e gatos domésticos, que, normalmente são vacinados para o vírus da raiva, considerou-se como ponto de corte títulos $\geq 0,50 \mathrm{UI} / \mathrm{ml}$, conforme recomendado pela Organização Mundial da Saúde (OMS, 1992). Para as onças-pintadas, que nunca tiveram contato com a vacina antirrábica, considerou-se como positivo o título $\geq 0,10 \mathrm{UI} / \mathrm{ml}$ (HILL; BERAN; CLARK, 1992; JORGE et al., 2010).

\subsubsection{Diagnóstico do vírus da cinomose}

Para pesquisa de anticorpos contra o vírus da cinomose foi utilizada a técnica de soroneutralização microscópica (APPEL; ROBSON, 1973). Primeiramente, os soros a serem testados foram inativados em banho-maria a $56^{\circ} \mathrm{C}$. Realizaram-se diluições seriadas dos soros, que foram alocados em placas de microtitulação, adicionando-se volumes constantes de meio $209(50 \mu \mathrm{l})$ e gentamicina $(0,625 \mathrm{~g} / \mathrm{ml})$. Nas microplacas sem células e com o soro diluído foram 
adicionados $50 \mu \mathrm{l}$ da suspensão viral contendo $100 \mathrm{TCI}_{50}$. Realizou-se a agitação cuidadosa das placas para a homogeneização da mistura vírus-soro e as mesmas foram colocadas em estufa úmida a $-37^{\circ} \mathrm{C}$, com 3 a $5 \%$ de $\mathrm{CO}_{2}$ por uma hora. Em seguida, acrescentou-se $100 \mu \mathrm{l}$ de suspensão de fibroblastos de embriões de galinha, contendo, aproximadamente, 50.000 células. As microplacas foram incubadas em estufa úmida a $37^{\circ} \mathrm{C}$, com 3 a $5 \%$ de $\mathrm{CO}_{2}$ por cinco dias. Cada placa possuía controle de células, controle de vírus, e soro padrão. Após a incubação, as placas foram lidas em microscópio invertido para verificar a presença ou ausência de efeito citopático. O efeito citopático, quando presente, indica a ausência de anticorpos em títulos suficientes para neutralizar o antígeno. Os títulos foram determinados como o inverso da maior diluição que determinou proteção completa do tapete celular. Títulos $\geq 8$ foram considerados positivos (COURTENAY; QUINNELL; CHALMERS, 2001).

4.4.1.6 Diagnóstico do vírus da imunodeficiência felina e leucemia felina

Para o diagnóstico da imunodeficiência felina (FIV) e leucemia felina (FeLV) foi utilizado o teste de ELISA com os ensaios imunoenzimáticos comercias Snap ${ }^{T M}$ Combo FeLV Antigen/FIV Antibody Test Kit (IDEXX Laboratories), realizado de acordo com as orientações do fabricante. Esses kits combinam um teste direto para identificação do antígeno viral p27 do FeLV e um teste indireto para identificação de anticorpos específicos contra o vírus da imunodeficiência felina.

\subsubsection{Testes moleculares nas amostras sanguíneas}

Para extração do DNA para a pesquisa dos hemoparasitas, as amostras de sangue total foram submetidas à incubação com a enzima proteinase $\mathrm{K}$, durante 4 horas, por $56^{\circ} \mathrm{C}$ e, posteriormente, durante 15 minutos, por $70^{\circ} \mathrm{C}$ (RUBINI et al., 2005). Durante todo o tempo da incubação, o sangue e a proteinase $\mathrm{K}$ foram mantidos sob agitação constante. A partir de alíquotas sanguíneas de $200 \mu \mathrm{l}$, o DNA foi isolado empregando o kit GFX Genomic Blood DNA Purification (GE Healthcare), seguindo as recomendações do fabricante. Cada amostra de DNA foi eluída em $100 \mu$ l de tampão TE. 
Posteriormente às reações, os produtos amplificados nos testes moleculares foram analisados em gel de agarose $1 \%$ corado com gel Red $\left(0,05 \mu \mathrm{l} / \mathrm{ml}\right.$; Uniscience $\left.{ }^{\circledR}\right)$ em alíquotas de 5 $\mu \mathrm{l}$. As eletroforeses ocorreram a $80 \mathrm{~V}$, por 30 minutos, em tampão TAE, e os produtos foram visualizados através de um transiluminador UV. Os fragmentos de PCR amplificados foram estimados através da comparação com marcadores moleculares de DNA de 100 pares de base (Invitrogen ${ }^{\circ}$ ). Foram considerados positivos os fragmentos que apresentaram banda de tamanho específico e compatível com o produto amplificado por cada reação.

Os detalhes dos métodos de pesquisa para cada um dos hemoparasitas seguem abaixo:

\subsubsection{Diagnóstico de Hepatozoon spp.}

Realizou-se a reação em cadeia de polimerase (PCR) utilizando oligonucleotídeos iniciadores (ou "primers") Hep F (5'-ATA-CAT-GAG-CAA-AAT-CTC-AAC-3') e Hep R (5'-CTT-ATTATT-CCA-TGC-TGC-AG-3') para amplificação de um fragmento da região do gene $18 \mathrm{~S}$ rRNA (INOKUMA et al., 2002; METZGER et al., 2008). A reação de amplificação foi realizada em $25 \mu \mathrm{l}$ contendo: $10 \mathrm{mM}$ de Tris- $\mathrm{HCl}$ em pH 8.3, $50 \mathrm{mM}$ de $\mathrm{KCl}, 1 \mathrm{mM}$ de $\mathrm{MgCl}_{2}$ (GE Healthcare), 0,2 $\mu \mathrm{l}$ de dNTPs, 1,5 U de DNA taq polimerase (GE Healthcare), $1 \mu \mathrm{M}$ de cada "primer" e $5 \mu$ ldo DNA extraído. O controle negativo da reação não continha DNA e o controle positivo usado foi isolado de Hepatozoon sp. de uma jaguatirica (Genbank EU 028344) proveniente do Maranhão, diagnosticado por Metzger et al. (2008), e/ou um cão doméstico no Brasil, diagnosticado por Rubini et al. (2005).

Para as reações de PCR, utilizou-se termociclador Biometra thermal cycler (gradiente T) a $94^{\circ} \mathrm{C}$ por 3 minutos e 35 ciclos repetidos de $94^{\circ} \mathrm{C}$ por 1 minuto, $57^{\circ} \mathrm{C}$ por 2 minutos e $72^{\circ} \mathrm{C}$ por 2 minutos, seguidos por uma extensão final de $72^{\circ} \mathrm{C}$ por 7 minutos.

4.4.2.2 Diagnóstico dos Piroplasmas: Babesia spp. e Cytauxzoon spp.

Para a realização do PCR utilizou-se os oligonucleotídeos iniciadores Bab F (5'TGACACAGGGAGGTAGT-3') e Bab R (5'-CAACAAAATAGAACCAAAG-3') para amplificação de 
fragmentos da região do gene 18S rRNA de 293 a 318 pares de base (METZGER, 2009). Esse fragmento corresponde às sequências conservadas do DNA das espécies de piroplasmas descritas no quadro 2. Esses oligonucleotídeos iniciadores foram desenhados exclusivamente para amplificarem fragmentos de Babesia spp., Cytauxzoon spp. e Theileria sp.

\begin{tabular}{|ll|lc|}
\hline \multicolumn{1}{|c|}{ Espécie } & No Genbak & \multicolumn{1}{c|}{ Espécie } & No Genbak \\
\hline Babesia canis vogeli Brazil & AY371196 & Babesia canis canis Europa & AY072926 \\
Babesia Okinawa & AY077719 & Babesia felis & AF965742 \\
Babesia canis vogeli USA & $A Y 371198$ & Babesia leo & AF244912 \\
Babesia canis vogeli Egypt & $A Y 371197$ & Gato Brasil & EF636702 \\
Babesia canis canis Russia & $A Y 649326$ & Babesia felis & AF244912 \\
Babesia canis canis Europa & $A Y 072926$ & Babesia sp. & AF244913 \\
Babesia sp. & $A F 244914$ & Babesia canis vogeli & AY072925 \\
Babesia rodhaini & M87565.1 & Babesia okinawa & AY077719 \\
Babesia gibsoni & $A F 175300$ & Babesia canis canis & AY072926 \\
Babesia sp. & $A F 396748$ & Babesia canis vogeli & DQ439545 \\
Babesia sp. okinawa & $A F 271082$ & Theileria sp. & DQ866842 \\
Babesia sp. Israeli & $A Y 272047$ & Cytauxzoon felis & AF399930 \\
Babesia microti & AB071177 & Cytauxzoon felis & L19080 \\
\hline
\end{tabular}

Quadro 2 - Espécies de piroplasmas, com seus respectivos números de acesso no GenBank, que foram utilizadas para o alinhamento -uma das etapas para a construção de oligonucleotídeos iniciadores que amplificam fragmentos da região do gene $18 \mathrm{~S}$ rRNA - respectivos às sequências conservadas de Babesia spp., Cytauxzoon spp. e Theileria sp

A reação de amplificação foi realizada em $25 \mu$ l contendo: 1 x Go Taq Colorless Mastermix (Promega), $10 \mathrm{pmol}$ de cada oligonucleotídeo iniciador, $1 \mu \mathrm{MgCl}_{2} 50 \mathrm{mM}$ (Invitrogen ${ }^{\circledast}$ ), $5 \mu$ l do DNA extraído e água ultrapura (MiliQ ${ }^{\circledR}$ ) q.s.p. Em todas as reações foi utilizado um controle negativo através da substituição do DNA da amostra por água ultrapura (MiliQ ${ }^{\circledR}$ ). Os controles positivos consistiram de: um isolado de Babesia canis vogeli de cão doméstico no Brasil, diagnosticado por Lopes (2006), um isolado de Babesia canis rossi, cedido pelo Prof. João Pessoa Araújo, do Laboratório de Microbiologia e Imunologia do Instituto de Biociências, UNESP-Botucatu e de um isolado de Cytauxzoon felis de uma onça-parda proveniente de Minas Gerais, diagnosticado por Metzger (2009). As amostras utilizadas como controle positivo foram previamente sequenciadas geneticamente, confirmando a especificidade da técnica.

Para as reações de PCR, utilizou-se termociclador Mastercycler Gradient, Eppendorf ${ }^{\oplus}$ (EUA) a $95^{\circ} \mathrm{C}$ por 5 minutos, $52^{\circ} \mathrm{C}$ por 1 minuto e $72^{\circ} \mathrm{C}$ por 2 minutos e 35 ciclos repetidos de 
$94^{\circ} \mathrm{C}$ por 30 segundos, $52^{\circ} \mathrm{C}$ por 20 segundos e $72^{\circ} \mathrm{C}$ por 20 segundos, seguidos por uma extensão final de $72^{\circ} \mathrm{C}$ por 7 minutos.

Como a PCR utilizada amplifica tanto o gênero Babesia spp. quanto Cytauxzoon spp., os dois piroplasmas foram diferenciados pela diferença de tamanho dos seus fragmentos na visualização do gel de agarose após eletroforese. Com a finalidade de confirmar o agente envolvido e identificar possível coinfecção com ambos os agentes, realizaram-se em todos os felídeos positivos dois protocolos de PCR, cada um amplificando separadamente Babesia canis vogelis e Cytauxzoon felis, como descrito abaixo.

Para o diagnóstico de Cytauxzoon felis, um fragmento de $284 \mathrm{pb}$ da região do gene $18 \mathrm{~S}$ rRNA foi amplificado utilizando os oligonucleotídeos iniciadores 5'GCGAATCGCATTGCTTTATGCT-3' e 5'-CCAATTGATACTCCGGAAAGAG-3' (BIRKENHEUER et al. 2006), que correspondem às sequências conservadas de Cytauxzoon felis. A reação de amplificação foi realizada em um total de $25 \mu \mathrm{l}$, contendo: 1 x GO Taq Colorless Mastermix (Promega ${ }^{\circledR}$ ), 10 pmol de cada oligonucleotídeo iniciador, $5 \mu \mathrm{l}$ da amostra de DNA extraído e água ultrapura (MiliQ ${ }^{\circledR}$ ) q.s.p. O controle negativo da reação não continha DNA e o controle positivo utilizado foi um isolado de Cytauxzoon felis proveniente de uma onça-parda diagnosticado por Metzger (2009).

As reações de PCR foram realizadas utilizando o termociclador Biometra thermal cycler (gradiente $\mathrm{T}$ ), a $95^{\circ} \mathrm{C}$ por 5 minutos seguidos de 40 ciclos repetidos de $95^{\circ} \mathrm{C}$ por 45 segundos, $59^{\circ} \mathrm{C}$ por 45 segundos e $72^{\circ} \mathrm{C}$ por 60 segundos, seguidos por uma extensão final de $72^{\circ} \mathrm{C}$ por 5 minutos.

Para o diagnóstico de Babesia canis vogeli, realizou-se um PCR amplificando fragmentos da região do gene $18 \mathrm{~S}$ rRNA, de aproximadamente $340 \mathrm{pb}$, utilizando os oligonucleotídeos iniciadores $\quad 455-479 \quad \mathrm{~F} \quad$ (5'-GTCTTGTAATTGGAATGATGGTGAC-3') e 793-772 $\mathrm{R} \quad\left(5^{\prime}\right.$ ATGCCCCCAACCGTTCCTATTA-3'). Esse fragmento corresponde às sequências conservadas de Babesia gibsoni (AF 271081; AF 271082; AF 205636; AF 175300; AF 175301), Babesia canis vogeli (AJ 009796; AY 072925), Babesia canis canis (AY 072926; AJ 009795) e Babesia canis rossi (L 19079) (BIRKENHEUER; LEVY; BREITSCHWERDT, 2003).

A reação de amplificação foi realizada em um total de $25 \mu$, contendo: 1 x Go Taq Colorless Mastermix (Promega ${ }^{\circledR}$ ), 10 pmol de cada oligonucleotídeo iniciador, $5 \mu$ l da amostra de DNA extraído e água ultrapura (MilliQ ${ }^{\circledR}$ ) q.s.p. O controle negativo da reação não continha DNA e o controle positivo usado foi um isolado de Babesia canis vogeli de cão doméstico no Brasil, diagnosticado por Lopes (2006). 
As reações de PCR foram realizadas utilizando o termociclador Mastercycler Gradient (Eppendorf $\left.{ }^{\oplus}, \mathrm{EUA}\right)$ a $95^{\circ} \mathrm{C}$ por 5 minutos seguidos de 50 ciclos repetidos de $95^{\circ} \mathrm{C}$ por 45 segundos, $58^{\circ} \mathrm{C}$ por 45 segundos e $72^{\circ} \mathrm{C}$ por 45 segundos, seguidos por uma extensão final de $72^{\circ} \mathrm{C}$ por 5 minutos.

Em seguida, realizou-se uma "Semi- nested" PCR que amplificou fragmentos da região do gene 18S rRNA de 192 pares de base que correspondem à sequência conservada de Babesia canis vogeli. Essa reação teve um volume final de $25 \mu \mathrm{l}$ e foi utilizado $0,5 \mu \mathrm{l}$ do produto amplificado pela PCR. Os componentes dessa reação foram iguais aos da PCR, diferenciando-se apenas pelo oligonucleotídeo iniciador "sense ou forward", que foi o BCV F (5'GTTCGAGTTTGCCATTCGTT-3') (BIRKENHEUER; LEVY; BREITSCHWERDT, 2003). Foi mantido o mesmo oligonucleotídeo iniciador "anti-sense ou reverse" da primeira reação (PCR). A programação dos ciclos de temperaturas utilizada foi igual ao da PCR, com exceção dos ciclos de amplificação, que foram reduzidos de 50 para 30.

4.4.2.3 Diagnóstico dos hemoplasmas felinos: Mycoplasma haemofelis, 'Candidatus Mycoplasma haemominutum' e 'Candidatus Mycoplasma turicensis'

Através da PCR, amplificou-se fragmentos da região do gene 16S rRNA, de 595 pb para M. haemofelis e $618 \mathrm{pb}$ para 'Ca. Mycoplasma haemominutum', utilizando os seguintes primers: HBT-F (5'-ATACGGCCCATATTCCTACG-3') e HBT-R (5'-TGCTCCACCACTTGTTCA-3') (CRIADOFORNELIO et al., 2003). A reação foi realizada em $25 \mu$ l contendo 1 x Go Taq Colorless mastermix (Promega ${ }^{\circledR}$ ), 10 pmol de cada oligonucleotídeo iniciador, $5 \mu$ de DNA extraído e água ultrapura $\left(\mathrm{MiliQ}^{\circledR}\right)$ q.s.p. O controle negativo da reação não continha DNA e os controles positivos foram: um isolado de $\mathrm{M}$. haemofelis e outro de 'Ca. Mycoplasma haemominutum' provenientes, respectivamente, de uma jaguatirica e de um gato mourisco, ambos diagnosticados por Metzger (2009). Os controles positivos foram previamente sequenciados confirmando a especificidade da técnica.

As reações de PCR foram realizadas usando o termociclador Mastercycler Gradient (Eppendorf ${ }^{\oplus}$, EUA) com os ciclos de temperatura programados para $94^{\circ} \mathrm{C}$ por 10 minutos, seguidos de 40 ciclos repetidos de $95^{\circ} \mathrm{C}$ por 30 segundos, $60^{\circ} \mathrm{C}$ por 30 segundos e $72^{\circ} \mathrm{C}$ por 30 segundos, além de um ciclo final de $72^{\circ} \mathrm{C}$ por 10 minutos para a extensão final. 
Após a eletroforese e a visualização do gel de agarose foi realizada uma nested-PCR para a identificação das espécies de hemoplasmas que foram amplificadas pela PCR anterior, segundo protocolo descrito por Fujihara et al. (2007). A PCR amplificou fragmentos do gene 165 rRNA de $616 \mathrm{pb}$ para M. haemofelis, $654 \mathrm{pb}$ para 'Ca. Mycoplasma haemominutum' e 559 pb para ' Ca. Mycoplasma turicensis'. Os oligonucleotídeos iniciadores usados na primeira reação da nestedPCR foram: Mhfe F1 (5'-TTAATGCTGATGGTATGCCT-3'), Mhfe R1 (5'-TGCTTAATTCCGAAACTCCC3'), Mhmn F1 (5'-GATtAATGCTGGTGGTATGC-3'), Mhmn R1 (5'-CATTGAATtCCAGTATCTCC-3'), Mtrc F1 (5'-GAACTCTCCAAAAGGCAGTT-3') e Mtrc R1 (5'-TGAATAGTATTCGGCACAAA-3') (FUJIHARA et al., 2007; METZGER, 2009).

A reação de amplificação foi realizada em $25 \mu$ l contendo: 1 x Go Taq Colorless mastermix (Promega ${ }^{\circledR}$ ), 10 pmol de cada oligonucleotídeo iniciador, $5 \mu$ lo DNA extraído e água ultrapura (MiliQ ${ }^{\circ}$ ) q.s.p. Os controles negativos da reação não continham DNA e os controles positivos foram os mesmos utilizados na PCR anterior.

Para as reações de PCR, utilizou-se o termociclador Mastercycler Gradient (Eppendorf, EUA) a $94^{\circ} \mathrm{C}$ por 1 minuto e 30 ciclos repetidos de $94^{\circ} \mathrm{C}$ por 30 segundos, $55^{\circ} \mathrm{C}$ por 2 minutos e $72^{\circ} \mathrm{C}$ por 1 minuto, seguidos por uma extensão final de $72^{\circ} \mathrm{C}$ por 5 minutos.

A nested-PCR amplificou fragmentos de $272 \mathrm{pb}$ para M. haemofelis, $403 \mathrm{pb}$ para 'Ca. Mycoplasma haemominutum' e 319 pb para 'Ca. Mycoplasma turicensis'. Os oligonucleotídeos iniciadores utilizados na nested-PCR foram: Mhfe F2 (5'-GATTAATCCCCATAGGAAG-3'), Mhfe R2 (5'-ACTATCATAATTATCCCTCG-3'), Mhmn F2 (5'-TACTCTCTTAGTGgCGAACG-3'), Mhmn R2 (5'AATCAAgGCTTAATCATTTC-3'), Mtrc F2 (5'-TAATGTCCTATAGTATCCTC-3') e Mtrc R2 (5'TGCTGTCACTTATTCAGAGG-3') (FUJIHARA et al., 2007; METZGER, 2009).

Utilizou-se nessa reação $0,5 \mu \mathrm{l}$ do produto amplificado pela PCR, os mesmos componentes da primeira reação de PCR com volume final de $25 \mu \mathrm{l}$, diferenciando-se pelos oligonucleotídeos iniciadores utilizados, que nessa reação foram os descritos acima. Utilizou-se a mesma programação dos ciclos de temperaturas.

Os cuidados com a esterilização e a manipulação para evitar a contaminação com os produtos previamente amplificados (ou "amplicons"), também conhecidos como "carry over", foram muito mais exacerbados e rigorosos quando comparados aos cuidados da PCR. As reações foram preparadas em sala específica para manipulação de reagentes da PCR, previamente esterilizada de 30 a 40 minutos, com o uso de ultravioleta, hipoclorito de sódio a 10\%, álcool absoluto e cloreto de benzalcômio em todas as superfícies e equipamentos utilizados. 0 tratamento com ultravioleta incluiu luvas de procedimento, tubos e microtubos de PCR, 
ponteiras de filtro e pipetas. Os produtos da PCR foram manipulados no interior de capela de fluxo laminar, previamente esterilizada. A manipulação de todos os reagentes e produtos da PCR foi feita com extrema cautela: microtubos contendo produtos de PCR permaneciam sempre tampados e eram abertos somente para serem pipetados. Após a manipulação com cada tubo, as luvas eram imediatamente borrifadas com hipoclorito de sódio $10 \%$ e secas com gases estéreis. Eram utilizados somente microtubos de 0,2 $\mu$ individuais e não em conjunto de oito (ou "strips"), como geralmente usado em outras reações. Os tubos contendo produto da PCR permaneciam dispostos bem distantes uns dos outros e em suportes diferentes. Cada reação continha no máximo 15 amostras, possibilitando distância e maior cautela na manipulação. Além disso, foram sempre utilizados três controles negativos, sem DNA, cada qual referente a um par de oligonucleotídeos iniciador, para cada espécie de hemoplasma felino.

\subsubsection{Sequenciamento dos hemoparasitas}

Os produtos da PCR de algumas amostras positivas foram enviados para a Macrogen Company Limited ${ }^{1}$ na Coréia do Sul para purificação e sequenciamento. As sequências obtidas foram submetidas ao Basic Local Alignment Search Tool ${ }^{2}$ (BLAST) para verificação da similaridade genética.

\subsubsection{Testes moleculares nas amostras de fezes}

Para a pesquisa de protozoários, as amostras fecais foram submetidas ao procedimento de extração de DNA empregando-se o kit Invitek (PSP Spin DNA Stool kit, Berlim) com algumas alterações: primeiramente $300 \mu$ das suspensões de amostras fecais foram transferidas para um microtubo e submetidas à centrifugação por $10.000 \mathrm{~g}$ por 5 minutos. Os sedimentos resultantes foram lavados em TE (TrisHCl 10mM, EDTA $1 \mathrm{mM}$ ) por duas vezes. Após a última lavagem, o sedimento de cada amostra foi ressuspendido em solução de lise fornecida no próprio kit, seguindo-se a partir deste momento, as recomendações do fabricante. Para cada um dos protozoários, empregou-se uma reação molecular: nested-PCR-18S para pesquisa de 
Cryptosporidium spp, nested-PCR-bg para pesquisa de Giardia intestinalis e nested-PCR-ITS-1 para pesquisa de protozoários da Família Sarcocystidae.

\subsubsection{Diagnóstico de Cryptosporidium spp.}

Para pesquisa de Cryptosporidium spp. foi realizada a amplificação da subunidade $18 \mathrm{~S}$ do RNA ribossômico através da técnica de nested-PCR com os seguintes primers: F1 (5'TTCTAGAGCTAATACATGCG-3') e R1 (5'-CCCATTTCCTTCGAAACAGGA-3') na reação primária, originando uma sequência com aproximadamente 1300 pb (XIAO et al., 1999); F2 (5'GGAAGGGTTGTATTTATTAGATAAAG-3') e R2 (5'-AAGGAGTAAGGAACAACCTCCA-3') na reação secundária, originando uma sequência com aproximadamente 826 a 864 pb, dependendo da espécie (XIAO et al., 1999). A reação primária foi realizada em $50 \mu$ de solução contendo $5 \mu$ de DNA extraído, $5 \mu$ de solução tampão para PCR (20 mM de Tris- $\mathrm{HCl}$ pH 8,4 e 50 mM de $\mathrm{KCl}$ ), 200 $\mu \mathrm{M}$ de dNTP $\left(0,25 \mathrm{mM}\right.$ de cada base), 2,0 $\mu \mathrm{l}$ de $\mathrm{MgCl}_{2}, 0,3 \mu \mathrm{l}$ de cada oligonucleotídeo iniciador da reação primária (30 pmol), 1,25 unidade da enzima Taq DNA polimerase (Invitrogen Life Technologies, Cat \# 18038-42) e 31,2 $\mu$ l de água ultra pura autoclavada.

As reações de PCR foram realizadas com os ciclos de temperatura programados para $94^{\circ} \mathrm{C}$ por 3 minutos, seguidos de 35 ciclos repetidos de $94^{\circ} \mathrm{C}$ por 45 segundos, $55^{\circ} \mathrm{C}$ por 45 segundos e $72^{\circ} \mathrm{C}$ por 60 segundos, seguidos de uma extensão final de $72^{\circ} \mathrm{C}$ por 7 minutos. A nested-PCR foi realizada com as mesmas condições da amplificação da PCR, porém com os primers da reação secundária e $2,5 \mu \mathrm{l}$ da primeira reação como amostra.

\subsubsection{Diagnóstico de Giardia intestinalis}

Para pesquisa de Giardia intestinalis foi realizada a amplificação primária de um fragmento de aproximadamente $753 \mathrm{pb}$, utilizando os primers: G7 (5'AAGCCCGACGACCTCACCCGCAGTGC-3') e G759 (5'-GAGGCCGCCCTGGATCTTCGAGACGAC-3') (CACCIO; DE GIACOMO; POZIO, 2002). 
O protocolo de reação empregado utilizou um mix de reagente contendo $34,6 \mu$ lde água ultrapura (MiliQ $\left.{ }^{\circledR}\right) ; 1 \mu \mathrm{lNTP}(10 \mathrm{mM}) ; 1 \mu \mathrm{L}$ de cada primer (10 pmol/ $\left.\mu \mathrm{l}\right) ; 5 \mu \mathrm{l}$ de 10X PCR Buffer; $2 \mu \mathrm{l} \mathrm{MgCl}(50 \mathrm{mM}) ; 0,4 \mu \mathrm{l}$ taq Polimerase $(5 \mathrm{U} / \mu \mathrm{l})$ e $5 \mu \mathrm{l}$ de DNA extraído, resultando um volume final de $50 \mu \mathrm{l}$ em cada microtubo. As reações de PCR foram realizadas no termociclador com ciclos de temperatura programados para $94^{\circ} \mathrm{C}$ por 5 minutos; 35 ciclos repetidos de $94^{\circ} \mathrm{C}$ por 30 segundos; $65^{\circ} \mathrm{C}$ por 30 segundos e $72^{\circ} \mathrm{C}$ por 60 segundos, seguidos de um aquecimento final de $72^{\circ} \mathrm{C}$ por 7 minutos.

Para a amplificação secundária, com o intuito de amplificar um fragmento de aproximadamente 511 pb, foi utilizado um par de primers interno em relação aos primeiros: BGNst-F (5'-GAACGAACGAGATCGAGGTCCG-3') e BG-Nst-R (5'-CTCGACGAGCTTCGTGTT-3') (LALLE et al., 2005). O protocolo de reação empregado utilizou mix de reagente contendo $38,6 \mu$ de água ultrapura (MiliQ $\left.{ }^{\circledR}\right) ; 1 \mu \mathrm{ldNTP}(10 \mathrm{mM}) ; 1 \mu \mathrm{l}$ de cada primer (10 pmol/ $\left.\mu \mathrm{l}\right) ; 5 \mu \mathrm{l}$ de 10X PCR Buffer; $2 \mu \mathrm{l} \mathrm{MgCl}(50 \mathrm{mM}) ; 0,4 \mu \mathrm{l}$ taq Polimerase (5U/ $\mu \mathrm{l})$ e $1 \mu \mathrm{l}$ do produto da amplificação primária resultando um volume final de $50 \mu \mathrm{l}$ em cada microtubo que foi levado ao temociclador. Os parâmetros para o termociclador foram programados para aquecimento inicial de $94^{\circ} \mathrm{C}$ por 5 minutos, 35 ciclos de $94^{\circ} \mathrm{C}$ por 30 segundos, $55^{\circ} \mathrm{C}$ por 30 segundos, $72^{\circ} \mathrm{C}$ por 60 segundos, seguidos de um aquecimento final de $72^{\circ} \mathrm{C}$ por 7 minutos.

4.4.3.3 Diagnóstico de protozoários da Família Sarcocystidae

Para pesquisa de protozoários da Família Sarcocystidae, as sequências de DNA alvo foram primeiramente amplificadas pela PCR com o uso dos primers externos JS4 (5'CGAAATGGGAAGTTTTGTGAAC-3') (SLAPETA et al., 2002) e CT2c (5'-CTGCAATTCACATTGCGTTTCGC3') (MURADIAN, 2009) seguida de uma nested-PCR com os primers internos CT2b (5'TTGCGCGAGCCAAGACATC-3') (MONTEIRO et al., 2007) e JS4b (5'-AGTCGTAACAAGGTTTCCGTAGG3') (MURADIAN, 2009). Os primers senso empregados neste ensaio hibridizam contra a região 3' terminal do gene codificador do RNA da menor unidade ribossômica (18S), enquanto os primers antissenso hibridizam contra a região 5' terminal do gene codificador da fração $5.8 S$ do RNA ribossômico. A nested-PCR amplifica, portanto, a região completa referente ao espaçador interno transcrito 1 (internal transcribed spacer-1) de todos os organismos pertencentes à Família Sarcocystidae. Os diferentes organismos pertencentes a esta família possuem sequências 
de nucleotídeos diferentes na região codificadora do espaçador interno transcrito 1 (ITS-1), de forma que a análise deste lócus permite distinguir estes organismos.

Para uma reação de $50 \mu \mathrm{l}$ foi utilizado $31,2 \mu \mathrm{l}$ de água ultrapura autoclavada; $5 \mu \mathrm{l}$ de tampão de reação 10x (KCL 50 mM: Tris- $\mathrm{HCl} 10$ mM, pH 9.0, Invitrogen ${ }^{\circledR}$, USA); $1 \mu \mathrm{l}$ da mistura de dNTPs (10 mM de cada nucleotídeo: dATP, dTTP, dCTP, dGTP, Invitrogen ${ }^{\circledR}$, USA); $3 \mu \mathrm{l}$ da solução de primers externos senso $(10 \mu \mathrm{M}) ; 3 \mu \mathrm{l}$ da solução de primers externos antissenso (10 $\mu \mathrm{M}) ; 1,5 \mu \mathrm{l}$ de $\mathrm{MgCl}_{2}(50 \mathrm{mM}) ; 0,3 \mu \mathrm{l}$ de Taq DNA polimerase platinum Invitrogen ${ }^{\circledR}(5 \mathrm{U} / \mu \mathrm{l}) ; 5 \mu \mathrm{l}$ da amostra de DNA.

Para a nested-PCR foram utilizadas as mesmas quantidades e reagentes substituindo-se somente os primers externos pelos internos e amostra de DNA pela mesma quantidade de produto amplificado na primeira reação de PCR. O ciclo empregado na PCR foi aquecimento inicial de $94^{\circ} \mathrm{C}$ por 3 minutos, 35 ciclos de $94^{\circ} \mathrm{C}$ por 45 segundos, $56^{\circ} \mathrm{C}$ por 30 segundos, e extensão de $72^{\circ} \mathrm{C}$ por 30 segundos.

\subsubsection{Visualização do produto amplificado}

Os fragmentos amplificados foram visualizados através da técnica de eletroforese em gel de agarose a 1,5\% em cuba horizontal, previamente imerso em tampão TBE (Tris-Borato 0,045 M; EDTA pH $8.01 \mathrm{mM}$ ). Após a corrida eletroforética, executada a uma voltagem adequada às dimensões do gel ( 1 a $10 \mathrm{~V} / \mathrm{cm}$ de gel), o gel foi corado em solução de brometo de etídeo a 0,5 $\mu \mathrm{g} / \mathrm{ml}$ durante 20 minutos. Para a visualização dos produtos amplificados o gel foi observado em transiluminador ultravioleta. As dimensões dos fragmentos amplificados foram comparadas a um padrão de peso molecular com fragmentos múltiplos de 100 pb disposto no gel juntamente com as amostras analisadas.

\subsubsection{Diagnóstico de Mycobacterium spp.}

As fezes de onças-pintadas foram submetidas à tentativa de isolamento de micobactérias, conforme descrito pelo Centro Panamericano de Zoonosis (1972). Foram 
utilizados meios de cultura de Lowenstein-Jensen e Stonebrink com adição de antibióticos ( $B B L$ MGIT PANTA ${ }^{T M}$ composto por polimixina $B$, anfotericina $B$, ácido nalidixico, trimetoprima, azlocilina) para diminuir a contaminação proveniente das amostras fecais. Os processos de elaboração dos meios de cultura foram efetuados de acordo com as instruções dos fabricantes e adaptados para os meios utilizados. Para o isolamento, as fezes foram descongeladas e introduzidas em bolsas de plástico estéreis para Stomacher ${ }^{\circledR}$; aproximadamente $1 \mathrm{~g}$ de fezes das amostras individuais foi separado e adicionado $9 \mathrm{ml}$ de solução salina a 0,85\% estéril, macerado por 1 minuto no Stomacher ${ }^{\circledR}$, e em seguida $1 \mathrm{ml}$ do homogeneizado foi misturado com $1 \mathrm{ml}$ de $\mathrm{NaOH} 4 \%$ e 2 gotas de vermelho de fenol, e incubado na estufa a $37^{\circ} \mathrm{C}$ por 25 minutos. A mistura foi então neutralizada com $\mathrm{HCl} 1 \mathrm{~N}(\mathrm{pH} \cong 6,8-7,0)$ e centrifugada a 2.500 rpm por 20 minutos. Desprezou-se o sobrenadante, e suspendeu-se novamente o pellet em $1 \mathrm{ml}$ de solução salina $0,85 \%$ estéril. Homogeneizou-se e semeou-se $100 \mu \mathrm{l}$ no meio de cultura, fazendo cada meio de cultura em duplicata e incubando em estufa a $37^{\circ} \mathrm{C}$. A leitura foi realizada uma vez por semana durante um período total de 60 dias após a incubação.

As colônias com características sugestivas de micobactérias foram fenotipicamente caracterizadas e submetidas para confirmação pela técnica de PCR-PRA (TELENTI et al., 1993). Para a extração do DNA, uma pequena quantidade da massa bacteriana das colônias foi retirada com o auxílio de uma alça descartável estéril e transferida para um microtubo de $1.500 \mu \mathrm{l}$ com $400 \mu$ l de tampão TE (10 mM Tris-HCl, 1 mM EDTA pH 8), que foi homogeneizado e incubado a $80^{\circ} \mathrm{C}$ por 20 minutos para inativação dos bacilos (BREMER-MELHIOR; DRUGEON, 1999). Foi adicionado $50 \mu \mathrm{l}$ de $10 \mathrm{mg} / \mathrm{ml}$ de lisozima, homogeneizado e incubado a $37^{\circ} \mathrm{C}$ "overnight". Em seguida foi adicionado $5 \mu \mathrm{l}$ de Proteinase $\mathrm{K}(10 \mathrm{mg} / \mathrm{ml})$ e $70 \mu \mathrm{l}$ de SDS (10\%), que foi homogeneizado e incubado a $65^{\circ} \mathrm{C}$ por 10 minutos. Adicionou-se $100 \mu \mathrm{lde} \mathrm{NaCl}(5 \mathrm{M})$ e $100 \mu \mathrm{l}$ de $\mathrm{CTAB} / \mathrm{NaCl}\left(4,1 \mathrm{~g} \mathrm{NaCl}\right.$ e $10 \mathrm{~g} \mathrm{CTAB}$ em $\left.100 \mathrm{ml} \mathrm{H} \mathrm{H}_{2} \mathrm{O}\right)$ pré-aquecido a $65^{\circ} \mathrm{C}$, homogeneizou-se e incubou a $65^{\circ} \mathrm{C}$ por 10 minutos. Em seguida, foi acrescentado $750 \mu$ le clorofórmio: álcool isoamílico (24:1), agitou-se por 10 minutos e centrifugou-se a 12.000 g por 7 minutos. Transferiu-se o sobrenadante para novos tubos. O DNA foi precipitado com $450 \mu$ de isopropanol resfriado a $-20^{\circ} \mathrm{C}$ por 30 minutos, e posteriormente centrifugado a $12.000 \mathrm{~g}$ por 15 minutos, e desprezado o sobrenadante. Adicionou-se $1000 \mu \mathrm{l}$ de etanol a $70 \%$ e centrifugou-se por mais 5 minutos. O sobrenadante foi desprezado, e colocou-se a amostra em banho seco a $56^{\circ} \mathrm{C}$ por 10 minutos, suspendendo-se novamente o sedimento seco com $30 \mu \mathrm{l}$ de TE. A amostra foi armazenada a $-20^{\circ} \mathrm{C}$. 
Foram realizadas reações de $50 \mu \mathrm{l}$ contendo: 8,0 $\mu \mathrm{l}$ dNTP (1,25 mM); $5 \mu \mathrm{l}$ 10x Buffer; 2,5

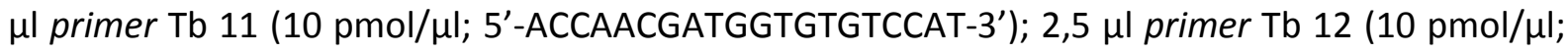
5'- CTTGTCGAACCGCATACCCT - 3'); 1,5 $\mathrm{MgCl}_{2}$ (50 mM); 0,3 $\mu \mathrm{L}$ de TAQ polimerase (1,25 U); 25,2 $\mu$ água ultra pura e $5 \mu$ do DNA. Os primers utilizados nesse processo amplificam um fragmento de 439 bp, responsável pela codificação da proteína de choque térmico (hsp 65), que caracteriza o isolado como pertencente ao gênero Mycobacterium. Empregou-se o seguinte ciclo de PCR: $94^{\circ} \mathrm{C}$ por 1 minuto, $60^{\circ} \mathrm{C}$ por 1 minuto, $72^{\circ} \mathrm{C}$ por 1 minuto e ciclo de extensão final de $72^{\circ} \mathrm{C}$ por 10 minutos. $O$ produto amplificado foi analisado em gel de agarose $2 \%$ corado com brometo de etídio, e a eletroforese ocorreu a 90V.

O produto de PCR de 439 pb foi submetido à digestão pelas enzimas de restrição Haelll e BstEll. Foram realizadas reações de $20 \mu \mathrm{l}$ com 0,5 $\mu \mathrm{l}$ da enzima Haelll; $2 \mu \mathrm{l}$ REact2; 7,5 $\mu \mathrm{l} \mathrm{H}_{2} \mathrm{O}$ ultra pura e $10 \mu \mathrm{l}$ do produto amplificado a $60^{\circ} \mathrm{C}$ por 60 minutos. Para a reação com BSA foram realizadas reações de $20 \mu \mathrm{l}$ com 0,5 $\mu \mathrm{l}$ da enzima BstEll; 0,2 $\mu \mathrm{l} \mathrm{BSA}$ (soro albumina bovina); $2 \mu \mathrm{l} D$ $10 x$ Buffer; $7,3 \mu \mathrm{l}$ água ultra pura e $10 \mu \mathrm{l}$ do produto amplificado a $37^{\circ} \mathrm{C}$ por 60 minutos. As eletroforeses foram feitas com agarose 3-4\%, 60V, utilizando 3 marcadores moleculares $25 \mathrm{pb}$, $50 \mathrm{pb}, 100 \mathrm{pb}$. As dimensões dos fragmentos amplificados foram comparadas a um padrão de peso molecular com fragmentos múltiplos de 100 pares de base disposto no gel.

\subsubsection{Pesquisa de ectoparasitas}

A identificação taxonômica das espécies de ectoparasitas foi realizada com auxílio de estereomicroscópio e literatura correspondente (GUIMARÃES; TUCCI; BARROS-BATTESTI, 2001; BARROS-BATTESTI; ARZUA; BECHARA, 2006). Imaturos do gênero Amblyomma não puderam ser identificados em nível de espécie, uma vez que não havia literatura disponível. Os ectoparasitas identificados das onças-pintadas foram apresentados pelo total de eventos de captura, e para os animais domésticos, pelo número de propriedades amostradas em cada área de estudo. Para as onças-pintadas destacaram-se nos resultados quais animais parasitados por carrapatos foram também expostos aos hemoparasitas. 


\subsection{TESTE DE TUBERCULINIZAÇÃO}

Nos bovinos, realizou-se o diagnóstico alérgico da tuberculose bovina através da prova de tuberculinização intradérmica, Teste da Prega Caudal (TPC) (BRASIL, 2006). A tuberculina PPD bovina foi inoculada via intradérmica na dosagem de 0,1 $\mathrm{ml}$, entre 6 e $10 \mathrm{~cm}$ da base da cauda, na junção da pele pilosa e da pele glabra.

A leitura do teste foi realizada após $72 \pm 6$ horas da inoculação, comparando-se, por avaliação visual e palpação, a prega inoculada com a prega do lado oposto. Qualquer aumento de espessura na prega inoculada foi classificado como reagente.

Devido à dificuldade logística o teste de tuberculinização foi realizado em apenas três propriedades rurais do entorno do PNE e em duas propriedades rurais do entorno do Parque Estadual do Cantão. Não foi realizado na região do Pantanal.

\subsection{QUESTIONÁRIO EPIDEMIOLÓGICO}

Em cada propriedade amostrada, além da coleta de material biológico, aplicou-se um questionário epidemiológico aos gerentes ou proprietários. Foram elaboradas questões sobre as práticas de manejo empregadas para o rebanho bovino, incluindo questões a respeito da predação do gado por onça-pintada (Apêndice B). Aos proprietários dos cães e gatos domésticos foram feitas questões com o intuito de obter informações a respeito da vacinação, alimentação e hábitos dos cães e gatos domésticos (Figura 30; Apêndice C).

\subsection{MONITORAMENTO DAS ONÇAS-PINTADAS}

Uma vez equipadas com o radiotransmissor, as onças-pintadas foram monitoradas através da radiotelemetria ou armadilhas fotográficas. Foram monitoradas em períodos noturnos e diurnos. 
Através da radiotelemetria, os sinais de seus rádios eram captados por uma antena e radio-receptor. A estimativa da localização do transmissor (animal) foi feita através do método de triangulação, resultado de duas ou mais posições direcionais obtidas de coordenadas geográficas conhecidas e distantes. Utilizou-se o programa de computador LOCATE II (versão 1.6, Pacer, Canadá) para obter as coordenadas finais. Esse monitoramento foi realizado na região do Parque Nacional das Emas e Pantanal com o objetivo de acumular o maior número de localizações de cada indivíduo. Embora equipadas com radiotransmissor, não foi possível obter localizações geográficas das onças-pintadas da região do Parque Estadual do Cantão, pois os aparelhos apresentaram problemas de funcionamento.

As armadilhas fotográficas foram instaladas ao longo das áreas de estudo, em árvores próximas a trilhas e estradas a uma altura média de $45 \mathrm{~cm}$ do solo e aproximadamente 2 metros do ponto alvo da fotografia (Figura 31). As armadilhas fotográficas foram ativadas por sensores infravermelhos de movimento e calor, e vistoriadas quinzenalmente para reposição de filmes e baterias. Análoga a uma impressão digital humana, as malhas da onça-pintada são características únicas de cada indivíduo, o que permite a individualização dos animais através das fotografias. Desta forma, os registros fotográficos das onças-pintadas obtidos juntamente com os padrões de pelagem registrados durante as capturas das onças-pintadas permitiram a individualização e monitoramento dos animais.

O período de monitoramento das onças-pintadas compreendeu o intervalo entre o dia de sua captura e a última localização obtida até novembro de 2008, com exceção de um animal que foi monitorado até fevereiro de 2010. Durante esse período, alguns indivíduos vieram a óbito; porém, como não se possui dados consistentes sobre a causa da morte dessas onçaspintadas, essa informação não foi utilizada no presente estudo.

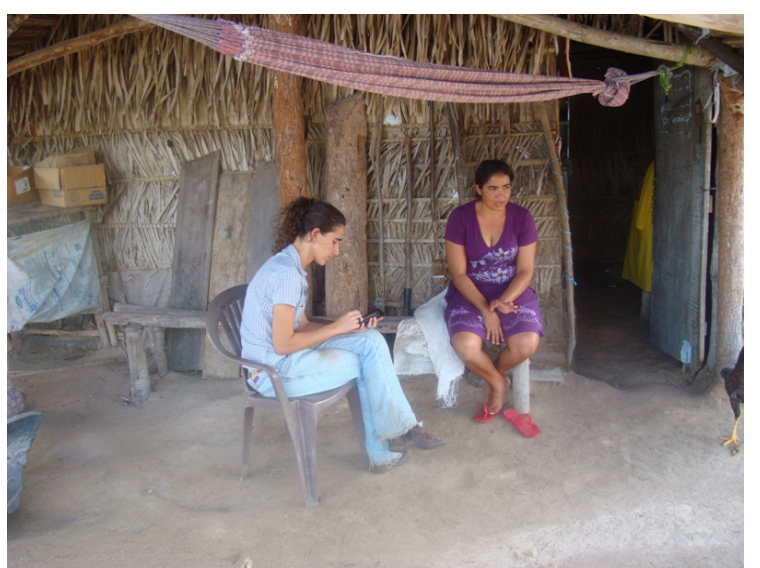

Figura 30 - Aplicação de questionário à proprietária de gato em assentamento rural no entorno do PEC

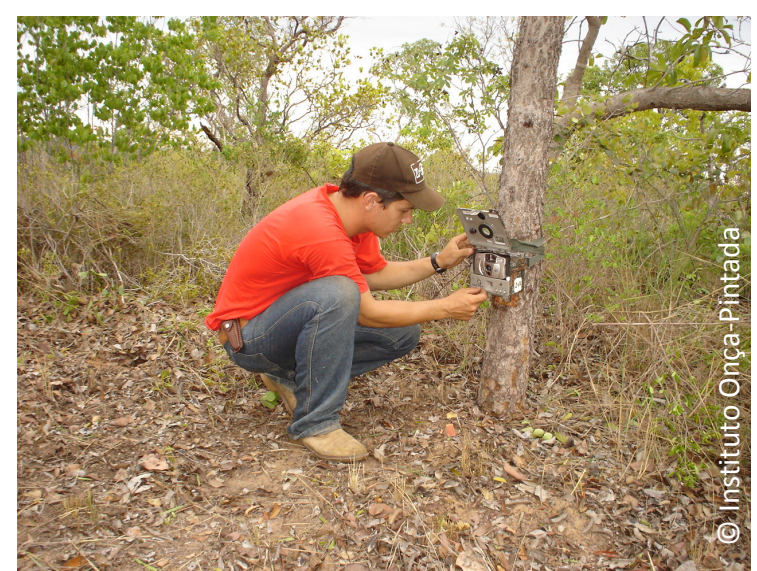

Figura 31 - Instalação de armadilha fotográfica para monitoramento de onçaspintadas no PNE 


\subsection{TRATAMENTO DOS DADOS}

Primeiramente, foram apresentados os resultados das análises laboratoriais obtidos para as todos os eventos de captura das onças-pintadas das três áreas de estudo (captura e posterior recaptura). Em seguida, os diagnósticos foram apresentados levando em consideração a espécie e a área preservada amostrada. Para a elaboração das tabelas e análises estatísticas, os resultados dos testes das onças-pintadas recapturadas foram interpretados em paralelo (o animal que apresentou pelo menos um resultado positivo na captura ou recaptura foi considerado positivo), evitando a pseudorreplicação e garantindo a independência dos dados (PATERSON; LELLO, 2003).

Para a interpretação de diferentes títulos de anticorpos diagnosticados nas onçaspintadas recapturadas, apenas as mudanças geométricas quádruplas ou superiores foram consideradas significativas (THRUSFIELD, 2004).

O monitoramento das onças-pintadas e os diagnósticos laboratoriais permitiram a elaboração de mapas temáticos e caracterização da distribuição espacial dos patógenos nas áreas de estudo. A propriedade com pelo menos um animal diagnosticado positivo para determinado patógeno foi considerada foco da infecção.

\subsubsection{Análises estatísticas}

Para comparar os diagnósticos obtidos para as diferentes espécies amostradas e áreas de estudo, e testar o efeito do sexo e idade nos diagnósticos das onças-pintadas utilizou-se um Modelo Linear Generalizado (MLG) com distribuição de erro binomial e função de ligação logit, que corresponde a uma regressão logística. O MLG é um modelo estatístico utilizado para analisar a associação de dados independentes que não seguem obrigatoriamente a distribuição Normal e variáveis dependentes (PATERSON; LELLO, 2003). Os modelos foram implementados utilizando o programa computacional R, versão 2.10.1 (R. Development Core Team, 2009). 
4.8.1.1 Efeito da área de estudo e espécie amostrada na ocorrência dos patógenos selecionados

Cada patógeno pesquisado foi analisado com um modelo separado. Para cada indivíduo $i$ amostrado, as análises realizadas permitiram a obtenção de um resultado $\left(\mathrm{R}_{\mathrm{i}}\right)$ negativo ou positivo (0 ou 1) para o diagnóstico de cada patógeno. Esse resultado foi modelado como uma variável randômica de Bernoulli com a probabilidade $p$ de ser positivo, sendo que, a probabilidade da ocorrência do patógeno pode ser influenciada pelas variáveis independentes categóricas: espécie ( $e_{i}$, onça-pintada, bovino, cão e gato doméstico) ou área de estudo ( $b_{i}$, Parque Nacional das Emas, Pantanal e Parque Estadual do Cantão). Não há interação entre espécie e área de estudo. Para modelar a probabilidade $p$ como uma função linear das variáveis independentes, $p$ é transformada, através da função de ligação Logit. Assim, o modelo completo é:

$$
\begin{aligned}
& \mathrm{R}_{i} \sim \operatorname{Benoulli}\left(p_{i}\right) \\
& \text { Logit }\left(p_{i}\right)=\alpha+\beta_{1}\left(e_{i}\right)+\beta_{2}\left(b_{i}\right) \\
& p_{i}=1 / 1+\exp \left(\text { Logit }\left[p_{i}\right]\right)
\end{aligned}
$$

Onde, $R_{i}=$ resultado $\left(0\right.$ ou 1 ); $p_{i}=$ probabilidade do indivíduo $i$ ser positivo para o diagnóstico do patógeno; $e=$ espécie; $b$ = área de estudo; $\alpha=$ intercepto; $\beta_{1}=$ coeficiente que representa o efeito da espécie e na probabilidade do indivíduo ser positivo; $\beta_{2}=$ coeficiente que representa o efeito da área de estudo $b$ na probabilidade do indivíduo ser positivo.

Para cada modelo aplicado foi apresentado uma tabela com as estimativas dos coeficientes, juntamente com seu erro padrão (SE), intervalo de confiança de 95\% (IC95) e valor de $p$. Coeficientes com valores de $p<0,05$ foram considerados ter um efeito estatisticamente significativos na probabilidade do indivíduo ser positivo.

\subsubsection{Efeito do sexo e idade na ocorrência de patógenos nas onças-pintadas}

Para pesquisar o efeito da idade na ocorrência dos patógenos nas onças-pintadas, indivíduos filhotes, jovens e subadultos foram agrupados em um único grupo (onças jovens) e comparados aos animais adultos ( $>2$ anos), independente da área de estudo em que foram capturadas. Novamente cada patógeno pesquisado foi analisado separadamente com um 
modelo similar ao anterior. Desta vez, a probabilidade $p$ do indivíduo $i$ ser positivo para um patógeno foi modelada em função do sexo ( $s_{i}$, fêmea e macho) e da idade ( $a_{i}$, jovem e adulto).

$$
\begin{aligned}
& R_{i} \sim \text { Benoulli }\left(p_{i}\right) \\
& \text { Logit }\left(p_{i}\right)=\alpha+\beta_{1}\left[s_{i}\right]+\beta_{2}\left[a_{i}\right] \\
& p_{i}=1 / 1+\exp \left(\operatorname{Logit}\left[p_{i}\right]\right)
\end{aligned}
$$

Onde, $R=$ resultado $(0$ ou 1 ); $p=$ probabilidade do indivíduo ser positivo para $\mathrm{o}$ diagnóstico do patógeno; $s=$ sexo; $a=$ idade; $\alpha=$ intercepto; $\beta_{1}=$ coeficiente que representa 0 efeito do sexo $s$ na probabilidade do indivíduo ser positivo; $\beta_{2}=$ coeficiente que representa $o$ efeito da idade $a$ na probabilidade do indivíduo ser positivo.

Para cada modelo aplicado foi apresentado uma tabela com as estimativas dos coeficientes, juntamente com seu erro padrão (SE), intervalo de confiança de 95\% (IC95) e valor de $p$. Coeficientes com valores de $p<0,05$ foram considerados ter um efeito estatisticamente significativos na probabilidade do indivíduo ser positivo. 


\section{$5 \quad$ RESULTADOS}

São descritos a seguir os resultados encontrados no presente estudo.

\subsection{CAPTURAS DE ONÇAS-PINTADAS}

Durante o período de estudo foram realizadas 30 campanhas para captura de onçaspintadas utilizando cães rastreadores no Parque Nacional das Emas, Pantanal e Parque Estadual do Cantão. No total de 141 dias de esforço foram obtidos 44 eventos de captura e sucesso de captura de $31,2 \%$ (Tabela 1 ).

Através das armadilhas do tipo gaiolas, no PNE, um indivíduo, previamente capturado em 2000 foi recapturado em 2004 durante uma campanha para captura de carnívoros de médio porte. Em 2007, realizou-se um esforço de 170 armadilhas-noites, sem nenhum evento de captura. Entre agosto e dezembro de 2008, acumulou-se um esforço de 2.296 armadilhas-noites, sem sucesso de captura. Embora durante esse último esforço, as onças não tenham sido capturadas, elas foram registradas através de armadilhas fotográficas instaladas em frente às gaiolas nas estradas do PNE (Figuras 32 e 33).

No PEC, através das armadilhas do tipo gaiolas, durante o ano de 2006, realizou-se um esforço de 189 armadilhas-noites, sem sucesso de captura.

As figuras 34 a 36 ilustram os locais de captura e recaptura dos felinos nas áreas de estudo.

Tabela 1 - Esforços amostrais para captura de onças-pintadas utilizando cães rastreadores: número de campanhas, dias de esforço, número de eventos e sucesso de captura no Parque Nacional das Emas (PNE), Pantanal (PAN) e Parque Estadual do Cantão (PEC) durante o período de fevereiro de 2000 a setembro de 2009

\begin{tabular}{|c|c|c|c|c|c|}
\hline \multirow{2}{*}{$\begin{array}{c}\text { Área } \\
\text { amostrada }\end{array}$} & \multirow{2}{*}{$\begin{array}{c}\mathbf{N}^{\circ} \\
\text { Campanhas }\end{array}$} & \multirow{2}{*}{$\begin{array}{l}\text { Dias de } \\
\text { esforço }\end{array}$} & \multicolumn{2}{|c|}{ Eventos de captura } & \multirow{2}{*}{$\begin{array}{l}\text { Sucesso de } \\
\text { captura }(\%)\end{array}$} \\
\hline & & & Captura & Recaptura & \\
\hline PNE & 6 & 37 & 5 & 3 & 21,6 \\
\hline PAN & 22 & 90 & 22 & 11 & 36,7 \\
\hline PEC & 2 & 14 & 3 & 0 & 21,4 \\
\hline Total & 30 & 141 & 30 & 14 & 31,2 \\
\hline
\end{tabular}




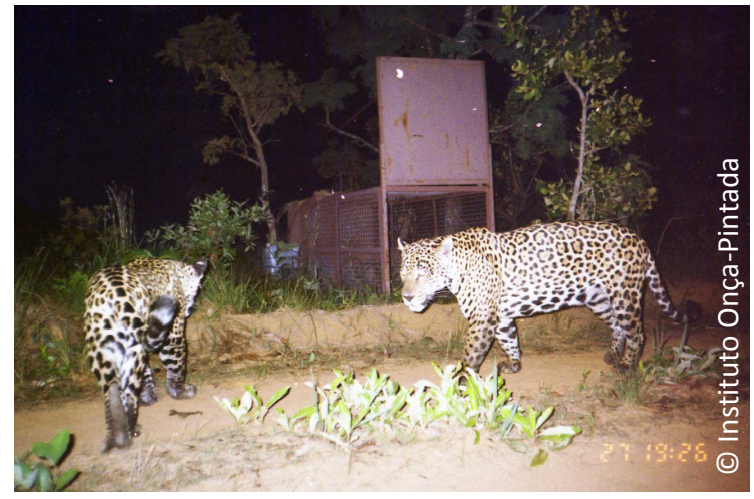

Figura 32 - Fêmea e filhote de onça pintada registrados através de armadilha fotográfica em frente à gaiola no PNE

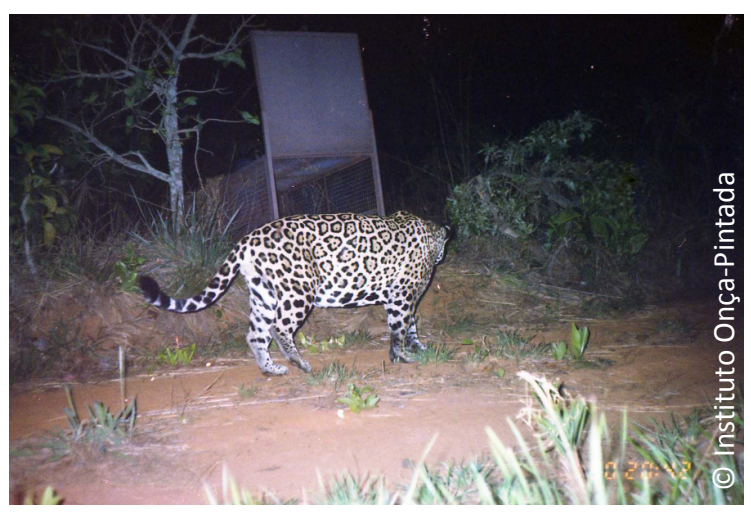

Figura 33 - Onça-pintada fotografada em frente à gaiola, durante deslocamento pelo PNE

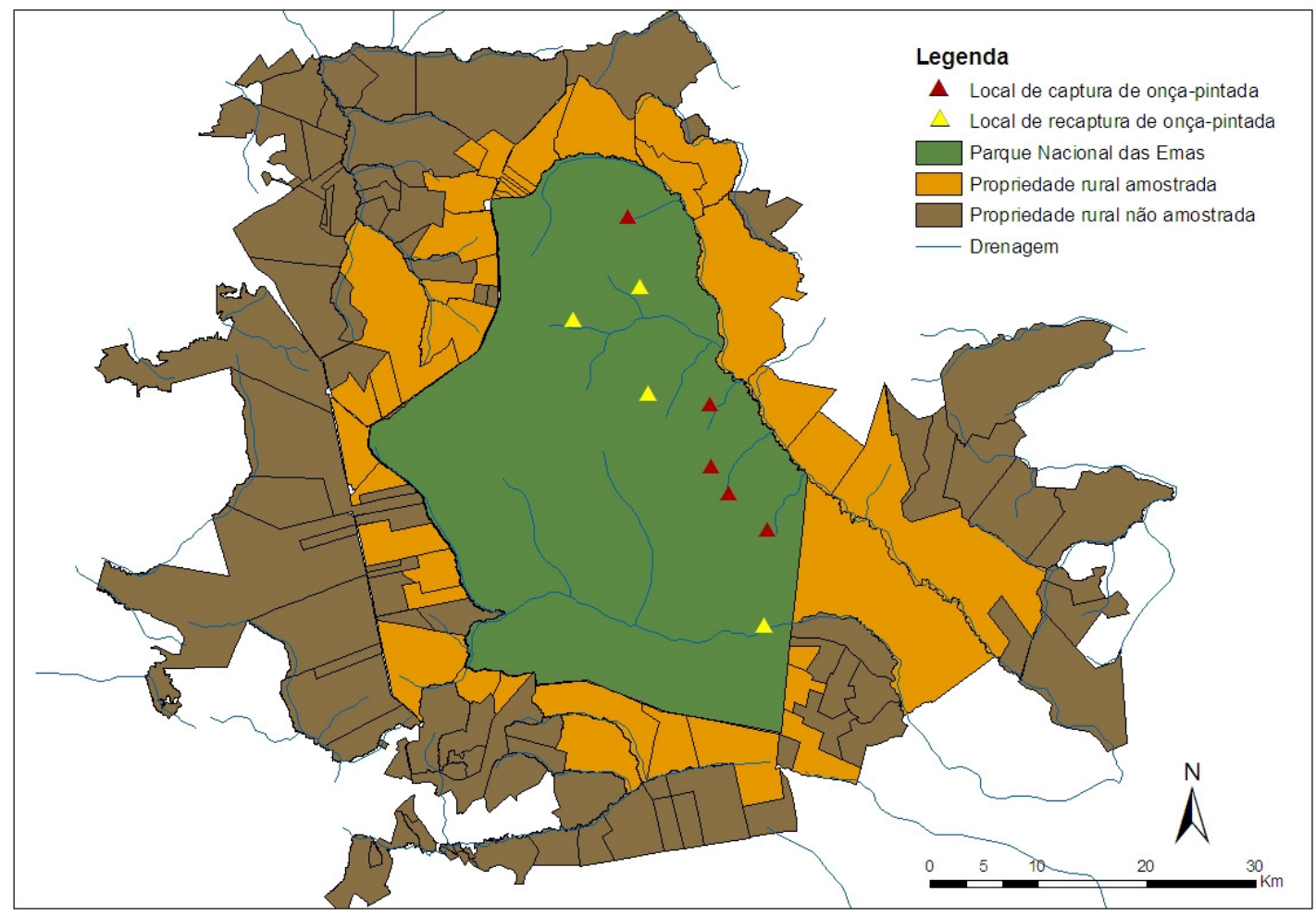

Figura 34 - Localização das capturas e recapturas das onças-pintadas no Parque Nacional das Emas 


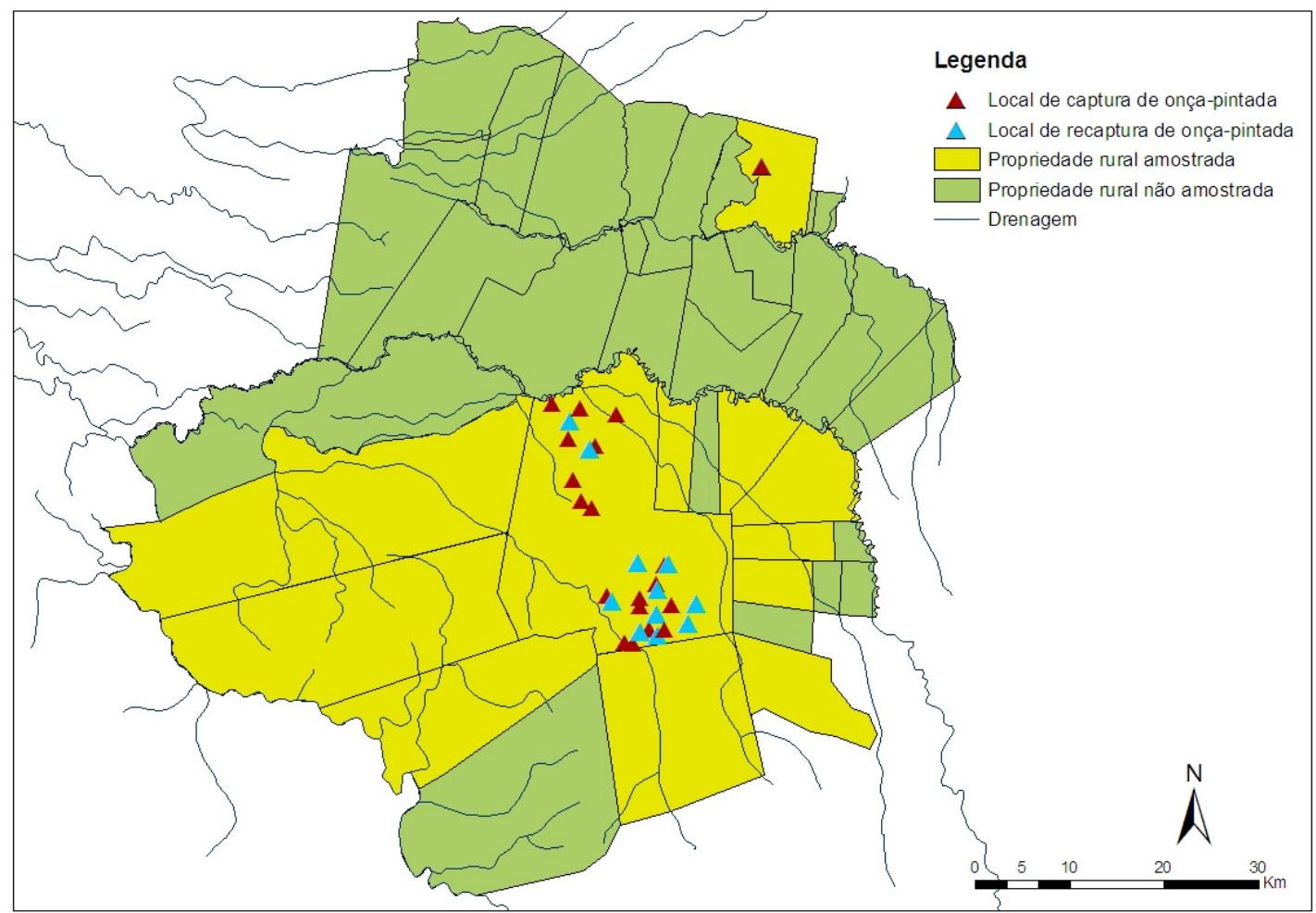

Figura 35 - Localização das capturas e recapturas das onças-pintadas no Pantanal

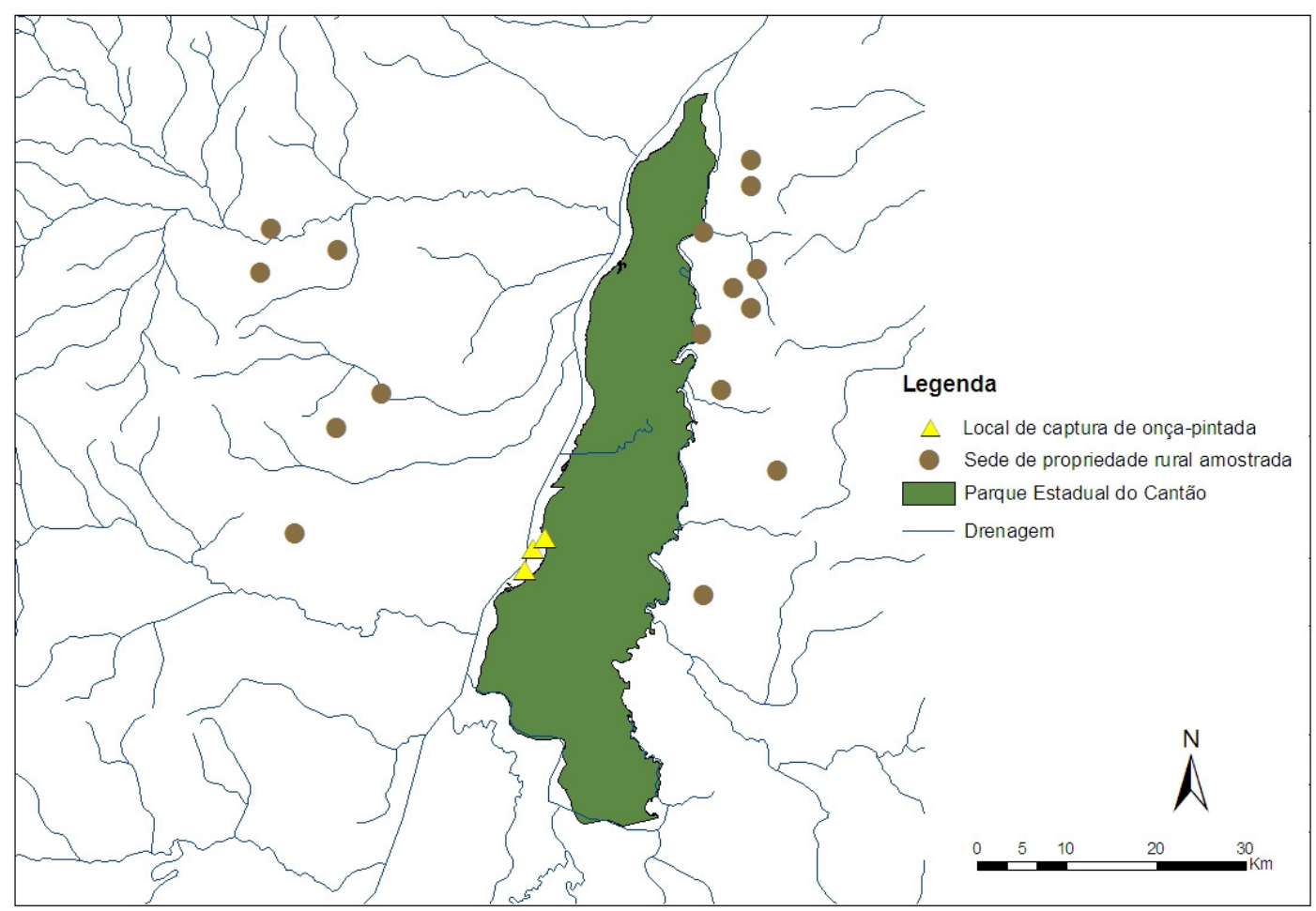

Figura 36 - Localização das capturas das onças-pintadas no Parque Estadual do Cantão 


\subsection{CARACTERIZAÇÃO DAS ONÇAS-PINTADAS CAPTURADAS}

As características (sexo, idade e peso) de cada onça-pintada, data dos eventos de captura, dose anestésica real administrada juntamente com o período de monitoramento dos indivíduos encontram-se nas tabelas 2 a 4. Os animais foram identificados pela frequência do radiotransmissor que receberam.

Tabela 2 - Caracterização (sexo, idade e peso), data de captura, dose anestésica administrada e período de monitoramento das onças-pintadas capturadas entre fevereiro de 2000 e maio de 2009 no Parque Nacional das Emas (PNE). Diferentes datas para um mesmo indivíduo referem-se à captura e subsequente recaptura

\begin{tabular}{|c|c|c|c|c|c|c|c|}
\hline Identificação & $\begin{array}{l}\text { Área de } \\
\text { estudo }\end{array}$ & Sexo & $\begin{array}{l}\text { Data de } \\
\text { captura }\end{array}$ & Idade & $\begin{array}{l}\text { Peso } \\
\text { (kg) }\end{array}$ & $\begin{array}{c}\text { Dose } \\
\text { anestésica } \\
\text { (mg/kg) }\end{array}$ & $\begin{array}{c}\text { Período de } \\
\text { monitoramento } \\
\text { (meses) }\end{array}$ \\
\hline \multirow{2}{*}{150.260} & PNE & $M^{1}$ & $28-f e v-00$ & $\mathrm{Ad}^{2}$ & 90 & 11,1 & \multirow{2}{*}{58} \\
\hline & PNE & $M$ & 15 -ago-04 & $\mathrm{Ad}$ & 80 & 12,5 & \\
\hline \multirow{2}{*}{150.220} & PNE & $F^{3}$ & 29-fev-00 & $\mathrm{Fl}^{4}$ & 23 & 13,0 & \multirow{2}{*}{6} \\
\hline & PNE & $\mathrm{F}$ & 13-jun-00 & $\mathrm{Jv}^{5}$ & 31 & 10,6 & \\
\hline \multirow{2}{*}{150.243} & PNE & M & 1-mar-00 & $\mathrm{FI}$ & 27 & 11,1 & \multirow{2}{*}{6} \\
\hline & PNE & M & 12 -jun-00 & $\mathrm{JV}$ & 43 & 11,6 & \\
\hline 150.410 & PNE & $M$ & 11-nov-00 & $\mathrm{Ad}$ & 85 & 9,4 & 91 \\
\hline \multirow{2}{*}{151.633} & PNE & $M$ & 24-fev-09 & $\mathrm{Ad}$ & 104 & 5,8 & \multirow{2}{*}{14} \\
\hline & PNE & $M$ & 01-maio-09 & $\mathrm{Ad}$ & 104 & 8,6 & \\
\hline
\end{tabular}

${ }^{1}$ Macho. ${ }^{2}$ Adulto. ${ }^{3}$ Fêmea. ${ }^{4}$ Filhote. ${ }^{5}$ Jovem.

Tabela 3 - Caracterização (sexo, idade e peso), data de captura, dose anestésica administrada e período de monitoramento das onças-pintadas capturadas entre agosto de 2006 e abril de 2007 no Parque Estadual do Cantão (PEC)

\begin{tabular}{ccccccc}
\hline Identificação & $\begin{array}{c}\text { Área de } \\
\text { estudo }\end{array}$ & Sexo & $\begin{array}{c}\text { Data de } \\
\text { captura }\end{array}$ & Idade & $\begin{array}{c}\text { Peso } \\
\text { (kg) }\end{array}$ & $\begin{array}{c}\text { Dose anestésica } \\
\text { (mg/kg) }\end{array}$ \\
\hline 151.722 & $\mathrm{PEC}$ & $\mathrm{M}^{1}$ & $07-a g o-06$ & $\mathrm{Ad}^{2}$ & 68 & 8,8 \\
\hline 151.834 & $\mathrm{PEC}$ & $\mathrm{F}^{3}$ & 08 -ago-06 & $\mathrm{Ad}$ & 35 & 11,4 \\
\hline 151.462 & $\mathrm{PEC}$ & $\mathrm{F}$ & 10 -ago-06 & $\mathrm{Ad}$ & 47 & 12,7 \\
\hline JovemPEC & $\mathrm{PEC}$ & $\mathrm{F}$ & 23 -abr-07 & $\mathrm{Jv}^{4}$ & 50 & 6,7 \\
\hline
\end{tabular}

${ }^{1}$ Macho. ${ }^{2}$ Adulto. ${ }^{3}$ Fêmea. ${ }^{4}$ Jovem. 
Tabela 4 - Caracterização (sexo, idade e peso), data de captura, dose anestésica administrada e período de monitoramento das onças-pintadas capturadas entre outubro de 2003 e novembro de 2008 no Pantanal (PAN). Diferentes datas para um mesmo indivíduo se referem à captura e subsequentes recapturas

\begin{tabular}{|c|c|c|c|c|c|c|c|}
\hline Identificação & $\begin{array}{l}\text { Área de } \\
\text { Estudo }\end{array}$ & Sexo & $\begin{array}{l}\text { Data de } \\
\text { captura }\end{array}$ & Idade & $\begin{array}{l}\text { Peso } \\
\text { (kg) }\end{array}$ & $\begin{array}{c}\text { Dose } \\
\text { anestésica } \\
\text { (mg/kg) }\end{array}$ & $\begin{array}{l}\text { Período de } \\
\text { monitoramento } \\
\text { (meses) }\end{array}$ \\
\hline 150.880 & PAN & $M^{1}$ & 21-out-03 & $\mathrm{Ad}^{2}$ & 85 & $\ldots^{3}$ & 2 \\
\hline \multirow{2}{*}{150.842} & \multirow{2}{*}{ PAN } & \multirow{2}{*}{$F^{4}$} & 23-out-03 & $\mathrm{Ad}$ & 75 & $\ldots$ & \multirow{2}{*}{38} \\
\hline & & & 5-jan-07 & $\mathrm{Ad}$ & 77 & 10,4 & \\
\hline 150.793 & PAN & M & 26-out-03 & $\mathrm{Ad}$ & 110 & $\ldots$ & 39 \\
\hline 150.811 & PAN & $\mathrm{F}$ & 26-out-03 & $\mathrm{Ad}$ & 70 & $\ldots$ & 24 \\
\hline \multirow{2}{*}{151.353} & \multirow{2}{*}{ PAN } & \multirow{2}{*}{$M$} & 05-dez-04 & $\mathrm{Ad}$ & 94 & 8,5 & \multirow{2}{*}{36} \\
\hline & & & 30-mar-06 & $\mathrm{Ad}$ & 96 & 11,4 & \\
\hline \multirow{2}{*}{151.343} & \multirow{2}{*}{ PAN } & \multirow{2}{*}{$\mathrm{F}$} & 17-jun-05 & $\mathrm{Jv}^{5}$ & 40 & 9,2 & \multirow{2}{*}{4} \\
\hline & & & 8-out-05 & $\mathrm{Sa}^{6}$ & 54 & 10,5 & \\
\hline \multirow{2}{*}{151.393} & \multirow{2}{*}{ PAN } & \multirow{2}{*}{$\mathrm{F}$} & 18-jun-05 & $\mathrm{Ad}$ & 76 & 14,8 & \multirow{2}{*}{39} \\
\hline & & & 20-jan-08 & $\mathrm{Ad}$ & 71 & 9,6 & \\
\hline \multirow{2}{*}{151.362} & \multirow{2}{*}{ PAN } & \multirow{2}{*}{$\mathrm{F}$} & 03-dez-05 & $\mathrm{Ad}$ & 86 & 9,7 & \multirow{2}{*}{35} \\
\hline & & & 01-abr-08 & $\mathrm{Ad}$ & 90 & 7,8 & \\
\hline 151.263 & PAN & $M$ & 26-jan-06 & $\mathrm{Ad}$ & 104 & 8,6 & 5 \\
\hline 151.374 & PAN & $M$ & 23-fev-06 & $\mathrm{Ad}$ & 112 & 7,1 & 17 \\
\hline \multirow{4}{*}{150.872} & \multirow{4}{*}{ PAN } & \multirow{4}{*}{$\mathrm{F}$} & $26-f e v-06$ & $\mathrm{Jv}$ & 60 & 11,6 & \multirow{4}{*}{31} \\
\hline & & & 8-jun-06 & Sa & 63 & 9,5 & \\
\hline & & & 20-set-06 & Sa & 71 & 9,8 & \\
\hline & & & 14-nov-07 & $\mathrm{Ad}$ & 75 & 8,0 & \\
\hline \multirow{2}{*}{151.452} & \multirow{2}{*}{ PAN } & \multirow{2}{*}{$\mathrm{F}$} & $24-a b r-06$ & JV & 46 & 10,9 & \multirow{2}{*}{7} \\
\hline & & & 28-jul-06 & $\mathrm{Jv}$ & 56 & 7,1 & \\
\hline 151341 & PAN & $\mathrm{F}$ & $24-a b r-06$ & Jv & 50 & 12,0 & 6 \\
\hline 131.341 & & & 22 -set-06 & Sa & 74 & 8,1 & \\
\hline 151443 & PAN & $\mathrm{F}$ & 3-jun-06 & $\mathrm{Ad}$ & 70 & 11,4 & 19 \\
\hline S1.4. & Thiv & 1 & 6-jan-07 & $\mathrm{Ad}$ & 86 & 7,0 & \\
\hline 151.422 & PAN & $\mathrm{F}$ & 5-jun-06 & $\mathrm{Sa}$ & 62 & 9,7 & 1 \\
\hline Jovem & PAN & $\mathrm{M}$ & 25-jan-07 & $\mathrm{JV}$ & 60 & 10,7 & $\therefore^{8}$ \\
\hline 151.351 & PAN & $\mathrm{F}$ & 26-jan-07 & $\mathrm{Ad}$ & 80 & 8,7 & $\therefore$ \\
\hline 151.762 & PAN & M & 3-nov-07 & $\mathrm{Ad}$ & 102 & 7,8 & $\therefore$ \\
\hline Filhote1 & PAN & $\mathrm{F}$ & 12-nov-07 & $\mathrm{Fl}^{7}$ & $\ldots$ & $\ldots$ & $\therefore$ \\
\hline 151.824 & PAN & $\mathrm{F}$ & 12-nov-07 & $\mathrm{Ad}$ & $\ldots$ & $\ldots$ & $\therefore$ \\
\hline Filhote2 & PAN & $\mathrm{F}$ & 23-jan-08 & $\mathrm{FI}$ & 36 & 6,1 & $\therefore$ \\
\hline 151.533 & PAN & $\mathrm{F}$ & 18-nov-08 & $\mathrm{Ad}$ & 77 & 10,4 & 14 \\
\hline
\end{tabular}

${ }^{1}$ Macho. ${ }^{2}$ Adulto. ${ }^{3}$ dado não disponível. ${ }^{4}$ Fêmea. ${ }^{5}$ Jovem. ${ }^{6}$ Subadulto. ${ }^{7}$ Filhote. ${ }^{8}$ não realizado. 
Os indivíduos capturados, em quase sua totalidade $(96,8 \%, n=30)$, apresentaram condição física ótima ou boa, estado geral ótimo ou bom, peso corpóreo adequado e ausência de alteração ou sinal clínico de enfermidade aparente. Uma única onça-pintada fêmea (151.834) capturada no Parque Estadual do Cantão apresentou baixo peso corpóreo e desidratada (Figura 37). Observada pelos pesquisadores na noite anterior à sua captura, o animal estava atento, sem qualquer alteração de comportamento. Estimou-se que essa fêmea tinha aproximadamente 10 anos de idade. O animal apresentou ausência do canino superior esquerdo e dos incisivos superiores e inferiores, além de caninos inferiores bastante desgastados (Figura 38).

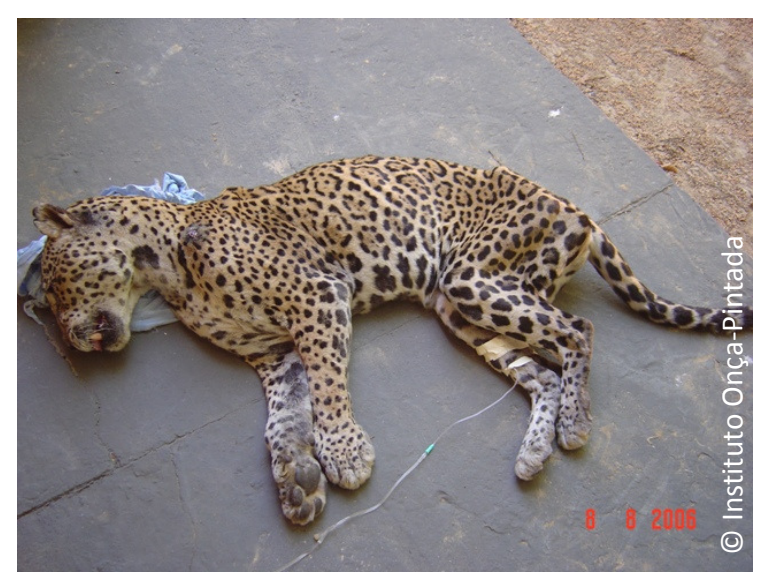

Figura 37 - Fêmea 151.834 capturada no PEC com baixo peso corpóreo

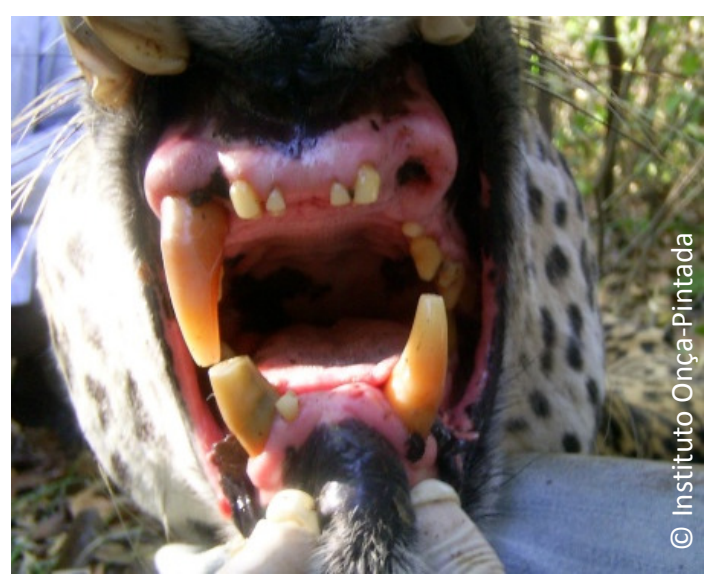

Figura 38 - Arcada dentária da fêmea 151.834 com ausências de canino superior esquerdo e de incisivos

\subsection{COLETA E ARMAZENAMENTO DE SANGUE E ECTOPARASITAS DAS ONÇAS-PINTADAS}

Ao todo, amostras biológicas de 46 eventos de captura foram coletadas e armazenadas para a realização das análises propostas neste estudo. Foram 31 indivíduos capturados e, 15 destes recapturados posteriormente.

Durante todos os eventos de captura foi possível a extração de soro para as análises de sorodiagnóstico. Com exceção de um indivíduo capturado no PNE, todos os indivíduos tiveram ao menos uma amostra de sangue total coletada em sua captura ou recaptura para o diagnóstico de hemoparasitas ( $n=37)$. Amostras de ectoparasitas só não foram coletadas em três recapturas realizadas no Pantanal $(n=43)$. 


\subsection{COLETA E ARMAZENAMENTO DE FEZES DAS ONÇAS-PINTADAS}

Foram coletadas 23 amostras de fezes de onças-pintadas (12 do PNE, 6 do Pantanal e 5 PEC) para pesquisa de parasitas intestinais. Para tentativa de isolamento de micobactérias foram coletadas 39 amostras (6 do PNE, 13 do Pantanal e 20 do PEC).

\subsection{CARACTERIZAÇÃO DAS PROPRIEDADES RURAIS AMOSTRADAS}

Foram amostradas 36 propriedades rurais do entorno do Parque Nacional das Emas, 12 no Pantanal e 12 propriedades mais 4 assentamentos rurais do entorno do Parque Estadual do Cantão (ver Figuras 34 a 36). No entorno do PNE, a principal atividade econômica registrada foi a agricultura, desenvolvida por $72,22 \%$ (26/36) das propriedades rurais, sendo que $13,89 \%$ (5/36) das demais propriedades praticavam tanto agricultura quanto pecuária, e 11,11\% (4/36) apenas a pecuária extensiva (Tabela 5). No Pantanal, a pecuária extensiva de corte foi a atividade econômica desenvolvida em todas as propriedades rurais (Tabela 6). E, na região do PEC, 37,5\% (6/16) das propriedades e assentamentos do entorno não desenvolviam atividade econômica, e entre as propriedades rurais que praticavam atividades, $80,0 \%(8 / 10)$ desenvolviam a pecuária, 10,0\% (1/10) praticavam a agricultura e a pecuária, e 10,0\% (1/10) apenas a agricultura (Tabela 7).

\subsection{COLETA E ARMAZENAMENTO DE SANGUE E ECTOPARASITAS DOS ANIMAIS DOMÉSTICOS}

Foram coletadas amostras biológicas de 564 animais domésticos no entorno do PNE (Tabela 5), 398 nas propriedades rurais do Pantanal (Tabela 6) e 499 no entorno do PEC (Tabela 7). 
Tabela 5 - Caracterização das propriedades rurais amostradas no entorno do Parque Nacional das Emas em relação à atividade desenvolvida, área da propriedade, tamanho do rebanho e quantidade de animais amostrados entre maio de 2008 e agosto de 2009

\begin{tabular}{|c|c|c|c|c|c|c|}
\hline \multirow{2}{*}{ Propriedade } & \multirow{2}{*}{ Atividade econômica } & \multirow{2}{*}{$\begin{array}{l}\text { Área } \\
\text { (ha) }\end{array}$} & \multirow{2}{*}{$\begin{array}{r}\text { Tamanho } \\
\text { rebanho }\end{array}$} & \multicolumn{3}{|c|}{$\mathbf{N}^{\circ}$ animais amostrados } \\
\hline & & & & Bovino & Cão & Gato \\
\hline Propriedade 1 & Pecuária & 8.000 & 6.000 & 86 & 4 & 0 \\
\hline Propriedade 2 & Agricultura/Pecuária & 9.144 & 3.000 & 62 & 3 & 0 \\
\hline Propriedade 3 & Agricultura/Pecuária & 3.400 & 600 & 64 & 1 & 0 \\
\hline Propriedade 4 & Pecuária & 3.500 & 1.000 & 68 & 7 & 0 \\
\hline Propriedade 5 & Pecuária & 12.000 & 1.000 & 54 & 2 & 0 \\
\hline Propriedade 6 & Agricultura & 1.500 & 0 & 0 & 1 & 0 \\
\hline Propriedade 7 & Agricultura & 4.219 & 0 & 0 & 2 & 0 \\
\hline Propriedade 8 & Agricultura & 2.231 & 0 & 0 & 2 & 0 \\
\hline Propriedade 9 & Agricultura/Pecuária & 3.318 & 1.007 & 65 & 4 & 1 \\
\hline Propriedade 10 & Agricultura & 5.026 & 0 & 0 & 1 & 0 \\
\hline Propriedade 11 & Agricultura & 1.450 & 0 & 0 & 1 & 0 \\
\hline Propriedade 12 & Agricultura & 2.200 & 0 & 0 & 3 & 0 \\
\hline Propriedade 13 & Agricultura & 601 & 0 & 0 & 1 & 1 \\
\hline Propriedade 14 & Agricultura & 1.376 & 0 & 0 & 1 & 0 \\
\hline Propriedade 15 & Agricultura & 2.300 & 0 & 0 & 1 & 2 \\
\hline Propriedade 16 & Agricultura & 832 & 0 & 0 & 4 & 0 \\
\hline Propriedade 17 & Agricultura & 4.200 & 0 & 0 & 2 & 0 \\
\hline Propriedade 18 & Agricultura & 1.600 & 0 & 0 & 3 & 1 \\
\hline Propriedade 19 & Agricultura & 1.200 & 0 & 0 & 1 & 0 \\
\hline Propriedade 20 & Agricultura & 1.057 & 0 & 0 & 5 & 0 \\
\hline Propriedade 21 & Agricultura & 10 & 420 & 0 & 6 & 2 \\
\hline Propriedade 22 & Pecuária & 3.500 & 1.200 & 0 & 2 & 0 \\
\hline Propriedade 23 & Agricultura & 1.470 & 0 & 1 & 4 & 1 \\
\hline Propriedade 24 & Agricultura/Pecuária & 2.800 & 200 & 10 & 2 & 1 \\
\hline Propriedade 25 & Agricultura & 3.850 & 0 & 0 & 2 & 0 \\
\hline Propriedade 26 & Agricultura & $\ldots{ }^{1}$ & 0 & 0 & 1 & 0 \\
\hline Propriedade 27 & $s / a^{2}$ & 27 & 0 & 0 & 0 & 1 \\
\hline Propriedade 28 & Agricultura & 74 & 0 & 0 & 2 & 0 \\
\hline Propriedade 29 & Agricultura & 450 & 0 & 0 & 2 & 0 \\
\hline Propriedade 30 & Agricultura & 1.600 & 0 & 0 & 3 & 0 \\
\hline Propriedade 31 & Agricultura & 251 & 0 & 0 & 0 & 1 \\
\hline Propriedade 32 & Agricultura/Pecuária & 3.700 & 600 & 57 & 4 & 0 \\
\hline Propriedade 33 & Agricultura & 4.080 & 0 & 0 & 3 & 0 \\
\hline Propriedade 34 & Agricultura & $\ldots$ & 0 & 0 & 2 & 0 \\
\hline Propriedade 35 & Agricultura & $\ldots$ & 0 & 0 & 3 & 0 \\
\hline \multirow[t]{2}{*}{ Propriedade 36} & Agricultura & $\ldots$ & 0 & 0 & 1 & 0 \\
\hline & & & TOTAL & 467 & 86 & 11 \\
\hline
\end{tabular}

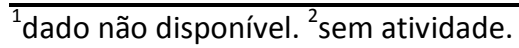


Tabela 6 - Caracterização das propriedades rurais amostradas no Pantanal em relação à atividade desenvolvida, área da propriedade, tamanho do rebanho e quantidade de animais amostrados entre novembro de 2008 a janeiro de 2010

\begin{tabular}{lcrrrrc}
\hline \multirow{2}{*}{ Propriedade } & Atividade econômica & $\begin{array}{r}\text { Área } \\
\text { (ha) }\end{array}$ & $\begin{array}{r}\text { Tamanho } \\
\text { rebanho }\end{array}$ & \multicolumn{3}{c}{$\mathbf{N}^{\circ}$ animais amostrados } \\
Bovino & Cão & Gato \\
\hline Propriedade 1 & Pecuária & 55.000 & 27.000 & 37 & 0 & 1 \\
Propriedade 2 & Pecuária & 4.412 & 2.500 & 63 & 4 & 0 \\
Propriedade 3 & Pecuária & 6.814 & 2.000 & 47 & 5 & 0 \\
Propriedade 4 & Pecuária & 9.795 & $\ldots$ & 0 & 1 & 0 \\
Propriedade 5 & Pecuária & 4.122 & $\ldots$ & 0 & 8 & 5 \\
Propriedade 6 & Pecuária & 4.137 & $\ldots$ & 0 & 0 & 1 \\
Propriedade 7 & Pecuária & 9.215 & $\ldots$ & 0 & 0 & 2 \\
Propriedade 8 & Pecuária & 25.872 & $\ldots$ & 0 & 5 & 0 \\
Propriedade 9 & Pecuária & 33.000 & 9.250 & 35 & 3 & 1 \\
Propriedade 10 & Pecuária & 41.011 & 7.000 & 60 & 5 & 1 \\
Propriedade 11 & Pecuária & 52.670 & $\ldots$ & 49 & 0 & 0 \\
Propriedade 12 & Pecuária & 11.000 & 2.000 & 64 & 0 & 1 \\
\hline & & & TOTAL & 355 & 31 & 12 \\
\hline
\end{tabular}

${ }^{1}$ dado não disponível.

Tabela 7 - Caracterização das propriedades rurais e assentamentos amostrados no entorno do Parque Estadual do Cantão, em relação à atividade desenvolvida, área da propriedade, tamanho do rebanho e quantidade de animais amostrados durante o mês de maio de 2009

\begin{tabular}{lcrrrrr}
\hline \multirow{2}{*}{ Propriedade } & Atividade econômica & $\begin{array}{r}\text { Área } \\
\text { (ha) }\end{array}$ & $\begin{array}{r}\text { Tamanho } \\
\text { rebanho }\end{array}$ & \multicolumn{2}{c}{$\mathbf{N}^{\circ}$ animais amostrados } \\
& & Bovino & Cão & Gato \\
\hline Propriedade 1 & Pecuária & 53.078 & 20.000 & 61 & 19 & 2 \\
Propriedade 2 & Pecuária & 57.000 & 14.200 & 119 & 5 & 1 \\
Propriedade 3 & Pecuária & 2.448 & 1.300 & 60 & 2 & 0 \\
Propriedade 4 & Agricultura & $\ldots$ & 0 & 0 & 2 & 0 \\
Propriedade 5 & Pecuária & $\ldots$ & $\ldots$ & 0 & 1 & 1 \\
Propriedade 6 & s/a ${ }^{2}$ & $\ldots$ & 0 & 0 & 1 & 2 \\
Propriedade 7 & s/a & $\ldots$ & 0 & 0 & 1 & 0 \\
Propriedade 8 & Pecuária & 4.352 & 3.000 & 60 & 3 & 1 \\
Propriedade 9 & Pecuária & $\ldots$ & $\ldots$ & 0 & 3 & 0 \\
Propriedade 10 & Pecuária & 761 & 4.500 & 64 & 3 & 0 \\
Propriedade 11 & Agricultura/Pecuária & $\ldots$ & $\ldots$ & 0 & 4 & 2 \\
Propriedade 12 & Pecuária & 10.000 & 2.000 & 60 & 1 & 0 \\
Assentamento 1 & s/a & $\ldots$ & - & 0 & 1 & 0 \\
Assentamento 2 & s/a & $\ldots$ & - & 0 & 1 & 0 \\
Assentamento 3 & s/a & $\ldots$ & - & 0 & 6 & 2 \\
Assentamento 4 & s/a & $\ldots$ & - & 0 & 9 & 2 \\
\hline & & & TOTAL & 424 & 62 & 13 \\
\hline
\end{tabular}

${ }^{1}$ dado não disponível. ${ }^{2}$ sem atividade. 


\subsection{ANÁLISES LABORATORIAIS}

Primeiramente são apresentados os diagnósticos encontrados para as onças-pintadas capturadas nas três áreas de estudo, e na sequência, os diagnósticos encontrados para as onças e os animais domésticos.

\subsubsection{Onças-pintadas}

Os resultados individualizados dos sorodiagnósticos e testes moleculares para as onçaspintadas encontram-se nas tabelas 8 a 10, e foram apresentados segundo o local de captura.

Todas as onças-pintadas $(n=31)$ das três áreas de estudo foram soropositivas para Toxoplasma gondii com títulos de anticorpos que variaram entre 25 e 3200 (Tabelas 8 a 10). Um único indivíduo do PNE (151.633) foi soropositivo para brucela lisa no evento de recaptura, aproximadamente 60 dias após a sua captura (Tabela 8). As onças-pintadas capturadas no PNE e no Pantanal foram soropositivas a diferentes sorovares de Leptospira spp. com títulos que variaram entre 100 e 6400 (Tabelas 8 e 10), enquanto as quatro onças-pintadas do PEC foram negativas para o agente (Tabela 9). Onças-pintadas soropositivas para o vírus da cinomose foram detectadas apenas no Pantanal com títulos de anticorpos de 8 a 32 (Tabela 10). Títulos de anticorpos $\geq 0,10 \mathrm{Ul} / \mathrm{ml}$ contra o vírus da raiva foram detectados na recaptura de uma onçapintada (150.243) do PNE (Tabela 8), e em 5 onças-pintadas do Pantanal (Tabela 10). O maior título encontrado para o vírus da raiva foi de $0,50 \mathrm{UI} / \mathrm{ml}$ na recaptura do indivíduo 151.433 que em sua captura, sete meses antes apresentou título = 0,12 UI/ml (Tabela 10). Nenhuma onçapintada das três áreas de estudo foi soropositiva ao vírus da imunodeficiência felina ou ao vírus da leucemia felina.

Todas as onças-pintadas amostradas no PNE e Pantanal e três de quatro onças do PEC foram positivas para Hepatozoon spp. e Cytauxzoon felis. Todos os indivíduos foram negativos para Babesia spp. Para os hemoplasmas felinos, o Mycoplasma haemofelis esteve presente em duas onças-pintadas do PEC e três do Pantanal, o 'Candidatus Mycoplasma haemominitum' foi encontrado em onças-pintadas das três áreas de estudo e, o 'Candidatus Mycoplasma turicensis' foi detectado em duas onças-pintadas do Pantanal (Tabelas 8 a 10). 
Tabela 8 - Resultados dos testes sorológicos e moleculares realizados para as amostras de onças-pintadas de vida livre capturadas no Parque Nacional das Emas (PNE) entre fevereiro de 2000 e maio de 2009

\begin{tabular}{|c|c|c|c|c|c|c|c|c|c|c|c|c|c|c|c|}
\hline \multirow{2}{*}{ ID $^{1}$} & \multirow{2}{*}{ Data } & \multirow{2}{*}{ Local } & \multicolumn{7}{|c|}{ Teste Sorológico } & \multicolumn{6}{|c|}{ Teste molecular } \\
\hline & & & $\operatorname{Tox}^{2}$ & $\mathrm{Bru}^{3}$ & Lep $^{4}$ & $\operatorname{Cin}^{5}$ & $\mathrm{Rai}^{6}$ & FIV & FeLV & Hep $^{7}$ & $\mathrm{Bab}^{8}$ & Cyt $^{9}$ & Mha $^{10}$ & $\mathrm{CMh}^{11}$ & $\mathrm{CMt}^{12}$ \\
\hline \multirow{2}{*}{150.260} & 28-fev-00 & PNE & $P^{13}(100)$ & -14 & $P\left[\operatorname{Gri}^{15}(1600)\right.$, Ict $\left.^{16}(100)\right]$ & - & - & - & - & $\ldots^{17}$ & $\cdots$ & $\ldots$ & $\ldots$ & $\cdots$ & $\ldots$ \\
\hline & 15-ago-04 & PNE & $P(200)$ & - & - & - & - & - & - & $\ldots$ & $\ldots$ & $\ldots$ & $\ldots$ & $\ldots$ & $\ldots$ \\
\hline \multirow{2}{*}{150.220} & 29-fev-00 & PNE & $P(50)$ & - & - & - & - & - & - & $\ldots$ & $\ldots$ & $\ldots$ & $\ldots$ & $\ldots$ & $\ldots$ \\
\hline & 13-jun-00 & PNE & $P(200)$ & - & - & - & $\ldots$ & - & - & $\mathrm{P}$ & - & $\mathrm{P}$ & - & - & - \\
\hline \multirow{2}{*}{150.243} & 1-mar-00 & PNE & $P(200)$ & - & - & - & - & - & - & $\ldots$ & $\ldots$ & $\ldots$ & $\ldots$ & $\ldots$ & $\ldots$ \\
\hline & 12-jun-00 & PNE & $P(200)$ & - & - & - & $P(0,11)$ & - & - & $\mathrm{P}$ & - & $\mathrm{P}$ & - & $\mathrm{P}$ & - \\
\hline 150.410 & $11-$ nov-00 & PNE & $P(200)$ & - & $P$ [Gri (3200)] & - & - & - & - & $\mathrm{P}$ & - & $\mathrm{P}$ & - & $\mathrm{P}$ & - \\
\hline \multirow{2}{*}{151.633} & 24-fev-09 & PNE & $P(200)$ & - & P [Gri (400)] & - & - & - & - & $\mathrm{P}$ & - & $\mathrm{P}$ & - & $\mathrm{P}$ & - \\
\hline & 01-maio-09 & PNE & $P(100)$ & $\mathrm{P}$ & - & - & - & - & - & $\mathrm{P}$ & - & $\mathrm{P}$ & - & $\mathrm{P}$ & - \\
\hline
\end{tabular}

$\overline{{ }^{1} \text { Identificação. }{ }^{2} \text { Toxoplasma gondii. }{ }^{3} \text { brucela lisa. }{ }^{4} \text { Leptospira spp. }{ }^{5} \text { vírus da cinomose. }{ }^{6} \text { vírus da raiva. }{ }^{7} \text { Hepatozoon spp. }{ }^{8} \text { Babesia spp. }{ }^{9} \text { Cytauxzoon felis. }{ }^{10} \text { Mycoplasma haemofelis. }}$

${ }^{11}$ 'Canditatus Mycoplasma haemominutum'. ${ }^{12}$ 'Candidatus Mycoplasma turicensis'. ${ }^{13}$ Positivo. ${ }^{14}$ Negativo. ${ }^{15}$ Grippotyphosa. ${ }^{16}$ Icterohaemorrhagiae. ${ }^{17}$ não realizado.

Tabela 9 - Resultados dos testes sorológicos e moleculares realizados para as amostras de onças-pintadas de vida livre capturadas na região do Parque Estadual do Cantão (PEC) entre agosto de 2006 e abril de 2007

\begin{tabular}{|c|c|c|c|c|c|c|c|c|c|c|c|c|c|c|c|}
\hline \multirow{2}{*}{ ID $^{1}$} & \multirow{2}{*}{ Data } & \multirow{2}{*}{ Local } & \multicolumn{7}{|c|}{ Teste Sorológico } & \multicolumn{6}{|c|}{ Teste molecular } \\
\hline & & & $\operatorname{Tox}^{2}$ & $\mathrm{Bru}^{3}$ & Lep $^{4}$ & $\operatorname{Cin}^{5}$ & Rai $^{6}$ & FIV & FeLV & Hep $^{7}$ & $\mathrm{Bab}^{8}$ & $\mathrm{Cyt}^{9}$ & $\mathrm{Mha}^{10}$ & $\mathrm{CMh}^{11}$ & $\mathrm{CMt}^{12}$ \\
\hline 151.722 & 7-ago-06 & PEC & $P^{13}(3200)$ & $-{ }^{14}$ & - & - & - & - & - & - & - & $\mathrm{P}$ & - & $\mathrm{P}$ & - \\
\hline 151.834 & 8-ago-06 & PEC & $P(400)$ & - & - & - & - & - & - & $P$ & - & $P$ & $P$ & $P$ & - \\
\hline 151.462 & 10-ago-06 & PEC & $P(400)$ & - & - & - & - & - & - & $P$ & - & $\mathrm{P}$ & $\mathrm{P}$ & $P$ & - \\
\hline JovemPEC & $23-a b r-07$ & PEC & $P(200)$ & - & - & - & - & - & - & $\mathrm{P}$ & - & - & - & - & - \\
\hline
\end{tabular}

${ }^{1}$ Identificação. ${ }^{2}$ Toxoplasma gondii. ${ }^{3}$ brucela lisa. ${ }^{4}$ Leptospira spp. ${ }^{5}$ vírus da cinomose. ${ }^{6}$ vírus da raiva. ${ }^{7}$ Hepatozoon spp. ${ }^{8}$ Babesia spp. ${ }^{9}$ Cytauxzoon felis. ${ }^{10}$ Mycoplasma haemofelis.

${ }^{11}$ 'Canditatus Mycoplasma haemominutum'. ${ }^{12}$ 'Candidatus Mycoplasma turicensis'. ${ }^{13}$ Positivo. ${ }^{14}$ Negativo. 
Tabela 10 - Resultados dos testes sorológicos e moleculares realizados para as amostras de onças-pintadas de vida livre capturadas no Pantanal (PAN) entre outubro de 2003 e novembro de 2008

\begin{tabular}{|c|c|c|c|c|c|c|c|c|c|c|c|c|c|c|c|}
\hline \multirow{2}{*}{$I^{1}$} & \multirow{2}{*}{ Data } & \multirow{2}{*}{ Local } & \multicolumn{7}{|c|}{ Teste Sorológico } & \multicolumn{6}{|c|}{ Teste molecular } \\
\hline & & & Tox $^{2}$ & $\mathrm{Bru}^{3}$ & Lep $^{4}$ & $\operatorname{Cin}^{5}$ & $\operatorname{Rai}^{6}$ & FIV & FeLV & Hep $^{7}$ & $\mathrm{Bab}^{8}$ & Cyt $^{9}$ & Mha $^{10}$ & $\mathrm{CMh}^{11}$ & $\mathrm{CMt}^{12}$ \\
\hline 150.880 & 21-out-03 & PAN & $P^{13}(100)$ & -14 & $P\left[\operatorname{Pyr}^{15}(6400)\right]$ & - & - & - & - & $P$ & - & $P$ & - & - & - \\
\hline \multirow{2}{*}{150.842} & 23-out-03 & PAN & $P(200)$ & - & - & $P(16)$ & - & - & - & $\mathrm{P}$ & - & $P$ & - & $P$ & - \\
\hline & 5-jan-07 & PAN & $P(800)$ & - & - & - & - & - & - & $P$ & - & $P$ & - & $P$ & - \\
\hline 150.811 & 26-out-03 & PAN & $P(25)$ & - & P [Pom $\left.{ }^{16}(200), \operatorname{Pyr}(200)\right]$ & $P(32)$ & - & - & - & $P$ & - & $P$ & - & $P$ & - \\
\hline 150.793 & 26-out-03 & PAN & $P(500)$ & - & - & - & - & - & - & $P$ & - & $P$ & - & $P$ & - \\
\hline \multirow{2}{*}{151.353} & 5-dez-04 & PAN & $P(500)$ & - & $\begin{array}{c}P\left[\text { But }^{17}(100), \text { Gri }^{18}(100),\right. \\
\text { Pom (1600)] }\end{array}$ & - & - & - & - & $P$ & - & $P$ & $P$ & $P$ & - \\
\hline & 30-mar-06 & PAN & $P(800)$ & - & $\begin{array}{c}P\left[\operatorname{Aut}^{19}(400), \text { Pom }\right. \\
(3200)]\end{array}$ & - & - & - & - & $\ldots^{20}$ & $\cdots$ & $\ldots$ & $\cdots$ & $\cdots$ & $\cdots$ \\
\hline \multirow{2}{*}{151.343} & 16-jun-05 & PAN & $P(3200)$ & - & - & - & - & - & - & $\mathrm{P}$ & - & $\mathrm{P}$ & - & - & - \\
\hline & 8-out-05 & PAN & $P(800)$ & - & - & $P(8)$ & - & - & - & $\ldots$ & $\ldots$ & $\ldots$ & $\ldots$ & $\ldots$ & $\ldots$ \\
\hline \multirow[t]{2}{*}{151.393} & 18-jun-05 & PAN & $P(500)$ & - & $\begin{array}{c}P \text { [Aut }(100), \text { Cop }^{21}(200), \\
\text { Pom }(1600)]\end{array}$ & $P(32)$ & $P(0,1)$ & - & - & $P$ & - & $P$ & - & $P$ & - \\
\hline & 20-jan-08 & PAN & $P(500)$ & - & P [Pom (400)] & $P(32)$ & - & - & - & $P$ & - & $P$ & $P$ & $P$ & - \\
\hline \multirow{2}{*}{151.362} & 3-dez-05 & PAN & $P(200)$ & - & - & - & - & - & - & $P$ & - & $\mathrm{P}$ & $P$ & $P$ & $P$ \\
\hline & $01-a b r-08$ & PAN & $P(100)$ & - & - & - & $P(0,1)$ & - & - & $\ldots$ & $\ldots$ & $\ldots$ & $\ldots$ & $\ldots$ & $\ldots$ \\
\hline 151.263 & 26-jan-06 & PAN & $P(200)$ & - & - & - & - & - & - & $P$ & - & $P$ & - & $P$ & - \\
\hline 151.374 & 23-fev-06 & PAN & $P(50)$ & - & - & $P(16)$ & - & - & - & $P$ & - & $P$ & - & $P$ & - \\
\hline \multirow{2}{*}{151.341} & 24-abr-06 & PAN & $P(25)$ & - & - & - & - & - & - & $\cdots$ & $\cdots$ & $\cdots$ & $\cdots$ & $\ldots$ & $\cdots$ \\
\hline & 22 -set-06 & PAN & $P(200)$ & - & - & - & - & - & - & $P$ & - & $P$ & - & $P$ & - \\
\hline
\end{tabular}


(conclusão)

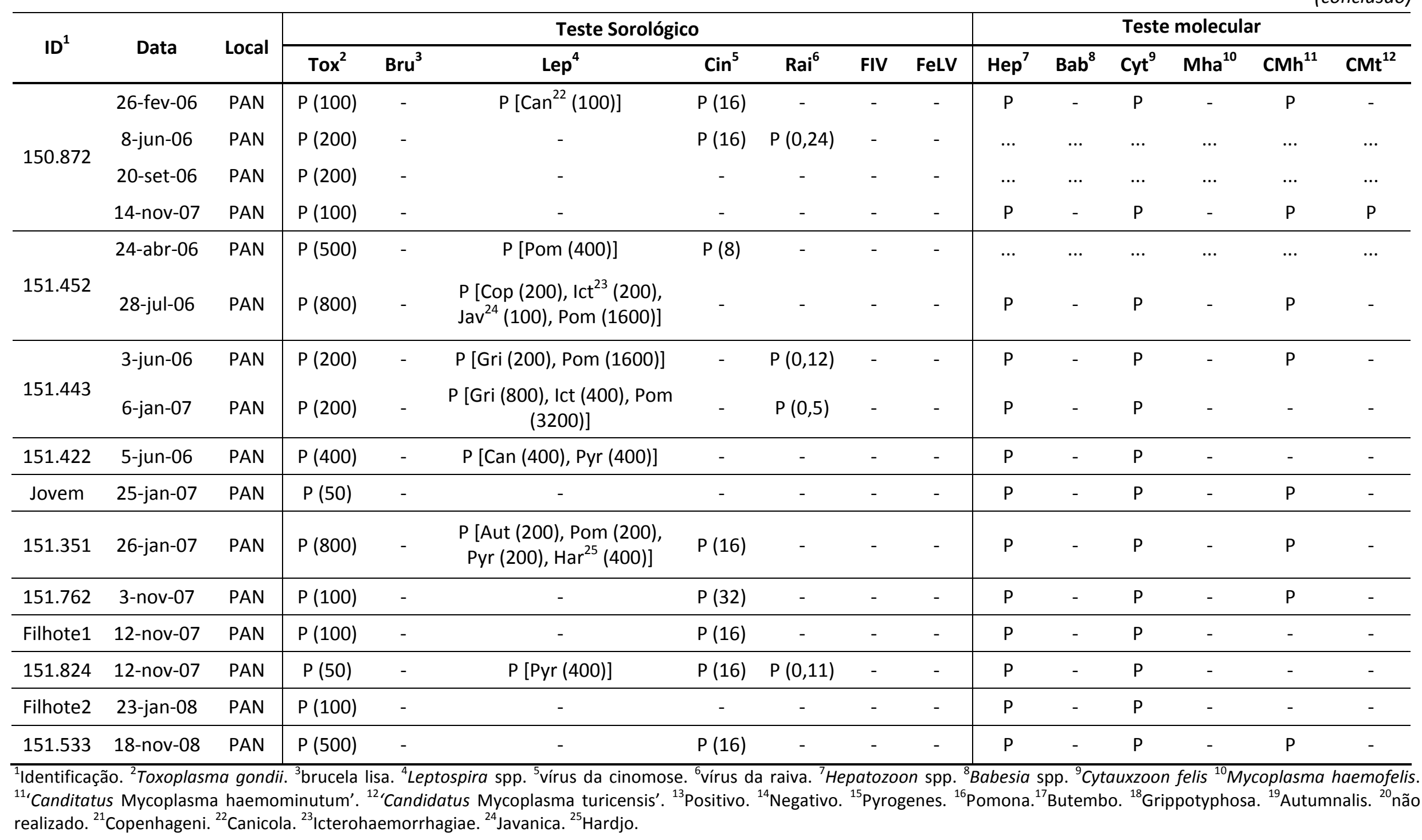


Foi possível analisar o efeito do sexo e idade nos diagnósticos para Leptospira spp., cinomose, raiva, Mycoplasma haemofelis e 'Candidatus Mycoplasma haemominutum' para as onças-pintadas, independente da área de estudo em que foram capturadas (Tabelas 11 a 15). Segundo as análises, as onças-pintadas fêmeas foram significativamente mais expostas ao vírus da cinomose do que as onças-pintadas machos $(p=0,040)$ (Tabela 13). Os animais adultos foram significativamente mais expostos ao 'Candidatus Mycoplasma haemominutum' do que os jovens $(p=0,016)$ (Tabela 15). Não foram detectadas outras associações significativas.

Não foi possível realizar as mesmas análises para os diagnósticos de brucelas lisas, $T$. gondii, Hepatozoon spp., Babesia spp., Cytauxzoon felis e 'Candidatus Mycoplasma turicensis' devido a maioria dos resultados terem sido positivos ou negativos para esses patógenos.

Tabela 11 - Parâmetros estimados pela regressão logística testando o efeito de sexo (coeficiente $\beta_{1}$ ) e idade (coeficiente $\beta_{2}$ ) em relação ao diagnóstico de Lesptospira spp. para as onças-pintadas capturadas no PNE, PEC e Pantanal entre fevereiro de 2000 e maio de 2009. Utilizando como categoria de referência para sexo: fêmea e para idade: jovem

\begin{tabular}{ccccc}
\hline Parâmetros & Estimativa & Erro Padrão & Valor $\boldsymbol{p}$ & IC 95\% \\
\hline Intercepto & $-1,462$ & 0,793 & 0,065 & {$[-3,359 ;-0,079]$} \\
$\beta_{1}$ (macho) & $-0,246$ & 0,827 & 0,766 & {$[-1,931 ; 1,355]$} \\
$B_{2}$ (adulto) & 1,585 & 0,945 & 0,093 & {$[-0,133 ; 3,705]$} \\
\hline
\end{tabular}

Tabela 12 - Parâmetros estimados pela regressão logística testando o efeito de sexo (coeficiente $\beta_{1}$ ) e idade (coeficiente $\beta_{2}$ ) em relação ao diagnóstico do vírus da raiva para as onças-pintadas capturadas no PNE, PEC e Pantanal entre fevereiro de 2000 e maio de 2009. Utilizando como categoria de referência para sexo: fêmea e para idade: jovem

\begin{tabular}{ccccc}
\hline Parâmetros & Estimativa & Erro Padrão & Valor $\boldsymbol{p}$ & IC 95\% \\
\hline Intercepto & $-1,324$ & 0,795 & 0,096 & {$[-3,221 ; 0,073]$} \\
$\beta_{1}$ (macho) & $-1,529$ & 1,208 & 0,206 & {$[-4,605 ; 0,571]$} \\
$\beta_{2}$ (adulto) & 0,528 & 1,015 & 0,603 & {$[-1,398 ; 2,730]$} \\
\hline
\end{tabular}

Tabela 13 - Parâmetros estimados pela regressão logística testando o efeito de sexo (coeficiente $\beta_{1}$ ) e idade (coeficiente $\beta_{2}$ ) em relação ao diagnóstico do vírus da cinomose para as onçaspintadas capturadas no PNE, PEC e Pantanal entre fevereiro de 2000 e maio de 2009. Utilizando como categoria de referência para sexo: fêmea e para idade: jovem

\begin{tabular}{ccccc}
\hline Parâmetros & Estimativa & Erro Padrão & Valor $\boldsymbol{p}$ & IC 95\% \\
\hline Intercepto & $-0,306$ & 0,654 & 0,640 & {$[-1,682 ; 0,967]$} \\
$\beta_{1}$ (macho) & $-1,988$ & 0,968 & 0,040 & {$[-4,158 ;-0,243]$} \\
$\beta_{2}$ (adulto) & 0,789 & 0,881 & 0,371 & {$[-0,884 ; 2,622]$} \\
\hline
\end{tabular}


Tabela 14 - Parâmetros estimados pela regressão logística testando o efeito de sexo (coeficiente $\beta_{1}$ ) em relação ao diagnóstico de Mycoplasma haemofelis para as onças-pintadas capturadas no PNE, PEC e Pantanal entre fevereiro de 2000 e maio de 2009. Utilizando como categoria de referência para sexo: fêmea*

\begin{tabular}{ccccc}
\hline Parâmetros & Estimativa & Erro Padrão & Valor $\boldsymbol{p}$ & IC 95\% \\
\hline Intercepto & $-1,322$ & 0,563 & 0,019 & {$[-2,577 ;-0,308]$} \\
$\beta_{1}$ (macho) & $-0,981$ & 1,190 & 0,410 & {$[-4,031 ; 1,105]$} \\
\hline
\end{tabular}

*Modelo não identificado para o efeito idade

Tabela 15 - Parâmetros estimados pela regressão logística testando o efeito de sexo (coeficiente $\beta_{1}$ ) e idade (coeficiente $\beta_{2}$ ) em relação ao diagnóstico de 'Candidatus Mycoplasma haemominutum' para as onças-pintadas capturadas no PNE, PEC e Pantanal entre fevereiro de 2000 e maio de 2009. Utilizando como categoria de referência para sexo: fêmea e para idade: jovem

\begin{tabular}{ccccc}
\hline Parâmetros & Estimativa & Erro Padrão & Valor $\boldsymbol{p}$ & IC 95\% \\
\hline Intercepto & $-0,706$ & 0,718 & 0,326 & $-2,282 ; 0,648$ \\
$\beta_{1}$ (macho) & 1,451 & 1,265 & 0,252 & $-0,812 ; 4,600$ \\
$\beta_{2}$ (adulto) & 2,445 & 1,014 & 0,016 & 0,$582 ; 4,686$ \\
\hline
\end{tabular}

\subsubsection{Animais domésticos $x$ Onças-pintadas}

A seguir, encontram-se os resultados das análises laboratoriais para os animais domésticos e as onças-pintadas, separados por patógenos pesquisados e áreas de estudo. Os resultados dos animais domésticos por propriedade encontram-se nos apêndices $D$ a J.

5.7.2.1 Diagnóstico sorológico para brucelas lisas

Os resultados do teste sorológico para brucelas lisas estão organizados na tabela 16.

Todas as propriedades do Pantanal e do PEC, onde os bovinos foram amostrados, apresentaram ao menos um indivíduo soropositivo para brucelas lisas, e cães de uma propriedade do Pantanal foram soropositivos para o agente.

De acordo com as análises estatísticas, indivíduos amostrados da região do PNE foram mais expostos às brucelas lisas do que os indivíduos da região do PEC $(p=0,032)$, e os bovinos 
foram significativamente mais expostos às brucelas lisas do que os cães domésticos $(p=0,014)$. Não foram detectadas outras associações significativas (Tabela 17).

A movimentação da onça-pintada capturada no PNE soropositiva para brucela lisa encontra-se na figura 39.

\subsubsection{Diagnóstico sorológico para Leptospira spp.}

Os resultados do teste sorológico para Leptospira spp. estão organizados na tabela 18 , apresentando os indivíduos soropositivos para qualquer sorovar de Leptospira spp. e o sorovar mais provável mais frequentemente diagnosticado para cada espécie.

Todas as propriedades onde os bovinos foram amostrados apresentaram sorologia positiva para Leptospira spp. Os bovinos apresentaram frequência de 68,4\% (Pantanal) a 73,7\% (PNE) de positividade para Leptospira spp., sendo o sorovar Hardjo o mais encontrado para a espécie nas três áreas. A soropositividade dos cães variou de 7,2\% no PNE a 24,1\% no Pantanal. Apenas um gato amostrado no Pantanal foi soropositivo. Os sorovares mais prováveis mais frequentemente encontrado nas onças-pintadas foram Grippothyphosa no PNE e Pomona no Pantanal.

Os bovinos foram significativamente mais expostos à Leptospira spp. do que os cães domésticos $(p<0,001)$, gatos $(p<0,001)$ e onças-pintadas $(p<0,001)$. Não foram detectadas outras associações significativas (Tabela 19).

As figuras 40 e 41 mostram as porcentagens de ocorrência dos sorovares mais encontrados em bovinos e cães domésticos, e as figuras 42 a 44 ilustram as propriedades foco de leptospirose e movimentação das onças-pintadas nas áreas de estudo.

\subsubsection{Diagnóstico sorológico para Toxoplasma gondii}

Os resultados do teste sorológico para Toxoplasma gondii estão organizados na tabela 20, apresentando a variação dos títulos de anticorpos encontrados. 
Os bovinos apresentaram soropositividade inferior a 1,0\% para $T$. gondii nas três áreas de estudo, cães apresentaram frequências de soropositividade entre 29,1 e 47,8\%, gatos de 77,8 e $90,0 \%$, e as onças-pintadas, $100 \%$ de soropositividade.

Entre os animais domésticos, os gatos e os cães foram significativamente mais expostos ao Toxoplasma gondii do que os bovinos $(p<0,001)$. Não foram detectadas outras associações significativas (Tabela 21). Não foi possível incluir as onças-pintadas na análise realizada devido à alta exposição da espécie ao T. gondii.

As figuras 45 a 47 ilustram as propriedades foco de toxoplasmose e movimentação das onças-pintadas soropositivas para o agente. 
Tabela 16 - Resultados do teste sorológico para brucelas lisas, distribuídos em função das áreas de estudo e das espécies amostradas entre fevereiro de 2000 e janeiro de 2010

\begin{tabular}{|c|c|c|c|c|c|c|c|c|c|c|}
\hline \multirow{2}{*}{ Espécie } & \multirow{2}{*}{ Categoria } & \multicolumn{3}{|c|}{ Parque Nacional das Emas } & \multicolumn{3}{|c|}{ Pantanal } & \multicolumn{3}{|c|}{ Parque Estadual do Cantão } \\
\hline & & Examinados & Positivos & $\%$ & Examinados & Positivos & $\%$ & Examinados & Positivos & $\%$ \\
\hline Onça-pintada & animais & 5 & 1 & 20,0 & 22 & 0 & 0 & 4 & 0 & 0 \\
\hline Bovino & propriedades & 9 & 6 & 66,7 & 7 & 7 & 100,0 & 6 & 6 & 100,0 \\
\hline \multirow{2}{*}{ Cão doméstico } & propriedades & 25 & 0 & 0 & 6 & 1 & 16,7 & 13 & 0 & 0 \\
\hline & animais & 48 & 0 & 0 & 22 & 2 & 9,1 & 39 & 0 & 0 \\
\hline
\end{tabular}

Tabela 17 - Parâmetros estimados pela regressão logística testando o efeito da espécie amostrada (coeficiente $\beta_{1}$ ) e área de estudo (coeficiente $\beta_{2}$ ) para o diagnóstico de brucelas lisas. Utilizando como categoria de referência para espécie, os bovinos, e para área de estudo, o Parque Nacional das Emas

\begin{tabular}{lcccc}
\hline \multicolumn{1}{c}{ Parâmetros } & Estimativa & Erro Padrão & Valor $\boldsymbol{p}$ & IC 95\% \\
\hline Intercepto & $-2,055$ & 0,145 & $<0,001$ & {$[-2,351 ;-1,780]$} \\
$\beta_{1}$ (cão doméstico) & $-1,767$ & 0,721 & 0,014 & {$[-3,577 ;-0,600]$} \\
$\beta_{1}$ (onça-pintada) & $-1,280$ & 1,025 & 0,212 & {$[-4,168 ; 0,286]$} \\
$\beta_{2}$ (Pantanal) & $-0,018$ & 0,220 & 0,936 & {$[-0,454 ; 0,412]$} \\
$\beta_{2}$ (PEC) & $-0,506$ & 0,236 & 0,032 & {$[-0,977 ;-0,050]$} \\
\hline
\end{tabular}


Tabela 18 - Resultados do teste sorológico para Leptospira spp. e provável sorovar mais encontrado, distribuídos em função das áreas de estudo e espécies amostradas entre fevereiro de 2000 e janeiro de 2010

\begin{tabular}{|c|c|c|c|c|c|c|c|c|c|c|c|c|c|}
\hline \multirow{2}{*}{ Espécie } & \multirow{2}{*}{ Categoria } & \multicolumn{4}{|c|}{ Parque Nacional das Emas } & \multicolumn{4}{|c|}{ Pantanal } & \multicolumn{4}{|c|}{ Parque Estadual do Cantão } \\
\hline & & Exam. $^{1}$ & Positivos & $\%$ & Sorovar ${ }^{2}$ & Exam. & Positivos & $\%$ & Sorovar & Exam. & Positivos & $\%$ & Sorovar \\
\hline $\begin{array}{c}\text { Onça- } \\
\text { pintada }\end{array}$ & animais & 5 & 3 & 60,0 & Grippotyphosa & 22 & 10 & 45,5 & Pomona & 4 & 0 & 0 & \\
\hline \multirow{2}{*}{ Bovino } & propriedades & 9 & 9 & 100,0 & \multirow{2}{*}{ Hardjo } & 7 & 7 & 100,0 & \multirow{2}{*}{ Hardjo } & 6 & 6 & 100 & \multirow{2}{*}{ Hardjo } \\
\hline & animais & 464 & 342 & 73,7 & & 345 & 236 & 68,4 & & 424 & 312 & 73,6 & \\
\hline \multirow{2}{*}{$\begin{array}{c}\text { Cão } \\
\text { doméstico }\end{array}$} & propriedades & 34 & 5 & 14,7 & \multirow{2}{*}{ Autumnalis } & 7 & 3 & 42,9 & \multirow{2}{*}{ Canicola } & 16 & 6 & 37,5 & \multirow{2}{*}{ Hardjo } \\
\hline & animais & 83 & 6 & 7,2 & & 29 & 7 & 24,1 & & 56 & 9 & 16,1 & \\
\hline \multirow{2}{*}{$\begin{array}{c}\text { Gato } \\
\text { doméstico }\end{array}$} & propriedades & 8 & 0 & 0 & & 6 & 1 & 16,7 & \multirow{2}{*}{ Hardjo } & 6 & 0 & 0 & \\
\hline & animais & 9 & 0 & 0 & & 10 & 1 & 10,0 & & 10 & 0 & 0 & \\
\hline
\end{tabular}

${ }^{1}$ Examinados. ${ }^{2}$ Sorovar mais provável mais frequentemente detectado.

Tabela 19 - Parâmetros estimados pela regressão logística testando o efeito da espécie amostrada (coeficiente $\beta_{1}$ ) e área de estudo (coeficiente $\beta_{2}$ ) para o diagnóstico de Leptospira spp. Utilizando como categoria de referência para espécie, os bovinos, e para área de estudo, o Parque Nacional das Emas

\begin{tabular}{lcccc}
\hline \multicolumn{1}{c}{ Variáveis } & Estimativa & Erro Padrão & Valor $\boldsymbol{p}$ & IC 95\% \\
\hline Intercepto & 0,978 & 0,101 & $<0,001$ & {$[0,782 ; 1,179]$} \\
$\beta_{1}$ (cão doméstico) & $-2,862$ & 0,238 & $<0,001$ & {$[-3,354 ;-2,416]$} \\
$\beta_{1}$ (gato doméstico) & $-4,281$ & 1,019 & $<0,001$ & {$[-7,164 ;-2,731]$} \\
$\beta_{1}$ (onça-pintada) & $-1,273$ & 0,369 & $<0,001$ & {$[-2,019 ;-0,557]$} \\
$\beta_{2}$ (Pantanal) & $-0,129$ & 0,150 & 0,388 & {$[-0,423 ; 0,165]$} \\
$\beta_{2}$ (PEC) & 0,038 & 0,144 & 0,793 & {$[-0,244 ; 0,320]$} \\
\hline
\end{tabular}




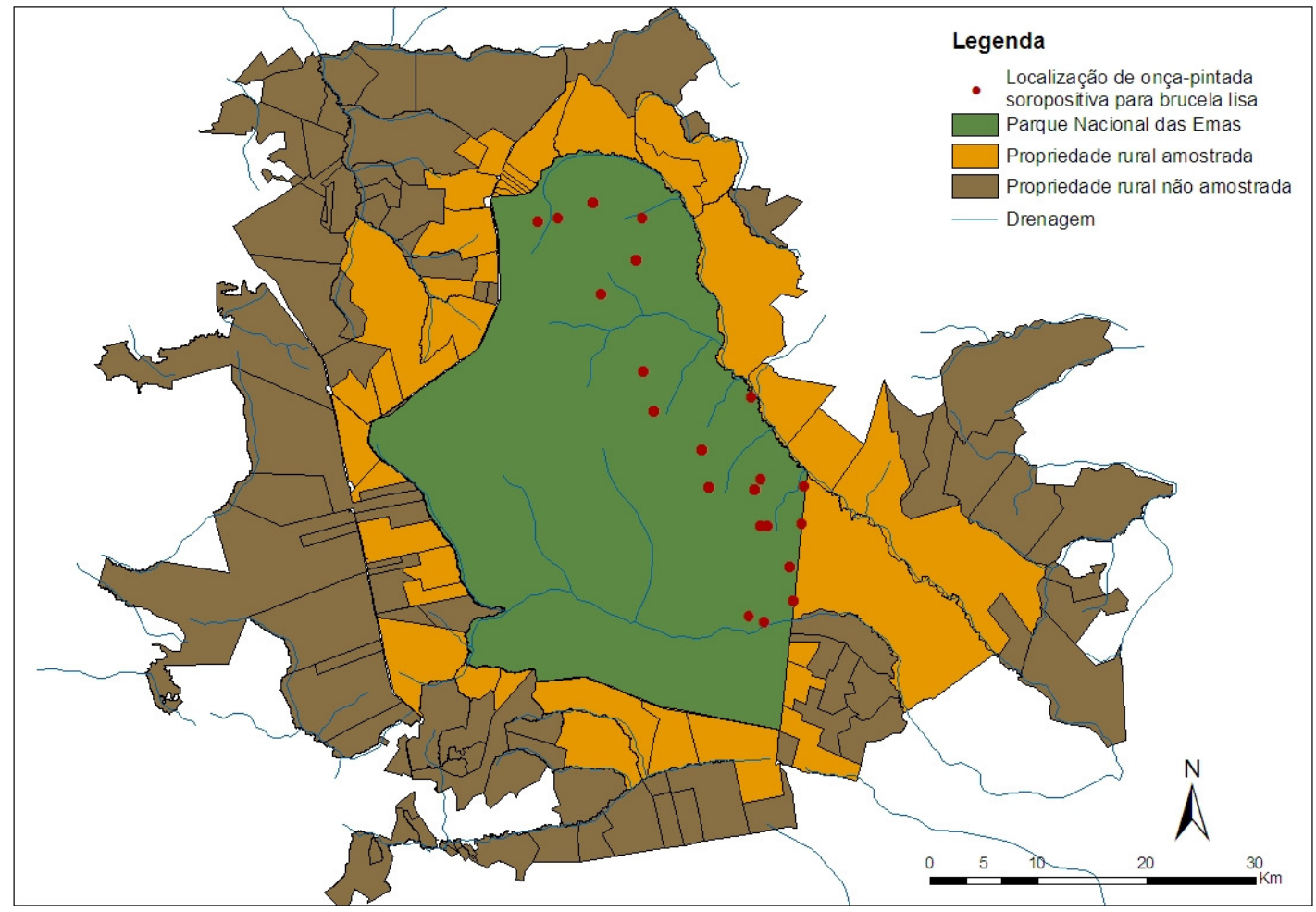

Figura 39 - Localizações da onça-pintada soropositiva para brucela lisa na região do Parque Nacional das Emas

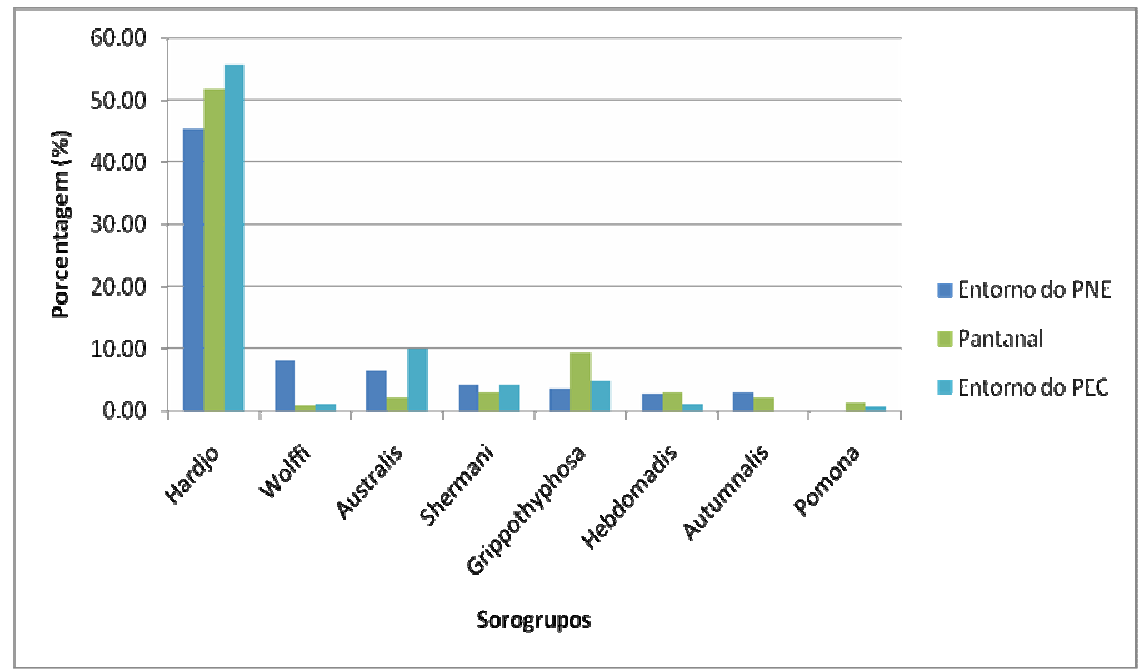

Figura 40 - Porcentagem de ocorrência dos sovorares mais prováveis detectados em bovinos das propriedades rurais das regiões do Parque Nacional das Emas, Pantanal e Parque Estadual do Cantão 


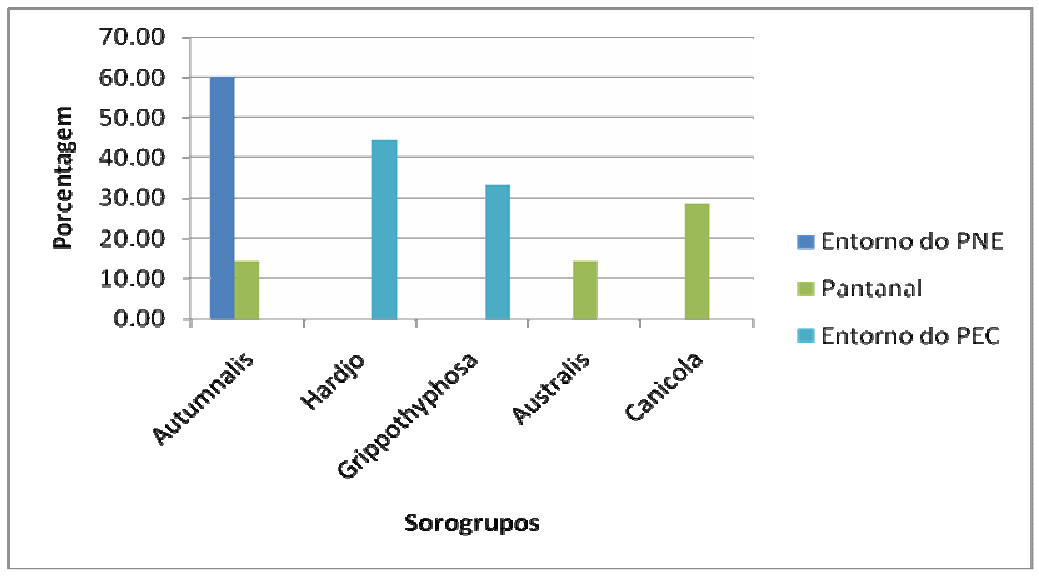

Figura 41 - Porcentagem de ocorrência dos sovorares mais prováveis detectados em cães domésticos das propriedades rurais das regiões do Parque Nacional das Emas, Pantanal e Parque Estadual do Cantão

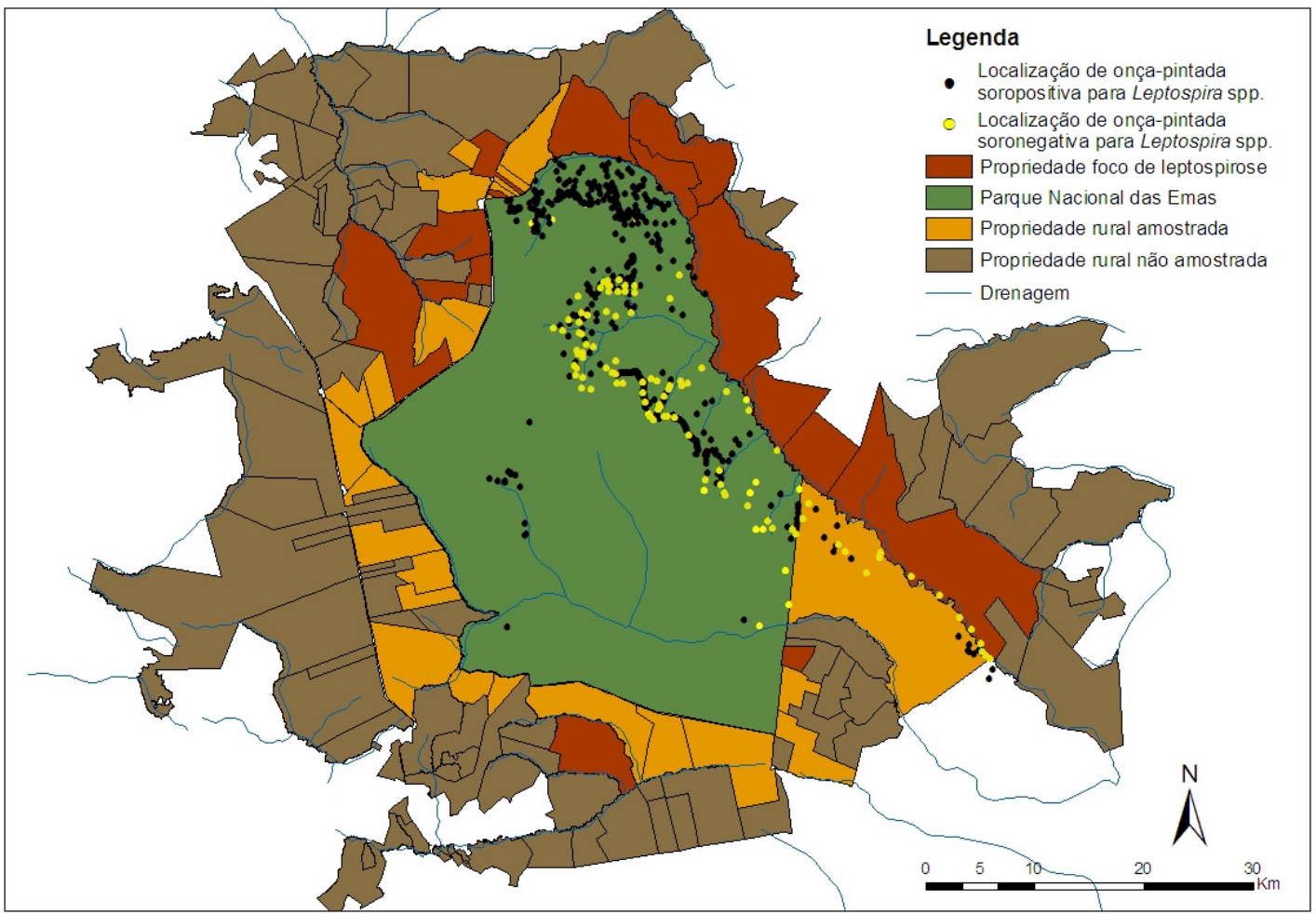

Figura 42 - Localizações das onças-pintadas soropositivas e soronegativas para Leptospira spp. e propriedades focos de leptospirose na região do Parque Nacional das Emas 


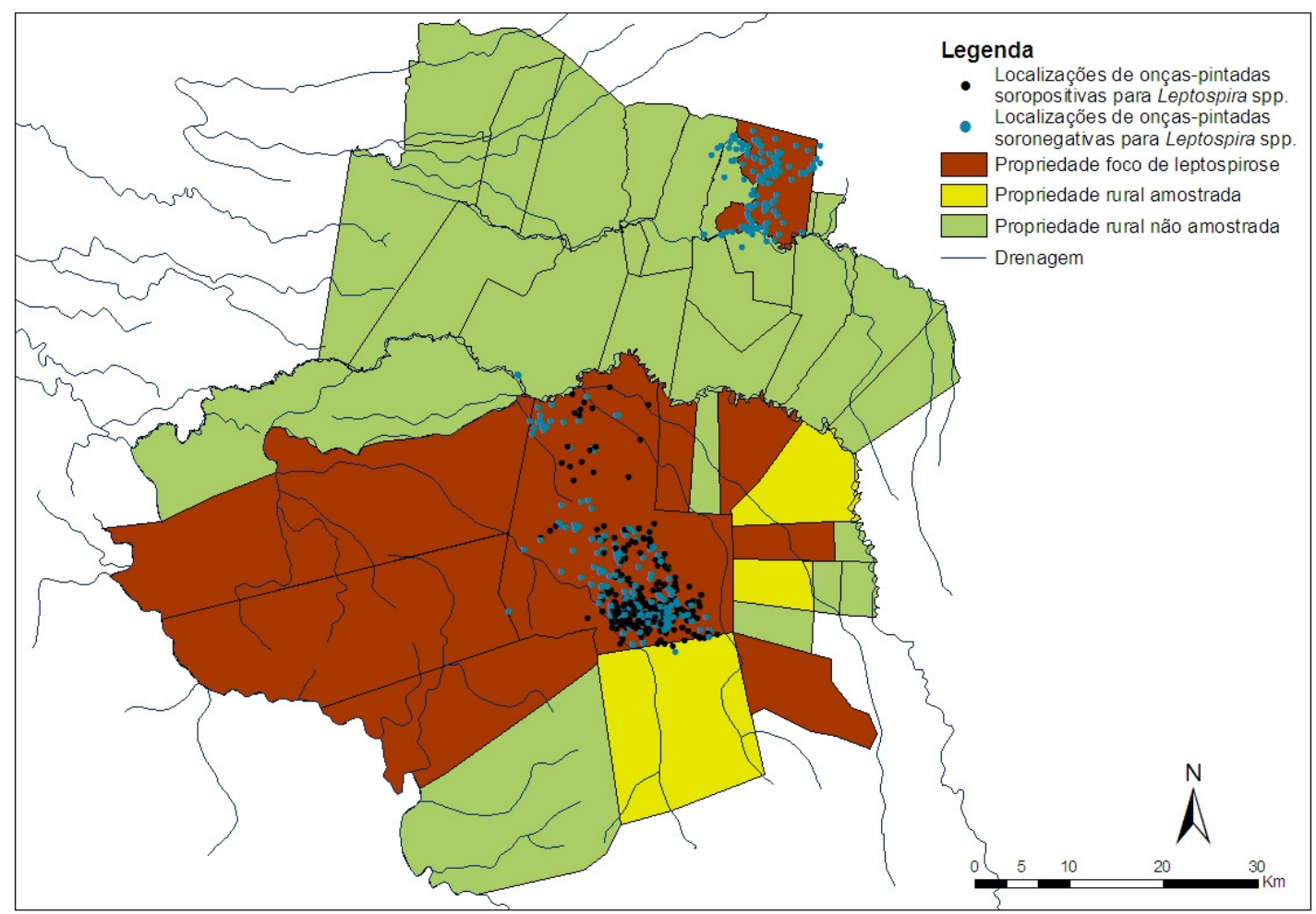

Figura 43 - Localizações das onças-pintadas soropositivas e soronegativas para Leptospira spp. e propriedades focos de leptospirose na região do Pantanal

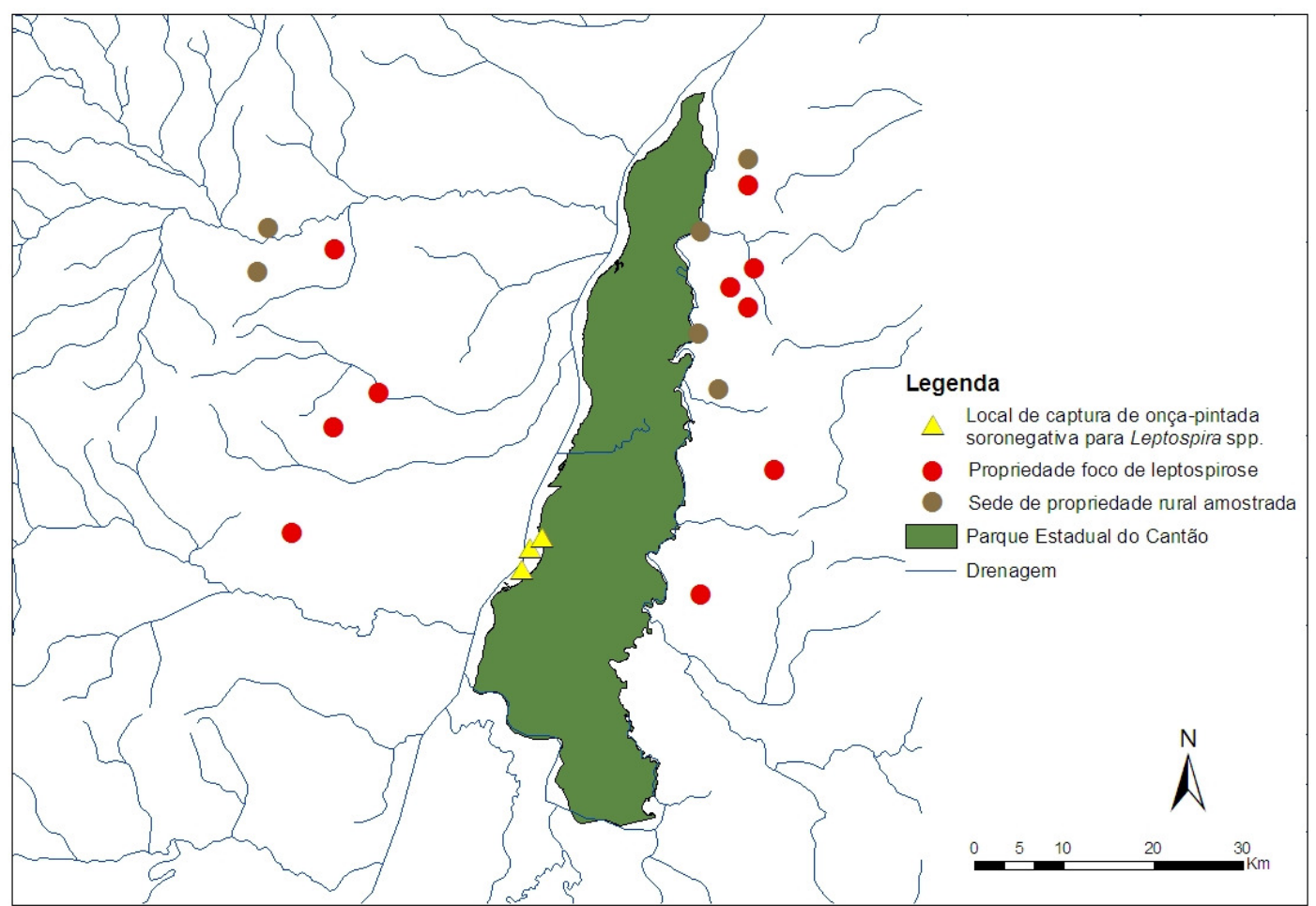

Figura 44 - Locais de captura das onças-pintadas soronegativas para Leptospira spp. e propriedades foco de leptospirose na região do Parque Estadual do Cantão 
Tabela 20 - Resultados do teste sorológico para Toxoplasma gondii e variação de títulos de anticorpos encontrados, distribuídos em função das áreas de estudo e espécies amostradas entre fevereiro de 2000 e janeiro de 2010 . Utilizando como ponto de corte para onças-pintadas, títulos = 25 , para bovinos, 64 e para cães e gatos, 16

\begin{tabular}{|c|c|c|c|c|c|c|c|c|c|c|c|c|c|}
\hline \multirow{2}{*}{ Espécie } & \multirow{2}{*}{ Categoria } & \multicolumn{4}{|c|}{ Parque Nacional das Emas } & \multicolumn{4}{|c|}{ Pantanal } & \multicolumn{4}{|c|}{ Parque Estadual do Cantão } \\
\hline & & Exam. $^{1}$ & Pos. $^{2}$ & $\%$ & Títulos $^{3}$ & Exam. & Pos. & $\%$ & Títulos & Exam. & Pos. & $\%$ & Títulos \\
\hline $\begin{array}{c}\text { Onça- } \\
\text { pintada }\end{array}$ & animais & 5 & 5 & 100,0 & 200 & 22 & 22 & 100,0 & $25-3200$ & 4 & 4 & 100,0 & $200-3200$ \\
\hline \multirow{2}{*}{ Bovino } & propriedades & 9 & 2 & 22,2 & \multirow{2}{*}{$64-128$} & 7 & 2 & 28,6 & \multirow{2}{*}{128} & 6 & 1 & 16,7 & \multirow{2}{*}{256} \\
\hline & animais & 454 & 2 & 0,4 & & 348 & 2 & 0,6 & & 422 & 1 & 0,2 & \\
\hline \multirow{2}{*}{$\begin{array}{c}\text { Cão } \\
\text { doméstico }\end{array}$} & propriedades & 26 & 13 & 50,0 & \multirow{2}{*}{$16-512$} & 7 & 7 & 100,0 & \multirow{2}{*}{$16-2048$} & 14 & 11 & 78,6 & \multirow{2}{*}{$16-512$} \\
\hline & animais & 55 & 16 & 29,1 & & 27 & 11 & 40,7 & & 46 & 22 & 47,8 & \\
\hline \multirow{2}{*}{$\begin{array}{c}\text { Gato } \\
\text { doméstico }\end{array}$} & propriedades & 8 & 6 & 75,0 & \multirow{2}{*}{$16-1024$} & 6 & 5 & 83,3 & \multirow{2}{*}{$32-2048$} & 6 & 5 & 83,3 & \multirow{2}{*}{$32-2048$} \\
\hline & animais & 9 & 7 & 77,8 & & 10 & 9 & 90,0 & & 10 & 8 & 80,0 & \\
\hline
\end{tabular}

${ }^{1}$ Examinados. ${ }^{2}$ Positivos. ${ }^{3}$ Variação de títulos de anticorpos

Tabela 21 - Parâmetros estimados pela regressão logística testando o efeito da espécie amostrada (coeficiente $\beta_{1}$ ) e área de estudo (coeficiente $\beta_{2}$ ) para o diagnóstico de Toxoplasma gondii. Utilizando como categoria de referência para espécie, os bovinos, e para área de estudo, o Parque Nacional das Emas*

\begin{tabular}{lcccc}
\hline \multicolumn{1}{c}{ Variáveis } & Estimativa & Erro Padrão & Valor $\boldsymbol{p}$ & IC 95\% \\
\hline Intercepto & $-5,895$ & 0,514 & $<0,001$ & {$[-7,028 ;-4,985]$} \\
$\beta_{1}$ (cão doméstico) & 5,078 & 0,487 & $<0,001$ & {$[4,214 ; 6,162]$} \\
$\beta_{1}$ (gato doméstico) & 7,091 & 0,669 & $<0,001$ & {$[5,879 ; 8,531]$} \\
$\beta_{2}$ (Pantanal) & 0,564 & 0,419 & 0,179 & {$[-0,260 ; 1,390]$} \\
$\beta_{2}$ (PEC) & 0,587 & 0,371 & 0,114 & {$[-0,137 ; 1,324]$} \\
\hline
\end{tabular}

*Modelo não identificado para as onças-pintadas 


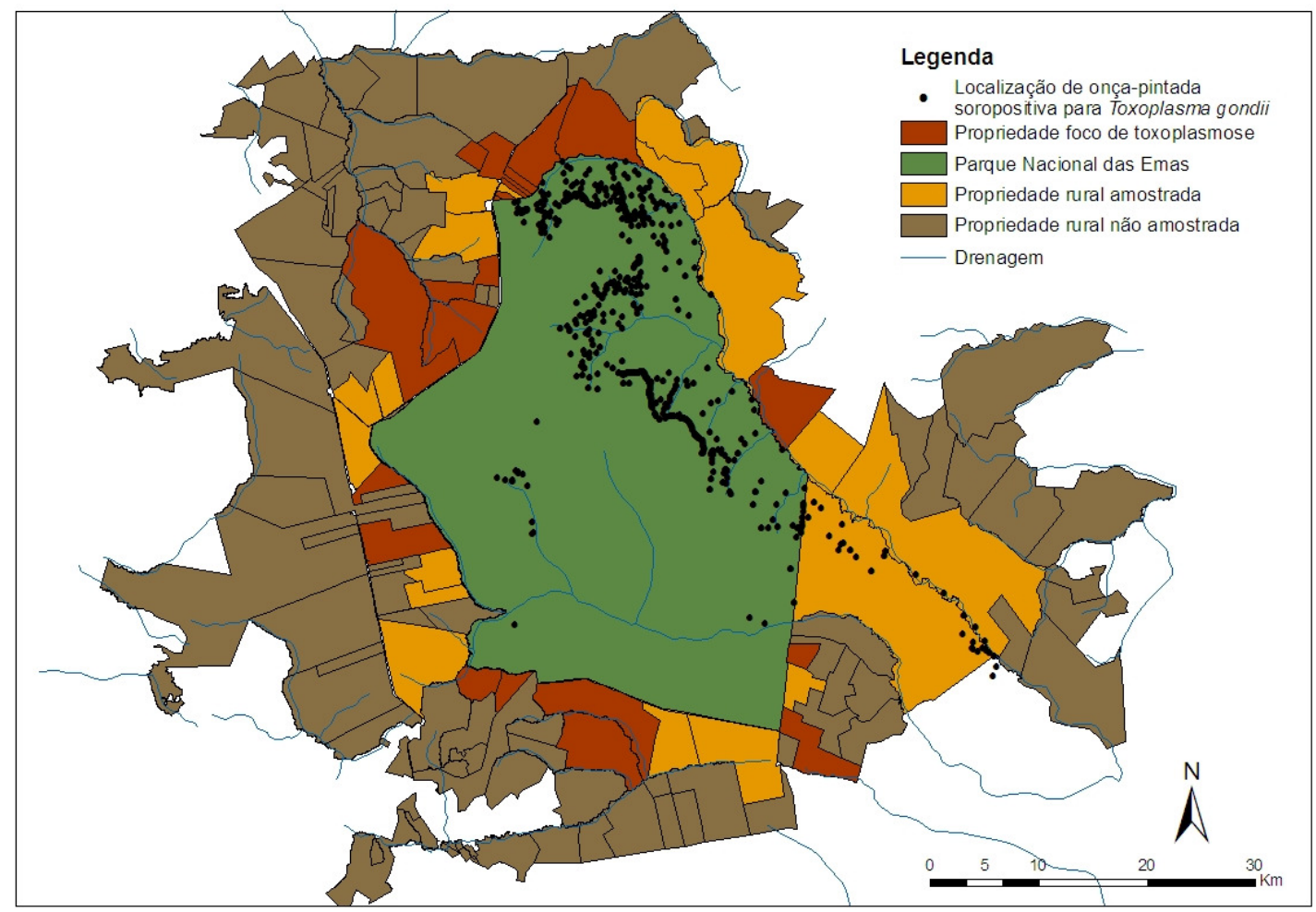

Figura 45 - Localizações das onças-pintadas soropositivas para Toxoplasma gondii e propriedades rurais foco de toxoplasmose na região do Parque Nacional das Emas

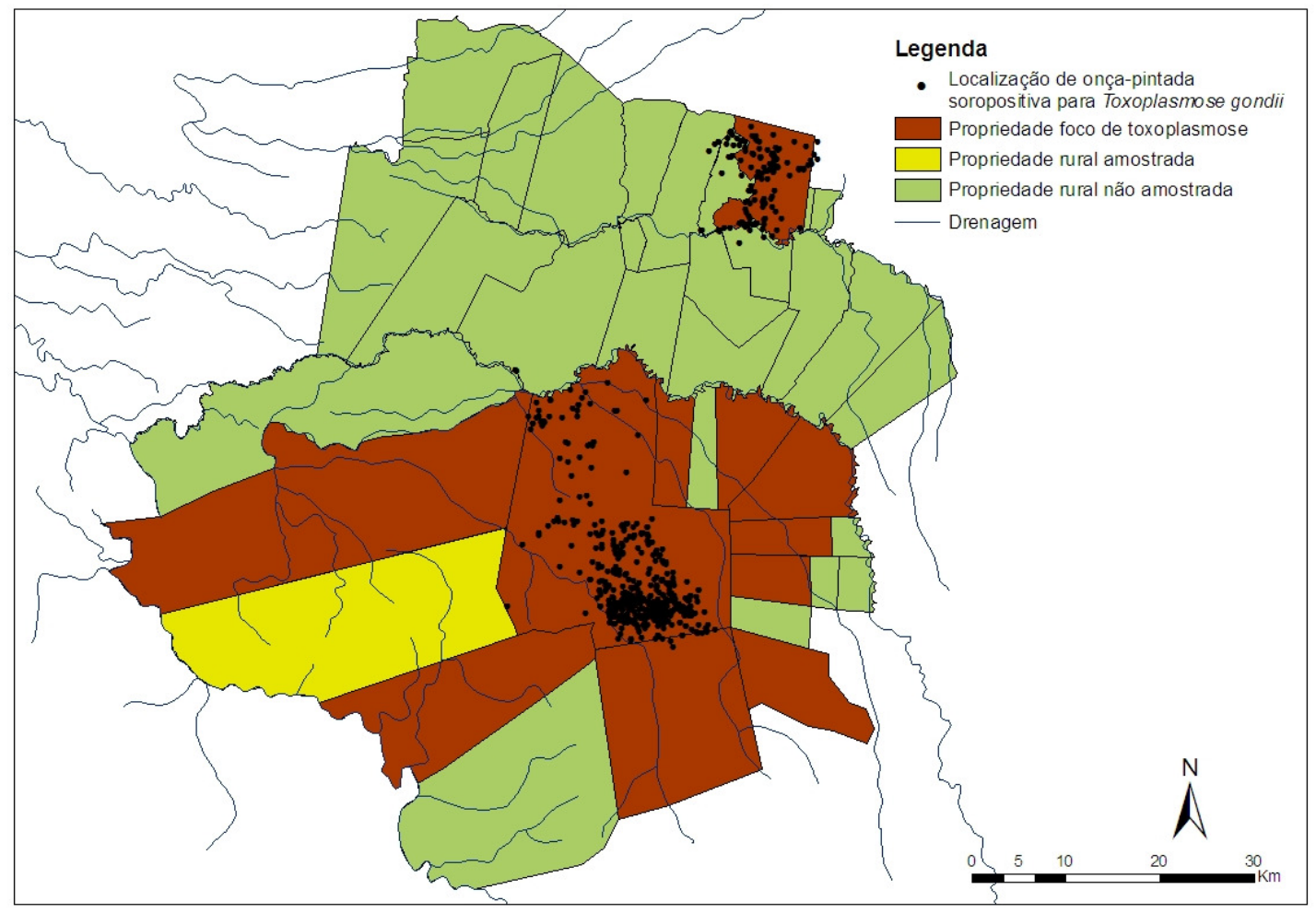

Figura 46 - Localizações das onças-pintadas soropositivas para Toxoplasma gondii e propriedades rurais foco de toxoplasmose no Pantanal. 


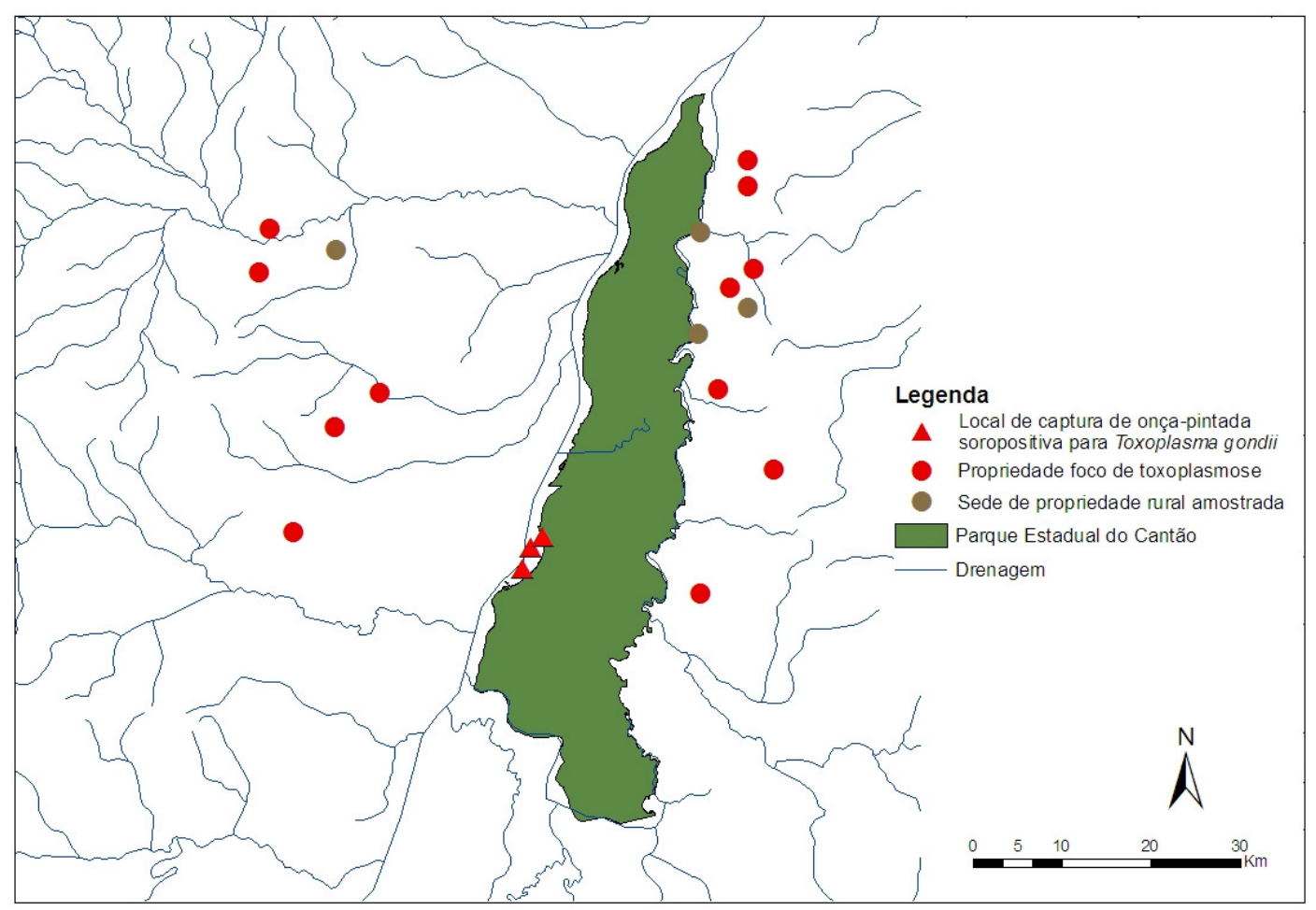

Figura 47 - Locais de captura de onças-pintadas soropositivas para Toxoplasma gondii e propriedades rurais foco de toxoplasmose na região do Parque Estadual do Cantão

\subsubsection{Diagnóstico sorológico para o vírus da raiva}

Os resultados do teste sorológico para o vírus da raiva estão organizados na tabela 22 , apresentado a variação dos títulos de anticorpos encontrados.

Os cães domésticos das três áreas de estudo apresentaram frequência de soropositividade entre 8 e 31,8\%, com títulos de anticorpos entre 0,50 e 68,34 UI/ml. Gatos domésticos do entorno do PEC e das propriedades do Pantanal foram soropositivos ao vírus em frequências de 11,1 a 20,0\% respectivamente. E, $20 \%$ das onças-pintadas do PNE e $22,7 \%$ do Pantanal apresentaram títulos $\geq 0,10$.

Indivíduos da região do PNE e entorno apresentaram significativamente mais diagnósticos positivos para o vírus da raiva do que os animais do Parque Estadual do Cantão $(p=0,006)$. Não foram detectadas outras associações significativas (Tabela 23).

As figuras 48 e 49 ilustram a movimentação das onças-pintadas soropositivas e soronegativas para o vírus da raiva no PNE e Pantanal, respectivamente. 
5.7.2.5 Diagnóstico sorológico para o vírus da cinomose

Os resultados do teste sorológico para o vírus da cinomose estão organizados na tabela 24, apresentando a variação dos títulos de anticorpos encontrados.

Os cães domésticos das três áreas de estudo apresentaram soropositividade para o vírus da cinomose em frequências de 36,1 (PNE) a 53,6\% (Pantanal) com títulos de anticorpos que variaram de 8 a 1024. No PEC e Pantanal, $81,3 \%$ e $85,7 \%$ das propriedades apresentaram, respectivamente, ao menos um cão soropositivo para o agente. As onças-pintadas do Pantanal apresentaram frequência de soropositividade de 54,5\% e títulos que variaram entre 8 e 32 .

Indivíduos amostrados das propriedades rurais do Pantanal foram mais expostos à cinomose do que os indívíduos da região do PNE $(p=0,009)$. Não foram detectadas outras associações significativas (Tabela 25).

As figuras 50 a 52 ilustram as propriedades foco de cinomose e movimentação das onçaspintadas nas áreas de estudo.

5.7.2.6 Diagnóstico sorológico para o vírus da imunodeficiência felina e leucemia felina

Os resultados dos testes sorológicos para o FIV e FeLV estão organizados na tabela 26. Tanto os gatos domésticos, quanto as onças-pintadas das três áreas de estudo foram negativos para o FIV, e apenas dois gatos domésticos do entorno do PEC foram soropositivos para o vírus da leucemia felina.

As regressões logísticas não foram identificadas para esses patógenos devido a ausência de indivíduos positivos para o FIV e pequeno número de indivíduos da mesma espécie positivos para FeLV.

A figura 53 ilustra as propriedades foco do FeLV e local de captura das onças-pintadas no PEC. 
Tabela 22 - Resultados do teste sorológico para o vírus da raiva e variação de títulos de anticorpos encontrados, distribuídos em função das áreas de estudo e espécies amostradas entre fevereiro de 2000 e janeiro de 2010 . Utilizando como ponto de corte para as onças-pintadas, títulos $=0,10$ UI/ml e para os cães e gatos domésticos, $0,50 \mathrm{Ul} / \mathrm{ml}$

\begin{tabular}{|c|c|c|c|c|c|c|c|c|c|c|c|c|c|}
\hline \multirow{2}{*}{ Espécie } & \multirow{2}{*}{ Categoria } & \multicolumn{4}{|c|}{ Parque Nacional das Emas } & \multicolumn{4}{|c|}{ Pantanal } & \multicolumn{4}{|c|}{ Parque Estadual do Cantão } \\
\hline & & Exam. $^{1}$ & Positivos & $\%$ & Título $^{2}$ & Exam. & Positivos & $\%$ & Título & Exam. & Positivos & $\%$ & Título \\
\hline $\begin{array}{l}\text { Onça- } \\
\text { pintada }\end{array}$ & animais & 5 & 1 & 20,0 & 0,11 & 22 & 5 & 22,7 & $0,1-0,5$ & 4 & 0 & 0 & \\
\hline \multirow{2}{*}{$\begin{array}{c}\text { Cão } \\
\text { doméstico }\end{array}$} & propriedades & 31 & 15 & 48,4 & \multirow{2}{*}{$0,5-68,34$} & 7 & 3 & 42,9 & \multirow{2}{*}{$0,5-2,74$} & 14 & 3 & 21,4 & \multirow{2}{*}{$0,5-1,91$} \\
\hline & animais & 66 & 21 & 31,8 & & 24 & 5 & 20,8 & & 50 & 4 & 8,0 & \\
\hline \multirow{2}{*}{$\begin{array}{c}\text { Gato } \\
\text { doméstico }\end{array}$} & propriedades & 7 & 0 & 0 & & 6 & 2 & 33,3 & \multirow{2}{*}{$74,74-81,73$} & 6 & 1 & 16,7 & \multirow{2}{*}{17,87} \\
\hline & animais & 9 & 0 & 0 & & 10 & 2 & 20,0 & & 9 & 1 & 11,1 & \\
\hline
\end{tabular}

${ }^{1}$ Examinados. ${ }^{2}$ Variação de títulos de anticorpos

Tabela 23 - Parâmetros estimados pela regressão logística testando o efeito da espécie amostrada (coeficiente $\beta_{1}$ ) e área de estudo (coeficiente $\beta_{2}$ ) para o diagnóstico do vírus da raiva. Utilizando como categoria de referência para espécie, os cães, e para área de estudo, o Parque Nacional das Emas

\begin{tabular}{lcccc}
\hline \multicolumn{1}{c}{ Variáveis } & Estimativa & Erro Padrão & Valor $\boldsymbol{p}$ & IC 95\% \\
\hline Intercepto & $-0,873$ & 0,260 & $<0,001$ & {$[-1,401 ;-0,379]$} \\
$\beta_{1}$ (gato doméstico) & $-0,853$ & 0,661 & 0,197 & {$[-2,358 ; 0,319]$} \\
$\beta_{1}$ (onça-pintada) & $-0,287$ & 0,560 & 0,608 & {$[-1,452 ; 0,772]$} \\
$\beta_{2}$ (Pantanal) & $-0,187$ & 0,456 & 0,682 & {$[-1,105 ; 0,696]$} \\
$\beta_{2}$ (PEC) & $-1,471$ & 0,531 & 0,006 & {$[-2,620 ;-0,500]$} \\
\hline
\end{tabular}


Tabela 24 - Resultados do teste sorológico para o vírus da cinomose e variação de títulos de anticorpos encontrados, distribuídos em função das áreas de estudo e espécies amostradas entre fevereiro de 2000 e janeiro de 2010

\begin{tabular}{|c|c|c|c|c|c|c|c|c|c|c|c|c|c|}
\hline \multirow{2}{*}{ Espécie } & \multirow{2}{*}{ Categoria } & \multicolumn{4}{|c|}{ Parque Nacional das Emas } & \multicolumn{4}{|c|}{ Pantanal } & \multicolumn{4}{|c|}{ Parque Estadual do Cantão } \\
\hline & & Exam. ${ }^{1}$ & Positivos & $\%$ & Título $^{2}$ & Exam. & Positivos & $\%$ & Título & Exam. & Positivos & $\%$ & Título \\
\hline $\begin{array}{l}\text { Onça- } \\
\text { pintada }\end{array}$ & animais & 5 & 0 & 0 & 0 & 22 & 12 & 54,5 & $8-32$ & 4 & 0 & 0 & 0 \\
\hline \multirow{2}{*}{$\begin{array}{c}\text { Cão } \\
\text { doméstico }\end{array}$} & propriedades & 34 & 15 & 44,1 & \multirow{2}{*}{$8-1024$} & 7 & 6 & 85,7 & \multirow{2}{*}{$8-128$} & 16 & 13 & 81,3 & \multirow{2}{*}{$16-256$} \\
\hline & animais & 83 & 30 & 36,1 & & 28 & 15 & 53,6 & & 63 & 26 & 41,3 & \\
\hline
\end{tabular}

${ }^{1}$ Examinados. ${ }^{2}$ Variação de títulos de anticorpos.

Tabela 25 - Parâmetros estimados pela regressão logística testando o efeito da espécie amostrada (coeficiente $\beta_{1}$ ) e área de estudo (coeficiente $\beta_{2}$ ) para o diagnóstico do vírus da cinomose. Utilizando como categoria de referência para espécie, os cães, e para área de estudo, o Parque Nacional das Emas

\begin{tabular}{lcccc}
\hline \multicolumn{1}{c}{ Variáveis } & Estimativa & Erro Padrão & Valor $\boldsymbol{p}$ & IC 95\% \\
\hline Intercepto & $-0,626$ & 0,226 & 0,006 & {$[-1,082 ;-0,191]$} \\
$\beta_{1}$ (onça-pintada) & $-0,653$ & 0,470 & 0,164 & {$[-1,610 ; 0,243]$} \\
$\beta_{2}$ (Pantanal) & 1,078 & 0,412 & 0,009 & {$[0,283 ; 1,908]$} \\
$\beta_{2}$ (PEC) & 0,206 & 0,338 & 0,541 & {$[-0,457 ; 0,869]$} \\
\hline
\end{tabular}


Tabela 26 - Resultados dos testes sorológicos para o vírus da imunodeficiência felina (FIV) e leucemia felina (FeLV), distribuídos em função das áreas de estudo e espécies amostradas entre fevereiro de 2000 e janeiro de 2010

\begin{tabular}{|c|c|c|c|c|c|c|c|c|c|c|c|c|c|}
\hline \multirow{2}{*}{ Espécie } & \multirow{2}{*}{ Categoria } & \multicolumn{4}{|c|}{ Parque Nacional das Emas } & \multicolumn{4}{|c|}{ Pantanal } & \multicolumn{4}{|c|}{ Parque Estadual do Cantão } \\
\hline & & Exam. $^{1}$ & Pos $^{2}$. FIV & Pos. FeLV & $\%$ FeLV & Exam. & Pos. FIV & Pos. FelV & $\%$ FeLV & Exam. & Pos. FIV & Pos. FeLV & $\%$ FeLV \\
\hline $\begin{array}{l}\text { Onça- } \\
\text { pintada }\end{array}$ & animais & 5 & 0 & 0 & 0 & 22 & 0 & 0 & 0 & 4 & 0 & 0 & 0 \\
\hline \multirow{2}{*}{$\begin{array}{c}\text { Gato } \\
\text { doméstico }\end{array}$} & propriedades & 9 & 0 & 0 & 0 & 6 & 0 & 0 & 0 & 8 & 0 & 2 & 25,0 \\
\hline & animais & 11 & 0 & 0 & 0 & 11 & 0 & 0 & 0 & 13 & 0 & 2 & 15,4 \\
\hline
\end{tabular}




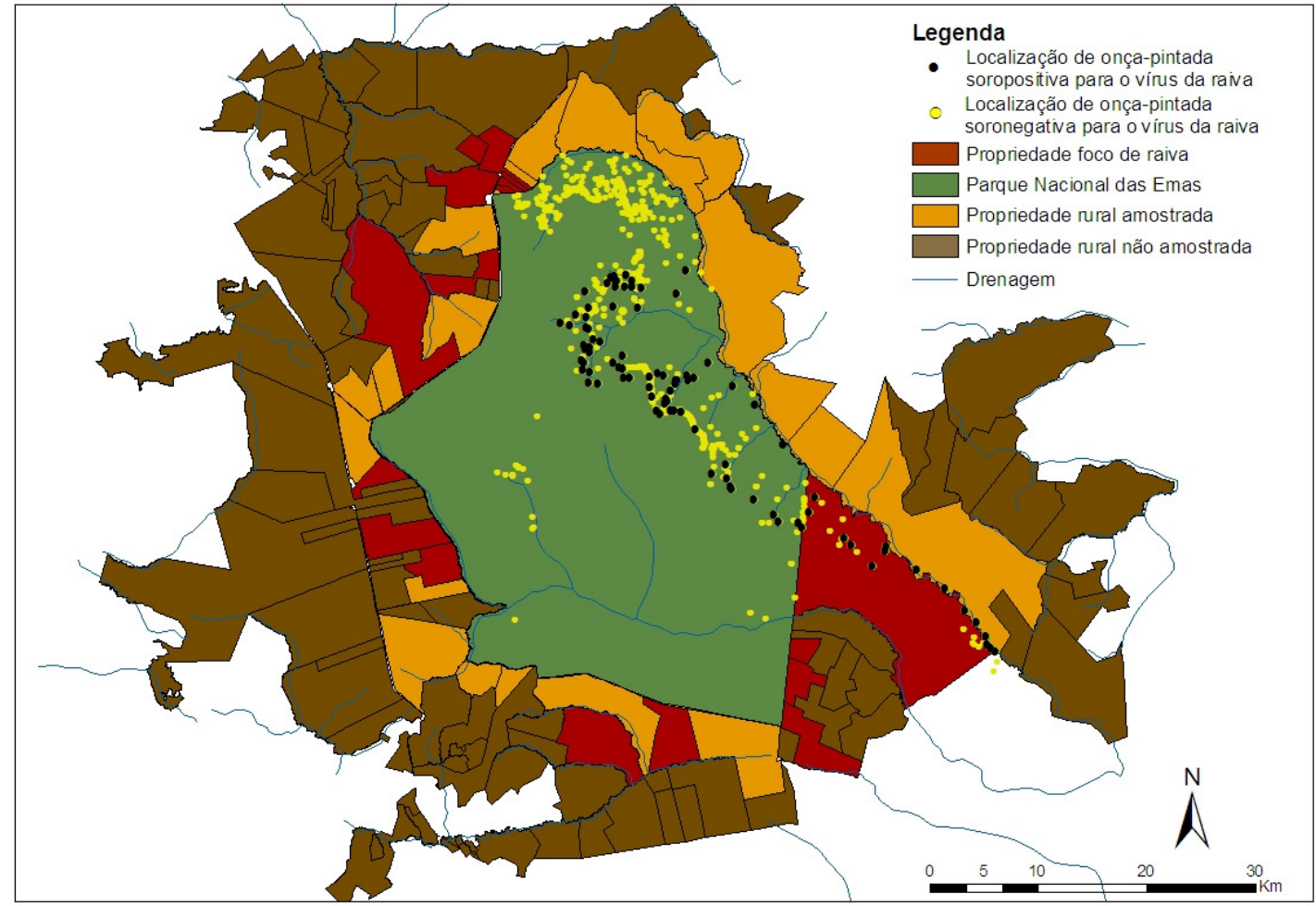

Figura 48 - Localizações das onças-pintadas soronegativas e soropositiva para o vírus da raiva e propriedades rurais foco de raiva na região do Parque Nacional das Emas

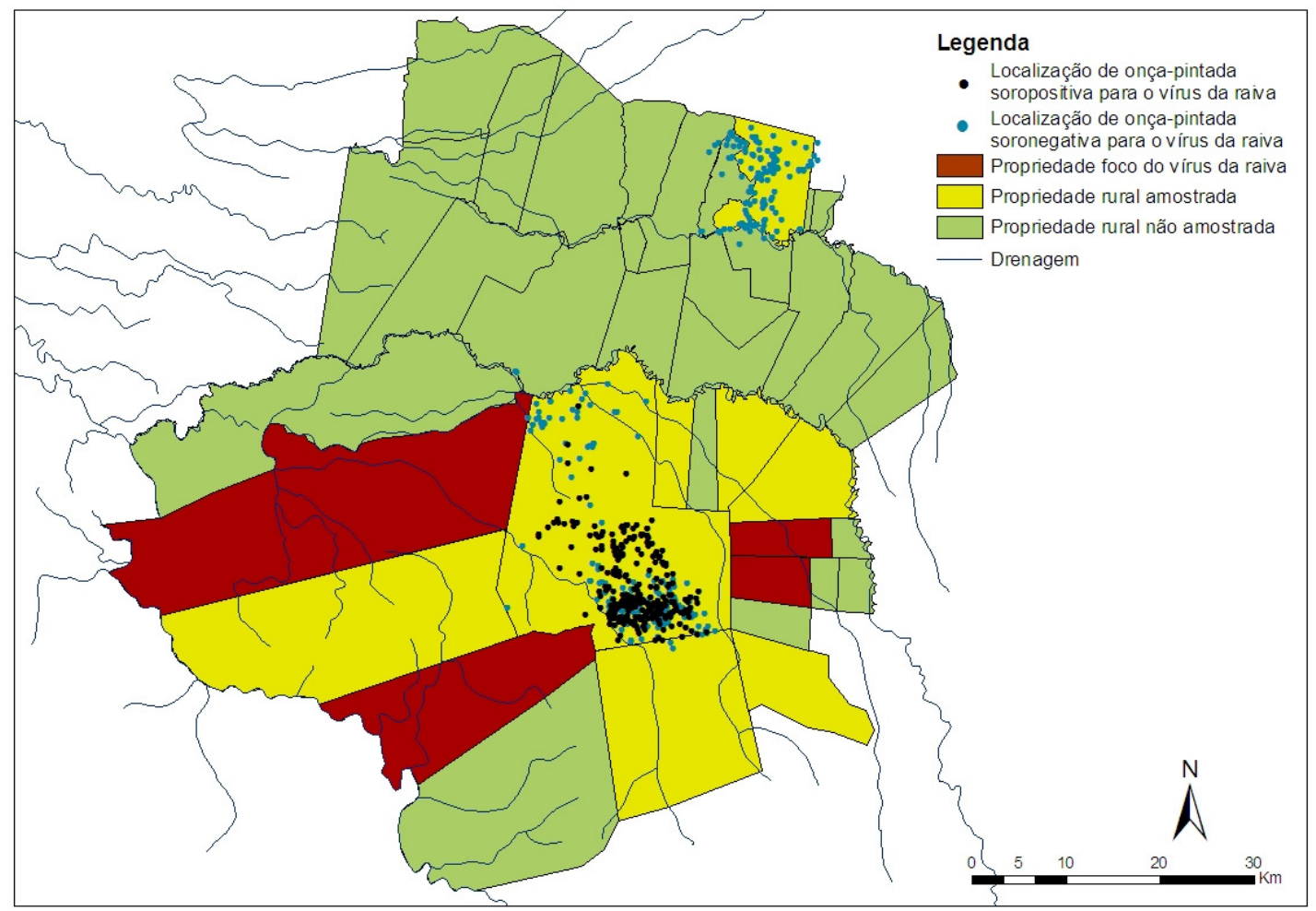

Figura 49 - Localizações das onças-pintadas soropositivas e soronegativas para o vírus da raiva e propriedades rurais foco de raiva no Pantanal 


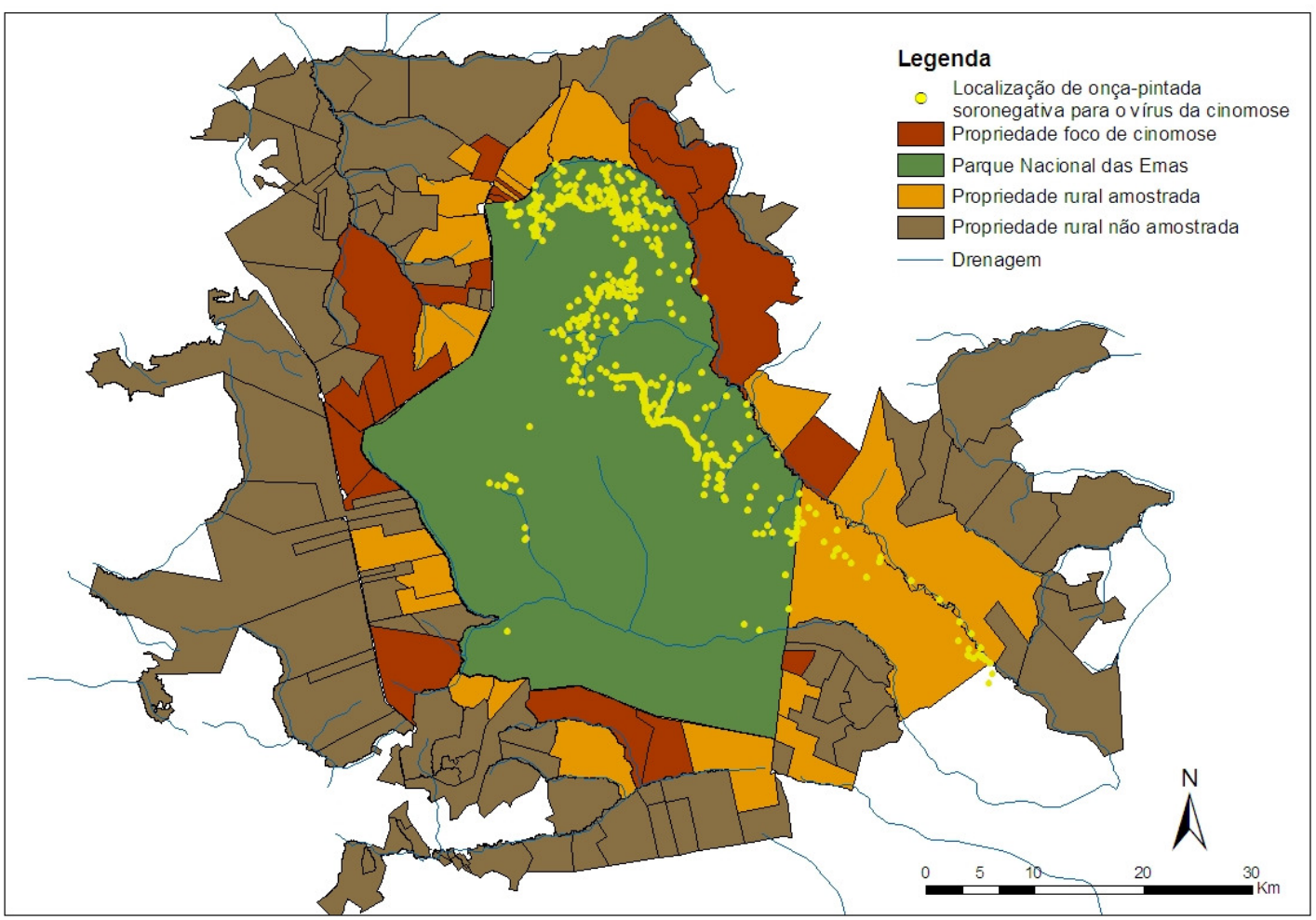

Figura 50 - Localizações das onças-pintadas soronegativas para o vírus da cinomose e propriedades rurais foco de cinomose na região do Parque Nacional das Emas

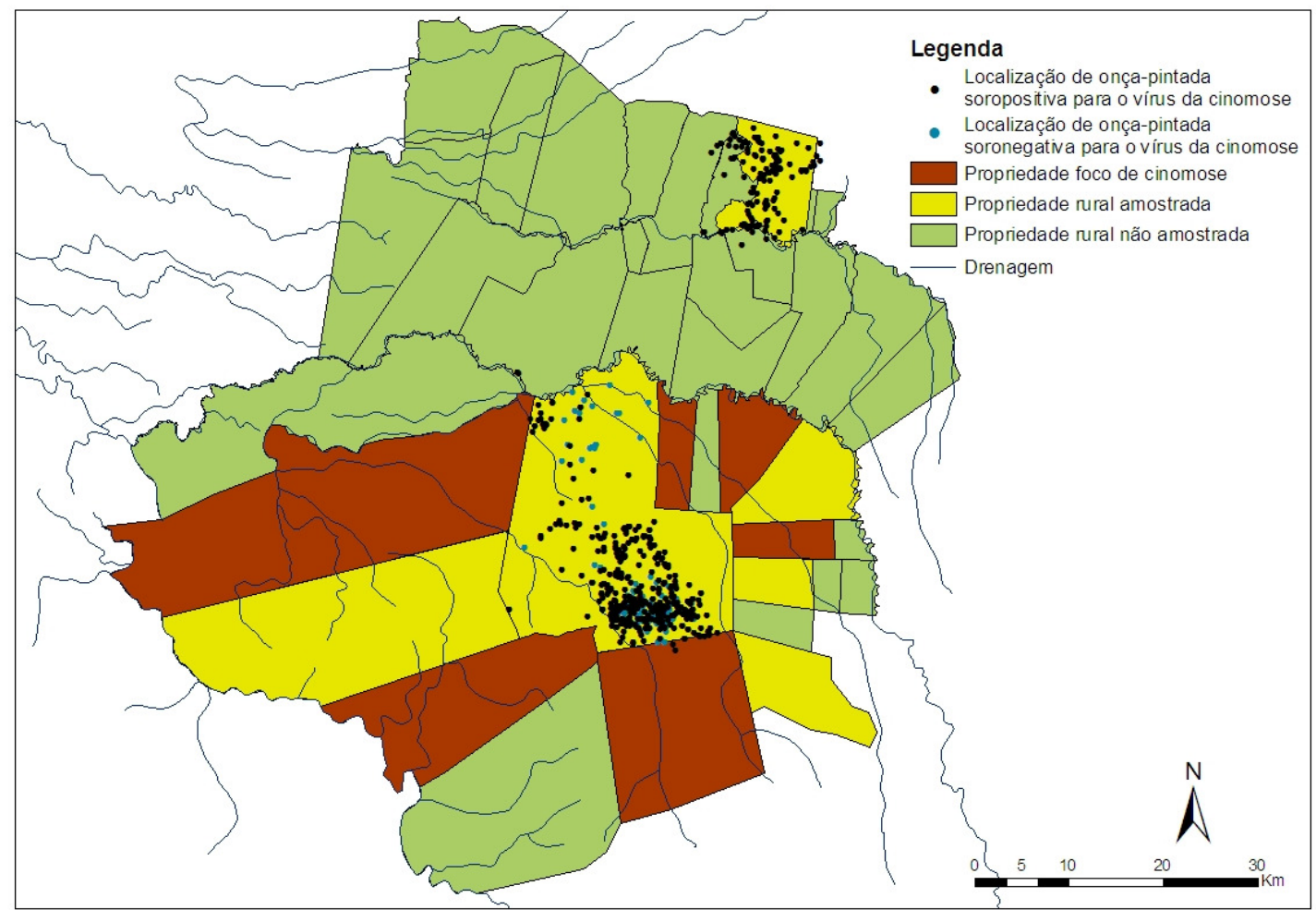

Figura 51 - Localizações das onças-pintadas soropositivas e soronegativas para o vírus da cinomose e propriedades rurais foco da cinomose no Pantanal 


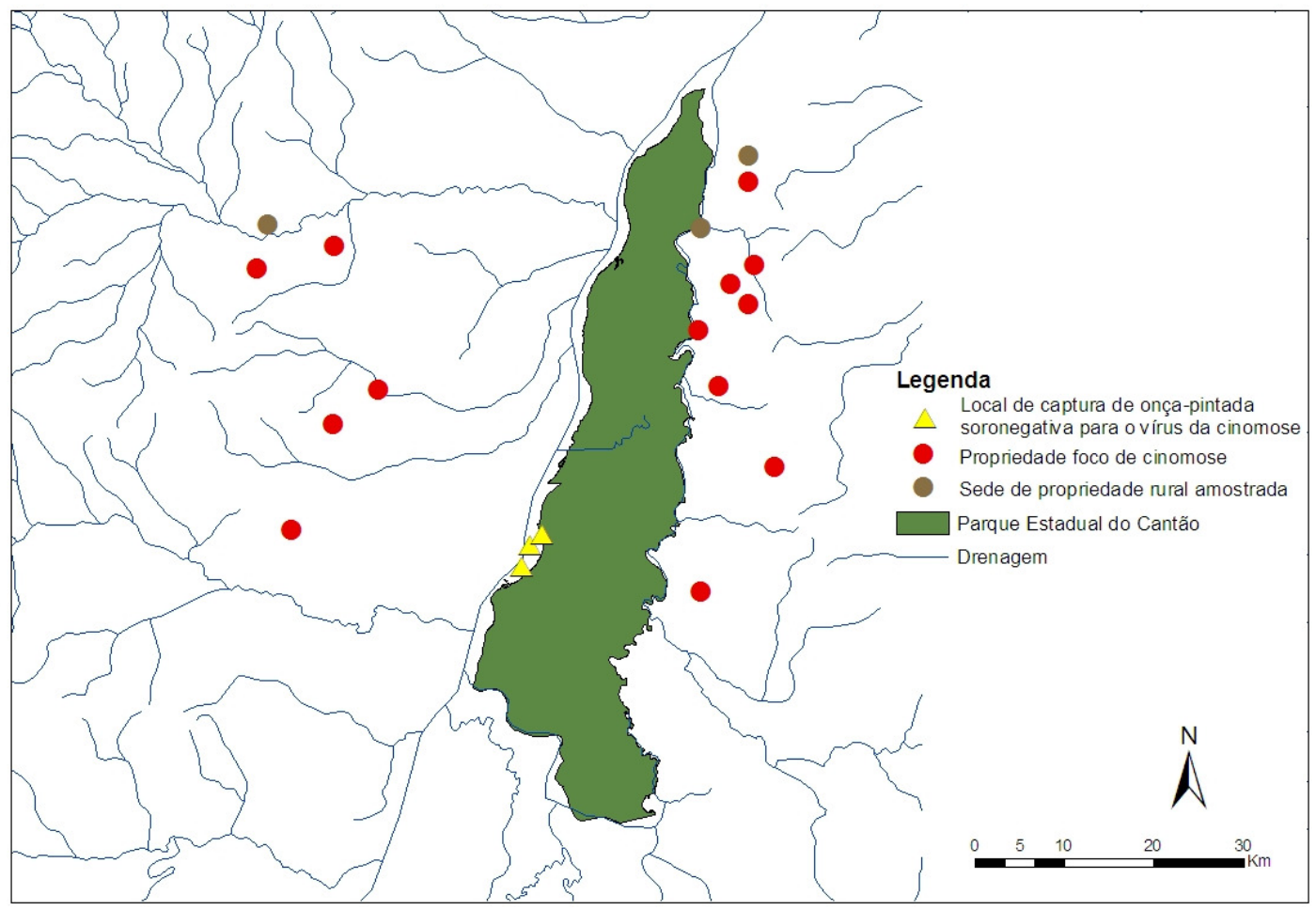

Figura 52 - Locais de captura de onças-pintadas soronegativas para o vírus da cinomose e propriedades foco da cinomose na região do Parque Estadual do Cantão

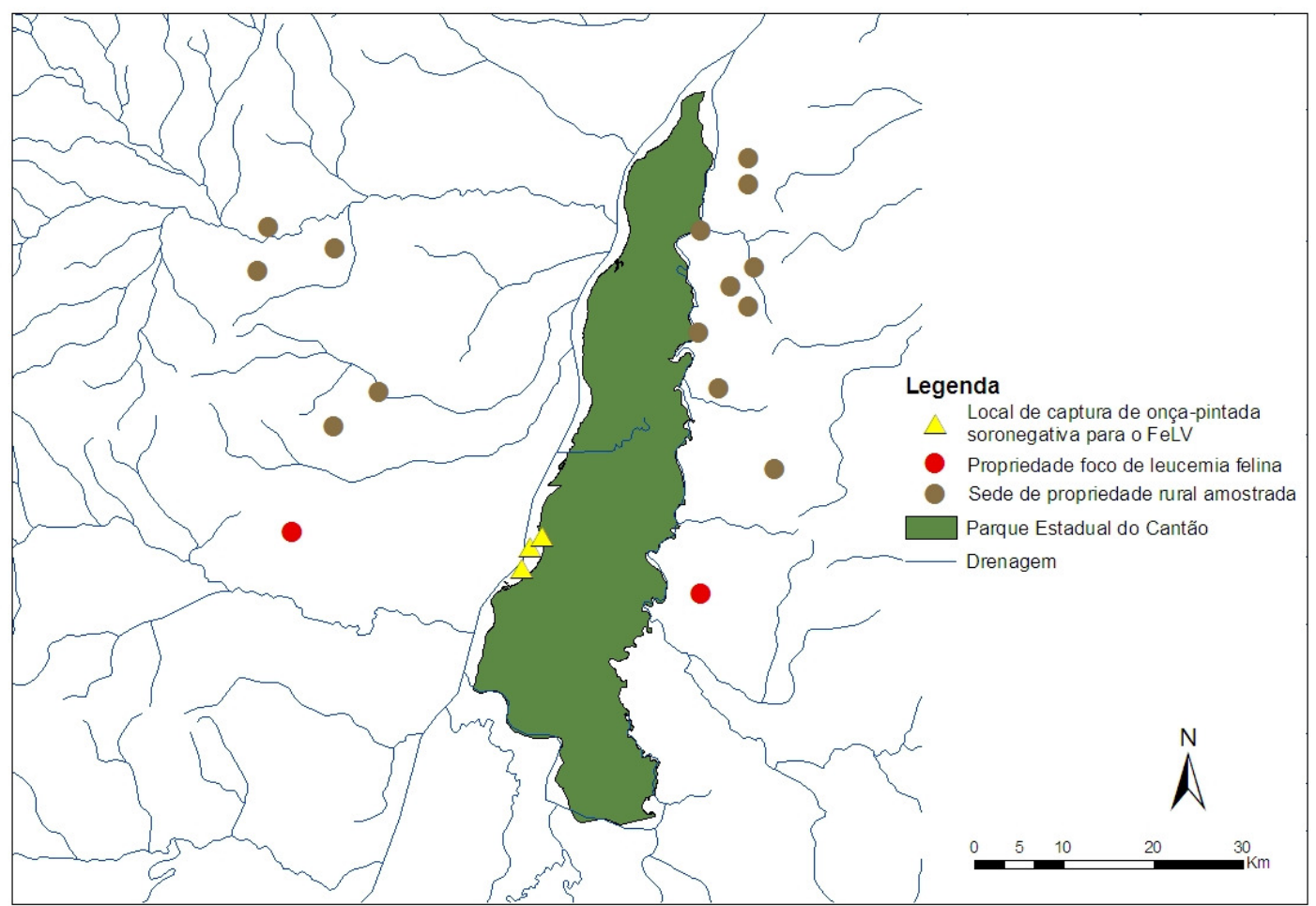

Figura 53 - Locais de captura de onças-pintadas soronegativas para o FeLV e propriedades foco da leucemia felina na região do Parque Estadual do Cantão 
5.7.2.7 Diagnóstico molecular para Hepatozoon spp.

Os resultados do teste molecular para Hepatozoon spp. estão organizados na tabela 27.

A presença de Hepatozoon spp. foi diagnosticada nos cães domésticos das três áreas em frequências de 46,0\% (PNE) a 84,2\% (Pantanal). Nos gatos domésticos, as frequências variaram entre $42,9 \%$ no PNE e 40,0\% nas propriedades rurais do Pantanal. Todas as onças-pintadas do PNE e Pantanal, e 75\% das onças do PEC foram positivas para Hepatozoon spp.

Os indivíduos amostrados da região do Pantanal e do PEC foram significativamente mais expostos ao Hepatozoon spp. do que os da região do $\operatorname{PNE}(p=0,003$, e $p=0,017$, respectivamente). As onças-pintadas foram significativamente mais expostas ao Hepatozoon spp. do que os cães domésticos ( $p=0,035$ ) e os gatos (IC $95 \%$ não sobrepostos). Os cães foram significativamente mais expostos ao agente do que os gatos $(p=0,002)$. Não foram detectadas outras associações significativas (Tabela 28).

As figuras 54 a 56 ilustram as propriedades foco do Hepatozoon spp. e a movimentação ou local de captura das onças-pintadas nas áreas de estudo.

5.7.2.8 Diagnóstico molecular dos Piroplasmas: Babesia spp. e Cytauxzoon spp.

Os resultados do teste molecular para Babesia spp. e Cytauxzoon spp. estão organizados nas tabelas 29 e 30 , respectivamente.

Todos os felinos silvestres e domésticos amostrados foram negativos para Babesia spp., sendo que cães do entorno do PNE e PEC foram positivos para o agente em frequências de 7,9\% e $10,6 \%$, respectivamente.

Apenas as onças-pintadas das três áreas de estudo foram positivas para Cytauxzoon felis.

As regressões logísticas não foram identificadas para esses patógenos devido ao baixo número de indivíduos positivos de uma mesma espécie para Babesia spp. e ao alto número de indivíduos positivos de uma mesma espécie para Cytauxzoon felis. 
5.7.2.9 Diagnóstico molecular dos hemoplasmas felinos: Mycoplasma haemofelis, 'Candidatus Mycoplasma haemominutum' e 'Candidatus Mycoplasma turicensis'

Os resultados dos diagnósticos moleculares para os hemoplasmas felinos para cada área de estudo estão organizados nas tabelas 31 a 33.

Um gato doméstico do entorno do PNE e um do Pantanal foram positivos para Mycoplasma haemofelis. Assim como três onças-pintadas capturadas no Pantanal e duas capturadas no PEC (Tabela 31). Um gato doméstico do entorno do PNE e duas onças-pintadas do Pantanal foram positivos para 'Candidatus Mycoplasma turicensis' (Tabela 32). A presença de 'Candidatus Mycoplasma haemominutum' foi detectada em dois gatos domésticos do Pantanal e em frequências superiores a 72,7\% nas onças-pintadas do PNE, PEC e Pantanal (Tabela 33).

As associações analisadas não apresentaram diferenças significativas para Mycoplasma haemofelis e 'Ca. Mycoplasma turicensis' (Tabelas 34 e 35). Onças-pintadas foram significativamente mais expostas ao 'Ca. Mycoplasma haemominutum' do que os gatos domésticos $(p<0,001)$. Não foram detectadas outras associações significativas (Tabela 36).

A figura 57 ilustra a propriedade foco de Mycoplasma haemofelis e movimentação das onças-pintadas positivas e negativas para o agente no Pantanal. A figura 58 ilustra a ocorrência do 'Candidatus Mycoplasma turicensis' no Pantanal. As figuras 59 e 60 ilustram a ocorrência do 'Candidatus Mycoplasma haemominutum no PNE e Pantanal. 
Tabela 27 - Resultados do teste molecular para Hepatozoon spp., distribuídos em função das áreas de estudo e espécies amostradas entre fevereiro de 2000 e janeiro de 2010

\begin{tabular}{|c|c|c|c|c|c|c|c|c|c|c|}
\hline \multirow{2}{*}{ Espécie } & \multirow{2}{*}{ Categoria } & \multicolumn{3}{|c|}{ Parque Nacional das Emas } & \multicolumn{3}{|c|}{ Pantanal } & \multicolumn{3}{|c|}{ Parque Estadual do Cantão } \\
\hline & & Examinados & Positivos & $\%$ & Examinados & Positivos & $\%$ & Examinados & Positivos & $\%$ \\
\hline $\begin{array}{l}\text { Onça- } \\
\text { pintada }\end{array}$ & Animais & 4 & 4 & 100,0 & 22 & 22 & 100,0 & 4 & 3 & 75,0 \\
\hline \multirow{2}{*}{$\begin{array}{c}\text { Cão } \\
\text { doméstico }\end{array}$} & propriedades & 28 & 17 & 60,7 & 6 & 6 & 100,0 & 13 & 12 & 92,3 \\
\hline & animais & 63 & 29 & 46,0 & 19 & 16 & 84,2 & 47 & 36 & 76,6 \\
\hline \multirow{2}{*}{$\begin{array}{c}\text { Gato } \\
\text { doméstico }\end{array}$} & propriedades & 6 & 3 & 50,00 & 7 & 3 & 42,9 & 3 & 0 & 0 \\
\hline & animais & 7 & 3 & 42,9 & 10 & 4 & 40,0 & 5 & 0 & 0 \\
\hline
\end{tabular}

Tabela 28 - Parâmetros estimados pela regressão logística testando o efeito da espécie amostrada (coeficiente $\beta_{1}$ ) e área de estudo (coeficiente $\beta_{2}$ ) para o diagnóstico do Hepatozoon spp. Utilizando como categoria de referência para espécie, os cães, e para área de estudo, o Parque Nacional das Emas

\begin{tabular}{lcccc}
\hline \multicolumn{1}{c}{ Variáveis } & Estimativa & Erro Padrão & Valor $\boldsymbol{p}$ & IC 95\% \\
\hline Intercepto & $-0,006$ & 0,246 & 0,981 & $-0,491 ; 0,478$ \\
$\beta_{1}$ (gato doméstico) & $-1,811$ & 0,573 & 0,002 & $-3,023 ;-0,745$ \\
$\beta_{1}$ (onça-pintada) & 2,236 & 1,063 & 0,035 & 0,$548 ; 5,161$ \\
$\beta_{2}$ (Pantanal) & 1,638 & 0,548 & 0,003 & 0,$620 ; 2,797$ \\
$\beta_{2}$ (PEC) & 0,935 & 0,391 & 0,017 & 0,$181 ; 1,720$ \\
\hline
\end{tabular}


Tabela 29 - Resultados do teste molecular para Babesia spp., distribuídos em função das áreas de estudo e espécies amostradas entre fevereiro de 2000 e janeiro de 2010

\begin{tabular}{|c|c|c|c|c|c|c|c|c|c|c|}
\hline \multirow{2}{*}{ Espécie } & \multirow{2}{*}{ Categoria } & \multicolumn{3}{|c|}{ Parque Nacional das Emas } & \multicolumn{3}{|c|}{ Pantanal } & \multicolumn{3}{|c|}{ Parque Estadual do Cantão } \\
\hline & & Examinados & Positivos & $\%$ & Examinados & Positivos & $\%$ & Examinados & Positivos & $\%$ \\
\hline $\begin{array}{l}\text { Onça- } \\
\text { pintada }\end{array}$ & animais & 4 & 0 & 0 & 22 & 0 & 0 & 4 & 0 & 0 \\
\hline \multirow{2}{*}{$\begin{array}{c}\text { Cão } \\
\text { doméstico }\end{array}$} & propriedades & 28 & 4 & 14,3 & 6 & 0 & 0 & 13 & 2 & 15,4 \\
\hline & animais & 63 & 5 & 7,9 & 19 & 0 & 0 & 47 & 5 & 10,6 \\
\hline \multirow{2}{*}{$\begin{array}{c}\text { Gato } \\
\text { doméstico }\end{array}$} & propriedades & 6 & 0 & 0 & 7 & 0 & 0 & 3 & 0 & 0 \\
\hline & animais & 7 & 0 & 0 & 10 & 0 & 0 & 5 & 0 & 0 \\
\hline
\end{tabular}

Tabela 30 - Resultados do teste molecular para Cytauxzoon spp., distribuídos em função das áreas de estudo e espécies amostradas entre fevereiro de 2000 e janeiro de 2010

\begin{tabular}{|c|c|c|c|c|c|c|c|c|c|c|}
\hline \multirow{2}{*}{ Espécie } & \multirow{2}{*}{ Categoria } & \multicolumn{3}{|c|}{ Parque Nacional das Emas } & \multicolumn{3}{|c|}{ Pantanal } & \multicolumn{3}{|c|}{ Parque Estadual do Cantão } \\
\hline & & Examinados & Positivos & $\%$ & Examinados & Positivos & $\%$ & Examinados & Positivos & $\%$ \\
\hline $\begin{array}{l}\text { Onça- } \\
\text { pintada }\end{array}$ & animais & 4 & 4 & 100,0 & 22 & 22 & 100,0 & 4 & 3 & 75,0 \\
\hline \multirow{2}{*}{$\begin{array}{c}\text { Cão } \\
\text { doméstico }\end{array}$} & propriedades & 28 & 0 & 0 & 6 & 0 & 0 & 13 & 0 & 0 \\
\hline & animais & 63 & 0 & 0 & 19 & 0 & 0 & 47 & 0 & 0 \\
\hline \multirow{2}{*}{$\begin{array}{c}\text { Gato } \\
\text { doméstico }\end{array}$} & propriedades & 6 & 0 & 0 & 7 & 0 & 0 & 3 & 0 & 0 \\
\hline & animais & 7 & 0 & 0 & 10 & 0 & 0 & 5 & 0 & 0 \\
\hline
\end{tabular}


Tabela 31 - Resultados do teste molecular para Mycoplasma haemofelis, distribuídos em função das áreas de estudo e espécies amostradas entre fevereiro de 2000 e janeiro de 2010

\begin{tabular}{|c|c|c|c|c|c|c|c|c|c|c|}
\hline \multirow{2}{*}{ Espécie } & \multirow{2}{*}{ Categoria } & \multicolumn{3}{|c|}{ Parque Nacional das Emas } & \multicolumn{3}{|c|}{ Pantanal } & \multicolumn{3}{|c|}{ Parque Estadual do Cantão } \\
\hline & & Examinados & Positivos & $\%$ & Examinados & Positivos & $\%$ & Examinados & Positivos & $\%$ \\
\hline $\begin{array}{l}\text { Onça- } \\
\text { pintada }\end{array}$ & animais & 4 & 0 & 0 & 22 & 3 & 13,6 & 4 & 2 & 50,0 \\
\hline \multirow{2}{*}{$\begin{array}{c}\text { Gato } \\
\text { doméstico }\end{array}$} & propriedades & 6 & 1 & 16,7 & 7 & 1 & 14,3 & 3 & 0 & 0 \\
\hline & animais & 7 & 1 & 14,3 & 10 & 1 & 10,0 & 5 & 0 & 0 \\
\hline
\end{tabular}

Tabela 32 - Resultados do teste molecular para 'Candidatus Mycoplasma turicensis', distribuídos em função das áreas de estudo e espécies amostradas entre fevereiro de 2000 e janeiro de 2010

\begin{tabular}{|c|c|c|c|c|c|c|c|c|c|c|}
\hline \multirow{2}{*}{ Espécie } & \multirow{2}{*}{ Categoria } & \multicolumn{3}{|c|}{ Parque Nacional das Emas } & \multicolumn{3}{|c|}{ Pantanal } & \multicolumn{3}{|c|}{ Parque Estadual do Cantão } \\
\hline & & Examinados & Positivos & $\%$ & Examinados & Positivos & $\%$ & Examinados & Positivos & $\%$ \\
\hline $\begin{array}{l}\text { Onça- } \\
\text { pintada }\end{array}$ & animais & 4 & 0 & 0 & 22 & 2 & 9,1 & 4 & 0 & 0 \\
\hline \multirow{2}{*}{$\begin{array}{c}\text { Gato } \\
\text { doméstico }\end{array}$} & propriedades & 6 & 1 & 16,7 & 7 & 0 & 0 & 3 & 0 & 0 \\
\hline & animais & 7 & 1 & 14,3 & 10 & 0 & 0 & 5 & 0 & 0 \\
\hline
\end{tabular}

Tabela 33 - Resultados do teste molecular para 'Candidatus Mycoplasma haemominutum', distribuídos em função das áreas de estudo e espécies amostradas entre fevereiro de 2000 e janeiro de 2010

\begin{tabular}{|c|c|c|c|c|c|c|c|c|c|c|}
\hline \multirow{2}{*}{ Espécie } & \multirow{2}{*}{ Categoria } & \multicolumn{3}{|c|}{ Parque Nacional das Emas } & \multicolumn{3}{|c|}{ Pantanal } & \multicolumn{3}{|c|}{ Parque Estadual do Cantão } \\
\hline & & Examinados & Positivos & $\%$ & Examinados & Positivos & $\%$ & Examinados & Positivos & $\%$ \\
\hline $\begin{array}{l}\text { Onça- } \\
\text { pintada }\end{array}$ & animais & 4 & 3 & 75,0 & 22 & 16 & 72,7 & 4 & 3 & 75,0 \\
\hline \multirow{2}{*}{$\begin{array}{c}\text { Gato } \\
\text { doméstico }\end{array}$} & propriedades & 6 & 0 & 0 & 7 & 2 & 28,6 & 3 & 0 & 0 \\
\hline & animais & 7 & 0 & 0 & 10 & 2 & 20,0 & 5 & 0 & 0 \\
\hline
\end{tabular}


Tabela 34 - Parâmetros estimados pela regressão logística testando o efeito da espécie amostrada (coeficiente $\beta_{1}$ ) e área de estudo (coeficiente $\beta_{2}$ ) para o diagnóstico do Mycoplasma haemofelis. Utilizando como categoria de referência para espécie, os gatos domésticos, e para área de estudo, o Parque Nacional das Emas

\begin{tabular}{lcccc}
\hline \multicolumn{1}{c}{ Variáveis } & Estimativa & Erro Padrão & Valor $\boldsymbol{p}$ & IC 95\% \\
\hline Intercepto & $-2,652$ & 1,162 & 0,023 & $-5,724 ;-0,797$ \\
$\beta_{1}$ (onça-pintada) & 0,792 & 0,935 & 0,397 & $-0,938 ; 2,888$ \\
$\beta_{2}$ (Pantanal) & 0,114 & 1,214 & 0,926 & $-2,051 ; 3,188$ \\
$\beta_{2}$ (PEC) & 1,004 & 1,333 & 0,451 & $-1,547 ; 4,202$ \\
\hline
\end{tabular}

Tabela 35 - Parâmetros estimados pela regressão logística testando o efeito da espécie amostrada (coeficiente $\beta_{1}$ ) e área de estudo (coeficiente $\beta_{2}$ ) para o diagnóstico do 'Candidatus Mycoplasma turicensis'. Utilizando como categoria de referência para espécie, os gatos domésticos, e para área de estudo, o Parque Nacional das Emas

\begin{tabular}{lcccc}
\hline \multicolumn{1}{c}{ Variáveis } & Estimativa & Erro Padrão & Valor $\boldsymbol{p}$ & IC 95\% \\
\hline Intercepto & $-2,483$ & 1,211 & 0,040 & $-5,752 ;-0,580$ \\
$\beta_{1}$ (onça-pintada) & 0,444 & 1,336 & 0,740 & $-2,089 ; 3,662$ \\
$\beta_{2}$ (Pantanal) & $-0,548$ & 1,348 & 0,684 & $-3,149 ; 2,663$ \\
\hline
\end{tabular}

Tabela 36 - Parâmetros estimados pela regressão logística testando o efeito da espécie amostrada (coeficiente $\beta_{1}$ ) e área de estudo (coeficiente $\beta_{2}$ ) para o diagnóstico do 'Candidatus Mycoplasma haemominutum'. Utilizando como categoria de referência para espécie, os gatos domésticos, e para área de estudo, o Parque Nacional das Emas

\begin{tabular}{lcccc}
\hline \multicolumn{1}{c}{ Variáveis } & Estimativa & Erro Padrão & Valor $\boldsymbol{p}$ & IC 95\% \\
\hline Intercepto & $-2,648$ & 1,038 & 0,011 & $-5,005 ;-0,866$ \\
$\beta_{1}$ (onça-pintada) & 3,199 & 0,857 & $<0,001$ & 1,$693 ; 5,191$ \\
$\beta_{2}$ (Pantanal) & 0,629 & 0,972 & 0,518 & $-1,334 ; 2,598$ \\
$\beta_{2}$ (PEC) & 0,107 & 1,243 & 0,931 & $-2,386 ; 2,609$ \\
\hline
\end{tabular}




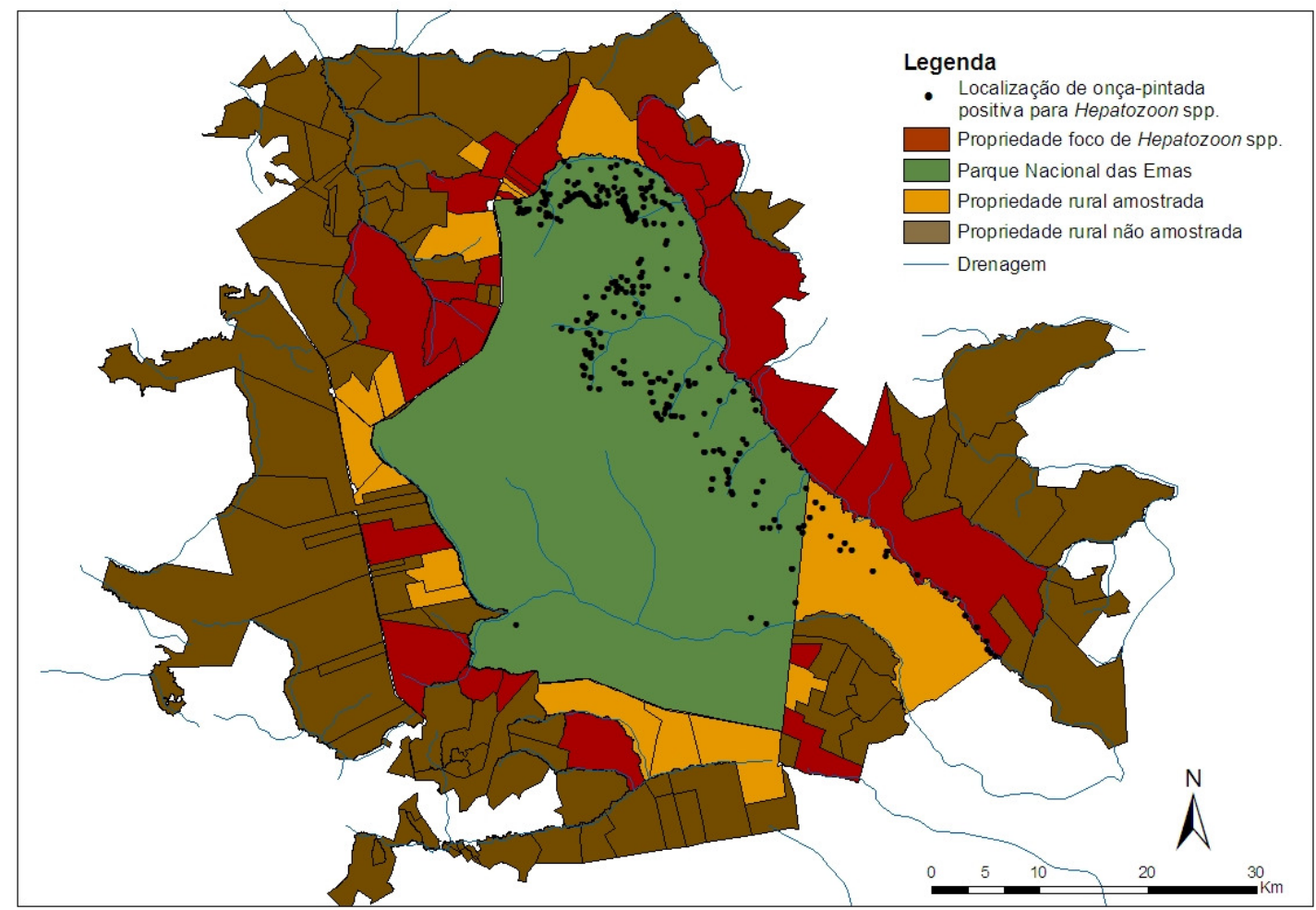

Figura 54 - Localizações das onças-pintadas positivas para Hepatozoon spp. e propriedades rurais foco do agente na região do Parque Nacional das Emas

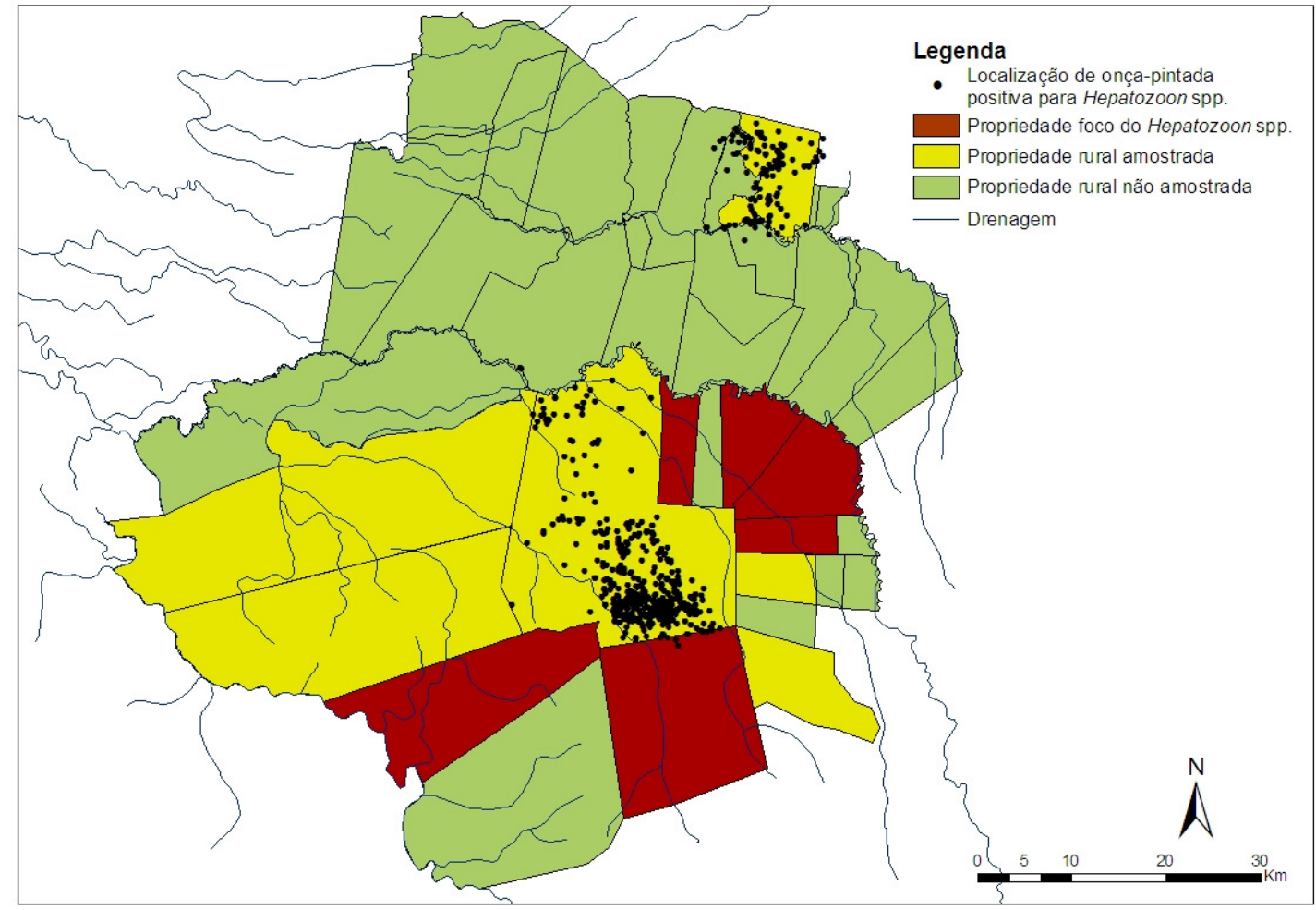

Figura 55 - Localizações das onças-pintadas positivas para Hepatozoon spp. e propriedades rurais foco do agente no Pantanal 


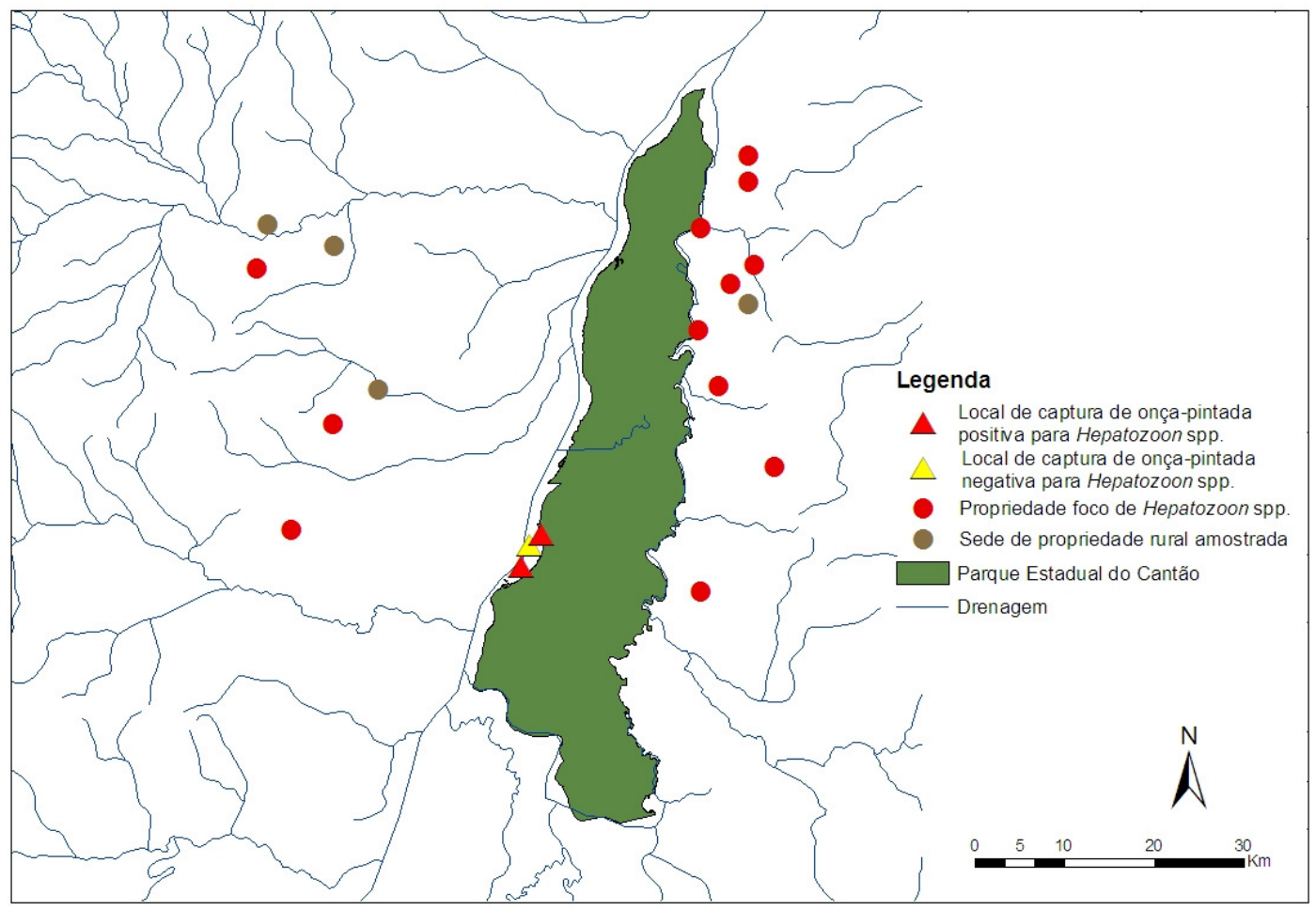

Figura 56 - Locais de captura das onças-pintadas positivas e negativa para Hepatozoon spp. e propriedades rurais foco do agente na região do Parque Estadual do Cantão

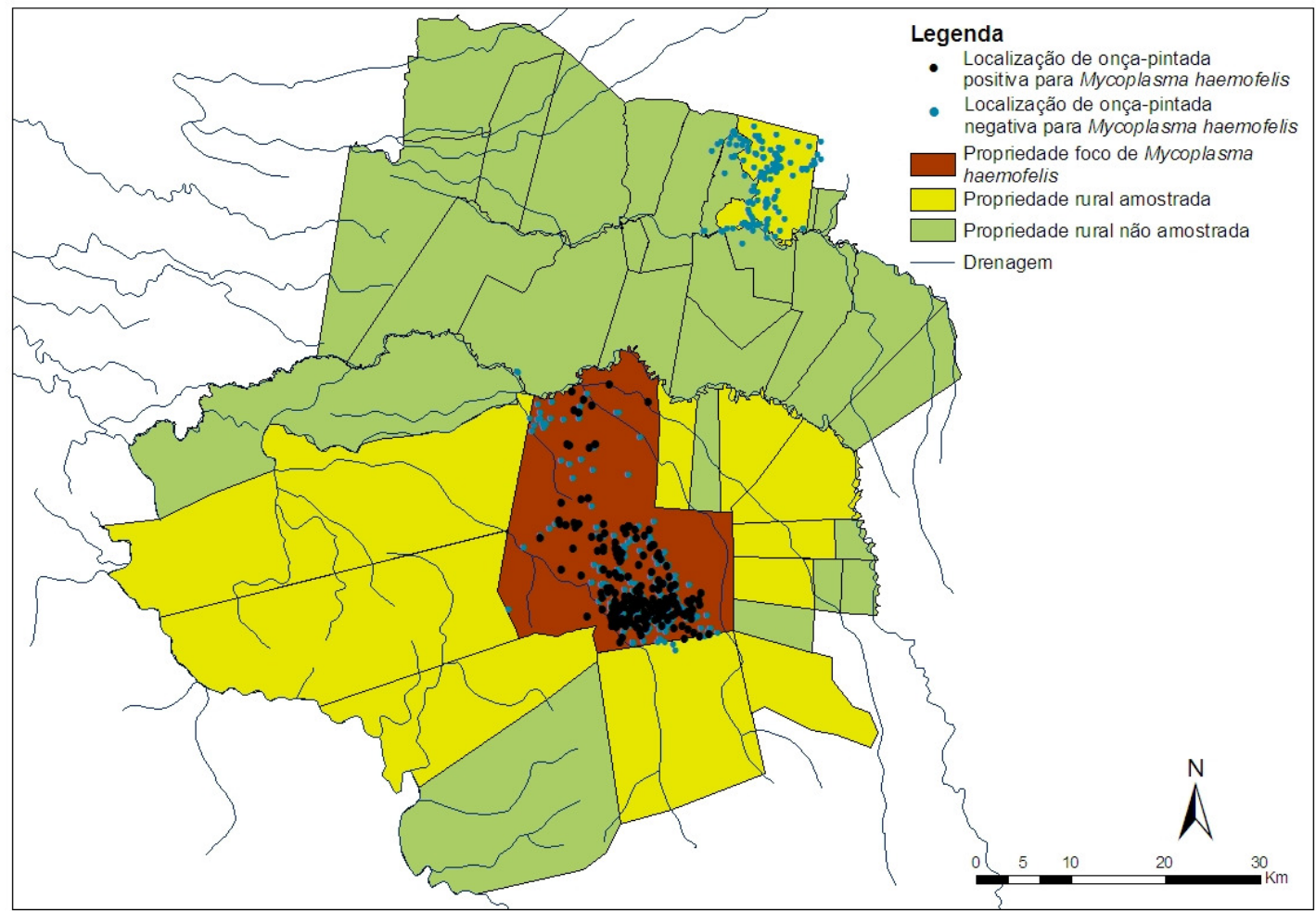

Figura 57 - Localizações das onças-pintadas positivas e negativas para Mycoplasma haemofelis e propriedade foco do agente no Pantanal 


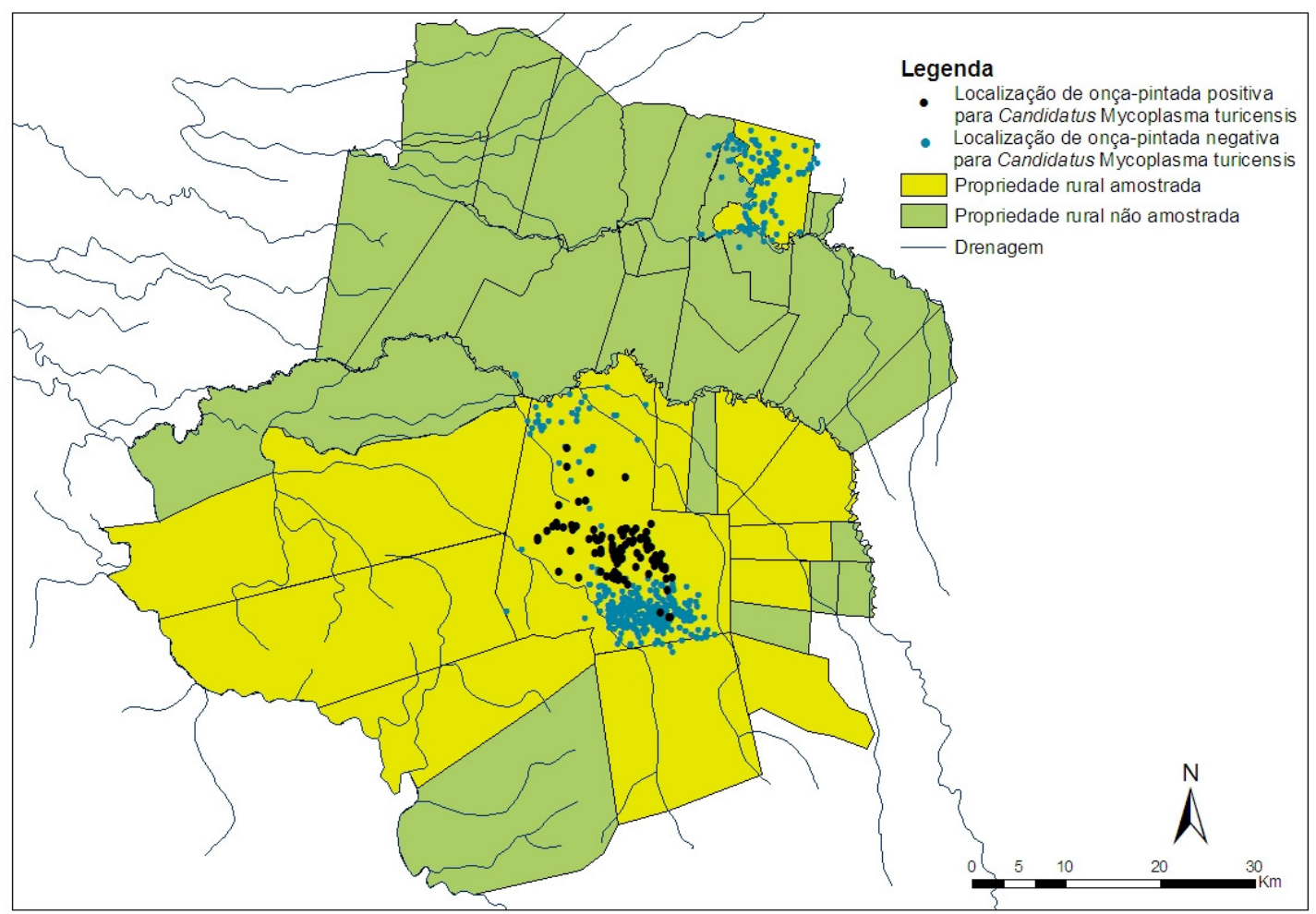

Figura 58 - Localizações das onças-pintadas positivas e negativas para 'Candidatus Mycoplasma turicensis' no Pantanal

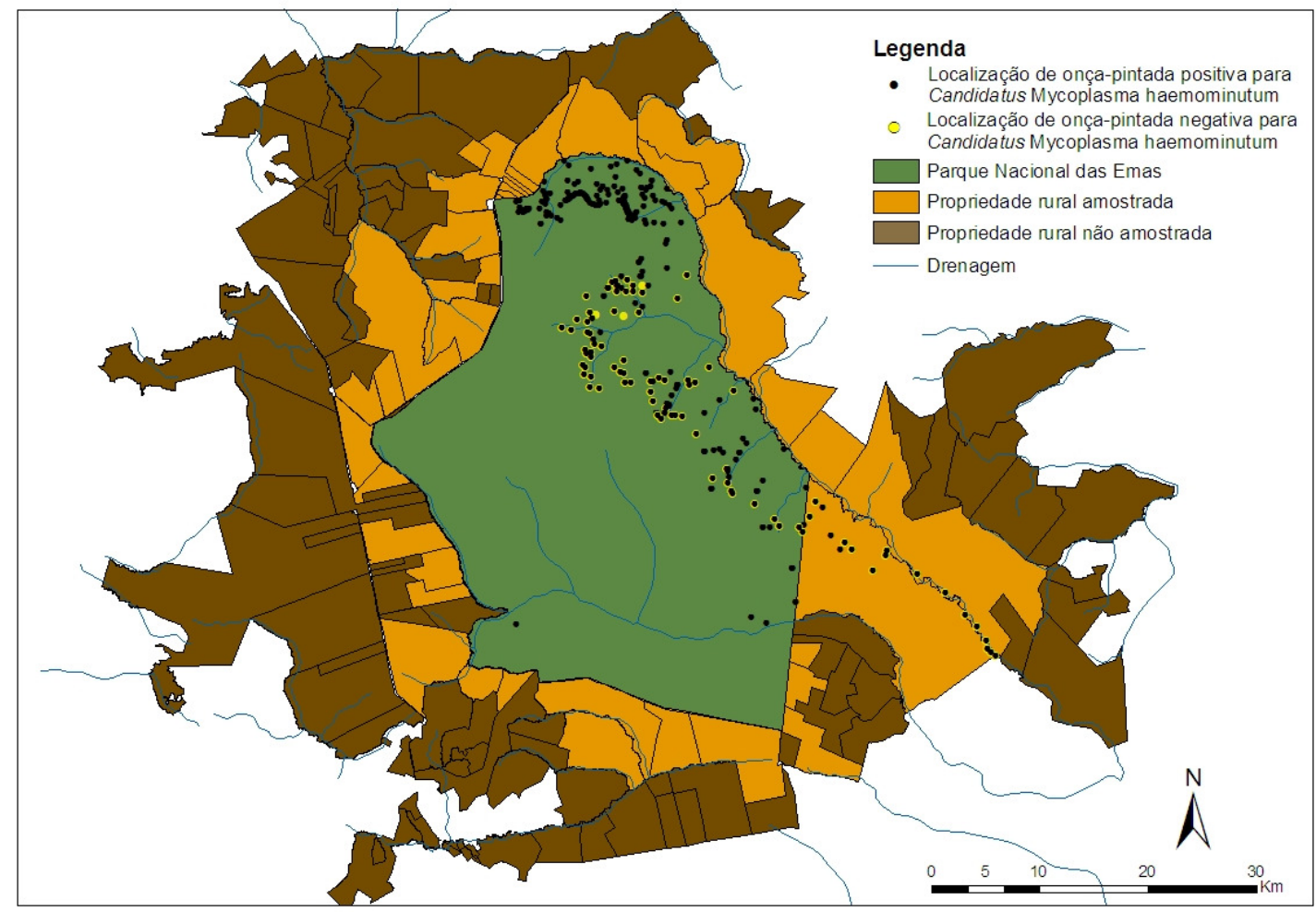

Figura 59 - Localizações das onças-pintadas positivas e negativas para 'Candidatus Mycoplasma haemominutum' na região do Parque Nacional das Emas 


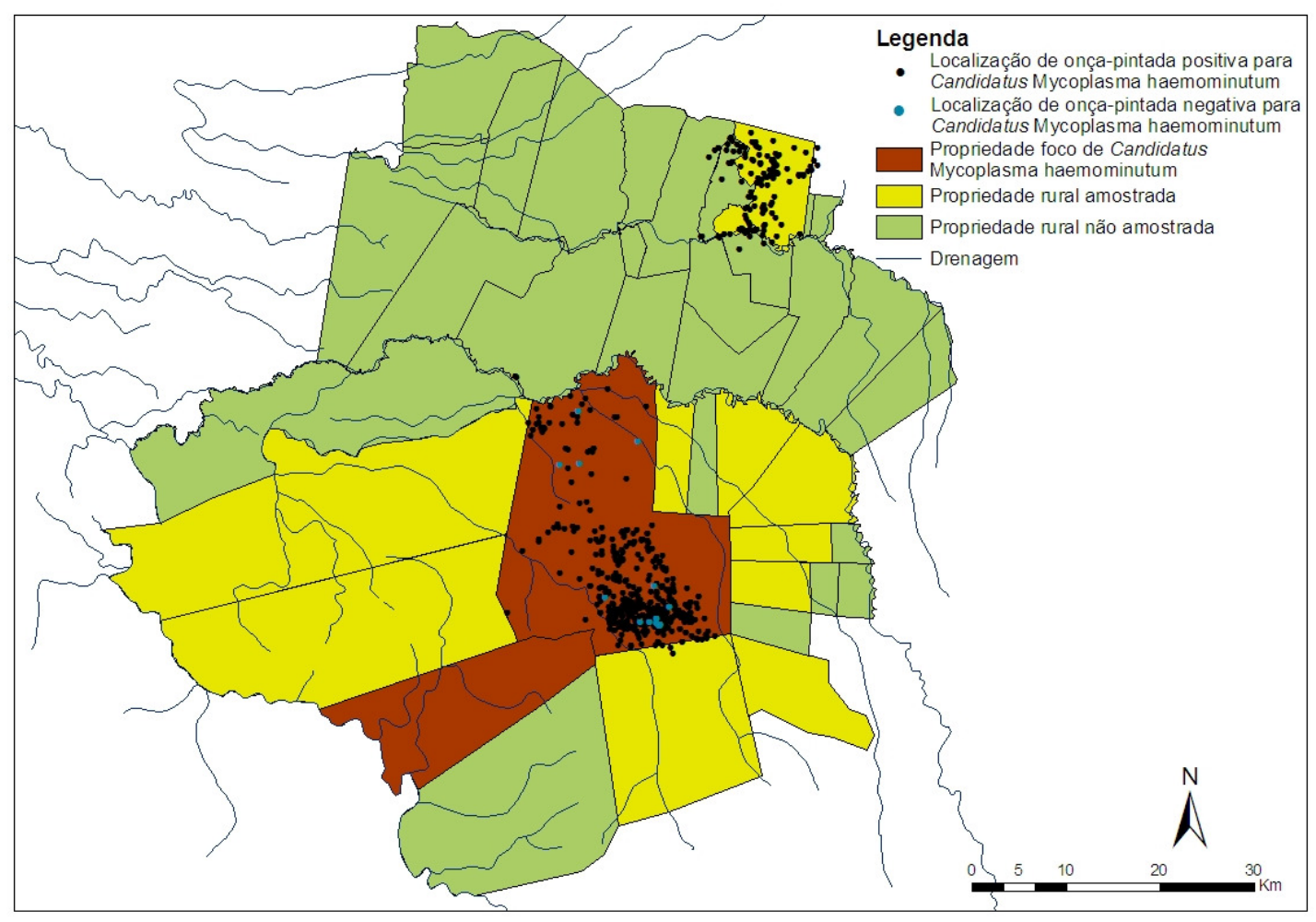

Figura 60 - Localizações das onças-pintadas positivas e negativas para 'Candidatus Mycoplasma haemominutum' e propriedades rurais foco do agente no Pantanal

5.7.2.10 Sequenciamento dos hemoparasitas

Pelo sequenciamento genético, os produtos provenientes de um cão doméstico do entorno do PNE e de dois cães do entorno PEC positivos para Babesia spp. apresentaram, respectivamente, $98 \%, 96 \%$ e $99 \%$ de similaridade com as sequências de isolado de Babesia canis vogeli de cão doméstico no Brasil (GQ214514.1).

Para as amostras de onças-pintadas positivas para Cytauxzoon felis, produtos provenientes de duas onças do Pantanal, duas do PEC e três do PNE apresentaram 98\% de similaridade genética com as sequências de isolado de Cytauxzoon felis de gato doméstico nos Estados Unidos (AF 399930.1). Um produto de onça-pintada do Pantanal e um do PEC apresentaram 99\% de similaridade para essa mesma amostra.

Para os cães domésticos positivos para Hepatozoon spp., a análise do sequenciamento de um produto proveniente de cão do entorno do PNE apresentou $100 \%$ de similaridade genética para Hepatozoon canis de raposa na Europa (AY 150067.2), e produtos de um cão do Pantanal e um cão do PEC apresentaram 99\% de similaridade genética para essa mesma 
amostra. Para as amostras de felinos positivas para Hepatozoon spp., os produtos de duas onçaspintadas e de dois gatos domésticos do Pantanal, de duas onças do PNE, e de uma onça do PEC apresentaram 98\% de similaridade genética para Hepatozoon felis-like de Prionaiturus bengalensis na Coréia - isolado número 1 (GQ 377218.1).

Das 39 amostras de fezes de onça-pintada submetidas à tentativa de isolamento de Mycobacterium spp. (6 do PNE, 20 do PEC e 13 do Pantanal), 27 foram negativas (5 do PNE, 17 do PEC e 5 do Pantanal), 3 amostras contaminaram (1 de cada área de estudo) e em 9 amostras (7 do Pantanal e 2 do PEC) houve crescimento de colônias sugestivas à Mycobacterium spp. Os isolados dessas nove amostras foram submetidos ao PRA e classificados como Mycobacterium spp. Adicionalmente, os resultados permitiram concluir que nenhum isolado apresentou padrão de restrição compatível com as espécies pertencentes ao Complexo Mycobacterium tuberculosis.

Os resultados para o teste molecular de parasitas intestinais encontram-se na tabela 37. Apenas duas amostras do PNE foram positivas para Cryptosporidium spp. e Giardia intestinalis.

Tabela 37 - Resultados dos testes moleculares para Cryptosporidium spp., Giardia intestinalis e protozoários da Família Sarcocystidae em onças-pintadas, segundo as reservas amostradas

\begin{tabular}{l|ccc|ccc|ccc}
\hline \multirow{2}{*}{ Patógeno } & \multicolumn{2}{|c|}{ Parque Nacional das Emas } & \multicolumn{3}{c|}{ Pantanal } & \multicolumn{3}{c}{ Parque Estadual do Cantão } \\
& Exam. & Eos. $^{\mathbf{2}}$ & \% & Exam. & Pos. & \% & Exam. & Pos. & \% \\
\hline Cryptosporidium spp. & 12 & 1 & 8.33 & 6 & 0 & 0 & 5 & 0 & 0 \\
Giardia intestinalis & 12 & 1 & 8.33 & 6 & 0 & 0 & 5 & 0 & 0 \\
Sarcocystidae & 12 & 0 & 0 & 6 & 0 & 0 & 5 & 0 & 0 \\
\hline
\end{tabular}

${ }^{1}$ Examinados. ${ }^{2}$ Positivos. 
5.7.2.13 Pesquisa de ectoparasitas

Foram identificadas cinco espécies de carrapatos parasitando as onças-pintadas, quatro destas identificadas também em bovinos ou cães domésticos das propriedades rurais amostradas. As identificações dos carrapatos e outros três ectoparasitas encontrados em onçaspintadas estão na tabela 38.

\subsection{TESTE DE TUBERCULINIZAÇÃO}

O teste de tuberculinização foi realizado em 123 bovinos em três propriedades do entorno do PNE, e em 121 vacas em duas propriedades do entorno do PEC. Todos os indivíduos apresentaram resultados negativos.

\subsection{QUESTIONÁRIO EPIDEMIOLÓGICO}

A tabela 39 sintetiza as respostas dos questionários aplicados aos proprietários ou gerentes das propriedades nas quais foram realizadas as coletas de amostras biológicas dos bovinos. A maioria dessas propriedades fazia divisa com áreas protegidas $(100 \%, n=8$, das propriedades do PNE, 60\% (3/5) das propriedades do Pantanal e 83,3\% (5/6) das propriedades do PEC). Todas as propriedades do Pantanal e do entorno do PEC e 62,5\% (5/8) das propriedades do entorno do PNE confirmaram a presença da onça-pintada em sua propriedade. A predação do gado por onça-pintada foi relatada em $37,5 \%$ (3/8), 80,0\% (4/5) e 100,0\% ( $n=6)$ das propriedades do entorno do PNE, Pantanal e PEC, respectivamente.

As tabelas 40 e 41 apresentam as respostas dos questionários aplicados aos proprietários dos cães e gatos domésticos amostrados nas três áreas. Durante a visita à propriedade para coleta do material biológico, um dos cães do entorno do PNE encontrava-se anêmico e apático, e cinco cães do Pantanal e dois do entorno do PEC encontravam-se magros. 
Tabela 38 - Ectoparasitas identificados em onças-pintadas, bovinos e cães domésticos da região do Parque Nacional das Emas, Pantanal e Parque Estadual do Cantão entre fevereiro de 2000 e janeiro de 2010

\begin{tabular}{|c|c|c|c|c|c|c|c|c|}
\hline \multirow{3}{*}{ Ectoparasitas } & \multicolumn{8}{|c|}{$\mathbf{N}^{\circ}$ ectoparasitas identificados ( $\mathrm{n}^{\circ}$ amostradas coletadas ${ }^{1}$ ) } \\
\hline & \multicolumn{3}{|c|}{ Onça-pintada } & \multicolumn{2}{|c|}{ Bovino } & \multicolumn{3}{|c|}{ Cão doméstico } \\
\hline & PNE & Pantanal & PEC & PNE & PEC & PNE & Pantanal & PEC \\
\hline \multicolumn{9}{|l|}{ Amblyomma sp. } \\
\hline Larva & 0 & $7\left(1^{5}\right)$ & 0 & 0 & 0 & 0 & 0 & 0 \\
\hline Ninfa & $65\left(4^{2}\right)$ & $110\left(12^{5}\right)$ & 0 & 0 & 0 & 0 & 0 & $3(2)$ \\
\hline \multicolumn{9}{|c|}{ Amblyomma cajennense } \\
\hline Macho & $5\left(3^{2}\right)$ & $29\left(13^{5}\right)$ & 0 & 0 & 0 & 0 & $1(1)$ & $1(1)$ \\
\hline Fêmea & $6\left(3^{2}\right)$ & $84\left(20^{5}\right)$ & 0 & 0 & $5(2)$ & 0 & 0 & 0 \\
\hline \multicolumn{9}{|l|}{ Amblyomma ovale } \\
\hline Macho & & $26\left(16^{4}\right)$ & $1\left(1^{3}\right)$ & 0 & 0 & 0 & 0 & 0 \\
\hline Fêmea & & $48\left(20^{5}\right)$ & $1\left(1^{3}\right)$ & 0 & 0 & 0 & 0 & $1(1)$ \\
\hline \multicolumn{9}{|l|}{ Amblyomma tigrinum } \\
\hline Macho & $2\left(3^{2}\right)$ & 0 & 0 & 0 & 0 & 0 & 0 & 0 \\
\hline Fêmea & $6\left(4^{2}\right)$ & 0 & 0 & 0 & 0 & 0 & 0 & 0 \\
\hline \multicolumn{9}{|l|}{ Amblyomma triste } \\
\hline Macho & $1\left(1^{2}\right)$ & 0 & 0 & 0 & 0 & 0 & 0 & 0 \\
\hline Fêmea & $3\left(3^{2}\right)$ & $2\left(1^{2}\right)$ & 0 & $1(1)$ & 0 & 0 & 0 & 0 \\
\hline \multicolumn{9}{|l|}{ A. oblongoguttatum } \\
\hline $\begin{array}{l}\text { Macho } \\
\text { Rhipicephalus microplus }\end{array}$ & \multicolumn{7}{|c|}{ Rhipicephalus microplus } & $1(1)$ \\
\hline Ninfa & 0 & $2\left(1^{5}\right)$ & 0 & $5(1)$ & 0 & 0 & 0 & 0 \\
\hline Macho & 0 & $2\left(2^{5}\right)$ & 0 & $3(3)$ & $8(2)$ & 0 & 0 & 0 \\
\hline Fêmea & 0 & $4\left(4^{2}\right)$ & 0 & $14(4)$ & $47(5)$ & 0 & 0 & 0 \\
\hline \multicolumn{9}{|l|}{ Rhipicephalus sanguineus } \\
\hline Ninfa & 0 & 0 & 0 & 0 & 0 & 0 & 0 & $6(3)$ \\
\hline Macho & 0 & 0 & 0 & 0 & 0 & $2(2)$ & 0 & $10(3)$ \\
\hline Fêmea & 0 & 0 & 0 & 0 & 0 & $3(2)$ & $1(1)$ & $24(4)$ \\
\hline \multicolumn{9}{|l|}{ Cochliomyia sp. } \\
\hline Larva & 0 & $3(3)$ & 0 & 0 & 0 & 0 & 0 & 0 \\
\hline \multicolumn{9}{|l|}{ Dermatobia hominis } \\
\hline Larva & 0 & $2(2)$ & $8(3)$ & 0 & 0 & 0 & 0 & 0 \\
\hline Tunga penetrans & 0 & $8(1)$ & 0 & 0 & 0 & 0 & 0 & 0 \\
\hline
\end{tabular}

${ }^{1} n^{\circ}$ eventos de captura para onça-pintada ou $n^{\circ}$ propriedades amostradas para bovinos e cães domésticos.

'onças positivas para Hepatozoon spp., Cytauxzoon felis e 'Ca. M. haemominutum'.

'onças positivas para Cytauxazoon felis e 'Ca. M. haemominutum'.

${ }^{4}$ onças positivas para Hepatozoon spp., Cytauxzoon felis, M. haemofelis e 'Ca. M. haemominutum'.

5onças positivas para Hepatozoon spp., Cytauxzoon felis, M. haemofelis, 'Ca. M. turicensis' e 'Ca. M. haemominutum'. 
Tabela 39 - Caracterização das propriedades rurais que praticam a pecuária extensiva nas três áreas de estudo e informações a respeito do manejo do rebanho bovino. Dados obtidos através dos questionários aplicados aos gerentes ou proprietários das propriedades rurais entre maio de 2008 e maio de 2009

\begin{tabular}{|c|c|c|c|}
\hline Parâmetro & $\begin{array}{r}\text { PNE } \\
(n=8) \\
\%\end{array}$ & $\begin{array}{r}\text { PAN } \\
(n=5) \\
\%\end{array}$ & $\begin{array}{r}\text { PEC } \\
(n=6) \\
\%\end{array}$ \\
\hline Rebanho extensivo & 100,0 & 100,0 & 100,0 \\
\hline Exploração de corte & 100,0 & 100,0 & 100,0 \\
\hline Tem mais que 50 fêmeas acima de 24 meses & 75,0 & 80,0 & 100,0 \\
\hline Contato com ovinos/caprinos & 50,0 & 60,0 & 0,0 \\
\hline Contato com equinos & 100,0 & 100,0 & 100,0 \\
\hline Contato com suínos & 12,5 & 20,0 & 0,0 \\
\hline Contato com aves & 62,5 & 60,0 & 100,0 \\
\hline Contato com cão & 100,0 & 60,0 & 100,0 \\
\hline Contato com gato & 62,5 & 80,0 & 66,7 \\
\hline Contato com animais silvestres & 100,0 & 100,0 & 100,0 \\
\hline Utiliza inseminação artificial & 25,0 & 20,0 & 33,3 \\
\hline Compra animais para reprodução & 37,5 & 50,0 & 83,3 \\
\hline Vende animais para reprodução & 12,5 & 60,0 & 50,0 \\
\hline Tem histórico de aborto nos últimos 12 meses & 12,5 & 100,0 & 50,0 \\
\hline Deixa produto do aborto na pastagem & 50,0 & 100,0 & 50,0 \\
\hline Abate animais na propriedade & 0,0 & 0,0 & 0,0 \\
\hline Aluga pasto & 0,0 & 0,0 & 0,0 \\
\hline Tem pasto em comum com outras propriedades & 0,0 & 0,0 & 0,0 \\
\hline Tem áreas alagadiças na propriedade & 62,5 & 100,0 & 100,0 \\
\hline Tem piquete de parição & 100,0 & 60,0 & 100,0 \\
\hline Vacina fêmeas entre 3 e 8 meses contra brucelose & 100,0 & 80,0 & 83,3 \\
\hline Vacina contra aftosa & 100,0 & 100,0 & 100,0 \\
\hline Vacina contra raiva & 87,5 & 100,0 & 66,7 \\
\hline Animais tratados com carrapaticida & 100,0 & 100,0 & 100,0 \\
\hline Faz teste para diagnóstico de brucelose quando exigido & 50,0 & 40,0 & 33,3 \\
\hline Faz teste para diagnóstico de brucelose uma vez ao ano & 25,0 & 0,0 & 0,0 \\
\hline Faz teste para diagnóstico de tuberculose apenas quando exigido & 12,5 & 20,0 & 16,7 \\
\hline Faz teste para diagnóstico de tuberculose uma vez ao ano & 0,0 & 0,0 & 0,0 \\
\hline Aquisição de bovinos nos últimos dois anos & 62,5 & 60,0 & 16,7 \\
\hline Aquisição de bovinos diretamente de outras fazendas & 37,5 & 60,0 & 16,7 \\
\hline Não tem assistência veterinária & 37,5 & 40,0 & 50,0 \\
\hline Produz queijo na propriedade para consumo próprio & 75,0 & 100,0 & 66,7 \\
\hline
\end{tabular}


Tabela 40 - Informações obtidas através dos questionários aplicados aos proprietários dos cães domésticos amostrados nas três áreas de estudo entre maio de 2008 e janeiro de 2010

\begin{tabular}{|c|c|c|c|}
\hline Parâmetro & $\begin{array}{r}\text { PNE } \\
(n=76) \\
(\%) \\
\end{array}$ & $\begin{array}{r}\text { PAN } \\
(n=26) \\
(\%)\end{array}$ & $\begin{array}{r}\text { PEC } \\
(n=63) \\
(\%)\end{array}$ \\
\hline Cães adultos ( $\geq 24$ meses) & 59,7 & 57,7 & 65,0 \\
\hline Cães machos & 61,8 & 61,5 & 63,5 \\
\hline Cães vacinados contra raiva & 78,4 & 80,8 & 77,8 \\
\hline Cães vacinados contra cinomose e parvovirose & 20,3 & 3,8 & 9,5 \\
\hline Cães vermifugados & 69,2 & 73,1 & 40,7 \\
\hline Cães alimentados apenas com comida & 76,3 & 76,9 & 83,9 \\
\hline Cães alimentados com carne crua & 51,3 & 95,0 & 88,3 \\
\hline Cães em boas condições físicas durante coleta & 94,7 & 80,8 & 96,8 \\
\hline Cães que já apresentaram problemas de saúde & 9,1 & 20,0 & 6,5 \\
\hline Cães que vivem soltos & 84,2 & 100,0 & 96,8 \\
\hline Cães com hábito de caça & 5,3 & 19,2 & 51,6 \\
\hline Cães com hábito de comer carniça & 15,8 & 26,9 & 47,5 \\
\hline Cães em contato com bovinos & 68,4 & 38,5 & 66,7 \\
\hline Cães em contato com aves & 78,9 & 50,0 & 52,4 \\
\hline Cães em contato com gatos & 73,7 & 57,7 & 38,1 \\
\hline Cães em contato com suínos & 63,2 & 26,9 & 17,5 \\
\hline Cães em contato com outros cães & 92,1 & 76,9 & 87,3 \\
\hline Propriedade com presença de animais silvestres & 78,9 & 100,0 & 100,0 \\
\hline Presença de roedor na propriedade & 94,5 & 42,3 & 65,6 \\
\hline
\end{tabular}


Tabela 41 - Informações obtidas através dos questionários aplicados aos proprietários dos gatos domésticos amostrados nas três áreas de estudo entre maio de 2008 e janeiro de 2010.

\begin{tabular}{|c|c|c|c|}
\hline Parâmetro & $\begin{array}{r}\text { PNE } \\
(n=5) \\
(\%) \\
\end{array}$ & $\begin{array}{r}\text { PAN } \\
(n=12) \\
(\%) \\
\end{array}$ & $\begin{array}{r}\text { PEC } \\
(\mathrm{n}=13) \\
(\%) \\
\end{array}$ \\
\hline Gatos adultos ( $\geq 24$ meses) & 40,0 & 58,3 & 25,0 \\
\hline Gatos machos & 40,0 & 66,7 & 46,2 \\
\hline Gatos vacinados contra raiva & 60,0 & 83,3 & 30,8 \\
\hline Gatos vacinados contra tríplice felina & 0,0 & 0,0 & 0,0 \\
\hline Gatos vermifugados & 40,0 & 8,3 & 30,8 \\
\hline Gatos alimentados apenas com comida & 80,0 & 66,7 & 76,9 \\
\hline Gatos alimentados com carne crua & 80,0 & 83,3 & 76,9 \\
\hline Gatos em boas condições físicas durante coleta & 100,0 & 83,3 & 100,0 \\
\hline Gatos que já apresentaram problemas de saúde & 0,0 & 0,0 & 0,0 \\
\hline Gatos que vivem soltos & 80,0 & 100,0 & 100,0 \\
\hline Gatos com hábito de caça & 100,0 & 75,0 & 100,0 \\
\hline Gatos com hábito de comer carniça & 100,0 & 75,0 & 38,5 \\
\hline Gatos em contato com bovinos & 20,0 & 66,7 & 61,5 \\
\hline Gatos em contato com aves & 100,0 & 50,0 & 69,2 \\
\hline Gatos em contato com cães & 100,0 & 66,7 & 69,2 \\
\hline Gatos em contato com suínos & 100,0 & 41,7 & 7,7 \\
\hline Cães em contato com outros gatos & 100,0 & 58,3 & 30,8 \\
\hline Propriedade com presença de animais silvestres & 100,0 & 100,0 & 100,0 \\
\hline Presença de roedor na propriedade & 100,0 & 50,0 & 84,6 \\
\hline
\end{tabular}




\section{DISCUSSÃO}

A discussão deste trabalho foi divida em tópicos, iniciando com as capturas de onçaspintadas e na sequência, um tópico para cada patógeno pesquisado.

\subsection{CAPTURAS DE ONÇAS-PINTADAS}

As três áreas de estudo apresentaram sucessos de captura semelhantes utilizando cães rastreadores (Tabela 1). Entretanto, na região do Pantanal, mais campanhas foram realizadas, proporcionando maior número de eventos de captura. A logística e a alta densidade da espécie no Pantanal (SOISALO; CAVALCANTI, 2006) também contribuíram para esse resultado.

Os registros das onças-pintadas na frente das gaiolas do PNE (Figuras 32 e 33) comprovou a ineficiência dessas armadilhas na área de estudo, apesar do esforço realizado. As onças podem ter evitado entrar nas gaiolas pela: (a) não familiaridade com a isca utilizada (porco doméstico) ou (b) abundância de presas silvestres naturais no parque, não despertando na onçapintada o interesse pela isca doméstica. Além de não ter apresentado sucesso de captura, a desvantagem desse método foi que, durante o período em que ficavam abertas, as armadilhas tinham que ser revisadas diariamente para alimentação da isca, envolvendo grande esforço pessoal e logístico. Assim, a utilização de cães rastreadores para localização da onça-pintada foi o método mais eficiente para as três áreas neste estudo. Resultado que concorda com McBride Júnior e McBride (2007) no Chaco Paraguaio. Cães rastreadores para captura de onças-pintadas são frequentemente utilizados em projetos de pesquisa (RABINOWITZ, 1986; CRAWSHAW; QUIGLEY, 1991; SILVEIRA, 2004; SOISALO; CAVALCANTI, 2006; AZEVEDO; MURRAY, 2007b; FURTADO et al., 2008), sendo que a escolha do método depende da área de estudo, recursos disponíveis e experiência da equipe, e deve fornecer plena segurança para os envolvidos. 
Para o diagnóstico das brucelas lisas, optou-se pela utilização do teste do AAT, por se tratar de um teste consagrado, qualitativo, com alta sensibilidade e especificidade (POESTER; GONCALVES; LAGE, 2002; BRASIL, 2006). Além disso, é um teste robusto, tendo como sinal a aglutinação macroscópica e como antígeno a célula inteira da Brucella abortus, cepa 1119-3 (BRASIL, 2006). Dentre os testes existentes para o diagnóstico da brucelose, é também o mais indicado para animais silvestres (MUÑOZ et al., 2010).

Embora as populações de bovino das três áreas de estudo tenham apresentado alta exposição às brucelas lisas, apenas uma onça-pintada capturada no Parque Nacional das Emas foi soropositiva (Tabela 16). A positividade ao AAT pode ser decorrente de infecção por $B$. abortus, B. suis ou B. mellitensis (ACHA; SZYFRES, 2001), sendo essa última considerada exótica no Brasil (PAULIN; FERREIRA NETO, 2003).

A brucelose bovina causada pela $B$. abortus é a mais prevalente das infecções causadas pelo gênero Brucella no Brasil (POESTER; GONCALVES; LAGE, 2002) e os resultados positivos em bovinos podem, inequivocadamente, ser atribuídos à B. abortus (BRASIL, 2006). Os bovinos das três áreas de estudo mostraram ocorrências importantes de infecção por B. abortus (Tabela 16), concordando com estudos realizados nos estados de Goiás (ROCHA et al., 2009), Tocantins (OGATA et al., 2009) e Pantanal do Mato Grosso do Sul (CHATE et al., 2009).

A exposição de cães domésticos a brucelas lisas foi baixa, e esteve presente apenas na região do Pantanal (Tabela 16), concordando com os estudos realizados em Minas Gerais e na Paraíba que registraram 2,8\% e 0,85\% de soropositividade respectivamente, e em São Paulo e Rio de Janeiro, onde não foram detectados cães positivos (MAIA et al., 1999; ALMEIDA et al., 2004; MALEK DOS REIS et al., 2008). Os cães do presente estudo podem ter sido infectados através do contato com material infectante oriundo de bovinos (B. abortus) ou de suídeos e taiassuídeos domésticos ou silvestres (B. suis). Entretanto, o papel do cão na transmissão de brucelas lisas é insignificante (PRIOR, 1976; FORBES, 1990). Como os cães do Pantanal eram criados soltos (Tabela 40), podem ter ingerido placenta, feto abortado ou leite de bovino infectado em função do estreito contato com os bovinos (PRIOR, 1976; ADESIYUN; ABDULLAHI; ADEYANJU, 1986; FORBES, 1990; MORSHEDI; SOLTANI, 1998; MEGID et al., 2007; SHARMA et al., 2008), ou ter entrado em contato com placenta ou feto abortado de suídeos ou taiassuídeos. 
Sendo que, queixadas do Pantanal sul mato-grossense já foram relatados soropositivos para brucelose (ITO et al., 1998) e poderiam ser a fonte de infecção para os cães.

Excluindo a possibilidade de falso positivo, este é o primeiro relato de exposição de onças-pintadas de vida livre do bioma Cerrado a brucelas lisas (Tabela 16). Onças-pintadas soropositivas para brucelose através do teste do AAT já foram relatadas em animal de vida livre na Mata Atlântica brasileira (NAVA, 2008) e em exemplar mantido em cativeiro no Chile (OLIVARES; RIVEROS; PINOCHET, 1993).

A onça-pintada exposta ao agente utilizou como parte de sua área de vida ambiente próximo à divisa do Parque Nacional das Emas com propriedades rurais que praticavam a pecuária extensiva (Figura 39). É importante ressaltar também, que essa onça soroconverteu na ocasião de sua recaptura, pouco mais de 60 dias após o evento de captura, intervalo no qual, provavelmente infectou-se. A infecção pode ter ocorrido através da predação de bovinos infectados (B. abortus), ingestão de placenta ou feto abortado de vaca infectada ou de água infectada, visto que esses são os principais modos de transmissão da brucelose em carnívoros (ACHA; SZYFRES, 2001). O entorno das três áreas estudadas é constituído por propriedades rurais com importantes frequências de bovinos soropositivos para brucelose. Curiosamente, a predação do gado por onça-pintada nas propriedades do entorno do PNE, onde foi detectado a onça-pintada soropositiva, foi menos relatada do que nas outras duas áreas estudadas. Outra hipótese seria a presença do foco da brucelose no ambiente silvestre do PNE. Embora veadoscampeiros, tamanduás-bandeira e antas do parque tenham sido negativos para brucelose em estudos anteriores (MATHIAS; GIRIO; DUARTE, 1999; MIRANDA, 2008; FURTADO et al., 2010), os queixadas apresentaram 20\% de soropositividade pelo teste do AAT (KASHIVAKURA et al., 2004) e são uma das principais presas das onças-pintadas na região (SILVEIRA, 2004). Assim, a onçapintada soropositiva pode também ter sido infectada por $B$. suis.

O monitoramento da onça soropositiva para brucelose por 12 meses não mostrou alteração no deslocamento padrão da espécie, e sua visualização nas fotos de armadilhas fotográficas comprovou que se manteve em ótimo estado geral, sem manifestações aparentes da doença. O que condiz com o relatado para gatos domésticos, de que os felinos são resistentes à infecção por Brucella spp. (ACHA; SZYFRES, 2001).

Em relação aos resultados estatísticos, a maior exposição dos bovinos à $B$. abortus do que os cães era esperada, visto que os bovinos são considerados os hospedeiros naturais do agente (THORNE, 2001). Porém, a ausência de diferença significativa nas exposições de bovinos e onças-pintadas à $B$. abortus provavelmente está relacionada ao baixo número de onças- 
pintadas amostradas. Portanto, esses dados devem ser utilizados com ressalvas para essa afirmação. A presença de mais diagnósticos positivos no PNE do que no PEC sugere que as onças-pintadas do PNE estejam mais expostas ao patógeno do que as onças-pintadas do PEC, resultado que pode ser apoiado pela presença da única onça-pintada soropositiva no PNE. Entretanto, essa associação não se explica pelo manejo dos bovinos relatado pelos proprietários: (1) todas as propriedades amostradas do entorno do PNE afirmaram vacinar as fêmeas de 3 a 8 meses contra brucelose, (2) houve menor histórico de aborto no entorno do PNE do que nas propriedades do Pantanal e PEC e, (3) apenas 50\% dos proprietários do entorno do PNE relataram deixar fetos abortados nas pastagens (contra $100 \%$ das propriedades do Pantanal) (Tabela 39).

Esses resultados mostram que a brucelose é endêmica nas populações de bovino no entorno das áreas preservadas estudadas, que as onças-pintadas, assim como os demais carnívoros (ROELKE et al., 1993; ACHA; SZYFRES, 2001; FIORELLO et al., 2007) têm um baixo risco de exposição ao agente e, que provavelmente não possuem um papel importante para a manutenção das brucelas lisas nos ambientes estudados.

\subsection{Lepstospira spp.}

As onças-pintadas do Parque Nacional das Emas e do Pantanal foram expostas à Leptospira spp., assim como bovinos e cães das três áreas de estudo, e um gato doméstico do Pantanal (Tabela 18).

A presença de pelo menos um bovino soropositivo para Leptospira spp. em todas as propriedades amostradas indicou a ampla disseminação do agente nas três áreas (Tabela 18). As altas frequências de exposição encontradas concordam com as frequências relatadas no Mato Grosso do Sul (FAVERO et al., 2001) e em Goiás (JULIANO et al., 2000). Nos estados do Tocantins e Pará há relatos de $42,2 \%$ e 38,3\% de bovinos soropositivos, respectivamente (FAVERO et al., 2001). A identificação do sorovar Hardjo como mais frequente na espécie (Figura 40) está de acordo com o relatado em diferentes regiões brasileiras (LILENBAUM; SANTOS, 1996; VASCONCELLOS et al., 1997; FAVERO et al., 2001; HOMEM et al., 2001; ARAÚJO et al., 2005; MINEIRO et al., 2007; FIGUEIREDO et al., 2009). 
As frequências de cães domésticos soropositivos nas propriedades do Pantanal e entorno do Parque Estadual do Cantão concordam com as frequências de $28,85 \%$ relatadas no Rio Grande do Sul (FURTADO et al., 1997) e 21,6\% em São Paulo (YASUDA et al., 1980). As frequências de cães soropositivos aparentemente superiores no Pantanal e PEC em relação ao PNE, provavelmente estão relacionadas às características climáticas do PEC e Pantanal, que possuem elevada umidade relativa do ar, e padrão de inundação sazonal, favorecendo a epidemiologia e disseminação do patógeno, que pode sobreviver por longos períodos na água ou solo úmido (VIJAYACHARI; SUGUNAN; SHRIRAM, 2008).

A identificação de diferentes sorovares nos cães examinados (Figura 41) corrobora as observações de André-Fontaine (2006). O sorovar Canicola mais frequentemente detectado como mais provável nos cães do Pantanal, tem os cães como principais hospedeiros (ACHA; SZYFRES, 1986; ANDRÉ-FONTAINE, 2006), e foram também relatados por Furtado et al. (1997), Yasuda et al. (1980) e Jouglard e Brod (2000). O sorovar Hardjo, mais frequentemente detectado como mais provável nos cães do PEC, provavelmente está relacionado com o contato dos canídeos com os bovinos no ambiente rural. Os roedores provavelmente agiram como fonte de infecção para o sorovar Autumnalis, mais frequentemente detectado como mais provável nos cães do entorno do PNE, visto que são importantes reservatórios da leptospira (ACHA; SZYFRES, 1986) e estiveram presentes nas propriedades do entorno do parque (Tabela 40). O sorovar Autumnalis foi previamente relatado em cães da Paraíba e São Paulo (ALVES et al., 2000; LOPES et al., 2005). O cão normalmente é um hospedeiro acidental da leptospira, e apresenta infecções brandas ou ausência de sinais clínicos específicos (BROWN et al., 1996), conforme foi observado nos cães soropositivos do presente estudo, que apresentavam-se em boas condições físicas durante a coleta das amostras biológicas (Tabela 40).

O gato do Pantanal soropositivo para o sorovar Hardjo, provavelmente entrou em contato ou utilizou os mesmos ambientes que os bovinos. A presença desse sorovar já foi relatada em gatos domésticos de área rural na Escócia (AGUNLOYE; NASH, 1996). A baixa frequência ou ausência de leptospiras em gatos no presente estudo está de acordo com as observações de Acha e Szyfres (1986) e Vijayachari, Sugunan e SHRIRAM (2008), de que raramente $o$ agente é encontrado na espécie.

A ausência de onças-pintadas soropositivas para Leptospira spp. no Parque Estadual do Cantão (Figura 44) não era esperada, pois, como mencionado, o patógeno é transmitido e sobrevive muito bem em ambientes úmidos como os encontrados no PEC, onde há grande 
predominância de rios e lagos. E, os altos níveis de infecção nos bovinos nessa região indicaram que o ambiente é propício à transmissão da leptospirose.

Diferentemente das onças-pintadas do PEC, as onças do PNE e do Pantanal apresentaram alta exposição à Leptospira spp. O sorovar mais provável encontrado no Pantanal foi o mesmo diagnosticado por Nava (2008) em onça-pintada de vida livre na Mata Atlântica (sorovar Pomona), e o sorovar Hardjo, identificado como mais provável em uma onça-pintada do Pantanal (Tabela 10), foi previamente relatado em onças-pintadas mantidas em cativeiro no Brasil (CORRÊA, 2000; GUERRA NETO et al., 2004).

A transmissão da leptospira pode ocorrer através de água e solos contaminados pela urina do animal excretor (ACHA; SZYFRES, 1986), ou ainda pela ingestão de animais infectados (REILLY; HANSON; FERRIS, 1970; SHOPHET; MASHALL, 1980). No PNE, as onças-pintadas soropositivas deslocaram-se principalmente em áreas próximas a cursos d'água (Figura 42), o que pode ter favorecido a transmissão indireta e alta exposição ao agente. Ou ainda, roedores e marsupiais, eventuais presas de onças-pintadas do PNE (IOP dados não publicados), poderiam ser as fontes de infecção, visto que o sorovar mais frequentemente encontrado nas onças dessa área foi o Grippotyphosa, que já foi isolado dessas espécies silvestres em outras regiões do Brasil (SANTAROSA et al., 1975; SANTAROSA et al., 1980; LINS; LOPES, 1984). Outras espécies de mamíferos silvestres de médio e grande porte do PNE apresentaram baixas frequências de soropositividade para Leptospira spp. (MATHIAS; GIRIO; DUARTE, 1999; FURTADO et al., 2010; IOP dados não publicados), e, provavelmente, não agiram como fonte de infecção para as onçaspintadas.

O sorovar Pomona, frequentemente detectado como mais provável nas onças-pintadas do Pantanal, tem o bovino e o porco doméstico como hospedeiros principais (ACHA; SZYFRES, 1986), mas foi encontrado em baixa frequência nos bovinos examinados neste estudo (Figura 40). E, embora as propriedades do Pantanal possuíssem porcos domésticos, esses animais não foram amostrados. Além dos porcos domésticos, poder-se-ia aventar a hipótese de fonte de infecção silvestre, sobretudo em taiassuídeos e porcos-monteiros, principais presas da onçapintada na região (AZEVEDO; MURRAY, 2007b; PORFIRIO, 2009). Girio et al. (2004) e Ito et al. (1998) não identificaram o sorovar Pomona em catetos, queixadas, porcos-monteiros e capivaras soropositivos para Leptospira spp. na região do Pantanal sul mato-grossense. Porém, devido ao baixo número de animais amostrados por esses autores, acredita-se que mais estudos são necessários para verificar o papel dessas espécies como fonte de infecção para as onçaspintadas, assim como a pesquisa de leptospiras nos porcos domésticos das propriedades. 
Algumas onças-pintadas apresentaram altos títulos de anticorpos contra Leptospira spp., indicando infecções recentes ou ativas. Entretanto, o monitoramento dos animais através da radio telemetria não mostrou alterações no deslocamento padrão da espécie (Figura 43), sugerindo, assim como Lilenbaum et al. (2004), que provavelmente as onças não apresentam sinais clínicos para a leptospirose. Corrêa et al. (2006), por sua vez, sugerem que a Família Felidae é mais resistente à leptospirose, devido ao habitual comportamento de predarem roedores, tornando-se assim imunes ao agente.

O aumento da concentração de anticorpos nas onças-pintadas recapturadas (Tabela 10) pode ter ocorrido pela constante exposição ao agente ou evolução da infeç̧ão (ARDUINO et al., 2009), e o declínio dos anticorpos, sugere a ausência da exposição à leptospira nesse período e não produção de anticorpos.

Os resultados sugerem que o risco de exposição das onças-pintadas à leptospirose variou em função da área de estudo, sendo alto no Pantanal e PNE, e baixo no PEC. Os bovinos foram mais expostos à Leptospira spp. do que as outras espécies examinadas por serem considerados hospedeiros de manutenção do sorovar Hardjo.

Assim, como os sorovares mais prováveis encontrados para as onças-pintadas foram distintos dos detectados para os bovinos, cães e gatos, tudo indica que a epidemiologia da leptospirose nas onças não envolve esses animais domésticos como reservatórios. Porém, principalmente na região do Pantanal, a presença da Leptospira spp. deveria ser pesquisada em suínos domésticos.

\subsection{Toxoplasma gondii}

Todas as onças-pintadas das três áreas preservadas foram expostas ao Toxoplasma gondii (Tabelas 8 a 10). Entre os animais domésticos, gatos e cães apresentaram exposição importante ao agente e apenas cinco de 1224 bovinos examinados foram classificados positivos (Tabela 20).

A exposição dos poucos bovinos ao T. gondii nas três áreas de estudo parece inferior às descritas para o território brasileiro por diversos autores (COSTA et al., 2001; DAGUER et al., 2004; OGAWA et al., 2005; SANTOS et al., 2009b; SPAGNOL et al., 2009; SANTOS et al., 2010). Entre os trabalhos realizados com bovinos em regiões próximas às áreas do presente estudo, 
destacam-se os relatos de 4,29\% (ARAÚJO; CARVALHO; BALBUENA, 1998) e 3,09\% (MARQUES et al., 2009) para o estado do Mato Grosso do Sul. As taxas de prevalência do Toxoplasma gondii são discrepantes e variam de acordo com a região (MILLAR et al., 2008).

Os baixos títulos de anticorpos encontrados nos bovinos no atual estudo (Tabela 20), assim como relatado por Garrido et al. (1972), possivelmente indicam uma infecção latente. Títulos semelhantes foram relatados por Costa e Costa (1978), Marana et al. (1994), Albuquerque et al. (2005), Ogawa et al. (2005), Marques et al. (2009) e Spagnol et al. (2009). Segundo Dubey (2007), não existem relatos confirmados de toxoplasmose clínica em bovinos. Os bovinos das três áreas, provavelmente, infectaram-se através da ingestão de oocistos presentes no ambiente.

A porcentagem de cães soropositivos encontrada nas propriedades rurais do Pantanal $(40,7 \%)$ foi semelhante à relatada por Marques et al. (2009) em cães de área rural no Mato Grosso do Sul (47,61\%). Em Goiás, onde se localiza o PNE, Fernandes e Barbosa (1972) observaram uma frequência de $57,1 \%$ de cães soropositivos, e no presente estudo a frequência de cães soropositivos no entorno do PNE foi de $29,1 \%$. No Brasil, as frequências de cães soropositivos para T. gondii variam de 3,1\% no Rio Grande do Sul (CHAPLIN et al., 1984) a 91\% em São Paulo (GERMANO; ERBOLATO; ISHIZUKA, 1985).

Os títulos de anticorpos encontrados para os cães, na sua maioria baixos (Tabela 20), estão de acordo com os valores relatados por Azevedo et al. (2005) e Silva et al. (2002), e são sugestivos de uma infecção latente (FIORELLO et al., 2004). Um dos cães soropositivos do Pantanal apresentou títulos de anticorpos compatíveis de infecção ativa ou recente (2048), porém o animal encontrava-se em boas condições no momento da coleta (Tabela 40). Quando presentes, os sinais clínicos da toxoplasmose podem envolver os sistemas neuromuscular, respiratório e gastrointestinal (BRITO et al., 2002).

Os hábitos alimentares e comportamentais dos cães nas três áreas favoreceram a infecção ao $T$. gondii: em sua maioria eram criados soltos, alimentados com resto de comida humana e carne crua e, alguns tinham o hábito de comer carniça e caçar (Tabela 40). Dessa forma, os cães provavelmente infectaram-se principalmente através da ingestão de cistos teciduais presentes nas carcaças. Não é possível, porém, descartar a infecção pela ingestão de comida ou água contaminada com oocistos, visto que frequentemente os cães eram criados nos mesmos ambientes que os gatos domésticos. A provável menor frequência de cães soropositivos no PNE pode estar relacionada às diferenças dos hábitos alimentares e comportamentais em comparação aos cães do PEC e Pantanal. No PNE, os cães alimentavam-se menos de carne crua, 
de carniça e de caça (Tabela 40). Os cães podem atuar como hospedeiros intermediários e mecânicos do $T$. gondii, mas sozinhos, não são capazes de manter o agente na natureza (LINDSAY, BLAGBURN; DUBEY, 1997).

A alta porcentagem de gatos domésticos soropositivos para o Toxoplasma gondii indica, como esperado, que a espécie provavelmente contribui para manter o agente circulante nas três áreas de estudo. Os felinos, tanto domésticos quanto silvestres, são os únicos hospedeiros definitivos do T. gondii capazes de eliminar oocistos pelas fezes (FRENKEL; DUBEY; MILLER, 1970; MILLER; FRENKEL; DUBEY, 1972; DUBEY; BEATIE, 1988). A frequência de gatos soropositivos no Pantanal $(90,0 \%)$ foi aparentemente superior a 57,14\% relatada por Marques et al. (2009) em ambiente rural do Mato Grosso do Sul. Altas frequências de soropositividade em gatos domésticos já foram relatadas no Brasil por Ferraroni e Marzochi (1978), Carletti et al. (2002), Dubey (2004) e Cavalcante et al. (2006).

Os títulos de anticorpos identificados para os gatos domésticos (Tabela 20) foram semelhantes aos relatados por Marques et al. (2009) no Mato Grosso do Sul, Cavalcante et al. (2006) em Rondônia, e Pena et al. (2006) e Bresciani et al. (2007) em São Paulo. Sendo que, títulos iguais ou acima de 750 para gatos são condizentes com infecção ativa ou recente (FIORELLO et al., 2004). Os animais que apresentaram títulos elevados no presente estudo não exibiram sinais clínicos aparentes no momento da coleta (Tabela 41), corroborando a afirmação de Fialho, Teixeira e Araújo (2009), de que gatos domésticos raramente manifestam a doença clínica.

Assim como os cães domésticos, os hábitos alimentares e comportamentais dos gatos das três áreas favoreceram a alta frequência de exposição ao T. gondii: a maioria dos gatos era alimentada com restos de comida humana, comia carne crua, vivia solta, tinha o hábito de caçar e, nas propriedades rurais do Pantanal e do entorno do Parque Nacional das Emas comia carniça (Tabela 41). Esses gatos provavelmente infectaram-se através da ingestão de cistos teciduais. Embora possam infectar-se também através da ingestão de oocistos esporulados no ambiente, ou pela via transplacentária, essas não são as vias mais eficientes para os felinos (DUBEY; FRENKEL, 1976; DUBEY, 1996; URQUHART et al., 1998; FIALHO; TEIXEIRA; ARAÚJO, 2009). Para que ocorra a infecção através da ingestão de oocistos esporulados presentes no ambiente, em gatos, é necessária a ingestão de aproximadamente 1000 oocistos ou mais, mesmo assim, apenas alguns gatos serão capazes de eliminá-los nas fezes (DUBEY, 1996; DUBEY, 2006). Por outro lado, se ingerirem cistos teciduais, 3 a 10 dias depois eliminarão milhões de oocistos por um período de 1 a 2 semanas, contaminando o ambiente (FRENKEL; DUBEY; MILLER, 1970; 
DUBEY, 2004). A alta soropositividade dos gatos deste estudo indicou que provavelmente já eliminaram os oocistos nas fezes, uma vez que a produção de anticorpos para $T$. gondii ocorre após o pico de eliminação (DUBEY 1986; DUBEY, 1987; FIALHO; TEIXEIRA; ARAÚJO, 2009). Porém, como o hábito de caçar favorece a reexposição ao agente, é possível que voltem a eliminar oocistos (DUBEY, 1987; PENA et al. 2006).

A soropositividade para $T$. gondii em todas as onças-pintadas e em todos os eventos de captura (Tabelas 8 a 10) sugere que a espécie seja um hospedeiro definitivo do agente no meio silvestre nas três áreas de estudo - corcondando com Demar et al. (2008), que fez a mesma afirmação ao isolar T. gondii de uma onça-pintada de vida livre na Guiana Francesa. Embora a exposição ao T. gondii já tenha sido relatada em onças-pintadas mantidas em cativeiro nos Estados Unidos (SPENCER; HIGGINBOTHAM; BLAGBURN, 2003; DE CAMPS; DUBEY; SAVILLE, 2008) e no Brasil (SILVA et al., 2001a; RIVETTI JÚNIOR et al., 2008; PIMENTEL et al., 2009), e que oocistos similares à $T$. gondii tenham sido isolados de fezes de onças-pintadas de vida livre em Belize (PATTON et al,. 1986), este é o primeiro relato da exposição em onças-pintadas de vida livre no Brasil.

No mapa de ocorrência do T. gondii no Parque Nacional das Emas (Figura 45) não foi observada relação entre as movimentações das onças soropositivas e as propriedades foco de toxoplasmose. Como o PNE é uma área protegida, onde a circulação de animais domésticos é proibida, esta ausência de relação é mais visível. No Pantanal, entretanto, como as áreas amostradas são propriedades rurais, as onças-pintadas movimentaram-se no interior das propriedades foco da infecção (Figura 46), e uma vez que a grande maioria das propriedades apresentou ao menos um indivíduo soropositivo para toxoplasmose, não foi possível a mesma observação. Para a região do Parque Estadual do Cantão podemos apenas sugerir que as onças foram capturadas em locais próximos às propriedades foco do agente (Figura 47).

Embora não seja possível afirmar o modo de infecção das onças-pintadas, acredita-se que tenham se infectado principalmente através da ingestão de cistos teciduais presentes em hospedeiros intermediários. T. gondii é biologicamente adaptado a felinos, e mais eficientemente transmitido nesta família pelo carnivorismo do que pela contaminação fecal (SILVA et al., 2001b). Da mesma forma que em gatos, as onças-pintadas soropositivas para $T$. gondii, em algum momento de suas vidas eliminaram oocistos no ambiente, e podem ser constantemente reexpostas ao agente. Entretanto, acredita-se que o número de oocistos liberados por um felino silvestre seja inferior ao liberado por gatos domésticos (DUBEY, 1986). Os cães e gatos infectados poderiam ser a fonte de infecção para as onças-pintadas, mas esses 
animais domésticos não foram encontrados como itens alimentares das onças nas três áreas de estudo (NUNO, 2007; PORFÍRIO, 2009; IOP, dados não publicados). Embora, os bovinos façam parte da dieta das onças-pintadas nas três áreas (NUNO, 2007; PORFÍRIO, 2009; IOP, dados não publicados), a baixa exposição da espécie ao $T$. gondii, sugere que esses não sejam a fonte de infecção do agente. No PNE, queixadas e antas, duas das principais presas alimentares da onçapintada (SILVEIRA, 2004) já foram diagnosticadas soropositivas para T. gondii (SOUZA et al., 2006; FURTADO et al., 2010), podendo vir a ser a fonte de infecção para as onças. Esses dados fortalecem a hipótese de que a infecção é endêmica da população de onças-pintadas, e que, a espécie é capaz de manter um ciclo silvestre do agente. Ciclos silvestres no Brasil já foram relatados para outras espécies como gambás, capivaras e canídeos silvestres (CANON-FRANCO et al., 2003; YAl et al., 2003; GENNARI et al., 2004).

A maioria dos títulos de anticorpos encontrada para as onças-pintadas (Tabelas 8 a 10) foi inferior a titulação de 4.000 relatada para a onça-pintada de vida livre da Guiana Francesa (DEMAR et al., 2008). Comparando os resultados do presente estudo com as titulações relatadas para onças-pintadas mantidas em cativeiro, os animais de vida livre deste estudo apresentaram títulos superiores aos relatados por Silva et al. (2001a), Spencer, Higginbotham e Blagburn (2003), De Camps, Dubey e Saville (2008) e Pimentel et al. (2009), que relataram a maioria dos títulos $\leq$ 100. A diferença provavelmente está relacionada aos hábitos alimentares e comportamentais distintos entre os animais de cativeiro e vida livre.

As onças que foram recapturadas continuaram apresentando anticorpos contra $T$. gondii, mesmo com curto ou longo intervalo entre os eventos de captura, evidenciando a persistência do agente no ambiente e, possivelmente, repetidos estímulos a que foram expostas. $\mathrm{O}$ aumento dos títulos de anticorpos nas recapturas de três onças-pintadas sugere que foram reexpostas ao T. gondii nesse intervalo. O título de 3200 na captura de uma onça-pintada jovem no Pantanal sugere uma infecção recente com consequente queda na titulação em sua recaptura (Tabela 10).

Embora pouco se conheça sobre o papel desse patógeno na mortalidade e morbidade dos felinos silvestres (SILVA et al., 2001a), nenhuma onça-pintada amostrada neste estudo apresentou sinais clínicos da toxoplasmose. O bom estado geral dos animais no momento da captura e o monitoramento dos indivíduos pela radiotelemetria confirmaram essa afirmação.

Não houve diferenças estatísticas significativas na exposição ao T. gondii nas três áreas de estudo, indicando que o patógeno encontra-se ampla e igualmente disseminado nessas regiões. A maior exposição de cães e gatos ao agente do que bovinos, sugere que a difusão da 
infecção pela ingestão de oocistos esporulados é menos eficiente do que a ingestão de cistos teciduais.

Os resultados encontrados sugerem a existência de um ciclo silvestre da toxoplasmose, onde as onças-pintadas têm um papel destacado na eliminação de oocistos para o ambiente, permitindo a infecção e formação de cistos teciduais nas suas presas. Provavelmente esse ciclo mantém-se independente do ciclo doméstico.

\subsection{VÍRUS DA RAIVA}

A presença de títulos de anticorpos contra o vírus da raiva $\geq 0,10 \mathrm{UI} / \mathrm{ml}$ nas onçaspintadas sugere a exposição da espécie ao agente no Parque Nacional das Emas e Pantanal (Tabelas 8 e 10).

Nos cães domésticos, como não é possível distinguir os anticorpos vacinais dos adquiridos naturalmente (RODRIGUEZ et al., 2007), a presença de anticorpos contra o vírus da raiva detectada nas três áreas de estudo (Tabela 22 ) foi atribuída à vacinação desses cães nas campanhas anuais do Programa Nacional do Controle da Raiva, como relatado pela maioria dos proprietários (Tabela 40). Entretanto, as baixas frequências de cães soropositivos (8 a 31,8\%) encontradas não condizem com as informações obtidas nos questionários epidemiológicos de que a grande maioria dos cães era vacinada. Assim, a ausência de anticorpos na maioria desses animais possivelmente ocorreu devido à falha na revacinação anual dos cães, resposta imune inadequada, baixa qualidade da vacina aplicada (BRONSON et al., 2008), ou mesmo, equívoco nas respostas por parte dos proprietários.

Os gatos das propriedades rurais do Pantanal e do Parque Estadual do Cantão que apresentaram altos títulos de anticorpos contra o vírus (Tabela 22), de acordo com seus proprietários, foram vacinados (Tabela 41). Provavelmente, seguindo corretamente o protocolo de revacinação anual.

Para as onças-pintadas, optou-se por utilizar como ponto de corte título $\geq 0,10 \mathrm{UI} / \mathrm{ml}$, pois esses animais nunca entraram em contato com a vacina antirrábica e, portanto, a presença de baixos títulos de anticorpos, provavelmente se refere à exposição natural ao vírus, corroborando as observações de Rosatte e Gunson (1984), Hill, Beran e Clark (1992) e Jorge et al. (2010). Por outro lado, Deem, Davis e Pacheco (2004) relataram que inibições inespecíficas nos 
testes sorológicos para a raiva podem ocorrer em baixas titulações, mas dificilmente ocorrem em títulos maiores do que $0,25 \mathrm{Ul} / \mathrm{ml}$, dificultando a interpretação dos resultados do presente estudo. Das seis onças-pintadas consideradas soropositivas para raiva, cinco apresentaram títulos entre 0,10 e $0,24 \mathrm{UI} / \mathrm{ml}$ (Tabelas 8 e 10), que poderiam ser interpretados como falsos positivos. O outro indivíduo apresentou título igual a $0,5 \mathrm{UI} / \mathrm{ml}$, que seria considerado positivo mesmo se fosse utilizado o mesmo ponto de corte dos animais domésticos, sugerindo a real exposição ao agente. Dado que as onças-pintadas soropositivas do atual estudo não apresentaram sinais clínicos de raiva no momento de captura e, que esses animais movimentaram-se normalmente por períodos de 6 a 39 meses (Tabelas 2 e 4; Figuras 48 e 49), é possível afirmar que nenhum deles apresentou infecção letal da doença. Segundo Acha e Szyfres (1986), a presença de anticorpos em animais selvagens sugere que nem sempre a infecção pelo vírus da raiva resulta em morte.

Estes resultados estão de acordo com os relatos em onças-pintadas de vida livre no Pantanal do Mato Grosso do Sul com títulos de 0,12 UI/ml (WIDMER, 2009) e em outros carnívoros silvestres de vida livre: um gato-do-mato-pequeno na Bolívia (DEEM; DAVIS; PACHECO, 2004), guepardos na Namíbia (THALWITZER et al., 2010), hienas no Serengeti (EAST et al., 2001) e carnívoros neotropicais no Brasil (JORGE et al., 2010). Em onças-pintadas, há também relatos de diagnósticos positivos para raiva por Santos e Tokarnia (1969 apud JAYAKUMAR et al., 1989, p. 1076) e, por Piccinini e Freitas (1985).

Para explicar os resultados do presente estudo, foram levantadas as seguintes hipóteses: 1) as onças-pintadas foram expostas a uma cepa menos virulenta e patogênica ou atenuada do vírus da raiva; 2) as onças-pintadas são mais resistentes ao vírus rábico; ou, 3) a ocorrência de reações inespecíficas no teste utilizado. Embora, os resultados obtidos não permitam inferir sobre a fonte de infecção e modo de transmissão do vírus da raiva para as onças-pintadas, sabese que a transmissão do vírus ocorre principalmente através da mordedura de animais infectados (ACHA; SZYFRES, 1986; RUPPRECHT, 1999), e que é possível a transmissão através da ingestão de carcaças infectadas (RAMSDEN; JOHNSTON, 1975). Esses dois mecanismos poderiam estar envolvidos na exposição dessas onças ao vírus. Porém, considerando que a espécie é um predador topo de cadeia alimentar, a hipótese de transmissão da raiva pela predação de animais infectados parece a mais provável. O vírus poderia estar presente em animais domésticos, visto que ruminantes da América do Sul são vítimas de morcegos hematófagos (BRANDÃO, 2009) e que, no Brasil, os casos de raiva notificados em herbívoros na região Centro-Oeste aumentaram entre 1997 e 2006 (RODRIGUEZ et al., 2007). Ou mesmo, o vírus poderia estar presente em 
ambiente silvestre, uma vez que Carnieli Júnior et al. (2009) identificaram linhagens diferentes do vírus da raiva em cachorros-do-mato e cães domésticos no nordeste brasileiro, sugerindo a existência de um ciclo silvestre, independente do cão doméstico (CARNIELI JÚNIOR et al., 2006; CARNIELI JÚNIOR et al., 2008; CARNIELI JÚNIOR et al., 2009). A transmissão oral do vírus embora raramente resulte em raiva, leva à resposta humoral específica de longa duração, que consequentemente aumenta os níveis de imunidade entre os carnívoros (CHARLTON; CASEY, 1979; ZHANG et al., 2008), o que, provavelmente, pode ter ocorrido nas onças-pintadas do presente estudo.

No mapa de ocorrência do vírus da raiva do Parque Nacional das Emas (Figura 48), a onça-pintada soropositiva utilizou como parte de sua área de vida, áreas no interior do parque e em propriedades rurais, em contato com espécies de animais silvestres e domésticos. No PNE, outros carnívoros silvestres já foram relatados soropositivos para o vírus da raiva, com títulos entre 0,10 e 0,27 UI/ml, também, sem manifestações de sinais clínicos da doença (JORGE et al., 2010). A movimentação das onças-pintadas no Pantanal, em áreas de pastagens (Figura 49), sugere a hipótese da presença do vírus em animais domésticos. Porém, a fonte de infecção para o agente permanece desconhecida.

Os títulos de anticorpos das onças recapturadas indicaram que os animais provavelmente entraram em contato com o vírus no intervalo entre as coletas de material biológico, produziram uma resposta primária rápida e curta e, não sendo novamente expostos ao vírus, não desenvolveram uma resposta secundária. O indivíduo com título de 0,5 UI/ml em sua recaptura, provavelmente sofreu nova exposição ao vírus após sua captura apresentando título crescente de anticorpos (Tabela 10).

Ao comparar os diagnósticos encontrados e as áreas de estudo, os indivíduos examinados da região do PNE foram mais expostos ao vírus da raiva do que os da região do PEC, porém, esses resultados levaram em consideração o número de cães domésticos que apresentaram anticorpos vacinais. Essa diferença, provavelmente, está relacionada com a localização das propriedades do entorno do PNE, em uma região mais desenvolvida e com mais acesso às campanhas de vacinação do que o entorno do Parque Estadual do Cantão.

Os dados apresentados são relevantes, principalmente considerando o impacto do vírus da raiva no declínio populacional de canídeos silvestres na África (GASCOYNE et al., 1993; SILLERO-ZUBIRI; KING; MACDONALD, 1996). Entretanto, os baixos títulos encontrados e apenas uma onça com titulo igual a 0,50 sugerem que embora expostas ao vírus, as onças não desempenham importante papel no ciclo natural do agente. Não existindo evidências para 
colocá-los como reservatórios da doença, concordando com Acha e Szyfres (1986), Jayakumar et al. (1989) e Rupprecht (1999).

Assim, excluindo a possibilidade de falso positivo, a forma de exposição natural mais plausível para as onças-pintadas, parece ser o contato com vírus atenuado presente em carcaças de animais silvestres ou domésticos que vieram a óbito em decorrência da raiva.

\subsection{VÍRUS DA CINOMOSE}

Os cães domésticos das três áreas de estudo e as onças-pintadas capturadas no Pantanal foram expostos ao vírus da cinomose (Tabela 24).

A grande maioria das propriedades rurais do Pantanal $(85,7 \%)$ e do entorno do Parque Estadual do Cantão $(81,3 \%)$ apresentou ao menos um cão doméstico soropositivo para o vírus da cinomose, evidenciando a ampla distribuição do vírus nessas regiões. Considerando os cães soropositivos, as três áreas de estudo apresentaram frequências aparentemente superiores a 27,3\% descrita por Dezengrini, Weiblen e Flores (2007) em estudo realizado com cães sem histórico de vacinação para cinomose no Rio Grande Sul. As propriedades do Pantanal apresentaram frequência similar a 54,5\% relatada por Del Puerto et al. (2010) em Minas Gerais e 58,3\% por Hass et al. (2008) no Rio Grande do Sul. A presença de anticorpos circulantes nos cães amostrados do presente estudo indica imunidade ao vírus da cinomose, que pode ter sido adquirida pela exposição natural ao agente ou através da vacinação. As três áreas de estudo apresentaram baixas porcentagens de cães vacinados segundo relatos dos proprietários (Tabela 40) e, mesmo apresentando a maior ocorrência de cães vacinados, o entorno do PNE apresentou menor frequência de animais soropositivos para o vírus. Esse resultado parece incoerente, sugerindo possível falha na vacinação desses animais, devido a um esquema de vacinação inadequado, vacinas comerciais de baixa qualidade, ou mesmo, equívoco nas respostas obtidas no questionário epidemiológico. Os resultados mostraram também que, embora as vacinas contra a cinomose estejam disponíveis para cães desde 1950 (GREENE, 1990), poucos cachorros nas áreas rurais foram vacinados, concordando com Megid et al. (2009). De acordo com esse histórico, a maioria dos resultados positivos em cães deste estudo foi atribuída à exposição natural ao agente. 
A cinomose é endêmica no Brasil (HEADLEY; GRAÇA, 2000; MEGID et al., 2009) e a maioria dos cães desenvolve uma resposta imune eficaz e não manifesta sinais clínicos da infecção (ARNS; SPILKI; ALMEIDA, 2007). Os cães deste estudo que apresentaram altos títulos de anticorpos poderiam sugerir uma infecção ativa, entretanto, a maioria encontrava-se em boas condições físicas durante a coleta do material e poucos problemas de saúde nos animais foram relatados pelos proprietários (Tabela 40). Cães sem histórico de vacinação ou infecção podem apresentar altos títulos de anticorpos, desenvolver infecções inaparentes e tornar-se portadores sãos do agente (ARNS; SPILKI; ALMEIDA, 2007). Os resultados aqui apresentados confirmam a exposição dos cães ao agente, mas não permitem afirmar se os animais desenvolveram ou não a doença. Cães que produzem anticorpos possuem menor chance de se infectar e cães que não produzem, ou produzem poucos anticorpos são mais vulneráveis ao desenvolvimento da infecção (WINTERS et al., 1984; CHALMERS; BAXENDALE, 1994; DEEM et al., 2000).

Os gatos domésticos examinados no presente estudo não foram analisados para o vírus da cinomose. Devido à quantidade de soro insuficiente para todas as análises, priorizou-se a pesquisa de patógenos mais relevantes para a espécie. Gatos domésticos são suscetíveis ao vírus, mas não manifestam sinais clínicos e não são capazes de eliminar e transmitir o vírus (APPEL et al., 1974; IKEDA et al., 2001).

A alta soropositividade das onças-pintadas do Pantanal para a cinomose $(54,5 \%)$ foi também encontrada por Nava et al. (2008) em onças-pintadas de vida livre na Mata Atlântica (60\%). A exposição ao vírus da cinomose já foi relatada também para duas onças-pintadas mantidas em cativeiro, e como causa morte de uma onça-pintada durante um surto que acometeu as espécies do gênero Panthera entre 1992-1993 em zoológicos dos Estados Unidos (APPEL et al., 1994).

A maioria dos títulos encontrados para as onças-pintadas no presente estudo (Tabela 10) foi inferior aos relatados para as onças-pintadas de vida livre na Mata Atlântica (32-82; NAVA et al., 2008) e para as duas onças-pintadas do zoológico dos Estados Unidos (100 e 200, APPEL et al., 1994). Possivelmente os baixos títulos encontrados estejam relacionados com a baixa exposição ao vírus. Esses títulos foram semelhantes aos relatados para diferentes espécies de carnívoros silvestres do Pantanal mato-grossense (JORGE, 2008).

O baixo número de cães vacinados para cinomose nas propriedades das três áreas de estudo representa uma possível ameaça para as populações de onça-pintada. Entretanto, apenas as onças do Pantanal apresentaram soropositividade para o vírus. A região do Pantanal é a única, entre as três áreas amostradas, composta apenas por propriedades rurais, onde cães 
domésticos podem circular livremente no seu interior, acompanhando os funcionários no trabalho de campo. O PNE e o PEC são Unidades de Conservação, onde a entrada de cães domésticos no seu interior não é permitida (Figura 50 e 52). Embora cães domésticos já tenham sido avistados utilizando as áreas do PNE próximas às propriedades rurais, não utilizam o interior do parque. Assim, locais em que onças-pintadas e cães domésticos utilizam os mesmos hábitats com mais frequência podem favorecer a disseminação do agente. Esses resultados estão de acordo com Nava et al. (2008), que amostraram duas regiões distintas, encontrando onças soropositivas apenas no local onde os animais domésticos tinham acesso ao parque. $O$ vírus da cinomose é transmitido principalmente por aerossóis de secreções respiratórias dos animais infectados, embora possa também ser excretado por todos os fluídos corporais (APPEL; SUMMERS, 1995; KENNEDY-STOSKOPF, 1999; DEEM et al., 2000; ARNS; SPILKI; ALMEIDA, 2007). Normalmente, as onças-pintadas evitam contatos próximos com cães domésticos, o que dificultaria a transmissão do vírus pelo contato direto, porém, indiretamente essa transmissão poderia ocorrer. No entanto, o vírus sobrevive poucas horas no ambiente ( 1 a 3 horas a $37^{\circ} \mathrm{C}$; APPEL, 1987). Há também a hipótese de outros animais silvestres agirem como hospedeiros de transição, como, provavelmente, ocorreu com os leões no Serengeti (ROELKE-PARKER et al., 1996; CLEAVELAND et al., 2000). Outras espécies silvestres mais habituadas ao contato com os cães poderiam servir como disseminadoras da doença no meio silvestre, infectando assim, as onças-pintadas. O estudo realizado por Megid et al. (2009) corrobora essa hipótese, uma vez que encontrou o vírus da cinomose filogeneticamente semelhante ao vírus do cão doméstico em um cachorro-do-mato de área suburbana no Brasil. Podería-se aventar também que o patógeno estivesse sendo mantido e transmitido no meio silvestre sem a interferência dos cães domésticos. Lembrando que no surto de cinomose que ocorreu nos zoológicos dos Estados Unidos, a infecção, provavelmente, foi originada de carnívoros silvestres dos arredores dos parques (APPEL et al., 1994). A exposição de carnívoros silvestres ao vírus da cinomose foi relatada no Pantanal do Mato Grosso (JORGE, 2008), mas não se conhece a origem do patógeno. Para fortalecer esta hipótese, observando o mapa de ocorrência da cinomose no Pantanal (Figura 51), percebe-se a movimentação das onças-pintadas soropositivas em propriedades que não eram foco da cinomose, sugerindo que o vírus poderia estar presente nos animais silvestres. Esse mapa mostra também que indivíduos soropositivos e soronegativos convivem no mesmo ambiente, ou seja, mesmo com a alta densidade da onça-pintada na região (SOISALO; CAVALCANTI, 2006), o hábito solitário da espécie (SEYMOUR, 1989) contribui para a baixa transmissão viral intraespecífica. 
Ao analisar-se as onças-pintadas com mais de um evento de captura (Tabela 10), foi possível observar que mais da metade dos animais apresentaram sorodiagnósticos semelhantes nas diferentes coletas. Uma das onças soroconverteu na recaptura, indicando que possivelmente entrou em contato com o vírus no intervalo entre as capturas. Em três casos acredita-se que, após a exposição ao vírus e produção detectável de anticorpos, os animais não sofreram novas exposições, e foram negativos ao teste.

O fato da maioria das onças-pintadas soropositivas ter sido monitorada por um período de 4 a 39 meses (Tabela 4) sem apresentar alteração de movimentação, indica que esses animais provavelmente não foram acometidos fatalmente pelo patógeno. Lembrando que a cinomose é conhecida por causar significativos declínios populacionais em diferentes espécies de carnívoros silvestres (THORNE; WILLIAMS, 1988; ALEXANDER; APPEL, 1994; ROELKE-PARKER et al., 1996). Munson et al. (2008) demonstraram que a coinfecção da cinomose com a Babesia spp. contribuiu para a epidemia fatal na população de leões no Serengeti.

Interpretando os modelos estatísticos, os indivíduos da região do Pantanal foram mais expostos ao vírus da cinomose do que os da região do PNE, fato que provavelmente está relacionado ao tipo de ocupação das áreas de estudo, como comentado anteriormente. E, entre as espécies, a ausência de diferença significativa para a exposição ao vírus, pode estar relacionada ao pequeno tamanho amostral das onças-pintadas capturadas, não sendo possível, com os dados apresentado, sustentar essa afirmação. A presença de mais fêmeas de onçaspintadas expostas ao vírus da cinomose do que machos não era esperada, uma vez que não há relatos da associação entre sexo e ocorrência da cinomose em cães domésticos (MCCAW et al., 1998; TWARK; DODDS, 2000). No entanto, essa informação deve ser interpretada com ressalvas, uma vez que o vírus da cinomose esteve presente apenas nas onças-pintadas do Pantanal. Para confirmar essa diferença, mais estudos devem ser realizados.

Haja vista a existência de duas hipóteses para a exposição das onças ao vírus da cinomose: contato com cães domésticos ou com animais silvestres, a comparação das cepas de vírus circulantes nessas populações deveria ser alvo de futuras investigações, envolvendo técnicas de isolamento e caracterização molecular dos isolados. Tratando-se das onças, como o vírus nem sempre está presente na corrente sanguínea, o momento de captura do animal deveria coincidir com a fase aguda da infecção e eliminação do vírus pelos exsudatos (DEEM et al., 2000). Nesta fase, deveriam ser coletados suabes oculares, nasais, saliva, urina e sangue total (STANTON et al., 2003; ARNS; SPILKI; ALMEIDA, 2007; KAPIL et al., 2008). Como o isolamento do 
vírus é difícil de ser realizado em cultura celular (DEEM et al., 2000), a tentativa de isolamento poderia ser feita a partir das papas de leucócitos (APPEL; SUMMERS, 1995).

Assim, tendo em vista o impacto já comprovado da cinomose em populações de várias espécies de carnívoros silvestres, a exposição de onças-pintadas do Pantanal ao vírus da cinomose é relevante e justifica investigações ulteriores, voltadas principalmente à caracterização das fontes de infecção.

\subsection{FIV}

Não houve evidências sorológicas de que as populações de onça-pintada e gato doméstico das três áreas de estudo tivessem sido expostas ao vírus da imunodeficiência felina (Tabela 26).

Em gatos domésticos, o FIV é transmitido pelo contato direto, pela mordida através da saliva (RAVAZZOLO; COSTA, 2007; HOSIE et al., 2009). Acredita-se que o modo de transmissão em felinos silvestres seja similar (TROYER et al., 2008), de forma que o hábito solitário da onçapintada não favorece a transmissão desse agente: interagem com outros indivíduos da espécie apenas no período reprodutivo e com as mães até completarem aproximadamente 1 ano e 1/2 de idade (SEYMOUR, 1989) e, evitam o contato com outras espécies.

No Brasil, estudos realizados com gatos domésticos nos estados de São Paulo, Rio de Janeiro e Minas Gerais relataram frequências do FIV entre 2,7\% e 75,8\% (MENDES-DE-ALMEIDA et al., 2004; CAXITO et al., 2006; LARA; TANIWAKI; ARAÚJO, 2007; MENDES-DE-ALMEIDA et al., 2007; LARA; TANIWAKI; ARAÚJO, 2008; MACIEIRA et al., 2008). Não foram encontrados relatos da ocorrência do agente para as regiões Norte ou Centro-Oeste.

Os diagnósticos negativos do FIV em populações com baixa frequência do patógeno, como neste estudo, geralmente são acurados (HOSIE et al., 2009). Entretanto, poderiam representar falsos negativos em decorrência de: 1) infecção recente, ainda sem produção de anticorpos; 2) animais amostrados em estágios terminais da doença que, devido à imunossupressão, não produziriam anticorpos em níveis detectáveis; 3) presença de altas concentrações do vírus no sangue, que sequestrariam os anticorpos anti-FIV na forma de complexos imunes; 4) presença de cepas de anticorpos específicos para felinos não domésticos 
que não reagiriam com os antígenos do teste utilizado (BARR, 1996; FILONI et al., 2003; HOSIE et al., 2009).

Os felinos amostrados, em quase sua totalidade $(96,8 \%$ das onças-pintadas e $93,3 \%$ dos gatos), encontravam-se em boas condições de saúde e certamente não estavam em fases terminais da doença. Assim, seriam descartados os resultados falsos negativos dos itens 2 e 3 apresentados acima. A presença de anticorpos contra o FIV pode ser evidenciada por testes sorológicos de 2 a 4 semanas após a infecção (RAVAZZOLO; COSTA, 2007), resultando no falso negativo do item 1. Espécies-específicas de FIV já foram isoladas para outros felinos do gênero Panthera (leão e leopardo), mas não para onças-pintadas, sendo que diferentes características do vírus poderiam levar ao falso negativo do item 4. Mesmo com suas limitações, os testes sorológicos ainda são os mais recomendados para o diagnóstico do FIV, uma vez que a técnica da PCR vem apresentando resultados discrepantes, sensibilidade e especificidade em torno de 40100\% (BIENZLE et al., 2004) e falhas na detecção das variações genômicas do vírus (RAVAZZOLO; COSTA, 2007; FILONI et al., 2008; HOSIE et al., 2009).

Os resultados do presente estudo corroboram os de Nava (2008), em estudo realizado na Mata Atlântica com 17 gatos domésticos e 8 onças-pintadas de vida livre, sendo todos negativos para o FIV e o de Olmsted et al. (1992) em estudo realizado com onças-pintadas mantidas em cativeiro, também negativas para o agente. Há relatos de exposição ao FIV em onças-pintadas de cativeiro (BARR et al., 1989; BROWN, MITHTHAPALA; OBRIEN, 1993) e detecção do agente em cinco de oito onças-pintadas examinadas no Brasil (LEAL; RAVAZZOLO, 1998). Em felinos de vida livre, há relato de onças-pardas expostas ao FIV no Pantanal (FILONI et al., 2006), confirmando a presença do agente nesse bioma.

Embora não seja possível descartar a presença do vírus nas populações estudadas devido ao baixo número de animais amostrados, os resultados sugerem que o vírus da imunodeficiência felina não representa uma ameaça para as populações de onça-pintada das três áreas de estudo.

\section{$6.8 \quad$ FELV}

Embora tenha sido identificada a presença do antígeno viral da leucemia felina em dois gatos domésticos do entorno do Parque Estadual do Cantão (Figura 53), não houve evidências 
sorológicas de que o vírus estivesse presente nas populações de onça-pintada das três áreas preservadas (Tabela 26$)$.

O diagnóstico sorológico, mesmo sendo o mais indicado para a detecção do FeLV (KENNEDY-STOSKOPF, 1999; ARJONA et al., 2007; RAVAZZOLO; COSTA, 2007), pode originar resultados falsos positivos e falsos negativos. A infecção aguda do FeLV pode evoluir para a recuperação clínica, infecção latente, ou viremia persistente e manifestação da doença no hospedeiro (ROJKO; KOCIBA, 1991; BARR, 1996; TORRES; MATHIASON; HOOVER, 2005; RAVAZZOLO; COSTA, 2007). O teste Elisa do kit comercial Snap ${ }^{T M}$ Combo (IDEXX laboratories), utilizado neste estudo, detecta a proteína solúvel p27 do FeLV na circulação periférica do hospedeiro, indicando uma infecção ativa e potencial transmissão viral (KENNEDY-STOSKOPF et al., 1999). Acredita-se que o vírus do FeLV em felinos silvestres e domésticos seja o mesmo, permitindo a utilização desse ELISA para ambos os grupos de animais (HOFMANN-LEHMANN et al., 1996). Assim, os resultados negativos obtidos neste estudo poderiam corretamente indicar a ausência dos antígenos p27 nos hospedeiros ou poderiam ser falsos negativos, com o animal na fase aguda da infecção e os antígenos presentes em níveis não detectáveis pelo teste, ou ainda, os felinos poderiam estar na fase regressiva da infecção, caracterizada pela presença do DNA pró-viral, ausência da eliminação do vírus e não detecção do antígeno (FILONI et al., 2003; LEVY et al., 2008).

Os gatos domésticos positivos encontravam-se em bom estado geral no momento da coleta do material e sem relatos de problemas de saúde pelos proprietários (Tabela 41). Esses animais poderiam estar na fase de viremia transitória do FeLV - em que são capazes de produzir uma resposta imune eficiente e eliminar a infecção (BARR, 1996; ROJKO; KOCIBA, 1991). No Brasil, a ocorrência do FeLV já foi confirmada em gatos nos estados do Rio de Janeiro e São Paulo em frequências de até 39,4\% (SOUZA; TEIXEIRA; GRAÇA., 2002; MENDES-DE-ALMEIDA et al., 2004; MENDES-DE-ALMEIDA et al., 2007; JUNQUEIRA-JORGE, 2005; MACIEIRA et al., 2008).

A ausência do FeLV em onças-pintadas, como detectado no presente estudo, também foi relatada por Nava (2008) para onças-pintadas de vida livre da Mata Atlântica. Todavia, em onças-pintadas mantidas em cativeiro no Brasil, a exposição ao FeLV foi relatada por Schmitt et al. (2003) e a detecção de DNA pró-viral do agente foi citada por Guimarães et al. (2009). Filoni et al. (2006) detectaram exposição de onças-pardas de vida livre ao agente no Pantanal.

O gato doméstico é o principal transmissor do FeLV, sendo que a maioria dos casos relatados em felinos silvestres foi resultado do contato direto com gatos domésticos, através de agressão ou predação (CITINO, 1986; JESSUP et al., 1993; KENNEDY-STOSKOPF, 1999; LÓPEZ et 
al., 2009). Embora o vírus tenha como vias de eliminação as secreções e excreções, dada sua fragilidade no meio ambiente, a transmissão ocorre principalmente através de contato direto com saliva e secreções nasais (HOOVER; MULLINS, 1991; KENNEDY-STOSKOPF, 1999; RAVAZZOLO; COSTA, 2007). Novamente, os hábitos das onças-pintadas tornam baixas as oportunidades de contato com o vírus: são solitárias, sendo que o encontro com gato doméstico na natureza é um evento raro. Deve-se reforçar que estudos de dieta realizados no PEC não relataram o gato-doméstico como item alimentar da onça-pintada (NUNO, 2007).

Assim, os resultados sugerem que o FeLV não representa uma ameaça para as populações de onça-pintada das três áreas estudadas.

\subsection{Hepatozoon spp.}

Todas as onças-pintadas do Parque Nacional das Emas e do Pantanal e três das quatro onças-pintadas do Parque Estadual do Cantão foram altamente expostas para Hepatozoon spp., assim como cães e gatos domésticos das áreas de estudo (Tabela 27).

Os cães no Pantanal e PEC foram altamente expostos ao agente, apresentando frequências de positividade aparentemente superiores à encontrada no entorno do PNE. A atividade predominante no entorno do PNE, diferentemente das outras áreas, é a agricultura (Tabela 5 a 7), fazendo com que os cães do Pantanal e PEC tivessem mais contato com áreas de pastagens e matas e, consequentemente, mais contato com o carrapato vetor do Hepatozoon spp. No mapa de ocorrência do Hepatozoon spp. para a região do PNE observa-se uma concentração dos diagnósticos positivos nas propriedades que praticam a pecuária extensiva, ao leste do PNE (Figura 54), evidenciando esta relação. A alta frequência de cães positivos para Hepatozoon spp. nas três áreas concorda com O'dwyer, Massard e Souza (2001) que relataram alta infecção de cães de área rural para o agente. Cães com altas frequências de positividade para Hepatozoon spp., 53,3\% a 67,6\%, foram também relatadas em São Paulo e Espírito Santo (RUBINI et al., 2005; RUBINI et al., 2008; SPOLIDORIO et al., 2009). A frequência de cães positivos no entorno do PNE foi similar a 39,2\% relatada em cães de área rural no Rio de Janeiro (O'DWYER; MASSARD; SOUZA, 2001) e 44\% no Rio Grande do Sul (CRIADO-FORNELIO, et al., 2006). 
A alta similaridade genética do agente isolado dos cães do presente estudo com Hepatozoon canis sugere ser este o agente etiológico presente nas três áreas de estudo, concordando com diversos autores, de que essa é a espécie responsável pela hepatozoonose canina no Brasil (O'DWYER et al., 2004; PALUDO et al., 2005; RUBINI et al., 2005; SPOLIDORIO et al., 2009).

A infecção ocorre através da ingestão do artrópode vetor contendo o oocisto do Hepatozoon spp. (BANETH, 2003). No presente estudo, parasitando os cães foram identificados Rhipicephalus sanguineus e diferentes espécies de Amblyomma spp. (Tabela 38). Entretanto a amostragem de carrapatos não foi criteriosa e não permite interpretações mais detalhadas sobre o vetor do Hepatozoon spp. nessas áreas. O carrapato Rhipicephalus sanguineus é considerado o principal vetor do H. canis (BANETH, 2003), sendo que Amblyomma ovale também é comprovadamente capaz transmitir o patógeno (FORLANO et al., 2005; RUBINI et al. 2009).

Dois dos cães positivos para Hepatozoon spp. no presente estudo encontravam-se com baixo peso corpóreo e anêmicos - sinais compatíveis com a hepatozoonose canina (GONDIM et al., 1998; BANETH, 2003; O'DWYER et al., 2006). Porém os sinais clínicos da doença podem ser secundários a outras enfermidades, dependendo da imunidade do animal (URQUHART et al., 1998; O'DWYER; MASSARD; SOUZA, 2001; BANETH, 2003; MUNDIM et al., 2008; SPOLIDORIO et al., 2009). Assim, os dados deste estudo não são suficientes para essa afirmação.

A ocorrência do Hepatozoon spp. em gatos domésticos foi similar nas regiões do Parque Nacional das Emas e Pantanal. Apesar da ausência da infecção em gatos no entorno do Parque Estadual do Cantão não é possível descartar a ocorrência do agente nessa região, uma vez que o número de gatos amostrados foi pequeno. A hepatozoonose felina é rara e o agente etiológico da doença ainda não foi identificado (BANETH, 2003; PEREZ; RUBINI; O'DWYER, 2004; ORTUÑO et al., 2008). No Brasil, há apenas dois relatos recentes que identificaram a ocorrência de Hepatozoon spp. semelhantes a $H$. canis em gatos domésticos (PEREZ; RUBINI; O'DWYER, 2004; RUBINI et al., 2006). Este é o primeiro relato da presença de Hepatozoon felis-like em gatos domésticos no Brasil.

Os gatos amostrados não apresentaram sinais clínicos para a hepatozoonose. Acredita-se que, assim como em cães, o agente tenha baixa virulência, manifestando-se principalmente em animais imunossuprimidos (PEREZ; RUBINI; O'DWYER, 2004). Os gatos examinados viviam soltos nas áreas rurais (Tabela 41), provavelmente em contato com diferentes espécies de ixodídeos. Como não foram coletados carrapatos desses animais, não é possível inferir sobre a forma de transmissão na espécie. Rubini et al. (2006) sugerem que diferentes espécies de Amblyomma 
estejam envolvidas na transmissão e McCully et al. (1975) e Smith (1996) sugerem a possibilidade da contaminação através da predação de animais parasitados com artrópodes infectados.

A alta exposição das onças-pintadas ao Hepatozoon spp. (Tabela 27) evidenciou a disseminação do agente em ambientes silvestres nas três áreas de estudo e, assim como CriadoFornelio et al. (2009) e Widmer (2009), sugere a participação das onças pintadas como potenciais reservatórios do Hepatozoon spp. na natureza. Os resultados concordam com Widmer (2009) que relatou todas as onças-pintadas de vida livre amostradas ( $n=10)$ no Pantanal sul mato-grossense positivas para o agente e identificou alta similaridade genética com Hepatozoon felis. Por sua vez, Criado-Fornellio et al. (2009) identificaram a presença do Hepatozoon canis em uma onça-pintada de vida livre na Venezuela, e Thoisy et al. (2000) não encontraram o agente em onça-pintada de natureza na Guiana Francesa. Os resultados são também similares ao relatado por Averbeck et al. (1990), que diagnosticaram Hepatozoon spp. em $100 \%$ de leões e guepardos de vida livre amostrados no Serengeti, evidenciando o papel dos felinos silvestres na manutenção do agente.

A ausência de sinais clínicos aparentes, assim como de alterações nas movimentações das onças-pintadas durante o período em que foram monitoradas sugere que os animais positivos não desenvolveram a doença. Concordando com Mc Cully et al. (1975), Averbeck et al. (1990) e East et al. (2008) que relataram infecções subclínicas causadas por Hepatozoon spp. em animais silvestres. Entretanto, assim como em cães, o Hepatozoon spp. pode ser um patógeno oportunista, principalmente em felinos selvagens imunossuprimidos (KUBO; MIYOSHI; YASUDA, 2006), reforçando a importância do monitoramento do agente em espécies ameaçadas de extinção.

Os resultados aqui apresentados não permitem inferir sobre o modo de infecção dessas onças-pintadas, que pode ter sido por ingestão de vetores ou predação de presas infectadas. Diferentes espécies de Amblyomma spp. foram encontradas parasitando as onças, e poderiam ter agido como vetores para o agente. Assim como em gatos domésticos, a forma de transmissão da hepatozoonose em felinos silvestres não é conhecida (BANETH, 2003).

Em relação aos modelos estatísticos, a menor exposição dos indivíduos examinados do PNE ao Hepatozoon spp., como já mencionado, provavelmente está relacionada com as diferentes formas de ocupação nas regiões. Entre as espécies, a maior exposição de onçaspintadas do que cães e gatos domésticos ao agente fortalece a hipótese da espécie silvestre agir 
como reservatório do agente na natureza e também a hipótese da transmissão do Hepatozoon spp. pela predação de presas infectadas, haja vista a onça ser animal topo de cadeia alimentar.

Ainda não está clara a existência de diferentes espécies de Hepatozoon spp. infectando cães e gatos (PEREZ; RUBINI; O'DWYER, 2004; RUBINI et al., 2006) e Metzger et al. (2008) sugerem que os felinos podem ser infectados por mais de uma espécie de Hepatozoon spp. Mais estudos devem ser realizados para a confirmação que Hepatozoon felis-like é a única espécie infectando os felinos nas três áreas de estudo.

Este é o primeiro relato da presença de Hepatozoon spp. em onças-pintadas de vida livre do bioma Cerrado e em área transição dos biomas Cerrado e Amazônia, sendo que a alta exposição ao agente sugere que a onça-pintada possui papel destacado na manutenção do Hepatozoon spp. no ambiente.

\subsection{Babesia spp.}

Não houve detecção de Babesia spp. em onças-pintadas ou gatos domésticos das três áreas de estudos, e somente os cães domésticos do entorno do PNE e do PEC foram expostos ao agente (Tabela 29).

As baixas exposições de cães à Babesia spp. no presente estudo estão de acordo com as frequências de 5,2\% e 18,8\% encontradas em cães do Rio de Janeiro (O'DWYER; MASSARD; SOUZA, 2001) e de Minas Gerais (MAIA et al., 2007). Outros estudos realizados em Minas Gerais, Paraná e São Paulo registraram alta exposição de cães ao hemoparasita (RIBEIRO et al., 1990; DELL'PORTO; OLIVEIRA; MIGUEL, 1993; BASTOS; MOREIRA; PASSOS, 2004; TRAPP et al., 2006). A presença dos cães positivos em sua maioria em bom estado geral (Tabela 40) sugere a presença de uma infecção subclínica da babesiose nesses animais.

A identificação de Babesia spp. com 96, 97 e 98\% de similaridade genética com Babesia canis vogelis em três dos cães positivos está de acordo com Passos et al. (2005) e Maia et al. (2007) de que essa é a espécie responsável pela maioria dos casos de babesiose canina no Brasil.

O carrapato Rhipicephalus sanguineus é o único vetor conhecido para a Babesia canis vogeli no país (DANTAS-TORRES, 2008). Assim, a presença desse ectoparasita em cães domésticos do entorno do PNE e do PEC (Tabela 38) sugere que a espécie possa ter agido como vetor para o parasita nas duas áreas de estudo. Porém, a presença do Amblyomma spp. 
parasitando os cães amostrados, também levanta a hipótese de espécies desse gênero agirem como vetores. Passos et al. (2005) relataram que há necessidade de mais estudos para identificação do vetor da Babesia spp. em meio rural.

A ausência do hemoparasita em gatos domésticos está de acordo com a literatura (DANTAS-TORRES; FIGUEREDO, 2006), que relata que gatos têm menor predisposição para contrair a infecção do que cães (AYOOB; HACKNER; PRITTIE, 2010). A babesiose felina foi recentemente diagnosticada e vem sendo regularmente relatada na África do Sul (PENZHORN; SCHOEMAN; JACOBSON, 2004; AYOOB; HACKNER; PRITTIE, 2010). Em gatos domésticos, no Brasil, apenas foram identificadas presenças de inclusões semelhantes à Babesia spp. em esfregaços sanguíneos (GAZETA; MONTEIRO; ABOUD-DUTRA, 2004; MENDES-DE-ALMEIDA et al., 2004; DANTAS-TORRES; FIGUEREDO, 2006), porém nenhum estudo molecular foi realizado para confirmação do agente.

Assim como no presente estudo, nenhuma onça-pintada de vida livre na Venezuela, Guiana Francesa e na região do Pantanal sul mato-grossense no Brasil, foram positivas para Babesia spp. (THOISY et al., 2000; CRIADO-FORNELIO et al., 2009; WIDMER, 2009). André (2008) relatou onças-pintadas mantidas em cativeiros soropositivas para Babesia canis, entretanto os mesmos indivíduos foram negativos quando realizado o teste molecular. $O$ teste molecular é o mais sensível e específico para a deteç̧ão da babesia felina (PENZHORN et al., 2001; CRIADOFORNELIO et al., 2003; AYOOB; HACKNER; PRITTIE, 2010), sendo capaz de diferenciar as espécies de Babesia spp. (AYOOB; HACKNER; PRITTIE, 2010) e diagnosticar a infecção em pequeno volume sanguíneo com parasitemia extremamente baixa (CRIADO-FORNELIO et al., 2003).

A ausência do carrapato Rhipicefalus sanguineus, vetor da Babesia canis vogeli, parasitando as onças-pintadas do presente estudo poderia ser um dos motivos para a ausência do diagnóstico do hemoparasita na espécie. Sendo que, esses resultados reforçam a especificidade de Babesia canis vogeli pelo vetor Rhipicephalus sanguineus. Muito embora o Rhipicefalus microplus tenha sido identificado nas onças-pintadas do Pantanal, não houve também a detecção de Babesia spp. comumente encontrada em bovinos. Sabe-se que a babesiose bovina é altamente prevalente na maioria das regiões do país (SOUZA et al., 2000; MADRUGA et al. 2001).

Munson et al. (2008) recentemente evidenciaram a importância da Babesia spp. ao demonstrar que uma coinfecção de diferentes espécies do parasita (B. felis, B. leo, B. gibsoni e Babesia spp.) e o vírus da cinomose, provavelmente alterou a relação hospedeiro-parasita, resultando no óbito dos leões no surto de 1994 no Serengeti. Assim, a presença do agente em 
cães domésticos no entorno do PNE e PEC deve ser monitorada, bem como sua ocorrência em onças-pintadas. Lembrando que as espécies de Babesia spp. possivelmente tenham especificidade por um hospedeiro e a infecção por espécies normalmente diagnosticadas em animais domésticos, poderia ser fatal em animais silvestres, principalmente em situações de estresse, animais imunossuprimidos ou em populações ameaçadas de extinção (PENZHORN, 2006).

Os resultados sugerem que Babesia spp. não representa uma ameaça para as populações de onça-pintada nas áreas de estudo, mas a ocorrência do hemoparasita em cães nas propriedades do entorno deve ser cuidadosamente monitorada devido ao histórico relacionado ao agente.

\subsection{Cytauxzoon spp.}

A presença de Cytauxzoon felis em todas as onças-pintadas do PNE e Pantanal e em três das quatro onças-pintadas amostradas no PEC sugere que o desafio por esse patógeno nas áreas de estudo é alto, e que a espécie pode agir como um reservatório importante do parasita no meio silvestre (Tabela 30). Este é o primeiro relato de Cytauxzoon felis em onças-pintadas de vida livre no bioma Cerrado e em área de transição dos biomas Cerrado e Amazônia.

A ausência do Cytauxzoon spp. em cães era esperada uma vez que, o C. felis, mais comumente diagnosticado, é um parasita exclusivo de felinos domésticos e silvestres (KIER; WIGHTMAN; WAGNER, 1982; MEINKOTH; KOCAN, 2005).

Para os gatos domésticos, a ausência do agente nas populações pode estar relacionada com a elevada taxa de mortalidade - próxima a 100\% - associada ao hemoparasita na espécie (BONDY; COHN; KERL, 2005; MEINKOTH; KOCAN, 2005; BROWN et al., 2008; REICHARD et al., 2008), o que dificultaria o encontro de animais infectados durante as visitas às propriedades, uma vez que normalmente o óbito ocorre de 5 a 20 dias após a infecção (KIER; WIGHTMAN; WAGNER, 1982; GLENN; STAIR, 1984; HOOVER; WALKER; HEDGES, 1994). No Brasil, Mendes-deAlmeida et al. (2007) relataram 48,5\% dos gatos domésticos positivos para Cytauxzoon spp. no Rio do Janeiro através da identificação do agente em esfregaços sanguíneos. Entretanto, morfologicamente é impossível distinguir piroplasmas em felídeos, sendo altamente 
recomendada a utilização de testes moleculares para confirmação do diagnóstico (BIRKENHEUER; LEVY; BREITSCHWERDT, 2003; BIRKENHEUER et al., 2006).

A quase totalidade $(96,78 \%)$ das onças-pintadas no presente estudo positiva para o agente (Tabela 30) foi similar ao encontrado por Widmer (2009) em onças-pintadas de vida livre no Pantanal sul mato-grossense, onde $100 \%$ dos 10 animais amostrados foram positivos para Cytauxzoon spp. Há também o relato, em menor porcentagem, de alguns indivíduos de onçaspintadas mantidos em cativeiro no Brasil positivos para o agente (SOARES, 2001; PEIXOTO et al., 2007; ANDRÉ et al., 2009). A diferença de porcentagens provavelmente está relacionada ao ambiente natural e maior exposição aos vetores pelas onças-pintadas de vida livre.

Cytauxzoon felis é transmitido através da saliva dos carrapatos e aderência do vetor por horas no hospedeiro (MEINKOTH; KOCAN, 2005). Nos Estados Unidos há relatos da competência dos carrapatos Dermacentor variabilis e Amblyomma americanum em transmitir C. felis (BLOUIN et al., 1984; REICHARD et al., 2009). Entretanto, como no Brasil não há a ocorrência desses carrapatos, provavelmente outras espécies de ixodídeos participam na transmissão do hemoparasita (PEIXOTO et al., 2007). No presente estudo, as onças-pintadas foram parasitadas principalmente por diferentes espécies do gênero Amblyomma (Tabela 38), podendo ser esse gênero, o vetor do $C$. felis.

A alta similaridade genética dos agentes isolados no presente estudo com Cytauxzoon felis está de acordo com as similaridades encontradas por André et al. (2009) e Widmer (2009) em onças-pintadas no Brasil.

A maioria das onças-pintadas positivas para Cytauxzoon felis não apresentaram sinais clínicos ou alterações no deslocamento padrão da espécie durante o período de monitoramento, sugerindo que não desenvolveram a forma clínica da doença, e fortalecendo a hipótese de agirem como um reservatório para o agente nas áreas de estudo. A onça-pintada capturada no PEC, que apresentou baixo peso corpóreo (Figura 37), foi positiva para o agente, porém a ausência de manifestações clínicas na maioria dos indivíduos positivos, a idade avançada do animal e a coinfecção com $M$. haemofelis, sugerem que os sinais apresentados não estejam relacionados com a presença do agente. André et al. (2009) acreditam que os felinos selvagens brasileiros podem agir como potenciais reservatórios do $C$. felis, assim como os linces-pardos (GLENN; KOCAN; BLOUIN, 1983; BLOUIN et al., 1984) e as onças-pardas (ROTSTEIN et al., 1999) nos Estados Unidos. Embora não sejam frequentes, há relatos de infecções fatais causadas pelo Cytauxzoon felis em linces-pardos (NIETFELD; POLLOCK, 2002), tigres (GARNER et al., 1996) e leões (PEIXOTO et al. 2007) - evidenciando a importância do monitoramento dos animais 
infectados, e não descartando potencial ameaça para animais imunossuprimidos ou com baixa variabilidade genética.

A onça-pintada criada na aldeia indígena apresentou o único resultado negativo para Cytauxzoon felis. Provavelmente, por ficar restrita na área da aldeia e não se deslocar pelos hábitats naturais da espécie, esta onça teve menos contato com os carrapatos normalmente presentes em ambientes silvestres. As quatro onças-pintadas que foram positivas no evento de recaptura confirmaram a presença do agente após intervalos de 7 a 38 meses, sugerindo infecções persistentes, assim como relatado para linces-pardos (MEINKOTH; KOCAN, 2005).

Os resultados sugerem a participação da onça-pintada como reservatório do Cytauxazoon felis e a existência de um ciclo silvestre do agente nas áreas de estudo.

\subsection{HEMOPLASMAS FELINOS}

Este é o primeiro relato da presença de Mycoplasma haemofelis, 'Candidatus Mycoplasma haemominutum' e 'Candidatus Mycoplasma turicensis' em onças-pintadas de vida livre (Tabelas 31 a 33).

Apesar do pequeno número de gatos amostrados e baixas frequências de positividade encontradas, os resultados mostraram a circulação de $M$. haemofelis e 'Ca. Mycoplasma haemominutum' no Pantanal, e de $M$. haemofelis e 'Ca. Mycoplasma turicensis' no entorno do PNE. No Brasil, existem relatos da ocorrência de hemoplasmas felinos em gatos domésticos das regiões Sul e Sudeste (BAUMANN et al., 2006; HORA, 2008; MACIEIRA et al. 2008; BIONDO et al., 2009; SANTOS et al., 2009a), sendo este, o primeiro relato para a região Centro-Oeste.

As altas exposições de onças-pintadas ao 'Ca. Mycoplasma haemominutum' (>70,0\%) nas três áreas de estudo sugerem a participação da espécie como reservatório do agente na natureza. Assim como relatado por Willi et al. (2007c) e Tasker (2010), 'Ca. Mycoplasma haemominutum' foi o hemoplasma mais comumente encontrado. Para onças-pintadas existem duas pesquisas realizadas para Mycoplasma haemofelis em animais mantidos em cativeiro: um animal, nos Estados Unidos, negativo para o agente (HAEFNER et al., 2003) e, um animal, no Brasil, positivo para o agente pela análise de esfregaço sanguíneo (RIVETTI JÚNIOR, 2006). Segundo Willi et al. (2007c), felinos de vida livre são mais infectados pelos hemoplasmas felinos do que animais mantidos em cativeiro. 
A coinfecçao de onças-pintadas com M. haemofelis e 'Ca. Mycoplasma haemominutum', relatada em cinco indivíduos neste estudo, já foi previamente relatada para felinos domésticos (WILLI et al., 2006a; SYKES et al., 2007; GENTILINI et al., 2009) e silvestres (WILLI et al., 2007c; METZGER, 2009). M. haemofelis é o hemoplasma felino mais patogênico, sendo os sinais clínicos mais comuns da sua infeç̧ão, a anorexia, perda de peso, mucosas hipocoradas e desidratação (SYKES, 2003; SYKES, 2010; TASKER, 2010). Nenhuma das onças-pintadas positivas para esse hemoplasma no Pantanal apresentou sinais clínicos de infecção ou alterações em seus deslocamentos, tendo sido monitoradas por períodos de 35 a 39 meses (Tabela 4). No Parque Estadual do Cantão, uma das duas onças-pintadas positivas para o agente foi o animal que estava abaixo do peso corpóreo (Figura 37). Assim, embora não se possa descartar a hipótese das alterações apresentadas pelo indivíduo terem sido causadas pelo $M$. haemofelis, a presença da maioria das onças positivas para o agente em bom estado geral, a presença de mucosas normocoradas no indivíduo (Figura 38) e a idade avançada do animal não fortalecem essa hipótese, fornecendo indícios de que os sinais apresentados não estejam relacionados a esse hemoparasita. Entretanto, os dados disponíveis não permitem essa conclusão.

A alta frequência de onças-pintadas expostas ao ' $\mathrm{Ca}$. Mycoplasma haemominutum' em bom estado geral, sem alterações de deslocamento e sendo monitoradas por períodos de até 91 meses (Tabelas 2 e 4; Figuras 59 e 60), fortalecem a hipótese de participação da espécie na manutenção do agente no meio ambiente, agindo como portadores assintomáticos desse hemoplasma - corcondando com Willi et al. (2007b, 2007c).

A presença do ' $\mathrm{C} a$. Mycoplasma turicensis' em apenas duas onças-pintadas coinfectadas com outros hemoplasmas foi similar ao encontrado por outros autores (PETERS et al., 2008; GENTILINI et al., 2009), que relataram a ocorrência desse hemoplasma quase sempre em associação com 'Ca. Mycoplasma haemominutum'. É possível que esses dois hemoplasmas tenham modos de transmissão similares (Willi et al., 2006b, 2007a).

O modo de transmissão dos hemoplasmas felinos ainda não foi identificado (SYKES, 2003; WILLI et al., 2007c; TASKER, 2010). No presente estudo, as onças-pintadas positivas para os hemoplasmas encontravam-se parasitadas por diferentes espécies de carrapatos (Tabela 38), porém, não foi realizada a pesquisa de patógenos nesses ectoparasitas, não sendo possível inferir sobre sua participação na transmissão dos hemoplasmas. A elevada exposição de onçaspintadas positivas ao ' $C a$. Mycoplasma haemominutum' fortalece a hipótese da transmissão do agente através de vetores, uma vez que as onças-pintadas possuem hábitos solitários - que dificultaria a transmissão direta do agente. Analisando o mapa de ocorrência do M. haemofelis 
no Pantanal (Figura 57) é possível observar que as onças-pintadas positivas se movimentaram em propriedade foco do agente, sugerindo a hipótese da transmissão por vetores, uma vez que gatos e onças dificilmente mantêm um contato próximo. Willi et al. (2007c) considerando a elevada ocorrência dos hemoplasmas em áreas tropicais e em felinos de vida livre, também sugerem o envolvimento de artrópodes hematófagos na transmissão dos hemoplasma.

A exposição de duas onças-pintadas ao M. haemofelis e 'Ca. Mycoplasma turicensis' após 32 e 31 meses de suas capturas, respectivamente, confirmaram a circulação dos agentes no Pantanal (Tabela 10; Figuras 57 e 58). A onça-pintada negativa para 'Ca. Mycoplasma haemominutum' em um segundo exame seis meses após sua captura (Tabela 10), sugere uma infecção não persistente, conforme também encontrado por Willi et al. (2006b, 2007c) ou a presença de níveis não detectáveis do hemoplasma no sangue pela PCR (TASKER, 2010). Diferentemente desse indivíduo, outras onças-pintadas permaneceram positivas para ' $C a$. Mycoplasma haemominutum' em intervalos de dois a 40 meses após o primeiro exame, concordando com Tasker (2006), que afirma que as infecções com 'Ca. Mycoplasma haemominutum' tendem a ser positivas por meses ou anos após a infeç̧ão.

Segundo os modelos estatísticos, a maior exposição ao 'Ca. Mycoplasma haemominutum' em onças-pintadas do que em gatos domésticos reforça a hipótese do felino silvestre agir como potencial reservatório do agente na natureza. A maior ocorrência de 'Ca. Mycoplasma haemominutum' em animais adultos do que em jovens está de acordo com o relatado para gatos domésticos (TASKER, 2006) uma vez que animais adultos são mais expostos ao patógeno ao longo da vida.

Esses resultados sugerem que a onça-pintada provavelmente desempenha importante papel na manutenção do 'Ca. Mycoplasma haemominutum' nas três áreas de estudo, e a alta exposição ao agente sugere o envolvimento de vetores na transmissão desse hemoplasma. As onças são suscetíveis ao Mycoplasma haemofelis e ao 'Ca. Mycoplasma turicensis', mas não parecem desempenhar papel importante para a manutenção desses agentes no ambiente.

\subsection{Mycobacterium bovis}

Não houve evidências de que os bovinos do entorno do PNE e PEC, e as onças-pintadas das três áreas de estudo tivessem sido expostos ao Micobacterium bovis. 
A dificuldade logística das áreas de estudo não permitiu que o teste de tuberculinização fosse realizado em todas as propriedades previstas. Entretanto, mesmo com um pequeno número de animais testados, o resultado condiz com a expectativa de baixa prevalência da tuberculose bovina para o território brasileiro, sobretudo para as regiões Norte e Centro-Oeste, tradicionais pelo sistema extensivo de criação de gado (SILVA et al., 2009; informação verbal ${ }^{1}$ ).

A ausência do $M$. bovis nas fezes das onças-pintadas está de acordo com a literatura que não relata a presença do patógeno na espécie. Normalmente, os carnívoros são acidentalmente infectados e não são capazes de propagar a doença (MORRIS; PFEIFFER; JACKSON, 1994; BENGIS, 1999). Em grandes felinos do gênero Panthera, o M. bovis já foi isolado de leões e leopardos de vida livre no Serengeti (KEET et al., 1996; DE VOS et al., 2001; CLEAVELAND et al., 2005).

Embora a identificação dos isolados de Mycobacterium spp. não tenham atingido o nível de espécie, foi possível identificá-los como micobactérias ubiquitárias. No entanto, a presença dessas micobactérias nas fezes das onças-pintadas deve ser interpretada com cuidado, uma vez que as fezes foram coletadas diretamente do solo, e assim o Micobacterium spp. isolado poderia advir do ambiente e não das fezes analisadas. Solos e águas possuem uma ampla variedade de micobactérias ambientais (FALKINHAM, 2002). Parte desse problema poderia ser resolvido pareando-se as coletas de fezes com amostras de solo, entretanto, essas coletas não foram realizadas no presente estudo. As micobactérias ambientais podem ser patógenos oportunistas (CHIMARA et al., 2008), mas raramente doenças causadas por essas micobactérias são reportadas em animais silvestres (BERCOVIER; VINCENT, 2001).

A pesquisa de Mycobacterium spp. em fezes exigiu técnicas especiais devido à alta contaminação das amostras, haja vista a contaminação ocorrida em três delas. O protocolo aplicado mostrou-se viável, porém seria interessante a realização de mais estudos visando o desenvolvimento de protocolos mais eficazes, equilibrando a capacidade de impedir o crescimento de contaminantes e permitir o crescimento das micobactérias. Os métodos descontaminantes podem reduzir o número de micobactérias viáveis contidas nas amostras (BROOKS et al., 1984).

Os resultados sugerem que o $M$. bovis não representa uma ameaça sanitária importante para as onças-pintadas das três áreas estudadas.

\footnotetext{
${ }^{1}$ Informação fornecida por José Soares Ferreira Neto em São Paulo, em 2010
} 


\subsection{PARASITAS INTESTINAIS}

O diagnóstico de duas amostras de fezes de onças-pintadas do Parque Nacional das Emas positivas para parasitas intestinais é o primeiro relato de Cryptosporidium spp. e Giardia intestinalis para onças-pintadas de vida livre (Tabela 37).

As baixas frequências de Giardia intestinalis encontradas podem estar relacionadas com a eliminação intermitente dos cistos (PAPINI et al., 2007), limitando sua detecção nas fezes. Desta forma, não é possível descartar também a presença do agente nas populações do Parque Estadual do Cantão e Pantanal. Podem ser necessárias diversas coletas e análises de amostras fecais para diagnóstico de um animal positivo (DRYDEN; PAYNE; SMITH, 2006).

A infecção das onças-pintadas do PNE pode ter ocorrido através da ingestão de água contaminada (ROBERTSON; THOMSON, 2002) - uma vez que utilizaram preferencialmente áreas próximas a cursos d'água (Figura 45) - ou de presas contaminadas. Pequenos mamíferos são considerados potenciais fontes de infecção da Giardia spp. e do Cryptosporidium spp. (LALLO et al., 2009) e foram encontrados, embora em baixa frequência, na dieta da onça-pintada do PNE (IOP dados não publicados). Há também a possibilidade de animais domésticos das propriedades rurais do entorno terem sido fontes de infecções para essas onças-pintadas. Porém, amostras de animais domésticos não foram coletadas para esse propósito no presente estudo.

Silva et al. (2008) sugerem que os felinos silvestres possam agir como potenciais hospedeiros para Giardia spp., sendo capazes de disseminar o agente no ambiente. Entretanto, não se conhece o papel das onças-pintadas na manutenção desses agentes. Geralmente a ocorrência de Cryptosporidium spp. em carnívoros é menor do que em roedores (FENG, 2010).

Existem relatos de onças-pintadas mantidas em cativeiro positivas para Giardia spp. no Brasil (MÜLLER; GREINERT; SILVA FILHO, 2005), e negativas para Cryptosporidium spp. (ALVES et al., 2005; MATSUBAYASHI et al., 2005; LIM et al., 2008) e Giardia spp. (MATSUBAYASHI et al., 2005).

É importante considerar que as amostras de fezes do presente estudo foram coletadas em campo e muitas vezes encontravam-se expostas no ambiente por horas ou dias, o que pode ter interferido nos resultados. Sendo que: (a) os oocistos ou cistos dos parasitos identificados poderiam estar presentes no ambiente e não nas fezes analisadas (BARWICK et al., 2003); (b) os oocistos ou cistos dos parasitos poderiam estar presentes nas presas consumidas pelas onçaspintadas e não representar infecção do predador (PATTON et al., 1986; PATTON; RABINOWITZ, 
1994; HAMNES et al., 2007); ou ainda, (c) os resultados negativos poderim ter ocorrido devido à desintegração dos cistos ou oocistos dos parasitos pela exposição prolongada no ambiente (PAPINI et al., 2007). Assim, esses resultados devem ser interpretados com ressalvas.

Nenhuma amostra foi positiva para protozoários da Família Sarcocystidae, concordando com De Camps, Dubey e Saville (2008), que também não encontraram nenhum oocisto de Toxoplasma gondii em amostra fecal de onça-pintada. Como as onças-pintadas das áreas de estudo foram altamente soropositivas para T. gondii (Tabela 20), a ausência de oocistos nas fezes era esperado, uma vez que o período de eliminação de oocistos é curto - diminuindo as chances de sua detecção nas fezes (DUBEY, 1986; DUBEY; THULLIEZ, 1989). Em Belize, oocistos de Hammondia pardalis e oocistos semelhantes a Toxoplasma gondii foram isolados de amostras fecais de onças-pintadas de vida livre, e oocistos de Sarcocystis spp. também não foram identificados (PATTON et al., 1986).

Mais estudos devem ser realizados para descobrir o potencial zoonótico desses protozoários a partir das amostras de onça-pintada. Porém, acredita-se que a ocorrência de Cryptosporidium spp. e Giardia intestinalis nas fezes de onças-pintadas pode ser uma importante informação para a epidemiológica dos parasitas no Parque Nacional das Emas.

\subsection{ECTOPARASITAS}

Todas as associações carrapato-hospedeiro encontradas no presente estudo (Tabela 38) já foram relatadas anteriormente (ARAGÃO, 1936; ARAGÃO; FONSECA, 1961; SINKOC et al., 1998; LABRUNA et al., 2002; LABRUNA et al., 2005; NAVA, 2008; MARTINS et al., 2009; WIDMER, 2009).

Em cães domésticos, Rhipicephalus sanguineus foi a espécie de carrapato mais identificada nas três áreas de estudo, similar ao relatado por Szabó et al. (2010) em área rural. Essa espécie de carrapato é considerada vetor da Babesia canis vogeli (DANTAS-TORRES; FIGUEREDO, 2006), mas não foi identificada nas onças-pintadas capturadas.

As onças-pintadas do Pantanal apresentaram a maior diversidade de carrapatos, entretanto essa informação deve ser cuidadosamente interpretada, uma vez que nesse bioma houve mais eventos de captura em comparação às demais áreas (Tabela 38). 
Rhipicephalus microplus, identificado nos bovinos do presente estudo, é a espécie de carrapato mais prevalente em bovinos no Brasil (LABRUNA et al., 2005) e foi também encontrado nas onças-pintadas do Pantanal. Nesse bioma, devido ao fenômeno de inundação sazonal, o gado foi introduzido nos hábitats naturais das onças-pintadas (CANÇADO et al., 2008), fazendo com que as duas espécies utilizassem mais áreas em comum do que nas regiões do PNE e PEC. A ocorrência de $R$. microplus em onças-pintadas foi previamente relatada por Labruna et al. (2002), Labruna et al. (2005) e Nava (2008).

As onças-pintadas, assim como os demais carnívoros, são predadores topo de cadeia alimentar e podem se infestar com carrapatos que parasitam suas presas naturais (LABRUNA et al., 2005), sendo mais expostas a diferentes espécies de carrapatos. A alta frequência do $A$. cajennense encontrada no PNE e Pantanal sugere a boa adaptação dessa espécie de ectoparasita nas onças-pintadas. A espécie é endêmica da região neotropical e parasita principalmente herbívoros como antas, capivaras e queixadas (ARAGÃO, 1936; BARROS-BATTESTI; ARZUA; BECHARA, 2006). Possui baixa especificidade por hospedeiros (PEREIRA et al., 2000; LABRUNA et al., 2002), tendo sido também identificada em cães e bovinos do presente estudo. Em onçaspintadas, A. cajennense já foi relatado por Aragão (1936), Labruna et al. (2005), Durden et al. (2006) e Widmer (2009).

A. ovale, identificado em onças-pintadas do Pantanal e Parque Estadual do Cantão e cães domésticos do entorno do PEC, é normalmente encontrado em animais silvestres (ARAGÃO, 1936; LABRUNA et al., 2002; BARROS-BATTESTI; ARZUA; BECHARA, 2006). A espécie foi previamente relatada parasitando onças-pintadas por Aragão e Fonseca (1961), Sinkoc et al. (1998) e Labruna et al. (2005). A. triste, identificado em onças do Parque Nacional das Emas e Pantanal, tem como principais hospedeiros na natureza os cervos e veados (BARROS-BATTESTI; KNYSAK, 1999; SZABÓ et al., 2003). Sendo que a associação A. triste e onça-pintada foi previamente relatada por Durden et al. (2006), Labruna et al. (2005) e Widmer (2009). A. tigrinum, por sua vez, foi apenas encontrado nas onças-pintadas do Parque Nacional das Emas, e acredita-se que parasite exclusivamente carnívoros (GUGLIELMONE et al., 2000). Em onçaspintadas, já foi relatado por Labruna et al. (2005) e Durden et al. (2006). Por último, o carrapato A. oblongoguttatum identificado em cães do entorno do Parque Estadual do Cantão, também relatado por Martins et al. (2009), não foi encontrado em onças-pintadas no presente estudo, mas anteriormente foi descrita na espécie por Labruna et al. (2005).

Entre os demais ectoparasitas identificados nas onças-pintadas, a Tunga penetrans foi relatada em menor frequência neste estudo do que por Widmer e Azevedo (2009) em onças- 
pintadas do Pantanal. Tunga penetrans é endêmica no Brasil e, animais domésticos e silvestres podem agir como seu reservatório (PILGER et al., 2008). Não se conhece o papel das onçaspintadas na manutenção desse ectoparasita na natureza.

Algumas lesões nas peles das onças-pintadas, causadas por mordidas de carrapatos, brigas intra ou interespecíficas provavelmente deram início as infestações por larvas de Cochliomyia sp. encontradas nos animais do Pantanal. Larvas de Cochliomyia sp. foram também relatadas em onças-pintadas por Rawlins (1985) na Guiana, porém não foram encontrados registros de larvas de Dermatobia hominis na espécie. A larva de Dermatobia hominis possui baixa especificidade parasitária sendo relatada em diversas espécies animais e considerada a principal agente da miíase na América do Sul (SILVA-JÚNIOR; LEANDRO; MOYA-BORJA, 1998; VEROCAI et al., 2010). Segundo Souza, Verocai e Ramadinha (2010), as infestações por Cochiliomyia hominivorax são consideradas mais agressivas, porém infestações pequenas e superficiais, como as observadas no presente estudo, normalmente são benignas.

Durden et al. (2006) relataram que a fauna de ectoparasitas associadas com as onças varia ao longo de sua área de distribuição. Outras espécies de ectoparasitas, diferentes das encontradas neste estudo, já foram identificadas em onças-pintadas: Ixodes boliviensis, I. affinis, Ctenocephalides felis e Juxtapulex echidnophagoides no Panamá, Pulex simulans e Ornithodoros rostratus no Chaco Paraguaio, Pulex irrittans no Brasil, Pulex porcinuns no México, e Felicola oncae na Costa Rica (revisado por DURDEN et al., 2006).

A erradicação ou controle de doenças transmitidas por carrapatos pode ser mais complicado do que responder a um surto de doenças infecciosas (GEORGE; DAVEY; POUND, 2002). Assim, a identificação de ectoparasitas em onças-pintadas é importante não apenas para entender o papel desse felino na manutenção dos vetores na natureza, mas também conhecer possíveis agentes que possam ser veiculados por eles. Embora não realizada neste estudo, considera-se de extrema importância a coleta de carrapatos para extração de material genético e pesquisa de patógenos através de testes moleculares. 


\section{CONCLUSÕES}

- $\quad$ Este é o primeiro estudo de patógenos com enfoque em medicina da conservação para as populações de onça-pintada, cães, gatos e bovinos nas regiões do Parque Nacional das Emas, Parque Estadual do Cantão e Pantanal sul mato-grossense.

- A Brucella abortus é endêmica nas populações de bovinos, mas aparentemente as brucelas lisas não representam uma ameaça sanitária para as onças-pintadas nas três áreas de estudo.

- A epidemiologia da leptospirose nas onças-pintadas não envolve bovinos, cães ou gatos domésticos como reservatórios no Parque Nacional das Emas e Pantanal.

- As populações de onça-pintada das três áreas de estudos provavelmente mantêm um ciclo silvestre do Toxoplasma gondii na natureza, aparentemente não envolvendo animais domésticos.

- As onças-pintadas do Pantanal provavelmente foram expostas ao vírus da raiva e não apresentaram infecção letal da doença.

- As onças-pintadas do Pantanal foram expostas ao vírus da cinomose, sendo necessários mais estudos para elucidar o papel dos cães domésticos como fonte de infecção para o agente.

- $\quad$ O FIV não representa uma ameaça para as populações de onça-pintada e gato doméstico das três áreas de estudo.

- O FelV, mesmo presente em gatos domésticos do entorno do Parque Estadual do Cantão, não representa uma ameaça para as populações de onça-pintada das três áreas de estudo. 
- Embora cães dos entornos do Parque Nacional das Emas e Parque Estadual do Cantão sejam expostos a Babesia spp., esse hemoparasita não representa uma ameaça para as populações de onça-pintada nas três áreas de estudo.

- As onças-pintadas das três áreas de estudo provavelmente possuem um papel na manutenção do Cytauxzoon felis, Hepatozoon spp. e 'Candidatus Mycoplasma haemominutum' na natureza.

- Cães e gatos domésticos das três áreas de estudo não parecem estar envolvidos na transmissão do Cytauxzoon felis para as onças-pintadas.

- As onças-pintadas são suscetíveis ao Mycoplasma haemofelis e ao 'Candidatus Mycoplasma turicensis', mas parecerem não desempenhar papel na manutenção desses agentes no ambiente.

- Mycobacterium bovis não representa uma ameaça sanitária para as populações de onçapintada nas três áreas de estudo.

- São necessários mais estudos para confirmar a presença de Giardia intestinalis e Cryptosporidium spp. em onças-pintadas no Parque Nacional das Emas.

- Deve-se pesquisar a presença de Cytauxzoon felis; Hepatozoon spp., 'Candidatus Mycoplasma haemominutum', 'Candidatus Mycoplasma turicensis' e Mycoplasma haemofelis em carrapatos que parasitam as onças-pintadas nas três áreas de estudo.

- É necessário o monitoramento em longo prazo das populações de onça-pintada e animais domésticos nas regiões do Parque Nacional das Emas, Pantanal e Parque Estadual do Cantão. 


\section{CONSIDERAÇÕES FINAIS}

Este estudo representa o primeiro relato de patógenos circulantes nas populações de onça-pintada e animais domésticos com enfoque em medicina da conservação para as regiões do Parque Nacional das Emas, Parque Estadual do Cantão e Pantanal sul mato-grossense.

Trata-se de um primeiro passo, mas muito ainda precisa ser estudado, notadamente em relação ao papel dos animais domésticos na cadeia de transmissão dos patógenos detectados.

De uma maneira geral as onças-pintadas das três áreas encontravam-se saudáveis, em boas condições físicas, e pareceram não estar ameaçadas pela presença de patógenos em suas populações ou ambientes em que vivem. Porém, conhecendo a importância de medidas de controle para prevenção de surtos epidêmicos (CLEAVELAND et al., 2000) e o histórico de animais domésticos como fontes de infecção de doenças que causaram declínios populacionais significativos em espécies ameaçadas (GASCOYNE et al., 1993; ROELKE-PARKER et al., 1996; SILLERO-ZUBIRI; KING; MACDONALD, 1996; LAURENSON et al., 1998; LÓPEZ et al., 2009), considera-se saudável refletir sobre um conjunto de medidas preventivas que poderiam ser adotadas nas áreas do entorno do PNE, PEC e propriedades rurais do Pantanal sul matogrossense.

Para tanto, e tendo em vista os resultados obtidos, elaborou-se uma escala dos riscos sanitários aos quais as populações de onça-pintada das três áreas estão expostas: a cinomose e a raiva foram consideradas potenciais ameaças; a brucelose e a leptospirose merecem atenção pela possibilidade de envolvimento de animais domésticos como reservatórios; os hemoparasitas necessitam ser mais estudados, principalmente para elucidar as relações hospedeiro-parasita e a importância desses agentes para a onça-pintada; os demais agentes parecem não representar uma ameaça sanitária e, quando detectados, pareceram ser oriundos do próprio ambiente silvestre.

Assim, os riscos de transmissão de patógenos dos animais domésticos para as onçaspintadas poderiam ser mitigados pela adoção das seguintes medidas, em ordem de importância:

1) Vacinação de cães contra a cinomose. Vacinação de bovinos, cães e gatos contra a raiva;

2) Implementação de ações de controle da brucelose recomendadas pelo PNCEBT, e verificação da necessidade de vacinação de suínos contra leptospirose;

3) Combate a ectoparasitas nos animais domésticos; 
4) Proibição de animais domésticos no interior das Unidades de Conservação e restrição da circulação de espécies domésticas em ambientes adjacentes às áreas preservadas;

5) Erradicação de cães e gatos ferais.

Deve-se também enfatizar a importância desse manejo adequado aos proprietários e funcionários das propriedades rurais e aos gerentes das Unidades de Conservação - fornecendo informações sobre as possíveis doenças que podem ser transmitidas entre os animais domésticos e silvestres.

Apenas o monitoramento em longo prazo dessas populações permitirá definir o papel das espécies na transmissão dos agentes, reconhecer quais patógenos são endêmicos ou podem representar uma ameaça para a onça-pintada. Sabe-se que muitas das medidas recomendadas são difíceis de serem praticadas, pois envolvem, além de recursos logísticos e financeiros, mudanças nos costumes das comunidades. Para que comecem a ser praticadas, é necessária a realização de mais debates sobre o tema entre pesquisadores, órgãos ambientais e da saúde, expondo os dados gerados até o momento e os riscos a que essas populações estão suscetíveis. Só assim será possível avançar e começar a praticar ações de manejo epidemiológico para a conservação de animais silvestres.

Para garantir a qualidade das informações coletadas deve-se também padronizar os protocolos de coletas de material biológico e os métodos diagnósticos utilizados, maximizando os esforços em projetos de pesquisas (FURTADO; FILONI, 2008).

Deve-se incentivar investigações sobre as causas de mortalidade das onças-pintadas. Essas informações são extremamente difíceis de serem coletadas, pela dificuldade tanto de se encontrar animais de vida livre morrendo em decorrência de doenças infecciosas (MURRAY et al., 1999), quanto de encontrar materiais biológicos adequados para esses estudos.

O mapeamento da ocorrência dos patógenos e a inserção de dados ecológicos, como realizado no presente estudo, mostraram que, além de ilustrar a presença dos agentes no ambiente, facilitam a visualização das possíveis vias de transmissão dos patógenos, devendo, sempre que possível, serem inseridos em estudos epidemiológicos - observações relatadas previamente por Riley, Foley e Chomel (2004), Ostfeld, Glass e Keesing (2005) e Norman (2008).

O conhecimento dos patógenos circulantes nessas populações será útil também para futuros projetos que envolvam a translocação ou reintrodução de onças-pintadas na natureza. 
Embora ainda não seja uma prática adotada, sugere-se que os patógenos aqui selecionados sejam pesquisados, dando atenção especial aos agentes virais e parasitários.

Muitos dos patógenos estudados possuem potencial zoonótico, colocando em risco não apenas os animais, mas também as populações humanas das áreas de estudo. Propõe-se que, futuramente, sejam realizados estudos epidemiológicos com as comunidades humanas nas regiões do PNE, PEC e Pantanal, completando, assim, o estudo de medicina da conservação nas áreas - um projeto multidisciplinar - envolvendo médicos e profissionais da área da saúde.

Evidentemente, não será possível prever todos os surtos de doenças na população e conduzir estratégias de controle para cada uma delas (ACEVEDO-WHITEHOUSE, 2009; WOODFORD, 2009). Porém, o levantamento prévio dos patógenos circulantes e o monitoramento desses animais servirão de base para determinar quais merecem atenção especial.

Ainda hoje, programas de monitoramento epidemiológico em animais silvestres são limitados, e, apesar de destacar a importância das doenças para espécies ameaçadas, é urgente que os riscos da presença dos patógenos nas populações sejam identificados, para que estratégias de controle sejam planejadas (SAINSBURY et al., 2001; LANFRANCHI et al., 2003; ACEVEDO-WHITEHOUSE, 2009). O papel da medicina da conservação está em solucionar problemas e não apenas relatá-los (LANFRANCHI et al., 2003). O simples relato de ocorrência de patógenos nas populações de animais selvagens tem valor limitado, mas ganha relevância para a conservação quando acompanhado de recomendações de manejo (GORTAZAR et al., 2007). 


\section{REFERÊNCIAS}

ACEVEDO-WHITEHOUSE, K. The importance of disease management programmes for wildlife conservation. Animal Conservation, v. 12, n. 3, p. 185-186, 2009.

ACHA, P. N.; SZYFRES, B. Zoonoses and communicable diseases common to man and animals. 3. ed. Washington, D. C.: Pan American Health Organization, 2001. V. 1, 398 p.

ACHA, P. N.; SZYFRES, B. Zoonosis y enfermidades transmissibles comunes al hombre y a los animales. 2. ed. Washington: Organizacion Panamericana de la Salud, 1986. 989 p.

ADESIYUN, A. A.; ABDULLAHI, S. U.; ADEYANJU, J. B. Prevalence of Brucella abortus and Brucella canis antibodies in dogs in Nigeria. Journal of Small Animal Practice, v. 27, n. 1, p. 31-37, 1986.

AGUIRRE, A. A. Wild canids as sentinels of ecological health: a conservation medicine perspective.

Parasites and Vectors, v. 2, 2009.

AGUIRRE, A. A.; STARKEY, E. E. Wildlife disease in United States National Parks: historical and coevolutionary perspectives. Conservation Biology, v. 8, n. 3, p. 654-661, 1994.

AGUNLOYE, C.; NASH, A. Investigation of possible leptospiral infection in cats in Scotland. Journal of Small Animal Practice, v. 37, p. 126-129, 1996.

ALBUQUERQUE, G. R.; MUNHOZ, A. D.; FLAUSINO, W.; SILVA, R. T.; ALMEIDA, C. R. R.; MEDEIROS, S. M.; LOPES, C. W. G. Prevalência de anticorpos anti-Toxoplasma gondii em bovinos leiteiros do vale do Paraíba Sul Fluminense, estado do Rio de Janeiro. Revista Brasileira de Parasitologia Veterinária, v. 14, n. 3, p. 125-128, 2005.

ALENCAR, N. X.; KOHAYAGAWA, A.; SANTAREM, V. A. Hepatozoon canis infection of wild carnivores in Brazil. Veterinary Parasitology, v. 70, n. 4, p. 279-282, 1997.

ALEXANDER, K. A.; APPEL, M. J. G. African wild dogs (Lycaon pictus) endangered by a canine distemper epizootic among domestic dogs near the Masai Mara national reserve, Kenya. Journal of Wildlife Diseases, v. 30, n. 4, p. 481-485, 1994.

ALEXANDER, K. A.; KAT, P. W.; FRANK, L. G.; HOLEKAMP, K. E.; SMALE, L.; HOUSE, C.; APPEL, M. J. G. Evidence of canine distemper virus infection among free-ranging spotted hyenas (Crocuta crocuta) in the Masai Mara, Kenya. Journal of Zoo and Wildlife Medicine, v. 26, n. 2, p. 201-206, 1995.

ALMEIDA, A. C.; SANTORELLI, A.; BRUZADELLI, R. M. Z.; OLIVEIRA, M. Seroepidemiology of canine brucellosis caused by Brucella canis and Brucella abortus in Alfenas, MG, Brazil. Arquivo Brasileiro de Medicina Veterinária e Zootecnia, v. 56, n. 2, p. 275-276, 2004. 
ALMEIDA, V. T.; PEREIRA, L. H. C.; SOUZA, N. F.; MENESES, A. M. C.; MORAES, C. C. G.; KURODA, R. B. S.; LIMA, D. J. S.; FIGUEIREDO, M. J. F. M.; PEREIRA, A. C. A.; LANGONI, H.; SILVA, R. C.; ALVES, M. A. M. K.; DIAS NETO, R. N.; ANDRADE, R. F.; BASTOS, R. K. G.; CARDOSO, A. C. F.; SEIXES, L. S.; ANDRADE, E. N. L.; OLIVEIRA, G. S.; REIS, K. A.; LACRETA JUNIOR, A. C. C.; BRANCA, E. R.; OLIVEIRA, F. C. M.; LEANDRO, B. M. A. Leptospira spp. (Larrey 1800) serological evaluation in Pantera onca (Linnaeus 1758) and Leopardus pardalis (Linnaeus 1771) kept in captivity at Belem and Capitão Poco, Pará state, Brazil. Clínica Veterinária (São Paulo), ano XIV, p. 99-100, 2009. Suplemento.

ALTIZER, S.; HARVELL, D.; FRIEDLE, E. Rapid evolutionary dynamics and disease threats to biodiversity. Trends in Ecology and Evolution, v. 18, n. 11, p. 589-596, 2003.

ALVES, C. J.; ANDRADE, J. S. L.; VASCONCELLOS, S.A.; MORAES, Z. M.; AZEVEDO, S. S.; SANTOS, F. A. Avaliação dos níveis de aglutinação anti-leptospira cães no Município de Patos, PB, Brasil. Revista Brasileira de Ciência Veterinária, v. 7, n. 1, p. 17-21, 2000.

ALVES, L. C. Prevalência de babesiose em gado leiteiro no município de Garanhuns, estado de Pernambuco. 1987. 124 f. Dissertação (Mestrado) - Faculdade de Medicina Veterinária e Zootecnia, Universidade de São Paulo, São Paulo, 1987.

ALVES, M.; XIAO, L. H.; LEMOS, V.; ZHOU, L.; CAMA, V.; DA CUNHA, M. B.; MATOS, O.; ANTUNES, F. Occurrence and molecular characterization of Cryptosporidium spp. in mammals and reptiles at the Lisbon Zoo. Parasitology Research, v. 97, n. 2, p. 108-112, 2005.

ANDERSON, A. J.; GREINER, E. C.; ATKINSON, C. T.; ROELKE, M. E. Sarcocysts in the Florida bobcat (Felis rufus floridanus). Journal of Wildlife Diseases, v. 28, n. 1, p. 116-120, 1992.

ANDERSON, E. C. Morbillivirus infections in wildlife (in relation to their population biology and disease control in domestic animals). Veterinary Microbiology, v. 44, n. 2-4, p. 319-332, 1995.

ANDERSON, J. F.; MAGNARELLI, L. A. Biology of ticks. Infectious Disease Clinics of North America, v. 22, n. 2, p. 195, 2008.

ANDRÉ, M. R. Detecção molecular e sorológica de Ehrlichia canis e Babesia canis em felídeos selvagens brasileiros mantidos em cativeiro. 2008. 78 f. Dissertação (Mestrado) - Faculdade de Ciências Agrárias e Veterinárias, Universidade Estadual de São Paulo, São Paulo, 2008.

ANDRÉ, M. R.; ADANIA, C. H.; MACHADO, R. Z.; ALLEGRETTI, S. M.; FELIPPE, P. A. N.; SILVA, K. F.; NAKAGHI, A. C. H.; DAGNONE, A. S. Molecular detection of Cytauxzoon spp. in asymptomatic Brazilian wild captive felids. Journal of Wildlife Diseases, v. 45, n. 1, p. 234-237, 2009.

ANDRÉ-FONTAINE, G. Canine leptospirosis - Do we have a problem? Veterinary Microbiology, v. 117, n. 1, p. 19-24, 2006. 
APPEL, M. J. G. Citation classic: pathogenesis of canine distemper. Current Contents. Agriculture biology \& environmental sciences, v. 19, p. 14, 1987.

APPEL, M. J. G.; ROBSON, D. S. A microneutralization test for canine distemper virus. American Journal of Veterinary Research, v. 34, n. 11, p. 1459-1463, 1973.

APPEL, M. J. G.; SHEFFY, B. E.; PERCY, D. H.; GASKIN, J. M. Canine distemper virus in domesticated cats and pigs. American Journal of Veterinary Research, v. 35, n. 6, p. 803-806, 1974.

APPEL, M. J. G.; SUMMERS, B. A. Pathogenicity of morbilliviruses for terrestrial carnivores. Veterinary Microbiology, v. 44, n. 2-4, p. 187-191, 1995.

APPEL, M. J. G.; YATES, R. A.; FOLEY, G. L.; BERNSTEIN, J. J.; SANTINELLI, S.; SPELMAN, L. H.; MILER, L. D.; ARP, L. H.; ANDERSON, M.; BARR, M.; PEARCE-KELLING, S.; SUMMERS, B. A. Canine distemper enzootic in lions, tigers, and leopards in North America. Journal Veterinary Diagnostic Investigation, v. 6, n. 3, p. $277-$ 288, 1994.

APPELBEE, A. J.; THOMPSON, R. C. A.; OLSON, M. E. Giardia and Cryptosporidium in mammalian wildlife current status and future needs. Trends in Parasitology, v. 21, n. 8, p. 370-376, 2005.

ARAGÃO, H. D. B. Ixodidas brasileiros e de alguns paizes limitrophes. Memórias do Instituto Oswaldo Cruz, v. 31, n. 4, p. 759-843, 1936.

ARAGÃO, H.; DA FONSECA, F. Notas de ixodologia. VIII. Lista e chave para os representantes da fauxa ixodológica brasileira. Memórias do Instituto Oswaldo Cruz, v. 59, n. 2, p. 115-129, 1961.

ARAÚJO, F. R.; CARVALHO, C. M. E.; BALBUENA, C. B. Levantamento sorológico para Toxoplasma gondii em bovinos de corte do estado do Mato Grosso do Sul, Brasil. Revista Brasileira de Medicina Veterinária, v. 20, n. 5, p. 201-203, 1998.

ARAÚJO, V. E. M.; MOREIRA, E. C.; NAVEDA, L. A. B.; SILVA, J. A.; CONTRERAS, R. L. Frequency of antiLeptospira interrogans agglutinins in bovine serum samples in Minas Gerais, Brazil, 1980 to 2002. Arquivo Brasileiro de Medicina Veterinária e Zootecnia, v. 57, n. 4, p. 430-435, 2005.

ARDUINO, G. D. C.; GIRIO, R. J. S.; MAGAJEVSKI, F. S.; PEREIRA, G. T. Agglutinating antibody titers induced by commercial vaccines against bovine leptospirosis. Pesquisa Veterinária Brasileira, v. 29, n. 7, p. 575$582,2009$.

ARJONA, A.; BARQUERO, N.; DOMENECH, A.; TEJERIZO, G.; COLLADO, V. M.; TOURAL, C.; MARTIN, D.; GOMEZ-LUCIA, E. Evaluation of a novel nested PCR for the routine diagnosis of feline leukemia virus (FeLV) and feline immunodeficiency virus (FIV). Journal of Feline Medicine and Surgery, v. 9, n. 1, p. 1422, 2007. 
ARNS, C. W.; SPILKI, F. R.; ALMEIDA, R. S. Paramyxoviridae. In: FLORES, E. F. Virologia Veterinária. Santa Maria: Editora da UFSM, 2007. cap. 26, p. 659-688.

ASTETE, S.; SOLLMANN, R.; SILVEIRA, L. Comparative ecology of jaguars in Brazil. Cat News, special issue, The jaguar in Brazil, n. 4, p. 9-14, 2008.

AVERBECK, G. A.; BJORK, K. E.; PACKER, C.; HERBST, L. Prevalence of hematozoans in lions (Panthera leo) and cheetah (Acinonyx-jubatus) in Serengeti National Park and Ngorongoro Crater, Tanzania. Journal of Wildlife Diseases, v. 26, n. 3, p. 392-394, 1990.

AYOOB, A. L.; HACKNER, S. G.; PRITTIE, J. Clinical management of canine babesiosis. Journal of Veterinary Emergency and Critical Care, v. 20, n. 1, p. 77-89, 2010.

AZEVEDO, F. C. C.; MURRAY, D. L. Evaluation of potential factors predisposing livestock to predation by jaguars. The Journal of Wildlife Management, v. 71, n. 7, p. 2379-2386, 2007a.

AZEVEDO, F. C. C.; MURRAY, D. L. Spatial organization and food habits of jaguars (Panthera onca) in a floodplain forest. Biological Conservation, v. 137, n. 3, p. 391-402, 2007b.

AZEVEDO, S. S.; BATISTA, C. S. A.; VASCONCELlOS, S. A.; AGUIAR, D. M.; RAGOZO, A. M. A.; RODRIGUES, A. A. R.; ALVES, C. J.; GENNARI, S. M. Seroepidemiology of Toxoplasma gondii and Neospora caninum in dogs from the state of Paraiba, Northeast region of Brazil. Research in Veterinary Science, v. 79, n. 1, p. 51-56, 2005.

BAJER, A. Cryptosporidium and Giardia spp. infections in humans, animals and the environment in Poland. Parasitology Research, v. 104, n. 1, p. 1-17, 2008.

BANETH, G. Disease risks for the travelling pet: hepatozoonosis. In Practice, v. 25, n. 5, p. 272, 2003.

BANETH, G.; AROCH, I.; TAL, N.; HARRUS, S. Hepatozoon species infection in domestic cats: a retrospective study. Veterinary Parasitology, v. 79, n. 2, p. 123-133, 1998.

BARR, M. C. FIV, FeLV, and FIPV: interpretation and misinterpretation of serological test results. Seminars in Veterinary Medicine and Surgery Small Animal, v. 11, n. 3, p. 144-153, 1996.

BARR, M. C.; CALLE, P. P.; ROELKE, M. E.; SCOTT, F. W. Feline immunodeficiency virus infection in nondomestic felids. Journal of Zoo and Wildlife Medicine, v. 20, n. 3, p. 265-272, 1989.

BARR, S. C.; BOWMAN, D. D.; PHILLIPS, L. G.; BARR, M. C. Trypanosoma manulis n. sp. from the Russian Pallas cat (Felis manul). Journal of Eukaryotic Microbiology, v. 40, n. 3, p. 233-237, 1993. 
BARROS-BATTESTI, D. M.; ARZUA, M.; BECHARA, G. H. Carrapatos de importância médico veterinária da Região Neotropical: um guia ilustrado para identificação de espécies. São Paulo: Vox/ICTTD/Butantan, 2006. 223 p.

BARROS-BATTESTI, D. M.; KNYSAK, I. Catalogue of the Brazilian Ixodes (Acari: Ixodidae) material in the mite collection of Instituto Butantan, São Paulo, Brazil. Papéis Avulsos de Zoologia (São Paulo), v. 41, n. 3, p. 49-57, 1999.

BARWICK, R. S.; MOHAMMED, H. O.; WHITE, M. E.; BRYANT, R. B. Factors associated with the likelihood of Giardia spp. and Cryptosporidium spp. in soil from dairy farms. Journal of Dairy Science, v. 86, n. 3, p. 784791, 2003.

BASTOS, C. V.; MOREIRA, S. M.; PASSOS, L. M. F. Retrospective study (1998-2001) on canine babesiosis in Belo Horizonte, Minas Gerais State. Brazil. Annals of the New York Academy o Sciences, v. 1026, n. 1, p. 158-160, 2004.

BAUMANN, A.; GUIMARAES, A. M. S.; SILVA, C. C.; YAMAGUTI, M.; KOZEMJAKIM, D. A.; MESSICK, J. B.; BIONDO, A. W.; TIMENETSKY, J. Mycoplasma haemofelis and 'Candidatus Mycoplasma haemominutum' detection by PCR in anemic domestic cats (Felis catus) from Curitiba, Brazil: a preliminary study. Veterinary Clinical Pathology, v. 35, n. 3, p. 370, 2006. Apresentado no American Society for Veterinary clinical Pathology Annual Meeting, 41.; American College of Veterinary Pathologists Annual Meeting, $57 .$, 2006, Tucson, Arizona.

BEAUFILS, J. P.; MARTIN-GRANEL, J.; JUMELLE, P. Hepatozoon spp. parasitemia and feline leukemia virus infection in two cats. Feline Practice, v. 26, n. 3, p. 10-13, 1998.

BELOTTO, A. J. Organization of mass vaccination for dog rabies in Brazil. Reviews of Infectious Diseases, v. 10, p. 693-696, 1988. Supplement 4.

BELOTTO, A. J.; LEANES, L. F.; SCHNEIDER, M. C.; TAMAYO, H.; CORREA, E. Overview of rabies in the Americas. Virus Research, v. 111, n. 1, p. 5-12, 2005.

BENGIS, R. G. Tuberculosis in free-ranging mammals. In: Zoo and wildlife animal medicine: current therapy. 4 ed. Philadelphia: WB Saunders, 1999. p. 101-114.

BENGIS, R. G.; KOCK, R. A.; FISCHER, J. Infectious animal diseases: the wildlife/livestock interface. Revue Scientifique et Technique del Office International des Epizooties, v. 21, n. 1, p. 53-65, 2002.

BENGIS, R. G.; KRIEK, N. P. J.; KEET, D. F.; RAATH, J. P.; DEVOS, V.; HUCHZERMEYER, H. An outbreak of bovine tuberculosis in a free-living African buffalo (Syncerus caffer-Sparrman) population in the Kruger National Park: a preliminary report. Onderstepoort Journal of Veterinary Research, v. 63, n. 1, p. 15-18, 1996. 
BERCOVIER, H.; VINCENT, V. Mycobacterial infections in domestic and wild animals due to Mycobacterium marinum, $M$. fortuitum, $M$. chelonae, $M$. porcinum, $M$. farcinogenes, $M$. smegmatis, $M$. scrofulaceum, $M$. xenopi, M. kansasii, M. simiae, and M. genavense. Revue Scientifique et Technique del Office International des Epizooties, v. 20, n. 1, p. 265-269, 2001.

BIENEN, L.; TABOR, G. Applying an ecosystem approach to brucellosis control: can an old conflict between wildlife and agriculture be successfully managed? Frontiers in Ecology and the Environment, v. 4, n. 6, p. 319-327, 2006.

BIENZLE, D.; REGGETI, F.; WEN, X.; LITTLE, S.; HOBSON, J.; KRUTH, S. The variability of serological and molecular diagnosis of feline immunodeficiency virus infection. Canadian Veterinary Journal, v. 45, n. 9, p. 753-757, 2004.

BIONDO, A. W.; SANTOS, A. P.; GUIMARÃES, A. M. S.; VIEIRA, R. F. D.; VIDOTTO, O.; MACIEIRA, D. D.; ALMOSNY, N. R. P.; MOLENTO, M. B.; TIMENETSKY, J.; MORAIS, H. A.; GONZALEZ, F. H. D.; MESSICK, J. B. A review of the occurrence of hemoplasmas (Hemotrophic mycoplasmas) in Brazil. Revista Brasileira de Parasitologia Veterinária, v. 18, n. 3, p. 1-7, 2009.

BIRKENHEUER, A. J.; LEVY, M. G.; BREITSCHWERDT, E. B. Development and evaluation of a seminested PCR for detection and differentiation of Babesia gibsoni (Asian genotype) and B-canis DNA in canine blood samples. Journal of Clinical Microbiology, v. 41, n. 9, p. 4172-4177, 2003.

BIRKENHEUER, A. J.; MARR, H.; ALLEMAN, A. R.; LEVY, M. G.; BREITSCHWERDT, E. B. Development and evaluation of a PCR assay for the detection of Cytauxzoon felis DNA in feline blood samples. Veterinary Parasitology, v. 137, n. 1-2, p. 144-149, 2006.

BLANCO, K.; PRENDAS, J.; CORTES, R.; JIMENEZ, C.; DOLZ, G. Seroprevalence of viral infections in domestic cats in Costa Rice. Journal of Veterinary Medical Science, v. 71, n. 5, p. 661-663, 2009.

BLANTON, J. D.; ROBERTSON, K.; PALMER, D.; RUPPRECHT, C. E. Rabies surveillance in the United States during 2008. Journal of the American Veterinary Medical Association, v. 235, n. 6, p. 676-689, 2009.

BLOUIN, E. F.; KOCAN, A. A.; GLENN, B. L.; KOCAN, K. M.; HAIR, J. A. Transmission of Cytauxzoon felis from bobcats Felis rufus to domestic cats by dermacentor variabilis. Journal of Wildlife Diseases, v. 20, n. 3, p. 241-242, 1984.

BLYTHE, L. L.; SCHMITZ, J. A.; ROELKE, M.; SKINNER, S. Chronic encephalomyelitis caused by canine distemper virus in a bengal tiger. Journal of the American Veterinary Medical Association, v. 183, n. 11, p. $1159-1162,1983$.

BOID, R.; MCORIST, S.; JONES, T. W.; EASTERBEE, N.; HUBBARD, A. L.; JARRETT, O. Isolation of FeLV from a wild felid (Felis silvestris). Veterinary Record, v. 128, n. 11, p. 256-256, 1991. 
BOLZONI, L.; DOBSON, A. P.; GATTO, M.; LEO, G. A. Allometric scaling and seasonality in the epidemics of wildlife diseases. American Naturalist, v. 172, n. 6, p. 818-828, 2008.

BONDY, P. J.; COHN, L. A.; KERL, M. E. Feline cytauxzoonosis. Compendium on Continuing Education for the Practicing Veterinarian, v. 27, n. 1, p. 69-75, 2005.

BOSMAN, A. M.; VENTER, E. H.; PENZHORN, B. L. Occurrence of Babesia felis and Babesia leo in various wild felid species and domestic cats in Southern Africa, based on reverse line blot analysis. Veterinary Parasitology, v. 144, n. 1-2, p. 33-38, 2007.

BOWMAN, D.D. Georgi's parasitology for veterinarians. Philadelphia: W. B. Saunders, 1999. p. 119-120.

BRACCINI, G. L.; CHAPLIN, E. L.; STOBE, N. S.; ARAÚJO, F. A. P.; SANTO, N. R. Resultados de exames laboratoriais realizados no setor de protozoologia da Faculdade de Veterinária da UFRGS, Porto Alegre, nos anos de 1986 a 1990. Arquivos da Faculdade de Veterinária da UFRGS, v. 20, p. 134-149, 1992.

BRANDÃO, P. E. On the interference of clinical outcome on rabies transmission and perpetuation. Journal of Venomous Animals and Toxins Including Tropical Diseases, v. 15, n. 2, p. 190-203, 2009.

BRASIL. Ministério da Agricultura, Pecuária e Abastecimento. Programa Nacional de Controle e Erradicação da Brucelose e da Tuberculose Animal (PNCEBT). Brasília: MAPA, 2006. p. 188.

BREMER-MELHIOR, P.; DRUGEON, H. B. Inativation of Mycobacterium tuberculosis for DNA typing analysis. Journal of Clinical Microbiology, v. 37, n. 7, p. 2350-2351, 1999.

BRESCIANI, K. D. S.; COSTA, A. J.; NAVARRO, I. T.; TONIOLLO, G. H.; SAKAMOTO, C. A. M.; ARANTES, T. P.; GENNARI, S. M. Canine toxoplasmosis: clinical and pathological aspects. Semina: ciências agrárias, v. 29, n. 1, p. 189-201, 2008.

BRESCIANI, K. D. S.; GENNARI, S. M.; SERRANO, A. C. M.; RODRIGUES, A. A. R.; UENO, T.; FRANCO, L. G.; PERRI, S. H. V.; AMARANTE, A. F. T. Antibodies to Neospora caninum and Toxoplasma gondii in domestic cats from Brazil. Parasitology Research, v. 100, n. 2, p. 281-285, 2007.

BRIGGS, M. B.; LEATHERS, C. W.; FOREYT, W. J. Sarcocystis felis in captive cheetahs (Acinonyx jubatus). Journal of the Helminthological Society of Washington, v. 60, n. 2, p. 277-279, 1993.

BRIONES, V.; JUAN, L.; SÁNCHEZ, C.; VELA, A. I.; GALKA, M.; MONTERO, N.; GOYACHE, J.; ARANAZ, A.; MATEOS, A.; DOMÍNGUEZ, L. Bovine tuberculosis and the endangered Iberian lynx. Emerging Infectious Diseases, v. 6, n. 2, p. 189-191, 2000. 
BRITO, A. F.; SOUZA, L. C.; SILVA, A. V.; LANGONI H. Epidemiological and serological aspects in canine toxoplasmosis in animals with nervous symptoms. Memórias do Instituto Oswaldo Cruz, v. 97, n. 1, p. 3135, 2002.

BROCKLESBY, D. W.; VIDLER, B. O. Some new host records for Hepatozoon specis in Kenya. Veterinary Record, v. 75, p. 1265, 1963.

BRONSON, E.; EMMONS, L. H.; MURRAY, S.; DUBOVI, E. J.; DEEM, S. L. Serosurvey of pathogens in domestic dogs on the border of Noel Kempff Mercado National Park, Bolivia. Journal of Zoo and Wildlife Medicine, v. 39, n. 1, p. 28-36, 2008.

BROOKS, R. W.; GEORGE, K. L.; PARKER, B. C.; FALKINHAM III, J. O.; GRUFT, H. Recovery and survival of nontuberculous mycobacteria under various growth and decontamination conditions. Canadian Journal of Microbiology, v. 30, n. 9, p. 1112-1117, 1984.

BROWN, C. A.; ROBERTS, A. W.; MILLER, M. A.; DAVIS, D. A.; BROWN, S. A.; BOLIN, C. A.; JARECKIBLACK, J.; GREENE, C. E.; MILLERLIEBL, D. Leptospira interrogans serovar grippotyphosa infection in dogs. Journal of the American Veterinary Medical Association, v. 209, n. 7, p. 1265, 1996.

BROWN, E. W.; MITHTHAPALA, S.; OBRIEN, S. J. Prevalence of exposure to feline immunodeficiency virus in exotic felid species. Journal of Zoo and Wildlife Medicine, v. 24, n. 3, p. 357-364, 1993.

BROWN, E. W.; YUHKI, N.; PACKER, C.; OBRIEN, S. J. A lion lentivirus related to feline immunodeficiency virus: epidemiologic and phylogenetic aspects. Journal of Virology, v. 68, n. 9, p. 5953-5968, 1994.

BROWN, H. M.; LATIMER, K. S.; ERIKSON, L. E.; CASHWELL, M. E.; BRITT, J. O.; PETERSON, D. S. Detection of persistent Cytauxzoon felis infection by polymerase chain reaction in three asymptomatic domestic cats. Journal of Veterinary Diagnostic Investigation, v. 20, n. 4, p. 485-488, 2008.

BROWN, M.; LAPPIN, M. R.; BROWN, J. L.; MUNKHTSOG, B.; SWANSON, W. F. Exploring the ecologic basis for extreme susceptibility of Pallas cats (Otocolobus manul) to fatal toxoplasmosis. Journal of Wildlife Diseases, v. 41, n. 4, p. 691-700, 2005.

BRUNING-FANN, C. S.; SCHMITT, S. M.; FITZGERALD, S. D.; PAYEUR, J. B.; WHIPPLE, D. L.; COOLEY, T. M.; CARLSON, T.; FRIEDRICH, P. Mycobacterium bovis in coyotes from Michigan. Journal of Wildlife Diseases, v. 34, n. 3, p. 632-636, 1998.

BWANGAMOI, O.; ROTTCHER, D.; WEKESA, C. Rabies, microbesnoitiosis and sarcocystosis in a lion. Veterinary Record, v. 127, n. 16, p. 411-411, 1990. 
CACCIO, S. M.; DE GIACOMO, M.; POZIO, E. Sequence analysis of the beta-giardin gene and development of a polymerase chain reaction-restriction fragment length polymorphism assay to genotype Giardia duodenalis cysts from human faecal samples. International Journal of Parasitology, v. 32, n. 8, 10231030, 2002.

CAMARGO, M. E. Improved technique of indirect immunofluorescence for serological diagnosis of toxoplasmosis. Revista do Instituto de Medicina Tropical, v. 6, n. 3, p. 117-118, 1964.

CAMICAS, J.-L.; HERVY, J.-P.; ADAM, F.; MOREL, P.-C. The ticks of the world (Acarida, Ixodida). Nomenclature, described stages, hosts, distribution (including new species described before 1/01/96). Paris: Editions de l'Orstom, 1998. 233 p.

CANÇADO, P. H. D.; PIRANDA, E. M.; MOURAO, G. M.; FACCINI, J. L. H. Spatial distribution and impact of cattle raising on ticks in the Pantanal region of Brazil by using the CO2 tick trap. Parasitology Research, v. 103, n. 2, p. 371-377, 2008.

CANNON, R. M.; ROE, R. T. Livestock disease surveys: a field manual for veterinarians. Canberra: Australian Government Publishing Service, 1982. 35 p.

CANON-FRANCO, W. A.; YAI, L. E. O.; JOPPERT, A. M.; SOUZA, C. E.; D'AURIA, S. R. N.; DUBEY, J. R.; GENNARI, S. M. Seroprevalence of Toxoplasma gondii antibodies in the rodent capybara (Hidrochoeris hidrochoeris) from Brazil. Journal of Parasitology, v. 89, n. 4, p. 850-850, 2003.

CAPORALE, G. M. M.; SILVA, A. D. R.; PEIXOTO, Z. M. P.; CHAVES, L. B.; CARRIERI, M. L.; VASSAO, R. C. First production of fluorescent anti-ribonucleoproteins conjugate for diagnostic of rabies in Brazil. Journal of Clinical Laboratory Analysis, v. 23, n. 1, p. 7-13, 2009.

CARLETTI, R. T.; CONTENTE, A. P. A.; NAVARRO, I. T.; PRUDENCIO, L. B.; TSUTSUI, V. S.; MARANA, E. R. M.; ROMÃO, G. O. Surto de toxoplasmose em Santa Isabel do Ivaí - PR, Brasil: sorologia em animais domésticos. In: CONGRESSO BRASILEIRO DE MEDICINA VETERINÁRIA, 29., 2002, Gramado. Anais... Gramado: Sociedade Brasileira de Medicina Veterinária, 2002. p. 60.

CARNIELI JÚNIOR, P.; BRANDÃO, P. E.; CARRIERI, M. L.; CASTILHO, J. G.; MACEDO, C. I.; MACHADO, L. M.; RANGEL, N.; CARVALHO, R. C.; CARVALHO, V. A.; MONTEBELLO, L.; WADA, M.; KOTAIT, I. Molecular epidemiology of rabies virus strains isolated from wild canids in Northeastern Brazil. Virus Research, $v$. 120, n. 1-2, p. 113-120, 2006.

CARNIELI JÚNIOR, P.; CASTILHO, J. G.; FAHL, W. D.; VERAS, N. M. C.; CARRIERI, M. L.; KOTAIT, I. Molecular characterization of rabies virus isolates from dogs and crab-eating foxes in Northeastern Brazil. Virus Research, v. 141, n. 1, p. 81-89, 2009. 
CARNIELI JÚNIOR, P.; FAHL, W. O.; CASTILHO, J. G.; OLIVEIRA, R. N.; MACEDO, C. I.; DURYMANOVA, E.; JORGE, R. S. P.; MORATO, R. G.; SPINDOLA, R. O.; MACHADO, L. M.; SÁ, J. E. U.; CARRIERI, M. L.; KOTAIT, I. Characterization of Rabies virus isolated from canids and identification of the main wild canid host in Northeastern Brazil. Virus Research, v. 131, n. 1, p. 33-46, 2008.

CARPENTER, M. A.; APPEL, M. J. G.; ROELKE-PARKER, M. E.; MUNSON, L.; HOFER, H.; EAST, M.; O'BRIEN, S. J. Genetic characterization of canine distemper virus in Serengeti carnivores. Veterinary Immunology and Immunopathology, v. 65, n. 2-4, p. 259-266, 1998.

CARPENTER, M. A.; BROWN, E. W.; JOHNSON, W. E.; BROUSSET, D.; OBRIEN, S. J. Variation in the pol gene of feline immunodeficiency virus in pumas from North, Central and South America. Aids Research and Human Retroviruses, v. 11, p. S94-S94, 1995. Supplement.

CARPENTER, M. A.; OBRIEN, S. J. Coadaptation and immunodeficiency virus: lessons from the Felidae. Current Opinion in Genetics and Development, v. 5, n. 6, p. 739-745, 1995.

CAVALCANTE, G. T.; AGUIAR, D. M.; CHIEBAO, D. P.; DUBEY, J. P.; RUIZ, V. L. A.; DIAS, R. A.; CAMARGO, L. M. A.; LABRUNA, M. B.; GENNARI, S. M. Seroprevalence of Toxoplasma gondii antibodies in cats and pigs from rural Western Amazon, Brazil. Journal of Parasitology, v. 92, n. 4, p. 863-864, 2006.

CAVALCANTI, R. B.; JOLY, C. A. Biodiversity and conservation priorities in the Cerrado region. In: OLIVEIRA, P. S.; MARQUIS, R. J. The cerrados of Brazil: ecology and natural history of a neotropical savannah. New York: Columbia University Press, 2002. p. 351-367.

CAVALCANTI, S. M. C.; GESE, E. M. Kill rates and predation patterns of jaguars (Panthera onca) in the Southern Pantanal, Brazil. Journal of Mammalogy, v. 91, n. 3, p. 722-736, 2010.

CAXITO, F. A.; COELHO, F. M.; OLIVEIRA, M. E.; RESENDE, M. Feline immunodeficiency virus subtype B in domestic cats in Minas Gerais, Brazil. Veterinary Research Communications, v. 30, n. 8, p. 953-956, 2006.

CENTRO PANAMERICANO DE ZOONOSIS. Diagnóstico de laboratório de la tuberculosis animal. Buenos Aires, 1972. 48 p. (Nota técnia, 26).

CHALMERS, R. M.; DAVIES, A. P. Minireview: clinical cryptosporidiosis. Experimental Parasitology, v. 124, n. 1, p. 138-146, 2010.

CHALMERS, W. S.; BAXENDALE, W. A comparison of canine distemper vaccine and measles vaccine for the prevention of canine distemper in young puppies. Veterinary Record, v. 135, n. 15, p. 349-353, 1994.

CHAPLIN, E. L.; SILVA, N. R. S.; SEBBEN, J. C.; ARAÚJO, F. A. P.; MENDEZ, L. D. V. Cadeia epidemiológica de toxoplasmose em Guaporé, RS, relacionando humanos e seus animais domésticos. Arquivos da Faculdade de Veterinária UFRGS, v. 12, n. 1, p. 25-34, 1984. 
CHARLTON, K. M.; CASEY, G. A. Experimental rabies in skunks: oral, nasal, tracheal and intestinal exposure. Canadian Journal of Comparative Medicine, v. 43, n. 2, p. 168-172, 1979.

CHATE S. C.; DIAS, R. A.; AMAKU, M.; FERREIRA, F.; MORAES, G. M.; COSTA NETO, A. A.; MONTEIRO, L. A. R. C.; LÔBO, J. R.; FIGUEIREDO, V. C. F.; GONÇALVES, V. S. P.; FERREIRA NETO, J. S. Situação epidemiológica da brucelose bovina no Estado do Mato Grosso do Sul. Arquivo Brasileiro de Medicina Veterinária e Zootecnia, v. 61, n. 1, p. 46-55, 2009.

CHAVES, L. B; MAZUTTI, A. L. C.; CAPORALE, G. M. M.; SCHEFFER, K. C.; SILVA, A. C. R. Comparasion of RFFIT performed in lab-tek ${ }^{\circledR}$ and in 96-well microtitre plates. In: INTERNATIONAL CONFERENCE ON RABIES IN THE AMERICA, 17., 2006, Brasília. Anais... Brasília: 2006.

CHIMARA, E.; FERRAZOLI, L.; UEKY, S. Y. M.; MARTINS, M. C.; DURHAM, A. M.; ARBEIT, R. D.; LEÃO, S. C. Reliable identification of mycobacterial species by PCR-Restriction Enzyme Analysis (PRA)-hsp65 in a reference laboratory and elaboration of a sequence based extended algorithm of PRA-hsp65 patterns. BCM Microbiology, v. 8: 48, 2008. Disponível em: < http://www.biomedcentral.com/147-2180/8/48> Acesso em: 27 maio 2010.

CITINO, S. B. Transient FelV viremia in a clouded leopard. Journal of Zoo Animal Medicine, v. 17, n. 1, p. 57, 1986.

CLEAVELAND, S.; APPEL, M. G. J.; CHALMERS, W. S. K.; CHILLINGWORTH, C.; KAARE, M.; DYE, C. Serological and demographic evidence for domestic dogs as a source of canine distemper virus infection for Serengeti wildlife. Veterinary Microbiology, v. 72, n. 3-4, p. 217-227, 2000.

CLEAVELAND, S.; LAURENSON, M. K.; TAYLOR, L. H. Diseases of humans and their domestic mammals: pathogen characteristics, host range and the risk of emergence. Philosophical Transactions of the Royal Society of London Series B Biological Sciences, v. 356, n. 1411, p. 991-999, 2001.

CLEAVELAND, S.; MLENGEYA, T.; KAARE, M.; HAYDON, D.; LEMBO, T.; LAURENSON, M. K.; PACKER, C. The conservation relevance of epidemiological research into carnivore viral diseases in the Serengeti.

Conservation Biology, v. 21, n. 3, p. 612-622, 2007.

CLEAVELAND, S.; MLENGEYA, T.; KAZWALA, R. R.; MICHEL, A.; KAARE, M. T.; JONES, S. L.; EBLATE, E.; SHIRIMA, G. M.; PACKER, C. Tuberculosis in Tanzanian wildlife. Journal of Wildlife Diseases, v. 41, n. 2, p. 446-453, 2005.

CLIFFORD, D. L.; MAZET, J. A. K.; DUBOVI, E. J.; GARCELON, D. K.; COONAN, T. J.; CONRAD, P. A.; MUNSON, L. Pathogen exposure in endangered island fox (Urocyon littoralis) populations: implications for conservation management. Biological Conservation, v. 131, n. 2, p. 230-243, 2006.

CLIFTON-HADLEY, R. S.; SAUTER-LOUIS, C. M.; LUGTON, I. W.; JACKSON, R.; DURR, P. A.; WILESMITH, J. W. Mycobacterium bovis infections. In: WILLIAMS, E. S.; BARKER, I. K. Infectious diseases of wild mammals. 3. ed. Ames: Iowa State University Press, 2001. p. 340-361. 
COLLINS, J. D. Tuberculosis in cattle: new perspectives. Tuberculosis, v. 81, n. 1-2, p. 17-21, 2001.

COLLY, L. P.; NESBIT, J. W. Fatal acute babesiosis in a juvenile wild dog (Lycaon-pictus). Journal of the South African Veterinary Association Tydskrif Van Die Suid Afrikaanse Veterinere Vereniging, v. 63, n. 1, p. 36-38, 1992.

CONCEIÇÃO-SILVA, F. M.; ABRANCHES, P.; SILVA-PEREIRA, M. C. D.; JANZ, J. G. Hepatozoonosis in foxes from Portugal. Journal of Wildlife Diseases, v. 24, n. 2, p. 344-347, 1988.

CONDE, D. A.; COLCHERO, F.; ZARZA, H.; CHRISTENSEN, N. L.; SEXTON, J. O.; MANTEROLA, C.; CHAVEZ, C.; RIVERA, A.; AZUARA, D.; CEBALLOS, G. Sex matters: modeling male and female habitat differences for jaguar conservation. Biological Conservation, v. 143, n. 9, p. 1980-1988, 2010.

CONFORTI, V. A.; AZEVEDO, F. C. C. Local perceptions of jaguars (Panthera onca) and pumas (Puma concolor) in the Iguaçu National Park area, South Brazil. Biological Conservation, v. 111, n. 2, p. 215-221, 2003.

CORRÊA, S. H. R. Epidemiologia da leptospirose em animais silvestres da Fundação Parque Zoológico de São Paulo. 2000. 68 f. Dissertação (Mestrado) - Faculdade de Medicina Veterinária e Zootecnia, Universidade de São Paulo, São Paulo, 2000.

CORRÊA, S. H. R. Leptospirose. In: CUBAS, Z. S.; SILVA, J. C. R.; CATÃO-DIAS, J. L. Tratado de animais selvagens: medicina veterinária. São Paulo: Roca, 2006. p. 358-377.

CORRÊA, S. H. R.; PASSOS, E. C. Wild animals and public health. In: FOWLER, M. E.; CUBAS, Z. S. Biology, medicine, and surgery of South American wild animals. Ames: lowa University Press, 2001. p. 493-499.

CORRÊA, S. H. R.; TEIXEIRA, R. H. F. Ocorrência de Haemobartonella felis e Babesia sp. em felinos neotropicais cativos na Fundação Parque Zoológico de São Paulo. In: CONGRESSO DE ZOOLÓGICOS DO BRASIL, 27., 2003, Bauru. Resumos... Bauru: Sociedade de Zoológicos do Brasil, 2003.

COSTA, A. J.; COSTA, E. P. Incidence of Toxoplasma gondii in bovines, through indirect immunofluorescence in Poços de Caldas - MG, Brazil. Arquivos da Escola de Veterinária da Universidade Federal de Minas Gerais, v. 30, n. 1, p. 47-51, 1978.

COSTA, E. O.; DINIZ, L. S. M.; FAVA NETTO, C. Ecological aspects of fungal and bacterial infections of wild mammals in South America. Israel Journal of Veterinary Medicine, v. 52, n. 4, p. 137-140, 1997.

COSTA, G. H. N.; CABRAL, D. D.; VARANDAS, N. P.; SOBRAL, E. A.; BORGES, F. A.; CASTAGNOLLI, K. C. Frequência de anticorpos anti-Neospora caninum e anti-Toxoplasma gondii em soros de bovinos pertencentes aos estados de São Paulo e de Minas Gerais. Semina: ciências agrárias, v. 22, n. 1, p. 61-66, 2001. 
COURTENAY, O.; QUINNELL, R. J.; CHALMERS, W. S. K. Contact rates between wild and domestic canids: no evidence of parvovirus or canine distemper virus in crab-eating foxes. Veterinary Microbiology, v. 81, n. 1, p. 9-19, 2001.

CRAWSHAW, P. G; QUIGLEY, H. B. Jaguar and puma feeding habits in the Pantanal, Brazil, with implications for their management and conservation. In: MEDELLIN, R. A.; CHETKIEWICZ; RABINOWITZ, A.; REDFORD, K. H.; ROBINSON, J. G.; SANDERSON, E. W.; TABER, A. B. (Ed.). El Jaguar en el nuevo milenio. Una evaluacion de su estado, deteccion de prioridades y recomendaciones para la conservacion de los jaguars en America. México, D. F.: Universidad Nacional Autonoma de Mexico/Wildlife Conservation Society, 2002. p. 223-235.

CRAWSHAW, P. G.; QUIGLEY, H. B. Jaguar spacing, activity and habitat use in a seasonally flooded environment in Brazil. Journal of Zoology, v. 223, n. 3, p. 357-370, 1991.

CRIADO-FORNELIO, A.; BULING, A.; CASADO, N.; GIMENEZ, C.; RUAS, J.; WENDT, L.; DA ROSA-FARIAS, N.; PINHEIRO, M.; REY-VALEIRON, C.; BARBA-CARRETERO, J. C. Molecular characterization of arthropod-borne hematozoans in wild mammals from Brazil, Venezuela and Spain. Acta Parasitologica, v. 54, n. 3, p. 187193, 2009.

CRIADO-FORNELIO, A.; MARTINEZ-MARCOS, A.; BULING-SARANA, A.; BARBA-CARRETERO, J. C. Presence of Mycoplasma haemofelis, Mycoplasma haemominutum and piroplasmids in cats from Southern Europe: a molecular study. Veterinary Microbiology, v. 93, n. 4, p. 307-317, 2003.

CRIADO-FORNELIO, A.; RUAS, J. L.; CASADO, N.; FARIAS, N. A. R.; SOARES, M. R.; MULLER, G.; BRUM, J. G. W.; BERNE, M. E. A.; BULING-SARANA, A.; BARBA-CARRETERO, J. C. New molecular data on mammalian Hepatozoon species (Apicomplexa : Adeleorina) from Brazil and Spain. Journal of Parasitology, v. 92, n. 1, p. 93-99, 2006.

CROSS, M. L.; BUDDLE, B. M.; ALDWELL, F. E. The potential of oral vaccines for disease control in wildlife species. Veterinary Journal, v. 174, n. 3, p. 472-480, 2007.

CROSS, M. L.; LAMBETH, M. R.; ALDWELL, F. E. An oral Mycobacterium bovis BCG vaccine for wildlife produced in the absence of animal derived reagents. Clinical and Vaccine Immunology, v. 16, n. 9, p. 1378-1380, 2009.

CROSS, P. C.; COLE, E. K.; DOBSON, A. P.; EDWARDS, W. H.; HAMLIN, K. L.; LUIKART, G.; MIDDLETON, A. D.; SCURLOCK, B. M.; WHITE, P. J. Probable causes of increasing brucellosis in free-ranging elk of the Greater Yellowstone Ecosystem. Ecological Applications, v. 20, n. 1, p. 278-288, 2010.

CULLEN, L.; ALGER, K.; RAMBALDI, D. M. Land reform and biodiversity conservation in Brazil in the 1990s: Conflict and the articulation of mutual interests. Conservation Biology, v. 19, n. 3, p. 747-755, 2005. 
CUNNINGHAM, M, W.; BROWN, M. A.; SHINDLE, D. B.; TERRELL, S. P.; HAYES, K. A.; FERREE, B. C.; MCBRIDE, R. T.; BLANKENSHIP, E. L.; JANSEN, D.; CITINO, S. B.; ROELKE, M. E.; KILTIE, R. A.; TROYER, J. L.; O'BRIEN, S. J. Epizootiology and management of feline leukemia virus in the Florida puma. Journal of Wildlife Disease, v. 44, n. 3, p. 537-552, 2008.

CURI, N. H. A.; TALAMONI, S. A. Trapping, restraint and clinical-morphological traits of wild canids (Carnivora, Mammalia) from the Brazilian Cerrado. Revista Brasileira de Zoologia, v. 23, n. 4, p. 11481152, 2006.

CUTLER, S. J.; WHATMORE, A. M.; COMMANDER, N. J. Brucellosis - new aspects of an old disease. Journal of Applied Microbiology, v. 98, n. 6, p. 1270-1281, 2005.

DAGUER, H.; VICENTE, R. T.; COSTA, T.; HAMANN, M. P. V.; AMENDOEIRA, M. R. R. Soroprevalência de anticorpos anti-Toxoplasma gondii em bovinos e funcionários de matadouros da microrregião de Pato Branco, Paraná, Brasil. Ciência Rural, v. 34, n. 4, p. 1133-1137, 2004.

DANIELS, M. J.; GOLDER, M. C.; JARRETT, O.; MACDONALD, D. W. Feline viruses in wildcats from Scotland. Journal of Wildlife Diseases, v. 35, n. 1, p. 121-124, 1999.

DANTAS-TORRES, F. Canine vector-borne diseases in Brazil. Parasites and Vectors, v. 1, n. 1, p. $25,2008$.

DANTAS-TORRES, F.; FERREIRA, D. R. A.; MELO, L. M.; LIMA, P.; SIQUEIRA, D. B.; RAMEH-DEALBUQUERQUE, L. C.; MELO, A. V.; RAMOS, J. A. C. Ticks on captive and free-living wild animals in Northeastern Brazil. Experimental and Applied Acarology, v. 50, n. 2, p. 181-189, 2010.

DANTAS-TORRES, F.; FIGUEREDO, L. A. Canine babesiosis: a Brazilian perspective. Veterinary Parasitology, v. 141, n. 3-4, p. 197-203, 2006.

DANTAS-TORRES, F.; FIGUEREDO, L. A.; BRANDÃO, S. P. Rhipicephalus sanguineus (Acari: Ixodidae), the brown dog, tick parasitizing humans in Brazil. Revista da Sociedade Brasileira de Medicina Tropical, v. 39, n. 1, p. 64-67, 2006.

DASZAK, P.; CUNNINGHAM, A. A.; HYATT, A. D. Anthropogenic environmental change and the emergence of infectious diseases in wildlife. Acta Tropica, v. 78, n. 2, p. 103-116, 2001.

DASZAK, P.; CUNNINGHAM, A. A.; HYATT, A. D. Wildlife ecology - Emerging infectious diseases of wildlife Threats to biodiversity and human health. Science, v. 287, n. 5452, p. 443-449, 2000.

DAVIDSON, W. R.; NETTLES, V. F.; HAYES, L. E.; HOWERTH, E. W.; COUVILLION, C. E. Diseases diagnosed in gray foxes (Urocyon cinereoargenteus) from the Southeastern United-States. Journal of Wildlife Diseases, v. 28, n. 1, p. 28-33, 1992. 
DAVIS, D. S. Brucellosis in wildlife. In: NIELSEN, K.; DUNCAN, R. J. Animal brucellosis. Boca Raton: CRC Press, 1990. p. 321-334.

DAVIS, D. S.; ELZER, P. H. Brucella vaccines in wildlife. Veterinary Microbiology, v. 90, n. 1-4, p. 533-544, 2002.

DAVIS, D. S.; ROBINSON, R. M.; CRAIG, T. M. Naturally occurring hepatozoonosis in a coyote. Journal of Wildlife Diseases, v. 14, n. 2, p. 244-246, 1978.

DAVIS, L. J. On a piroplasm of the Sudanese wild cat (Felis ocreata). Transactions of the Royal Society of Tropical Medicine and Hygiene, v. 22, n. 6, p. 535-537, 1929.

DEAN, R. S.; HELPS, C. R.; JONES, T. J. G.; TASKER, S. Use of real-time PCR to detect Mycoplasma haemofelis and 'Candidatus Mycoplasma haemominutum' in the saliva and salivary glands of haemoplasma-infected cats. Journal of Feline Medicine and Surgery, v. 10, n. 4, p. 413-417, 2008.

DE CAMPS, S.; DUBEY, J. P.; SAVILLE, W. J. A. Seroepidemiology of Toxoplasma gondii in zoo animals in selected zoos in the Midwestern United States. Journal of Parasitology, v. 94, n. 3, p. 648-653, 2008.

DEEM, S. L.; DAVIS, R.; PACHECO, L. F. Serologic evidence of nonfatal rabies exposure in a free-ranging oncilla (Leopardus tigrinus) in Cotapata National Park, Bolivia. Journal of Wildlife Diseases, v. 40, n. 4, p. 811-815, 2004.

DEEM, S. L.; EMMONS, L. H. Exposure of free-ranging maned wolves (Chrysocyon brachyurus) to infectious and parasitic disease agents in the Noel Kempff Mercado National Park, Bolivia. Journal of Zoo and Wildlife Medicine, v. 36, n. 2, p. 192-197, 2005.

DEEM, S. L.; KARESH, W. B.; WEISMAN, W. Putting theory into practice: wildlife health in conservation. Conservation Biology, v. 15, n. 5, p. 1224-1233, 2001.

DEEM, S. L.; SPELMAN, L. H.; YATES, R. A.; MONTALI, R. J. Canine distemper in terrestrial carnivores: a review. Journal of Zoo and Wildlife Medicine, v. 31, n. 4, p. 441-451, 2000.

DE KANTOR, I. N.; AMBROGGI, M.; POGGI, S.; MORCILLO, N.; TELLES, M.; RIBEIRO, M. O.; TORRES, M. C. G.; POLO, C. L.; RIBON, W.; GARCIA, V.; KUFFO, D.; ASENCIOS, L.; CAMPOS, L. M. V.; RIVAS, C.; DE WAARD, J. H. Human Mycobacterium bovis infection in ten Latin American countries. Tuberculosis, v. 88, n. 4, p. 358-365, 2008.

DELAHAY, R. J.; CHEESEMAN, C. L.; CLIFTON-HADLEY, R. S. Wildlife disease reservoirs: the epidemiology of Mycobacterium bovis infection in the European badger (Meles meles) and other British mammals. Tuberculosis, v. 81, n. 1-2, p. 43-49, 2001. 
DEL PUERTO, H. L.; VASCONCElOS, A. C.; MORO, L.; ALVES, F.; BRAZ, G. F.; MARTINS, A. S. Canine distemper virus detection in asymptomatic and non vaccinated dogs. Pesquisa Veterinária Brasileira, $v$. 30, n. 2, p. 139-144, 2010.

DELL'PORTO, A.; OLIVEIRA, M. R.; MIGUEL, O. Babesia canis in stray dogs from the city of São Paulo comparative studies between the clinical and hematological aspects and the indirect fluorescence antibody test. Revista Brasileira de Parasitologia Veterinária, v. 2, n. 1, p. 37-40, 1993.

DEMAR, M.; AJZENBERG, D.; SERRURIER, B.; DARDE, M. L.; CARME, B. Case report: a typical Toxoplasma gondii strain from a free-living jaguar (Panthera onca) in French Guiana. American Journal of Tropical Medicine and Hygiene, v. 78, n. 2, p. 195-197, 2008.

DENNING, H. K.; BROCKLES.D. W. Babesia pantherae sp.nov., a piroplasm of leopard (Panthera pardus). Parasitology, v. 64, n. 3, p. 525, 1972.

DE SANTIS-KERR, A. C.; RAGHAVAN, M.; GLICKMAN, N. W.; CALDANARO, R. J.; MOORE, G. E.; LEWIS, H. B.; SCHANTZ, P. M.; GLICKMAN, L. T. Prevalence and risk factors for Giardia and coccidia species of pet cats in 2003-2004. Journal of Feline Medicine and Surgery, v. 8, n. 5, p. 292-301, 2006.

DE VOS, V.; BENGIS, R. G.; KRIEK, N. P. J.; MICHEL, A.; KEET, D. F.; RAATH, J. P.; HUCHZERMEYER, H. The epidemiology of tuberculosis in free-ranging African buffalo (Syncerus caffer) in the Kruger National Park, South Africa. Onderstepoort Journal of Veterinary Research, v. 68, n. 2, p. 119-130, 2001.

DEZENGRINI, R.; WEIBLEN, R.; FLORES, E. F. Seroprevalence of parvovirus, adenovirus, coronavirus and canine distemper virus infections in dogs of Santa Maria, Rio Grande do Sul, Brazil. Ciência Rural, v. 37, n. 1, p. 183-189, 2007.

DOBSON, A.; FOUFOPOULOS, J. Emerging infectious pathogens of wildlife. Philosophical Transactions of the Royal Society of London Series B-Biological Sciences, v. 356, n. 1411, p. 1001-1012, 2001.

DORNY, P.; FRANSEN, J. Toxoplasmosis in a siberian tiger (Panthera tigris altaica). Veterinary Record, v. 125, n. 26-27, p. 647-647, 1989.

DRICIRU, M.; SIEFERT, L.; PRAGER, K. C.; DUBOVI, E.; SANDE, R.; PRINCEE, F.; FRIDAY, T.; MUNSON, L. A serosurvey of viral infections in lions (Panthera leo), from Queen Elizabeth National Park, Uganda. Journal of Wildlife Diseases, v. 42, n. 3, p. 667-671, 2006.

DRYDEN, M. W.; PAYNE, P. A.; SMITH, V. Accurate diagnosis of Giardia spp. and proper fecal examination procedures. Veterinary Therapeutics, v. 7, n. 1, p. 4-14, 2006.

DUBEY, J. P. Advances in the life cycle of Toxoplasma gondii. International Journal for Parasitology, v. 28, n. 7, p. 1019-1024, 1998. 
DUBEY, J. P. Comparative infectivity of oocysts and bradyzoites of Toxoplasma gondii for intermediate (mice) and definitive (cats) hosts. Veterinary Parasitology, v. 140, n. 1-2, p. 69-75, 2006.

DUBEY, J. P. Oocyst shedding by cats fed isolated bradyzoites and comparison of infectivity of bradyzoites of the VEG strain Toxoplasma gondii to cats and mice. Journal of Parasitology, v. 87, n. 1, p. 215-219, 2001.

DUBEY, J. P. Pathogenicity and infectivity of Toxoplasma gondii oocysts for rats. Journal of Parasitology, v. 82, n. 6, p. 951-956, 1996.

DUBEY, J. P. Review of sarcocystis of domestic animals and of other coccidia of cats and dogs. Journal of the American Veterinary Medical Association, v. 169, n. 10, p. 1061-1078, 1976.

DUBEY, J. P. Sarcocystis and other coccidia in foxes and other wild carnivores from Montana. Journal of the American Veterinary Medical Association. v. 181, n. 11, p. 1270-1271, 1982.

DUBEY, J. P. The history and life cycle of Toxoplasma gondii. In: WEISS, L. M.; KIM, K. Toxoplasma gondii. The model apicomplexan: perspectives and methods. New York: Academic Press, 2007. p. 1-17.

DUBEY, J. P. The history of Toxoplasma gondii: the first 100 years. Journal of Eukaryotic Microbiology, v. 55, n. 6, p. 467-475, 2008.

DUBEY, J. P. Toxoplasmosis. Journal of the American Veterinary Medical Association, v. 205, n. 11, p. 1593-1598, 1994.

DUBEY, J. P. Toxoplasmosis. Veterinary Clinics of North America: small animal practice, v. 17, n. 6, p. 1389-1404, 1987.

DUBEY, J. P. Toxoplasmosis: a waterborne zoonosis. Veterinary Parasitology, v. 126, n. 1-2, p. 57-72, 2004.

DUBEY, J. P. Toxoplasmosis in cats. Feline Practice, v. 16, n. 4, p. 12, 1986.

DUBEY, J. P.; BEATTIE, C. P. Toxoplasmosis of animals and man. Boca Raton: CRC Press, 1988. 220 p.

DUBEY, J. P.; BWANGAMOI, O. Sarcocystis felis (Protozoa: Sarcocystidae) from the African lion (Panthera leo). Journal of the Helminthological Society of Washington, v. 61, n. 1, p. 113-114, 1994.

DUBEY, J. P.; DESMONTS, G. Serological responses of equids fed Toxoplasma gondii oocysts. Equine Veterinary Journal, v. 19, n. 4, p. 337-339, 1987. 
DUBEY, J. P.; FRENKEL, J. K. Feline toxoplasmosis from acutely infected mice and development of toxoplasma cysts. Journal of Protozoology, v. 23, n. 4, p. 537-546, 1976.

DUBEY, J. P.; GOMEZ-MARIN, J. E.; BEDOYA, A.; LORA, F.; VIANNA, M. C. B.; HILL, D.; KWOK, O. C.; SHEN, S. K.; MARCET, P. L.; LEHMANN, T. Genetic and biologic characteristics of Toxoplasma gondii isolates in freerange chickens from Colombia, South America. Veterinary Parasitology, v. 134, n. 1-2, p. 67-72, 2005.

DUBEY, J. P.; HAMIR, A. N.; KIRKPATRICK, C. E.; TODD, K. S.; RUPPRECHT, C. E. Sarcocystis felis sp. n. (Protozoa: Sarcocystidae) from the bobcat (Felis rufus). Journal of the Helminthological Society of Washington, v. 59, n. 2, p. 227-229, 1992.

DUBEY, J. P.; SREEKUMAR, C. Redescription of Hammondia hammondi and its differentiation from Toxoplasma gondii. International Journal for Parasitology, v. 33, n. 13, p. 1437-1453, 2003.

DUBEY, J. P.; SU, C. Population biology of Toxoplasma gondii: what's out and where did they come from. Memórias do Instituto Oswaldo Cruz, v. 104, n. 2, p. 190-195, 2009.

DUBEY, J. P.; THULLIEZ, P. Serologic diagnosis of toxoplasmosis in cats fed Toxoplasma gondii tissue cysts. Journal of the American Veterinary Medical Association, v. 194, n. 9, p. 1297-1299, 1989.

DUBEY, J. P.; WEIGEL, R. M.; SIEGEL, A. M.; THULLIEZ, P.; KITRON, U. D.; MITCHELL, M. A.; MANNELLI, A.; MATEUSPINILLA, N. E.; SHEN, S. K.; KWOK, O. C. H.; TODD, K. S. Sources and reservoirs of Toxoplasma gondii infection on 47 swine farms in Illinois. Journal of Parasitology, v. 81, n. 5, p. 723-729, 1995.

DURDEN, L. A.; CUNNINGHAM, M. W.; MCBRIDE, R.; FERREE, B. Ectoparasites of free-ranging pumas and jaguars in the Paraguayan Chaco. Veterinary Parasitology, v. 137, n. 1-2, p. 189-193, 2006.

EAST, M. L.; HOFER, H.; COX, J. H.; WULLE, U.; WIIK, H.; PITRA, C. Regular exposure to rabies virus and lack of symptomatic disease in Serengeti spotted hyenas. Proceedings of the National Academy of Sciences of the United States of America, v. 98, n. 26, p. 15026-15031, 2001.

EAST, M. L.; WIBBELT, G.; LIECKFELDT, D.; LUDWIG, A.; GOLLER, K.; WILHELM, K.; SCHARES, G.; THIERER, D.; HOFER, H. A Hepatozoon species genetically distinct from $H$. canis infecting spotted hyenas in the Serengeti ecosystem, Tanzania. Journal of Wildlife Diseases, v. 44, n. 1, p. 45-52, 2008.

EATON, R. L. Why some felids copulate so much: a model for the evolution of copulation frequency. Carnivore, v. 1, n. 1, p. 42-51, 1978.

ENDO, Y.; UEMA, M.; MIURA, R.; TSUKIYAMA-KOHARA, K.; TSUJIMOTO, H.; YONEDA, K.; KAI, C. Prevalence of canine distemper virus, feline immunodeficiency virus and feline leukemia virus in captive African lions (Panthera leo) in Japan. Journal of Veterinary Medical Science, v. 66, n. 12, p. 1587-1589, 2004. 
EPIPHANIO, S.; GUIMARÃES, M.; FEDULLO, D. L.; CORREA, S. H. R.; CATÃO-DIAS, J. L. Toxoplasmosis in golden-headed lion tamarins (Leontopithecus chrysomelas) and emperor marmosets (Saguinus imperator) in captivity. Journal of Zoo and Wildlife Medicine, v. 31, n. 2, p. 231-235, 2000.

FAINE, S. Guidelines for the control of leptospirosis. Geneva: World Health Organization, 1982, 171 p. (WHO off set Publication, 67).

FALKINHAM, J. O. Nontuberculous mycobacteria in the environment. Clinics in Chest Medicine, v. 23, n. 3, p. 529, 2002.

FAVERO, M.; PINHEIRO, S. R.; VASCONCELLOS, S. A.; MORAIS, Z. M.; FERREIRA, F.; FERREIRA-NETO, J. S. Leptospirose bovina: variantes sorológicas predominantes em colheitas efetuadas no período de 1984 a 1997 em rebanhos de 21 estados do Brasil. Arquivos do Instituto Biológico, v. 68, n. 2, p. 29-35, 2001.

FAVORETTO, S. R.; MATTOS, C. C.; MORAIS, N. B.; CARRIERI, M. L.; ROLIM, B. N.; SILVA, L. M.; RUPPRECHT, C. E.; DURIGON, E. L.; MATTOS, C. A. Rabies virus maintained by dogs in humans and terrestrial wildlife, Ceará State, Brazil. Emerging Infectious Diseases, v. 12, n. 12, p. 1978-1981, 2006.

FAYER, R. Cryptosporidium: a water borne zoonotic parasite. Veterinary Parasitology, v. 126, n. 1-2, p. 3756, 2004.

FENG, Y. Cryptosporidium in wild placental mammals. Experimental Parasitology, v. 124, n. 1, p. 128-137, 2010.

FENG, Y.; ALDERISIO, K. A.; YANG, W.; BLANCERO, L. A.; KUHNE, W. G.; NADARESKI, C. A.; REID, M.; XIAO, L. Cryptosporidium genotypes in wildlife from a New York watershed. Applied and Environmental Microbiology, v. 73, n. 20, p. 6475-6483, 2007.

FERNANDES, W. J.; BARBOSA, W. Toxoplasmose: notas sobre sua ocorrência em animais domésticos em Goiânia - (1970). Revista de Patologia Tropical, v. 1, n. 2, p. 259-265, 1972.

FERRARONI, J. J.; MARZOCHI, M. C. D. A. Toxoplasmosis in domestic and wild animals of Manaus Amazonas Brazil. Acta Amazonica, v. 8, n. 1, p. 83-90, 1978.

FERREYRA, H.; CALDERON, M. G.; MARTICORENA, D.; MARULL, C.; LEONARDO, B. C. Canine distemper infection in crab-eating fox (Cerdocyon thous) from Argentina. Journal of Wildlife Diseases, v. 45, n. 4, p. 1158-1162, 2009.

FIALHO, C. G.; TEIXEIRA, M. C.; ARAÚJO, F. A. P. Animal toxoplasmosis in Brazil. Acta Scientiae Veterinariae, v. 37, n. 1, p. 1-23, 2009. 
FIGUEIREDO, A. D.; PELLEGRIN, A. O.; GONCALVES, V. S. P.; FREITAS, E. B.; MONTEIRO, L.; OLIVEIRA, J. M.; OSORIO, A. Prevalence and risk factors for bovine leptospirosis in Mato Grosso do Sul, Brazil. Pesquisa Veterinária Brasileira, v. 29, n. 5, p. 375-381, 2009.

FIGUEIREDO, P. C.; LOPES, C. W. G.; SERRA-FREIRE, N.M. Espécies do gênero Sarcocystis Lankaster, 1882 (Apicomplexa: Sarcocystidae), parasitas de ruminantes domésticos que têm o cão como hospedeiro definitivo. Arquivos da Universidade Federal Rural do Rio de Janeiro, v. 14, n.1, p. 1-12, 1991.

FILONI, C. Exposição de felídeos selvagens a agentes infecciosos selecionados. 2006. $126 \mathrm{f}$. Tese (Doutorado) - Faculdade de Medicina Veterinária e Zootecnia, Universidade de São Paulo, São Paulo, 2006.

FILONI, C.; ADANIA, C. H.; DURIGON, E. L.; CATÃO-DIAS, J. L. Serosurvey for feline leukemia virus and lentiviruses in captive small neotropic felids in São Paulo state, Brazil. Journal of Zoo and Wildlife Medicine, v. 34, n. 1, p. 65-68, 2003.

FILONI, C.; CATÃO-DIAS, J. L.; BAY, G.; DURIGON, E. L.; JORGE, R. S. P.; LUTZ, H.; HOFMANN-LEHMANN, R. First evidence of feline herpesvirus, calicivirus, parvovirus, and ehrlichia exposure in Brazilian free-ranging felids. Journal of Wildlife Diseases, v. 42, n. 2, p. 470-477, 2006.

FILONI, C.; CATÃO-DIAS, J. L.; LUTZ, H.; HOFMANN-LEHMANN, R. Retrovirus infections and Brazilian wild felids. Brazilian Journal of Veterinary Pathology, v. 1, n. 2, p. 88-96, 2008.

FIORELLO, C. V.; DEEM, S. L.; GOMPPER, M. E.; DUBOVI, E. Seroprevalence of pathogens in domestic carnivores on the border of Madidi National Park, Bolivia. Animal Conservation, v. 7, n. 1, p. 45-54, 2004.

FIORELLO, C. V.; NOSS, A. J.; DEEM, S. L.; MAFFEI, L.; DUBOVI, E. J. Serosurvey of small carnivores in the Bolivian Chaco. Journal of Wildlife Diseases, v. 43, n. 3, p. 551-557, 2007.

FIORELLO, C. V.; ROBBINS, R. G.; MAFFEI, L.; WADE, S. E. Parasites of free-ranging small canids and felids in the Bolivian Chaco. Journal of Zoo and Wildlife Medicine, v. 37, n. 2, p. 130-134, 2006.

FIX, A. S.; RIORDAN, D. P.; HILL, H. T.; GILL, M. A.; EVANS, M. B. Feline panleukopenia virus and subsequent canine distemper virus infection in 2 snow leopards (Panthera uncia). Journal of Zoo and Wildlife Medicine, v. 20, n. 3, p. 273-281, 1989.

FORBES, L. B. Brucella abortus infection in 14 farm dogs. Journal of the American Veterinary Medical Association, v. 196, n. 6, p. 911-916, 1990.

FORLANO, M.; SCOFIELD, A.; ELISEI, C.; FERNANDES, K. R.; EWING, S. A.; MASSARD, C. L. Diagnosis of Hepatozoon spp. in Amblyomma ovale and its experimental transmission in domestic dogs in Brazil. Veterinary Parasitology, v. 134, n. 1-2, p. 1-7, 2005. 
FOSTER, G.; OSTERMAN, B.; GODFROID, J.; JACQUES, I.; CLOECKAERT, A. Brucella ceti sp. nov. and Brucella pinnipedialis sp. nov. for Brucella strains with cetaceans and seals as their preferred hosts. International Journal of Systematic and Evolutionary Microbiology, v. 57, n. 11, p. 2688-2693, 2007.

FRANKLIN, S. P.; TROYER, J. L.; TERWEE, J. A.; LYREN, L. M.; BOYCE, W. M.; RILEY, S. P. D.; ROELKE, M. E.; CROOKS, K. R.; VANDEWOUDE, S. Frequent transmission of immunodeficiency viruses among bobcats and pumas. Journal of Virology, v. 81, n. 20, p. 10961-10969, 2007.

FRENKEL, J. K.; DUBEY, J. P.; MILLER, N. L. Toxoplasma gondii in cats. Fecal stages identified as coccidian oocysts. Science, v. 167, n. 3919, p. 893, 1970.

FROMONT, E.; SAGER, A.; LEGER, F.; BOURGUEMESTRE, F.; JOUQUELET, E.; STAHL, P.; PONTIER, D.; ARTOIS, M. Prevalence and pathogenicity of retroviruses in wildcats in France. Veterinary Record, v. 146, n. 11, p. 317-319, 2000.

FRYE, F. L.; CUCUEL, J. P. E. Rabies in an ocelot. Journal of the American Veterinary Medical Association, v. 153, n. 7, p. 789, 1968.

FU, Z. F. Rabies and rabies-research: past, present and future. Vaccine, v. 15, p. S20-S24, 1997. Supplement 1.

FUJIHARA, M.; WATANABE, M.; YAMADA, T.; HARASAWA, R. Occurrence of 'Candidatus Mycoplasma turicensis' infection in domestic cats in Japan. Journal of Veterinary Medical Science, v. 69, n. 10, p. 10611063, 2007.

FURTADO, L. R. I.; AVILA, O.; FEHLBERG, M. F. B.; TEIXEIRA, M. M.; ROSADO, R. L. I.; MARTINS, L. F. S.; BROD, C. S. Prevalência e avaliação de fatores de risco à leptospirose canina, no Município de Pelotas, RS. Arquivos do Instituto de Biologia, v. 64, n. 1, p. 57-61, 1997.

FURTADO, M. M.; CARRILLO-PERCASTEGUI, S. E.; JACOMO, A. T. A.; POWELL, G.; SILVEIRA, L.; VYNNE, C.; SOLLMANN, R. Studying jaguars in the wild: past experiences and future perspectives. Cat News, special issue, The jaguar in Brazil, n. 4, p. 41-47, 2008.

FURTADO, M. M.; FILONI, C. Diseases and their role for jaguar conservation. Cat News, special issue, The jaguar in Brazil, n. 4, p. 35-40, 2008.

FURTADO, M. M.; JÁCOMO, A. T. D.; KASHIVAKURA, C. K.; TÔRRES, N. M.; MARVULO, M. F. V.; RAGOZO, A. M. A.; SOUZA, S. L. P.; NETO, J. S. F.; VASCONCELLOS, S. A.; MORAIS, Z. M.; CORTEZ, A.; RICHTZENHAIN, L. J.; SILVA, J. C. R.; SILVEIRA, L. Serologic survey for selected infectious diseases in free-ranging Brazilian tapirs (Tapirus terrestris) in the Cerrado of central Brazil. Journal of Zoo and Wildlife Medicine, v. 41, n. 1, p. 133-136, 2010. 
FURTADO, M. M.; JÁCOMO, A. T. A.; SILVEIRA, L.; SOLLMANN, R.; TÔRRES, N. M.; IKUTA, C.; FERRERANETO, J. S. Epidemiologic relation between jaguars and domestic animal populations in three Brazilian biomes: Cerrado, Pantanal and Amazon. Oral presentation, Carnivores 2009. In: CARNIVORE CONSERVATION IN A CHANGING WORLD, 2009, Denver. Anais... Denver: Carnivore Conservation in a Changing World, 2009. p. 171.

FURTADO, M. M. ; KASHIVAKURA, C. K. ; FERREIRA NETO, J. S. ; JACOMO, A. T. A. ; SILVEIRA, L. Jaguar epidemiology program in Brazil. In: FELID BIOLOGY AND CONSERVATION AN INTERNATIONAL CONFERENCE, 2007, Oxford. Anais... Oxford: Felid Biology and Conservation an International Conference, 2007.

FUTTER, G. J.; BELONJE, P. C. Studies on feline babesiosis. 1. Historical review. Journal of the South African Veterinary Association Tydskrif Van Die Suid Afrikaanse Veterinere Vereniging, v. 51, n. 2, p. 105-106, 1980.

FYUMAGWA, R. D.; SIMMLER, P.; WILLI, B.; MELI, M. L.; SUTTER, A.; HOARE, R.; DASEN, G.; HOFMANNLEHMANN, R.; LUTZ, H. Molecular detection of haemotropic Mycoplasma species in Rhipicephalus sanguineus tick species collected on lions (Panthera leo) from Ngorongoro Crater, Tanzania. South African Journal of Wildlife Research, v. 38, n. 2, p. 117-122, 2008.

GARCIA-BOCANEGRA, I.; DUBEY, J. P.; MARTINEZ, F.; VARGAS, A.; CABEZON, O.; ZORRILLA, I.; ARENAS, A.; ALMERIA, S. Factors affecting seroprevalence of Toxoplasma gondii in the endangered Iberian lynx (Lynx pardinus). Veterinary Parasitology, v. 167, n. 1, p. 36-42, 2010.

GARNER, M. M.; LUNG, N. P.; CITINO, S.; GREINER, E. C.; HARVEY, J. W.; HOMER, B. L. Fatal cytauxzoonosis in a captive-reared white tiger (Panthera tigris). Veterinary Pathology, v. 33, n. 1, p. 82-86, 1996.

GARRIDO, J. A.; COUR BOVEDA, L.; SAUNAD, V. M.; SOPENA QUESADA, A. Estudios sobre la epidemiologia de la toxoplasmosis: la infeccion entre los animales de consumo, encuestas serologicas en Madrid, mediante la reaccion de inmunofluorescencia. Medicina Tropical, v. 48, n. 1/2, p. 11-23, 1972.

GASCOYNE, S. C.; KING, A. A.; LAURENSON, M. K.; BORNER, M.; SCHILDGER, B.; BARRAT, J. Aspects of rabies infection and control in the conservation of the African wild dog (Lycaon pictus) in the Serengeti region, Tanzania. Onderstepoort Journal of Veterinary Research, v. 60, n. 4, p. 415-420, 1993.

GAZETA, G. S.; MONTEIRO, A.; ABOUD-DUTRA, A. E. Babesiose felina no Brasil: uma nova espécie? Revista Brasileira de Parasitologia Veterinária, v. 13, n. 1, p. 228, 2004.

GENNARI, S. M.; CANON-FRANCO, W. A.; YAI, L. E. O.; SOUZA, S. L. P.; SANTOS, L. C.; FARIAS, N. A. R.; RUAS, J.; ROSSI, F. W.; GOMES, A. A. B. Seroprevalence of Toxoplasma gondii antibodies from wild canids from Brazil. Veterinary Parasitology, v. 121, n. 3-4, p. 337-340, 2004. 
GENTILINI, F.; NOVACCO, M.; TURBA, M. E.; WILLI, B.; BACCI, M. L.; HOFMANN-LEHMANN, R. Use of combined conventional and real-time PCR to determine the epidemiology of feline haemoplasma infections in northern Italy. Journal of Feline Medicine and Surgery, v. 11, n. 4, p. 277-285, 2009.

GEORGE, J. E.; DAVEY, R. B.; POUND, J. M. Introduced ticks and tick-borne diseases: the threat and approaches to eradication. Veterinary Clinics of North America-Food Animal Practice, v. 18, n. 3, p. 401, 2002.

GEORGE, J. W.; RIDEOUT, B. A.; GRIFFEY, S. M.; PEDERSEN, N. C. Effect of preexisting FeLV infection or FeLV and feline immunodeficiency virus coinfection on pathogenicity of the small variant of Haemobartonella felis in cats. American Journal of Veterinary Research, v. 63, n. 8, p. 1172-1178, 2002.

GERMANO, P. M. L.; ERBOLATO, E. B.; ISHIZUKA, M. M. Estudo sorológico da toxoplasmose canina, pela prova de imunofluorescência indireta, na cidade de Campinas, 1981. Revista da Faculdade de Medicina Veterinária e Zootecnia da Universidade de São Paulo, v. 22, n.1, p. 53-58, 1985.

GESE, E. M.; SCHULTZ, R. D.; RONGSTAD, O. J.; ANDERSEN, D. E. Prevalence of antibodies against canine parvovirus and canine distemper virus in wild coyotes in Southeastern Colorado. Journal of Wildlife Diseases, v. 27, n. 2, p. 320-323, 1991.

GILBERT, L. Altitudinal patterns of tick and host abundance: a potential role for climate change in regulating tick-borne diseases? Oecologia (Berlin), v. 162, n. 1, p. 217-225, 2010.

GIRIO, R. J. S.; PEREIRA, F. L. G.; MARCHIORI FILHO, M.; MATHIAS, L. A.; HERREIRA, R. C. P.; ALESSI, A. C.; GIRIO, T. M. S. Investigation of antibodies to Leptospira spp. in wild and feral animals from the region of Nhecolandia, Mato Grosso do Sul, Brazil. Use of the immunohistochemistry technique for the agent detection. Ciência Rural, v. 34, n. 1, p. 165-169, 2004.

GLEICH, S. E.; KRIEGER, S.; HARTMANN, K. Prevalence of feline immunodeficiency virus and feline leukaemia virus among client-owned cats and risk factors for infection in Germany. Journal of Feline Medicine and Surgery, v. 11, n. 12, p. 985-992, 2009.

GLENN, B. L.; KOCAN, A. A.; BLOUIN, E. F. Cytauxzoonosis in bobcats. Journal of the American Veterinary Medical Association, v. 183, n. 11, p. 1155-1158, 1983.

GLENN, B. L.; STAIR, E. L. Cytauxzoonosis in domestic cats: report of two cases in Oklahoma, with a review and discussion of the disease. Journal of the American Veterinary Medical Association, v. 84, n. 7, p. 822825, 1984.

GODFROID, J.; KASBOHRER, A. Brucellosis in the European Union and Norway at the turn of the twenty first century. Veterinary Microbiology, v. 90, n. 1-4, p. 135-145, 2002. 
GONDIM, L. F. P.; KOHAYAGAWA, A.; ALENCAR, N. X.; BIONDO, A. W.; TAKAHIRA, R. K.; FRANCO, S. R. V. Canine hepatozoonosis in Brazil: description of eight naturally occurring cases. Veterinary Parasitology, $v$. 74, n. 2-4, p. 319-323, 1998.

GORTAZAR, C.; FERROGLIO, E.; HOFLE, U.; FROLICH, K.; VICENTE, J. Diseases shared between wildlife and livestock: a European perspective. European Journal of Wildlife Research, v. 53, n. 4, p. 241-256, 2007.

GOULD, D. H.; FENNER, W. R. Paramyxovirus like nucleocapsids associated with encephalitis in a captive siberian tiger. Journal of the American Veterinary Medical Association, v. 183, n. 11, p. 1319-1322, 1983.

GOWTAGE-SEQUEIRA, S.; BANYARD, A. C.; BARRETT, T.; BUCZKOWSKI, H.; FUNK, S. M.; CLEAVELAND, S. Epidemiology, pathology, and genetic analysis of a canine distemper epidemic in Namíbia. Journal of Wildlife Diseases, v. 45, n. 4, p. 1008-1020, 2009.

GREENE, C. E. Infectious diseases of the dog and cat. Philadelphia: W. B. Saunders, 1990. p. 819-829.

GREINER, E. C.; ROELKE, M. E.; ATKINSON, C. T.; DUBEY, J. P.; WRIGHT, S. D. Sarcocystis sp. in muscles of free-ranging Florida panthers and cougars (Felis concolor). Journal of Wildlife Diseases, v. 25, n. 4, p.623628, 1989.

GUERRA NETO, G.; GIRIO, R. J. S.; ANDRADE, T. M.; KOPROSKI, L. P.; MORAES, W.; SANTOS, L. C. Ocorrências de anticorpos contra Leptospira spp. em felídeos neotropicais pertencentes ao criadouro de animais silvestres da Itaipu Binacional e ao Zoológico Municipal Bosque Guarani, Foz do Iguaçu, estado do Paraná. Ars Veterinaria, v. 20, n. 1, p. 75-80, 2004.

GUGlielmone, A. A.; MANGOLD, A. J.; LUCIANI, C. E.; VINABAL, A. E. Amblyomma tigrinum (Acari : Ixodidae) in relation to phytogeography of central-northern Argentina with notes on hosts and seasonal distribution. Experimental and Applied Acarology, v. 24, n. 12, p. 983-989, 2000.

GUIMARÃES, A. M. S. Detecção de micoplasmas, bartonelas e vírus da leucemia felina em pequenos felídeos neotropicais mantidos em cativeiro no Refúgio Bela Vista, Foz do Iguaçu. 2008. 129 f. Dissertação (Mestrado) - Faculdade de Medicina Veterinária e Zootecnia, Universidade de São Paulo, São Paulo, 2008.

GUIMARÃES, A. M. S.; BRANDÃO, P. E.; MORAES, W.; CUBAS, Z. S.; SANTOS, L. C.; VILLARREAL, L. Y. B.; ROBES, R. R.; COELHO, F. M.; RESENDE, M.; SANTOS, R. C. F.; OLIVEIRA, R. C.; YAMAGUTI, M.; MARQUES, L. M.; NETO, R. L.; BUZINHANI, M.; MARQUES, R.; MESSICK, J. B.; BIONDO, A. W.; TIMENETSKY, J. SUrvey of feline leukemia virus and feline coronaviruses in captive neotropical wild felids from Southern Brazil. Journal of Zoo and Wildlife Medicine, v. 40, n. 2, p. 360-364, 2009.

GUIMARÃES, A. M.; JAVOROUSKI, M. L.; BONAT, M. LACERDA, O.; BALBINOTTI, B.; QUEIROZ, L. G.; TIMENETSKY, J.; BIONDO, A. W.; MESSICK, J. B. Molecular detection of 'Candidatus Mycoplasma haemominutum' in a lion (Panthera leo) from a Brazilian zoological garden. Revista do Instituto de Medicina Tropical de São Paulo, v. 49, n. 3, p. 195-196, maio-jun. 2007. 
GUIMARÃES, J. H.; TUCCI, E. C.; BARROS-BATTESTI, D. M. Ectoparasitos de importância veterinária. São Paulo: Editora Plêiade, 2001. 213 p.

GUIMARÃES, M. C.; CÔRTES, J. A.; VASCONCELLOS, S. A.; ITO, F. H. Epidemiologia e controle da leptospirose em bovinos. Papel do portador e seu controle terapêutico. Comunicações Científicas da Faculdade de Medicina Veterinária e Zootecnia da Universidade de São Paulo, v. 6/7, n. 1/4 p. 21-34, 1982/83.

HABER, M. D.; TUCKER, M. D.; MARR, H. S.; LEVY, J. K.; BURGESS, J.; LAPPIN, M. R.; BIRKENHEUER, A. J. The detection of Cytauxzoon felis in apparently healthy free-roaming cats in the USA. Veterinary Parasitology, v. 146, n. 3-4, p. 316-320, 2007.

HAEFNER, M.; BURKE, T. J.; KITCHELL, B. E.; LAMONT, L. A.; SCHAEFFER, D. J.; BEHR, M.; MESSICK, J. B. Identification of Haemobartonella felis (Mycoplasma haemofelis) in captive nondomestic cats. Journal of Zoo and Wildlife Medicine, v. 34, n. 2, p. 139-143, 2003.

HAMNES, I. S.; GJERDE, B. K.; FORBERG, T.; ROBERTSON, L. J. Occurrence of Giardia and Cryptosporidium in Norwegian red foxes (Vulpes vulpes). Veterinary Parasitology, v. 143, n. 3-4, p. 347-353, 2007.

HAMPSON, K.; DUSHOFF, J.; CLEAVELAND, S.; HAYDON, D. T.; KAARE, M.; PACKER, C.; DOBSON, A. Transmission dynamics and prospects for the elimination of canine Rabies. Plos Biology, v. 7, n. 3, p. 462471, 2009.

HANSKI, I. Landscape fragmentation, biodiversity loss and the societal response: the longterm consequences of our use of natural resources may be surprising and unpleasant. Embo Reports, v. 6, n. 5, p. 388-392, 2005.

HARDER, T. C.; KENTER, M.; VOS, H.; SIEBELINK, K.; HUISMAN, W.; VANAMERONGEN, G.; ORVELL, C.; BARRETT, T.; APPEL, M. J. G.; OSTERHAUS, A. Canine distemper virus from diseased large felids: biological properties and phylogenetic relationships. Journal of General Virology, v. 77, n. 3, p. 397-405, 1996.

HARRIS, M. B.; TOMAS, W.; MOURÃO, G.; DA SILVA, C. J.; GUIMARÃES, E.; SONODA, F.; FACHIM, E. Safeguarding the Pantanal wetlands: threats and conservation initiatives. Conservation Biology, v. 19, n. 3, p. 714-720, 2005.

HARTLEY, W. J.; DUBEY, J. P.; SPIELMAN, D. S. Fatal toxoplasmosis in koalas (Phascolarctos cinereus). Journal of Parasitology, v. 76, n. 2, p. 271-272, 1990.

HARTMANN, K. Feline immunodeficiency virus infection: an overview. Veterinary Journal, v. 155, n. 2, p. 123-137, 1998.

HARTMANN, K.; BLOCK, A.; FERK, G.; BEER, B.; VOLLMAR, A.; LUTZ, H. Treatment of feline leukemia virus (FeLV) infection. Veterinary Microbiology, v. 69, n. 1-2, p. 111-113, 1999. 
HASS, R.; JOHANN, J. M.; CAETANO, C. F.; FISCHER, G.; VARGAS, G. D.; VIDOR, T.; HUBNER, S. O. Antibodies levels against canine distemper virus and canine parvovirus in vaccinated and unvaccinated dogs. Arquivo Brasileiro de Medicina Veterinária e Zootecnia, v. 60, n. 1, p. 270-274, 2008.

HEADLEY, S. A.; GRAÇA, D. L. Canine distemper: epidemiological findings of 250 cases. Brazilian. Journal of Veterinary Research and Animal Sciences, v. 37, n. 2, p. 136-140, 2000.

HENDERSON, H.; JACKSON, F.; BEAN, K.; PANASUK, B.; NIEZGODA, M.; SLATE, D.; LI, J. W.; DIETZSCHOLD, B.; MATTIS, J.; RUPPRECHT, C. E. Oral immunization of raccoons and skunks with a canine adenovirus recombinant rabies vaccine. Vaccine, v. 27, n. 51, p. 7194-7197, 2009.

HILL, N. J.; DUBEY, J. P.; VOGELNEST, L.; POWER, M. L.; DEANE, E. M. Do free-ranging common brushtail possums (Trichosurus vulpecula) play a role in the transmission of Toxoplasma gondii within a zoo environment? Veterinary Parasitology, v. 152, n. 3-4, p. 202-209, 2008.

HILL, R. E.; BERAN, G. W.; CLARK, W. R. Demonstration of rabies virus specific antibody in the sera of freeranging lowa raccoons (Procyon lotor). Journal of Wildlife Diseases, v. 28, n. 3, p. 377-385, 1992.

HOFMANN-LEHMANN, R.; FEHR, D.; GROB, M.; ELGIZOLI, M.; PACKER, C.; MARTENSON, J. S.; O’BRIEN, S. J.; LUTZ, H. Prevalence of antibodies to feline parvovirus, calicivirus, herpesvirus, coronavirus, and immunodeficiency virus and of feline leukemia virus antigen and the interrelationship of these viral infections in free ranging lions in East Africa. Clinical and Diagnostic Laboratory Immunology, v. 3, n. 5, p. 554-562, 1996.

HOME, R.; KELLER, C.; NAGEL, P.; BAUER, N.; HUNZIKER, M. Selection criteria for flagship species by conservation organizations. Environmental Conservation, v. 36, n. 2, p. 139-148, 2009.

HOMEM, V. S. F.; HEINEMANN, M. B.; MORAES, Z. M.; VASCONCELLOS, S. A.; FERREIRA, F.; FERREIRA NETO, J. S. Estudo epidemiológico da leptospirose bovina e humana na Amazônia oriental brasileira. Revista da Sociedade Brasileira de Medicina Tropical, v. 34, n. 2, p. 173-180, 2001.

HOOGESTEIJN, R.; MONDOLFI, E. The jaguar. Caracas: Armitano Publishers, 1992. 183 p.

HOOGSTRAAL, H. Changing patterns of tick borne diseases in modern society. Annual Review of Entomology, v. 26, p. 75-99, 1981.

HOOVER, E. A.; MULLINS, J. I. Feline leukemia virus infection and diseases. Journal of the American Veterinary Medical Association, v. 199, n. 10, p. 1287-1297, 1991.

HOOVER, E. A.; PERIGO, N. A.; QUACKENBUSH, S. L.; MATHIASONDUBARD, C. K.; OVERBAUGH, J. M.; KLOETZER, W. S.; ELDER, J. H.; MULLINS, J. I. Protection against feline leukemia virus infection by use of an inactivated virus vaccine. Journal of the American Veterinary Medical Association, v. 199, n. 10, p. 13921401, 1991. 
HOOVER, J. P.; WALKER, D. B.; HEDGES, J. D. Cytauxzoonosis in cats: 8 cases (1985-1992). Journal of the American Veterinary Medical Association, v. 205, n. 3, p. 455-460, 1994.

HORA, A. S. Associação da infecção por Mycoplasma haemofelis e o vírus da leucemia e imunodeficiência em felinos anêmicos. 2008. 115 f. Dissertação (Mestrado) -. Faculdade de Medicina Veterinária e Zootecnia, Universidade de São Paulo, São Paulo, 2008.

HOSIE, M. J.; ADDIE, D.; BELAK, S.; BOUCRAUT-BARALON, C.; EGBERINK, H.; FRYMUS, T.; GRUFFYDDJONES, T.; HARTMANN, K.; LLORET, A.; LUTZ, H.; MARSILIO, F.; PENNISI, M. G.; RADFORD, A. D.; THIRY, E.; TRUYEN, U.; HORZINEK, M. C. Feline immunodeficiency. ABCD guidelines on prevention and management. Journal of Feline Medicine and Surgery, v. 11, n. 7, p. 575-584, 2009.

ICTV - INTERNATIONAL COMMITTEE ON TAXONOMY OF VIRUSES. Virus Taxonomy: 2009 release, 2009. Disponível em: <http://www.ictvonline.org/virusTaxonomy.asp?version=2009>. Acesso em: 24 jun. 2010.

IKEDA, Y.; NAKAMURA, K.; MIYAZAWA, T.; CHEN, M. C.; KUO, T. F.; LIN, J. A.; MIKAMI, T.; KAI, C.; TAKAHASHI, E. Seroprevalence of canine distemper virus in cats. Clinical and Diagnostic Laboratory Immunology, v. 8, n. 3, p. 641-644, 2001.

INNES, E. A. A brief history and overview of Toxoplasma gondii. Zoonoses and Public Health, v. 57, n. 1, p. $1-7,2010$.

INOKUMA, H.; OKUDA, M.; OHNO, K.; SHIMODA, K.; ONISHI, T. Analysis of the 18S rRNA gene sequence of a Hepatozoon detected in two Japanese dogs. Veterinary Parasitology, v. 106, n. 3, p. 265-271, 2002.

ITO, F. H.; VASCONCELLOS, S. A.; BERNARDI, F.; NASCIMENTO, A. A.; LABRUNA, M. B.; ARANTES, I. G. Evidência sorológica de brucelose e leptospirose e parasitismo por ixodídeos em animais silvestres do pantanal sul-mato-grossense. Ars Veterinária, v. 14, n. 3, p. 302-310, 1998.

IUCN - INTERNATIONAL UNION FOR CONSERVATION OF NATURE. IUCN red list of threatened species. Disponível em: <www.iucnredlist.org>. Acesso em: 17 maio 2010.

JACKSON, A. C. Rabies. Neurologic Clinics, v. 26, n. 3, p. 717, 2008.

JAKOB, W.; WESEMEIER, H. H. A fatal infection in a Bengal tiger resembling cytauxzoonosis in domestic cats. Journal of Comparative Pathology, v. 114, n. 4, p. 439-444, 1996.

JAGUAR CONSERVATION FUND. The jaguar in Brazil. Cat News, special issue, The jaguar in Brazil, n. 4, p. $47,2008$.

JAYAKUMAR, S. R.; BABU, M. M.; GOPAL, T.; KESHAVAMURTHY, B. S. Rabies in a wild Leopard felis (Panthera) pardus. Indian Veterinary Journal, v. 66, n. 11, p. 1076-1077, 1989. 
JESSUP, D. A.; PETTAN, K. C.; LOWENSTINE, L. J.; PEDERSEN, N. C. Feline leukemia virus infection and renal spirochetosis in a free-ranging cougar (Felis concolor). Journal of Zoo and Wildlife Medicine, v. 24, n. 1, p. 73-79, 1993.

JORGE, R. S. P. Caracterização do estado sanitário dos carnívoros selvagens da RPPN SESC Pantanal e de animais domésticos da região. 2008. 105 f. Tese (Doutorado) - Faculdade de Medicina Veterinária e Zootecnia, Universidade de São Paulo, São Paulo, 2008.

JORGE, R. S. P.; PEREIRA, M.; MORATO, R. G.; SCHEFFER, K.; CARNIELI, P.; FERREIRA, F.; FURTADO, M. M.; KASHIVAKURA, C. K.; SILVEIRA, L.; JACOMO, A. T. A.; LIMA, E. S.; PAULA, R. C.; MAY JUNIOR, J. A. Detection of Rabies Virus antibodies in Brazilian free-ranging wild carnivores. Journal of Wildlife Diseases, 2010. In press.

JOUGLARD, S. D. D.; BROD, C. S. Leptospirose em cães: prevalência e fatores de risco no meio rural do município de Pelotas, RS. Arquivos do Instituto Biológico, v.67, n. 2, p. 181-185, 2000.

JULIANO, R. S.; CHAVES, N. S. T.; SANTOS, C. A.; RAMOS, L. S.; SANTOS, H. Q.; MEIRELES, L. R.; GORRSCHALK, S.; CORRÊA FILHO, R. A. C. Prevalência e aspectos epidemiológicos da leptospirose bovina em rebanho leiteiro na microrregião de Goiânia, GO. Ciência Rural, v. 30, n. 5, p. 857-862, 2000.

JUNQUEIRA-JORGE, J. Estudo dos fatores de risco da leucemia viral felina no município de São Paulo. 2005. 42 f. Dissertação (Mestrado) - Faculdade de Medicina Veterinária e Zootecnia, Universidade de São Paulo, São Paulo, 2005.

KAMGA-WALADJO, A. R.; GBATI, O. B.; KONE, P.; LAPO, R. A.; DOMBOU, E.; CHATAGNON, G.; BAKOU, S. N.; DIOP, P. E. H.; PANGUI, L. J.; TAINTURIER, D.; AKAKPO, J. A. Neospora caninum and Toxoplasma gondii in lion (Panthera leo) from Senegal, West Africa. Asian Journal of Animal and Veterinary Advances, v. 4, n. 6, p. 346-349, 2009.

KAPIL, S.; ALLISON, R. W.; JOHNSTON, L.; MURRAY, B. L.; HOLLAND, S.; MEINKOTH, J.; JOHNSON, B. Canine distemper virus strains circulating among North American dogs. Clinical and Vaccine Immunology, v. 15, n. 4, p. 707-712, 2008.

KASHIVAKURA, C. K.; FURTADO, M. M.; JACOMO, A. T. A.; MARVULO, M. F.; SILVA, J. C. R.; SUERO, D. R.; FERRO, C.; ASTETE, S.; TÔRRES, N. M.; SILVEIRA, L. Brucelose em queixadas (Tayassu pecari), de vida livre da região do Parque Nacional das Emas. In: CONGRESSO BRASILEIRO DE ZOOLOGIA, 25. 2004, Brasília. Anais... Brasília: Sociedade Brasileira de Zoologia, 2004.

KAT, P. W.; ALEXANDER, K. A.; SMITH, J. S.; MUNSON, L. Rabies and african wild dogs in Kenya. Proceedings of the Royal Society of London Series B-Biological Sciences, v. 262, n. 1364, p. 229-233, 1995. 
KEET, D. F.; KRIEK, N. P. J.; PENRITH, M. L.; MICHEL, A.; HUCHZERMEYER, H. Tuberculosis in buffaloes (Syncerus caffer) in the Kruger National Park: spread of the disease to other species. Onderstepoort Journal of Veterinary Research, v. 63, n. 3, p. 239-244, 1996.

KEIRANS, J. E. Systematics of the Ixodida (Argasidae, Ixodidae, Nuttalliellidae): an overview and some problems. In: FIVAZ, B. H.; PETNEY, T. N.; HORAK, I. G. Tick vector biology: medical and veterinary aspects. Berlin: Springer Verlag, 1992. p. 1-21.

KENNEDY-STOSKOPF, S. Emerging viral infections in large cats. In: FOWLER, M. E.; MILLER, R. E. Zoo and wild animal medicine current therapy. 4 ed. Philadelphia: W.B. Saunders, 1999. p. 401-410.

KETZ-RILEY, C. J.; REICHARD, M. V.; VAN DEN BUSSCHE, R. A.; HOOVER, J. P.; MEINKOTH, J.; KOCAN, A. A. An intraerythrocytic small piroplasm in wild caught Pallas's cats (Otocolobus manul) from Mongolia. Journal of Wildlife Diseases, v. 39, n. 2, p. 424-430, 2003.

KHAN, M. A.; GOYAL, S. M.; DIESCH, S. L.; MECH, L. D.; FRITTS, S. H. Seroepidemiology of leptospirosis in Minnesota wolves. Journal of Wildlife Diseases, v. 27, n. 2, p. 248-253, 1991.

KIER, A. B.; WAGNER, J. E.; KINDEN, D. A. The pathology of experimental cytauxzoonosis. Journal of Comparative Pathology, v. 97, n. 4, p. 415-432, 1987.

KIER, A. B.; WIGHTMAN, S. R.; WAGNER, J. E. Interspecies transmission of Cytauxzoon felis. American Journal of Veterinary Research, v. 43, n. 1, p. 102-105, 1982.

KIKUCHI, Y.; CHOMEL, B. B.; KASTEN, R. W.; MARTENSON, J. S.; SWIFT, P. K.; O'BRIEN, S. J. Seroprevalence of Toxoplasma gondii in American free-ranging or captive pumas (Felis concolor) and bobcats (Lynx rufus). Veterinary Parasitology, v. 120, n. 1-2, p. 1-9, 2004.

KILPATRICK, A. M.; GILLIN, C. M.; DASZAK, P. Wildlife-livestock conflict: the risk of pathogen transmission from bison to cattle outside Yellowstone National Park. Journal of Applied Ecology, v. 46, n. 2, p. 476-485, 2009.

KINGSCOTE, B. F. Leptospirosis in red foxes in Ontario. Journal of Wildlife Diseases, v. 22, n. 4, p. 475-478, 1986.

KINSEL, M. J.; BRIGGS, M. B.; VENZKE, K.; FORGE, O.; MURNANE, R. D. Gastric spiral bacteria and intramuscular sarcocysts in African lions from Namíbia. Journal of Wildlife Diseases, v. 34, n. 2, p. 317324, 1998.

KIOK, P.; GRUNBAUM, E. G.; LETZ, W.; UHL, W.; MIETH, K. Dog: source of re-infection of non brucellosis cattle herds. Monatshefte Fur Veterinarmedizin, v. 33, n. 18, p. 700-704, 1978. 
KIRBERGER, R. M.; KEET, D. F.; WAGNER, W. M. Radiologic abnormalities of the appendicular skeleton of the lion (Panthera leo): incidental findings and Mycobacterium bovis induced changes. Veterinary Radiology and Ultrasound, v. 47, n. 2, p. 145-152, 2006.

KIRKPATRICK, C. E.; DUBEY, J. P.; GOLDSCHMIDT, M. H.; SAIK, J. E.; SCHMITZ, J. A. Sarcocystis sp. in muscles of domestic cats. Veterinary Pathology, v. 23, n. 1, p. 88-90, 1986.

KLINK, C. A.; MOREIRA, A. G. Past and current human occupation, and land use. In: OLIVEIRA, P. S.; MARQUIS, J. The Cerrados of Brazil: ecology and natural history of a neotropical Savannah. New York: Columbia University Press, 2002. p. 68-88.

KOCAN, A. A.; KOCAN, K. M.; BLOUIN, E. F.; MUKOLWE, S. W. A redescription of schizogony of Cytauxzoon felis in the domestic cat. Tropical Veterinary Medicine: current issues perspectives, v. 653, p. 161-167, 1992.

KUBO, M.; MIYOSHI, N.; YASUDA, N. Hepatozoonosis in two species of Japanese wild cat. Journal of Veterinary Medical Science, v. 68, n. 8, p. 833-837, 2006.

LABRUNA, M. B.; DE PAULA, C. D.; LIMA, T. F.; SANA, D. A. Ticks (Acari: Ixodidae) on wild animals from the Porto Primavera Hydroelectric power station area, Brazil. Memórias do Instituto Oswaldo Cruz, v. 97, n. 8, p. 1133-1136, 2002.

LABRUNA, M. B.; JORGE, R. S. P.; SANA, D. A.; JACOMO, A. T. A.; KASHIVAKURA, C.; FURTADO, M.; FERRO, C.; PEREZ, S. A.; SILVEIRA, L.; SANTOS, T. S. S.; MARQUES, S. R.; MORATO, R. G.; NAVA, A.; ADANIA, C. H.; TEIXEIRA, R. H. F.; GOMES, A. A. B.; CONFORTI, V. A.; AZEVEDO, F. C. C.; PRADA, C. S.; SILVA, J. C. R.; BATISTA, A. F.; MARVULO, M. F. V.; MORATO, R. L. G.; ALHO, C. J. R.; PINTER, A.; FERREIRA, P. M.; FERREIRA, F.; BARROS-BATTESTI, D. M. Ticks (Acari: Ixodida) on wild carnivores in Brazil. Experimental and Applied Acarology, v. 36, n. 1, p. 149-163, 2005.

LACKAY, S. N.; KUANG, Y.; FU, Z. F. Rabies in small animals. Veterinary Clinics of North America: small animal practice, v. 38, n. 4, p. 851, 2008.

LAFFERTY, K. D.; GERBER, L. R. Good medicine for conservation biology: the intersection of epidemiology and conservation theory. Conservation Biology, v. 16, n. 3, p. 593-604, 2002.

LALLE, M.; POZIO, E.; CAPELLI, G.; BRUSCHI, F.; CROTTI, D.; CACCIÒ, S. M. Genetic heterogeneity at the $\beta$ giardin locus among human and animal isolates of Giardia duodenalis and identification of potentially zoonotic subgenotypes. International Journal of Parasitology, v. 35, n. 2, p.207-213, 2005

LALLO, M. A.; PEREIRA, A.; ARAÚJO, R.; FAVORITO, S. E.; BERTOLLA, P.; BONDAN, E. F. Ocorrência de Giardia, Cryptosporidium and microsporídios em animais silvestres em area de desmatamento no Estado de São Paulo, Brasil. Ciência Rural, v. 39, n. 5, p. 1465-1470, 2009. 
LANE, J. R.; KOCAN, A. A. Hepatozoon sp. infection in bobcats. Journal of the American Veterinary Medical Association, v. 183, n. 11, p. 1323-1324, 1983.

LANFRANCHI, P.; FERROGLIO, E.; POGLAYEN, G.; GUBERTI, V. Wildlife veterinarian, conservation and public health. Veterinary Research Communications, v. 27, n. 7, p. 567-574, 2003.

LANGONI, H. Leptospirose: aspectos de saúde animal e de saúde pública. Revista de Educação Continuada do CRMV-SP, v. 2, n. 1, p. 52-58, 1999.

LAPPIN, M. R.; UNGAR, B.; BROWNHAHN, B.; COOPER, C. M.; SPILKER, M.; THRALL, M.; HILL, S. L.; CHENEY, J.; TATONALLEN, G. Enzyme-linked immunosorbent assay for the detection of Cryptosporidium parvum IgG in the serum of cats. Journal of Parasitology, v. 83, n. 5, p. 957-960, 1997.

LARA, V. M.; TANIWAKI, S. A.; ARAÚJO, F. P. Occurrence of feline immunodeficiency virus infection in cats. Ciência Rural, v. 38, n. 8, p. 2245-2249, 2008.

LARA, V. M.; TANIWAKI, S. A.; ARAÚJO, J. P. Phylogenetic characterization of feline immunodeficiency virus (FIV) isolates from the state of São Paulo. Pesquisa Veterinária Brasileira, v. 27, n. 11, p. 467-470, 2007.

LASTA, C. S.; SANTOS, A. P.; MELLO, F. P. S.; LACERDA, L. A.; MESSICK, J. B.; DIÁZ GONZALEZ, F. H. Infecção por Hepatozoon canis em canino domestic na região Sul do Brasil confirmada por técnicas moleculares. Ciencia Rural, v. 39, n. 7, p. 2135-2140, 2009.

LAURENSON, K.; SILLERO-ZUBIRI, C.; THOMPSON, H.; SHIFERAW, F.; THIRGOOD, S.; MALCOLM, J. Disease as a threat to endangered species: Ethiopian wolves, domestic dogs and canine pathogens. Animal Conservation, v. 1, n. 4, p. 273-280, 1998.

LAURENSON, M. K.; MLENGEYA, T.; SHIFERAW, F.; CLEAVELAND, S. Approaches to disease control in domestic canids for the conservation of endangered wild carnivores. In: CLEAVELAND, S.; KARESH, W. B.; KOCK, D.; NYHUS, P. J.; STARR, L.; YANG , A. Conservation and development interventions at the wildlife/livestock Interface. Cambridge: IUCN Publications Services Unit, 2005. p. 141-146.

LEAL, E. S.; RAVAZZOLO, A. P. Deteç̧ão do vírus da imunodeficiência felina (FIV) em felídeos selvagens pertencentes à região neotropical, através da técnica de reação em cadeia da polimerase (PCR). A Hora Veterinária, v. 17, n. 101, p. 57-60, 1998.

LEITE, M. R. P.; BOULHOSA, R. L. P.; GALVÃO, F.; CULLEN JÚNIOR, L. Conservación del jaguar en las areas protegidas del bosque atlántico de la costa de Brasil. In: MEDELLIN, R. A.; CHETKIEWICZ; RABINOWITZ, A.; REDFORD, K. H.; ROBINSON, J. G.; SANDERSON, E. W.; TABER, A. B. (Ed.). El Jaguar en el nuevo milenio. Una evaluacion de su estado, deteccion de prioridades y recomendaciones para la conservacion de los jaguars en America. México, D. F.: Universidad Nacional Autonoma de Mexico/Wildlife Conservation Society, 2002. p. 25-42. 
LEUTENEGGER, C. M.; HOFMANN-LEHMANN, R.; RIOLS, C.; LIBEREK, M.; WOREL, G.; LUPS, P.; FEHR, D.; HARTMANN, M.; WEILENMANN, P.; LUTZ, H. Viral infections in free-living populations of the European wildcat. Journal of Wildlife Diseases, v. 35, n. 4, p. 678-686, 1999.

LEVETT, P. N. Leptospirosis. Clinical Microbiology Reviews, v. 14, n. 2, p. 296, 2001.

LEVY, J.; CRAWFORD, C.; HARTMANN, K.; HOFMANN-LEHMANN, R.; LITTLE, S.; SUNDAHL, E.; THAYER, V. American Association of Feline Practitioners' feline retrovirus management guidelines. Journal of Feline Medicine and Surgery, v. 10, n. 3, p. 300-316, 2008.

LEVY, J. K.; SCOTT, H. M.; LACHTARA, J. L.; CRAWFORD, P. C. Seroprevalence of feline leukemia virus and feline immunodeficiency virus infection among cats in North America and risk factors for seropositivity. Journal of the American Veterinary Medical Association, v. 228, n. 3, p. 371-376, 2006.

LI, Y. H.; WANG, C. M.; ALLEN, K. E.; LITTLE, S. E.; AHLUWALIA, S. K.; GAO, D. Y.; MACINTIRE, D. K.; BLAGBURN, B. L.; KALTENBOECK, B. Diagnosis of canine Hepatozoon spp. infection by quantitative PCR. Veterinary Parasitology, v. 157, n. 1-2, p. 50-58, 2008.

LILENBAUM, W.; MONTEIRO, R. V.; ALBUQUERQUE, C. E.; RISTOW, P.; FRAGUAS, S.; CARDOSO, V. S.; FEDULLO, L. P. L. Leptospiral antibodies in wild felines from Rio de Janeiro Zoo, Brazil. Veterinary Journal, v. 168, n. 2, p. 191-193, 2004.

LILENBAUM, W.; SANTOS, M. R. C. Effect of management systems on the prevalence of bovine leptospirosis. Veterinary Record, v. 138, n. 23, p. 570-571, 1996.

LIM, Y. A. L.; NGUI, R.; SHUKRI, J.; ROHELA, M.; NAIM, H. R. M. Intestinal parasites in various animals at a zoo in Malaysia. Veterinary Parasitology, v. 157, n. 1-2, p. 154-159, 2008.

LIMA E SILVA, M. F.; SZABO, M. P. J.; BECHARA, G. H. Microscopic features of tick-bite lesions in anteaters and armadillos. Annals of the New York Academy of Sciences, v. 1026, p. 235-241, 2004.

LINDSAY, D. S.; BLAGBURN, B. L.; DUBEY, J. P. Feline toxoplasmosis and the importance of the Toxoplasma gondii oocyst. Compendium on Continuing Education for the Practicing Veterinarian, v. 19, n. 4, p. 448461, 1997.

LINHARES, G. F. C.; MASSARD, C. L.; ARAÚJO, J. L. B.; ALVES, L. C. Levantamento sorológico para Babesia bigemina (Smith, Kilborne, 1893) e Babesia bovis (Babes, 1888) em bovinos da região Centro-Oeste do Brasil. Arquivos da Universidade Federal Rural do Rio de Janeiro, v. 15, n. 1, p. 85-91, 1992.

LINS, Z. C.; LOPES, M. L. Isolation of leptospira from wild forest animals in Amazonian Brazil. Transactions of the Royal Society of Tropical Medicine and Hygiene, v. 78, n. 1, p. 124-126, 1984. 
LOPES, A. L. S.; SILVA, W. B.; PADOVANI, C. R.; LANGONI, H.; MODOLO, J. R. Frequência sorológica antileptospírica em cães: sua correlação com roedores e fatores ambientais, em área territorial urbana. Arquivos do Instituto Biológico, v. 72, n. 3, p.289-296, 2005.

LOPES, C. W. G. O gênero Sarcocystis (Lankaster, 1882) (Apicomplexa: Sarcocystidae), uma questão a ser reavaliada no Brasil. Revista Brasileira de Parasitologia Veterinária, v. 13, n. 1, p. 14-16, 2004.

LOPES, V. V. A. Estudo parasitológico e molecular da infecção por Babesia spp. em cães de áreas rurais do Estado de São Paulo. 2006. 61 f. Dissertação (Mestrado) - Faculdade de Medicina Veterinária e Zootecnia, Universidade Estadual Paulista, Botucatu, 2006.

LÓPEZ, G.; LÓPEZ-PARRA, M.; FERNÁNDEZ, L.; MARTÍNEZ-GRANADOS; MARTÍNEZ, F.; MELI, M. L.; GILSÁNCHEZ, J. M.; VIQUEIRA, N.; DÍAZ-PORTERO, M. A.; CADENAS, R.; LUTZ, H.; VARGAS, A.; SÍMON, M. A. Management measures to control a feline leukemia vírus outbreak in the endangered Iberian Lynx. Animal Conservation, v. 12, n. 3, p. 173-182, 2009.

LOPEZ-GONZALEZ, C. A.; MILLER, B. J. Do jaguars (Panthera onca) depend on large prey? Western North American Naturalist, v. 62, n. 2, p. 218-222, 2002.

LOPEZ-REBOLLAR, L. M.; PENZHORN, B. L.; DE WAAL, D. T.; LEWIS, B. D. A possible new piroplasm in lions from the Republic of South Africa. Journal of Wildlife Diseases, v. 35, n. 1, p. 82-85, 1999.

LUACES, I.; AGUIRRE, E.; GARCIA-MONTIJANO, M.; VELARDE, J.; TESOURO, M. A.; SANCHEZ, C.; GALKA, M.; FERNANDEZ, P.; SAINZ, A. First report of an intraerythrocytic small piroplasm in wild Iberian lynx (Lynx pardinus). Journal of Wildlife Diseases, v. 41, n. 4, p. 810-815, 2005.

LUNA, J. O.; SANTOS, M. A. A.; DURIGON, E. L.; ARAÚJO JÚNIOR, J. P.; DUARTE, J. M. B. Ausência de tuberculose numa população de cervos-do-pantanal (Blastoceurus dichotomus) de vida livre. In: CONGRESSO DA ASSOCIAÇÃO BRASILEIRA DE VETERINÁRIOS DE ANIMAIS SELVAGENS, 6.; ENCONTRO DA ASSOCIAÇÃO BRASILEIRA DE VETERINÁRIOS DE ANIMAIS SELVAGENS, 11., 2002, Guarapari. Resumos... Guarapari: ABRAVAS, 2002. P. 47.

LUNA-ALVAREZ, M. A.; MOLES-CERVANTES, L. P.; TORRES-BARRANCA, J. I.; GUAL-SILL, F. Serological survey of leptospirosis in captive wildlife at the Chapultepec Zoo in Mexico City. Veterinaria México, v. 27, n. 3, p. 229-234, 1996.

LURIA, B. J.; LEVY, J. K.; LAPPIN, M. R.; BREITSCHWERDT, E. B.; LEGENDRE, A. M.; HERNANDEZ, J. A.; GORMAN, S. P.; LEE, I. T. Prevalence of infectious diseases in feral cats in Northern Florida. Journal of Feline Medicine and Surgery, v. 6, n. 5, p. 287-296, 2004.

LUTZ, H.; ISENBUGEL, E.; LEHMANN, R.; SABAPARA, R. H.; WOLFENSBERGER, C. Retrovirus infections in non-domestic felids: serological studies and attempts to isolate a lentivirus. Veterinary Immunology and Immunopathology, v. 35, n. 1-2, p. 215-224, 1992. 
LYLES, A. M.; DOBSON, A. P. Infectious disease and intensive management - population dynamics, threatened hosts, and their parasites. Journal of Zoo and Wildlife Medicine, v. 24, n. 3, p. 315-326, 1993.

MAIA, G. R.; ROSSI, C. R. S.; ABADDIA, F.; VIEIRA, D. K.; MORAES, I. A. Prevalência da Brucelose canina nas cidades do Rio de Janeiro e Niterói. Revista Brasileira de Reprodução Animal, v. 23, n. 3, p. 425-427, 1999.

MAIA, L. M. P. Cytauxzoonose felina. 2007. 32 f. Monografia (Especialização) - Instituto Qualittas, Universidade Castelo Branco, Rio de Janeiro, 2007.

MAIA, M. G.; COSTA, R. T.; HADDAD, J. P. A.; PASSOS, L. M. F.; RIBEIRO, M. F. B. Epidemiological aspects of canine babesiosis in the semiarid area of the state of Minas Gerais, Brazil. Preventive Veterinary

Medicine, v. 79, n. 2-4, p. 155-162, 2007.

MAIA, O. B.; GOUVEIA, A. M. G. Birth and mortality of maned wolves Chrysocyon brachyurus (Illiger, 1811) in captivity. Brazilian Journal of Biology, v. 62, n. 1, p. 25-32, 2002.

MAIA, O. M.; VELOSO, I.; VIANA, F. J.; GUIMARÃES, P. H. S.; LEITE, R. M.; LAGE, A. P. Avaliação sorológica para leptospirose e brucelose em lobos guarás (Chrysocyon brachyurus Illiger, 1811) provenientes da natureza e de cativeiro. In: CONGRESSO BRASILEIRO DA SOCIEDADE DE ZOOLÓGICOS DO BRASIL, 24.; ENCONTRO INTERNACIONAL DE ZOOLÓGICOS, 5., 2000, Belo Horizonte. Anais...Belo Horizonte, 2000. p. 43.

MACIEIRA, D. B.; MENEZES, R. C. A. A.; DAMICO, C. B.; ALMOSNY, N. R. P.; MCLANE, H. L.; DAGGY, J. K.; MESSICK, J. B. Prevalence and risk factors for hemoplasmas in domestic cats naturally infected with feline immunodeficiency virus and/or feline leukemia virus in Rio de Janeiro - Brazil. Journal of Feline Medicine and Surgery, v. 10, n. 2, p. 120-129, 2008.

MACIEIRA, D. B.; MENEZES, R. C. A. A.; DAMICO, C. B.; ALMOSNY, N. R. P; MCLANE, H. L.; MESSICK, J. B. Hemoplasmas in domestic cats and possible association to feline immunodeficiency virus (FIV) and/or feline leukemia virus (FeLV) in naturally infected animals. Veterinary Clinical Pathology, v. 35, n. 3, p. 368, 2006. Apresentado no American Society for Veterinary clinical Pathology Annual Meeting, 41.; American College of Veterinary Pathologists Annual meeting, 57., 2006, Tucson, Arizona.

MAdRUGA, C. R.; MARQUES, A. P. C.; ARAÚJO, F. R.; MIGUITA, M.; CARVALHO, C. M. E.; ARAÚJO, F. S.; UMAKI, A. C. S.; CROCCI, A. J.; QUEIROZ, R. A. Evaluation of an ELISA for detection of antibodies to Babesia bigemina in cattle and it's application in an epidemiological survey in Brazil. Pesquisa Veterinária Brasileira, v. 21, n. 2, p. 72-76, 2001.

MALEK DOS REIS, C. B.; HOFFMANN, R. C.; SANTOS, R. S.; TURRI, E. J. G.; ORIANI, M. R. G. Pesquisa de anticorpos anti-Brucella canis e anti-Brucella abortus em cães errantes da cidade de São João da Boa Vista, Estado de São Paulo, Brasil (2002-2003). Brazilian Journal of Veterinary Research and Animal Science, v. 45, n. 1, p. 32-34, 2008. 
MARANA, E. R. M.; NAVARRO, I. T.; VIDOTTO, O.; FREIRE, R. L.; LOTT, R. Ocorrência de anticorpos antiToxoplasma gondii em bovinos de corte, abatidos em matadouros do Norte do Paraná - Brasil. Semina: ciências agrárias, v. 15, n. 1, p. 38-40, 1994.

MARKER, L.; MUNSON, L.; BASSON, P. A.; QUACKENBUSH, S. Multicentric T-cell lymphoma associated with feline leukemia virus infection in a captive Namibian cheetah (Acinonyx jubatus). Journal of Wildlife Diseases, v. 39, n. 3, p. 690-695, 2003.

MARQUES, J. M.; ISBRECHT, F. B.; LUCAS, T. M.; GUERRA, I. M. P.; DALMOLIN, A.; DA SILVA, R. C.; LANGONI, H.; SILVA, A. V. Anti-Toxoplasma gondii antibody detection in animals from farms of a rural community of South of Mato Grosso do Sul, Brasil. Semina: ciências agrárias, v. 30, n. 4, p. 889-897, 2009.

MARTIN-ATANCE, P.; PALOMARES, F.; GONZALEZ-CANDELA, M.; REVILLA, E.; CUBERO, M. J.; CALZADA, J.; LEON-VIZCAINO, L. Bovine tuberculosis in a free ranging red fox (Vulpes vulpes) from Donana National Park (Spain). Journal of Wildlife Diseases, v. 41, n. 2, p. 435-436, 2005.

MARTINS, T. F.; SPOLIDORIO, M. G.; BATISTA, T. C. A.; OLIVEIRA, I. A. S.; YOSHINARI, N. H.; LABRUNA, M. B. Occurrence of ticks (Acari: Ixodidae) in the municipality of Goiatins, Tocantins. Revista Brasileira de Parasitologia Veterinária, v. 18, n. 2, p. 50-52, 2009.

MATHIAS, L. A.; GIRIO, R. J. S.; DUARTE, J. M. B. Serosurvey for antibodies against Brucella abortus and Leptospira interrogans in pampas deer from Brazil. Journal of Wildlife Diseases, v. 35, n. 1, p. 112-114, 1999.

MATJILA, P. T.; LEISEWITZ, A. L.; JONGEJAN, F.; BERTSCHINGER, H. J.; PENZHORN, B. L. Molecular detection of Babesia rossi and Hepatozoon sp. in African wild dogs (Lycaon pictus) in South Africa. Veterinary Parasitology, v. 157, n. 1-2, p. 123-127, 2008.

MATSUBAYASHI, M.; TAKAMI, K.; KIMATA, I.; NAKANISHI, T.; TANI, H.; SASAI, K.; BABA, E. Survey of Cryptosporidium spp. and Giardia spp. infections in various animals at a zoo in Japan. Journal of Zoo and Wildlife Medicine, v. 36, n. 2, p. 331-335, 2005.

MAY, R. M. Conservation and disease. Conservation Biology, v. 2, n. 1, p. 28-30, 1988.

MAYOR, P.; LE PENDU, Y.; GUIMARÃES, D. A.; SILVA, J. V.; TAVARES, H. L.; TELLO, M.; PEREIRA, W.; LOPEZBEJAR, M.; JORI, F. A health evaluation in a colony of captive collared peccaries (Tayassu tajacu) in the Eastern Amazon. Research in Veterinary Science, v. 81, n. 2, p. 246-253, 2006.

MAZZOLLI, M. Loss of historical range of jaguars in Southern Brazil. Biodiversity and Conservation, v. 18, n. 6, p. 1715-1717, 2009.

MCALLISTER, M. M. A decade of discoveries in veterinary protozoology changes our concept of "subclinical" toxoplasmosis. Veterinary Parasitology, v. 132, n. 3-4, p. 241-247, 2005. 
MCBRIDE JÚNIOR, R. T.; MCBRIDE, R. T. Safe and selective capture technique for jaguars in the Paraguayan Chaco. The Southwestern Naturalist, v. 52, n. 4, p. 570-577, 2007.

MCCALLUM, H.; JONES, M.; HAWKINS, C.; HAMEDE, R.; LACHISH, S.; SINN, D. L.; BEETON, N.; LAZENBY, B. Transmission dynamics of Tasmanian devil facial tumor disease may lead to disease-induced extinction. Ecology, v. 90, n. 12, p. 3379-3392, 2009.

MCCAW, D. L.; THOMPSON, M.; TATE, D.; BONDERER, A.; CHEN, Y. J. Serum distemper virus and parvovirus antibody titers among dogs brought to a veterinary hospital for revaccination. Journal of the American Veterinary Medical Association, v. 213, n. 1, p. 72, 1998.

MCCULLY, R. M.; BASSON, P. A.; BIGALKE, R. D.; DE VOS, V.; YOUNG, E. Observations on naturally acquired hepatozoonosis of wild carnivores and dogs in South Africa. Onderstepoort Journal of Veterinary

Research, v. 42, n. 4, p. 117-134, 1975.

MCORIST, S.; BOID, R.; JONES, T. W.; EASTERBEE, N.; HUBBARD, A. L.; JARRETT, O. Some viral and protozool diseases in the European wildcat (Felis silvestris). Journal of Wildlife Diseases, v. 27, n. 4, p. 693-696, 1991.

MEDINA-VOGEL, G. Ecology of emerging infectious diseases and wild species conservation. Archivos de Medicina Veterinária, v. 42, n. 1, p. 11-24, 2010.

MEGID, J.; SALGADO, V. R.; KEIA, L. B.; SIQUEIRA, A. K.; MEIRELLES, C. E.; MORETTI, D. M. Brucella abortus infection in dog: case report. Arquivo Brasileiro de Medicina Veterinária e Zootecnia, v. 59, n. 6, p. 15831585, 2007.

MEGID, J.; SOUZA, V. A. F.; TEIXEIRA, C. R.; CORTEZ, A.; AMORIN, R. L.; HEINEMMAN, M. B.; CAGNINI, D. Q.; RICHTZENHAIN, L. J. Canine distemper virus in a crab-eating fox (Cerdocyon thous) in Brazil: case report and phylogenetic analyses. Journal of Wildlife Diseases, v. 45, n. 2, p. 527-530, 2009.

MEINKOTH, J. H.; KOCAN, A. A. Feline cytauxzoonosis. Veterinary Clinics of North America: small animal practice, v. 35, n. 1, p. 89, 2005.

MEINKOTH, J.; KOCAN, A. A.; WHITWORTH, L.; MURPHY, G.; FOX, J. C.; WOODS, J. P. Cats surviving natural infection with Cytauxzoon felis: 18 cases (1997-1998). Journal of Veterinary Internal Medicine, v. 14, n. 5, p. 521-525, 2000.

MELI, M. L.; CATTORI, V.; MARTÍNEZ, F.; LÓPEZ, G.; VARGAS, A.; SIMÓN, M. A.; ZORRILLA, I.; MUÑOZ, A.; PALOMARES, F.; LÓPEZ-BAO, J. V.; PASTOR, J.; TANDON, R.; WILLI, B.; HOFMANN-LEHMANN, R.; LUTZ, H. Feline leukemia virus and other pathogens as important threats to the survival of the critically endangered Iberian lynx (Lynx pardinus). PLoS One, v. 4, n. 3, 2009. Disponível em: $<$ http://www.plosone.org/article/info\%3Adoi\%2F10.1371\%2Fjournal.pone.0004744>. Acesso em: 26 out. 2010. 
MENDES-DE-ALMEIDA, F.; FARIA, M. C. F.; BRANCO, A. S.; SERRÃO, M. L.; SOUZA, A. M.; ALMOSNY, N.; CHARME, M.; LABARTHE, N. Sanitary conditions of a colony of urban feral cats (Felis catus LINNAEUS, 1758), in a zoological garden of Rio de Janeiro, Brazil. Revista do Instituto de Medicina Tropical de São Paulo, v. 46, n. 5, p.269-274, 2004.

MENDES-DE-ALMEIDA, F.; LABARTHE, N.; GUERRERO, J.; FARIA, M. C. F.; BRANCO, A. S.; PEREIRA, C. D.; BARREIRA, J. D.; PEREIRA, M. J. S. Follow-up of the health conditions of an urban colony of free-roaming cats (Felis catus Linnaeus, 1758) in the city of Rio de Janeiro, Brazil. Veterinary Parasitology, v. 147, n. 1-2, p. 9-15, 2007.

MERCER, S. H.; JONES, L. P.; RAPPOLE, J. H.; TWEDT, D.; LAACK, L. L.; CRAIG, T. M. Hepatozoon sp. in wild carnivores in Texas. Journal of Wildlife Diseases, v. 24, n. 3, p. 574-576, 1988.

MESSICK, J. B. New perspectives about Hemotrophic mycoplasma (formerly, Haemobartonella and Eperythrozoon species) infections in dogs and cats. Veterinary Clinics of North America: small animal practice, v. 33, n. 6, p. 1453, 2003.

METZGER, B. Diagnóstico de hemoparasitas em felídeos neotropicais provenientes de vida livre no Brasil. 2009. 108 f. Dissertação (Mestrado) - Faculdade de Medicina Veterinária e Zootecnia, Universidade Estadual Paulista, Botucatu, 2009.

METZGER, B.; PADUAN, K. D.; RUBINI, A. S.; OLIVEIRA, T. G.; PEREIRA, C.; O'DWYER, L. H. The first report of Hepatozoon sp. (Apicomplexa: Hepatozoidae) in neotropical felids from Brazil. Veterinary Parasitology, $v$. 152, n. 1-2, p. 28-33, 2008.

MEYER, M. E.; MEAGHER, M. Brucellosis in free-ranging bison (Bison bison) in Yellowstone National Park, Grand Teton National Park, and Wood Buffalo National Park - A review. Journal of Wildlife Diseases, v. 31, n. 4, p. 579-598, 1995.

MICHALSKI, F.; PERES, C. A. Disturbance-mediated mammal persistence and abundance area relationships in Amazonian forest fragments. Conservation Biology, v. 21, n. 6, p. 1626-1640, 2007.

MICHEL, A. L.; MULLER, B.; VAN HELDEN, P. D. Mycobacterium bovis at the animal human interface: a problem, or not? Veterinary Microbiology, v. 140, n. 3-4, p. 371-381, 2010.

MILLÁN, J.; CANDELA, M. G.; PALOMARES, F.; CUBERO, M. J.; RODRIGUEZ, A.; BARRAL, M.; DE LA FUENTE, J.; ALMERIA, S.; LEON-VIZCAINO, L. Disease threats to the endangered Iberian lynx (Lynx pardinus).

Veterinary Journal, v. 182, n. 1, p. 114-124, 2009.

MILLÁN, J.; NARANJO, V.; RODRÍGUEZ, A.; PÉREZ DE LA LASTRA, J. M.; MANGOLD, A. J.; DE LA FUENTE, J. Prevalence of infection and 18S rRNA gene sequences of Cytauxzoon species in Iberian lynx (Lynx pardinus) in Spain. Parasitology, v. 134, n. 7, p. 995-1001, 2007. 
MILLAR, P. R.; SOBREIRO, L. G.; BONNA, I. C. F.; AMENDOEIRA, M. R. R. The importance of food animals in the infection for Toxoplasma gondii in Brazil. Semina: ciências agrárias, v. 29, n. 3, p. 693-706, 2008.

MILLER, M. A.; GRIGG, M. E.; KREUDER, C.; JAMES, E. R.; MELLI, A. C.; CROSBIE, P. R.; JESSUP, D. A.; BOOTHROYD, J. C.; BROWNSTEIN, D.; CONRAD, P. A. An unusual genotype of Toxoplasma gondii is common in California sea otters (Enhydra lutris nereis) and is a cause of mortality. International Journal for Parasitology, v. 34, n. 3, p. 275-284, 2004.

MILLER, N. L.; FRENKEL, J. K.; DUBEY, J. P. Oral infections with Toxoplasma cysts and oocysts in felines, other mammals and birds. Journal of Parasitology, v. 58, n. 5, p. 928-937, 1972.

MINEIRO, A.; BEZERRA, E. E. A.; VASCONCELLOS, S. A.; COSTA, F. A. L.; MACEDO, N. A. Leptospiral infection in bovine and its association with reproductive failure and climatic conditions. Arquivo Brasileiro de Medicina Veterinária e Zootecnia, v. 59, n. 5, p. 1103-1109, 2007.

MINISTÉRIO DO MEIO AMBIENTE. Secretaria de Biodiversidade e Florestas. Livro vermelho da fauna brasileira ameaçada de extinção. Brasília: MMA, 2008. 510 p.

MIRANDA, F. R. Pesquisa de anticorpos contra bactérias do gênero Brucella spp., Leptospira spp., Chlamydophila spp. em tamanduás-bandeira (Myrmecophaga tridactyla, Linnaeus, 1758), da RPPN SESC Pantanal, Parque Nacional da Serra da Canastra e Parque Nacional das Emas. 2008. 116 f. Dissertação (Mestrado) - Escola Superior de Agricultura Luiz de Queiroz, Universidade de São Paulo, Piracicaba, 2008.

MONTALI, R. J.; TELL, L.; BUSH, M.; CAMBRE, R. C.; KENNY, D.; SUTHERLAND-SMITH, M.; APPEL, M. J. G. Vaccination against canine distemper in exotic carnivores: successes and failures. Proceedings American Association of Zoo Veterinarians Annual, p. 340-344, 1994.

MONTEIRO, R. M.; RICHTZENHAIN, L. J.; PENA, H. F. J.; SOUZA, S. L. P.; FUNADA, M. R.; GENNARI, S. M.; DUBEY, J. P.; SREEKUMAR, C.; KEID, L. B.; SOARES, R. M. Molecular phylogenetic analysis in Hammondialike organisms based on partial Hsp 70 coding sequences. Parasitology, v. 134, n. 9, p. 1195-1203, 2007.

MONTOYA, J. G.; LIESENFELD, D. O. Toxoplasmosis. The Lancet, v. 363, n. 9425, p. 1956-1976, 2004.

MORATO, R. G.; PAULA, R. C.; CAMPOS, C. B.; LEMOS, F.; CHEIDA, C.; MAFFEI, L. First jaguar photo trapped in the Caatinga of Bahia state, Brazil. Cat News, v. 47, p. 23, 2007.

MORRIS, P. J.; THOEN, C. O.; LEGENDRE, A. M. Pulmonary tuberculosis in an African lion (Panthera leo). Journal of Zoo and Wildlife Medicine, v. 27, n. 3, p. 392-396, 1996.

MORRIS, R. S.; PFEIFFER, D. U.; JACKSON, R. The epidemiology of Mycobacterium bovis infections. Veterinary Microbiology, v. 40, n. 1-2, p. 153-177, 1994. 
MORSHEDI, A.; SOLTANI, M. M. A survey on the seroprevalence of Brucella abortus infection in dogs (West Azarbyjan of Iran). Indian Veterinary Journal, v. 75, n. 12, p. 1083-1084, 1998.

MORTON, D. C.; DEFRIES, R. S.; SHIMABUKURO, Y. E.; ANDERSON, L. O.; ARAI, E.; ESPIRITO-SANTO, F. D.; FREITAS, R.; MORISETTE, J. Cropland expansion changes deforestation dynamics in the Southern Brazilian Amazon. Proceedings of the National Academy of Sciences of the United States of America, v. 103, n. 39, p. 14637-14641, 2006.

MOTZEL, S. L.; WAGNER, J. E. Treatment of experimentally induced cytauxzoonosis in cats with parvaquone and buparvaquone. Veterinary Parasitology, v. 35, n. 1-2, p. 131-138, 1990.

MÜLLER, G. C. K.; GREINERT, J. A.; SILVA FILHO, H. H. Frequência de parasitas intestinais em felines mantidos em zoológicos. Arquivo Brasileiro de Medicina Veterinária e Zootecnia, v. 57, n. 4, p. 559-561, 2005.

MUNDIM, A. V.; MORAIS, L. A.; TAVARES, M.; CURY, M. C.; MUNDIM, M. J. S. Clinical and hematological signs associated with dogs naturally infected by Hepatozoon sp and with other hematozoa: a retrospective study in Uberlândia, Minas Gerais, Brazil. Veterinary Parasitology, v. 153, n. 1-2, p. 3-8, 2008.

MUNDIM, M. J. S.; SOUZA, S. Z.; HORTENCIO, S. M.; CURY, M. C. Frequency of Giardia spp. for two diagnosis methods in feces of dogs. Arquivo Brasileiro de Medicina Veterinaria e Zootecnia, v. 55, n. 6, p. 770-773, 2003.

MUÑOZ, P. M.; BOADELLA, M.; ARNAL, M.; DE MIGUEL, M. J.; REVILLA, M.; MARTÍNEZ, D.; VICENTE, J.; ACEVEDO, P.; OLEAGA, A.; RUIZ-FONS, F.; MARÍN, C. M.; PRIETO, J. M.; DE LA FUENTE, J.; BARRAL, M.; BARBERÁN, M.; LUCO, D. F.; BLASCO, J. M.; GORTÁZAR, C. Spatial distribution and risk factors of Brucellosis in Iberian wild ungulates. BMC Infectious Diseases, v. 10, n. 46, 2010. Disponível em: <http://www.biomedcentral.com/1471-2334/10/46>. Acesso em: 26 out. 2010.

MUNSON, L.; MARKER, L.; DUBOVI, E.; SPENCER, J. A.; EVERMANN, J. F.; O'BRIEN, S. J. Serosurvey of viral infections in free-ranging Namibian cheetahs (Acinonyx jubatus). Journal of Wildlife Diseases, v. 40, n. 1 , p. 23-31, 2004.

MUNSON, L.; TERIO, K. A.; KOCK, R.; MLENGEYA, T.; ROELKE, M. E.; DUBOVI, E.; SUMMERS, B.; SINCLAIR, A. R. E.; PACKER, C. Climate extremes promote fatal co-infections during canine distemper epidemics in African lions. PLoS One, v. 3, n. 6, 2008. Disponível em: $<$ http://www.plosone.org/article/info\%3Adoi\%2F10.1371\%2Fjournal.pone.0002545>. Acesso em 26 out. 2010.

MURADIAN, V. Isolamento e caracterização molecular e biológica de Toxoplasma gondii e pesquisa de Neospora caninum em roedores urbanos da Grande São Paulo (SP). Tese (Doutorado)-Faculdade de Medicina Veterinária e Zootecnia, Universidade de São Paulo, São Paulo, 2009. 
MURRAY, D. L.; KAPKE, C. A.; EVERMANN, J. F.; FULLER, T. K. Infectious disease and the conservation of free-ranging large carnivores. Animal Conservation, v. 2, n. 4, p. 241-254, 1999.

MUSEUX, K.; BORETTI, F. S.; WILLI, B.; RIOND, B.; HOELZLE, K.; HOELZLE, L. E.; WITTENBRINK, M. M.; TASKER, S.; WENGI, N.; REUSCH, C. E.; LUTZ, H.; HOFMANN-LEHMANN, R. In vivo transmission studies of 'Candidatus Mycoplasma turicensis' in the domestic cat. Veterinary Research, v. 40, n. 5, 2009. Disponível em:<http://www.vetres.org/index.php?option=com article\&access=standard\&/temid=129\&url=/articles/ vetres/full html/2009/05/v09191/v09191.html>. Acesso em 26 out. 2010.

MYERS, N.; MITTERMEIER, R. A.; MITTERMEIER, C. G.; FONSECA, G. A. B.; KENT, J. Biodiversity hotspots for conservation priorities. Nature, v. 403, n. 6772, p. 853-858, 2000.

NASPHV - NATIONAL ASSOCIATION OF STATE PUPLIC HEALTH VETERINARIANS. Compendium of animal rabies prevention and control. Journal of the American Veterinary Medical Association, v. 128, n. 1, p 2631, 2001.

NAVA, A. F. D. Espécies sentinelas para a Mata Atlântica: as consequências epidemiológicas da fragmentação florestal no Pontal do Paranapanema, São Paulo. 2008. 147 f. Tese (Doutorado) - Faculdade de Medicina Veterinária e Zootecnia, Universidade de São Paulo, São Paulo, 2008.

NAVA, A. F. D.; CULLEN, L.; SANA, D. A.; NARDI, M. S.; RAMOS FILHO, J.; LIMA, T. F.; ABREU, K. C.; FERREIRA, F. First evidence of canine distemper in Brazilian free-ranging felids. Ecohealth, v. 5, n. 4, p. 513-518, 2008.

NEGRÕES, N. Human and wildlife coexistence: challenges of carnivore conservation. 2009. Tese (Doutorado) - Universidade de Aveiro, Aveiro, 2009.

NIETFELD, J. C.; POLLOCK, C. Fatal cytauxzoonosis in a free-ranging bobcat (Lynx rufus). Journal of Wildlife Diseases, v. 38, n. 3, p. 607-610, 2002.

NISHIMURA, Y.; GOTO, Y.; YONEDA, K.; ENDO, Y.; MIZUNO, T.; HAMACHI, M.; MARUYAMA, H.; KINOSHITA, H.; KOGA, S.; KOMORI, M.; FUSHUKU, S.; USHINOHAMA, K.; AKUZAWA, M.; WATARI, T.; HASEGAWA, A.; TSUJIMOTO, $\mathrm{H}$. Interspecies transmission of feline immunodeficiency virus from the domestic cat to the Tsushima cat (Felis bengalensis euptilura) in the wild. Journal of Virology, v. 73, n. 9, p. 7916-7921, 1999.

NORMAN, S. A. Spatial epidemiology and GIS in marine mammal conservation medicine and disease research. EcoHealth, v. 5, n. 3, p. 257-267, 2008.

NUNO, A. M. Conserving carnivores: A. Attitudes of Portuguese high school students towards carnivores. B. Feeding habits of the jaguar: local and regional perspectives. 2007. 105 f. Dissertação (Mestrado) University of Leeds, United Kingdom, 2007. 
O’BRIEN, D. J.; SCHMITT, S. M.; FITZGERALD, S. D.; BERRY, D. E.; HICKLING, G. J. Managing the wildlife reservoir of Mycobacterium bovis: The Michigan, USA, experience. Veterinary Microbiology, v. 112, n. 2/4, p. 313-323, 2006a.

O'BRIEN, S. J.; TROYER, J. L.; ROELKE, M.; MARKER, L.; PECON-SLATTERY, J. Plagues and adaptation: lessons from the Felidae models for SARS and AIDS. Biological Conservation, v. 131, n. 2, p. 255-267, 2006b.

OCHOLI, R. A.; KALEJAIYE, J. O.; OKEWOLE, P. A. Acute disseminated toxoplasmosis in 2 captive lions (Panthera leo) in Nigeria. Veterinary Record, v. 124, n. 19, p. 515-516, 1989.

O'DWYER, L. H.; MASSARD, C. L.; SOUZA, J. C. P. Hepatozoon canis infection associated with dog ticks of rural areas of Rio de Janeiro State, Brazil. Veterinary Parasitology, v.94, n. 3, p. 143-150, 2001.

O'DWYER, L. H.; SAITO, M. E.; HASEGAWA, M. Y.; KOHAYAGAWA, A. Prevalence, hematology and serum biochemistry in stray dogs naturally infected by Hepatozoon canis in São Paulo. Arquivo Brasileiro de Medicina Veterinária e Zootecnia, v. 58, n. 4, p. 688-690, 2006.

O'DWYER, L. H.; SAITO, M. E.; HASEKAWA, M. Y.; KOHAYAGAWA, A. Tissue stages of Hepatozoon canis in naturally infected dogs from São Paulo State, Brazil. Parasitology Research, v. 94, n. 3, p. 240-242, 2004.

OGATA, V. S. P.; GONÇALVES, V. C. F.; FIGUEIREDO, J. R.; LÔBO, A. L.; RODRIGUES, M.; AMAKU, M.; FERREIRA, F.; FERREIRA-NETO, J. S. Situação epidemiológica da brucelose bovina no Estado do Tocantins. Arquivo Brasileiro de Medicina Veterinária e Zootecnia, v. 61, p. 126-134, 2009. Suplemento 1.

OGAWA, L.; FREIRE, R. L.; VIDOTTO, O.; GONDIM, L. F. P.; NAVARRO, I. T. Occurrence of antibodies to Neospora caninum and Toxoplasma gondii in dairy cattle from the northern region of the Paraná State, Brazil. Arquivo Brasileiro de Medicina Veterinária e Zootecnia, v. 57, n. 3, p. 312-316, 2005.

OIE - OFFICE INTERNATIONAL DES EPIZOOTIES. Terrestrial animal health code 2008. Paris: OIE, 2008. Disponível em: <http://www.oie.int>. Acesso em: 12 mar. 2010.

O'KEEFE, J. S. A brief review on the laboratory diagnosis of leptospirosis. New Zealand Veterinary Journal, v. 50, n. 1, p. 9-13, 2002.

OLIVARES, R.; RIVEROS, V.; PINOCHET, L. Brucellosis: serologic survey of animals in a zoo. Archivos de Medicina Veterinária, v. 25, n. 1, p. 101-105, 1993.

OLIVEIRA, C. B.; SOARES, J. F.; SILVA, A. S.; SILVA, M. K.; SALOMAO, E. L.; MONTEIRO, S. G. Occurrence of Giardia sp. and Cryptosporidium sp. in Leopardus weidii of wild life. Ciência Rural, v. 38, n. 2, p. 546-547, 2008. 
OLMSTED, R. A.; LANGLEY, R.; ROELKE, M. E.; GOEKEN, R. M.; ADGERJOHNSON, D.; GOFF, J. P.; ALBERT, J. P.; PACKER, C.; LAURENSON, M. K.; CARO, T. M.; SCHEEPERS, L.; WILDT, D. E.; BUSH, M.; MARTENSON, J. S.; OBRIEN, S. J. Worldwide prevalence of lentivirus infection in wild feline species: epidemiologic and phylogenetic aspects. Journal of Virology, v. 66, n. 10, p. 6008-6018, 1992.

OMS - ORGANIZAÇÃO MUNDIAL DA SAÚDE. Rabies, 2010a. Disponível em:

<http://www.who.int/zoonoses/diseases/rabies/en/>. Acesso em: 10 maio 2010.

OMS - ORGANIZAÇÃO MUNDIAL DA SAÚDE. Tuberculose bovina, 2010b. Disponível em: $<$ http://www.who.int/es/>. Acesso em: 20 maio 2010.

OMS - ORGANIZAÇÃO MUNDIAL DA SAÚDE. WHO Expert committee on rabies: eight report. Technical Report Series, 824. Geneva: World Health Organization, 1992. 84 p.

O'REILLY, L. M.; DABORN, C. J. The epidemiology of Mycobacterium-bovis infections in animals and man: a review. Tubercle and Lung Disease, v. 76, n. 1, p. 1-46, 1995.

ORTUÑO, A.; CASTELLA, J.; CRIADO-FORNELLO, A.; BULING, A.; BARBA-CARRETERO, J. C. Molecular detection of a Hepatozoon species in stray cats from a feline colony in North Eastern Spain. Veterinary Journal, v. 177, n. 1, p. 134-135, 2008.

OSAVA, C. F.; SALABERRY, S. R. S.; NASCIMENTO, C. C. N.; LIMA-RIBEIRO, A. M. C.; MOREIRA, R. Q.; CASTRO, J. R.; RIGO, V. H. B. Occurrence of Leptospira spp. antibodies in pigs from different housing systems. Bioscience Journal, v. 26, n. 2, p. 202-207, 2010.

OSOFSKY, S. A.; HIRSCH, K. J. Chemical restraint of endangered mammals for conservation purposes: a practical primer. Oryx, v. 34, n. 1, p. 27-33, 2000.

OSOFSKY, S. A.; HIRSCH, K. J.; ZUCKERMAN, E. E.; HARDY, W. D. Feline lentivirus and feline oncovirus status of free-ranging lions (Panthera leo), leopards (Panthera pardus), and cheetahs (Acinonyx jubatus) in Botswana: a regional perspective. Journal of Zoo and Wildlife Medicine, v. 27, n. 4, p. 453-467, 1996.

OSTFELD, R. S.; GLASS, G. E.; KEESING, F. Spatial epidemiology: an emerging (or re-emerging) discipline. Trends in Ecology and Evolution, v. 20, p. 328-336, 2005.

OSTROWSKI, S.; VAN VUUREN, M.; LENAIN, D. M.; DURAND, A. A serologic survey of wild felids from central west Saudi Arabia. Journal of Wildlife Diseases, v. 39, n. 3, p. 696-701, 2003.

PACKER, C.; ALTIZER, S.; APPEL, M.; BROWN, E.; MARTENSON, J.; O'BRIEN, S. J.; ROELKE-PARKER, M.; HOFMANN-LEHMANN, R.; LUTZ, H. Viruses of the Serengeti: patterns of infection and mortality in African lions. Journal of Animal Ecology, v. 68, n. 6, p. 1161-1178, 1999. 
PALMER, M. V.; WATERS, W. R.; WHIPPLE, D. L. Susceptibility of raccoons (Procyon lotor) to infection with Mycobacterium bovis. Journal of Wildlife Diseases, v. 38, n. 2, p. 266-274, 2002.

PALUDO, G. R.; DELL'PORTO, A.; CASTRO E TRINDADE, A. R.; MCMANUS, C.; FRIEDMAN, H. Hepatozoon spp.: report of some cases in dogs in Brasília, Brazil. Veterinary Parasitology, v. 118, n. 3/4, p. 243-248, 2003.

PALUDO, G. R.; FRIEDMANN, H.; DELL'PORTO, A.; MACINTIRE, D. K.; WHITLEY, E. M.; BOUDREAUX, M. K.; BANETH, G.; BLAGBURN, B. L.; DYKSTRA, C. C. Hepatozoon spp.: pathological and partial $18 S$ rRNA sequence analysis from three Brazilian dogs. Parasitology Research, v. 97, n. 2, p. 167-170, 2005.

PAPINI, R.; GIULIANI, G.; GORINI, G.; CARDINI, G. Survey of feline giardiasis by ELISA test in Italy. Veterinary Research Communications, v. 31, n. 3, p. 297-303, 2007.

PAPPAS, G.; PAPADIMITRIOU, P.; AKRITIDIS, N.; CHRISTOU, L.; TSIANOS, E. V. The new global map of human brucellosis. Lancet Infectious Diseases, v. 6, n. 2, p. 91-99, 2006.

PASSOS, L. M. F.; GEIGER, S. M.; RIBEIRO, M. F. B.; PFISTER, K.; ZAHLER-RINDER, M. First molecular detection of Babesia vogeli in dogs from Brazil. Veterinary Parasitology, v. 127, n. 1, p. 81-85, 2005.

PATERSON, S.; LELLO, J. Mixed models: getting the best use of parasitological data. Trends in Parasitology, v. 19, n. 8, p. 370-375, 2003.

PATTON, S.; RABINOWITZ, A. R. Parasites of wild felidae in Thailand: a coprological survey. Journal of Wildlife Diseases, v. 30, n. 3, p. 472-475, 1994.

PATTON, S.; RABINOWITZ, A.; RANDOLPH, S.; JOHNSON, S. S. A coprological survey of parasites of wild neotropical felidae. Journal of Parasitology, v. 72, n. 4, p. 517-520, 1986.

PAULIN, L. M.; FERREIRA NETO, J. S. O combate à brucelose bovina: situação brasileira. Jaboticabal: Funep, 2003. $154 \mathrm{p}$.

PAVIOLO, A.; DE ANGELO, C. D.; DI BLANCO, Y. E.; DI BITETTI, M. S. Jaguar Panthera onca population decline in the Upper Parana Atlantic Forest of Argentina and Brazil. Oryx, v. 42, n. 4, p. 554-561, 2008.

PAZIEWSKA, A.; BEDNARSKA, M.; NIEWEGLOWSKI, H.; KARBOWIAKL, G.; BAJER, A. Distribution of Cryptosporidium and Giardia spp. in selected species of protected and game mammals from NorthEastern Poland. Annals of Agricultural and Environmental Medicine, v. 14, n. 2, p. 265-270, 2007.

PECON-SLATTERY, J.; TROYER, J. L.; JOHNSON, W. E.; O'BRIEN, S. J. Evolution of feline immunodeficiency virus in Felidae: implications for human health and wildlife ecology. Veterinary Immunology and Immunopathology, v. 123, n. 1-2, p. 32-44, 2008. 
PEDERSEN, A. B.; JONES, K. E.; NUNN, C. L.; ALTIZER, S. Infectious diseases and extinction risk in wild mammals. Conservation Biology, v. 21, n. 5, p. 1269-1279, 2007.

PEIXOTO, P. V.; SOARES, C. O.; SCOFIELD, A.; SANTIAGO, C. D.; FRANCA, T. N.; BARROS, S. S. Fatal cytauxzoonosis in captive reared lions in Brazil. Veterinary Parasitology, v. 145, n. 3-4, p. 383-387, 2007.

PENA, H. F. J.; SOARES, R. M.; AMAKU, M.; DUBEY, J. P.; GENNARI, S. M. Toxoplasma gondii infection in cats from São Paulo state, Brazil: seroprevalence, oocyst shedding, isolation in mice, and biologic and molecular characterization. Research in Veterinary Science, v. 81, n. 1, p. 58-67, 2006.

PENZHORN, B. L. Babesiosis of wild carnivores and ungulates. Veterinary Parasitology, v. 138, n. 1-2, p. 11-21, 2006.

PENZHORN, B. L.; KJEMTRUP, A. M.; LOPEZ-REBOLLAR, L. M.; CONRAD, P. A. Babesia leo n. sp. from lions in the Kruger National Park, South Africa, and its relation to other small piroplasms. Journal of Parasitology, v. 87, n. 3, p. 681-685, 2001.

PENZHORN, B. L.; SCHOEMAN, T.; JACOBSON, L. S. Feline babesiosis in South Africa: a review. Annals of the New York Academy of Sciences, v. 1026, p. 183-186, 2004.

PENZHORN, B. L.; STYLIANIDES, E.; VAN VUUREN, M.; ALEXANDER, K.; MELTZER, D. G. A.; MUKARATI, N. Seroprevalence of Toxoplasma gondii in free-ranging lion and leopard populations in Southern Africa. South African Journal of Wildlife Research, v. 32, n. 2, p. 163-165, 2002.

PEREIRA, M. C.; SZABÓ, M. J. P.; BECHARA, G. H.; MATUSHIMA, E. R.; DUARTE, J. M. B; RECHAV, Y.; FIELDEN, L.; KEIRANS, J. E. Ticks (Acari: Ixodidae) associated with wild animals in the Pantanal region of Brazil. Journal of Medical Entomology, v. 37, n. 5, p. 979-983, 2000.

PEREZ, J.; CALZADA, J.; LEON-VIZCAINO, L.; CUBERO, M. J.; VELARDE, J.; MOZOS, E. Tuberculosis in an Iberian lynx (Lynx pardina). Veterinary Record, v. 148, n. 13, p. 414-415, 2001.

PEREZ, R. R.; RUBINI, A. S.; O'DWYER, L. H. The first report of Hepatozoon spp. (Apicomplexa, Hepatozoidae) in domestic cats from São Paulo state, Brazil. Parasitology Research, v. 94, n. 2, p. 83-85, 2004.

PETERS, I. R.; HELPS, C. R.; WILLI, B.; HOFMANN-LEHMANN, R.; TASKER, S. The prevalence of three species of feline haemoplasmas in samples submitted to a diagnostics service as determined by three novel realtime duplex PCR assays. Veterinary Microbiology, v. 126, n. 1-3, p. 142-150, 2008.

PFUKENYI, D. M.; PAWANDIWA, D.; MAKAYA, P. V.; USHEWOKUNZE-OBATOLU, U. A retrospective study of wildlife rabies in Zimbabwe, between 1992 and 2003. Tropical Animal Health and Production, v. 41, n. 4, p. 565-572, 2009. 
PICCININI, R. S.; FREITAS, C. E. A. Experiences with rabies control in Brazil. In: KUWERT, E.; MÉRIEUX, C.; KOPROWSKI, H.; BÖGEL, K. Rabies in the tropics. Berlin: Springer Verlag, 1985. p. 737-741.

PILGER, D.; SCHWALFENBERG, S.; HEUKELBACH, J.; WITT, L.; MEHLHORN, H.; MENCKE, N.; KHAKBAN, A.; FELDMEIER, H. Investigations on the biology, epidemiology, pathology, and control of Tunga penetrans in Brazil: VII. The importance of animal reservoirs for human infestation. Parasitology Research, v. 102, n. 5, p. 875-880, 2008.

PIMENTEL, J. S.; GENNARI, S. M.; DUBEY, J. P.; MARVULO, M. F. V.; VASCONCELLOS, S. A.; MORAIS, Z. M.; SILVA, J. C. R.; NETO, J. E. Serological survey of toxoplasmosis and leptospirosis in neotropical wild mammals from Aracaju Zoo, Sergipe, Brazil. Pesquisa Veterinária Brasileira, v. 29, n. 12, p. 1009-1014, 2009.

PLUMB, G.; BABIUK, L.; MAZET, J.; OLSEN, S.; PASTORET, P. P.; RUPPRECHT, C.; SLATE, D. Vaccination in conservation medicine. Revue Scientifique et Technique-Office International des Epizooties, v. 26, n. 1, p. 229-241, 2007.

POESTER, F. P.; GONCALVES, V. S. P.; LAGE, A. P. Brucellosis in Brazil. Veterinary Microbiology, v. 90, n. 14, p. 55-62, 2002.

POLI, A.; ABRAMO, F.; CAVICCHIO, P.; BANDECCHI, P.; GHELARDI, E.; PISTELLO, M. Lentivirus infection in an African lion: a clinical, pathological and virological study. Journal of Wildlife Diseases, v. 31, n. 1, p. 7074, 1995.

POLLEY, L. Navigating parasite webs and parasite flow: emerging and re-emerging parasitic zoonoses of wildlife origin. International Journal for Parasitology, v. 35, n. 11-12, p. 1279-1294, 2005.

PORFÍRIO, G. E. O. Ecologia alimentar da onça-pintada (Panthera onca) na sub-região do Pantanal de Miranda - MS. 2009. 87 f. Dissertação (Mestrado) - Programa de Pós-graduação em Ecologia e Conservação, Universidade Federal de Mato Grosso do Sul, Campo Grande, 2009.

PRIOR, M. G. Isolation of Brucella abortus from 2 dogs in contact with bovine brucellosis. Canadian Journal of Comparative Medicine Revue Canadienne De Medecine Comparee, v. 40, n. 1, p. 117-118, 1976.

PROFFITT, K. M.; WHITE, P. J.; GARROTT, R. A. Spatio-temporal overlap between Yellowstone bison and elk - implications of wolf restoration and other factors for brucellosis transmission risk. Journal of Applied Ecology, v. 47, n. 2, p. 281-289, 2010.

PURVIS, A.; GITTLEMAN, J. L.; COWLISHAW, G.; MACE, G. M. Predicting extinction risk in declining species. Proceedings of the Royal Society B-Biological Sciences, v. 267, n. 1456, p. 1947-1952, 2000. 
QUIGLEY, H. B.; CRAWSHAW, P. G. A conservation plan for the jaguar Panthera onca in the Pantanal region of Brazil. Biological Conservation, v. 61, n. 3, p. 149-157, 1992.

RABINOWITZ, A. R. Jaguar predation on domestic livestock in Belize. Wildlife Society Bulletin, v. 14, n. 2, p. 170-174, 1986.

RABINOWITZ, A.; ZELLER, K. A. A range-wide model of landscape connectivity and conservation for the jaguar, Panthera onca. Biological Conservation, v. 143, n. 4, p. 939-945, 2010.

RAMALHO, E. E.; MAGNUSSON, W. E. Habitat use by the jaguar (Panthera onca) in varzea lake areas, Mamiraua Sustainable Development Reserve. Uakari, v. 4, n. 2, p. 33-39, 2008.

RAMANATHAN, A.; MALIK, P. K.; PRASAD, G. Seroepizootiological survey for selected viral infections in captive Asiatic lions (Panthera leo persica) from Western India. Journal of Zoo and Wildlife Medicine, v. 38, n. 3, p. 400-408, 2007.

RAMSDEN, R. O.; JOHNSTON, D. H. Studies on the oral infectivity of rabies virus in carnivora. Journal of Wildlife Diseases, v. 11, n. 3, p. 318-324, 1975.

RASHEED, S.; GARDNER, M. B. Isolation of feline leukemia virus from a leopard cat cell-line and search for retrovirus in wild Felidae. Journal of the National Cancer Institute, v. 67, n. 4, p. 929-933, 1981.

RAVAZZOLO, A. P.; COSTA, U. M. Retroviridae. In: FLORES, E. F. Virologia veterinária. Santa Maria: Universidade Federal de Santa Maria, 2007. p. 810-836.

RAWLINS, S. Current trends in screwworm myiasis in the Caribbean region. Veterinary Parasitology, v. 18, p. 241-250, 1985.

REDFORD, K. H. The empty forest. Bioscience, v. 42, n. 6, p. 412-422, 1992.

REGO, A. A. M.; MATUSHIMA, E. R.; PINTO, C. M.; BIASIA, I. Cinomose em canídeos e mustelídeos brasileiros: relato de caso. Brazilian Journal of Veterinary Research and Animal Sciences, v. 34, p. 156158, 1997.

REICHARD, M. V.; BAUM, K. A.; CADENHEAD, S. C.; SNIDER, T. A. Temporal occurrence and environmental risk factors associated with cytauxzoonosis in domestic cats. Veterinary Parasitology, v. 152, n. 3-4, p. 314-320, 2008.

REICHARD, M. V.; MEINKOTH, J. H.; EDWARDS, A. C.; SNIDER, T. A.; KOCAN, K. M.; BLOUIN, E. F.; LITTLE, S. E. Transmission of Cytauxzoon felis to a domestic cat by Amblyomma americanum. Veterinary

Parasitology, v. 161, n. 1-2, p. 110-115, 2009. 
REICHARD, M. V.; VAN DEN BUSSCHE, R. A.; MEINKOTH, J. H.; HOOVER, J. P.; KOCAN, A. A. A new species of Cytauxzoon from Pallas' cats caught in Mongolia and comments on the systematics and taxonomy of piroplasmids. Journal of Parasitology, v. 91, n. 2, p. 420-426, 2005.

REILLY, J. R.; HANSON, L. E.; FERRIS, D. H. Experimentally induced predator chain transmission of Leptospira grippotyphosa from rodents to wild marsupialia and carnivora. American Journal of Veterinary Research, v. 31, n. 8, p. 1443-1448, 1970.

RENWICK, A. R.; WHITE, P. C. L.; BENGIS, R. G. Bovine tuberculosis in Southern African wildlife: a multi species host-pathogen system. Epidemiology and Infection, v. 135, n. 4, p. 529-540, 2007.

RHYAN, J. C.; SPRAKER, T. R. Emergence of diseases from wildlife reservoirs. Veterinary Pathology, v. 47, n. 1, p. 34-39, 2010.

RIBEIRO, M. F. B.; LIMA, J. D.; PASSOS, L. M. F.; GUIMARÃES, A. M. Frequência de anticorpos fluorescentes anti-Babesia canis em cães de Belo Horizonte, Minas Gerais. Arquivos Brasileiros de Medicina Veterinária e Zootecnia, v. 42, n. 6, p. 511-517, 1990.

RICHARDSON, D. J.; GAUTHIER, J. L. A serosurvey of leptospirosis in Connecticut peridomestic wildlife. Vector-Borne and Zoonotic Diseases, v. 3, n. 4, p. 187-193, 2003.

RILEY, S. P. D.; FOLEY, J.; CHOMEL, B. Exposure to feline and canine pathogens in bobcats and gray foxes in urban and rural zones of a National Park in California. Journal of Wildlife Diseases, v. 40, n. 1, p. 11-22, 2004.

RIVETTI JÚNIOR, A. V. Retroviroses, Toxoplasma gondii e Mycoplasma haemofelis em gatos errantes e felinos selvagens do zoológico de Belo Horizonte - MG. 2006. 38 f. Dissertação (Mestrado) - Escola de Veterinária, Universidade Federal de Minas Gerais, Belo Horizonte, 2006.

RIVETTI JÚNIOR, A. V.; CAXITO, F. A.; RESENDE, M.; LOBATO, Z. I. P. Serological evaluation for Toxoplasma gondii by indirect immunofluorescence and detection of feline immunodeficiency virus by nested PCR in wild felines. Arquivo Brasileiro de Medicina Veterinaria e Zootecnia, v. 60, n. 5, p. 1281-1283, 2008.

ROBERGE, J. M.; ANGELSTAM, P. Usefulness of the umbrella species concept as a conservation tool. Conservation Biology, v. 18, n. 1, p. 76-85, 2004.

ROBERTSON, I. D.; THOMSON, R. C. Enteric parasitic zoonoses of domesticated dogs and cats. Microbes and Infection, v. 4, n. 8, p. 867-873, 2002.

ROCHA, W. V.; GONÇALVES, V. S. P.; COELHO, C. G. N. F. L.; BRITO, W. M. E. D.; DIAS, R. A.; DELPHINO, M. K. V. C.; FERREIRA, F.; AMAKU, M.; FERREIRA-NETO, J. S.; FIGUEIREDO, V. C. F.; LÔBO, J. R.; BRITO, L. A. B. Situação epidemiológica da brucelose bovina no Estado de Goiás. Arquivo Brasileiro de Medicina Veterinária e Zootecnia, v. 61, n. 1, p. 27-34, 2009. 
RODRIGUEZ, L. L.; ROEHE, P. M.; BATISTA, H.; KURATH, G. Rhabdoviridae. In: FLORES, E. F. Virologia veterinária. Santa Maria: UFSM, 2007. p. 691-718.

RODWELL, T. C.; KRIEK, N. P.; BENGIS, R. G.; WHYTE, I. J.; VILJOEN, P. C.; DE VOS, V.; BOYCE, W. M. Prevalence of bovine tuberculosis in African buffalo at Kruger National Park. Journal of Wildlife Diseases, v. 37, n. 2, p. 258-264, 2001.

ROELKE, M. E.; BROWN, M. A.; TROYER, J. L.; WINTERBACH, H.; WINTERBACH, C.; HEMSON, G.; SMITH, D.; JOHNSON, R. C.; PECON-SLATTERY, J.; ROCA, A. L.; ALEXANDER, K. A.; KLEIN, L.; MARTELLI, P.; KRISHNASAMY, K.; O'BRIEN, S. J. Pathological manifestations of feline immunodeficiency virus (FIV) infection in wild African lions. Virology, v. 390, n. 1, p. 1-12, 2009.

ROELKE, M. E.; FORRESTER, D. J.; JACOBSON, E. R.; KOLLIAS, G. V.; SCOTT, F. W.; BARR, M. C.; EVERMANN, J. F.; PIRTIE, E. Seroprevalence of infectious disease agents in free-ranging Florida panthers (Felis concolor coryl). Journal of Wildlife Diseases, v. 29, n. 1, p. 36-49, 1993.

ROELKE-PARKER, M. E.; MUNSON, L.; PACKER, C.; KOCK, R.; CLEAVELAND, S.; CARPENTER, M.; OBRIEN, S. J.; POSPISCHIL, A.; HOFMANNLEHMANN, R.; LUTZ, H.; MWAMENGELE, G. L. M.; MGASA, M. N.; MACHANGE, G. A.; SUMMERS, B. A.; APPEL, M. J. G. A canine distemper virus epidemic in Serengeti lions (Panthera leo). Nature, v. 379, n. 6564, p. 441-445, 1996.

ROJKO, J. L.; KOCIBA, G. J. Pathogenesis of infection by the feline leukemia virus. Journal of the American Veterinary Medical Association, v. 199, n. 10, p. 1305-1310, 1991.

ROSATTE, R. C.; GUNSON, J. R. Presence of neutralizing antibodies to rabies virus in striped skunks Mephitis mephitis from areas free of skunk rabies in Alberta Canada. Journal of Wildlife Diseases, v. 20, n. 3, p. 171-176, 1984.

ROTSTEIN, D. S.; TAYLOR, S. K.; HARVEY, J. W.; BEAN, J. Hematologic effects of cytauxzoonosis in Florida panthers and Texas cougars in Florida. Journal of Wildlife Diseases, v. 35, n. 3, p. 613-617, 1999.

RUBINI, A. S.; PADUAN, K. D.; CAVALCANTE, G. G.; RIBOLLA, P. E. M.; O'DWYER, L. H. Molecular identification and characterization of canine Hepatozoon species from Brazil. Parasitology Research, v. 97, n. 2, p. 91-93, 2005.

RUBINI, A. S.; PADUAN, K. D. S.; LOPES, V. V. A.; O'DWYER, L. H. Molecular and parasitological survey of Hepatozoon canis (Apicomplexa: Hepatozoidae) in dogs from rural area of Sao Paulo state, Brazil. Parasitology Research, v. 102, n. 5, p. 895-899, 2008.

RUBINI, A. S.; PADUAN, K. S.; MARTINS, T. F.; LABRUNA, M. B.; O'DWYER, L. H. Acquisition and transmission of Hepatozoon canis (Apicomplexa: Hepatozoidae) by the tick Amblyomma ovale (Acari: Ixodidae). Veterinary Parasitology, v. 164, n. 2-4, p. 324-327, 2009. 
RUBINI, A. S.; PADUAN, K. D.; PEREZ, R. R.; RIBOLLA, P. E. M.; O'DWYER, L. H. Molecular characterization of feline Hepatozoon species from Brazil. Veterinary Parasitology, v. 137, n. 1-2, p. 168-171, 2006.

RUPPRECHT, C. E. Rabies: global problem, zoonotic, threat, and preventive management. In: FOWLER, M. E.; MILLER, R. E. Zoo and wild animal medicine: current therapy. 4. ed. Philadelphia: WB Saunders, 1999. p. $136-146$.

SAINSBURY, A. W.; KIRKWOOD, J. K.; BENNETT, P. M.; CUNNINGHAM, A. A. Status of wildlife health monitoring in the United Kingdom. Veterinary Record, v. 148, n. 18, p. 558-563, 2001.

SALAZAR, D. G.; OTERO, F. D.; MEZA, L. J.; FLORES, M. A. S.; GARCIA, R. E.; ARRIAGA, C. D. Detection and anatomopathological description of tuberculosis in an Ankole Watusi colony. Técnica Pecuaria en México, v. 45 , n. 1, p. 101-109, 2007.

SANDERSON, E. W.; REDFORD, K. H.; CHETKIEWICZ, C. L. B.; MEDELLIN, R. A.; RABINOWITZ, A. R.; ROBINSON, J. G.; TABER, A. B. Planning to save a species: the jaguar as a model. Conservation Biology, v. 16, n. 1, p. 58-72, 2002.

SANTAROSA, C. A.; SULZER, C. R.; GIORGI, W.; SILVA, A. S. D.; YANAGUITA, R. M.; LOBAO, A. O. Leptospirosis in wildlife in Brazil: isolation of a new serotype in pyrogenes group. American Journal of Veterinary Research, v. 36, n. 9, p. 1363-1365, 1975.

SANTAROSA, C. A.; SULZER, C. R.; YANAGUITA, R. M.; SILVA, A. S. Leptospirosis in wildlife in Brazil: isolation of serovars canicola, pyrogenes and grippotyphosa. International Journal of Zoonoses, v. 7, n. 1, p. 40-43, 1980.

SANTOS, A. P. Infecção por hemoplasmas em felinos domésticos da região de Porto Alegre, Rio Grande do Sul, Brasil. 2008. 162 f. Tese (Doutorado) - Faculdade de Veterinária, Universidade Federal do Rio Grande do Sul, Rio Grande do Sul. 2008.

SANTOS, A. P.; MESSICK, J. B.; BIONDO, A. W.; OLIVEIRA, S. T.; PEDRALLI, V.; LASTA, C. S.; LACERDA, L. A.; ESTEVES, V. S.; HOFMANN-LEHMANN, R.; WILLI, B.; GONZALEZ, F. H. D. Design, optimization, and application of a conventional PCR assay with an internal control for detection of 'Candidatus Mycoplasma turicensis' 16S rDNA in domestic cats from Brazil. Veterinary Clinical Pathology, v. 38, n. 4, p. 443-452, 2009a.

SANTOS, S. L.; COSTA, K. D.; GONDIM, L. Q.; SILVA, M. S. A.; UZEDA, R. S.; ABE-SANDES, K.; GONDIM, L. F. P. Investigation of Neospora caninum, Hammondia sp., and Toxoplasma gondii in tissues from slaughtered beef cattle in Bahia, Brazil. Parasitology Research, v. 106, n. 2, p. 457-461, 2010.

SANTOS, T. R.; COSTA, A. J.; TONIOLLO, G. H.; LUVIZOTTO, M. C. R.; BENETTI, A. H.; SANTOS, R. R.; MATTA, D. H.; LOPES, W. D. Z.; OLIVEIRA, J. A.; OLIVEIRA, G. P. Prevalence of anti-Toxoplasma gondii antibodies in dairy cattle, dogs, and humans from the Jauru micro region, Mato Grosso state, Brazil. Veterinary Parasitology, v. 161, n. 3-4, p. 324-326, 2009 b. 
SCHALLER, G. B.; CRAWSHAW, P. G. Movement patterns of jaguar. Biotrópica, v. 12, n. 3, p. 161-168, 1980.

SCHMITT, A. C.; REISCHAK, D.; CAVIAC, C. L.; MONFORTE, C. H. L.; COUTO, F. T.; ALMEIDA, A. B. P. F.; SANTOS, D. G. G.; SOUZA, L.; ALVES, C.; VECCHI, K. Infecção pelos vírus da leucemia felina e da peritonite infecciosa felina em felídeo selvagem de vida livre e de cativeiro da região do Pantanal matogrossense. Acta Scientiae Veterinariae, v. 31, n. 3, p. 185-188, 2003.

SCHOLZ, H. C.; HUBALEK, Z.; SEDLÁCEK, I.; VERGNAUD, G.; TOMASO, H.; DAHOUK, S. A.; MELZER, F.; KAMPFER, P.; NEUBAUER, H.; CLOECKAERT, A.; MAQUART, M.; ZYGMUNT, M. S.; WHATMORE, A. M.; FALSEN, E.; BAHN, P.; GÖLLNER, C.; PFEFFER, M.; HUBER, B.; BUSSE, H.; NÖCKLER, K. Brucella microti sp. nov., isolated from the common vole Microtus arvalis. International Journal of Systematic and Evolutionary Microbiology, v. 58, n. 2, p. 375-382, 2008.

SCOTT, M. E. The impact of infection and disease on animal populations implications for conservation biology. Conservation Biology, v. 2, n. 1, p. 40-56, 1988.

SEYMOUR, K. L. Panthera onca. Mammalian Species, v. 340, p. 1-9, 1989.

SHARMA, S.; PATIL, P. K.; KAUR, K.; MEENAKSHI; MAHAJAN, V.; ALKA; SANDHU, K. S. Seroprevalence of Brucella abortus infection in dogs. Indian Veterinary Journal, v. 85, n. 10, p. 1113-1114, 2008.

SHOPHET, R.; MARSHALL, R. B. An experimentally induced predator chain transmission of Leptospira ballum from mice to cats. British Veterinary Journal, v. 136, n. 3, p. 265-270, 1980.

SIDDIKI, A. M. A. M. Z.; MASUDUZZAMAN, M. Cryptosporidium and cryptosporidiosis: a brief review. Bulgarian Journal of Veterinary Medicine, v. 12, n. 2, p. 91-111, 2009.

SILLERO-ZUBIRI, C.; KING, A. A.; MACDONALD, D. W. Rabies and mortality in Ethiopian wolves (Canis simensis). Journal of Wildlife Diseases, v. 32, n.1, p. 80-86, 1996.

SILVA, A. S.; SOARES, J. F.; FACCIO, L.; OTTO, M. A.; ZANETTE, R. A.; PEREIRA, P. L.; SALOMÃO, E. L.; MONTEIRO, S. G. Primeiro registro de parasitismo por Giardia sp. em Leopardus geoffroyi (gato-do-matogrande) mantido em cativeiro. Arquivo de Ciências Veterinárias e Zoologia da UNIPAR, v. 11, n. 1, p. 71$72,2008$.

SILVA, D. A. O.; SILVA, N. M.; MINEO, T. W. P.; NETO, A. A. P.; FERRO, E. A. V.; MINEO, J. R. Heterologous antibodies to evaluate the kinetics of the humoral immune response in dogs experimentally infected with Toxoplasma gondii RH strain. Veterinary Parasitology, v. 107, n. 3, p. 181-195, 2002.

SILVA, J. C. R.; OGASSAWARA, S.; ADANIA, C. H.; FERREIRA, F.; GENNARI, S. M.; DUBEY, J. P.; FERREIRANETO, J. S. Seroprevalence of Toxoplasma gondii in captive neotropical felids from Brazil. Veterinary Parasitology, v. 102, n. 3, p. 217-224, 2001a. 
SILVA, J. C. R.; OGASSAWARA, S.; MARVULO, M. F. V.; FERREIRA-NETO, J. S.; DUBEY, J. P. Toxoplasma gondii antibodies in exotic wild felids from Brazilian zoos. Journal of Zoo and Wildlife Medicine, v. 32, n. 3, p. 349-351, 2001b.

SILVA, M. C. P.; FERREIRA NETO, J. S.; GONÇALVES, V. S. P.; FERREIRA, F.; DIAS, R. A.; AMAKU, M.; KOLODA, M.; LOBO, J. R.; FIGUEIREDO, V. C. F.; MULLER, E. E. Herd prevalence of bovine tuberculosis in the state of Paraná, Brazil. In: Mycobacterium bovis V CONFERENCE, 2009, Wellington. Proceedings... Wellington: Animal Health Board, 2009.

SILVA, N. R. S.; CHAPLIN, E. L.; ARAÚJO, F. A. P.; MENDEZ, L. D. V. Frequência de anticorpos de Toxoplasma gondii em soros de bovinos de leite da Grande Porto Alegre, RS. Arquivos da Faculdade de Veterinária UFRGS, v. 10-11, p. 81-84, 1982/83.

SILVA-JÚNIOR, V. P.; LEANDRO, A.; MOYA-BORJA, G. E. Ocorrência do berne, Dermatobia hominis (Diptera: Cuterebridae) em vários hospedeiros, no Rio de Janeiro, Brasil. Parasitología al Dia, v. 22, N. 3/4, p. 97-101, 1998.

SILVEIRA, L. Ecologia comparada de onça-pintada (Panthera onca) e onça-parda (Puma concolor) no cerrado do Brasil. 2004. 235 f. Tese (Doutorado) - Universidade de Brasília, Distrito Federal, 2004.

SILVEIRA, L.; BOULHOSA, R.; ASTETE, S.; JÁCOMO, A. T. A. Management of domestic livestock predation by jaguars in Brazil. Cat News, special issue, The jaguar in Brazil, n. 4, p. 26-30, 2008.

SILVEIRA, L.; JÁCOMO, A. T. A. Conservacion del jaguar en el centro del cerrado de Brasil. In: MEDELLIN, R. A.; CHETKIEWICZ; RABINOWITZ, A.; REDFORD, K. H.; ROBINSON, J. G.; SANDERSON, E. W.; TABER, A. B. (Ed.). El Jaguar en el nuevo milenio. Una evaluacion de su estado, deteccion de prioridades y recomendaciones para la conservacion de los jaguars en America. México, D. F.: Universidad Nacional Autonoma de Mexico/Wildlife Conservation Society, 2002. p. 437-450.

SILVEIRA, L.; JÁCOMO, A. T. A.; ASTETE, S.; SOlLMANN, R.; TÔRRES, N. M.; FURTADO, M. M.; MARINHOFILHO, J. Jaguar density in the Caatinga of Northeastern Brazil. Oryx, v. 44, n. 1, p.104-109, 2009b.

SILVEIRA, L.; JACOMO, A. T. A.; FURTADO, M. M.; SOLLMANN, R.; TÔRRES, N. M.; COHEN, E.; DINIZ-FILHO, J. A. F. Jaguar corridors in Brazil. In: CARNIVORE CONFERENCE: Carnivore Conservation in a Changing World, 2009, Denver. Anais... Denver: Carnivore Conference, 2009a, p. 48.

SINKOC, A. L.; BRUM, J. G. W.; MORAES, W.; CRAWSHAW, P. Ixodidae parasites of some wild animals in the region of Foz do Iguaçu, Brazil and Argentina. Arquivos do Instituto Biológico São Paulo, v. 65, n. 1, p. 29-33, 1998.

SLAPETA, J. R.; KOUDELA, B.; VOTYPKA, J.; MODRY, D.; HOREJS, R.; LUKES, J. Coprodiagnosis of Hammondia heydomi in dogs by PCR based amplification of ITS 1 rRNA: differentiation from morphologically indistinguishable oocyst of Neospora caninum. Veterinary Journal, v. 163, n. 2, p. 147154, 2002. 
SLATE, P.; ALGEO, T. P.; NELSON, K. M.; CHIPMAN, R. B.; DONOVAN, D.; BLANTON, J. D.; NIEZGODA, M.; RUPPRECHT, C. E. Oral rabies vaccination in North America: opportunities, complexities, and challenges. Neglected Tropical Diseases, v. 3, n. 12, p. 549, 2009.

SMITH, J. S.; YAGER, P. A.; BAER, G. M. A rapid fluorescent focus inhibition test (RFFIT) for determining rabies virus neutralizing antibody. In: MESLIN, F. X.; KAPLAN, M. M.; KOPROWSKI, H. Laboratory techniques in rabies. 4. ed. Geneva: World Health Organization, 1996. p. 181-192.

SMITH, K. F.; BEHRENS, M. D.; SAX, D. F. Local scale effects of disease on biodiversity. Ecohealth, v. 6, n. 2, p. 287-295, 2009.

SMITH, K. F.; SAX, D. F.; LAFFERTY, K. D. Evidence for the role of infectious disease in species extinction and endangerment. Conservation Biology, v. 20, n. 5, p. 1349-1357, 2006.

SMITH, T. G. The genus Hepatozoon (Apicomplexa: Adeleina). Journal of Parasitology, v. 82, n. 4, p. 565$585,1996$.

SOARES, A. O.; SOUZA, A. D.; FELICIANO, E. A.; RODRIGUES, A. F.; D’AGOSTO, M.; DAEMON, E. Avaliação ectoparasitológica e hemoparasitológica em cães criados em apartamentos e casas com quintal na cidade de Juiz de Fora, MG. Revista Brasileira de Parasitologia Veterinária, v. 15, n. 1, p. 13-16, 2006.

SOARES, C. O. Cytauxzoonose felina é diagnosticada e isolada pela primeira vez na América Latina. Revista Clínica Veterinária, n. 32, p. 56-58. 2001.

SOARES, C. O.; SOUZA, J. C. P.; MADRUGA, C. R.; MADUREIRA, R. C.; MASSARD, C. L.; FONSECA, A. H. Seroprevalence of Babesia bovis in cattle in the "Norte Fluminense" mesoregion. Pesquisa Veterinária Brasileira, v. 20, n. 2, p. 75-79, 2000.

SOARES, J. F.; SILVA, A. S.; OLIVEIRA, C. B.; SILVA, M. K.; MARISCANO, G.; SALOMÃO, E. L.; MONTEIRO, S. G. Parasitism by Giardia sp. and Cryptosporidium sp. in Coendou villosus. Ciência Rural, v. 38, n. 2, p. 548550, 2008.

SOGORB, P.; JAMRA, L. F.; GUIMARÃES, E. C.; Toxoplasmose em animais de São Paulo, Brasil. Revista do Instituto de Medicina Tropical de São Paulo, v. 19, n. 3, p. 191-194, 1977.

SOISALO, M. K.; CAVALCANTI, S. M. C. Estimating the density of a jaguar population in the Brazilian Pantanal using camera-traps and capture-recapture sampling in combination with GPS radio-telemetry. Biological Conservation, v. 129, n. 4, p. 487-496, 2006.

SOLLMANN, R.; TÔRRES, N. M.; SILVEIRA, L. Jaguar conservation in Brazil: the role of protected areas. Cat News, special issue, The jaguar in Brazil, n. 4, p. 15-20, 2008. 
SOULÉ, M. E.; TERBORGH, J. The policy and science of regional conservation. In: Continental conservation: scientific foundations of regional reserve networks. Washington: The Wildlands Project, 1999. p. 17.

SOUZA, C. P.; VEROCAI, G. G.; RAMADINHA, R. H. R. Myiasis caused by the New World screwworm fly Cochliomyia hominivorax (Diptera: Calliphoridae) in cats from Brazil: report of five cases. Journal of Feline Medicine and Surgery, v. 12, n. 2, p. 166-168, 2010.

SOUZA, H. J. M.; TEIXEIRA, C. H. R.; GRAÇA, R. F. S. Estudo epidemiológico de infecções pelo vírus da leucemia felina e/ou imunodeficiência felina em gatos domésticos do Município do Rio de Janeiro. Clínica Veterinária, n. 36, p. 14-21, 2002.

SOUZA, J. C. P.; SOARES, C. O.; MASSARD. C. L.; SCOFIELD, A.; FONSECA, A. H. Soroprevalência de Anaplasma marginale em bovinos na mesoregião Norte Fluminense. Pesquisa Veterinária Brasileira, v. 20, n. 1, p. 97-101, 2000.

SOUZA, S. L. P.; MARVULO, M. F. V.; KASHIVAKURA, C. K.; FURTADO, M. M.; JACOMO, A. T. A.; SILVEIRA, L.; FERRO, C.; RAGOZO, A. M. A.; DUBEY, J. P.; GENNARI, S. M.; SILVA, J. C. R. Ocorrência de anticorpos antiToxoplasma gondii em mamíferos silvestres do Parque Nacional das Emas, GO. In: CONGRESSO BRASILEIRO DE PARASITOLOGIA VETERINÁRIA, 14.; SIMPÓSIO LATINO-AMERICANO DE RICKETTISIOSES, 2. 2006, Ribeirão Preto. p. 311.

SPAGNOL, F. H.; PARANHOS, E. B.; OLIVEIRA, L. L. D.; DE MEDEIROS, S. M.; LOPES, C. W. G.; ALBUQUERQUE, G. R. Prevalence of antibodies anti-Toxoplasma gondii in slaughtered cattle at stockyards in the State of Bahia, Brazil. Revista Brasileira de Parasitologia Veterinária, v. 18, n. 2, p. 42-45, 2009.

SPENCER, J. A.; HIGGINBOTHAM, M. J.; BLAGBURN, B. L. Seroprevalence of Neospora caninum and Toxoplasma gondii in captive and free-ranging nondomestic felids in the United States. Journal of Zoo and Wildlife Medicine, v. 34, n. 3, p. 246-249, 2003.

SPENCER, J. A.; MORKEL, P. Serological survey of sera from lions in Etosha-National Park. South African Journal of Wildlife Research, v. 23, n. 2, p. 60-61, 1993.

SPOLIDORIO, M. G.; LABRUNA, M. B.; ZAGO, A. M.; DONATELE, D. M.; CALIARI, K. M.; YOSHINARI, N. H. Hepatozoon canis infecting dogs in the State of Espirito Santo, southeastern Brazil. Veterinary Parasitology, v. 163, n. 4, p. 357-361, 2009.

STANTON, J. B.; GIVENS, L.; EVERMANN, J. F.; BROWN, C. C. Immunohistochemical analysis of two strains of lion (Panthera leo): adapted canine distemper virus in ferrets (Mustela putorius furo). Veterinary

Pathology, v. 40, n. 4, p. 464-467, 2003.

SWANK, W. G.; TEER, J. G. Status of the jaguar 1987. Oryx, v. 23, n. 1, p. 14-21, 1989. 
SYKES, J. E. Feline hemotropic mycoplasmas. Journal of Veterinary Emergency and Critical Care, v. 20, n. 1, p. 62-69, 2010.

SYKES, J. E. Feline hemotropic mycoplasmosis (feline hemobartonellosis). Veterinary Clinics of North America: small animal practice, v. 33, n. 4, p. 773-789, 2003.

SYKES, J. E.; DRAZENOVICH, N. L.; BALL, L. M.; LEUTENEGGER, C. M. Use of conventional and real-time polymerase chain reaction to determine the epidemiology of hemoplasma infections in anemic and nonanemic cats. Journal of Veterinary Internal Medicine, v. 21, n. 4, p. 685-693, 2007.

SZABÓ, M. P. J.; LABRUNA, M. B.; PEREIRA, M. C.; DUARTE, J. M. Ticks (Acari: Ixodidae) on wild marsh-deer (Blastocerus dichotomus) from Southeast of Brazil: infestations prior and after habitat loss. Journal of Medical Entomology, v. 40, n. 3, p.268-274, 2003.

SZABÓ, M. P. J.; SOUZA, L. G. A.; OLEGARIO, M. M. M.; FERREIRA, F. A.; NETO, A. D. P. Ticks (Acari: Ixodidae) on dogs from Uberlândia, Minas Gerais, Brazil. Transboundary and Emerging Diseases, v. 57, n. 1/2, p. 72-74, 2010.

TABOADA, J.; MERCHANT, S. R. Babesiosis of companian animals and man. Veterinary Clinics: small animal practice, v. 21, n. 1, p. 103-123, 1991.

TABOR, G. M. Defining conservation medicine. In: AGUIRRE, A. A.; OSTFELD, R. S.; TABOR, G. M.; HOUSE, C.; PEARL, M. C. Conservation medicine: ecologica health in practice. New York: Oxford University Press, 2002. p. 8-16.

TAROURA, S.; SHIMADA, Y.; SAKATA, Y.; MIYAMA, T.; HIRAOKA, H.; WATANABE, M.; ITAMOTO, K.; OKUDA, M.; INOKUMA, H. Detection of DNA of 'Candidatus Mycoplasma haemominutum' and Spiroplasma sp. in unfed ticks collected from vegetation in Japan. Journal of Veterinary Medical Science, v. 67, n. 12, p. 1277-1279, 2005.

TASKER, S. Current concepts in feline haemobartonellosis. In Practice, v. 28, n. 3, p. 136, 2006.

TASKER, S. Haemotropic mycoplasmas: what's their real significance in cats? Journal of Feline Medicine and Surgery, v. 12, n. 5, p. 369-381, 2010.

TASKER, S.; CANEY, S. M. A.; DAY, M. J.; DEAN, R. S.; HELPS, C. R.; KNOWLES, T. G.; LAIT, P. J. P.; PINCHES, M. D. G.; GRUFFYDD-JONES, T. J. Effect of chronic feline immunodeficiency infection, and efficacy of marbofloxacin treatment, on 'Candidatus Mycoplasma haemominutum' infection. Microbes and Infection, v. 8, n. 3, p. 653-661, 2006.

TASKER, S.; PETERS, I. R.; DAY, M. J.; WILLI, B.; HOFMANN-LEHMANN, R.; GRUFFYDD-JONES, T. J.; HELPS, C. R. Distribution of Mycoplasma haemofelis in blood and tissues following experimental infection. Microbial Pathogenesis, v. 47, n. 6, p. 334-340, 2009. 
TEIXEIRA, T. F.; HOLZ, C. L.; CAIXETA, S.; DEZEN, D.; CIBULSKI, S. P.; DA SILVA, J. R.; ROSA, J. C. A.; SCHMIDT, E.; FERREIRA, J. C.; BATISTA, H.; CALDAS, E.; FRANCO, A. C.; ROEHE, P. M. Rabies diagnosis in the state of Rio Grande do Sul, Brazil, from 1985 to 2007. Pesquisa Veterinária Brasileira, v. 28, n. 10, p. 515520, 2008.

TELENTI, A.; MARCHESI, F.; BALZ, M.; BALLY, F.; BOTTGER, E. C.; BODMER, T. Rapid identification of mycobacteria to the species level by polymerase chain-reaction and restriction enzyme analysis. Journal of Clinical Microbiology, v. 31, n. 2, p. 175-178, 1993.

TERBORGH, J. The big things that run the world - a sequel to E. O. Wilson. Conservation Biology, v. 2, n. 4, p. 402-403, 1988.

THALWITZER, S.; WACHTER, B.; ROBERT, N.; WIBBELT, G.; MULLER, T.; LONZER, J.; MELI, M. L.; BAY, G.; HOFER, H.; LUTZ, H. Seroprevalences to viral pathogens in free-ranging and captive cheetahs (Acinonyx jubatus) on Namibian Farmland. Clinical and Vaccine Immunology, v. 17, n. 2, p. 232-238, 2010.

THOEN, C.; LOBUE, P.; DE KANTOR, I. The importance of Mycobacterium bovis as a zoonosis. Veterinary Microbiology, v. 112, n. 2-4, p. 339-345, 2006.

THOISY, B.; MICHEL, J. C.; VOGEL, I.; VIÉ, J. C. A survey of hemoparasite infections in free-ranging mammals and reptiles in French Guiana. Journal of Parasitology, v. 86, n. 5, p. 1035-1040, 2000.

THOMPSON, J.; YANG, R. C.; POWER, M.; HUFSCHMID, J.; BEVERIDGE, I.; REID, S.; NG, J.; ARMSON, A.; RYAN, U. Identification of zoonotic Giardia genotypes in marsupials in Australia. Experimental Parasitology, v. 120, n. 1, p. 88-93, 2008.

THOMPSON, R. C. A. Giardiasis as a re-emerging infectious disease and its zoonotic potential. International Journal for Parasitology, v. 30, n. 12-13, p. 1259-1267, 2000.

THOMPSON, R. C. A.; KUTZ, S. J.; SMITH, A. Parasite zoonoses and wildlife: emerging issues. International Journal of Environmental Research and Public Health, v. 6, n. 2, p. 678-693, 2009.

THOMPSON, R. C.; MONIS, P. T. Variation in Giardia: implications for taxonomy and epidemiology. Advances in Parasitology, v. 58, p. 69-137, 2004.

THOREL, M. F.; KAROUI, C.; VARNEROT, A.; FLEURY, C.; VINCENT, V. Isolation of Mycobacterium bovis from baboons, leopards and a sea lion. Veterinary Research, v. 29, n. 2, p. 207-212, 1998.

THORNE, E. T. Brucellosis. In: WILLIANS, E. S.; BARKER, I. K. Infectious diseases of wild mammals. 3. ed. Ames: lowa State University Press, 2001. p. 372-395. 
THORNE, E. T.; WILLIAMS, E. S. Disease and endangered species the black-footed ferret as a recent example. Conservation Biology, v. 2, n. 1, p. 66-74, 1988.

THRUSFIELD, M. Epidemiologia veterinária. 2. ed. São Paulo: Roca, 2004. 556 p.

TORRES, A. N.; MATHIASON, C. K.; HOOVER, E. A. Re-examination of feline leukemia virus: host relationships using real-time PCR. Virology, v. 332, n. 1, p. 272-283, 2005.

TÔRRES, N. M.; DE MARCO, P., JR.; DINIZ FILHO, J. A. F.; SILVEIRA, L. Jaguar distribution in Brazil: past, present and future. Cat News, special issue, The jaguar in Brazil, n. 4, p. 4-8, 2008.

TRAPP, S. M.; DAGNONE, A. S.; VIDOTTO, O.; FREIRE, R. L.; AMUDE, A. M.; DE MORAIS, H. S. A. Seroepidemiology of canine babesiosis and ehrlichiosis in a hospital population. Veterinary Parasitology, v. 140, n. 3-4, p. 223-230, 2006.

TROYER, J. L.; PECON-SLATTERY, J.; ROELKE, M. E.; BLACK, L.; PACKER, C.; O'BRIEN, S. J. Patterns of feline immunodeficiency virus multiple infection and genome divergence in a free-ranging population of African lions. Journal of Virology, v. 78, n. 7, p. 3777-3791, 2004.

TROYER, J. L.; PECON-SLATTERY, J.; ROELKE, M. E.; JOHNSON, W.; VANDEWOUDE, S.; VAZQUEZ-SALAT, N.; BROWN, M.; FRANK, L.; WOODROFFE, R.; WINTERBACH, C.; WINTERBACH, H.; HEMSON, G.; BUSH, M.; ALEXANDER, K. A.; REVILLA, E.; O'BRIEN, S. J. Seroprevalence and genomic divergence of circulating strains of Feline immunodeficiency virus among Felidae and Hyaenidae species. Journal of Virology, v. 79, n. 13, p. 8282-8294, 2005.

TROYER, J. L.; VANDEWOUDE, S.; PECON-SLATTERY, J.; MCINTOSH, C.; FRANKLIN, S.; ANTUNES, A.; JOHNSON, W.; O'BRIEN, S. J. FIV Cross-species transmission: an evolutionary prospective. Veterinary Immunology and Immunopathology, v. 123, n. 1-2, p. 159-166, 2008.

TWARK, L.; DODDS, W. J. Clinical use of serum parvovirus and distemper virus antibody titers for determining revaccination strategies in healthy dogs. Journal of the American Veterinary Medical Association, v. 217, n. 7, p. 1021-1024, 2000.

UILENBERG, G. Babesia - A historical overview. Veterinary Parasitology, v. 138, n. 1-2, p. 3-10, 2006.

URQUHART, G. M.; ARMOUR, J.; DUNCAN, J. L.; DUNN, A. M.; JENNINGS, F. W. Parasitologia veterinária. 2. ed. Rio de Janeiro: Guanabara Koogan, 1998. 273 p.

VAN DE BILDT, M. W. G.; KUIKEN, T.; VISEE, A. M.; LEMA, S.; FITZJOHN, T. R.; OSTERHAUS, A. Distemper outbreak and its effect on African wild dog conservation. Emerging Infectious Diseases, v. 8, n. 2, p. 211213, 2002. 
VANDEWAT, C. C.; ZWART, P.; BAKKER, J. Cavernous tuberculosis of lungs and secondary hypertrophic osteoarthropathy in a Siberian tiger (Panthera tigrus). Journal of Small Animal Practice, v. 13, n. 6, p. 321$327,1972$.

VAN HEERDEN, J.; MILLS, M. G. L.; VANVUUREN, M. J.; KELLY, P. J.; DREYER, M. J. An investigation into the health status and diseases of wild dogs (Lycaon pictus) in the Kruger National Park. Journal of the South African Veterinary Association Tydskrif Van Die Suid Afrikaanse Veterinere Vereniging, v. 66, n. 1, p. 18$27,1995$.

VAN MOLL, P.; ALLDINGER, S.; BAUMGARTNER, W.; ADAMI, M. Distemper in wild carnivores: an epidemiological, histological and immunocytochemical study. Veterinary Microbiology, v. 44, n. 2-4, p. 192-199, 1995.

VASCONCELLOS, S. A.; BARBARINI JÚNIOR, O.; UMEHARA, O.; MORAIS, Z. M.; CORTEZ, A.; PINHEIRO, S. R.; FÁVERO, A. C. M.; FERREIRA NETO, J. S. Leptospirose bovina. Níveis de ocorrência e sorotipos predominantes em rebanhos dos Estados de Minas Gerais, São Paulo, Rio de janeiro, Paraná, Rio Grande do Sul e Mato Grosso do Sul. Período de janeiro a abril de 1996. Arquivos do Instituto Biológico, v. 64, n. 2, p. 7-15, 1997.

VEROCAI, G. G.; FERNANDES, J. I.; CORREIA, T. R.; DE SOUZA, C. P.; MELO, R.; SCOTT, F. B. Furuncular myiasis caused by the human bot-fly Dermatobia hominis in a domestic cat from Brazil. Journal of Feline Medicine and Surgery, v. 12, n. 6, p. 491-493, 2010.

VIDOTTO, O.; NAVARRO, I. T.; GIRALDI, N.; MITSUKA, R. FREIRE, R. L. Estudos epidemiológicos da toxoplasmose em suínos da região de Londrina - PR. Semina: ciências agrárias, v. 11, n. 1, p. 53-59, 1990.

VIJAYARANI, K.; NAGALAKSHMI, K. S.; MALATHI, G.; JAYATHANGARAJ, M. G.; SATHASIVAM, S.; KUMANAN, K. Leptospirosis in a lion. Indian Journal of Animal Sciences, v. 79, n. 4, p. 372-372, 2009.

VIJAYACHARI, P.; SUGUNAN, A. P.; SHRIRAM, A. N. Leptospirosis: an emerging global public health problem. Journal of Biosciences, v. 33, n. 4, p. 557-569, 2008.

VITALIANO, S. N.; SILVA, D. A. O.; MINEO, T. W. P.; FERREIRA, R. A.; BEVILACQUA, E.; MINEO, J. R. Seroprevalence of Toxoplasma gondii and Neospora caninum in captive maned wolves (Chrysocyon brachyurus) from southeastern and midwestern regions of Brazil. Veterinary Parasitology, v. 122, n. 4, p. 253-260, 2004.

WAGNER, J. E.; FERRIS, D. H.; KIER, A. B.; WIGHTMAN, S. R.; MARING, E.; MOREHOUSE, L.G.; HANSEN, R. D. Experimentally induced cytauxzoonosis-like disease in domestic cats. Veterinary Parasitology, v. 6, n. 4, p. 305-311, 1980.

WALKER, D. B.; COWELL, R. L. Survival of a domestic cat with naturally acquired cytauxzoonosis. Journal of the American Veterinary Medical Association, v. 206, n. 9, p. 1363-1365, 1995. 
WATKINS, R. A.; MOSHIER, S. E.; PINTER, A. J. The flea, Megabothris abantis: an invertebrate host of Hepatozoon sp. and a likely definitive host in Hepatozoon infections of the montane vole, Microtus montanus. Journal of Wildlife Diseases, v. 42, n. 2, p. 386-390, 2006.

WEBER, W.; RABINOWITZ, A. A global perspective on large carnivore conservation. Conservation Biology, v. 10 , n. 4, p. 1046-1054, 1996.

WENYON, C. M.; HAMERTON, A. E. Piroplasms of the West African civet cat (Viverra civetta) and the bay Iynx (Felis rufus) of North America. Transactions of the Royal Society of Tropical Medicine and Hygiene, v. 24, p. 7-8, 1930.

WHITEMAN, C. W. Conservação de carnívoros e a interface homem-fauna doméstica-fauna silvestre numa área fragmentada da Amazônia oriental brasileira. 2007. 87 f. Tese (Doutorado) - Escola Superior de Agricultura Luiz de Queiroz, Universidade de São Paulo, Piracicaba, 2007.

WHITEMAN, C. W.; MATUSHIMA, E. R.; CONFALONIERIC, U. E. C.; PALHA, M. D. C.; DA SILVA, A. D. L.; MONTEIRO, V. C. Human and domestic animal populations as a potential threat to wild carnivore conservation in a fragmented landscape from the Eastern Brazilian Amazon. Biological Conservation, v. 138, n. 1-2, p. 290-296, 2007.

WIDMER, C. E. Perfil sanitário de onças-pintadas (Panthera onca) de vida livre no Pantanal Sul do Mato Grosso do Sul - Brasil. 2009. 89 f. Dissertação (Mestrado) - Faculdade de Medicina Veterinária e Zootecnia, Universidade de São Paulo, São Paulo. 2009.

WIDMER, C. E.; AZEVEDO, F. C. C. Tungíase em onças-pintadas (Panthera onca) de vida livre no Pantanal Sul - MS. In: ENCONTRO INTERNACIONAL DE MEDICINA DA CONSERVAÇÃO, 2., 2009, Recife. Anais... Recife: Instituto Brasileiro para Medicina da Conservação, 2009.

WILCOVE, D. S.; CHEN, L. Y. Management costs for endangered species. Conservation Biology, v. 12, n. 6, p. 1405-1407, 1998.

WILLI, B.; BORETTI, F. S.; BAUMGARTNER, C.; TASKER, S.; WENGER, B.; CATTORI, V.; MELI, M. L.; REUSCH, C. E.; LUTZ, H.; HOFMANN-LEHMANN, R. Prevalence, risk factor analysis, and follow-up of infections caused by three feline hemoplasma species in cats in Switzerland. Journal of Clinical Microbiology, v. 44, n. 3, p. 961-969, 2006a.

WILLI, B.; BORETTI, F. S.; CATTORI, V.; TASKER, S.; MELI, M. L.; REUSCH, C.; LUTZ, H.; HOFMANNLEHMANN, R. Identification, molecular characterization, and experimental transmission of a new hemoplasma isolate from a cat with hemolytic anemia in Switzerland. Journal of Clinical Microbiology, v. 43, n. 6, p. 2581-2585, 2005. 
WILLI, B.; BORETTI, F. S.; MELI, M. L.; BERNASCONI, M. V.; CASATI, S.; HEGGLIN, D.; PUORGER, M.; NEIMARK, H.; CATTORI, V.; WENGI, N.; REUSCH, C. E.; LUTZ, H.; HOFMANN-LEHMANN, R. Real-time PCR investigation of potential vectors, reservoirs, and shedding patterns of feline hemotropic mycoplasmas. Applied and Environmental Microbiology, v. 73, n. 12, p. 3798-3802, 2007a.

WILLI, B.; BORETTI, F. S.; TASKER, S.; MELI, M. L.; WENGI, N.; REUSCH, C. E.; LUTZ, H.; HOFMANNLEHMANN, R. From Haemobartonella to hemoplasma: molecular methods provide new insights. Veterinary Microbiology, v. 125, n. 3/4, p. 197-209, 2007b.

WILLI, B.; FILONI, C.; CATÃO-DIAS, J. L.; CATTORI, V.; MELI, M. L.; VARGAS, A.; MARTINEZ, F.; ROELKE, M. E.; RYSER-DEGIORGIS, M. P.; LEUTENEGGER, C. M.; LUTZ, H.; HOFMANN-LEHMANN, R. Worldwide occurrence of feline hemoplasma infections in wild felid species. Journal of Clinical Microbiology, v. 45, n. 4, p. 1159-1166, 2007c.

WILLI, B.; TASKER, S.; BORETTI, F. S.; DOHERR, M. G.; CATTORI, V.; MELI, M. L.; LOBETTI, R. G.; MALIK, R.; REUSCH, C. E.; LUTZ, H.; HOFMANN-LEHMANN, R. Phylogenetic analysis of "Candidatus mycoplasma turicensis" isolates from pet cats in the United Kingdom, Australia, and South Africa, with analysis of risk factors for infection. Journal of Clinical Microbiology, v. 44, n. 12, p. 4430-4435, $2006 \mathrm{~b}$.

WILLIAMS, E. S.; THORNE, E. T.; ANDERSON, S. L.; HERRIGES, J. D. Brucellosis in free-ranging bison (Bison bison) from Teton County, Wyoming. Journal of Wildlife Diseases, v. 29, n. 1, p. 118-122, 1993.

WILLIAMS, E. S.; THORNE, E. T.; APPEL, M. J. G.; BELITSKY, D. W. Canine-distemper in black-footed ferrets (Mustela nigripes) from Wyoming. Journal of Wildlife Diseases, v. 24, n. 3, p. 385-398, 1988.

WINTERS, K. A.; MATHES, L. E.; KRAKOWKA, S.; OLSEN, R. G.; Immunoglobulin class response to canine distemper virus in gnotobiotic dogs. Veterinary Immunology and Immunopathology, v. 5, n.2, p. 209-215, 1984.

WOODROFFE, R. Managing disease threats to wild mammals. Animal Conservation, v. 2, n. 3, p. 185-193, 1999.

WOODFORD, M. H. Veterinary aspects of ecological monitoring: the natural history of emerging infectious diseases of humans, domestic animals and wildlife. Tropical Animal Health and Production, v. 41, n. 7, p. 1023-1033, 2009.

WOODS; J. E.; BREWE, M. M.; HAWLEY, J. R.; WISNEWSKI, N.; LAPPIN, M. R. Evaluation of experimental transmission of 'Candidatus Mycoplasma haemominutum' and Mycoplasma haemofelis by Ctenocephalides felis to cats. American Journal of Veterinary Research, v. 66, n. 6, p. 1008-1012, 2005.

WORLEY, M.; WILLIAMS, E. S.; BARKER, I. K. Retrovirus infections. In: WILLIAMS, E. S.; BARKER, I. K. Infectious diseases of wild mammals. 3. ed. Ames: lowa State, University Press, 2001. p. 213-222. 
XIANG, Z.; CHEN, X. W.; YANG, L. J.; HE, Y. S.; JIANG, R. S.; ROSENTHAL, B. M.; LUAN, P. T.; ATTWOOD, S. W.; ZUO, Y. X.; ZHANG, Y. P.; YANG, Z. Q. Non-invasive methods for identifying oocysts of Sarcocystis spp. from definitive hosts. Parasitology International, v. 58, n. 3, p. 293-296, 2009.

XIAO, L.; ESCALANTE, L.; YANG, C.; SULAIMAN, I.; ESCALANTE, A. A.; MONTALI, R. J.; FAYER, R.; LAL, A. A. Phylogenetic analysis of Cryptosporidium parasites based on the small-subunit rRNA gene locus. Applied and Environmental Microbiology, v. 65, n. 4, p. 1578-1583, 1999.

XIAO, L. H.; RYAN, U. M. Cryptosporidiosis: an update in molecular epidemiology. Current Opinion in Infectious Diseases, v. 17, n. 5, p. 483-490, 2004.

YABSLEY, M. J.; MURPHY, S. M.; CUNNINGHAM, M. W. Molecular detection and characterization of Cytauxzoon felis and a Babesia species in cougars from Florida. Journal of Wildlife Diseases, v. 42, n. 2, p. 366-374, 2006.

YAI, L. E. O.; CANON-FRANCO, W. A.; GERALDI, V. C.; SUMMA, M. E. L.; CAMARGO, M.; DUBEY, J. P.; GENNARI, S. M. Seroprevalence of Neospora caninum and Toxoplasma gondii antibodies in the South American opossum (Didelphis marsupialis) from the city of Sao Paulo, Brazil. Journal of Parasitology, v. 89, n. 4, p. 870-871, 2003.

YASUDA, P. H.; SANTA ROSA, C. A.; MYERS, D. M.; YANAGUITA, R. M. The isolation of leptospires from stray dogs in the city of São Paulo, Brazil. International Journal of Zoonosis, v. 7, n. 2, p.131-134, 1980.

ZANELLA, G.; DUVAUCHELLE, A.; HARS, J.; MOUTOU, F.; BOSCHIROLI, M. L.; DURAND, B. Patterns of lesion of bovine tuberculosis in wild red deer and wild boar. Veterinary Record, v. 163, n. 2, p. 43-47, 2008.

ZARNKE, R. L.; DUBEY, J. P.; KWOK, O. C. H.; VER HOEF, J. M. Serologic survey for Toxoplasma gondii in selected wildlife species from Alaska. Journal of Wildlife Diseases, v. 36, n. 2, p. 219-224, 2000.

ZARNKE, R. L.; DUBEY, J. P.; VER HOEF, J. M.; MCNAY, M. E.; KWOK, O. C. H. Serologic survey for Toxoplasma gondii in lynx from interior Alaska. Journal of Wildlife Diseases, v. 37, n. 1, p. 36-38, 2001.

ZELLER, K. Jaguars in the new millennium data base update: the state of the jaguar in 2006. New York: Wildlife Conservation Society, 2007. Jaguar Conservation Program.

ZHANG, S.; LIU, Y.; FOOKS, A. R.; ZHANG, F.; HU, R. Oral vaccination of dogs (Canis familiaris) with baits containing the recombinant rabies-canine adenovirus type-2 vaccine confers long-lasting immunity against rabies. Vaccine, v. 26, n. 3, p. 345-350, 2008.

ZHOU, L.; FAYER, R.; TROUT, J. M.; RYAN, U. A.; SCHAEFER, F. W.; XIAO, L. H. Genotypes of Cryptosporidium species infecting fur-bearing mammals differ from those of species infecting humans. Applied and Environmental Microbiology, v. 70, n. 12, p. 7574-7577, 2004. 
ZIEGLER, P. E.; WADE, S. E.; SCHAAF, S. L.; STERN, D. A.; NADARESKI, C. A.; MOHAMMED, H. O. Prevalence of Cryptosporidium species in wildlife populations within a watershed landscape in southeastern New York State. Veterinary Parasitology, v. 147, n. 1-2, p. 176-184, 2007.

ZINKL, J. G.; MCDONALD, S. E.; KIER, A. B.; CIPPA, S. J.; SMALL, P. J. Cytauxzoon-like organisms in erythrocytes of 2 cheetahs. Journal of the American Veterinary Medical Association, v. 179, n. 11, p. 1261-1262, 1981. 


\section{APÊNDICE A - FICHA CLÍNICA}

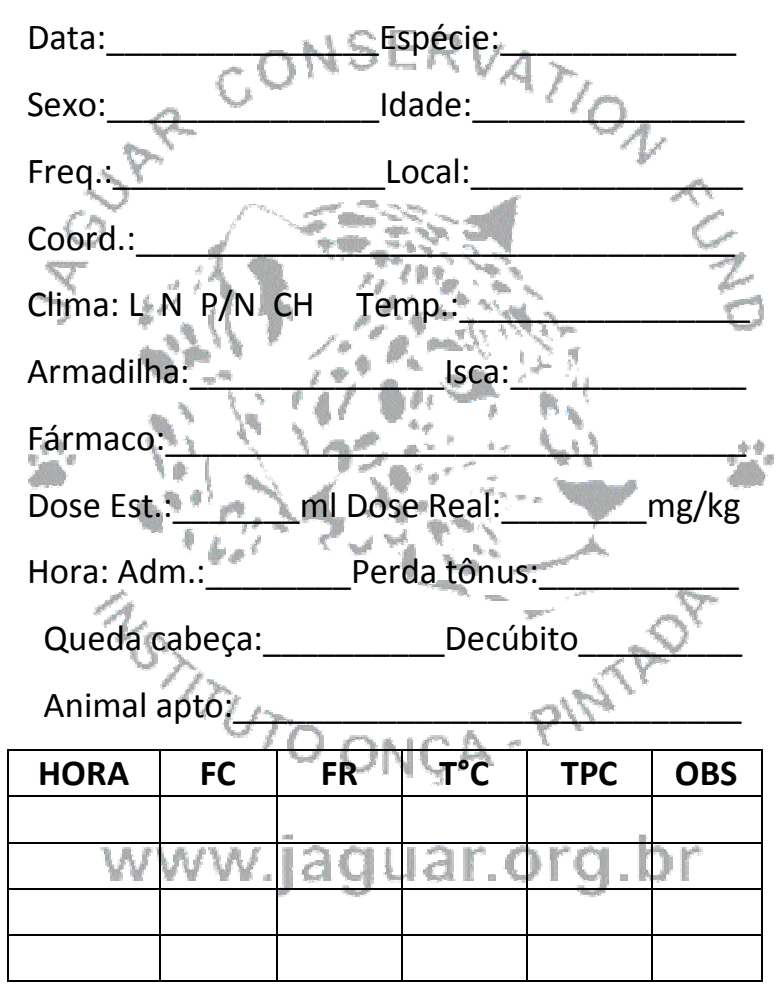

( ) Hipertonia muscular:ER

( ) Mioclonia: ( Mov. Pedalagem:

( ) Reflexo: lambedura:___Palpebral:

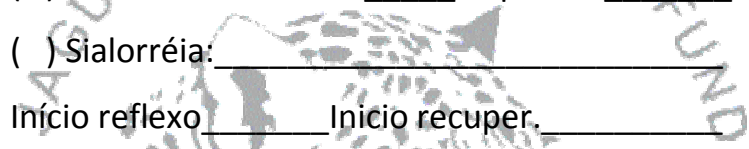

Fim procedimento :

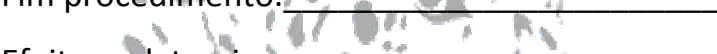

Efeitos colaterais

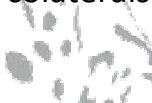

MATERIAL COLETADO:

Soro (S) Sangue total( )

Esfregaço sanguíneo: ( ) sim ( ) não

Ectoparasitas: ( ) sim () hão ( ) ausência

Fezes: ( ) sim ( ) não ( ) lausência g br

Urina: ( ) sim ( ) não ( ) ausência

\section{BIOMETRIA:}

Circ. Cabeça:

Circ. Pescoço:

Comp. Cabeça:

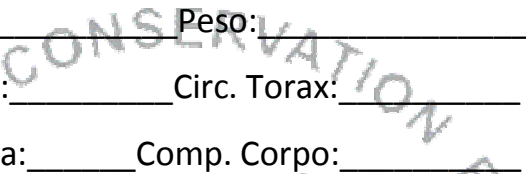

Comp. Cauda:

₹

Lartg. Oreltha: Comp. Corpo:

Pata Traseira:

Dentes:

Incisivo superior

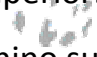

Comp Orelha:

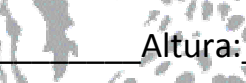

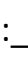

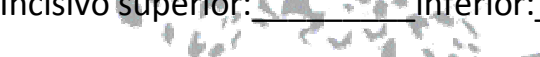

Comp. Canino superior: inferior:

Larg. Canino superior: inferior:

Testículo:

Comp. Testículo direito:

Larg. Testículo direito guatesquerdo:

\section{ASPECTOS FÍSICOS:}

Condições físicas:

Exame externo:

Pele/Anexo:

Hidratação:

Mucosas:

Dentição:

Sinais particulares:

Palpação:

Sistema músculoesquelético:

Sistema genitourinário:

Sistema digestório:

OBS:

ONCA

Equipe:HWW jaguar org br 


\section{APÊNDICE B - QUESTIONÁRIO APLICADO AOS GERENTES DAS PROPRIEDADES RURAIS}

1. Identificação da propriedade:

Município: Região:

UF: Data da visita e colheita:

Proprietário: Propriedade: Coordenadas:

2. Tipo da Exploração: $\square$ corte $\square$ leite $\square$ mista

3. Tipo de Criação: $\square$ confinado $\square$ semi-confinado $\square$ extensivo

4. $\mathrm{N}^{\circ}$ de Ordenhas por dia: $\square 1$ ordenha $\square 2$ ou 3 ordenhas $\square$ Não ordenha

5. Usa inseminação artificial? $\square$ não $\square$ usa inseminação artificial e touro $\square$ usa só inseminação artificial

6. Raça predominante de bovinos: $\square$ zebu $\square$ europeu de leite $\square$ europeu de corte $\square$ mestiço $\square$ outras

7. Bovinos existentes:

\begin{tabular}{|c|c|c|c|c|c|c|c|c|}
\hline Machos Castrados & \multicolumn{3}{|c|}{ Machos inteiros (meses) } & \multicolumn{5}{c|}{ Fêmeas (meses) } \\
\hline Total & $0-6$ & $6-12$ & $12-24$ & $>24$ & $0-6$ & $6-12$ & $12-24$ & $>24$ \\
\hline & & & & & & & & \\
\hline
\end{tabular}

8. Outras espécies na propriedade: $\square$ ovinos/caprinos $\square$ equídeos $\square$ suínos $\square$ aves $\square$ cão $\square$ gato

9. Espécies silvestres em vida livre na propriedade:

10. Alguma vaca abortou nos últimos 12 meses? $\square$ não $\square$ sim $\square$ não sabe

11. O que faz com o feto abortado e a placenta? $\square$ enterra/joga em fossa/queima $\square$ alimenta porco/cão não faz nada

12. Faz testes para diagnóstico de brucelose? $\square$ não $\square$ sim

Regularidade dos testes: $\square$ uma vez ao ano $\square$ duas vezes ao ano $\square$ quando compra animais

$\square$ quando há casos de aborto na fazenda $\square$ quando exigido para trânsito/eventos/crédito

13. Faz testes para diagnóstico de tuberculose? $\square$ não $\square$ sim

Regularidade dos testes: $\square$ uma vez ao ano $\square$ duas vezes ao ano $\square$ quando compra animais quando exigido para trânsito/eventos/crédito

14- Nos últimos 2 anos houve aquisição de bovinos? $\square$ não $\square$ sim

Onde/de quem: $\square$ em exposição $\square$ em leilão/feira $\square$ de comerciante de gado $\square$ diretamente de outras fazendas

15. Compra fêmeas ou machos com finalidade de reprodução? $\square$ não $\square$ sim

Onde/de quem: $\square$ em exposição $\square$ em leilão/feira $\square$ de comerciante de gado $\square$ diretamente de outras fazendas

16. Vende fêmeas ou machos para reprodução? $\square$ não $\square$ sim

A quem/onde: $\square$ em exposição $\square$ em leilão/feira $\square$ a comerciante de gado $\square$ diretamente a outras

fazendas

17. Vacina contra brucelose? $\square$ não $\square$ sim, apenas fêmeas até 8 meses de idade $\square$ sim, fêmeas de qualquer idade

18. Quais outras vacinas aplica e qual a peridiocidade?

19. Os animais são tratados com carrapaticida? Qual o protocolo utilizado? Para quais animais (sexo e idade)?

20. Local de abate das fêmeas e machos adultos no fim da vida reprodutiva:

$\square$ na própria fazenda $\square$ em estabelecimento sem inspeção veterinária

$\square$ em estabelecimento de abate com inspeção veterinária $\square$ não abate

21. Aluga pastos em alguma época do ano? $\square$ não $\square$ sim

22. Tem pastos em comum com outras propriedades? $\square$ não $\square$ sim

23. Compartilha outros itens com outras propriedades? $\square$ não $\square$ insumos $\square$ equipamentos $\square$ funcionários

24. Existem na propriedade áreas alagadiças às quais o gado tem acesso? $\square$ não $\square$ sim

25. Existem na propriedade áreas de concentração de animais próximo às areas alagadiças às quais o gado tem acesso? $\square$ não $\square$ sim

26. Tem piquete separado para fêmeas na fase de parto e/ou pós-parto? $\square$ não $\square$ sim

27. Qual a proximidade dos animais com as áreas de reserva?

28. Tem muitos animais sendo predado por onças-pintadas?

29. Já viu onça-pintada na propriedade?

30. Produz queijo e/ou manteiga na propriedade? $\square$ não $\square$ sim Finalidade: $\square$ p/ consumo próprio $\square$ p/ venda

31. Consome leite cru? $\square$ não $\square$ sim

32. Tem assistência veterinária? $\square$ não $\square$ sim De que tipo? $\square$ veterinário da cooperativa $\square$ veterinário particular. 


\section{APÊNDICE C - QUESTIONÁRIO APLICADO AOS PROPRIETÁRIOS DE CÃES E gATOS DOMÉSTICOS}

Data da coleta:

Propriedade:

Proprietário:

Telefone:

1. Identificação do Animal:

2. Espécie: ( ) canino ( ) felino ( ) outros

3. Sexo: ( ) Macho ( ) Fêmea

4. Idade:

5. Cor:

6. Porte: ( ) Pequeno ( ) Grande

7. Ectoparasitas: ( ) sim ( ) não ( ) coleta

8. Vacina: ( ) sim ( ) não

Se vacinado: ( ) V8/V10 ( ) Raiva ( ) Não sabe

9. Vermífugo: ( ) sim ( ) não

Se sim: ( ) qual

10. Alimentação: ( ) ração ( ) comida ( ) comida + ração não lembra ( )

Se comida: a carne é ( ) crua ( ) cozida

11. Condições físicas: ( ) boas ( ) regular ( ) ruim

12. Animal já teve problemas de saúde: ( ) sim ( ) não

Se sim, especificar:

13. Como vive: ( ) solto ( ) preso

14- Convivência com outros animais: (1) sim (2) não

$$
\begin{aligned}
& \text { 14.1- cães: (1) } 1 \quad \text { (2) } 1-3 \quad \text { (3) +3 } \\
& \text { 14.2- gatos: (1) } 1 \text { (2) } 1-3 \quad \text { (3) }+3 \\
& \text { 14.3- bovinos: (1) } 1 \text { (2) } 1-3 \quad \text { (3) }+3 \\
& \text { 14.4- suinos: (1) } 1 \quad \text { (2) } 1-3 \quad \text { (3) }+3 \\
& \text { 14.5- aves: (1) } 1 \text { (2) } 1-3 \quad \text { (3) +3 }
\end{aligned}
$$

15- Contato ou observação de animais silvetres: (1) sim (2) não

16- $O$ animal tem hábito de caça: (1) sim (2) não

17- Já viu o animal comendo carcaça de animais mortos? (1) sim (2) não

18- Há presença de roedores na propriedade? (1) sim (2) não

19- Há o controle de roedores na propriedade? (1) sim (2) não

de que forma? (1) gatos (2) veneno 


\section{APÊNDICE D - RESULTADOS DO TESTE SOROLÓGICO PARA BRUCELAS LISAS PARA OS ANIMAIS DOMÉSTICOS}

Resultado do teste sorológico para brucelas lisas realizado para os animais domésticos do entorno do PNE, distribuídos em função das espécies e propriedades amostradas

\begin{tabular}{|c|c|c|c|c|}
\hline Espécie & Local & Examinados & Positivos & \% Positivos \\
\hline \multirow{10}{*}{ Bovino } & Propriedade 1 & 86 & 13 & 15,1 \\
\hline & Propriedade 2 & 61 & 7 & 11,5 \\
\hline & Propriedade 3 & 64 & 13 & 20,3 \\
\hline & Propriedade 4 & 68 & 1 & 1,5 \\
\hline & Propriedade 5 & 53 & 7 & 13,2 \\
\hline & Propriedade 9 & 65 & 12 & 18,5 \\
\hline & Propriedade 23 & 1 & 0 & 0 \\
\hline & Propriedade 24 & 10 & 0 & 0 \\
\hline & Propriedade 33 & 57 & 0 & 0 \\
\hline & Total & 465 & 53 & 11,4 \\
\hline \multirow{26}{*}{ Cão doméstico } & Propriedade 1 & 1 & 0 & 0 \\
\hline & Propriedade 2 & 3 & 0 & 0 \\
\hline & Propriedade 3 & 1 & 0 & 0 \\
\hline & Propriedade 4 & 3 & 0 & 0 \\
\hline & Propriedade 5 & 1 & 0 & 0 \\
\hline & Propriedade 9 & 2 & 0 & 0 \\
\hline & Propriedade 10 & 1 & 0 & 0 \\
\hline & Propriedade 11 & 1 & 0 & 0 \\
\hline & Propriedade 12 & 1 & 0 & 0 \\
\hline & Propreidade 13 & 1 & 0 & 0 \\
\hline & Propriedade 14 & 1 & 0 & 0 \\
\hline & Propriedade 15 & 1 & 0 & 0 \\
\hline & Propriedade 16 & 4 & 0 & 0 \\
\hline & Propriedade 17 & 1 & 0 & 0 \\
\hline & Propriedade 18 & 1 & 0 & 0 \\
\hline & Propriedade 21 & 2 & 0 & 0 \\
\hline & Propriedade 22 & 5 & 0 & 0 \\
\hline & Propriedade 23 & 3 & 0 & 0 \\
\hline & Propriedade 24 & 1 & 0 & 0 \\
\hline & Propriedade 25 & 2 & 0 & 0 \\
\hline & Propriedade 29 & 2 & 0 & 0 \\
\hline & Propriedade 30 & 1 & 0 & 0 \\
\hline & Propriedade 32 & 3 & 0 & 0 \\
\hline & Propriedade 33 & 4 & 0 & 0 \\
\hline & Propriedade 35 & 2 & 0 & 0 \\
\hline & Total & 48 & 0 & 0 \\
\hline
\end{tabular}


Resultado do teste sorológico para brucelas lisas realizado para os animais domésticos do Pantanal, distribuídos em função das espécies e propriedades amostradas

\begin{tabular}{clccc}
\hline Espécie & \multicolumn{1}{c}{ Local } & Examinados & Positivos & \% Positivos \\
\hline \multirow{6}{*}{ Bovino } & Propriedade 1 & 37 & 2 & 5,4 \\
& Propriedade 2 & 63 & 6 & 9,5 \\
& Propriedade 3 & 47 & 8 & 17,0 \\
& Propriedade 9 & 35 & 18 & 51,4 \\
& Propriedade 10 & 49 & 1 & 2,0 \\
& Propriedade 11 & 61 & 2 & 3,3 \\
& Propriedade 12 & 64 & 2 & 3,1 \\
\cline { 2 - 5 } Cão doméstico & 356 & 39 & 11,0 \\
& Total & 3 & 0 & 0 \\
& Propriedade 2 & 3 & 0 & 0 \\
& Propriedade 3 & 1 & 0 & 0 \\
& Propriedade 4 & 8 & 0 & 0 \\
& Propriedade 5 8 & 5 & 2 & 40,0 \\
& Propriedade 9 & 2 & 0 & 9,1 \\
\cline { 2 - 5 } & Total & 22 & 2 & 0 \\
\hline
\end{tabular}

Resultado do teste sorológico para brucelas lisas realizado para os animais domésticos do entorno do Parque Estadual do Cantão, distribuídos em função das espécies e propriedades amostradas

\begin{tabular}{|c|c|c|c|c|}
\hline Espécie & Local & Examinados & Positivos & \% Positivos \\
\hline \multirow{7}{*}{ Bovino } & Propriedade 1 & 61 & 6 & 9,8 \\
\hline & Propriedade 2 & 119 & 10 & 8,4 \\
\hline & Propriedade 3 & 60 & 1 & 1,7 \\
\hline & Propriedade 8 & 60 & 3 & 5,0 \\
\hline & Propriedade 10 & 64 & 7 & 10,9 \\
\hline & Propriedade 12 & 60 & 4 & 6,7 \\
\hline & Total & 424 & 31 & 7,3 \\
\hline \multirow{14}{*}{ Cão doméstico } & Propriedade 1 & 12 & 0 & 0 \\
\hline & Propriedade 2 & 4 & 0 & 0 \\
\hline & Propriedade 3 & 1 & 0 & 0 \\
\hline & Propriedade 4 & 1 & 0 & 0 \\
\hline & Propriedade 6 & 1 & 0 & 0 \\
\hline & Propriedade 7 & 1 & 0 & 0 \\
\hline & Propriedade 8 & 2 & 0 & 0 \\
\hline & Propriedade 9 & 1 & 0 & 0 \\
\hline & Propriedade 10 & 3 & 0 & 0 \\
\hline & Propriedade 11 & 2 & 0 & 0 \\
\hline & Propriedade 12 & 1 & 0 & 0 \\
\hline & Assentamento 3 & 1 & 0 & 0 \\
\hline & Assentamento 4 & 9 & 0 & 0 \\
\hline & Total & 39 & 0 & 0 \\
\hline
\end{tabular}




\section{APÊNDICE E - RESULTADO DO TESTE SOROLÓGICO PARA Leptospira spp. PARA OS ANIMAIS DOMÉSTICOS}

Resultado do teste sorológico para Leptospira spp. para os animais domésticos do entorno do Parque Nacional das Emas, distribuído em função das espécies e propriedades amostradas

\begin{tabular}{|c|c|c|c|c|}
\hline Espécie & Local & Examinados & Positivos & $\%$ Positivos \\
\hline \multirow{10}{*}{ Bovino } & Propriedade 1 & 85 & 50 & 58,8 \\
\hline & Propriedade 2 & 60 & 46 & 76,7 \\
\hline & Propriedade 3 & 64 & 52 & 81,3 \\
\hline & Propriedade 4 & 68 & 61 & 89,7 \\
\hline & Propriedade 5 & 54 & 35 & 64,8 \\
\hline & Propriedade 9 & 65 & 40 & 61,5 \\
\hline & Propriedade 23 & 1 & 1 & 100,0 \\
\hline & Propriedade 24 & 10 & 6 & 60,0 \\
\hline & Propriedade 33 & 57 & 51 & 89,5 \\
\hline & Total & 464 & 342 & 73,7 \\
\hline \multirow{27}{*}{ Cão doméstico } & Propriedade 1 & 3 & 0 & 0 \\
\hline & Propriedade 2 & 3 & 2 & 66,7 \\
\hline & Propriedade 3 & 1 & 1 & 100,0 \\
\hline & Propriedade 4 & 7 & 0 & 0 \\
\hline & Propriedade 5 & 2 & 0 & 0 \\
\hline & Propriedade 6 & 1 & 0 & 0 \\
\hline & Propriedade 7 & 2 & 0 & 0 \\
\hline & Propriedade 8 & 2 & 0 & 0 \\
\hline & Propriedade 9 & 4 & 0 & 0 \\
\hline & Propriedade 10 & 1 & 0 & 0 \\
\hline & Propriedade 11 & 1 & 0 & 0 \\
\hline & Propriedade 12 & 3 & 0 & 0 \\
\hline & Propriedade 13 & 1 & 0 & 0 \\
\hline & Propriedade 14 & 1 & 0 & 0 \\
\hline & Propriedade 15 & 1 & 0 & 0 \\
\hline & Propriedade 16 & 4 & 0 & 0 \\
\hline & Propriedade 17 & 2 & 0 & 0 \\
\hline & Propriedade 18 & 3 & 0 & 0 \\
\hline & Propriedade 19 & 1 & 0 & 0 \\
\hline & Propriedade 20 & 5 & 0 & 0 \\
\hline & Propriedade 21 & 6 & 1 & 16,7 \\
\hline & Propriedade 22 & 2 & 0 & 0 \\
\hline & Propriedade 23 & 3 & 0 & 0 \\
\hline & Propriedade 24 & 2 & 0 & 0 \\
\hline & Propriedade 25 & 2 & 0 & 0 \\
\hline & Propriedade 26 & 1 & 0 & 0 \\
\hline & Propriedade 28 & 2 & 0 & 0 \\
\hline
\end{tabular}


(conclusão)

\begin{tabular}{ccccc}
\hline Espécie & Local & Examinados & Positivos & \% Positivos \\
\hline \multirow{4}{*}{ Cão doméstico } & Propriedade 29 & 2 & 0 & 0 \\
& Propriedade 30 & 2 & 1 & 50,0 \\
& Propriedade 32 & 3 & 0 & 0 \\
& Propriedade 33 & 4 & 0 & 0 \\
& Propriedade 34 & 2 & 0 & 0 \\
& Propriedade 35 & 3 & 1 & 33,3 \\
& Propriedade 36 36 & 1 & 0 & 0 \\
\cline { 2 - 5 } & Total & 83 & 6 & 7,2 \\
\hline \multirow{5}{*}{ Gato doméstico } & Propriedade 9 & 1 & 0 & 0 \\
& Propriedade 13 & 1 & 0 & 0 \\
& Propriedade 15 & 1 & 0 & 0 \\
& Propriedade 21 & 2 & 0 & 0 \\
& Propriedade 23 23 & 1 & 0 & 0 \\
& Propriedade 24 & 1 & 0 & 0 \\
& Propriedade 27 & 1 & 0 & 0 \\
\hline & Propriedade 31 & 1 & 0 & 0 \\
\cline { 2 - 5 } & Total & 9 & 0 & 0 \\
\hline
\end{tabular}


Resultado do teste sorológico para Leptospira spp. para os animais domésticos das propriedades rurais do Pantanal, distribuído em função das espécies e propriedades amostradas

\begin{tabular}{|c|c|c|c|c|}
\hline Espécie & Local & Examinados & Positivos & \% Positivos \\
\hline \multirow{8}{*}{ Bovino } & Propriedade 1 & 37 & 26 & 70,3 \\
\hline & Propriedade 2 & 63 & 43 & 68,3 \\
\hline & Propriedade 3 & 47 & 26 & 55,3 \\
\hline & Propriedade 9 & 35 & 29 & 82,9 \\
\hline & Propriedade 10 & 49 & 33 & 67,3 \\
\hline & Propriedade 11 & 50 & 33 & 66,0 \\
\hline & Propriedade 12 & 64 & 46 & 71,9 \\
\hline & Total & 345 & 236 & 68,4 \\
\hline \multirow{8}{*}{ Cão doméstico } & Propriedade 2 & 4 & 0 & 0 \\
\hline & Propriedade 3 & 5 & 1 & 20,0 \\
\hline & Propriedade 4 & 1 & 0 & 0 \\
\hline & Propriedade 5 & 8 & 5 & 62,5 \\
\hline & Propriedade 8 & 5 & 0 & 0 \\
\hline & Propriedade 9 & 3 & 0 & 0 \\
\hline & Propriedade 11 & 3 & 1 & 33,3 \\
\hline & Total & 29 & 7 & 24,1 \\
\hline \multirow{7}{*}{ Gato doméstico } & Propriedade 1 & 1 & 0 & 0 \\
\hline & Propriedade 5 & 4 & 0 & 0 \\
\hline & Propriedade 6 & 1 & 0 & 0 \\
\hline & Propriedade 7 & 2 & 1 & 50,0 \\
\hline & Propriedade 9 & 1 & 0 & 0 \\
\hline & Propriedade 11 & 1 & 0 & 0 \\
\hline & Total & 10 & 1 & 10,0 \\
\hline
\end{tabular}


Resultado do teste sorológico para Leptospira spp. para os animais domésticos do entorno do Parque Estadual do Cantão, distribuído em função das espécies e propriedades amostradas

\begin{tabular}{|c|c|c|c|c|}
\hline Espécie & Local & Examinados & Positivos & \% Positivos \\
\hline \multirow{7}{*}{ Bovino } & Propriedade 1 & 61 & 52 & 85,2 \\
\hline & Propriedade 2 & 119 & 66 & 55,5 \\
\hline & Propriedade 3 & 60 & 51 & 85,0 \\
\hline & Propriedade 8 & 60 & 51 & 85,0 \\
\hline & Propriedade 10 & 64 & 39 & 60,9 \\
\hline & Propriedade 12 & 60 & 53 & 88,3 \\
\hline & Total & 424 & 312 & 73,6 \\
\hline \multirow{17}{*}{ Cão doméstico } & Propriedade 1 & 18 & 3 & 16,7 \\
\hline & Propriedade 2 & 5 & 1 & 20,0 \\
\hline & Propriedade 3 & 2 & 0 & 0 \\
\hline & Propriedade 4 & 2 & 0 & 0 \\
\hline & Propriedade 5 & 1 & 1 & 100,0 \\
\hline & Propriedade 6 & 1 & 0 & 0 \\
\hline & Propriedade 7 & 1 & 0 & 0 \\
\hline & Propriedade 8 & 2 & 0 & 0 \\
\hline & Propriedade 9 & 2 & 0 & 0 \\
\hline & Propriedade 10 & 2 & 0 & 0 \\
\hline & Propriedade 11 & 4 & 2 & 50,0 \\
\hline & Propriedade 12 & 1 & 0 & 0 \\
\hline & Assentamento 1 & 1 & 1 & 100,0 \\
\hline & Assentamento 2 & 1 & 0 & 0 \\
\hline & Assentamento 3 & 4 & 0 & 0 \\
\hline & Assentamento 4 & 9 & 1 & 11,1 \\
\hline & Total & 56 & 9 & 16,1 \\
\hline \multirow{7}{*}{ Gato doméstico } & Propriedade 2 & 1 & 0 & 0 \\
\hline & Propriedade 6 & 2 & 0 & 0 \\
\hline & Propriedade 8 & 1 & 0 & 0 \\
\hline & Propriedade 11 & 2 & 0 & 0 \\
\hline & Assentamento 3 & 2 & 0 & 0 \\
\hline & Assentamento 4 & 2 & 0 & 0 \\
\hline & Total & 10 & 0 & 0 \\
\hline
\end{tabular}


Resultado do teste sorológico para Toxoplasma gondii realizado para os animais domésticos do entorno do Parque Nacional das Emas, distribuídos em função das espécies e propriedades amostradas e títulação máxima de anticorpos encontrada

(continua)

\begin{tabular}{|c|c|c|c|c|c|c|c|c|c|c|c|}
\hline \multirow{2}{*}{ Espécie } & \multirow{2}{*}{ Local } & \multirow{2}{*}{ Examinados } & \multicolumn{8}{|c|}{ Nº. Animais Positivos - Titulação Máxima } & \multirow{2}{*}{$\begin{array}{l}\text { Animais } \\
\text { positivos }\end{array}$} \\
\hline & & & 16 & 32 & 64 & 128 & 256 & 512 & 1024 & 2048 & \\
\hline \multirow{11}{*}{ Bovino } & Propriedade 1 & 85 & - & - & 0 & 0 & 0 & 0 & 0 & 0 & 0 \\
\hline & Propriedade 2 & 56 & - & - & 0 & 0 & 0 & 0 & 0 & 0 & 0 \\
\hline & Propriedade 3 & 61 & - & - & 0 & 0 & 0 & 0 & 0 & 0 & 0 \\
\hline & Propriedade 4 & 68 & - & - & 0 & 0 & 0 & 0 & 0 & 0 & 0 \\
\hline & Propriedade 5 & 54 & - & - & 0 & 0 & 0 & 0 & 0 & 0 & 0 \\
\hline & Propriedade 9 & 62 & - & - & 0 & 1 & 0 & 0 & 0 & 0 & 1 \\
\hline & Propriedade 23 & 1 & - & - & 0 & 0 & 0 & 0 & 0 & 0 & 0 \\
\hline & Propriedade 24 & 10 & - & - & 0 & 0 & 0 & 0 & 0 & 0 & 0 \\
\hline & Propriedade 33 & 57 & - & - & 1 & 0 & 0 & 0 & 0 & 0 & 1 \\
\hline & \multirow{2}{*}{\multicolumn{2}{|c|}{$\begin{array}{r}\text { Total } \\
\% \text { Positivos }\end{array}$}} & - & - & 1 & 1 & 0 & 0 & 0 & 0 & 2 \\
\hline & & & - & - & 0,2 & 0,2 & 0 & 0 & 0 & 0 & 0,4 \\
\hline \multirow{11}{*}{ Cão doméstico } & Propriedade 1 & 1 & 0 & 0 & 0 & 0 & 0 & 0 & 0 & 0 & 0 \\
\hline & Propriedade 2 & 3 & 0 & 0 & 0 & 0 & 0 & 0 & 0 & 0 & 0 \\
\hline & Propriedade 3 & 1 & 0 & 0 & 0 & 0 & 0 & 1 & 0 & 0 & 1 \\
\hline & Propriedade 4 & 6 & 0 & 0 & 0 & 0 & 0 & 0 & 0 & 0 & 0 \\
\hline & Propriedade 5 & 1 & 0 & 0 & 0 & 0 & 0 & 0 & 0 & 0 & 0 \\
\hline & Propriedade 8 & 1 & 0 & 0 & 0 & 0 & 0 & 0 & 0 & 0 & 0 \\
\hline & Propriedade 9 & 2 & 0 & 0 & 0 & 0 & 0 & 0 & 0 & 0 & 0 \\
\hline & Propriedade 10 & 1 & 0 & 0 & 0 & 1 & 0 & 0 & 0 & 0 & 1 \\
\hline & Propriedade 11 & 1 & 0 & 1 & 0 & 0 & 0 & 0 & 0 & 0 & 1 \\
\hline & Propriedade 12 & 2 & 0 & 0 & 0 & 1 & 0 & 0 & 0 & 0 & 1 \\
\hline & Propriedade 13 & 1 & 0 & 0 & 0 & 0 & 0 & 0 & 0 & 0 & 0 \\
\hline
\end{tabular}


(conclusão)

\begin{tabular}{|c|c|c|c|c|c|c|c|c|c|c|c|}
\hline \multirow{2}{*}{ Espécie } & \multirow{2}{*}{ Local } & \multirow{2}{*}{ Examinados } & \multicolumn{8}{|c|}{ Nº Animais Positivos - Titulação Máxima } & \multirow[t]{2}{*}{ Animais positivo } \\
\hline & & & 16 & 32 & 64 & 128 & 256 & 512 & 1024 & 2048 & \\
\hline \multirow{17}{*}{ Cão doméstico } & Propriedade 14 & 1 & 0 & 0 & 0 & 0 & 0 & 0 & 0 & 0 & 0 \\
\hline & Propriedade 15 & 1 & 0 & 0 & 0 & 0 & 0 & 0 & 0 & 0 & 0 \\
\hline & Propriedade 16 & 4 & 0 & 1 & 0 & 0 & 0 & 0 & 0 & 0 & 1 \\
\hline & Propriedade 17 & 1 & 0 & 0 & 0 & 0 & 0 & 0 & 0 & 0 & 0 \\
\hline & Propriedade 18 & 1 & 0 & 0 & 0 & 0 & 0 & 0 & 0 & 0 & 0 \\
\hline & Propriedade 21 & 5 & 0 & 0 & 1 & 0 & 0 & 0 & 0 & 0 & 1 \\
\hline & Propriedade 22 & 2 & 0 & 1 & 0 & 0 & 0 & 0 & 0 & 0 & 1 \\
\hline & Propriedade 23 & 3 & 0 & 0 & 0 & 1 & 0 & 0 & 0 & 0 & 1 \\
\hline & Propriedade 24 & 1 & 0 & 0 & 0 & 0 & 0 & 0 & 0 & 0 & 0 \\
\hline & Propriedade 25 & 2 & 0 & 0 & 0 & 0 & 0 & 0 & 0 & 0 & 0 \\
\hline & Propriedade 29 & 2 & 0 & 0 & 1 & 0 & 0 & 0 & 0 & 0 & 1 \\
\hline & Propriedade 30 & 2 & 2 & 0 & 0 & 0 & 0 & 0 & 0 & 0 & 2 \\
\hline & Propriedade 32 & 3 & 0 & 0 & 0 & 1 & 0 & 0 & 0 & 0 & 1 \\
\hline & Propriedade 33 & 4 & 2 & 0 & 0 & 0 & 0 & 0 & 0 & 0 & 2 \\
\hline & Propriedade 35 & 3 & 0 & 1 & 1 & 0 & 0 & 0 & 0 & 0 & 2 \\
\hline & Total & 55 & 4 & 4 & 3 & 4 & 0 & 1 & 0 & 0 & 16 \\
\hline & $\%$ Positivos & & 7,3 & 7,3 & 5,5 & 7,3 & 0 & 1,8 & 0 & 0 & 29,1 \\
\hline \multirow{10}{*}{ Gato doméstico } & Propriedade 9 & 1 & 0 & 0 & 0 & 0 & 0 & 0 & 0 & 0 & 0 \\
\hline & Propriedade 13 & 1 & 0 & 0 & 0 & 0 & 0 & 1 & 0 & 0 & 1 \\
\hline & Propriedade 15 & 1 & 0 & 0 & 0 & 0 & 0 & 0 & 1 & 0 & 1 \\
\hline & Propriedade 21 & 2 & 0 & 0 & 1 & 0 & 1 & 0 & 0 & 0 & 2 \\
\hline & Propriedade 23 & 1 & 0 & 0 & 0 & 0 & 0 & 0 & 1 & 0 & 1 \\
\hline & Propriedade 24 & 1 & 0 & 0 & 0 & 0 & 0 & 0 & 0 & 0 & 0 \\
\hline & Propriedade 27 & 1 & 0 & 0 & 0 & 0 & 0 & 0 & 1 & 0 & 1 \\
\hline & Propriedade 31 & 1 & 1 & 0 & 0 & 0 & 0 & 0 & 0 & 0 & 1 \\
\hline & Total & 9 & 1 & 0 & 1 & 0 & 1 & 1 & 3 & 0 & 7 \\
\hline & $\%$ Positivos & 9 & 11,1 & 0 & 11,1 & 0 & 11,1 & 11,1 & 33,3 & 0 & 77,8 \\
\hline
\end{tabular}



amostradas e titulação máxima de anticorpo encontrada

\begin{tabular}{|c|c|c|c|c|c|c|c|c|c|c|c|}
\hline \multirow{2}{*}{ Espécie } & \multirow{2}{*}{ Local } & \multirow{2}{*}{ Examinados } & \multicolumn{8}{|c|}{ Nºnimais Positivos - Titulação Máxima } & \multirow{2}{*}{$\begin{array}{l}\text { Animais } \\
\text { positivos }\end{array}$} \\
\hline & & & 16 & 32 & 64 & 128 & 256 & 512 & 1024 & 2048 & \\
\hline \multirow{9}{*}{ Bovino } & Propriedade 1 & 37 & - & - & 0 & 0 & 0 & 0 & 0 & 0 & 0 \\
\hline & Propriedade 2 & 61 & - & - & 0 & 0 & 0 & 0 & 0 & 0 & 0 \\
\hline & Propriedade 3 & 47 & - & - & 0 & 1 & 0 & 0 & 0 & 0 & 1 \\
\hline & Propriedade 9 & 30 & - & - & 0 & 0 & 0 & 0 & 0 & 0 & 0 \\
\hline & Propriedade 10 & 49 & - & - & 0 & 0 & 0 & 0 & 0 & 0 & 0 \\
\hline & Propriedade 11 & 61 & - & - & 0 & 0 & 0 & 0 & 0 & 0 & 0 \\
\hline & Propriedade 12 & 63 & - & - & 0 & 1 & 0 & 0 & 0 & 0 & 1 \\
\hline & Total & 348 & - & - & 0 & 2 & 0 & 0 & 0 & 0 & 2 \\
\hline & $\%$ Positivos & & - & - & 0 & 0,6 & 0 & 0 & 0 & 0 & 0,6 \\
\hline \multirow{9}{*}{ Cão doméstico } & Propriedade 2 & 3 & 0 & 0 & 1 & 1 & 0 & 0 & 0 & 0 & 2 \\
\hline & Propriedade 3 & 4 & 1 & 0 & 0 & 0 & 0 & 0 & 0 & 0 & 1 \\
\hline & Propriedade 4 & 1 & 0 & 0 & 1 & 0 & 0 & 0 & 0 & 0 & 1 \\
\hline & Propriedade 5 & 8 & 0 & 1 & 1 & 1 & 0 & 0 & 0 & 0 & 3 \\
\hline & Propriedade 8 & 5 & 0 & 0 & 1 & 0 & 0 & 0 & 0 & 0 & 1 \\
\hline & Propriedade 9 & 2 & 1 & 0 & 0 & 0 & 0 & 0 & 0 & 0 & 1 \\
\hline & Propriedade 11 & 4 & 0 & 0 & 0 & 1 & 0 & 0 & 0 & 1 & 2 \\
\hline & Total & 27 & 2 & 1 & 4 & 3 & 0 & 0 & 0 & 1 & 11 \\
\hline & $\%$ Positivos & & 7,4 & 3,7 & 14,8 & 11,1 & 0 & 0 & 0 & 3,7 & 40,7 \\
\hline \multirow{8}{*}{ Gato doméstico } & Propriedade 1 & 1 & 0 & 0 & 0 & 0 & 1 & 0 & 0 & 0 & 1 \\
\hline & Propriedade 5 & 4 & 0 & 0 & 0 & 0 & 2 & 0 & 0 & 2 & 4 \\
\hline & Propriedade 6 & 1 & 0 & 0 & 0 & 0 & 0 & 0 & 0 & 0 & 0 \\
\hline & Propriedade 7 & 2 & 0 & 1 & 0 & 0 & 1 & 0 & 0 & 0 & 2 \\
\hline & Propriedade 9 & 1 & 0 & 0 & 0 & 1 & 0 & 0 & 0 & 0 & 1 \\
\hline & Propriedade 11 & 1 & 0 & 0 & 0 & 0 & 0 & 0 & 1 & 0 & 1 \\
\hline & Total & 10 & 0 & 1 & 0 & 1 & 4 & 0 & 1 & 2 & 9 \\
\hline & $\%$ Positivos & & 0 & 10,0 & 0 & 10,0 & 40,0 & 0 & 10,0 & 20,0 & 90,0 \\
\hline
\end{tabular}


Resultado do teste sorológico para Toxoplasma gondii realizado para os animais domésticos do entorno do Parque Estadual do Cantão, distribuídos em função das espécies e propriedades amostradas e titulação máxima de anticorpos encontrada

\begin{tabular}{|c|c|c|c|c|c|c|c|c|c|c|c|}
\hline \multirow{2}{*}{ Espécie } & \multirow{2}{*}{ Local } & \multirow{2}{*}{ Examinados } & \multicolumn{8}{|c|}{ Nº Animais Positivos - Titulação Máxima } & \multirow{2}{*}{$\begin{array}{c}\text { Animais } \\
\text { positivos }\end{array}$} \\
\hline & & & 16 & 32 & 64 & 128 & 256 & 512 & 1024 & 2048 & \\
\hline \multirow{8}{*}{ Bovino } & Propriedade 1 & 61 & - & - & 0 & 0 & 0 & 0 & 0 & 0 & 0 \\
\hline & Propriedade 2 & 118 & - & - & 0 & 0 & 0 & 0 & 0 & 0 & 0 \\
\hline & Propriedade 3 & 60 & - & - & 0 & 0 & 0 & 0 & 0 & 0 & 0 \\
\hline & Propriedade 8 & 60 & - & - & 0 & 0 & 1 & 0 & 0 & 0 & 1 \\
\hline & Propriedade 10 & 63 & - & - & 0 & 0 & 0 & 0 & 0 & 0 & 0 \\
\hline & Propriedade 12 & 60 & - & - & 0 & 0 & 0 & 0 & 0 & 0 & 0 \\
\hline & Total & 422 & - & - & 0 & 0 & 1 & 0 & 0 & 0 & 1 \\
\hline & $\%$ Positivos & & - & - & 0 & 0 & 0,2 & 0 & 0 & 0 & 0,2 \\
\hline \multirow{16}{*}{ Cão doméstico } & Propriedade 1 & 14 & 3 & 0 & 1 & 3 & 0 & 1 & 0 & 0 & 8 \\
\hline & Propriedade 2 & 4 & 0 & 0 & 0 & 0 & 0 & 0 & 0 & 0 & 0 \\
\hline & Propriedade 3 & 2 & 0 & 0 & 0 & 1 & 0 & 0 & 0 & 0 & 1 \\
\hline & Propriedade 4 & 2 & 0 & 0 & 0 & 1 & 0 & 0 & 0 & 0 & 1 \\
\hline & Propriedade 6 & 1 & 0 & 0 & 1 & 0 & 0 & 0 & 0 & 0 & 1 \\
\hline & Propriedade 7 & 1 & 0 & 0 & 1 & 0 & 0 & 0 & 0 & 0 & 1 \\
\hline & Propriedade 8 & 2 & 0 & 0 & 0 & 1 & 0 & 0 & 0 & 0 & 1 \\
\hline & Propriedade 9 & 1 & 0 & 0 & 0 & 0 & 0 & 0 & 0 & 0 & 0 \\
\hline & Propriedade 10 & 3 & 0 & 1 & 0 & 1 & 0 & 0 & 0 & 0 & 2 \\
\hline & Propriedade 11 & 3 & 0 & 0 & 0 & 1 & 0 & 0 & 0 & 0 & 1 \\
\hline & Propriedade 12 & 1 & 0 & 1 & 0 & 0 & 0 & 0 & 0 & 0 & 1 \\
\hline & Assentamento 2 & 1 & 0 & 0 & 0 & 0 & 0 & 0 & 0 & 0 & 0 \\
\hline & Assentamento 3 & 2 & 0 & 0 & 0 & 1 & 0 & 0 & 0 & 0 & 1 \\
\hline & Assentamento 4 & 9 & 1 & 0 & 0 & 2 & 0 & 1 & 0 & 0 & 4 \\
\hline & Total & 46 & 4 & 2 & 3 & 11 & 0 & 2 & 0 & 0 & 22 \\
\hline & $\%$ Positivos & & 8,7 & 4,3 & 6,5 & 23,9 & 0 & 4,3 & 0 & 0 & 47,8 \\
\hline
\end{tabular}




\begin{tabular}{|c|c|c|c|c|c|c|c|c|c|c|c|}
\hline \multirow{2}{*}{ Espécie } & \multirow{2}{*}{ Local } & \multirow{2}{*}{ Examinados } & \multicolumn{8}{|c|}{ Nªnimais Positivos - Titulação Máxima } & \multirow{2}{*}{$\begin{array}{l}\text { Animais } \\
\text { positivo }\end{array}$} \\
\hline & & & 16 & 32 & 64 & 128 & 256 & 512 & 1024 & 2048 & \\
\hline \multirow{8}{*}{ Gato doméstico } & Propriedade 2 & 1 & 0 & 0 & 0 & 0 & 0 & 1 & 0 & 0 & 1 \\
\hline & Propriedade 6 & 2 & 0 & 1 & 0 & 1 & 0 & 0 & 0 & 0 & 2 \\
\hline & Propriedade 8 & 1 & 0 & 0 & 0 & 0 & 0 & 0 & 1 & 0 & 1 \\
\hline & Propriedade 11 & 2 & 0 & 0 & 0 & 0 & 0 & 0 & 0 & 0 & 0 \\
\hline & Assentamento 3 & 2 & 0 & 0 & 1 & 0 & 0 & 0 & 0 & 1 & 2 \\
\hline & Assentamento 4 & 2 & 0 & 0 & 0 & 0 & 0 & 1 & 1 & 0 & 2 \\
\hline & Total & 10 & 0 & 1 & 1 & 1 & 0 & 2 & 2 & 1 & 8 \\
\hline & $\%$ Positivos & & 0 & 10,0 & 10,0 & 10,0 & 0 & 20,0 & 20,0 & 10,0 & 80,0 \\
\hline
\end{tabular}




\section{APÊNDICE G - RESULTADO DO TESTE SOROLÓGICO PARA O VÍRUS DA RAIVA PARA OS ANIMAIS DOMÉSTICOS}

Resultado do teste sorológico para o vírus da raiva realizado para os animais domésticos do entorno do Parque Nacional das Emas, distribuídos em função das espécies e propriedades amostradas e título de anticorpo encontrado

\begin{tabular}{|c|c|c|c|c|}
\hline Espécie & Local & Examinados & $\begin{array}{l}\text { Total de animais } \\
\text { com título } \geq 0,50\end{array}$ & $\begin{array}{c}\% \\
\text { Positivos }\end{array}$ \\
\hline \multirow{32}{*}{ Cão doméstico } & Propriedade 1 & 1 & 0 & 0 \\
\hline & Propriedade 2 & 3 & 0 & 0 \\
\hline & Propriedade 3 & 1 & 0 & 0 \\
\hline & Propriedade 4 & 6 & 0 & 0 \\
\hline & Propriedade 5 & 1 & 0 & 0 \\
\hline & Propriedade 6 & 1 & 1 & 100,0 \\
\hline & Propriedade 7 & 1 & 0 & 0 \\
\hline & Propriedade 8 & 2 & 2 & 100,0 \\
\hline & Propriedade 9 & 2 & 1 & 50,0 \\
\hline & Propriedade 10 & 1 & 1 & 100,0 \\
\hline & Propriedade 11 & 1 & 0 & 0 \\
\hline & Propriedade 12 & 2 & 0 & 0 \\
\hline & Propriedade 13 & 1 & 0 & 0 \\
\hline & Propriedade 14 & 1 & 1 & 100,0 \\
\hline & Propriedade 15 & 1 & 1 & 100,0 \\
\hline & Propriedade 16 & 4 & 4 & 100,0 \\
\hline & Propriedade 17 & 1 & 0 & 0 \\
\hline & Propriedade 18 & 2 & 0 & 0 \\
\hline & Propriedade 20 & 3 & 0 & 0 \\
\hline & Propriedade 21 & 6 & 1 & 16,7 \\
\hline & Propriedade 22 & 2 & 0 & 0 \\
\hline & Propriedade 23 & 3 & 1 & 33,3 \\
\hline & Propriedade 24 & 1 & 0 & 0 \\
\hline & Propriedade 25 & 2 & 1 & 50,0 \\
\hline & Propriedade 28 & 2 & 1 & 50,0 \\
\hline & Propriedade 29 & 2 & 2 & 100,0 \\
\hline & Propriedade 30 & 2 & 1 & 50,0 \\
\hline & Propriedade 32 & 3 & 0 & 0,0 \\
\hline & Propriedade 33 & 4 & 0 & 0,0 \\
\hline & Propriedade 34 & 1 & 1 & 100,0 \\
\hline & Propriedade 35 & 3 & 2 & 66,7 \\
\hline & Total & 66 & 21 & 31,8 \\
\hline \multirow{8}{*}{ Gato doméstico } & Propriedade 9 & 1 & 0 & \\
\hline & Propriedade 13 & 1 & 0 & 0 \\
\hline & Propriedade 15 & 2 & 0 & $\begin{array}{l}0 \\
0\end{array}$ \\
\hline & Propriedade 21 & 2 & 0 & 0 \\
\hline & Propriedade 23 & 1 & 0 & 0 \\
\hline & Propriedade 27 & 1 & 0 & 0 \\
\hline & Propriedade 31 & 1 & 0 & 0 \\
\hline & Total & 9 & 0 & 0 \\
\hline
\end{tabular}


Resultado do teste sorológico para o vírus da raiva realizado para os animais domésticos das propriedades do Pantanal, distribuídos em função das espécies e propriedades amostradas e título de anticorpo encontrado

\begin{tabular}{|c|c|c|c|c|}
\hline Espécie & Local & Examinados & $\begin{array}{c}\text { Total de } \\
\text { animais com } \\
\text { título } \geq 0,50\end{array}$ & $\begin{array}{c}\% \\
\text { Positivos }\end{array}$ \\
\hline \multirow{8}{*}{ Cão doméstico } & Propriedade 2 & 3 & 0 & 0 \\
\hline & Propriedade 3 & 4 & 0 & 0 \\
\hline & Propriedade 4 & 1 & 0 & 0 \\
\hline & Propriedade 5 & 6 & 3 & 50,0 \\
\hline & Propriedade 8 & 3 & 0 & 0 \\
\hline & Propriedade 9 & 2 & 1 & 50,0 \\
\hline & Propriedade 11 & 5 & 1 & 20,0 \\
\hline & Total & 24 & 5 & 20,8 \\
\hline \multirow{7}{*}{ Gato doméstico } & Propriedade 1 & 1 & 0 & 0 \\
\hline & Propriedade 5 & 4 & 0 & 0 \\
\hline & Propriedade 6 & 1 & 1 & 100,0 \\
\hline & Propriedade 7 & 2 & 0 & 0 \\
\hline & Propriedade 9 & 1 & 1 & 100,0 \\
\hline & Propriedade 11 & 1 & 0 & 0 \\
\hline & Total & 10 & 2 & 20,0 \\
\hline
\end{tabular}


Resultado do teste sorológico para o vírus da raiva realizado para os animais domésticos do entorno do Parque Estadual do Cantão, distribuídos em função das espécies e propriedades amostradas e título de anticorpo encontrado

\begin{tabular}{|c|c|c|c|c|}
\hline Espécie & Local & Examinados & $\begin{array}{c}\text { Total de } \\
\text { animais com } \\
\text { título } \geq 0,50\end{array}$ & $\begin{array}{c}\% \\
\text { Positivos }\end{array}$ \\
\hline \multirow{15}{*}{ Cão doméstico } & Propriedade 1 & 15 & 2 & 13,3 \\
\hline & Propriedade 2 & 5 & 1 & 20,0 \\
\hline & Propriedade 3 & 2 & 0 & 0 \\
\hline & Propriedade 4 & 2 & 0 & 0 \\
\hline & Propriedade 6 & 1 & 0 & 0 \\
\hline & Propriedade 7 & 1 & 0 & 0 \\
\hline & Propriedade 8 & 2 & 0 & 0 \\
\hline & Propriedade 9 & 2 & 0 & 0 \\
\hline & Propriedade 10 & 3 & 0 & 0 \\
\hline & Propriedade 11 & 3 & 1 & 33,3 \\
\hline & Propriedade 12 & 1 & 0 & 0 \\
\hline & Assentamento 2 & 1 & 0 & 0 \\
\hline & Assentamento 3 & 3 & 0 & 0 \\
\hline & Assentamento 4 & 9 & 0 & 0 \\
\hline & Total & 50 & 4 & 8,0 \\
\hline \multirow{7}{*}{ Gato doméstico } & Propriedade 2 & 1 & 1 & 100,0 \\
\hline & Propriedade 6 & 2 & 0 & 0 \\
\hline & Propriedade 8 & 1 & 0 & 0 \\
\hline & Propriedade 11 & 2 & 0 & 0 \\
\hline & Assentamento 3 & 1 & 0 & 0 \\
\hline & Assentamento 4 & 2 & 0 & 0 \\
\hline & Total & 9 & 1 & 11,1 \\
\hline
\end{tabular}


Resultado do teste sorológico para o vírus da cinomose realizado para os cães domésticos do entorno do Parque Nacional das Emas, distribuídos em função das propriedades amostradas e titulação máxima de anticorpos encontrada

(continua)

\begin{tabular}{|c|c|c|c|c|c|c|c|c|c|c|c|}
\hline \multirow{2}{*}{ Espécie } & \multirow{2}{*}{ Local } & \multirow{2}{*}{ Examinados } & \multicolumn{8}{|c|}{ Nªnimais Positivos - Titulação Máxima } & \multirow{2}{*}{$\begin{array}{c}\text { Total de animais } \\
\text { com título } \geq 8\end{array}$} \\
\hline & & & 8 & 16 & 32 & 64 & 128 & 256 & 512 & 1024 & \\
\hline \multirow{23}{*}{ Cão doméstico } & Propriedade 1 & 3 & 0 & 1 & 1 & 0 & 1 & 0 & 0 & 0 & 3 \\
\hline & Propriedade 2 & 3 & 0 & 0 & 1 & 0 & 0 & 0 & 0 & 0 & 1 \\
\hline & Propriedade 3 & 1 & 0 & 0 & 0 & 0 & 0 & 0 & 0 & 0 & 0 \\
\hline & Propriedade 4 & 7 & 1 & 1 & 0 & 1 & 0 & 0 & 0 & 0 & 3 \\
\hline & Propriedade 5 & 2 & 0 & 0 & 0 & 0 & 0 & 0 & 0 & 0 & 0 \\
\hline & Propriedade 6 & 1 & 0 & 0 & 0 & 0 & 0 & 0 & 0 & 0 & 0 \\
\hline & Propriedade 7 & 2 & 0 & 0 & 0 & 0 & 0 & 0 & 0 & 0 & 0 \\
\hline & Propriedade 8 & 2 & 1 & 0 & 0 & 0 & 0 & 0 & 0 & 0 & 1 \\
\hline & Propriedade 9 & 4 & 0 & 0 & 0 & 0 & 0 & 0 & 0 & 0 & 0 \\
\hline & Propriedade 10 & 1 & 0 & 0 & 0 & 0 & 0 & 0 & 0 & 0 & 0 \\
\hline & Propriedade 11 & 1 & 0 & 0 & 0 & 1 & 0 & 0 & 0 & 0 & 1 \\
\hline & Propriedade 12 & 3 & 0 & 0 & 0 & 0 & 0 & 0 & 0 & 0 & 0 \\
\hline & Propriedade 13 & 1 & 0 & 0 & 0 & 0 & 0 & 0 & 0 & 0 & 0 \\
\hline & Propriedade 14 & 1 & 0 & 0 & 0 & 0 & 0 & 0 & 0 & 0 & 0 \\
\hline & Propriedade 15 & 1 & 0 & 0 & 0 & 0 & 0 & 0 & 0 & 0 & 0 \\
\hline & Propriedade 16 & 4 & 1 & 2 & 0 & 0 & 0 & 1 & 0 & 0 & 4 \\
\hline & Propriedade 17 & 2 & 1 & 0 & 0 & 1 & 0 & 0 & 0 & 0 & 2 \\
\hline & Propriedade 18 & 3 & 0 & 2 & 0 & 0 & 0 & 0 & 0 & 0 & 2 \\
\hline & Propriedade 19 & 1 & 0 & 0 & 0 & 0 & 0 & 0 & 1 & 0 & 1 \\
\hline & Propriedade 20 & 5 & 0 & 2 & 0 & 1 & 0 & 0 & 0 & 1 & 4 \\
\hline & Propriedade 21 & 6 & 0 & 1 & 1 & 0 & 0 & 0 & 0 & 0 & 2 \\
\hline & Propriedade 22 & 2 & 0 & 0 & 0 & 0 & 0 & 0 & 0 & 0 & 0 \\
\hline & Propriedade 23 & 3 & 0 & 1 & 0 & 0 & 0 & 0 & 0 & 0 & 1 \\
\hline
\end{tabular}


(conclusão)

\begin{tabular}{|c|c|c|c|c|c|c|c|c|c|c|c|}
\hline \multirow{2}{*}{ Espécie } & \multirow{2}{*}{ Local } & \multirow{2}{*}{ Examinados } & \multicolumn{8}{|c|}{ N Animais Positivos - Titulação Máxima } & \multirow{2}{*}{$\begin{array}{c}\text { Total de animais } \\
\text { com título } \geq 8\end{array}$} \\
\hline & & & 8 & 16 & 32 & 64 & 128 & 256 & 512 & 1024 & \\
\hline \multirow{13}{*}{ Cão doméstico } & Propriedade 24 & 2 & 0 & 0 & 0 & 0 & 0 & 0 & 0 & 0 & 0 \\
\hline & Propriedade 25 & 2 & 0 & 0 & 0 & 0 & 0 & 0 & 0 & 0 & 0 \\
\hline & Propriedade 26 & 1 & 0 & 0 & 0 & 0 & 0 & 0 & 0 & 0 & 0 \\
\hline & Propriedade 28 & 2 & 0 & 1 & 0 & 0 & 0 & 0 & 0 & 0 & 1 \\
\hline & Propriedade 29 & 2 & 0 & 0 & 0 & 0 & 0 & 0 & 0 & 0 & 0 \\
\hline & Propriedade 30 & 2 & 0 & 0 & 0 & 0 & 0 & 1 & 0 & 0 & 1 \\
\hline & Propriedade 32 & 3 & 0 & 0 & 0 & 0 & 0 & 0 & 0 & 0 & 0 \\
\hline & Propriedade 33 & 4 & 0 & 0 & 0 & 0 & 0 & 0 & 0 & 0 & 0 \\
\hline & Propriedade 34 & 2 & 0 & 0 & 0 & 0 & 0 & 0 & 0 & 0 & 0 \\
\hline & Propriedade 35 & 3 & 0 & 0 & 3 & 0 & 0 & 0 & 0 & 0 & 3 \\
\hline & Propriedade 36 & 1 & 0 & 0 & 0 & 0 & 0 & 0 & 0 & 0 & 0 \\
\hline & Total & 83 & 4 & 11 & 6 & 4 & 1 & 2 & 1 & 1 & 30 \\
\hline & $\%$ Positivos & & 4,8 & 13,3 & 7,2 & 4,8 & 1,2 & 2,4 & 1,2 & 1,2 & 36,1 \\
\hline
\end{tabular}


Resultado do teste sorológico para o vírus da cinomose realizado para os cães domésticos do Pantanal, distribuídos em função das propriedades amostradas e titulação máxima de anticorpos encontrada

\begin{tabular}{|c|c|c|c|c|c|c|c|c|c|c|c|}
\hline \multirow{2}{*}{ Espécie } & \multirow{2}{*}{ Local } & \multirow{2}{*}{ Examinados } & \multicolumn{8}{|c|}{$\mathbf{N}^{\circ}$ Animais Positivos - Titulação Máxima } & \multirow{2}{*}{$\begin{array}{c}\text { Total de animais } \\
\text { com título } \geq 8\end{array}$} \\
\hline & & & 8 & 16 & 32 & 64 & 128 & 256 & 512 & 1024 & \\
\hline \multirow{6}{*}{ Cão doméstico } & Propriedade 2 & 4 & 0 & 1 & 0 & 0 & 1 & 0 & 0 & 0 & 2 \\
\hline & Propriedade 3 & 5 & 0 & 0 & 0 & 0 & 2 & 0 & 0 & 0 & 2 \\
\hline & Propriedade 5 & 6 & 0 & 1 & 2 & 0 & 0 & 0 & 0 & 0 & 3 \\
\hline & Propriedade 8 & 4 & 1 & 0 & 0 & 1 & 2 & 0 & 0 & 0 & 4 \\
\hline & Total & 28 & 1 & 2 & 4 & 2 & 6 & 0 & 0 & 0 & 15 \\
\hline & $\%$ Positivos & & 3,6 & 7,1 & 14,3 & 7,1 & 21,4 & 0 & 0 & 0 & 53,6 \\
\hline
\end{tabular}


Resultado do teste sorológico para o vírus da cinomose realizado para os cães domésticos do entorno do Parque Estadual do Cantão, distribuídos em função das propriedades amostradas e titulação máxima de anticorpos encontrada

\begin{tabular}{|c|c|c|c|c|c|c|c|c|c|c|c|}
\hline \multirow{2}{*}{ Espécie } & \multirow{2}{*}{ Local } & \multirow{2}{*}{ Examinados } & \multicolumn{8}{|c|}{ N Animais Positivos - Titulação Máxima } & \multirow{2}{*}{$\begin{array}{c}\text { Total de animais } \\
\text { com título } \geq 8\end{array}$} \\
\hline & & & 8 & 16 & 32 & 64 & 128 & 256 & 512 & 1024 & \\
\hline \multirow{18}{*}{ Cão doméstico } & Propriedade 1 & 19 & 0 & 2 & 0 & 0 & 0 & 0 & 0 & 0 & 2 \\
\hline & Propriedade 2 & 6 & 0 & 1 & 0 & 0 & 0 & 0 & 0 & 0 & 1 \\
\hline & Propriedade 3 & 2 & 0 & 0 & 1 & 1 & 0 & 0 & 0 & 0 & 2 \\
\hline & Propriedade 4 & 2 & 0 & 1 & 0 & 0 & 1 & 0 & 0 & 0 & 2 \\
\hline & Propriedade 5 & 1 & 0 & 0 & 1 & 0 & 0 & 0 & 0 & 0 & 1 \\
\hline & Propriedade 6 & 1 & 0 & 0 & 0 & 0 & 0 & 0 & 0 & 0 & 0 \\
\hline & Propriedade 7 & 1 & 0 & 0 & 0 & 0 & 0 & 0 & 0 & 0 & 0 \\
\hline & Propriedade 8 & 3 & 0 & 1 & 0 & 2 & 0 & 0 & 0 & 0 & 3 \\
\hline & Propriedade 9 & 3 & 0 & 0 & 0 & 0 & 0 & 0 & 0 & 0 & 0 \\
\hline & Propriedade 10 & 3 & 0 & 2 & 1 & 0 & 0 & 0 & 0 & 0 & 3 \\
\hline & Propriedade 11 & 4 & 0 & 0 & 1 & 1 & 0 & 0 & 0 & 0 & 2 \\
\hline & Propriedade 12 & 1 & 0 & 0 & 0 & 0 & 1 & 0 & 0 & 0 & 1 \\
\hline & Assentamento 1 & 1 & 0 & 0 & 0 & 1 & 0 & 0 & 0 & 0 & 1 \\
\hline & Assentamento 2 & 1 & 0 & 0 & 0 & 1 & 0 & 0 & 0 & 0 & 1 \\
\hline & Assentamento 3 & 6 & 0 & 1 & 0 & 1 & 0 & 0 & 0 & 0 & 2 \\
\hline & Assentamento 4 & 9 & 0 & 1 & 1 & 2 & 0 & 1 & 0 & 0 & 5 \\
\hline & Total & 63 & 0 & 9 & 5 & 9 & 2 & 1 & 0 & 0 & 26 \\
\hline & $\%$ Positivos & & & 14,3 & 7,9 & 14,3 & 3,2 & 1,6 & 0 & 0 & 41,3 \\
\hline
\end{tabular}




\section{APÊNCIDE I - RESULTADO DOS TESTES MOLECULARES PARA Babesia spp. E Hepatozoon spp. PARA OS ANIMAIS DOMÉSTICOS}

Resultados dos testes moleculares para Babesia spp. e Hepatozoon spp. realizados para os animais domésticos do entorno do Parque Nacional das Emas, distribuídos em função das espécies e propriedades amostradas

\begin{tabular}{|c|c|c|c|c|c|c|}
\hline \multirow{2}{*}{ Espécie } & \multirow{2}{*}{ Local } & \multirow{2}{*}{ Examinados } & \multicolumn{2}{|c|}{ Babesia spp. } & \multicolumn{2}{|c|}{ Hepatozoon spp. } \\
\hline & & & Pos. & $\%$ & Pos. & $\%$ \\
\hline \multirow{29}{*}{ Cão doméstico } & Propriedade 1 & 3 & 0 & 0 & 2 & 66,7 \\
\hline & Propriedade 2 & 3 & 1 & 33,3 & 3 & 100,0 \\
\hline & Propriedade 3 & 1 & 1 & 100 & 1 & 100,0 \\
\hline & Propriedade 4 & 5 & 0 & 0 & 5 & 100,0 \\
\hline & Propriedade 5 & 2 & 0 & 0 & 1 & 50,0 \\
\hline & Propriedade 6 & 1 & 0 & 0 & 0 & 0 \\
\hline & Propriedade 7 & 1 & 0 & 0 & 0 & 0 \\
\hline & Propriedade 8 & 2 & 0 & 0 & 0 & 0 \\
\hline & Propriedade 9 & 4 & 0 & 0 & 2 & 50,0 \\
\hline & Propriedade 10 & 1 & 0 & 0 & 1 & 100,0 \\
\hline & Propriedade 12 & 2 & 0 & 0 & 2 & 100,0 \\
\hline & Propriedade 13 & 1 & 0 & 0 & 1 & 100,0 \\
\hline & Propriedade 14 & 1 & 0 & 0 & 0 & 0 \\
\hline & Propriedade 15 & 1 & 0 & 0 & 1 & 100,0 \\
\hline & Propriedade 16 & 4 & 0 & 0 & 0 & 0 \\
\hline & Propriedade 17 & 1 & 0 & 0 & 1 & 100,0 \\
\hline & Propriedade 18 & 2 & 0 & 0 & 0 & 0 \\
\hline & Propriedade 19 & 1 & 0 & 0 & 0 & 0 \\
\hline & Propriedade 20 & 4 & 2 & 50,0 & 0 & 0 \\
\hline & Propriedade 21 & 4 & 0 & 0 & 2 & 50,0 \\
\hline & Propriedade 22 & 2 & 1 & 50,0 & 1 & 50,0 \\
\hline & Propriedade 23 & 4 & 0 & 0 & 0 & 0 \\
\hline & Propriedade 25 & 2 & 0 & 0 & 1 & 50,0 \\
\hline & Propriedade 29 & 2 & 0 & 0 & 0 & 0 \\
\hline & Propriedade 30 & 2 & 0 & 0 & 1 & 50,0 \\
\hline & Propriedade 32 & 3 & 0 & 0 & 3 & 100,0 \\
\hline & Propriedade 34 & 1 & 0 & 0 & 0 & 0 \\
\hline & Propriedade 35 & 3 & 0 & 0 & 1 & 33,3 \\
\hline & Total & 63 & 5 & 7,9 & 29 & 46,0 \\
\hline \multirow{7}{*}{ Gato doméstico } & Propriedade 21 & 2 & 0 & 0 & 0 & 0 \\
\hline & Propriedade 15 & 1 & 0 & 0 & 1 & 100,0 \\
\hline & Propriedade 13 & 1 & 0 & 0 & 0 & 0 \\
\hline & Propriedade 23 & 1 & 0 & 0 & 0 & 0 \\
\hline & Propriedade 31 & 1 & 0 & 0 & 1 & 100,0 \\
\hline & Propriedade 9 & 1 & 0 & 0 & 1 & 100,0 \\
\hline & Total & 7 & 0 & 0 & 3 & 42,9 \\
\hline
\end{tabular}


Resultados dos testes moleculares para Babesia spp. e Hepatozoon spp. realizados para os animais domésticos do Pantanal, distribuídos em função das espécies e propriedades amostradas

\begin{tabular}{|c|c|c|c|c|c|c|}
\hline \multirow{2}{*}{ Espécie } & \multirow{2}{*}{ Local } & \multirow{2}{*}{ Examinados } & \multicolumn{2}{|c|}{ Babesia spp. } & \multicolumn{2}{|c|}{ Hepatozoon spp. } \\
\hline & & & Pos. & $\%$ & Pos. & $\%$ \\
\hline \multirow{7}{*}{ Cão doméstico } & Propriedade 2 & 3 & 0 & 0 & 2 & 66,7 \\
\hline & Propriedade 3 & 4 & 0 & 0 & 3 & 75,0 \\
\hline & Propriedade 4 & 1 & 0 & 0 & 1 & 100,0 \\
\hline & Propriedade 5 & 5 & 0 & 0 & 4 & 80,0 \\
\hline & Propriedade 8 & 4 & 0 & 0 & 4 & 100,0 \\
\hline & Propriedade 9 & 2 & 0 & 0 & 2 & 100,0 \\
\hline & Total & 19 & 0 & 0 & 16 & 84,2 \\
\hline \multirow{8}{*}{ Gato doméstico } & Propriedade 1 & 1 & 0 & 0 & 0 & 0 \\
\hline & Propriedade 5 & 3 & 0 & 0 & 2 & 66,7 \\
\hline & Propriedade 6 & 1 & 0 & 0 & 1 & 100,0 \\
\hline & Propriedade 7 & 2 & 0 & 0 & 1 & 50,0 \\
\hline & Propriedade 9 & 1 & 0 & 0 & 0 & 0 \\
\hline & Propriedade 11 & 1 & 0 & 0 & 0 & 0 \\
\hline & Propriedade 12 & 1 & 0 & 0 & 0 & 0 \\
\hline & Total & 10 & 0 & 0 & 4 & 40,0 \\
\hline
\end{tabular}

Resultados dos testes moleculares para Babesia spp. e Hepatozoon spp. realizados para os animais domésticos do entorno do Parque Estadual do Cantão, distribuídos em função das espécies e propriedades amostradas.

\begin{tabular}{|c|c|c|c|c|c|c|}
\hline \multirow{2}{*}{ Espécie } & \multirow{2}{*}{ Local } & \multirow{2}{*}{ Examinados } & \multicolumn{2}{|c|}{ Babesia spp. } & \multicolumn{2}{|c|}{ Hepatozoon spp. } \\
\hline & & & Pos. & $\%$ & Pos. & $\%$ \\
\hline \multirow{14}{*}{ Cão doméstico } & Propriedade 1 & 16 & 4 & 25,0 & 12 & 75,0 \\
\hline & Propriedade 2 & 5 & 0 & 0 & 3 & 60,0 \\
\hline & Propriedade 4 & 1 & 0 & 0 & 1 & 100,0 \\
\hline & Propriedade 6 & 1 & 0 & 0 & 0 & 0 \\
\hline & Propriedade 7 & 1 & 0 & 0 & 1 & 100,0 \\
\hline & Propriedade 8 & 2 & 0 & 0 & 2 & 100,0 \\
\hline & Propriedade 9 & 1 & 0 & 0 & 1 & 100,0 \\
\hline & Propriedade 10 & 3 & 0 & 0 & 3 & 100,0 \\
\hline & Propriedade 11 & 3 & 0 & 0 & 3 & 100,0 \\
\hline & Propriedade 12 & 1 & 0 & 0 & 1 & 100,0 \\
\hline & Assentamento 2 & 1 & 0 & 0 & 1 & 100,0 \\
\hline & Assentamento 3 & 4 & 0 & 0 & 2 & 50,0 \\
\hline & Assentamento 4 & 8 & 1 & 12,5 & 6 & 75,0 \\
\hline & Total & 47 & 5 & 10,6 & 36 & 76,6 \\
\hline \multirow{4}{*}{ Gato doméstico } & Propriedade 1 & 1 & 0 & 0 & 0 & 0 \\
\hline & Propriedade 6 & 2 & 0 & 0 & 0 & 0 \\
\hline & Propriedade 11 & 2 & 0 & 0 & 0 & 0 \\
\hline & Total & 5 & 0 & 0 & 0 & 0 \\
\hline
\end{tabular}




\section{APÊNDICE J - RESULTADO DOS TESTES MOLECULARES PARA OS HEMOPLASMAS FELINOS PARA OS GATOS DOMÉSTICOS}

Resultados dos testes moleculares para Mycoplasma haemofelis, 'Ca. Mycoplasma haemominutum' e 'Ca. Mycoplasma turicensis' realizados para os gatos domésticos do entorno do Parque Nacional das Emas, distribuídos em função das propriedades amostradas

\begin{tabular}{|c|c|c|c|c|c|c|c|c|}
\hline \multirow[t]{2}{*}{ Espécie } & \multirow[t]{2}{*}{ Local } & \multirow[t]{2}{*}{ Examinados } & \multicolumn{2}{|c|}{ M. haemofelis } & \multicolumn{2}{|c|}{$\begin{array}{c}\text { 'Ca. M. } \\
\text { haemominutum' }\end{array}$} & \multicolumn{2}{|c|}{$\begin{array}{c}\text { 'Ca. M. } \\
\text { turicensis' }\end{array}$} \\
\hline & & & Pos. & $\%$ & Pos. & $\%$ & Pos. & $\%$ \\
\hline \multirow{7}{*}{$\begin{array}{c}\text { Gato } \\
\text { doméstico }\end{array}$} & Propriedade 9 & 1 & 0 & 0 & 0 & 0 & 0 & 0 \\
\hline & Propriedade 13 & 1 & 0 & 0 & 0 & 0 & 0 & 0 \\
\hline & Propriedade 15 & 1 & 0 & 0 & 0 & 0 & 0 & 0 \\
\hline & Propriedade 21 & 2 & 1 & 50,0 & 0 & 0 & 0 & 0 \\
\hline & Propriedade 23 & 1 & 0 & 0 & 0 & 0 & 1 & 100,0 \\
\hline & Propriedade 31 & 1 & 0 & 0 & 0 & 0 & 0 & 0 \\
\hline & Total & 7 & 1 & 14,3 & 0 & 0 & 1 & 14,3 \\
\hline
\end{tabular}

Resultados dos testes moleculares para Mycoplasma haemofelis, 'Ca. Mycoplasma haemominutum' e 'Ca. Mycoplasma turicensis' realizados para os gatos domésticos do Pantanal, distribuídos em função das propriedades amostradas

\begin{tabular}{|c|c|c|c|c|c|c|c|c|}
\hline \multirow[t]{2}{*}{ Espécie } & \multirow[t]{2}{*}{ Local } & \multirow[t]{2}{*}{ Examinados } & \multicolumn{2}{|c|}{ M. haemofelis } & \multicolumn{2}{|c|}{$\begin{array}{c}\text { 'Ca. M. } \\
\text { haemominutum' }\end{array}$} & \multicolumn{2}{|c|}{$\begin{array}{c}\text { 'Ca. } \\
\text { M. turicensis' }\end{array}$} \\
\hline & & & Pos. & $\%$ & Pos. & $\%$ & Pos. & $\%$ \\
\hline \multirow{8}{*}{$\begin{array}{c}\text { Gato } \\
\text { domestico }\end{array}$} & Propriedade 1 & 1 & 1 & 100,0 & 1 & 100,0 & 0 & 0 \\
\hline & Propriedade 5 & 3 & 0 & 0 & 0 & 0 & 0 & 0 \\
\hline & Propriedade 6 & 1 & 0 & 0 & 0 & 0 & 0 & 0 \\
\hline & Propriedade 7 & 2 & 0 & 0 & 0 & 0 & 0 & 0 \\
\hline & Propriedade 9 & 1 & 0 & 0 & 1 & 100,0 & 0 & 0 \\
\hline & Propriedade 11 & 1 & 0 & 0 & 0 & 0 & 0 & 0 \\
\hline & Propriedade 12 & 1 & 0 & 0 & 0 & 0 & 0 & 0 \\
\hline & Total & 10 & 1 & 10,0 & 2 & 20,0 & 0 & 0 \\
\hline
\end{tabular}

Resultados dos testes moleculares para Mycoplasma haemofelis, 'Ca. Mycoplasma haemominutum' e 'Ca. Mycoplasma turicensis' realizados para os gatos domésticos do entorno do Parque Estadual do Cantão, distribuídos em função das propriedades amostradas

\begin{tabular}{|c|c|c|c|c|c|c|c|c|}
\hline \multirow[t]{2}{*}{ Espécie } & \multirow[t]{2}{*}{ Local } & \multirow[t]{2}{*}{ Examinados } & \multicolumn{2}{|c|}{ M. haemofelis } & \multicolumn{2}{|c|}{$\begin{array}{c}\text { 'Ca. M. } \\
\text { haemominutum' }\end{array}$} & \multicolumn{2}{|c|}{$\begin{array}{c}C a . \\
\text { M. turicensis' }\end{array}$} \\
\hline & & & Pos. & $\%$ & Pos. & $\%$ & Pos. & $\%$ \\
\hline \multirow{4}{*}{$\begin{array}{c}\text { Gato } \\
\text { doméstico }\end{array}$} & Propriedade 1 & 1 & 0 & 0 & 0 & 0 & 0 & 0 \\
\hline & Propriedade 6 & 2 & 0 & 0 & 0 & 0 & 0 & 0 \\
\hline & Propriedade 11 & 2 & 0 & 0 & 0 & 0 & 0 & 0 \\
\hline & Total & 5 & 0 & 0 & 0 & 0 & 0 & 0 \\
\hline
\end{tabular}

